
Aspectos sócio-históricos e linguísticos do português escrito em Santa Catarina nos séculos XIX e XX 
UNIVERSIDADE FEDERAL DE SANTA CATARINA

Reitor

Ubaldo Cesar Balthazar

Vice-Reitora

Cátia Regina Silva de Carvalho Pinto

EDITORA DA UFSC

Diretora Executiva Interina

Flavia Vicenzi

Conselho Editorial

Agripa Faria Alexandre

Antonio de Pádua Carobrez

Carolina Fernandes da Silva

Evelyn Winter da Silva

Fábio Augusto Morales Soares

Fernando Luís Peixoto

Ione Ribeiro Valle

Jeferson de Lima Tomazelli

Josimari Telino de Lacerda

Luis Alberto Gómez

Marília de Nardin Budó

Núbia Carelli Pereira de Avelar

Priscila de Oliveira Moraes

Sandro Braga

Vanessa Aparecida Alves de Lima

Editora da UFSC

Campus Universitário - Trindade

88040-900 - Florianópolis-SC

Fone: (48) 3721-9408

editora@contato.ufsc.br

www.editora.ufsc.br 


\author{
Izete Lehmkuhl Coelho \\ Isabel de Oliveira e Silva Monguilhott \\ Marco Antonio Rocha Martins \\ Edair Maria Görski \\ organização
}

\title{
Aspectos sócio-históricos e linguísticos do português escrito em Santa Catarina nos séculos XIX e XX
}

Edição em homenagem ao

Professor Emérito Paulino Vandresen 
(C) 2021 Editora da UFSC

Coordenação editorial:

Flavia Vicenzi

Projeto gráfico, capa e diagramação:

pamalero artes

Revisão:

Letícia Tambosi

\section{Sobre a coleção}

A coleção LinguísticaS é uma iniciativa do Programa de Pós-Graduação em Linguística da UFSC e pretende construir espaços de debates a respeito das pesquisas sobre a linguagem, em seus mais variados campos.

Catalogação na fonte pela Biblioteca Universitária da Universidade Federal de Santa Catarina

A838 Aspectos sócio-históricos e linguísticos do português escrito em Santa Catarina nos séculos XIX e XX [recurso eletrônico] / organização Izete Lehmkuhl Coelho ... [et al.]. - Florianópolis : Editora da UFSC, 2021.

399 p. : il. (Coleção LinguísticaS)

E-book (PDF)

Disponível em: https://doi.org/10.5007/978-65-5805-024-7

ISBN 978-65-5805-024-7

1. Língua portuguesa - Escrita - Santa Catarina - Séc. XIX. 2. Língua portuguesa - Escrita - Santa Catarina - Séc. XX. I. Coelho, Izete Lehmkuhl. II. Série.

CDU: 806.90(091)

Ficha catalográfica elaborada por Fabrício Silva Assumpção - CRB-14/1673

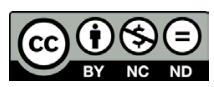

Este livro está sob a licença Creative Commons, que segue o princípio do acesso público à informação. O livro pode ser compartilhado desde que atribuídos os devidos créditos de autoria. Não é permitida nenhuma forma de alteração ou a sua utilização para fins comerciais.

br.creativecommons.org 


\section{Sumário}

Apresentação

Uma homenagem ao Professor Emérito Paulino

Vandresen.........................................................

Izete Lehmkuhl Coelho

Isabel de Oliveira e Silva Monguilhott

Marco Antonio Rocha Martins

Edair Maria Görski

\section{Capítulo 1}

Para a história do português brasileiro em Santa

Catarina

Izete Lehmkuhl Coelho

Isabel de Oliveira e Silva Monguilhott

Cecília Augusta Vieira Pinto

Érica Marciano de Oliveira

Helena Gouveia

Capítulo 2

Aspectos sócio-históricos, geográficos, políticos

e culturais de Santa Catarina

Edair Maria Görski

Paulino Vandresen

Cláudia Andrea Rost Snichelotto

Cristine Gorski Severo

Tatiana Schwochow Pimpão 
Capítulo 3

Aspectos do contato linguístico do vêneto no português escrito de Chapecó no século XX ................ 131

Marizete Bortolanza Spessatto

Loremi Loregian-Penkal

Ana Lívia Agostinho

Ivelã Pereira

Capítulo 4

Variação nós e a gente em Santa Catarina: do

presente para o passado

Isabel de Oliveira e Silva Monguilhott

Raquel Gomes Chaves

Ana Kelly Borba da Silva Brustolin

Juliana Flores das Chagas

Capítulo 5

A concordância verbal de terceira pessoa do plural em Santa Catarina: um olhar diacrônico

Raquel Gomes Chaves

Isabel de Oliveira e Silva Monguilhott

Patrícia Corrêa Ferminio

Capítulo 6

A trajetória da mudança na sintaxe do sujeito e do objeto direto em cartas pessoais catarinenses e

cariocas

Izete Lehmkuhl Coelho

Silvia Regina de Oliveira Cavalcante

Cecília Augusta Vieira Pinto

Anna Lyssa Machado

Anna Beatriz Cruz

Gésyka Mafra 
Capítulo 7

Análise diatópico-diacrônica dos clíticos em jornais brasileiros dos séculos XIX e XX e especificidades da escrita em Santa Catarina

Marco Antonio Rocha Martins

Aroldo Andrade

Grazielle Helena Scheidt

Juliana Regina da Silva

Capítulo 8

Convergências e divergências na expressão do dativo de segunda pessoa: análise de cartas pessoais catarinenses e cariocas dos séculos XIX e XX

Thiago Laurentino de Oliveira

Bruna Brasil Albuquerque de Carvalho

Thaissa Frota Teixeira Araujo Silva

Capítulo 9

Formas de tratamento nas cartas do escritor

catarinense Harry Laus para sua tradutora francesa..... 304

Vanessa Grando

Capítulo 10

A correlação tempo-modalidade e o uso variável do presente do modo subjuntivo em cartas ao redator de Lages e Florianópolis

Tatiana Schwochow Pimpão

Capítulo 11

Estratégias de interação em cartas pessoais íntimas em amostras do PHPB-SC

Carla Regina Martins Valle

Cláudia Andrea Rost Snichelotto

Érica Marciano de Oliveira

Sobre os autores 


\section{Apresentação}

\section{Uma homenagem ao Professor Emérito Paulino Vandresen}

Izete Lehmkuhl Coelho Isabel de Oliveira e Silva Monguilhott Marco Antonio Rocha Martins Edair Maria Görski

O livro Aspectos sócio-históricos e linguísticos do português escrito em Santa Catarina nos séculos XIX e XX reúne textos de pesquisadores de diferentes universidades brasileiras (UFSC, UFFS, UDESC, IFSC, FURG, UFRJ, UNICENTRO, UFPel, UFMG) que buscam contextualizar sóciohistoricamente quatro cidades que representam distintas microrregiões do estado de Santa Catarina (Grande Florianópolis, Serrana, Vale do Itajaí e Oeste Catarinense) e descrever e analisar diversos fenômenos linguísticos do português escrito nessa região nos séculos XIX e XX, a partir de documentos que constituem um corpus representativo da escrita catarinense.

A organização desse corpus - formado por anúncios, cartas de leitores, cartas de redatores, cartas pessoais e cartas oficiais coletados nas cidades de Florianópolis, Lages, Blumenau e Chapecó que também integram o banco de dados de fala do projeto Variação Linguística na Região Sul 
do Brasil (VARSUL/SC) www.varsul.org.br - é fruto de uma década de trabalho dos integrantes do projeto Para a História do Português Brasileiro em Santa Catarina (PHPB-SC) - vinculado ao projeto nacional Para a História do Português Brasileiro (PHPB) -, financiado inicialmente pelo Conselho Nacional de Desenvolvimento Científico e Tecnológico (CNPq), por meio do Edital Universal número 470689/2011-0, e desenvolvido no Departamento de Língua e Literatura Vernáculas e no Programa de PósGraduação em Linguística da Universidade Federal de Santa Catarina, no âmbito do núcleo VARSUL.

Ao mesmo tempo que apresentamos esta coletânea prestamos uma homenagem ao Professor Emérito da UFSC Paulino Vandresen por sua memorável contribuição aos estudos de Linguística no Brasil, em especial na área de Sociolinguística e Dialetologia, e por seu envolvimento marcante em atividades de pesquisa, ensino e extensão na UFSC e na formação de bancos de dados de língua oral e escrita.

\section{Para o homenageado}

É sabido, na área acadêmica, que a história de Paulino Vandresen se funde não só à história da Universidade Federal de Santa Catarina, onde ingressou como professor em 1966, mas também à história da linguística brasileira, estando diretamente envolvido na fundação da Associação Brasileira de Linguística (ABRALIN), conjuntamente com a promoção do Instituto Brasileiro de Linguística, em 1969, que até hoje oferece cursos promovidos pela ABRALIN, e na criação da Associação Nacional de PósGraduação e Pesquisa em Letras e Linguística (ANPOLL), da qual foi o primeiro presidente no biênio 1984-1986. No âmbito da ANPOLL, foi o primeiro coordenador do GT de Bilinguismo (1984-1986) e, posteriormente, foi vice-coordenador do GT de Sociolinguística (1996-1998). Teve, durante décadas, participação ativa nos encontros da ANPOLL e da ABRALIN, em conferências de abertura e em mesas-redondas, discutindo questões relativas a bilinguismo, variação e mudança linguística, política linguística e ensino da língua. Seu interesse por esses temas provavelmente é motivado por sua própria biografia: nascido em Rio Fortuna, sul de Santa Catarina, e filho de agricultores de origem holandesa e alemã, só foi 
aprender português aos sete anos, quando entrou para a escola local (GÖRSKI; COELHO, 2006).

Na UFSC, sua trajetória é marcante, com presença ativa desde a criação do Curso de Pós-Graduação em Letras, na década de 1970, do qual foi coordenador e do qual se originou o atual Programa de PósGraduação em Linguística (PPGLg), onde o professor Paulino atuou por mais de três décadas. Nos anos 1980, o PPGLg sediou o "Seminário aberto sobre variação linguística: o estudo dos dialetos sociais brasileiros”. Entre os projetos de pesquisa arrolados no relatório do Programa ao final dessa década, destacam-se: Elaboração de um Atlas Linguístico-Etnográfico da Região Sul; Variação Linguística urbana na Região Sul do país; Análise etnolinguística e sociolinguística do discurso. (GÖRSKI et al., 2012). Esses projetos tiveram impacto significativo na implementação de importantes projetos interinstitucionais de pesquisa na Região Sul: o ALERS e o VARSUL (este consolidado em 1989, tendo Paulino Vandresen como um de seus idealizadores e como coordenador geral por alguns anos) - ambos com sedes nos três estados da Região, onde funcionam com vitalidade.

O núcleo de pesquisa VARSUL agrega, desde a sua origem, pesquisadores de quatro instituições, UFSC, UFPR, UFRGS e PUC-RS, e, atualmente, pesquisadores da UFTPR, tendo como meta inicial a constituição de um banco de dados linguísticos dos três estados da Região Sul do Brasil, fonte para pesquisas de "Descrição linguística do português falado na Região Sul”. Para a formação desse banco, em cada um dos estados foram selecionados informantes nascidos em localidades etnicamente distintas para verificar se aspectos relacionados à etnia colonizadora poderiam explicar as variedades linguísticas encontradas nas entrevistas. Em Santa Catarina, por exemplo, foram entrevistados informantes de quatro regiões bem representativas: Florianópolis (etnia tipicamente açoriana), Blumenau (etnia tipicamente alemã), Lages (etnia tipicamente vicentista, influenciada por tropeiros e gaúchos) e Chapecó (etnia tipicamente italiana).

Paulino Vandresen foi pesquisador do CNPq (1986-1998), ministrou aulas na graduação e na pós-graduação, participou de inúmeras atividades de extensão, com destaque para o projeto interinstitucional "Resgate da história e da cultura material da escola catarinense" UDESC/UFSC/ Governo do estado de Santa Catarina (1993-1995), desempenhou várias funções administrativas e reúne mais de meia centena de produções 
bibliográficas, incluindo artigos, livros, organização de livros, capítulos de livros, publicados no Brasil e no exterior.

Sempre alinhado com a área da Sociolinguística e Dialetologia, Vandresen orientou dezenas de dissertações e teses sobre bilinguismo, contato linguístico, variação e mudança linguística, línguas indígenas, descrição linguística e ensino de línguas, desenvolvidas na UFSC, na FURB e na UCPel, onde atuou depois de ter se aposentado na UFSC em 1992:

DESCHAMPS, Dario. Mecanismos nasais do português. Dissertação (Mestrado em Linguística) - UFSC, 1976.

LENARD, Andrieta. Lealdade linguística em Rodeio. 1976. Dissertação (Mestrado em Linguística) - UFSC, 1976.

CRUZ, Edvaldo. Contribuição linguística ao ensino do português: as cláusulas relativas. Dissertação (Mestrado em Linguística) - UFSC, 1977.

CHOCIAI, Lauro. Complementos oracionais em português: uma abordagem transformacional. Dissertação (Mestrado em Linguística) - UFSC, 1977.

PEREIRA, Edna. Um estudo sociolinguístico na colônia Esperança. Dissertação (Mestrado em Linguística) - UFSC, 1977.

PEREIRA, Francisco Chagas. Em torno dos verbos de mudança de estado em português. Dissertação (Mestrado em Linguística) - UFSC, 1977.

ARAÚJO, Leopoldina Maria Souza de. Semântica gerativa: um estudo do dialeto Gavião “Je”. Dissertação (Mestrado em Linguística) - UFSC, 1977.

PAZINI, Maria Celi Beraldo. A posição do adjetivo na locução nominal em português. Dissertação (Mestrado em Linguística) - UFSC, 1977.

OLIVEIRA, Sidnei Gaspar de. Existe realmente semivogal no português? Dissertação (Mestrado em Linguística) - UFSC, 1978.

ALMEIDA FILHO, Bibiano Gomes de. O futuro do presente na língua portuguesa contemporânea. Dissertação (Mestrado em Linguística) - UFSC, 1978.

VIEIRA, Hilda Gomes. Um estudo fonológico gerativo dos diminutivos em português. Dissertação (Mestrado em Linguística) - UFSC, 1978.

LOPES, Sonia Aparecida Serveira. A alternância vocálica nos verbos regulares e nomes. Dissertação (Mestrado em Linguística) - UFSC, 1978.

PAGLIARINI, Maria Inês. Morfofonologia das formas verbais finitas: tratamento fonológico gerativo. Dissertação (Mestrado em Linguística) - UFSC, 1978.

ZIMMERMANN, Ivo. Interferência de um dialeto alemão na língua portuguesa. Dissertação (Mestrado em Linguística) - UFSC, 1981. 
CAMPOS, Selma Nery de. Complexidade sintática do discurso oral e escrito de crianças carentes culturais. Dissertação (Mestrado em Linguística) - UFSC, 1983. KAHMANN, Crista Ingri. A interferência da língua portuguesa em um dialeto alemão. Dissertação (Mestrado em Linguística) - UFSC, 1987.

STEINER, Maria Elaine Estivalete. O bilinguismo em áreas urbanas de colonização alemã: um estudo em Jaraguá do Sul. Dissertação (Mestrado em Linguística) UFSC, 1988.

RAMOS, Myrian Pereira Botelho. Formas de tratamento no falar de Florianópolis. Dissertação (Mestrado em Linguística) - UFSC, 1989.

DACOREGIO, Maria Salete Monteiro. Aspectos sociolinguísticos do Distrito de Invernada - Grão-Pará. Dissertação (Mestrado em Linguística) - UFSC, 1990.

RECH, Márcia Dresch. O conflito de expectativas na interação em sala de aula. Dissertação (Mestrado em Linguística) - UFSC, 1992.

COLLAÇO, Ana Cláudia. A direcionalidade dos processos de formação de palavras por derivação. Dissertação (Mestrado em Linguística) - UFSC, 1992.

BORSTEL, Clarisse Von. Aspectos do bilinguismo alemão português em Marechal Cândido Rondon. Dissertação (Mestrado em Linguística) - UFSC, 1992.

BOSO, Ivete Marli. Entre passado e futuro - bilinguismo em uma comunidade trentino-brasileira. Dissertação (Mestrado em Linguística) - UFSC, 1992.

CAVASSIN, Regina Back. A negação no português. Dissertação (Mestrado em Linguística) - UFSC, 1993.

VASCONCELOS, Heloiza Rotolo de. Estratégias discursivas de orientação de tópico. Dissertação (Mestrado em Linguística) - UFSC, 1993.

COUTO, Leticia Rebollo. Operações e representações discursivas da enunciação da hipótese em três línguas neolatinas. Dissertação (Mestrado em Linguística) UFSC, 1994.

BRESCANCINI, Cláudia Regina. A palatização da fricativa alveolar não morfêmica. Dissertação (Mestrado em Linguística) - UFSC, 1996.

HEROLD, Cristina. Aspectos da fonologia kaingang. Dissertação (Mestrado em Linguística) - UFSC, 1996.

DIAS, Juçá Fialho Vazzata. A concordância de número nos predicativos e nos particípios passivos. Dissertação (Mestrado em Linguística) - UFSC, 1996. FERNANDES, Marisa. A concordância nominal na Região Sul. Dissertação (Mestrado em Linguística) - UFSC, 1996.

LOREGIAN, Loremi. A concordância verbal com o pronome tu na fala do sul do Brasil. Dissertação (Mestrado em Linguística) - UFSC, 1996. 
RODRIGUES, Cássio. As estratégias de comunicação em uma língua estrangeira: a perspectiva da sala de aula. Dissertação (Mestrado em Linguística) - UFSC, 1997. BACK, Ângela. O uso variável do quantificador universal no sintagma nominal na língua falada em Florianópolis. Dissertação (Mestrado em Linguística) - UFSC, 2001.

WIESE, Harry. A inserção da língua portuguesa na colônia Hammonia. Dissertação (Mestrado em Letras) - FURB, 2002.

NUNES, Rosane Pereira. A evolução cíclica do futuro do presente: do Latim ao Português. Dissertação (Mestrado em Letras) - UCPel, 2003.

BRISOLERA, Luciene Bassols. A prosodização dos clíticos monominais no sul do Brasil: uma análise variacionista com base na elevação da vogal /e/. Dissertação (Mestrado em Letras) - UCPel, 2004.

COSTA, Geni Vanderléia Moura da. O uso do presente do subjuntivo em língua espanhola: contribuição para aprendizes brasileiros. Dissertação (Mestrado em Letras) - UCPel, 2004.

OLIVEIRA, Graciele Turchetti de. Análise de erros em alunos de espanhol do ensino fundamental e médio: pronomes pessoais átonos. Dissertação (Mestrado em Letras) - UCPel, 2006.

LOOSE, Roberta Egert. O papel da instrução explícita na aquisição/aprendizagem de estruturas do espanhol por falantes do português. Dissertação (Mestrado em Letras) - UCPel, 2006.

OGLIARI, Marlene Maria. As condições de resistência e vitalidade de uma língua minoritária no contexto sociolinguístico brasileiro. Tese (Doutorado em Linguística) - UFSC, 1999.

COELHO, Izete Lehmkuhl. A ordem V DP em construções monoargumentais: uma restrição sintático-semântica. Tese (Doutorado em Linguística) - UFSC, 2000. MELLO, Antonio Augusto Souza. Estudo histórico da família linguística TupiGuarani: aspectos fonológicos e lexicais. Tese (Doutorado em Linguística) UFSC, 2000.

SEARA, Izabel Christina. Estudo acústico perceptual da nasalidade das vogais do Português Brasileiro. Tese (Doutorado em Linguística) - UFSC, 2000.

WEININGER, Markus. Verbalkamer: estruturas verbais descontínuas em alemão. Tese (Doutorado em Linguística) - UFSC, 2000.

Dezenas de trabalhos na área de sociolinguística variacionista (teses, dissertações, monografias, relatórios de pesquisa e artigos), orientados por Paulino Vandresen, foram desenvolvidos a partir de amostras do banco de 
dados VARSUL. Destaquem-se especialmente os trabalhos de descrição das variedades do português falado no sul do Brasil na linha de pesquisa variação e mudança linguística, defendidos no Programa de Pós-Graduação em Linguística da UFSC: A palatização da fricativa alveolar não morfêmica, de Cláudia Regina Brescancini, defendido em 1996; A concordância de número nos predicativos e nos particípios passivos, de Juçá Fialho Vazzata Dias, defendido em 1996; A concordância nominal na Região Sul, de Marisa Fernandes, defendido em 1996; A concordância verbal com o pronome tu na fala do sul do Brasil, defendido por Loremi Loregian em 1996; A ordem V DP em construções monoargumentais: uma restrição sintático-semântica, de Izete Lehmkuhl Coelho, defendido em 2000; entre outros. Alguns resultados desses trabalhos encontram-se compilados nos dois volumes organizados posteriormente por Paulino Vandresen: Variação e mudança no português falado da Região Sul (2002) e Variação, mudança e contato linguístico no português da Região Sul (2006).

Paralelamente à ampliação do banco VARSUL, com a elaboração de novas entrevistas, um projeto de formação de um banco de dados de língua escrita aos poucos se delineia no âmbito do VARSUL da UFSC, o projeto PHPB-SC, vinculado aos objetivos do projeto nacional PHPB.

Em 2011, o projeto PHPB-SC nasce oficialmente, com o propósito de (i) levantar e catalogar os gêneros textuais anúncios, cartas de leitores (ou cartas ao redator), cartas de redatores, cartas pessoais e cartas oficiais, provenientes de acervos públicos ou particulares de quatro localidades de Santa Catarina: Florianópolis, Lages, Blumenau e Chapecó, no curso dos séculos XIX e XX; (ii) editar e disponibilizar os corpora coletados; e (iii) descrever aspectos da realidade sócio-histórica e fenômenos de variação e mudança linguística do português dessas quatro localidades catarinenses.

Esses locais foram escolhidos pelo grupo do projeto PHPB-SC nos moldes da coleta de entrevistas orais sociolinguísticas (LABOV, 1972) que o núcleo VARSUL da UFSC havia realizado na década de 1990, por serem localidades representativas das diferentes etnias que compõem o território catarinense. $^{1}$

Para uma discussão aprofundada acerca do contexto sócio-histórico do estado de Santa Catarina, remetemos o leitor ao Capítulo 2 deste livro Aspectos sócio-históricos, geográficos, políticos e culturais de Santa Catarina. 
Desde o primeiro momento, nas inúmeras reuniões do projeto PHPB-SC, contamos com a presença memorável do professor Paulino. Com foco na história das etnias colonizadores do estado de Santa Catarina, Paulino contextualizava os principais fatores sociais que levaram à inserção da língua portuguesa em regiões do Vale do Itajaí, como Blumenau e Nova Trento, colonizadas por italianos e alemães, respectivamente, na segunda metade do século XIX. Nos relatos que fazia, focalizava especialmente acontecimentos históricos e políticos, ligados à preservação das línguas de imigração em algumas comunidades e a políticas de imposição do uso do português em diversas escolas catarinenses.

A preocupação de Paulino Vandresen com a formação sócio-histórica e linguística do estado de Santa Catarina já se revelava em sua tese de doutorado, a respeito da Fonologia do vestfaliano de Rio Fortuna, defendida em 1971 na Pontifícia Universidade Católica do Rio Grande do Sul (PUCRS). Segundo Vandresen, Rio Fortuna pertence a um conglomerado de ilhas linguísticas do sudeste de Santa Catarina que inclui as comunidades de Águas Mornas, São Bonifácio, São Martinho, Braço do Norte, São Ludgero, Armazém, Santa Rosa de Lima, entre outras, conhecidas como comunidades teuto-brasileiras. A população dessas localidades é formada por alemães católicos da região da Westfália, na Alemanha, que vieram para o Brasil a partir de 1860 .

Desde o seu trabalho de tese, vários de seus artigos e capítulos de livros estão relacionados a temas de Sociolinguística e Dialetologia que incluem contato, bilinguismo e línguas de imigração, seja do ponto de vista da interferência das línguas de imigração no contato com o português do sul do Brasil, seja na atuação de políticas linguísticas concernentes ao ensino do português em áreas bilíngues. Destacam-se os textos: $O$ ensino do português em áreas bilíngues - uma perspectiva histórica (1995); A inserção da língua portuguesa em uma comunidade teuto-brasileira (2004); Política linguística e bilinguismo em uma comunidade teuto-brasileira (2006); O bilinguismo pomerano-português na região de Pelotas (2008); Estudo comparativo do bilinguismo em duas áreas de colonização alemã (2009); O papel da família e da religião na aculturação linguística e desenvolvimento educacional em Rio Fortuna (2010); entre outros.

Os encontros do PHPB-SC iam ganhando cor local com a descrição bem pormenorizada que Paulino Vandresen fazia das comunidades teuto- 
brasileiras instaladas em Santa Catarina, a partir de meados do século XIX. Nessas memórias vinham registros de alguns dos trabalhos sobre bilinguismo e línguas de imigração alemã e italiana orientados entre 1976 e 2000. Com respeito às línguas de imigração alemã em Santa Catarina, vale lembrar de dois trabalhos de seus orientandos: o de Ivo Zimmermann, Interferência de um dialeto alemão na língua portuguesa, defendido em 1981, e o de Maria Elaine Estivalete Steiner, O bilinguismo em áreas urbanas de colonização alemã: um estudo em Jaraguá do Sul, defendido em 1988. São trabalhos que investigam as escolhas linguísticas dentro da rede familiar, social e de relações preferenciais e as marcas do alemão no português em comunidades catarinenses bilíngues alemão-português.

Ressaltem-se também os trabalhos sobre imigração italiana dos seguintes orientandos: Andrieta Lenard, Lealdade linguística em Rodeio, defendido em 1976, que buscou verificar a fidelidade linguística dos falantes do município de Rodeio-SC, objetivando a compreensão dos elementos linguísticos e históricos que levaram os imigrantes italianos a desenvolver uma forte resistência à integração linguística na referida cidade; Maria Salete Monteiro Dacoregio, intitulado Aspectos sociolinguísticos do Distrito de Invernada - Grão-Pará, defendido em 1990, o qual procurou retratar o movimento migratório e o comportamento sociolinguístico da população de língua italiana no distrito de Invernada, em Grão-Pará-SC; Ivete Marli Boso, Entre passado e futuro - bilinguismo em uma comunidade trentinobrasileira, defendido em 1992. Nesse trabalho a autora observou que o processo discursivo da linguagem verbal dos colonos de Nova Trento-SC era também um ato de dominação, de interferência no sentido do próprio discurso.

Nesta coletânea, Paulino Vandresen é coautor do Capítulo 2, Aspectos sócio-históricos, geográficos, políticos e culturais de Santa Catarina, o qual focaliza aspectos constitutivos de cada uma das quatro cidades que integram o corpus do PHPB-SC, com ênfase nas línguas de imigração alemã e italiana nas localidades de Blumenau e Chapecó, respectivamente.

Paulino Vandresen, por sua trajetória de vida e especialmente por sua postura acadêmica e pessoal, é uma inspiração para nós, que tivemos e temos o privilégio de conviver com ele. Retomando as palavras de Görski e Coelho (2006, p. 21), destacamos: 
a relevância de seu papel político na construção da área de estudos sociolinguísticos no Brasil; sua preocupação com a busca de soluções para problemas sociais; o desprendimento que o leva a colocar em primeiro plano o aspecto institucional e coletivo, em detrimento, muitas vezes, de suas aspirações individuais; sua crença no trabalho cooperativo; a competência, a persistência e a elegância com que sempre se posiciona seja nos debates acadêmicos, seja em instâncias administrativas ou burocráticas; seu empenho constante em criar e oferecer condições para formação altamente qualificada; a sua missão de abrir caminhos...

\section{Organização do livro}

A obra contém um capítulo introdutório que contextualiza o projeto PHPB-SC e apresenta e descreve as amostras de escrita catarinense dos séculos XIX e XX constituídas pela equipe do projeto em Santa Catarina, um capítulo de caráter geral que contextualiza o estado e, particularmente as quatro cidades que compõem o projeto, considerando aspectos sóciohistóricos, geográficos, políticos e culturais, além de capítulos de descrição e análise linguística do corpus do PHPB-SC. Numa perspectiva comparativa, alguns dos capítulos com análises de fenômenos linguísticos buscam mapear diferenças diatópicas entre a escrita catarinense e a de outros estados brasileiros, mais especificamente das regiões Nordeste e Sudeste.

Em alguma medida, a perspectiva teórica que orienta os capítulos se fundamenta em pressupostos da Teoria da Variação e Mudança, numa perspectiva clássica e em desdobramentos mais recentes (mas que partem do texto embrionário de WEINREICH; LABOV; HERZOG, 2006 [1968]), e da sociolinguística histórica (cf. CONDE SILVESTRE, 2007), ao buscar compreender e explicar processos de variação e mudança em documentos escritos de sincronias passadas, que abrangem diferentes momentos dos séculos XIX e XX. Os textos assumem, em particular, os seguintes pressupostos centrais: (i) a variação é inerente ao sistema linguístico; (ii) a variabilidade estruturada caracteriza, portanto, o uso normal da língua; (iii) a mudança linguística é gradual; (iv) há correlações entre processos de variação/mudança linguística e fatores linguísticos e sociais; e (v) métodos quantitativos podem ajudar a explicar a variação e a mudança linguística. 
O primeiro capítulo, Para a história do português brasileiro em Santa Catarina, escrito por Izete Lehmkuhl Coelho, Isabel de Oliveira e Silva Monguilhott, Cecília Augusta Vieira Pinto, Érica Marciano de Oliveira e Helena Gouveia, contextualiza o projeto PHPB-SC no âmbito do estado catarinense. Além disso, traz uma série de informações a respeito das amostras, constituídas por textos manuscritos e impressos da escrita catarinense no curso dos séculos XIX e XX, ilustradas com transcrições de acordo com as normas do projeto nacional PHPB e alguns fac-símiles.

O capítulo 2, Aspectos sócio-históricos, geográficos, políticos e culturais de Santa Catarina, de autoria de Edair Maria Görski, Paulino Vandresen, Cláudia Andrea Rost Snichelotto, Cristine Gorski Severo e Tatiana Schwochow Pimpão, apresenta um panorama do contexto catarinense a partir do século XVI, contrapondo, em linhas gerais, as regiões litorânea e serrana e seus respectivos ciclos de ocupação e, em termos mais específicos, focalizando aspectos constitutivos de cada uma das quatro cidades que integram o corpus do PHPB-SC. Em relação a Florianópolis, os autores descrevem as fases sócio-históricas, políticas e culturais da ilha de Santa Catarina, (i) contemplando a diversidade étnica que incluiu povos indígenas, imigrantes açorianos, africanos (ex-) escravizados e residentes atraídos pela beleza da cidade; e (ii) abordando desde as primeiras ocupações e o consequente povoamento, passando pelo surgimento de uma nova elite até as configurações sociodemográficas contemporâneas decorrentes da urbanização e do turismo em Florianópolis. No que diz respeito a Lages, além de fatores concernentes à fundação e ao povoamento da cidade, os autores trazem à tona questões que ligam Lages ao Rio Grande do Sul e a São Paulo, salientando o papel do caminho dos tropeiros e aspectos dialetológicos conflitantes decorrentes das variedades paulista e açoriana faladas na localidade. Quanto a Blumenau, região de colonização alemã, o foco recai sobre fatores sócio-históricos relacionados à inserção da língua portuguesa na localidade, com ênfase nas políticas linguísticas tanto de instituições voltadas aos imigrantes (favorecendo o uso do alemão) como dos governos brasileiros (em favor do uso do português). Por fim, em relação a Chapecó, é delineado um histórico da integração territorial do Oeste ao estado de Santa Catarina, bem como da colonização da região basicamente por imigrantes ítalo-brasileiros e alemães, oriundos do Rio Grande do Sul. Os autores registram que tanto em Blumenau como em Chapecó o sistema 
escolar foi o grande fator social para levar a população local à aprendizagem e uso do português.

No capítulo Aspectos do contato linguístico do vêneto no português escrito de Chapecó no século XX, Marizete Bortolanza Spessatto, Loremi Loregian-Penkal, Ana Lívia Agostinho e Ivelã Pereira propõem-se a analisar a influência de línguas de imigração na escrita em português brasileiro de sujeitos residentes no Oeste de Santa Catarina, ao longo do século XX. A análise se debruça sobre a influência do dialeto vêneto manifestada na escrita de 11 cartas pessoais, redigidas no período de 1914 a 1970, e de 14 cartas de leitores, publicadas em jornais de Chapecó entre os anos de 1940 e 1990. As autoras pontuam que a presença de italianos e descendentes na região se dá pelo movimento migratório interno (do Rio Grande do Sul para Santa Catarina), pelo qual imigrantes europeus chegados ao sul do país no final dos anos 1800 vieram se juntar aos então chamados brasileiros (índios e caboclos que habitavam a região), em uma relação de oposição identitária. Os resultados da análise mostram que, de modo geral, as interferências do vêneto no português, na amostra analisada, caracterizam-se pelo emprego de termos do léxico dialetal; pelo uso de morfemas do vocabulário vêneto, combinando-os com morfemas portugueses; e pelas interferências fônicas na escrita em português. Foi identificada, ainda, a interferência da grafia do italiano standard no uso de consoantes duplas. As autoras concluem que, assim como ocorre na oralidade, as marcas de interferência da língua de imigração trazida para o Oeste Catarinense se fizeram presentes também na escrita desse grupo, ao longo dos anos, evidenciando a presença do multilinguismo, não obstante os processos de incriminação e silenciamento linguísticos sofridos pelos imigrantes no Brasil.

O quarto capítulo, intitulado $A$ variação nós e a gente em Santa Catarina: do presente para o passado, foi escrito por Isabel de Oliveira e Silva Monguilhott, Raquel Gomes Chaves, Ana Kelly Borba da Silva Brustolin e Juliana Flores das Chagas. As autoras abordam dois fenômenos variáveis no português brasileiro, interrelacionados: a variação na expressão de primeira pessoa do plural, nós e a gente, e a variação na marcação da concordância verbal de primeira pessoa do plural. Os fenômenos são investigados em amostras de cartas pessoais do $\mathrm{PHPB}-\mathrm{SC}$ de missivistas da região de Florianópolis dos séculos XIX e XX e os resultados são comparados aos de estudos sincrônicos com amostras de escrita catarinense. As autoras 
esboçam um percurso do uso - tanto dos pronomes quanto da marcação de concordância - que vai do uso categórico de nós e de concordância canônica, no século XIX, passando pelo uso variável entre nós e a gente e de concordância canônica com ambos os pronomes, no século XX, chegando, por fim, a um uso variável entre nós e a gente e a um uso também variável na concordância com ambos os pronomes, no século XXI.

No capítulo seguinte, A concordância verbal de terceira pessoa do plural em Santa Catarina: um olhar diacrônico, Raquel Gomes Chaves, Isabel de Oliveira e Silva Monguilhott e Patrícia Corrêa Ferminio investigam a variação na concordância verbal de terceira pessoa do plural em amostras escritas de Florianópolis pertencentes ao projeto PHPB-SC. As autoras fazem uma comparação dos resultados dessa análise diacrônica com resultados de estudos sincrônicos acerca do fenômeno em tela. Tal comparação evidencia a presença de uma marcação mais conservadora na concordância verbal no século XIX, em relação aos resultados do século XX. Já os resultados relativos à escrita desse século apresentam condicionamento semelhante ao encontrado em pesquisas que investigaram o fenômeno da concordância verbal em amostras de fala do projeto VARSUL/SC, tanto no século XX quanto no XXI.

No capítulo seguinte, A trajetória da mudança na sintaxe do sujeito e do objeto direto em cartas pessoais catarinenses e cariocas, Izete Lehmkuhl Coelho, Silvia Regina de Oliveira Cavalcante, Cecília Augusta Vieira Pinto, Anna Lyssa Machado, Anna Beatriz Cruz e Gésyka Mafra investigam a trajetória de mudança de três fenômenos linguísticos - ordem do sujeito, preenchimento do sujeito e objeto direto anafórico em contextos de terceira pessoa - em duas amostras de cartas pessoais, uma de cartas catarinenses e outra de cartas cariocas, escritas ao longo dos séculos XIX e $\mathrm{XX}$, pertencentes ao projeto nacional $\mathrm{PHPB}$. As autoras salientam que essa proposta suscita algumas questões importantes: Como esses três fenômenos estão encaixados nas amostras catarinense e carioca ao longo do tempo? Quais as condições linguísticas necessárias que uma mudança cria para que outras mudanças se efetivem? Como as variantes novas se implementam na escrita catarinense e carioca ao longo do tempo? Os resultados apontam que o português do século XIX ainda manifesta resquícios do sistema do português antigo, com propriedades do grupo românico (como o italiano e o espanhol), com índices produtivos de ordem VS, sujeito nulo e clítico 
acusativo, nas duas amostras investigadas. Já no século XX outro sistema está se implementando, gradativamente, com a seguinte configuração: ordem preferencialmente SV em contextos com verbos transitivos, uso majoritário de sujeito pronominal expresso e de objeto nulo. A trajetória de mudança relacionada a cada um dos fenômenos se manifesta nas duas variedades estudadas distintamente: há resultados robustos para acreditar que na escrita carioca a mudança já se encontra mais acelerada do que na escrita catarinense.

O sétimo capítulo, Análise diatópico-diacrônica dos clíticos em jornais brasileiros dos séculos XIX e XX e especificidades da escrita em Santa Catarina, escrito por Marco Antonio Rocha Martins, Aroldo Andrade, Grazielle Helena Scheidt e Juliana Regina da Silva, apresenta uma descrição e análise da sintaxe de posição e de colocação dos pronomes pessoais clíticos em uma amostra constituída de textos da imprensa brasileira dos séculos XIX e XX em estados de três regiões do Brasil: Ceará, Pernambuco e Bahia no Nordeste; Rio de Janeiro no Sudeste; e Santa Catarina no Sul. Os dados analisados foram retirados de cartas de leitores, cartas de redatores e anúncios dos corpora do projeto nacional PHPB. Os autores apresentam um mapeamento diatópico-diacrônico do sistema pronominal clítico com foco na escrita catarinense com o propósito de comparar esse quadro àquele encontrado em diferentes regiões do Brasil e contribuir, assim, para a descrição do português escrito em Santa Catarina. A análise de amostras de duas sincronias distintas, a primeira metade do século XIX e a segunda metade do século XIX e o século XX, aponta que diferentes forças linguísticas e extralinguísticas atuam no condicionamento da posição em próclise em sentenças com um único verbo e da colocação sem alçamento em predicados complexos nas diferentes sincronias, o que leva os autores à intepretação de que os dados da primeira metade do século XIX ainda refletem propriedades da gramática do português clássico. A hipótese apresentada para explicar os resultados encontrados é de que as mudanças na sintaxe dos pronomes clíticos apresentam uma evolução diatópicodiacrônica bastante heterogênea no território brasileiro no curso dos séculos XIX e XX, de modo que formas inovadoras se implementam primeiro da Região Nordeste, e evoluem para o Sudeste e para o Sul, mostrando ser a escrita de Santa Catarina mais conservadora. 
O oitavo capítulo, intitulado Convergências e divergências na expressão do dativo de segunda pessoa: análise de cartas pessoais catarinenses e cariocas dos séculos XIX e XX, é de autoria de Thiago Laurentino de Oliveira, Bruna Brasil Albuquerque de Carvalho e Thaissa Frota Teixeira Araujo Silva. A investigação tem por objetivo analisar a variação pronominal de segunda pessoa do singular (2SG) na função de dativo a partir de cartas pessoais escritas por remetentes de Santa Catarina e do Rio de Janeiro. Foram examinados dados produzidos em finais do século XIX e em finais do século XX, com o intuito de observar como se expressava a segunda pessoa do singular na função de dativo. Os autores entendem por dativo, consoante Mateus et al. (2003, p. 289), "o argumento interno de verbos de dois ou três lugares com o papel semântico de Alvo ou Fonte”. Além disso, assumem que o dativo é um constituinte preposicionado por a ou para, prototipicamente [+animado] e que admite cliticização. Através de uma análise comparativa, são investigadas as seguintes questões: Quais eram as formas de dativo de segunda pessoa do singular utilizadas na escrita particular de catarinenses e cariocas em fins do século XIX e na segunda metade do século XX? Que fatores linguísticos e extralinguísticos condicionavam o emprego das variantes? Existem semelhanças no uso dos dativos de $2 \mathrm{SG}$ da escrita catarinense e da escrita carioca? Quais são as principais diferenças na expressão do dativo das duas localidades em questão? Os resultados gerais apontam que (i) as mesmas variantes de dativo estão presentes nas amostras das duas localidades, havendo, contudo, diferenças quantitativas importantes; e (ii) fatores como a forma pronominal de 2 SG utilizada na posição de sujeito, o tema da carta e o sexo dos interlocutores condicionam a distribuição das variantes dativas nas amostras examinadas.

Na sequência, Vanessa Grando escreve sobre Formas de tratamento nas cartas do escritor catarinense Harry Laus para sua tradutora francesa. A amostra analisada é constituída por 93 cartas enviadas pelo escritor Harry Laus, de 1984 a 1992, para a tradutora francesa de suas obras, Claire Cayron. A autora busca (i) identificar, nas formas de tratamento, indícios mais formais ou menos formais; (ii) identificar os vocativos; (iii) descrever os paradigmas de $t u$ e você e os contextos sintáticos em que eles aparecem; (iv) analisar o assunto da carta e relacioná-lo à categoria profissional, pessoal ou mista; e (v) estabelecer uma correlação entre os paradigmas de $t u$ e você e o assunto das cartas e entre esses paradigmas e 
o período em que as cartas foram escritas, para compreender melhor as diferenças tratamentais. Foram encontradas 816 ocorrências de formas associadas ao tu e ao você. Quando usa dois paradigmas em uma mesma carta, Harry Laus seleciona você para tratar de assunto profissional e tu para assunto pessoal. Os resultados apontam para uma relação em que o autor brasileiro e a tradutora francesa passam da formalidade profissional para uma carinhosa relação de amizade. Tal processo de aproximação aconteceu gradualmente, ao longo dos anos, e se apresenta na forma de vocativos (de formais a afetuosos) e em diferentes contextos morfossintáticos, com a prevalência de formas associadas ao $t u$ sobre formas associadas ao você quando a relação entre escritor-tradutora fica mais íntima.

Tatiana Schwochow Pimpão, no capítulo A correlação tempomodalidade e o uso variável do presente do modo subjuntivo em cartas ao redator de Lages e Florianópolis, a partir de uma amostra de cartas ao redator publicadas em jornais das cidades de Florianópolis e de Lages, escritas nos séculos XIX e XX, discute aspectos metodológicos envolvidos na constituição da amostra e analisa o uso variável entre o presente do modo subjuntivo e o presente do modo indicativo. A autora considera quatro contextos linguísticos - orações com advérbio talvez e orações subordinadas substantivas, adjetivas e adverbiais -, tomando como referencial teórico o funcionalismo norte-americano. Os resultados evidenciam uma correlação entre modalidade deôntica, volição e projeção futura e o uso de formas verbais do presente do subjuntivo.

O último capítulo, Estratégias de interação em cartas pessoais intimas em amostras do PHPB-SC, de Carla Regina Martins Valle, Cláudia Andrea Rost Snichelotto e Érica Marciano de Oliveira, apresenta uma análise qualitativa de estratégias de interação em cartas pessoais íntimas, considerando o continuum fala-escrita. Alinha-se à perspectiva da sociolinguística histórica, que prevê que materiais históricos sejam estudados a partir da relação comunicativa entre os participantes em um determinado evento de fala, levando em conta fatores pessoais (locutor, interlocutor e tipo de relação entre eles) e fatores não pessoais (elementos discursivos e contextuais). Foram observadas três estratégias de interação em duas amostras do corpus do PHPB-SC. Na amostra Bertaso, composta por cartas de Elza Bertaso a seus pais e irmãos (de 1914 a 1929), foram investigadas as formas de tratamento nominal, expressões utilizadas para se dirigir aos participantes do discurso e que atuam como ferramentas para 
iniciar o contato, tais como: tu, você, amor e coração. Na amostra Cartas da Tia Ciça, composta por cartas de missivista catarinense a sua sobrinha (de 1988 a 2014), foram analisadas as sequências injuntivas (formas de imperativo de segunda pessoa e algumas perguntas diretas do locutor para o interlocutor como marca de interação) em 50 cartas. E, na amostra Cartas do Vale, formada por 25 cartas (da década de 1960), de missivistas do Vale do Itajaí-SC para um mesmo destinatário (namorado ou pretendente), foram analisados marcadores discursivos interacionais, que têm o papel de colocar foco, cumprindo funções relacionadas com o interlocutor e com a organização discursiva, tais como sabe? e tá certo?. Os resultados apontam para a presença significativa de estratégias de interação que se caracterizam pela sua multifuncionalidade, contribuindo para o estabelecimento e manutenção do contato íntimo entre missivistas e destinatários.

\section{Mais algumas palavras}

O repertório de trabalhos aqui publicados dá visibilidade aos estudos sócio-históricos e linguísticos da escrita catarinense no curso dos séculos XIX e XX, desenvolvidos no âmbito do projeto PHPB-SC. As abordagens não poderiam ser realizadas sem o apoio de uma base empírica sólida que se efetivou através da formação do corpus que ora disponibilizamos no endereço http://varsulsc.paginas.ufsc.br/ampostras-do-phpb-sc/ a partir do código ( $Q R$ Code) indicado ao final do Capítulo 1.

Vale lembrar que o trabalho de levantamento, catalogação, transcrição e edição dos textos impressos de jornais catarinenses (cartas de leitores, cartas de redatores e anúncios) e dos textos manuscritos (cartas pessoais e oficiais) que constituem esse corpus é um projeto coletivo, fruto do trabalho criterioso de um grupo de pesquisadores vinculados ao núcleo de pesquisa VARSUL nos dez últimos anos, ao qual muito agradecemos.

Destaque especial ao professor Paulino Vandresen, por seu trabalho para o desenvolvimento da Linguística no Brasil, de modo particular na Região Sul, e por sua incansável atuação na formação de bancos de dados de língua oral e escrita, fontes para pesquisas de descrição linguística do português da Região Sul. 


\section{Referências}

GÖRSKI, E. M.; COELHO, I. L. Paulino Vandresen: um breve perfil. In: GÖRSKI, E. M.; COELHO, I. L. (org.). Sociolinguística e ensino: contribuições para a formação do professor de língua. Florianópolis: Editora da UFSC, 2006. p. 17-21. GÖRSKI, E. M.; MARGOTTI, F. W.; VANDRESEN, P.; VALLE, C. R. M. Pós-Graduação em Letras na UFSC: da criação ao desmembramento. In: MARGOTTI, F. W.; GÖRSKI, E. M. (org.). Pós-Graduação em Letras na UFSC: uma história de 40 anos. Florianópolis: Terceiro Milênio, 2012. p. 11-35. VANDRESEN, P. O ensino do português em áreas bilíngues - uma perspectiva histórica. Boletim ABRALIN, v. 16, p. 97-101, 1995.

VANDRESEN, P. (org.). Variação e mudança no português falado na Região Sul. Pelotas: EDUCAT, 2002.

VANDRESEN, P. A inserção da língua portuguesa em uma comunidade teutobrasileira. Palavra, Rio de Janeiro, v. 11, p. 120-133, 2004.

VANDRESEN, P. (org.). Variação, mudança e contato linguístico no português da Região Sul. Pelotas: EDUCAT, 2006.

VANDRESEN, P. Política linguística e bilinguismo em uma comunidade teutobrasileira. In: VANDRESEN, P. (org.). Variação, mudança e contato linguístico no português da Região Sul. Pelotas: EDUCAT, 2006, p. 325-337.

HEYE, J.; VANDRESEN, P. Línguas em contato. In: CARDOSO, S. A. M.; MOTA, J. A.; MATTOS E SILVA, R. V. (org.). Quinhentos anos de história linguística do Brasil. Salvador: Secretaria da Cultura e Turismo do Estado da Bahia, 2006. p. 381-411.

VANDRESEN, P. O bilinguismo pomerano-português na região de Pelotas. In: RONCARATI, C.; ABRAÇADO, J. (org.). Português brasileiro II: contato linguístico, heterogeneidade e história. Niterói: Editora da UFF, 2008. p. 39-51. VANDRESEN, P.; RICKEN, T. D.; FREITAS, A. W. de. O sistema educacional de Rio Fortuna. In: RICKEN, I.; RICKEN, T. D. (org.). Rio Fortuna: resgatando as origens, cultivando valores, alicerçando o futuro. Rio Fortuna: Coan, 2008. p. 142-176.

VANDRESEN, P. Estudo comparativo do bilinguismo em duas áreas de colonização alemã. In: CARVALHO, A. M. (org.). Português em contato. Frankfurt am Main: Vervuert, 2009. p. 199-214.

VANDRESEN, P. O papel da família e da religião na aculturação linguística e desenvolvimento educacional em Rio Fortuna. In: MULLER, M. J.; RAUEN, F. J.; SÁ, J. B. de (org.). Encontro de estudos sobre a imigração alemã: os vales dos rios Braço do Norte e Capivari. Tubarão: Unisul, 2010. p. 39-56. 


\section{Capítulo 1}

\section{Para a história do português brasileiro em Santa Catarina}

Izete Lehmkuhl Coelho Isabel de Oliveira e Silva Monguilhott

Cecília Augusta Vieira Pinto Érica Marciano de Oliveira Helena Gouveia

\subsection{Introdução}

Este capítulo se propõe a relatar o projeto Para a História do Português Brasileiro em Santa Catarina (PHPB-SC) - das origens ao estado atual - com vistas a trazer algumas informações importantes a respeito da base de dados formada por textos manuscritos e impressos da escrita catarinense no curso dos séculos XIX e XX. Para além dessas informações, serão disponibilizados alguns fac-símiles dos documentos 
recolhidos bem como um Código $\mathrm{QR}^{1}$ para acesso a essa base de dados. A divulgação desses dados constitui um dos objetivos desta coletânea.

Há dez anos, a convite do professor Ataliba de Castilho, coordenador geral do projeto nacional Para a História do Português Brasileiro (PHPB), ${ }^{2}$ durante o ROSAE - I Congresso Internacional de Linguística Histórica, realizado em homenagem a Rosa Virgínia Mattos e Silva, Izete Lehmkuhl Coelho começa a coordenar a equipe do PHPB de Santa Catarina. ${ }^{3}$ Desde então, a equipe do PHPB-SC passa a coletar, editar e descrever documentos provenientes de uma gama variada de tipos de textos, impressos e manuscritos não literários, dos séculos XIX e XX, nos moldes do projeto nacional PHPB.

Para que esses documentos constituíssem um banco de dados minimamente representativo das diferentes etnias que compõem o estado catarinense, quatro localidades de Santa Catarina foram selecionadas para coleta: Florianópolis, Lages, Blumenau e Chapecó, seguindo os mesmos passos do projeto VARSUL. Esperávamos encontrar na escrita dessas localidades marcas da língua ou variedade do colonizador: em Florianópolis, da etnia açoriana; em Blumenau, da etnia alemã; em Lages, da variedade tipicamente vicentista, trazida pelos tropeiros paulistas; e, em Chapecó, da etnia italiana.

No PHPB-SC, tencionamos fazer pesquisas históricas partindo do presente para o passado, isto é, dos resultados que levavam em conta amostras de língua oral disponibilizadas no núcleo VARSUL para resultados provenientes de amostras da escrita catarinense no curso do tempo, tentando investigar em que medida princípios de mudança como o uniformitarismo linguístico estão atuando nos diferentes fenômenos investigados.

A escolha dos gêneros textuais coletados nesse projeto também não foi aleatória. Para encontrarmos reflexos do comportamento variável da

1 Através da leitura do Código QR é possível acessar as amostras do PHPB-SC descritas neste capítulo e que serviram de base para as análises realizadas sobre fenômenos linguísticos diversos que estão publicadas neste livro.

2 O professor Ataliba de Castilho foi coordenador geral do projeto nacional PHPB entre 1997 e 2019.

3 De 1998 a julho de 2009, a coordenação da equipe do PHPB em Santa Catarina esteve sob a responsabilidade do professor Gilvan Muller de Oliveira (UFSC). 
língua oral nos documentos escritos, optamos por textos que, no dizer de Conde Silvestre (2007, p. 45), transpõem, para o meio escrito, intercâmbios comunicativos que ocorreram ou poderiam ocorrer no meio oral. No caso dos textos impressos, anúncios e cartas de leitores são os gêneros textuais da modalidade escrita que talvez mais se aproximem da modalidade falada por uma comunidade, em diferentes épocas. Com respeito aos textos manuscritos, as cartas foram especialmente escolhidas por serem textos que apresentam registros escritos que podem reproduzir o vernáculo de indivíduos em diferentes circunstâncias, sejam pessoais, sejam oficiais, que se refletem na relação entre os remetentes das cartas e seus destinatários, em diferentes épocas.

Como buscamos tecer comparação entre as amostras do VARSUL e as do PHPB-SC, decidimos, portanto, fazer uma coleta de textos escritos mais próximos da oralidade que contemplasse essas quatro localidades representativas das diferentes etnias que compõem o território catarinense. ${ }^{4}$

A proposta metodológica do projeto $\mathrm{PHPB}-\mathrm{SC}$ de coleta, transcrição e edição de documentos segue os passos do projeto nacional PHPB de levantamento e catalogação de fontes específicas, representativas do português escrito ao longo dos séculos, oriundas de levantamentos em arquivos públicos do Brasil e de doação de arquivos pessoais de alguns catarinenses. Todos os documentos já coletados foram transcritos e revisados, considerando as normas do projeto nacional PHPB. ${ }^{5}$ Nesse sentido, está sendo efetuado não só um levantamento bibliográfico acerca da realidade sócio-histórica do estado, mas também de informações sobre os diferentes períodos de formação de Santa Catarina, que se encontram nos textos coletados.

O projeto nacional PHPB contou ao longo de sua história com encontros das equipes regionais em diferentes instituições brasileiras para darem ciência da constituição dos bancos de dados e apresentarem suas pesquisas históricas em andamento sobre fenômenos em variação e mudança do português brasileiro realizadas com linguistas especialistas

4 Para uma discussão aprofundada acerca do contexto sócio-histórico do estado de Santa Catarina, remetemos o leitor ao Capítulo 2 deste livro Aspectos sóciohistóricos, geográficos, políticos e culturais de Santa Catarina.

5 As normas de edição do projeto PHPB estão disponíveis no link https://sites.google.com/ site/corporaphpb/home/normas-de-edicao-do-phpb-2a-versao. 
de diversas partes do Brasil. Os resultados desses encontros podem ser conferidos nos vários volumes sobre a História do português brasileiro, publicados a partir de 2018. Membros da equipe do PHPB-SC participaram da (co)autoria de alguns capítulos de dois desses volumes: Mudança sintática do português brasileiro: perspectiva gerativista (cf. BERLINCK; COELHO, 2018; MARTINS, 2018) e Mudança sintática das classes de palavra: perspectiva funcionalista (cf. LOPES et al., 2018).

As amostras do projeto $\mathrm{PHPB}-\mathrm{SC}$ relatadas neste capítulo são oriundas de três diferentes períodos de tempo, seguindo os critérios do projeto nacional $\mathrm{PHPB}$ : (i) período 19.2, que corresponde à segunda metade do século XIX (de 1851 a 1900); (ii) período 20.1, que corresponde à primeira metade do século XX (de 1901 a 1950); e (iii) período 20.2, que corresponde à segunda metade do século XX (1951 a 2000). ${ }^{6}$ Uma prévia da amostra de Florianópolis já se encontra disponível, desde 2011, no site dos corpora do PHPB, em https://sites.google.com/site/corporaphpb/, como fonte preliminar de base de dados para pesquisas linguísticas. A partir de 2011 outros documentos foram coletados e editados pela equipe do projeto, constituindo assim um Banco de dados do $\mathrm{PHPB}-\mathrm{SC}^{7}$ formado por um corpus impresso e por um corpus manuscrito da escrita catarinense no curso dos séculos XIX e XX, conforme descrevemos nas seções a seguir.

Este capítulo está assim organizado: na Seção 2, é apresentado o corpus impresso do PHPB-SC, com uma breve descrição das amostras das cidades de Florianópolis, de Lages, de Blumenau e de Chapecó, por período de tempo. Na Seção 3, faz-se uma descrição do corpus manuscrito, as cartas pessoais e oficiais, considerando alguns conjuntos de cartas escritas por missivistas das diferentes localidades investigadas. No fim, na Seção 4, tecemos algumas considerações a respeito da disponibilização desse material e da equipe que participou das etapas de constituição dessa amostra de textos escritos dos séculos XIX e XX.

\footnotetext{
6 Todos os documentos foram transcritos e revisados considerando as normas do projeto nacional PHPB.

7 A formação deste Banco de dados do PHPB-SC está ainda em desenvolvimento.
} 


\subsection{Corpus impresso}

Descrevemos, nesta seção, o corpus formado por anúncios e cartas de leitores que foram coletados em jornais impressos catarinenses em cada uma das localidades investigadas no projeto PHPB-SC (Florianópolis, Lages, Blumenau e Chapecó), distribuídos por três períodos de tempo (19.2, 20.1 e 20.2).

\subsubsection{Amostra de Florianópolis}

Na localidade de Florianópolis, os textos que compõem os gêneros anúncio e carta de leitores foram coletados em jornais locais, disponíveis na Biblioteca Universitária da Universidade Federal de Santa Catarina e na Biblioteca Pública do Estado de Santa Catarina. Os jornais que trazem esses tipos de textos são os seguintes: O Despertador, O Estado, República: Orgam do Partido Republicano Catarinense, O Dia e Diário Catarinense.

O jornal O Despertador circulou na então Desterro entre 1863 e 1885. O jornal O Estado: Orgam do Partido Federalista teve sua circulação na capital catarinense no período de 1892 a 1902. Posteriormente, passou a ser denominado $O$ Estado apenas e foi o jornal de maior circulação em Florianópolis, entre 1915 e 2009. O periódico República: Orgam do Partido Republicano Catarinense circulou entre 1895 e 1897. O jornal O Dia teve sua circulação entre os anos de 1901 e 1918. E o jornal Diário Catarinense circula de 1986 até os dias atuais.

Para ilustrar o trabalho de coleta e edição de documentos da equipe do PHPB-SC, trazemos alguns fac-símiles de anúncios dos períodos investigados. 


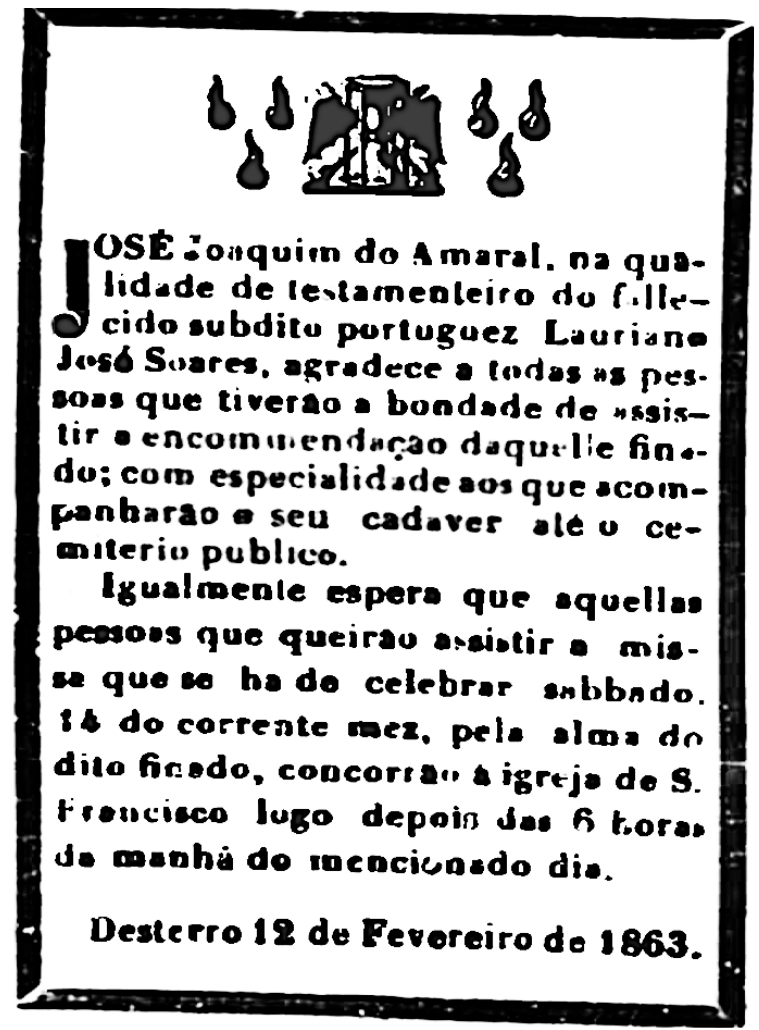

Século 19.2

Acervo: Biblioteca da Universidade Federal de Santa Catarina Jornal: O Despertador

Data de publicação: 13/2/1863

JOSÉ Joaquim do Amaral, na qua- | lidade de testamenteiro do falle- | cido subdito portuguez Lauriano | José Soares, agradece a todas as pes- | soas que tiverão a bondade de assis- | tir a encommendação daquelle fina- $\mid$ do; com especialidade aos que acom- | panharão o seu cadaver até o ce- | miterio publico. || Igualmente espera que aquellas | pessoas que queirão assistir a mis- | sa que se ha de celebrar sabbado, | 14 do corrente mez, pela alma do | dito finado, concorrão á igreja de S. | Francisco logo depois das 6 horas | da manhã do mencionado dia. || Desterro 12 de Fevereiro de 1863. 


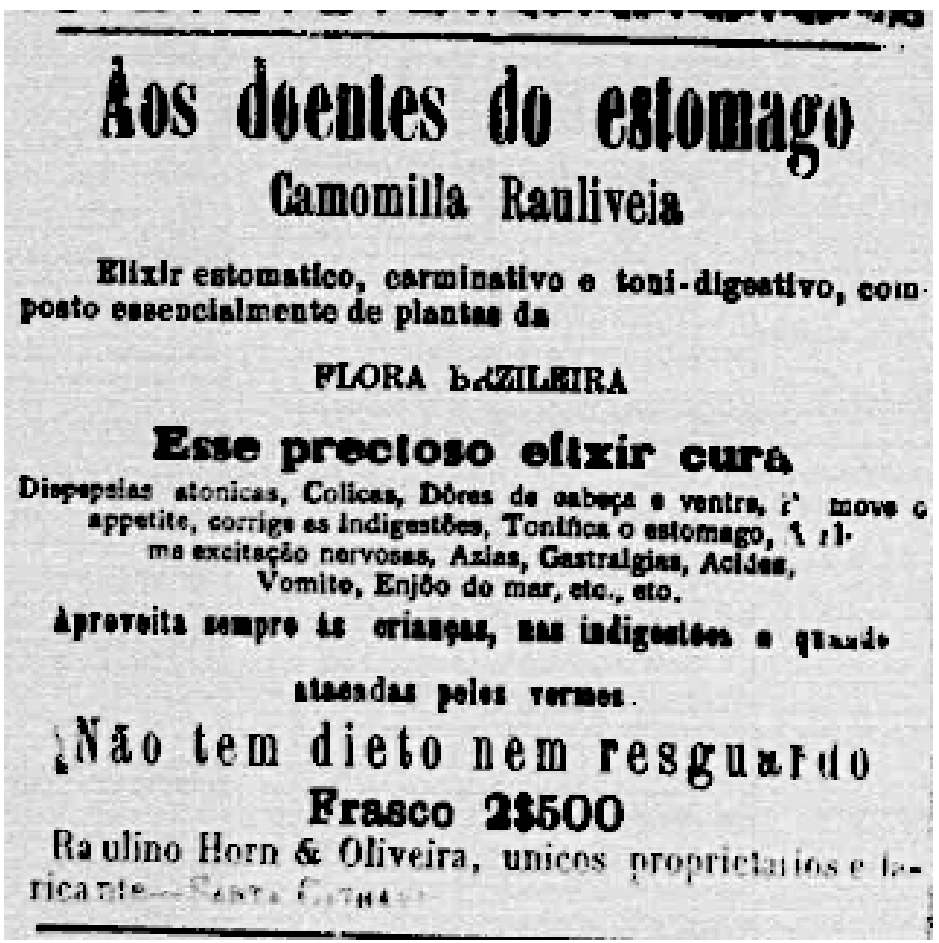

Século 20.1

Acervo: Biblioteca da Universidade Federal de Santa Catarina Jornal: O Estado

Data de publicação: 3/1/1901

Aos doentes do estomago || Camomilla Rauliveia || Elixir estomatico, carminativo e toni-digestivo, com- | posto essencialmente de plantas da || FLORA BRAZILEIRA || Esse precioso elixir cura || Dispepsias atonicas, Colicas, Dôres de cabeça e ventre, F move $\mid$ o appetite, corrige as indigestões, Tonifica o estomago, A [inint.]- | ma excitação nervosas, Azias, Gastralgias, Acides, | Vomito, Enjôo do mar, etc., etc. || Aproveita sempre ás crianças, nas indigestões e quando | atacadas pelos vermes. || Não tem dieto nem resguardo || Frasco $2 \$ 500$ || Raulino Horn \& Oliveira, unicos proprietarios e fa- | bricante - Santa Catharina. 


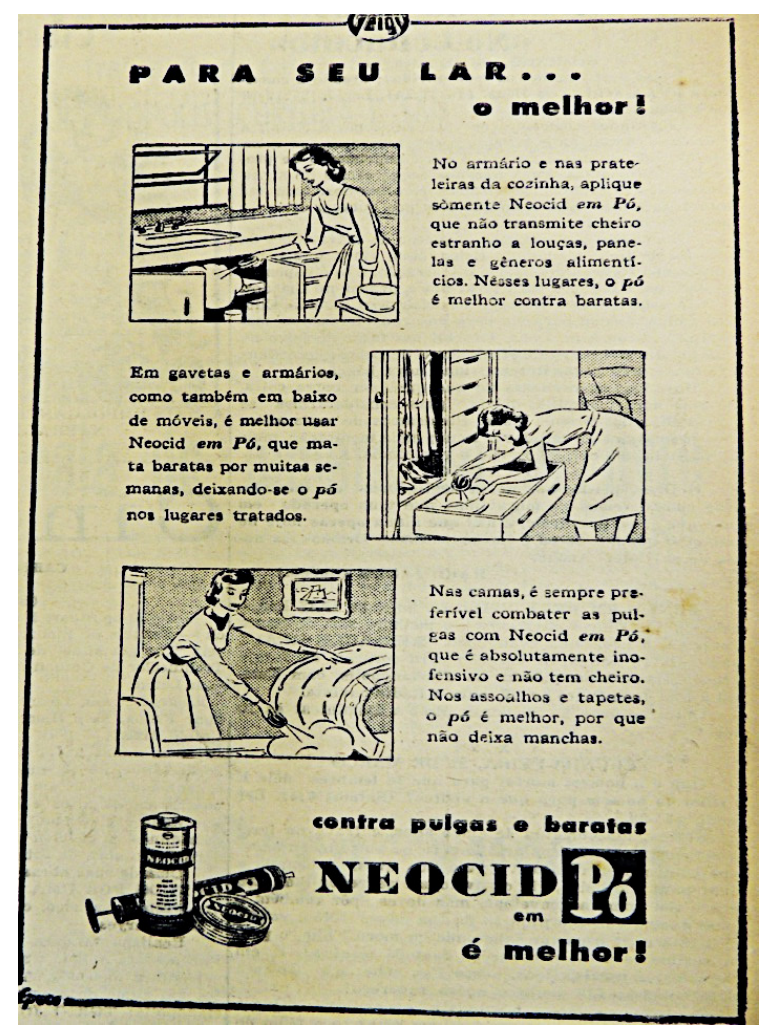

\section{Século 20.2}

Acervo: Biblioteca Pública do Estado de Santa Catarina Jornal: O Estado

Data de publicação: 20/3/1955

PARA SEU LAR... | o melhor! || [desenho] No armário e nas prate- | leiras da cozinha, aplique | sòmente Neocid em Pó, | que não transmite cheiro estranho a louças, pane- | las e gêneros alimentí- | cios. Nêsses lugares, o pó | é melhor contra baratas. || [desenho] Em gavetas e armários, | como também em baixo | de móveis, é melhor usar | Neocid em Pó, que ma- | ta baratas por muitas se- | manas, deixando-se o pó | nos lugares tratados. || [desenho] Nas camas, é sempre pre- | ferível combater as pul- | gas com Neocid em Pó, | que é absolutamente ino- | fensivo e não tem cheiro. | Nos assoalhos e tapetes, | o pó é melhor, por que | não deixa manchas. || [desenho] contra pulgas e baratas || NEOCID em Pó | é melhor! 


\subsubsection{Amostra de Lages}

Na localidade de Lages, os gêneros textuais anúncio e carta de leitores ${ }^{8}$ foram coletados em jornais locais disponíveis na Biblioteca Municipal de Lages e no Museu Thiago de Castro. Os jornais que trazem esses gêneros são: O Lageano, O Município, Cruzeiro do Sul, Região Serrana, A Epoca, Guia Serrano, Jornal de Lajes e Correio Lageano.

Em relação ao período de circulação, o jornal O Lageano circulou na cidade de Lages entre o período de 1883 e 1917. O periódico O Município iniciou sua publicação em 1890, encerrando em 1896. O Cruzeiro do Sul teve seu período de circulação entre os anos de 1902 e 1905. O jornal Região Serrana iniciou sua circulação no município de Lages em 1897, deixando de circular em 1955. O jornal A Epoca teve seu período de circulação compreendido entre 1924 e 1936. O periódico Guia Serrano circulou entre 1936 e 1970. O Jornal de Lajes circulou no ano de 1960 e o jornal Correio Lageano teve sua primeira publicação em 1939 e continua em circulação até os dias atuais.

Exemplos de anúncios para cada um dos períodos de tempo encontram-se disponíveis a seguir.

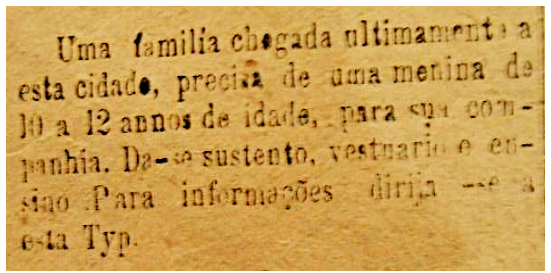

\section{Século 19.2}

Acervo: Biblioteca Municipal de Lages

Jornal: O Lageano

Data de publicação: 26/4/1883

Uma familia chegada ultimamente a $\mid$ esta cidade, preci $[z]$ a de uma menina de $\mid 10$ a 12 annos de idade, para $[s] \mathrm{u}[a] \operatorname{co}[m]-\mid$ panhia. Da-se sustento, vestuario e en- | sino. Para informações dirija-se a | esta Typographia.

8 A amostra cartas de leitores (ou cartas ao redator) coletada em Lages está descrita detalhadamente no Capítulo 10 deste volume. 


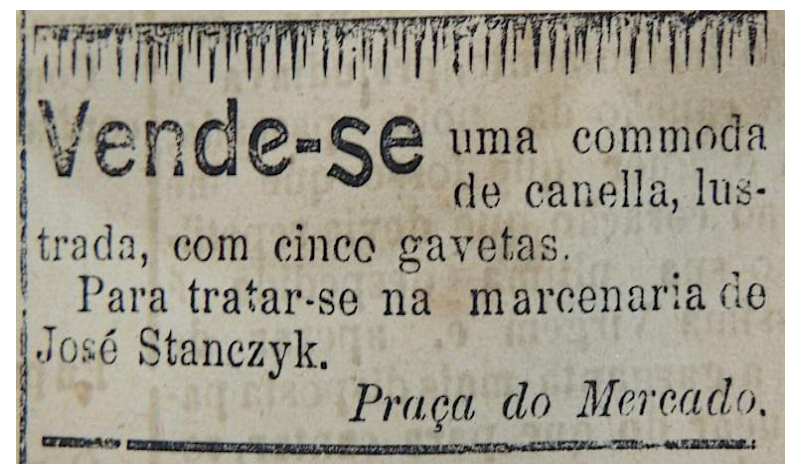

Século 20.1

Acervo: Museu Thiago de Castro

Jornal: Cruzeiro do Sul

Data de publicação: 16/11/1904

Vende-se uma commoda | de canella, lus- | trada, com cinco gavetas. || Para tratarse na marcenaria de | José Stanczyk. || Praça do Mercado.

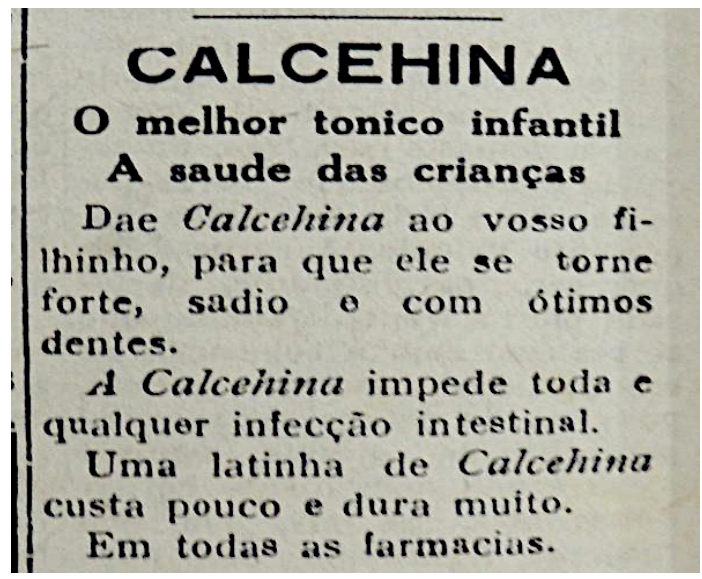

Século 20.2

Acervo: Biblioteca Municipal de Lages

Jornal: Guia Serrano

Data de publicação: 31/1/1953 
CALCEHINA || O melhor tonico infantil || A saude das crianças || Dae Calcehina ao vosso fi- | lhinho, para que ele se torne | forte, sadio e com ótimos | dentes. || A Calcehina impede toda e | qualquer infecção intestinal. || Uma latinha de Calcehina | custa pouco e dura muito. || Em todas as farmacias.

\subsubsection{Amostra de Blumenau}

Em Blumenau, os gêneros textuais anúncio e carta de leitores foram coletados em jornais disponíveis no Acervo Histórico de Blumenau: A Cidade, Novidades, Brazil e Jornal de Santa Catarina. Não conseguimos fazer coleta de material do período 19.2 por falta de jornais escritos em português nessa época. ${ }^{9}$

O jornal A Cidade foi o primeiro jornal de circulação contínua em português na cidade de Blumenau entre os anos de 1924 e 1974. Do jornal Novidades temos anúncios e cartas de leitores coletados e transcritos entre os anos de 1906 e 1909 e do jornal Brazil, somente do ano de 1920. O Jornal de Santa Catarina foi editado pela primeira vez em 22 de setembro de 1971 e circula até os dias atuais.

Trazemos, a seguir, anúncios de dois jornais para ilustrar o século XX.

9 Os jornais que circulavam em Blumenau no século XIX eram escritos em alemão. Mais detalhes sobre o contexto social dessa cidade podem ser encontrados no Capítulo 2 deste livro Aspectos sócio-históricos, geográficos, políticos e culturais de Santa Catarina. 


\section{Fabrica de cerveja}

DE

\section{Alois Kormann}

no

Bairro da Fazenda

Animados pela grande aceitação que dos consumidores itajahyenses tem tido a nossa cerveja, nos esforcamos por melhorar cada vez mais seu preparo. Assim prevenimos aos apreciadores da cerveja Kormann que as proximas fornadas serāo ainda mais excellertes.

Peçam cerveja Kormann

\section{Século 20.1}

Acervo: Acervo Histórico de Blumenau

Jornal: Novidades

Data de publicação: 6/1906

Fabrica de cerveja || DE | Alois Kormann | no | Bairro da Fazenda || Animados pela grande aceitação que | dos consumidores itajahyenses tem tido | a nossa cerveja, nos esforçamos por me- | lhorar cada vez mais seu preparo. As- | sim prevenimos aos apreciadores da cer- | veja Kormann que as proximas fornadas | serão ainda mais excellentes. || Peçam cerveja Kormann 


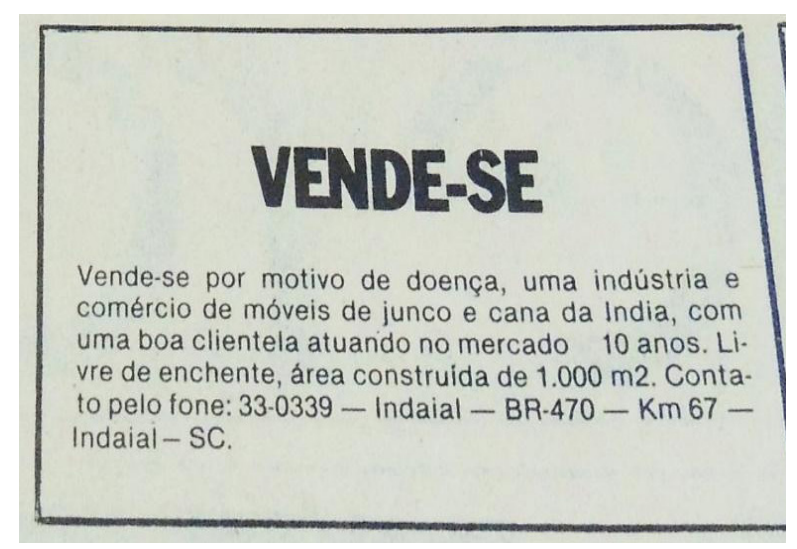

\section{Século 20.2}

Acervo: Acervo Histórico de Blumenau

Jornal: Jornal de Santa Catarina

Data de publicação: 6 e 7/11/1983

Vende-se || vende-se por motivo de doença, uma indústria e | comércio de móveis de junco e cana da India, com | uma boa clientela atuando no mercado [espaço] 10 anos. Li- | vre de enchente, área construída de $1.000 \mathrm{~m} 2$. Conta- | to pelo fone: 33-0339 - Indaial - BR-470 - Kilômetro 67 - | Indaial - SC.

\subsubsection{Amostra de Chapecó}

A coleta dos gêneros anúncio e carta de leitores de Chapecó foi realizada no Centro de Memória do Oeste de Santa Catarina e na Biblioteca Municipal Neiva Costa. Os jornais em que foram coletados os textos são: A Voz de Chapecó, Jornal do Povo, O Imparcial, Correio do Sul, Tribuna do Oeste e Folha D'Oeste.

O periódico A Voz de Chapecó circulava aos domingos em Chapecó e região. A primeira edição do jornal data de 03 de maio de 1939 e, depois de diversas suspensões, dada a censura da época, finaliza sua circulação em 1952. O Jornal do Povo foi fundado no dia 19 de janeiro de 1951 pelo advogado e servidor público Carlos Danilo de Quadros. O jornal O Imparcial começou a circular em 25 fevereiro de 1951 e circula até os dias 
atuais. O periódico Correio do Sul circulou na cidade de Chapecó na década de 1970. O jornal Tribuna do Oeste circulou no ano de 1976. O jornal Folha D’Oeste circulou entre 1960 e 1970.

A seguir, trazemos exemplos de anúncios nos dois períodos de tempo investigados (20.1 e 20.2).

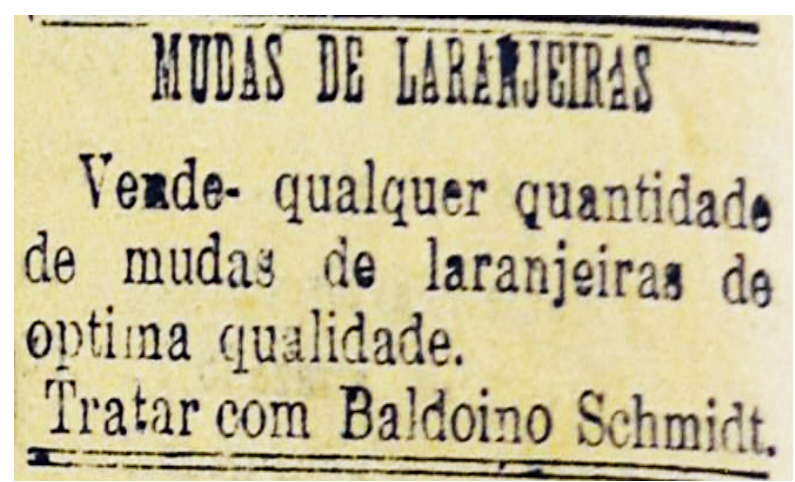

Século 20.1

Acervo: Centro de Memória do Oeste de Santa Catarina (CEOM)

Jornal: A Voz de Chapecó

Data de publicação: 7/4/1939

MUDAS DE LARANJEIRAS || Vende- qualquer quantidade | de mudas de laranjeiras de | optima qualidade. || Tratar com Baldoino Schmidt. 


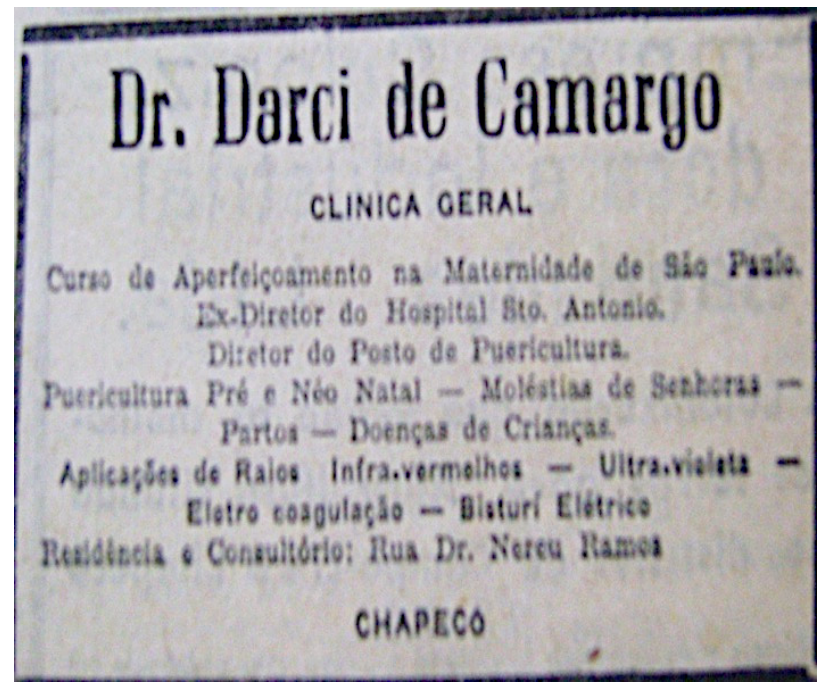

\section{Século 20.2}

Acervo: Centro de Memória do Oeste de Santa Catarina (CEOM) Jornal: Jornal do Povo

Data de publicação: 1\%/2/1951

Doutor. Darci de Camargo || CLINICA GERAL || Curso de Aperfeiçoamento na Maternidade de São Paulo. || Excelentíssimo Diretor do Hospital Santo Antonio. || Diretor do Porto de Puericultura. || Puericultura Pré e Néo Natal - Moléstias de Senhoras - | Partos - Doenças de Crianças. || Aplicações de Raios Infra.vermelhos - Ultra.violeta - | Eletro coagulação - Bisturi Elétrico || Residência e Consultório: Rua Doutor Nereu Ramos || CHAPECÓ.

\subsection{Corpus manuscrito}

Descrevemos, nesta seção, conjuntos de cartas pessoais e de cartas oficiais coletadas, transcritas e editadas pela equipe do PHPB-SC, distribuídas por localidade (Florianópolis, Lages, Blumenau e Chapecó) em distintos períodos de tempo. 


\subsubsection{Cartas pessoais de Florianópolis}

Em Florianópolis, as amostras do gênero carta pessoal compõem-se dos seguintes conjuntos de cartas: (i) Amostra Cruz e Sousa; (ii) Amostra Virgílio Várzea; (iii) Amostra de diferentes missivistas a José Boiteux; (iv) Amostra do Vale; (v) Amostra Harry Laus; e (vi) Amostra Tia Ciça, conforme descrevemos a seguir.

\subsubsection{Amostra Cruz e Sousa}

Essa amostra é composta por 26 cartas escritas por João da Cruz e Sousa, um dos precursores do Simbolismo no Brasil, entre 1885 e 1898. Nascido em 1861, em Desterro (antigo nome da cidade de Florianópolis), o escritor sofreu muito preconceito por ser negro, chegando a ser recusado como promotor da cidade de Laguna-SC (cf. ALVES, 1956; NUNES DE SOUZA, 2015). Trabalhou em jornais de Santa Catarina e do Rio de Janeiro, dirigindo um deles, o Tribuna Popular. Cruz e Sousa morreu muito pobre em 1898, com apenas 36 anos, vítima de tuberculose. Nessa amostra, todas as cartas são escritas por ele: quatro delas são destinadas a sua noiva Gavita, dez a seu amigo Nestor Vitor, cinco a seu amigo Araújo Figueiredo e outras sete cartas são escritas a diversos destinatários (incluindo uma carta a Virgílio Várzea). 


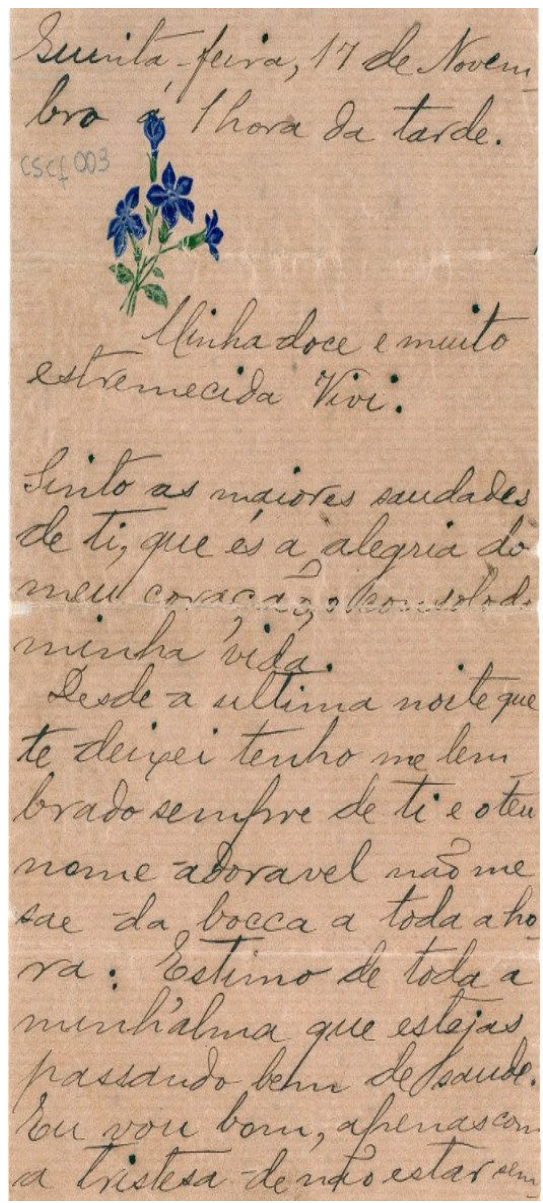

Remetente: Cruz e Sousa

Destinatário: noiva Gavita

Data de envio: 17/11/1892

[fol. 1r] Quinta-feira, 17 de Novem- | bro á 1 hora da tarde. || Minha doce e muito | estremecida Vivi. || Sinto as maiores saudades | de ti, és a alegria do | meu coração, o consolo da | minha vida. || Desde a ultima noite que | te deixei tenho me lem- | brado sempre de ti e o teu $\mid$ nome adoravel não me $\mid$ sae da boca a toda a ho- $\mid$ ra: Estimo de toda a | minhalma que estejas | passando bem de saude. | Eu vou bom, apenas com | a tristesa de não estar sem- | 


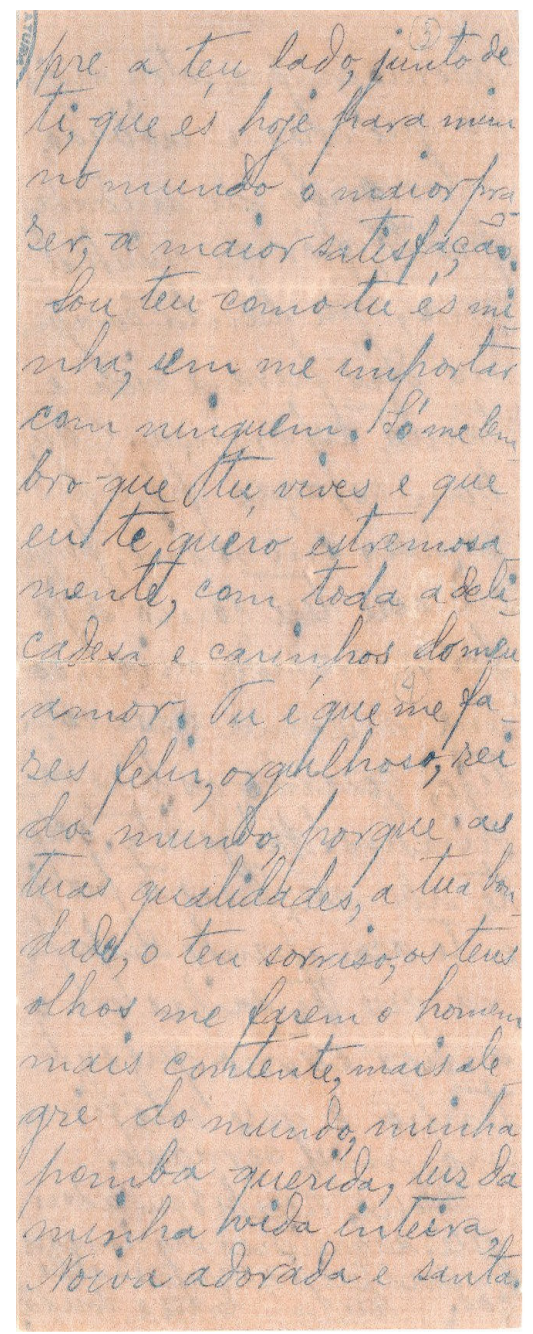

[fol. 2r] pre ao teu lado, junto de $\mid$ ti, que és hoje para mim $\mid$ no mundo o maior pra- | zer, a maior satisfação. | Sou teu como tu és mi- | nha; sem me importar |com ninguem. Só me lem- | bro que tu vives e que eu te quero estremosa- | mente, com toda a deli- | cadesa e carinhos do meu | amor. Tu é que me fa- | zes feliz, orgulhoso, rei $\mid$ do mundo, porque as $\mid$ tuas qualidades, a tua bon- $\mid$ dade, o teu sorriso, os teus | olhos me fazem o homem | mais contente, mais ale- | gre do mundo, minha | pomba querida, luz da | minha vida inteira, | Noiva adorada e santa. | 


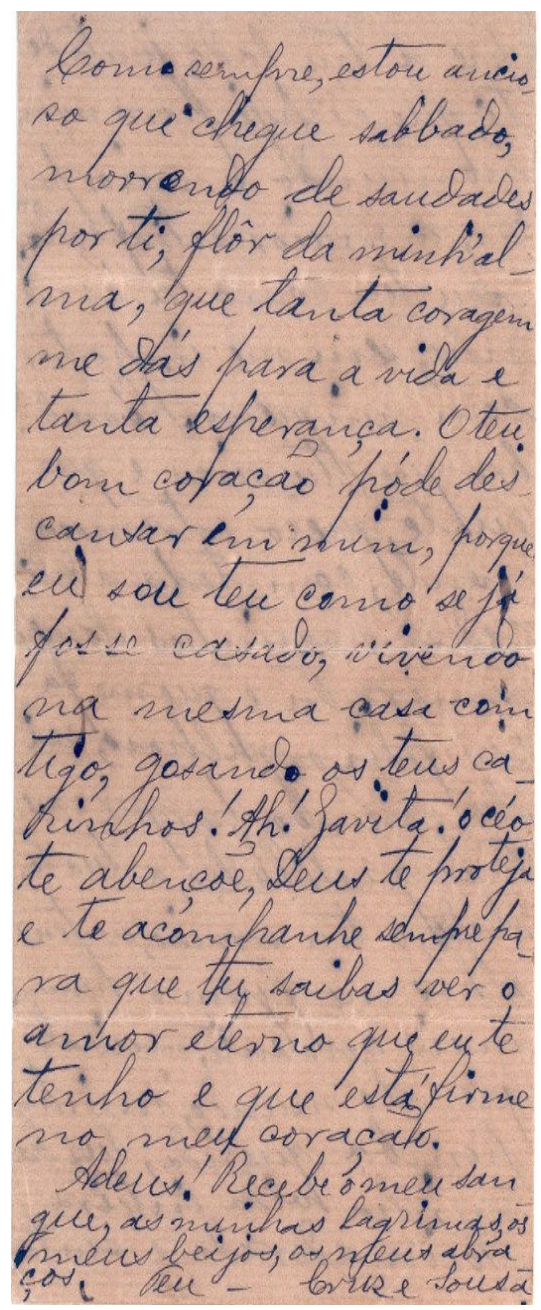

[fol. 2v] Como sempre, estou ancio- $\mid$ so que chegue sabbado, $\mid$ morrendo de saudades | por ti, flôr da minh'al- | ma, que tanta coragem | me dás para a vida e | tanta esperança. O teu | bom coração póde des- | cansar em mim, porque | eu sou teu como se já | fosse casado, vivendo | na mesma casa com- | tigo, gosando os teus ca- | rinhos! Ah! Gavita! o céo | te abençoe, Deus te proteja | e te acompanhe sempre pa- | ra que tu saibas ver o $\mid$ amor eterno que eu te $\mid$ tenho e que está firme | no meu coração. || Adeus! Recebe o meu san- | gue, as minhas lagrimas os | meus beijos, os meus abra- $\mid$ ços, teu - Cruz e Sousa. 


\subsubsection{Amostra Virgílio Várzea}

A amostra contém 15 cartas escritas por Virgílio Várzea a seu amigo Cruz e Sousa e outras seis cartas remetidas a seu filho Paulo. Algumas dessas cartas foram coletadas na Casa de Rui Barbosa e outras foram coletadas pelos membros do PHPB-SC no Arquivo Público Nacional do Rio de Janeiro. Virgílio Várzea nasceu em Desterro, em 1863, estudou jornalismo e literatura e, além de ter sido escritor e trabalhado em serviços burocráticos, foi jornalista e político catarinense. Liderou, de 1883 a 1887, a Guerrilha Literária Catarinense contra o conservadorismo romântico, visando à implantação da Ideia Nova - renovação estética do Realismo-Naturalismo (cf. ALVES, 1956; NUNES DE SOUZA, 2015). O escritor jamais aceitou o nome da cidade "Desterro", pois o achava ignorante e eivado de brutalidade (cf. ALVES, 1956). Fez uma campanha para que o nome da capital fosse mudado para Ondina ${ }^{10}$ e registrava esse nome em suas cartas. As missivas são datadas entre 1886 e 1941.

10 Na mitologia, "ondina” é um espírito da natureza que vive em rios, lagos e mares. Trata-se de uma espécie de sereia, figura da imaginação poética. 


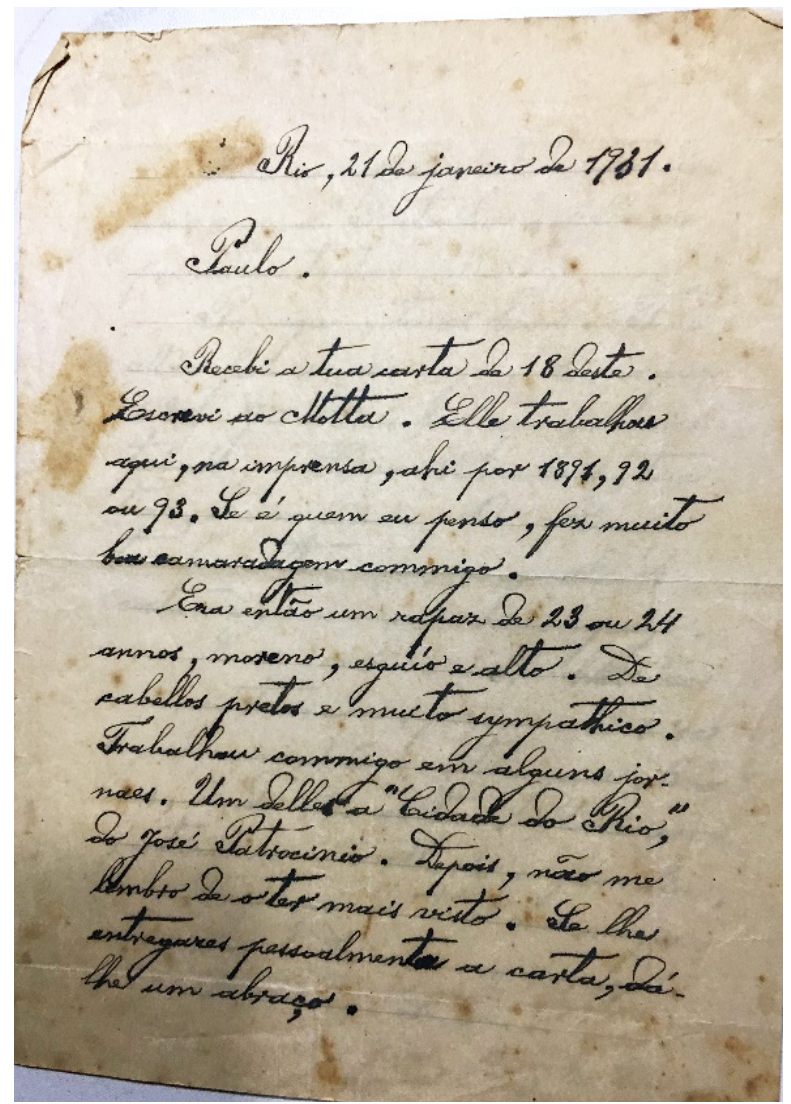

Remetente: Virgílio Várzea

Destinatário: filho Paulo

Data de envio: 21/1/1931

[fol. 1r] Rio, 21 de janeiro de 1931. || Paulo. || Recebi a tua carta da 18 deste. | Escrevi ao Motta. Elle trabalhou | aqui, na imprensa, ahi por 1891, 92 | ou 93. Se é quem eu penso, fez muito | boa camaradagem commigo. || Era então um rapaz de 23 ou 24 | annos, moreno, esguío e alto. De | cabellos pretos e muito sympathico. | Trabalhou commigo em alguns jor- | naes. Um delles a "Cidade do Rio", | do José Patrocinio. Depois, não me | lembro de o ter mais visto. Se lhe | entregares pessoalmente a carta, dá- | lhe um abraço. 


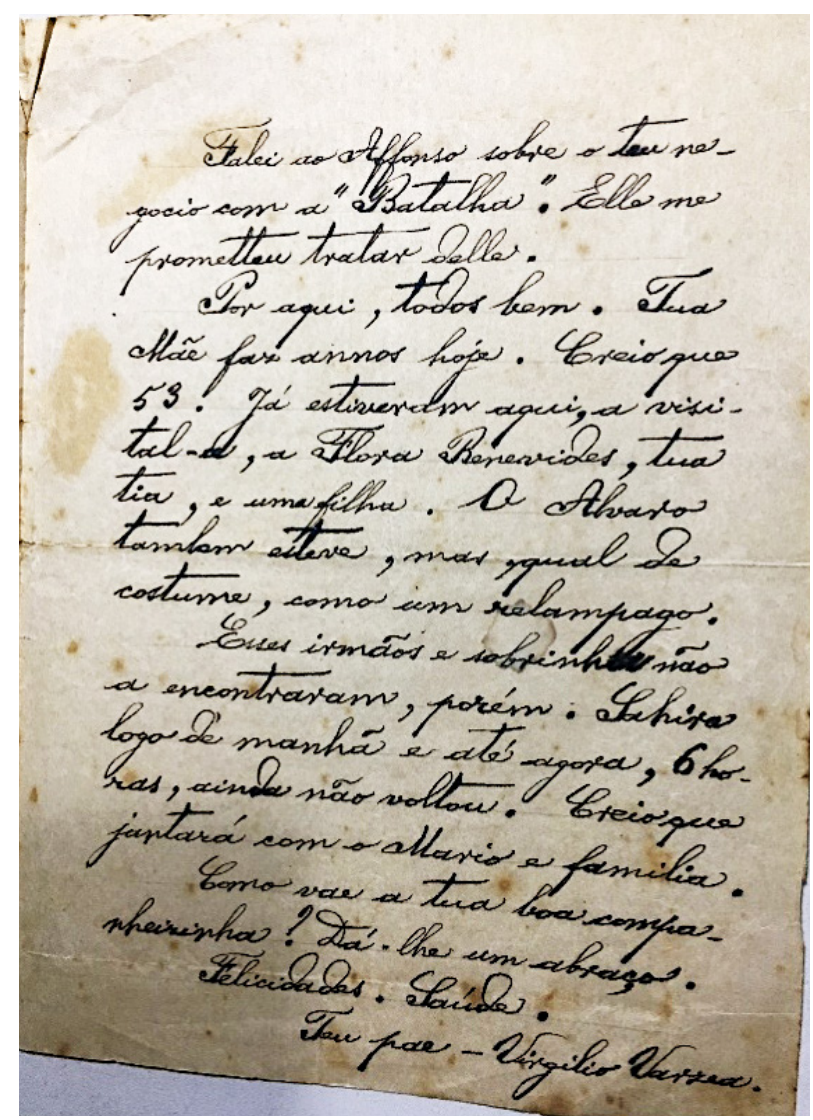

[fol. 2r] Falei ao Affonso sobre o teu ne- | gocio com a "Batalha”. Elle me | prometteu tratar delle. || Por aqui, todos bem. Tua | Mãe faz annos hoje. Creio que | 53. Já estiveram aqui, a visi- $\mid$ tal-a, a Flora Benevides, tua | tia, e uma filha. O Alvaro | tambem esteve, mas qual de | costume, como um relampago. || Esses irmãos e sobrinh $[a]$ não | a encontraram, porém. Sahira | logo de manhã e até agora, 6 ho- | ras, ainda não voltou. Creio que | jantará com o Mario e familia. || Como vae a tua boa compa- | nheirinha? Dá-lhe um abraço. || Felicidades. Saúde. || Teu pae Virgilio Varzea. 
1.3.1.3 Amostra de diferentes missivistas a José Boiteux

Essa amostra é formada por 30 cartas de diversos missivistas que escreveram a José Boiteux, coletadas pelo grupo do PHPB-SC no Instituto Histórico e Geográfico de Santa Catarina. José Boiteux, nascido em Tijucas, em 1865, foi professor, jornalista, literato e político catarinense. Exerceu diversos cargos políticos, como os de deputado estadual, deputado federal, secretário-geral do Governo do Estado e desembargador do Tribunal de Justiça. Alguns dos missivistas da amostra são catarinenses conhecidos, como Victor Konder, Vidal Ramos, Tito Carvalho e Virgílio Várzea. Outros missivistas não são conhecidos, mas as cartas são remetidas de Santa Catarina. 


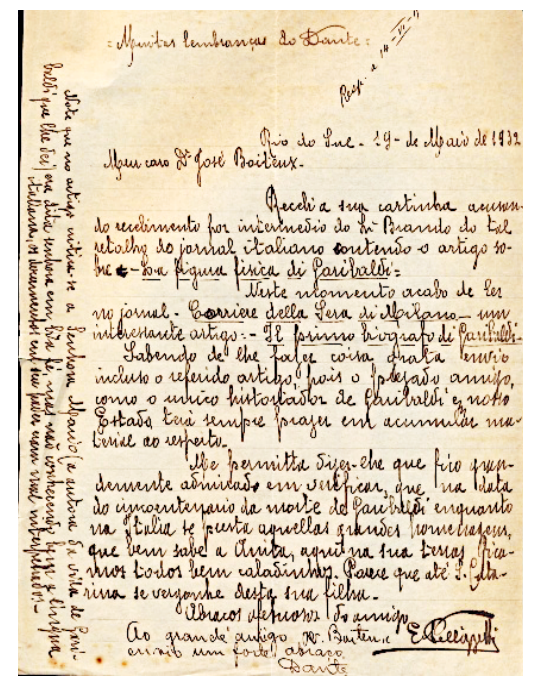

Remetente: E. Pellizzetti

Destinatário: José Boiteux

Data de envio: 19/5/1932

[fol. 1r] < Resp. a 14-VI-1932 $>^{11} \|<=$ Muitas lembranças do Dante $>^{12} \|$ Rio do Sul - 19 - de Maio de 1932 | Meu caro Doutor José Boiteux- || Recebi a sua cartinha acusan| do recebimento por intermedio do Sr. Brando do tal | retalho do jornal italiano contendo o artigo so- | bre - La figura fisica di Garibaldi= || Neste momento acabo de ler | no jornal - Corriere della Sera di Milano - um | interessante artigo: - $\underline{\text { Il primo }}$ biografo di Garibaldi. || Sabendo de lhe fazer coisa grata envio | incluso o referido artigo, pois o prezado amigo, | como o unico historiador de Garibaldi em nosso | Estado terà sempre prazer em acumular material ao respeito. || Me permitta dizerlhe que fico gran- | demente admirado em verificar, que na data $\mid$ do cincoentenario da morte de Garilbaldi enquanto | na Italia se presta aquellas grandes homenagens, | que bem sabe a Anita, aqui na sua terras fica- $\mid$ mos todos bem caladinhos. Parece que até Santa Cata- | rina se vergonhe desta sua filha. || Abraços afetuosos do amigo || E. Pellizzetti || <Ao grande amigo J. Boiteux | envio um forte abraço. || Dante $>^{13}||$ $<$ Note que no artigo critica-se a Senhora Maria (a autora da vida de Gari- | baldi que lhe dei) era dita senhora em bôa fé, mas não conhecendo bem a lingua | italiana, os documentos em seu poder eram mal interpretados- $>^{14}$

\footnotetext{
11 Escrito em diagonal ascendente da esquerda para a direita.

12 Talvez escrito por outro punho.

13 Parece ter sido escrito por outro punho. Assina: "Dante" (talvez Dante Pellizzetti).

14 Escrito na margem esquerda, de cima para baixo.
} 


\subsubsection{Amostra do Vale ${ }^{15}$}

Essa amostra é composta de 25 cartas, doadas de acervo particular ao PHPB-SC, datadas entre 1962 e 1970, escritas por 11 missivistas: jovens moças nascidas em Florianópolis e na região do Vale do Itajaí, que escrevem a um mesmo destinatário. ${ }^{16} \mathrm{O}$ destinatário, jovem na faixa dos 20 anos de idade na época em que as cartas foram escritas, trabalhava como professor de Língua Portuguesa e era integrante de uma banda de música da região.

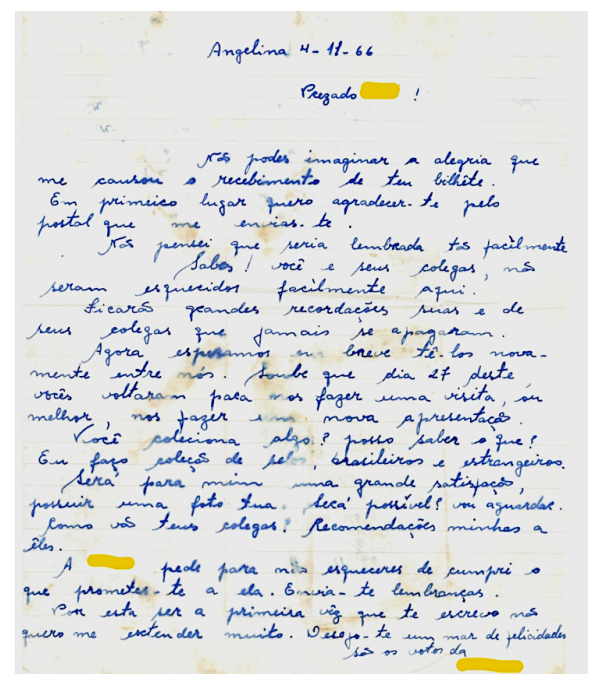

Remetente: B

Destinatário: $\mathrm{N}$

Data de envio: 4/11/1966

[fol. 1r] Angelina 4-11-66 | Prezado [Destinatário] N! | Não podes imaginar a alegria que | me causou o recebimento de teu bilhête. | Em primeiro lugar quero

15 A amostra cartas do Vale está mais bem detalhada no Capítulo 11 deste volume.

16 Nos casos das cartas pessoais que não são de domínio público, optamos por colocar apenas as iniciais dos nomes dos missivistas e dos seus destinatários para preservar as suas identidades. 
agradecer-te pelo | postal que me envias-te. || Não pensei que seria lembrada tão facilmente || Sabes! você e seus colegas, não | seram esquecidos facilmente aqui. || Ficarão grandes recordações suas e de | seus colegas que jamais se apagaram. || Agora esperamos em breve tê-los nova- | mente entre nós. Soube que dia 27 deste, | vocês voltaram para nos fazer uma visita, ou | melhor, nos fazer uma nova apresentação. || Você coleciona algo? posso saber o que? | Eu faço coleção de selos, brasileiros e estrangeiros. || Será para mim uma grande satisfação, | possuir uma foto tua. Será possível? vou aguardar. | Como vão teus colegas? Recomendações minhas a êles. || A S pede para não esqueceres de cumpri o | que prometes-te a ela. Envia-te lembranças. || Por esta ser a primeira vêz que te escrevo não | quero me extender muito. Desejo-te um mar de felicidades | são os votos da [Remetente] B

\subsubsection{Amostra Harry Laus ${ }^{17}$}

A amostra, reunida por Melo (2001), é composta de 93 cartas, datadas entre 1984 e 1992, do escritor catarinense Harry Laus para sua tradutora e amiga Claire Cayron. O autor nasceu em Tijucas, no ano de 1922, mas as cartas são escritas de Florianópolis, onde o autor residia no período de escrita das missivas. Antes de se consagrar como escritor, Harry Laus serviu o Exército e também foi jornalista e crítico de arte. Suas obras foram de pouco reconhecimento no Brasil, mas tiveram melhor repercussão na França, traduzidas por Claire Cayron. Trabalhou em diversos jornais e foi funcionário público nos museus de arte de Joinville e de Santa Catarina. Segundo seus diários e algumas cartas, o autor era homossexual e sofreu perseguição em sua vida por causa disso (cf. NUNES DE SOUZA, 2015; GRANDO, 2016). No início da amostra, os assuntos das cartas são apenas profissionais, mas no decorrer do tempo transparece a amizade que foi sendo construída entre missivista e destinatária, além da relação profissional.

17 A amostra Harry Laus está mais bem detalhada no Capítulo 9 deste volume. 


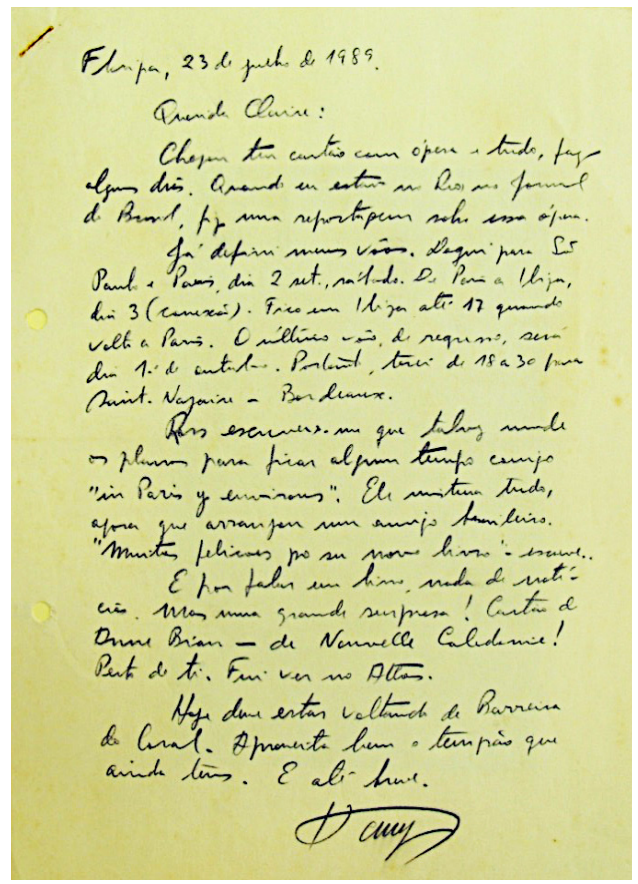

Remetente: Harry Laus

Destinatário: Claire Cayron

Data de envio: 23/7/1989

[fol. 1r] Floripa, 23 de julho de 1989. || Querida Claire: || Chegou teu cartão com ópera e tudo, faz | alguns dias. Quando eu estava no Rio, no Jornal | do Brasil, fiz uma reportagem sobre essa ópera. || Já defini meus vôos. Daqui para São | Paulo e Paris, dia 2 setembro, sábado. De Paris a Ibiza, | dia 3 (conexão). Fico em Ibiza até 17 quando | volto a Paris. O último vôo, de regresso, será | dia 1ํ de outubro. Portanto, terei de 18 a 30 para | Saint - Nazaire [e] Bordeaux. || Ross escreveu-me que talvez mude | os planos para ficar algum tempo comigo | "in Paris y environs". Ele mistura tudo, | agora que arranjou um amigo brasileiro. | "Muitas felicoes po su novo livro" - escreve. || E por falar em livro, nada de notí- | cias. Mas uma grande surpresa! Carta de | Anne Bian - de Nouvelle Calédonie! | Perto de ti. Fui ver no Atlas. || Hoje deve estar voltando de Barreira | do Coral. Aproveita bem o tempão que | ainda tens. E até breve. || Harry 


\subsubsection{Amostra Tia Ciça ${ }^{18}$}

Essa amostra é composta de 125 missivas endereçadas à sobrinha $\mathrm{T}$, escritas entre os anos de 1988 e 2014. As cartas foram doadas pela destinatária $\mathrm{T}$ ao projeto PHPB-SC. Tia Ciça é uma professora aposentada, filha de imigrantes poloneses. Nasceu no ano de 1934, em Itajaí-SC, onde cresceu e permaneceu até cursar a Escola Normal, como relata em uma das cartas. Depois dessa formação, prestou concurso para professora e passou a lecionar em uma escola básica de Florianópolis, na qual trabalhou até se aposentar. A sobrinha T, também professora, nasceu e cresceu em Lages-SC. Na década de 1980, passa a viver e a trabalhar na ilha de Santa Catarina.

${ }_{18}$ O perfil das interlocutoras (tia e sobrinha) está detalhado no Capítulo 11 deste volume. 


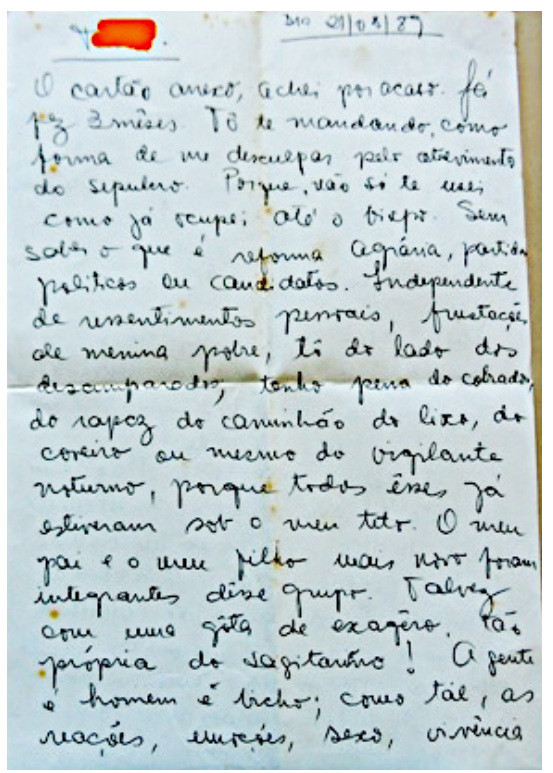

Remetente: Tia Ciça

Destinatário: sobrinha $\mathrm{T}$

Data de envio: 21/8/1989

[fol. 1r] Dia 21/08/89 || T. || O cartão anexo, achei por acaso. Já | fez 3 mêses. Tô te mandando, como | forma de me desculpar pelo atrevimento | do sepulcro. Porque, não só te usei | como já ocupei até o bispo. Sem | saber o que é reforma agrária, partidos $\mid$ políticos ou candidatos. Independente | de ressentimentos pessoais, frustrações | de menina pobre, tô do lado dos | desamparados, tenho pena do cobrador, | do rapaz do caminhão do lixo, do | coveiro ou mesmo do vigilante | noturno, porque todos êsses já | estiveram sob o meu teto. O meu | pai e o meu filho mais novo foram | integrantes dêsse grupo. Talvez | com uma gôta de exagêro, tão | própria de sagitariano! A gente | é homem é bicho; como tál, as | reações, emoções, sexo, vivência | 


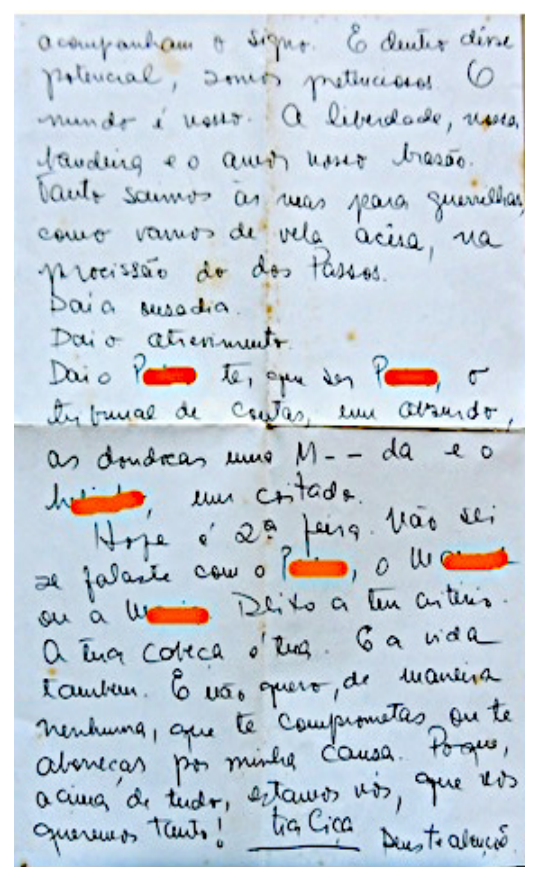

[fol. 1v] acompanham o signo. E dentro dêsse | potencial, somos pretenciosos. $\mathrm{O}$ | mundo é nosso. A liberdade, nossa | bandeira e o amor nosso brasão. || Tanto saimos às ruas para guerrilhas, | como vamos de vela acêsa, na | procissão do dos Passos. || Daí a ousadia. || Daí o atrevimento. || Daí o P. ter que ser P., o | tribunal de contas, um absurdo, | as dondocas uma $\mathrm{M}_{-}$da e o $\mid$h., um coitado. || Hoje é $2^{\mathrm{a}}$ feira. Não sei | se falaste com o P., o M. | ou a M. Deixo a teu critério. | A tua cabeça é tua. E a vida | tambem. E não quero, de maneira | nenhuma, que te comprometas ou te | aborreças por minha causa. Porque, | acima de tudo, estamos nós, que nos | queremos tanto! Tia Ciça || Deus te abençõe.

\subsubsection{Cartas pessoais de Lages}

As amostras de textos manuscritos coletadas na localidade de Lages apresentam os seguintes conjuntos de cartas pessoais: (i) amostra Brito; (ii) amostra Athaÿde; (iii) amostra Tota; (iv) amostra Sena; (v) amostra Salami; e (vi) amostra Medeiros, conforme descrevemos a seguir. 


\subsubsection{Amostra Brito}

A amostra é formada por 11 cartas datadas de 1883 a 1933, de uma família natural de Lages. Pelo conteúdo das cartas e de algumas informações recolhidas no Museu Thiago de Castro, a família Brito era religiosa e devota. Estavam sempre envolvidos em eventos da igreja e em caridade, tendo sido responsáveis por comprar um colégio para fazer dele um hospital. A maioria das missivas são destinadas a Basilissa, prima de Nereu Ramos - político brasileiro, que foi vice-presidente da República, de 1946 a 1951, e presidente durante dois meses, de novembro de 1955 a janeiro de 1956. Outras cartas são de familiares que escrevem sobre o nascimento de Basilissa, em 1883, bem como de amigos que escrevem sobre o falecimento de seu pai, Victor, em 1914. 


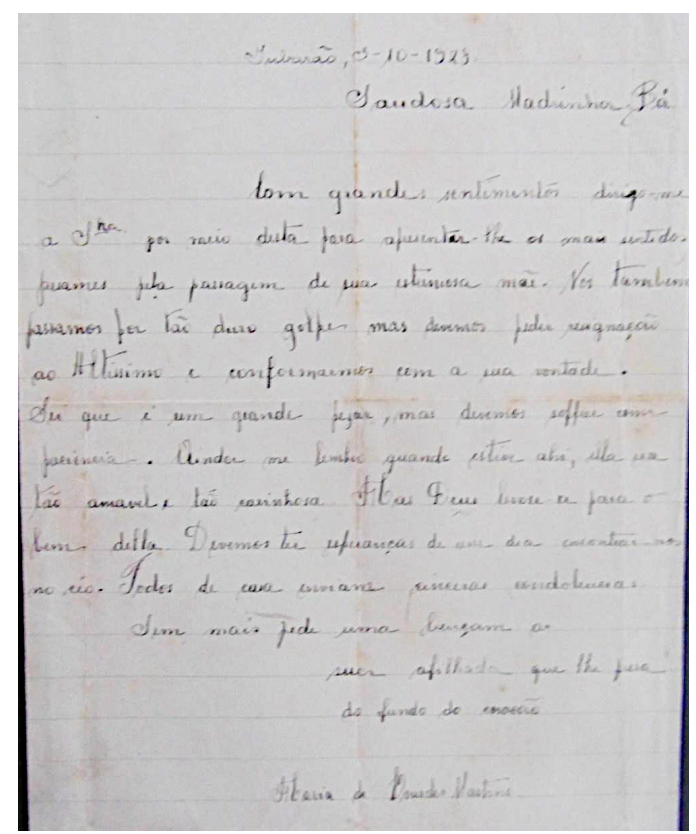

Remetente: Maria de Lourdes Martins (afilhada de Basilissa de Brito) Destinatário: Basilissa de Brito

Data de envio: 3/10/1928

[fol. 1r] Tubarão, 3-10-1928. || Saudosa Madrinha Bá || Com grandes sentimentos dirijo-me | a Senhora por meio desta para apresentar-lhe os mais sentidos | pesames pela passagem de sua estimosa mãe. Nos tambem | passamos por tão duro golpes mas devemos pedir resignação | ao Altissimo e conformarmos com a sua vontade. || Sei que é um grande pezar, mas devemos soffrer com $\mid$ paciencia. Ainda me lembro quando estive ahi, ella era | tão amavel e tão carinhosa. Mas Deus levou-a para o | bem della. Devemos ter esperanças de um dia encontrar-nos | no céo. Todos de casa enviam cinceras condolencias. || Sem mais pede uma bençam a | sua afilhada que lhe presa | do fundo do corasão | Maria de Lourdes Martins

\subsubsection{Amostra Athaÿde}

A amostra é formada por 24 cartas coletadas no Museu Thiago de Castro pelo PHPB-SC, datadas entre 1899 e 1917, escritas de Lages por cinco missivistas homens. Os remetentes escrevem para Athaÿde dando-lhe 
notícias sobre inventários, testamentos e justificativas relacionadas ao recolhimento de impostos de contribuintes da cidade. Ao que tudo indica, o destinatário é o chefe dos remetentes. O conteúdo das cartas é profissional.

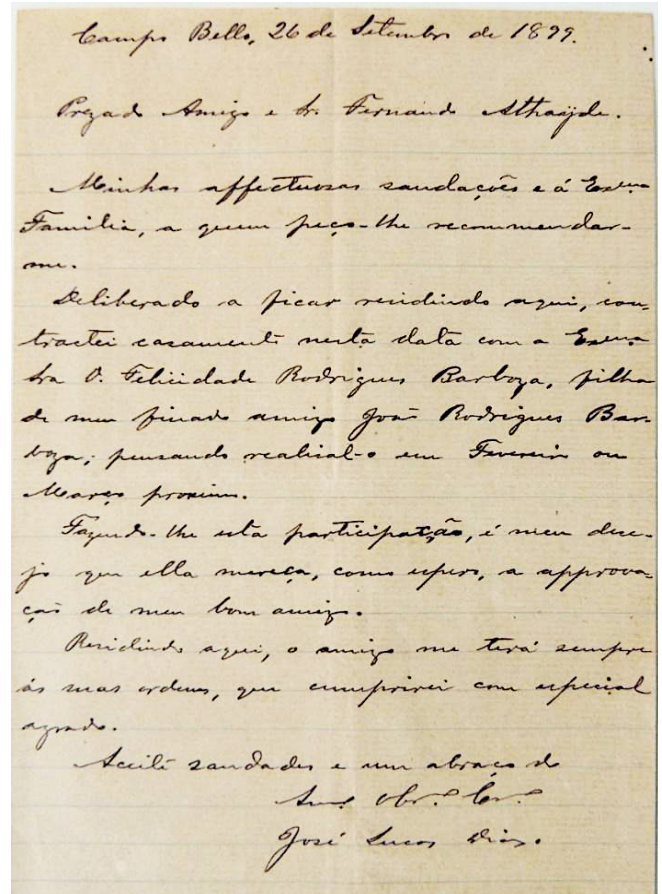

Remetente: José Lucas

Destinatário: Fernando Affonso de Athaÿde

Data de envio: 26/9/1899

[fol. 1r] Campo Bello, 26 de setembro de 1899. || Prezado Amigo e Senhor Fernando Athaÿde. || Minhas affectuosas saudações e á Excelentíssima | Familia, a quem peçolhe recommendar- | me. || Deliberado a ficar residindo aqui, con- | tractei caramente nesta data com a Excelentíssima | Senhora Dona Felicidade Rodrigues Barboza, filha | de meu finado amigo João Rodrigues Bar- | boza; pensando realisal-o em Fevereiro ou | Março proximo. || Fazendo-lhe esta participação, é meu dese- | jo que ella mereça, como espero, a aprova- |ção de meu bom amigo. || Residindo aqui, o amigo me terá sempre | ás suas ordens, que cumprirei com especial | agrado. || Aceite saudades e um abraço do || Amigo [inint.] [inint.] || José Lucas Dias. 


\subsubsection{Amostra Tota}

A amostra é composta de nove cartas coletadas no Museu Thiago de Castro pelos membros do PHPB-SC, contendo missivas datadas de 1910 a 1933, escritas em sua maioria por um professor ao amigo e seu ex-professor Deca. Tota foi um conhecido professor de Lages que, na época das missivas, lecionava em fazendas de outras cidades de Santa Catarina, de onde escreve: Bom Jesus, Monte Alegre, Arvoredo, Lavatudo (lugar perto da cidade de São Joaquim). O amigo Deca era escrivão de paz, e Tota pede alguns favores relacionados à sua certidão de casamento, além de dar notícias ao amigo sobre sua vida, sua esposa e filho. Além dessas, temos também na amostra uma carta do filho de Tota a seu amigo e uma carta de um chefe escolar que escreve sobre a escola em que Tota trabalha. 


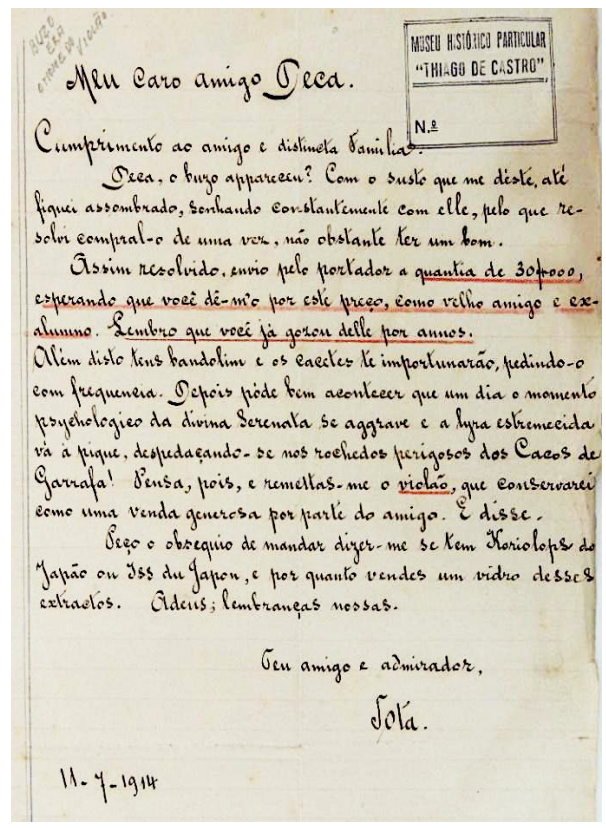

Remetente: Tota

Destinatário: amigo Deca

Data de envio: 11/7/1914

[fol. 1r] Meu caro amigo Deca. ${ }^{19}$ || Cumprimento ao amigo e distincta Familia. || Deca, o buzo appareceu? | Com o susto que me déste, até | fiquei assombrado, sonhando constantemente com elle, pelo que re- | solvi compral-o de uma vez, não obstante ter um bom. \| Assim resolvido, envio pelo portador a quantia de

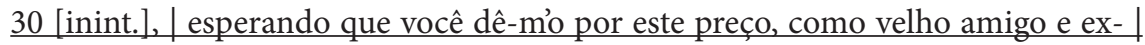
alumno. Lembro que você já gozou delle por annos. ${ }^{20} \|$ Além disto tens bandolim e os cacetes te importunarão, pedindo-o | com frequencia. Depois póde bem acontecer que um dia o momento | psychologico da divina Serenata se aggrave e a lyra estremecida | vá á pique, despedaçando-se nos rochedos perigosos dos Cacos de | Garrafa! Pensa, pois, remettas-me o violão, que conservarei | como uma venda generosa por parte do amigo. E disse. || Peço o obsequio de mandar dizer-

19 Na margem superior esquerda, encontra-se escrito por outro punho: "BUZO | ERA | O NOME DO | VIOLÃO.

20 Os destaques sublinhados neste documento são possivelmente feitos por outro punho. 
me se tem Kariolops do | Japão ou ISS du Japan, e por quanto vendes um vidro desses | extractos. Adeus; lembranças nossas. || Teu amigo e admirador, || Tota. || 11-7-1914

\subsubsection{Amostra Sena}

Essa amostra foi doada de acervo particular ao PHPB-SC e é formada por seis missivas escritas de Lages, entre os anos de 1951 e 1976, por dois diferentes remetentes. Pelo conteúdo das cartas, são dois homens jovens que escrevem missivas de amor e de amizade para três mulheres.

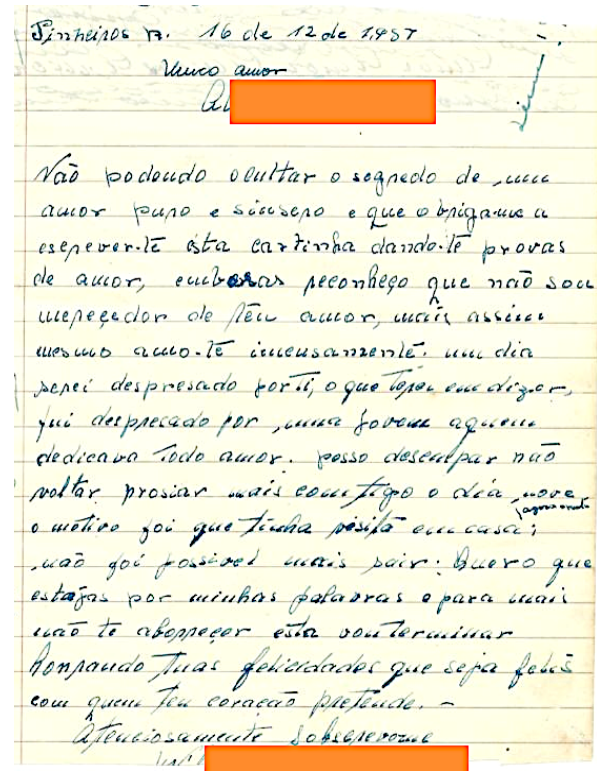

Remetente: W

Destinatário: namorada A

Data de envio: 16/12/1957

[fol. 1r] Pinheiros Ralos 16 de 12 de 1.957 || Unico amor || A || Não podendo ocultar o segredo de um | amor puro e sinsero e que obriga-me a | escrever-te ésta cartinha dando-te provas $\mid$ de amor, emboras ${ }^{21}$ reconheço que não sou $\mid$ mereçedor

21 "emboras" provavelmente "embora". 
de teu amor, mais assim $\mid$ mesmo amo-te imensamente. um dia $\mid$ serei despresado por ti, o que terei em dizer, | fui despresado por uma jovem aquem | dedicava todo amor. posso desculpar não | voltar prosiar mais comtigo o dia [nove] | o motivo foi que tinha visita em casa; <个agora [ilegível] > | não foi possivel mais sair: Quero que | estejas por minhas palavras e para mais | não te aborreçer esta vou terminar | honrando tuas felicidades que seja felís | com quem teu coração pretende. || Atenciosamente sobscrevo-me

\subsubsection{Amostra Salami}

A amostra é formada por 25 missivas datadas de 1973 a 1976, escritas por Arduíno Salami a Dom Honorato. As missivas foram coletadas na Cúria Diocesana de Lages pelo grupo do PHPB-SC. Dom Honorato, nascido em 1911 em Jaraguá do Sul, foi o segundo bispo diocesano de Lages, assumindo a diocese da cidade em 1973. Nesse período, Arduíno, nascido em Brunópolis, em 1927, era discípulo do bispo e estava em Florianópolis em seus estudos missionários. 


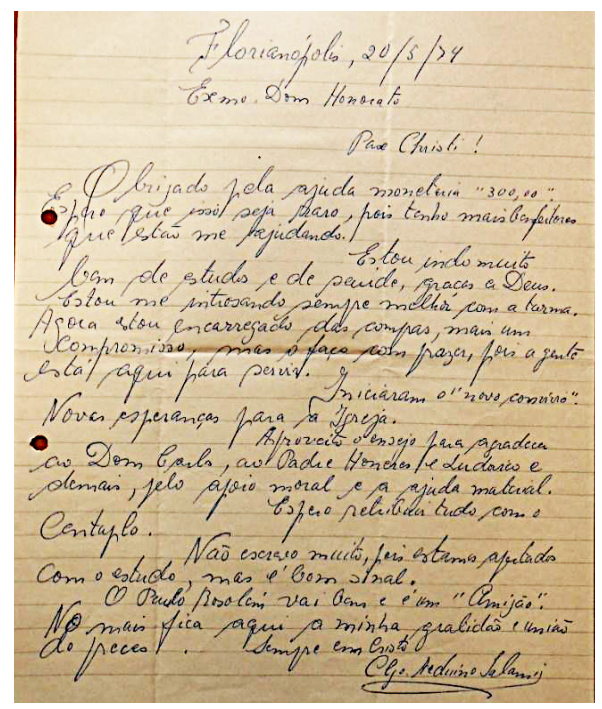

Remetente: Arduíno Salami

Destinatário: Dom Honorato (bispo de Lages)

Data de envio: 20/5/1974

[fol. 1r] Florianópolis, 20/5/74 || Excelentíssimo Dom Honorato || Pax Christi! ${ }^{22}$ || Obrigado pela ajuda monetária " 300,00 ”. | Espero que isso seja raro, pois tenho mais benfeitores | que estão me ajudando. || Estou indo muito | bem de estudos e de saúde, graças a Deus. | Estou me introsando sempre melhor com a turma. | Agora estou encarregado das compras, mais um | compromisso, mas o faço com prazer, pois a gente | está aqui para servir. || Iniciaram o "novo convívio". | Novas esperanças para a Igreja. || Aproveito o ensejo para agradecer | ao Dom Carlos, ao Padre Honéres e Ludarico e | demais, pelo apoio moral e a ajuda material. || Espero retribuir tudo com o | Centuplo. || Não escrevo muito, pois estamos afetados | com o estudo, mas é bom sinal. || O Paulo Bosolim vai bem e é um "Amigão" | No mais fica aqui minha gratidão e união | de preces. Sempre em Cristo || Clérigo Arduíno Salami.

\subsubsection{Amostra Medeiros}

A amostra é formada por 54 missivas, foi doada de arquivo pessoal ao PHPB-SC e é datada de 1980 a 1984. São diferentes missivistas que

22 Frase em latim cuja tradução é "Paz de Cristo!". 
escrevem para uma mesma destinatária, que nasceu em Urubici, mas vivia em Lages com sua família - a não ser no período em que fez sua faculdade em Florianópolis. É nesse tempo em que estava estudando na capital que recebe cartas de Lages. Seu namorado é quem escreve a maioria das missivas dessa amostra. $\mathrm{H}$ nasceu em Florianópolis, se formou em Engenharia Agronômica e se mudou para Lages por causa do trabalho.

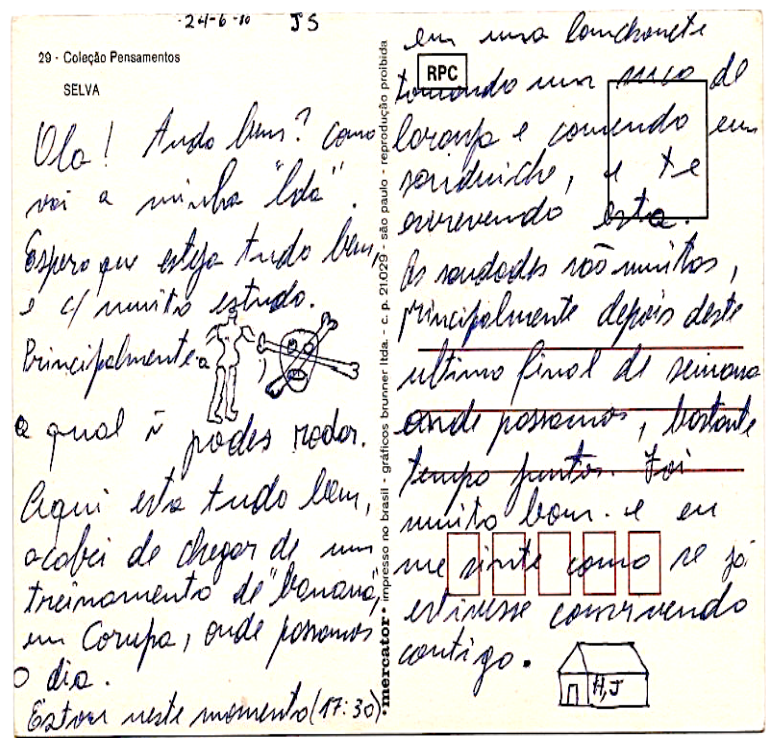

Remetente: $\mathrm{H}$

Destinatário: namorada J

Data de envio: 24/6/1980

[fol 1v] ${ }^{23}$ 24-6-8024 Jaraguá do Sul || Ola! tudo bem? Como | vai a minha "linda". | Espero que esteja tudo bem, | e com muito estudo. || Principalmente a [desenho] | a qual não podes rodar. | Aqui esta tudo bem, | acabei de chegar de um | treinamento

23 Esta carta foi escrita no verso de um cartão-postal.

24 No cartão-postal está timbrado: no canto superior esquerdo, 29 - Coleção Pensamentos SELVA; no meio, está escrito, verticalmente, “mercator” impresso no brasil - gráficos brunner ltda. - c.p. 21.029 - são paulo - reprodução proibida; na parte superior direita, "RPC". 
de "banana", | em Corupa, onde passamos | o dia. || Estou neste momento (17:30) | em uma lanchonete | tomando um suco de | laranja e comendo um | sanduiche, e te | escrevendo esta. || As saudades são muitas, | principalmente depois deste | ultimo final de semana $\mid$ onde passamos, bastante | tempo juntos. Foi | muito bom. e eu | me sinto como se já | estivesse convivendo | contigo. | [desenho]

\subsubsection{Cartas pessoais e oficiais de Blumenau}

Em Blumenau, o acervo de textos manuscritos é composto por amostras de cartas distintas das demais localidades, pois não conseguimos reunir cartas de um mesmo remetente ou de um mesmo destinatário. Tivemos dificuldade em receber doação de cartas de acervo pessoal, por isso coletamos apenas cartas em arquivos públicos e todas com um perfil mais de carta oficial do que de carta pessoal. No entanto, por entendermos que o material pode se constituir em fonte de pesquisa a depender do fenômeno linguístico investigado, optamos por trazer a amostra também no conjunto de cartas organizado. A amostra do período 19.2 é composta por 11 cartas que vão do ano de 1848 até o ano de 1879; a amostra do período 20.1 compõe-se de sete cartas de 1907 até 1950; e a amostra do período 20.2 apresenta sete missivas de 1951 até 1997. 


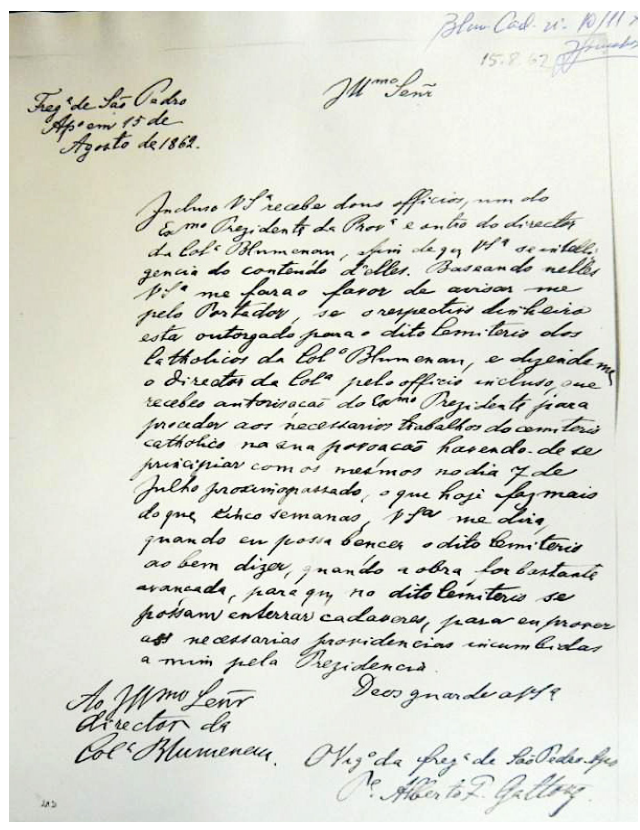

\section{Século 19.2}

Remetente: Vigário Alberto Gattone

Destinatário: Senhor Diretor da Colônia Blumenau

Data de envio: 15/8/1862

[Fol. 1r] Freguesia de São Pedro || Apenso em 15 de || Agosto de 1862. || Illustríssimo Senhor || Incluso Vossa Senhoria receb[a] [d]ous officios, um do | Excelentíssimo Prezidente da Província e outro do director | da Colonia Blumenau, afim de que Vossa Senhoria se [...]| gencia do conteúdo d'elles. Baseando nelles | Vossa Senhoria me fara o favor de avisar me | pelo Portador, se o respectivo dinheiro | esta outorgado para o dito Cemiterio dos | Catholicos da Colonia Blumenau, e dizendo-me | o director da Colonia pelo officio incluso, que | recebes autorisação do Excelentíssimo Prezidente para proceder aos necessarios trabalhos do cemintério | catholico na sua povoação havendo-de se | principiar com os mesmos no dia de 7 de | Julho proximo passado, o que hoje faz mais | do que cinco semanas, Vossa Senhoria me diria, | quando eu [possa bencer] o dito Cemiterio | ao bem 
dizer, quando a obra for bastante | avançada, para que no dito Cemiterio se | possam enterrar cadaveres, para eu propor | as necessarias providencias incumbidas | a mim pela Prezidencia. || Deos guarde a Vossa Senhoria || Ao Illustríssimo Senhor director da Colonia Blumenau. || O Vigário da Freguesia de São Pedro [inint.] | Padre Alberto [F.] Gattone.

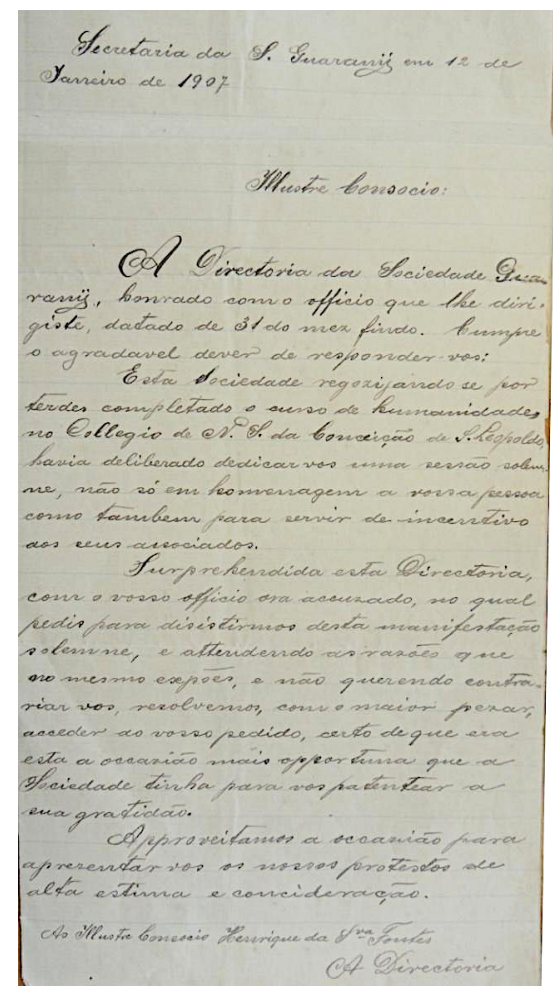

\section{Século 20.1}

Remetente: Directoria da Secretaria da Sociedade Guarany

Destinatário: Consocio Henrique da Silva Fontes

Data de envio: 12/1/1907

[fol. 1r] Secretaria da Sociedade Guaranÿ em 12 de | Janeiro de 1907 || Illustre Consocio: || A Directoria da Sociedade Gua- | ranÿ, honrado com o officio que lhe diri- | giste, datado de 31 do mez findo. Cumpre | o agradavel dever de 
responder-vos: || Esta Sociedade regozijando se por | terdes completado o curso de humanidades | no Collegio de Nossa Senhora da Conceição de São Leopoldo, | havia deliberado dedicar vos uma sessão solem- | ne, não só em homenagem a vossa pessoa | como tambem para servir de incentivo | aos seus associados. || Surprehendida esta Directoria, | com o vosso officio ora accuzado, no qual | pedis para disistirmos desta manifestação | solemne, e attendendo as razões que | no mesmo expões, e não querendo contra- | riar vos, resolvemos, com o maior pezar, | acceder ao vosso pedido, certo de que era | esta a occazião mais opportuna que a | Sociedade tinha para vos patentear a | sua gratidão. || Approveitamos a occazião para | apresentar vos os nossos protestos de | alta estima e concideração. || Ao Illustre Consocio Henrique da Silva Fontes || A Directoria 


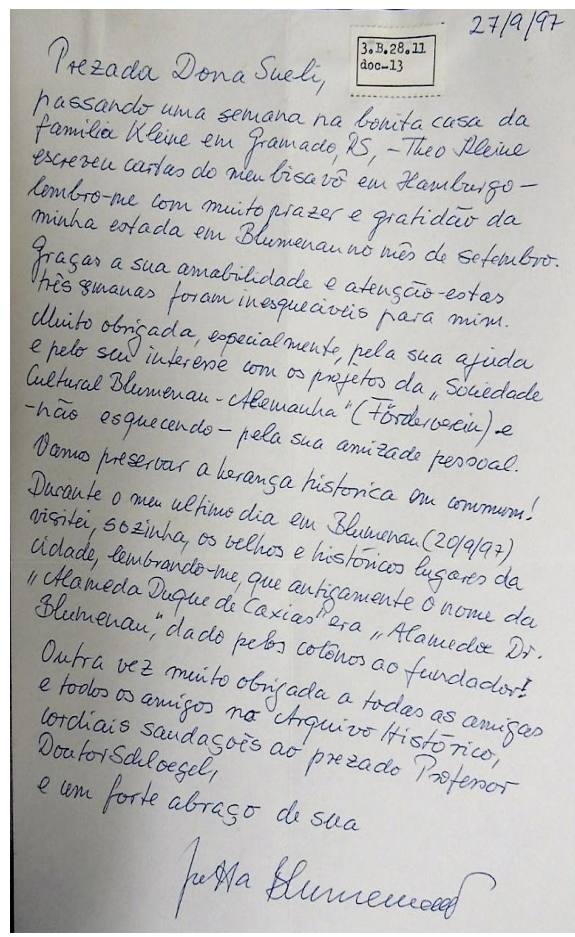

\section{Século 20.2}

Remetente: Jutta Blumenau

Destinatário: Sueli Petry

Data de envio: 27/9/1997

[fol. 1r] 27/9/97 || Prezada Dona Sueli, || passando uma semana na bonita casa da | familia Kleine em Gramado, RS, - Theo Kleine | escreveu cartas do meu bisavô em Hamburgo - || lembro-me com muito prazer e gratidão da minha | estada em Blumenau no mês de setembro. | Graças a sua amabilidade e atenção - estas || três semanas foram inesqueciveis para mim. | Muito obrigada, especialmente, pela sua ajuda | e pelo seu interesse com os projetos da "Sociedade | Cultural BlumenauAlemanha" ([inint.]) e | - não esquecendo - pela sua amizade pessoal. | Vamos preservar a herança historica em commum!| Durante o meu ultimo dia em Blumenau (20/9/97) | visitei, sozinha, os velhos e históricos lugares da | cidade, lembrando-me, que antigamente o nome da | "Alameda Duque de Caxias" era "Alameda Doutor. | Blumenau", dado pelos colônos ao fundador! | Outra vez muito 
obrigada a todas as amigas | e todos os amigos no Arquivo Histórico, | cordiais saudações ao prezado Professor | Doutor Schloegel, || e um forte abraço de sua || Jutta Blumenau

\subsubsection{Cartas pessoais de Chapecó}

A amostra da localidade de Chapecó compõe-se de um conjunto de cartas da família Bertaso. Foi coletada pelo grupo do PHPB-SC no Centro de Memória do Oeste de Santa Catarina (CEOM), contendo mais de 240 cartas, escritas entre os anos de 1914 e 1939.

O coronel Ernesto Bertaso, nascido em 1874, em Verona, na Itália, era um dos proprietários da empresa colonizadora Bertaso, Maia e Cia, que era responsável pela mercantilização da propriedade da terra em parte do oeste catarinense. A colonizadora foi fundada em 1918, em GuaporéRS, mas em seguida adquiriu as fazendas Saudades, Chapecó e Rodeio Bonito através de concessão estadual. A partir de 1923, a empresa passou a pertencer apenas a Ernesto Bertaso, que contou com a ajuda dos filhos e do genro na administração. A colonizadora foi responsável por desocupar as áreas antes da chegada dos colonos. Por vezes, isso acontecia com violência, expulsando "intrusos" que penetrassem ou que ainda estivessem nas terras, como os caboclos e os indígenas que antes ali habitavam e que "atrapalhavam" a política de colonização do estado e das companhias de colonização (cf. WENCZENOVICZ, 2015).

\subsubsection{Amostra Bertaso}

Nessa amostra, a maioria das cartas foi escrita pelos filhos do coronel, Elza $^{25}$ e Serafim, que escrevem um para o outro e para os pais, quando estudavam fora de Santa Catarina. Serafim, posteriormente à época das missivas, teve carreira política, tendo sido prefeito de Chapecó, presidente da Câmara de Vereadores, deputado federal e primeiro-secretário do Oeste. Os assuntos das cartas são familiares, em que os missivistas dão notícias sobre como andam os estudos e o dia a dia.

25 A amostra cartas de Elza Bertaso está detalhada no Capítulo 11 deste volume. 


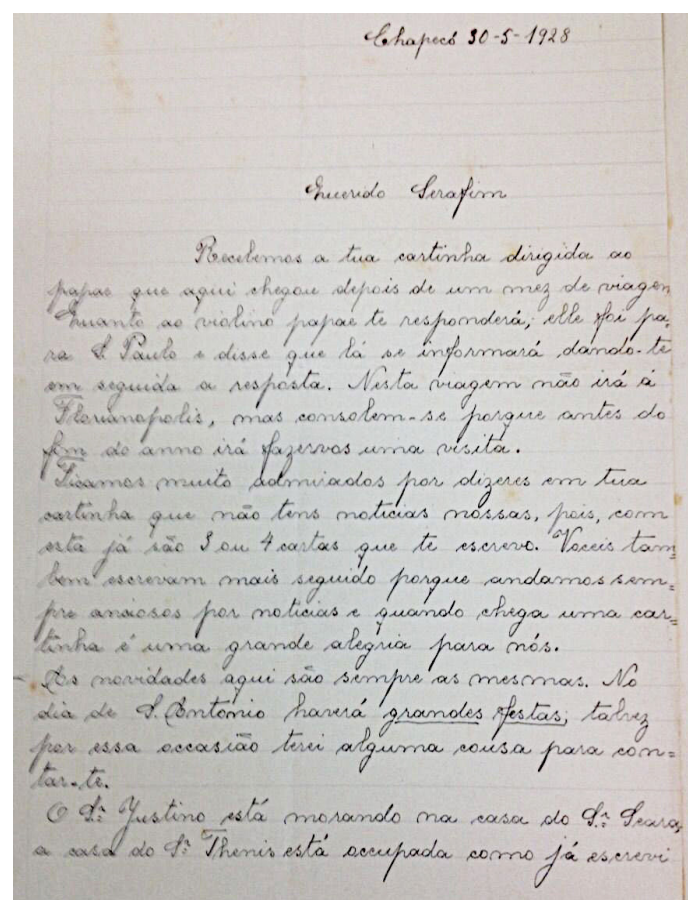

Remetente: Elza

Destinatário: irmão Serafim

Data de envio: $30 / 5 / 1928$

[fol. 1r] Chapecó 30-5-1928 || Querido Serafim || Recebemos a tua cartinha dirigida ao papae que aqui chegou depois de um mez de viagem || Quanto ao violino papae te responderá; elle foi pa- | ra São Paulo e disse que lá se informará dando-te | em seguida a resposta. Nesta viagem não irá á | Florianopolis, mas consolem-se porque antes do | fim do anno irá fazervos uma visita. || Ficamos muito admirados por dizeres em tua | cartinha que não tens noticias nossas, pois, com | esta já são 3 ou 4 cartas que te escrevo. Voceis tam $=\mid$ bem escrevam mais seguido porque andamos sem $=\mid$ pre anciosos por noticias e quando chega uma car $=\mid$ tinha é uma grande alegria para nós. || As novidades aqui são sempre as mesmas. No | dia de Santo Antonio haverá grandes festas; talvez | por essa occasião terei alguma cousa para con= | tar-te. || O Senhor Justino está morando na casa do Senhor Seara | a casa do Senhor Thenis está occupada como já escrevi | 


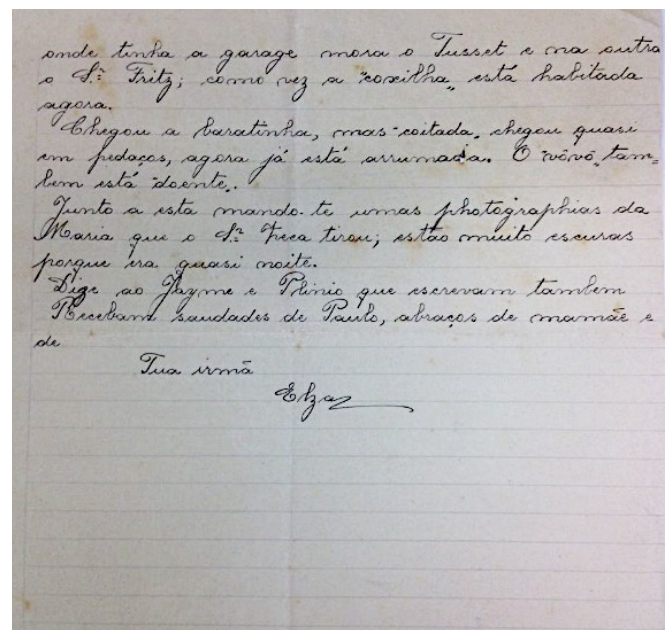

[fol. 1v] onde tinha a garage mora o Tusset e na outra | o Senhor Fritz; como vez a "coxilha" está habitada | agora. || Chegou a baratinha, mas "coitada" chegou quasi | em pedaços, agora já está arrumada. O "vôvô" tam= | bem está "doente". || Junto a esta mando-te umas photographias da | Maria que o Senhor Treca tirou; estão muito escuras | porque era quasi noite. || Dize ao Jayme e Plinio que escrevam tambem || Recebam saudades de Paulo, abraços de mamãe e | de || Tua irmã | Elza

\subsection{Algumas considerações}

A descrição aqui apresentada constitui uma mostra basicamente ilustrativa do que se encontra no arquivo Banco de dados do PHPB-SC. Esse material do banco de dados está disponível no Código QR, gerado no final deste capítulo, e no site http://varsulsc.paginas.ufsc.br/ para consulta.

$\mathrm{O}$ banco de dados disponibilizado reúne textos representativos da escrita catarinense dos séculos XIX e XX, permitindo não só a realização de análises linguísticas, como também o acesso a informações relevantes a respeito das fontes em que o texto foi coletado, dos destinatários, tornando possível também vislumbrar, a partir do gênero textual, aspectos da história social do território catarinense no curso dos dois séculos.

Sabemos que a informação sobre os dados do passado é "fragmentária, escassa e dificilmente vinculável com a produção real de seus falantes" 
(CONDE SILVESTRE, 2007, p. 35). No entanto, quando o acesso aos textos e às informações sociais sobre as cidades onde os jornais circulavam ou ainda circulam e (principalmente) quando o material coletado, especialmente do gênero cartas pessoais, contém informação sobre seus autores e as possíveis relações entre eles e seus interlocutores, assim como dados sobre o contexto social em que se enquadram as missivas, é possível reconstruir parte da história social e linguística de sincronias passadas, fazendo assim "o melhor uso dos maus dados de que dispomos” (cf. LABOV, 1994, p. 100).

Os documentos aqui descritos trazem informações importantes a respeito da base de dados utilizada pelos autores desta coletânea ao analisarem aspectos da escrita catarinense em sincronias passadas. Essas informações são imprescindíveis para a pesquisa histórica.

\section{Referências}

ALVES, H. L. Cruz e Sousa: o Dante negro. São Paulo: Associação Cultural do Negro, 1956.

BERLINCK, R. de A.; COELHO, I. L. A ordem do sujeito em construções declarativas na história do português brasileiro. In: CYRINO, S.; TORRES MORAIS, M. A. (coord.). História do português brasileiro. v. 6: Mudança sintática do português brasileiro: perspectiva gerativista. São Paulo: Contexto, 2018. p. 308-381.

CONDE SILVESTRE, J. C. Sociolingüística histórica. Madrid: Gredos, 2007.

GRANDO, V. Formas de tratamento nas cartas de Harry Laus para Claire Cayron: uma análise sociolinguística. 2016. $71 \mathrm{f}$. Trabalho de Conclusão de Curso (Bacharelado em Letras-Língua Portuguesa) - Universidade Federal de Santa Catarina, Florianópolis, 2016.

LABOV, W. Sociolinguistic Patterns. Philadelphia: University of Pennsylvania Press, 1972.

LABOV, W. Principles of linguistic change. v. 1: Internal factors. Oxford/ Cambridge: Blackwell, 1994.

LOPES, C. R. dos S.; MARCOTULIO, L. L.; RUMEU, M. C de B.; ANDRADE, A. de; COELHO, I. L.; MARTINS, M. A.; LACERDA, M. de O.; GOMES, V. S.; MONTE, V. M.; CARNEIRO, Z. N.; NUNES DE SOUZA, C. M.; BALSALOBRE, S.; SOUZA, J. P. de; OLIVEIRA, T. L. de; MOURA, K. K. de; CRUZ. I.; CARDOSO, N. D. A reorganização do sistema pronominal de $2^{a}$ pessoa na 
história do português brasileiro: a posição de sujeito. In: LOPES, C. R. dos S. (coord.). História do português brasileiro. v. 4: Mudança sintática das classes de palavra: perspectiva funcionalista. São Paulo: Contexto, 2018. p. 24-141.

MARTINS, M. A. Competição de gramáticas do português na escrita catarinense dos séculos 19 e 20. 2009. 326 f. Tese (Doutorado em Linguística) - Programa de Pós-Graduação em Linguística, Universidade Federal de Santa Catarina, Florianópolis, 2009.

MARTINS, M. A. A sintaxe dos pronomes pessoais clíticos na história do português brasileiro. In: CYRINO, S.; TORRES MORAIS, M. A. (coord.). História do português brasileiro. v. 6: Mudança sintática do português brasileiro: perspectiva gerativista. São Paulo: Contexto, 2018. p. 150-209.

MONGUILHOTT, I. de O. e S. Estudo sincrônico e diacrônico da concordância verbal de terceira pessoa do plural no PB e no PE. 2009. 229 f. Tese (Doutorado em Linguística) - Programa de Pós-Graduação em Linguística, Universidade Federal de Santa Catarina, Florianópolis, 2009.

NUNES DE SOUZA, C. M. A alternância entre tu $e$ você na correspondência de florianopolitanos ilustres no decorrer de um século. 2015. 210 f. Tese (Doutorado em Linguística) - Programa de Pós-Graduação em Linguística, Universidade Federal de Santa Catarina, Florianópolis, 2015.

SOUZA, L. A. Os desclassificados do destino: Cruz e Sousa e os primeiros simbolistas (Rio de Janeiro, 1888-1898). 2017. 546 f. Tese (Doutorado em História) - Programa de Pós-Graduação em História, Universidade Federal de Santa Catarina, Florianópolis, 2017.

WENCZENOVICZ, T. J. Olhares ao campo: educação, história e desenvolvimento. Revolução e-book, 2015.

Código QR criado para o acesso aos documentos:

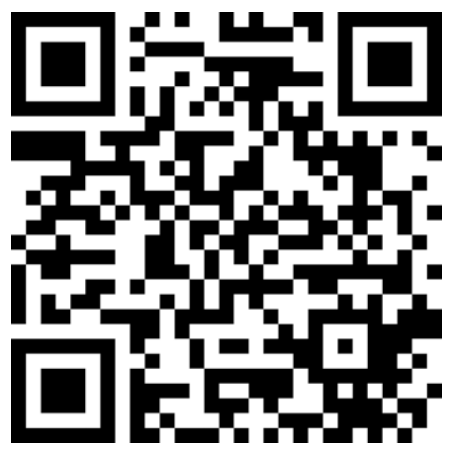




\section{Capítulo 2}

\section{Aspectos sócio-históricos, geográficos, políticos e culturais de Santa Catarina}

Edair Maria Görski

Paulino Vandresen Cláudia Andrea Rost Snichelotto

Cristine Gorski Severo Tatiana Schwochow Pimpão

\subsection{Introdução}

Este capítulo tem como objetivo apresentar um panorama do contexto sócio-histórico, geográfico, político e cultural do estado de Santa Catarina a partir do século XVI, contrapondo as regiões litorânea e serrana e seus respectivos ciclos de ocupação; levando em conta a diversidade étnica; e considerando aspectos sociolinguísticos. $\mathrm{O}$ foco principal são as localidades de Florianópolis, Lages, Blumenau e Chapecó - cidades catarinenses que compõem o banco de dados de fala do VARSUL/SC e do PHPB-SC. Antes 
de tratar dessas cidades isoladamente, delineamos, na primeira seção, uma breve contextualização de Santa Catarina no século XVI.

$\mathrm{Na}$ segunda seção, destinada a Florianópolis, descrevemos as fases sócio-históricas, políticas e culturais da ilha de Santa Catarina, considerando a existência de uma diversidade étnica e cultural que incluiu povos indígenas, imigrantes açorianos, africanos (ex-) escravizados e residentes atraídos pela beleza da cidade. O percurso sócio-histórico tem início no século XVII e vai até o século XXI, contemplando desde as primeiras ocupações e o consequente povoamento, passando pelo surgimento de uma nova elite até as configurações sociodemográficas contemporâneas decorrentes da urbanização e do turismo em Florianópolis.

Na terceira seção, reservada a Lages, expomos um painel sobre sua localização, fundação, povoamento e população; sobre a discutível ligação entre Lages e o Rio Grande do Sul, focalizando o papel do caminho dos tropeiros (não só do ponto de vista geográfico, mas também sociocultural); e sobre aspectos dialetológicos envolvidos nos ciclos vicentista (variedade paulista) e açoriano (variedade açoriana) de ocupação do território catarinense, provocando variedades em conflito.

$\mathrm{Na}$ seção seguinte, que diz respeito a Blumenau, apresentamos os principais fatores sociais que levaram à inserção da língua portuguesa nessa região de colonização alemã, abordando acontecimentos históricos a eles conectados. Destaque especial é dado às políticas linguísticas, tanto de instituições ligadas aos imigrantes (em favor do uso do alemão) como dos governos estadual e federal (em favor do uso do português), apontando-se também algumas características do português local.

Por fim, no que tange a Chapecó, delineamos um histórico da integração territorial do Oeste ao estado de Santa Catarina, uma vez que toda essa área fora contestada (primeiro entre Portugal e Espanha, depois entre Brasil e Argentina e, em seguida, entre Santa Catarina e o estado do Paraná), com solução definitiva somente em setembro de 1917. Focalizamos a colonização do Velho Chapecó por imigrantes ítalo-brasileiros e alemães do Rio Grande do Sul e poloneses vindos de colônias do Paraná. Salientamos que, assim como ocorreu em Blumenau, também em Chapecó o sistema escolar foi o grande fator social para levar a população local à aprendizagem e uso do português.

As quatro cidades catarinenses - Florianópolis, Lages, Blumenau e Chapecó - fazem parte, respectivamente, das mesorregiões Grande 
Florianópolis (3), Serrana (5), Vale do Itajaí (2) e Oeste Catarinense (6), conforme localizado na Figura 2.1.

Figura 2.1 - Mesorregiões de Santa Catarina

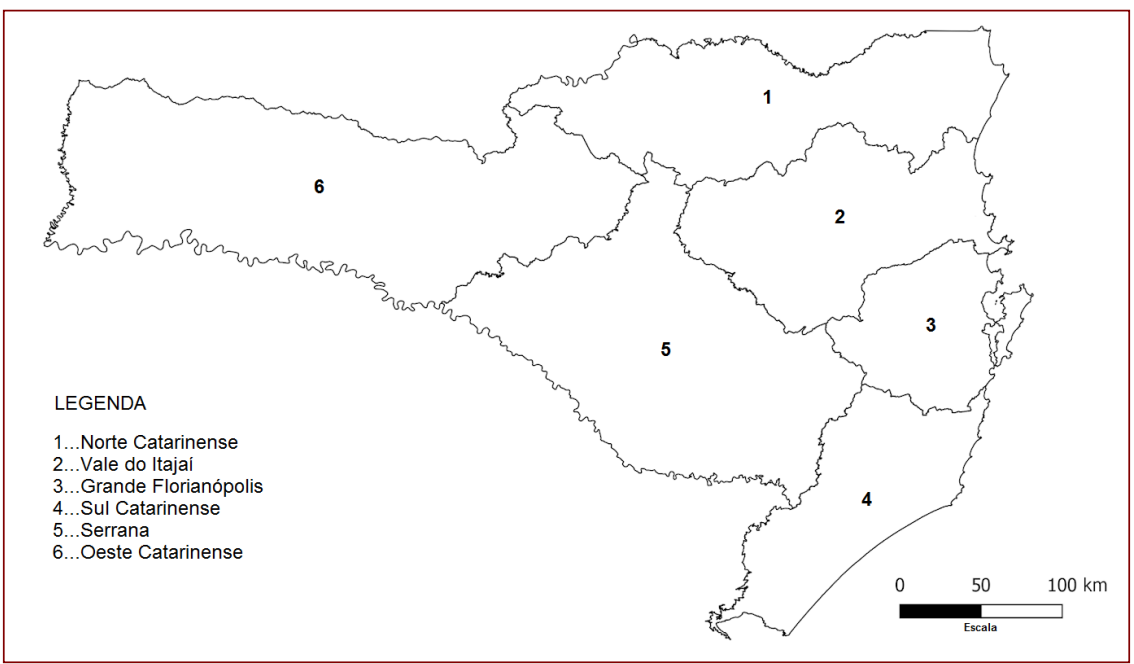

Fonte: Base geográfica do IBGE.

\subsection{Contextualizando: Santa Catarina no século XVI}

De acordo com a historiografia, a Europa passou por significativas transformações ao longo do século XV, envolvendo, entre outros feitos, as Grandes Navegações. Os reinos de Espanha e de Portugal, potências militares e econômicas da época, tinham os mesmos interesses exploratórios na expansão marítima, com vistas tanto a ampliar seus domínios territoriais como a encontrar caminhos alternativos para a realização de comércio, o que os levou, na tentativa de evitar guerras pela posse das terras descobertas, a assinarem o Tratado de Tordesilhas (em 1494) - uma linha imaginária a 370 léguas a oeste do Arquipélago de Cabo Verde, ficando as terras a oeste dessa linha para a Espanha e as terras a leste para Portugal. As explorações marítimas resultaram no "descobrimento da América", por Cristóvão Colombo (em 1942), em expedição patrocinada pela Espanha e no "descobrimento do Brasil", por Pedro Álvares Cabral (em 1500), em expedição patrocinada por Portugal. 
Nos termos do Tratado, as terras da América do Sul eram divididas por um meridiano que passava na altura de Belém (Pará) e de Laguna (Santa Catarina). Ocorre que, em razão de alguns pontos obscuros envolvidos na negociação, havia um impasse em relação às terras do extremo sul, especialmente ao atual litoral catarinense: enquanto os espanhóis supunham que a ilha e seus limites litorâneos pertenciam a eles, os portugueses julgavam que essa região lhes cabia (SANTOS, 2004). Do ponto de vista político, Santa Catarina ${ }^{1}$ tornou-se alvo de disputas entre as coroas espanhola e portuguesa, ao longo do século XVI, em razão de sua localização privilegiada - seja para reabastecimento (água, alimentos e lenha), seja para reparos nas caravelas danificadas por tempestades -, uma vez que era passagem obrigatória dos navios europeus que rumavam para o sul do continente. $\mathrm{O}$ acesso ao rio da Prata era igualmente cobiçado por espanhóis e portugueses, por sua localização estratégica e pelas riquezas em metais e pedras preciosas encontradas próximas à região. $\mathrm{O}$ fato é que inúmeras expedições espanholas e portuguesas se aventuraram pelo litoral de Santa Catarina e pelo rio da Prata nesse período, com tentativas infrutíferas de povoamento em São Francisco e em Laguna (portos bastante disputados entre Espanha e Portugal).

Mosimann nos informa que a ocupação humana do território catarinense data de, no mínimo, 4.500 anos. Os habitantes mais longínquos eram os sambaquis, seguidos pelo povo Itararé (do grupo Jê), cujas culturas foram extintas antes do advento do homem branco na região. ${ }^{2} \mathrm{Na}$ era dos descobrimentos, quem habitava o litoral eram os Carijó, "que atuaram como os primeiros agentes da história catarinense, ao manterem um contato espontâneo e direto com os primeiros europeus que aqui aportaram" (MOSIMAN, 2010, p. 11).

Mas não eram apenas esses os habitantes indígenas dessa época. Segundo registro de Santos (2004), em meados do século XVI Santa Catarina era assim habitada: i) no litoral, pelos Carijó (pertencentes ao tronco Tupi-Guarani) - grupos sedentários que praticavam a agricultura

A denominação de Santa Catarina foi dada em 1526, por Sebastião Caboto, à chamada até então "ilha dos Patos" (LOHN, 2004). O nome seria uma homenagem de Caboto à esposa Catarina de Medrano, devota de Santa Catarina de Alexandria.

2 A única herança dos sambaquis e dos Itararé são vestígios arqueológicos, sem uma contribuição para a gênese do povo catarinense (MOSIMANN, 2010). 
e, sobretudo, a pesca, e que ocupavam a maior parte do litoral brasileiro; ii) no planalto, pelos Kaingang (pertencentes ao tronco Jê) - seminômades que se mantinham de uma agricultura rudimentar complementada pela caça; e iii) nas florestas entre o litoral e o planalto, pelos Xokleng (também pertencentes ao tronco Jê) - nômades que viviam da caça e coleta de frutos, raízes etc. Esses índios tinham grande conhecimento da fauna e da flora, bem como dos acidentes geográficos da região: "Todo esse conhecimento [...] foi oferecido aos europeus e logo utilizado para garantir a exploração da terra e o pronto alcance de riquezas" (SANTOS, 2004, p. 23). Ainda nos termos do autor: "Os indígenas formavam sociedades organizadas e plenamente adaptadas ao ambiente americano. Haviam desenvolvido uma tecnologia adequada para este ambiente" (SANTOS, 2004, p. 24).

O primeiro contato de um homem branco com os índios reportado em solo catarinense foi o da tripulação do navio L'Espoir, comandado pelo capitão Binot Paulmier de Gonneville, em 1504, na ilha de São Francisco do Sul. Binot teria levado consigo para a França dois índios: o velho "Namoa" e o jovem "Iça Mirim" (Essomericq, como ficou conhecido no país europeu), que teria casado com uma parente de Binot e "havido descendentes" (BOITEUX, 1912, p. 100-103). Entre as expedições que aportaram no litoral, vale citar: i) a de João Dias de Solis (sucessor de Américo Vespúcio), de 1516, com três caravelas, uma das quais naufragou; seus sobreviventes (um deles chamado Aleixo Garcia) foram acolhidos pelos Carijó e se tornaram os primeiros europeus a habitar a então ilha dos Patos, no território catarinense; e ii) a de Sebastião Caboto, de 1526, responsável pela designação de "Santa Catarina" à ilha e ao estado, que perdeu ali sua nau capitânia e, ao partir, deixou desterrado na ilha seu imediato e pelo menos mais três desertores.

Nos anos seguintes, mais náufragos, desertores ou desterrados se fixaram, pelo menos temporariamente, no litoral catarinense. Em 1538, temos notícia de dois missionários franciscanos: frei Bernardo de Armenta e frei Afonso Lebron, que encontraram náufragos e desertores espanhóis e portugueses e se dedicaram à evangelização dos Carijó. Em 1549, já havia padres jesuítas criando missões indígenas. Tanto os freis franciscanos como os jesuítas (padre Leonardo Nunes, entre eles) davam, através de cartas, notícias sobre esses náufragos (casados com índias) e sobre seu trabalho missionário entre os autóctones. O alemão Hans Staden, que esteve na ilha em 
1549, também atestou em seu livro a presença de europeus casados e tendo filhos com indígenas; é dele o primeiro mapa do litoral de Santa Catarina (SANTOS, 2004). Vemos, pois, que os primeiros habitantes europeus da ilha e do litoral catarinense foram esses náufragos, desertores ou desterrados das expedições espanholas e portuguesas. Eles aprenderam o carijó e serviram como intérpretes e fornecedores de víveres a outros visitantes. Merece destaque a mobilidade dos Carijó nessa época, que guiavam os missionários e outros sobreviventes das expedições até o Paraguai.

É interessante observar que o tupinambá, tomado como a língua mais próxima do carijó, teria sido a base da Língua Geral Brasílica, presente na gramática e autos do padre Anchieta, e que o guarani do Paraguai seria a base para a gramática do padre Antonio Ruiz de Montoya, usada nas missões espanholas.

Vale salientar que até 1530 não havia ocupação efetiva do território brasileiro. Dom João III desenvolveu um projeto para estabelecer núcleos populacionais permanentes e pôr fim às incursões estrangeiras na sua colônia, e Martin Afonso de Souza foi encarregado de executar o projeto conhecido como Capitanias Hereditárias (1534). São Vicente tornou-se, então, a base para a ocupação da colônia, e os Carijó do litoral catarinense passaram a ser aprisionados e vendidos como escravos em São Vicente-SP e também na Bahia. ${ }^{3}$

Em 1580, o impasse entre Espanha e Portugal teve uma trégua, com o domínio de Felipe II da Espanha sobre ambas as coroas, e a ilha de Santa Catarina bem como o litoral fronteiro passaram a pertencer indistintamente a espanhóis e portugueses. Em 1640, com a restauração da Coroa portuguesa, Portugal voltou sua atenção para o sul do Brasil, procurando firmar posição política para garantir o acesso ao rio da Prata (SANTOS, 2004).

Feita essa retrospectiva histórica com foco no século XVI, passamos, a seguir, a tratar especificamente de cada uma das cidades que compõem o banco de dados linguísticos do projeto VARSUL/SC e do PHPB-SC, a saber: Florianópolis, Lages, Blumenau e Chapecó.

3 Consta que nem os esforços dos jesuítas, já no século XVII, preocupados em converter os indígenas e dar-lhes proteção contra os paulistas que vinham aprisioná-los surtiram efeito, e os índios acabaram em ruína, após prestarem grande contribuição para a sobrevivência dos europeus na região ao longo do século XVI (SANTOS, 2004). 


\subsection{Florianópolis: percurso sócio-histórico-cultural e aspectos linguísticos}

Nesta seção, apresentamos as fases sócio-históricas, políticas e culturais da ilha de Santa Catarina, buscando mostrar a maneira como práticas de homogeneização e diversificação cultural, política e linguística andaram lado a lado. São abordados os seguintes aspectos: as primeiras ocupações da ilha e o surgimento da vila do Desterro no século XVII, e o consequente povoamento da região com a vinda de casais açorianos no século XVIII; um novo cenário político-cultural e o surgimento de uma elite no século XIX, na esteira da circulação intensa de jornais e da formação da norma culta; por fim, as novas configurações sociodemográficas decorrentes da urbanização e do turismo em Florianópolis nos séculos XX e XXI.

\subsubsection{A colonização da ilha e o surgimento da vila do Desterro}

No século XVII, no embalo da colonização da região meridional do Brasil, instauraram-se na ilha, em 1651, as bandeiras vicentistas. O lugar passou a ser habitado pelo bandeirante e comerciante paulista Francisco Dias Velho, que chegou à localidade com um grupo de mais de 300 pessoas, entre indígenas escravizados, jesuítas e familiares. Foi o momento em que a ilha de Santa Catarina, em 1673, tornou-se vila do Desterro. Um dos registros dessa época foi a construção da Capela de Nossa Senhora do Desterro, atual praça XV de novembro, localizada na região central da cidade (MATTOS, 2013). Por fim, a presença vicentista em Desterro, embora forte, não pareceu ter durado muito: em tempos de disputas territoriais e interesses comerciais, piratas holandeses pilharam a ilha e mataram Francisco Dias Velho, juntamente com parte da população (SALOMON, 2004).

Ainda no século XVII, a ilha de Santa Catarina, assim como o Brasil de forma geral, tornou-se um lugar de envio de sujeitos degredados da Coroa portuguesa como forma de punição e estratégia colonizatória de afirmação da posse portuguesa das terras: "A ilha, afastada do continente e isolada pelas águas do mar que a vigiam, assume a função punitiva de afastar e isolar aqueles que comprometem a ordem na sociedade" (SALOMON, 2004, p. 80). Foi no ensejo da necessidade de ocupação militar que, em 
1738, foi criada a capitania de Santa Catarina, sob a ordem de Dom João V, englobando os atuais estados de Santa Catarina e do Rio Grande do Sul; a capital era a vila de Nossa Senhora do Desterro e o primeiro governador foi o brigadeiro José da Silva Paes. No contexto das disputas por terras no Brasil meridional entre Portugal e Espanha, a ilha assumiu, então, posição estratégica na conservação dos limites territoriais portugueses. A sua povoação funcionou com fins de proteção e segurança dos interesses da metrópole, fato que não impediu a invasão espanhola da ilha em 1777; a situação de domínio das terras foi regularizada pelo Tratado de Santo Ildefonso em 1778 (MIRANDA, 2004). Juntamente com a sustentação do aparato militar (construção de fortes e fornecimento de alimentos), os açorianos que migraram para a ilha atuaram economicamente - por meio da exploração da mão de obra escrava - na produção de farinha de mandioca e de açúcar, na pesca e na caça de baleias, tratando-se, sobretudo, de um sistema de policultura e agricultura familiar (KNORST, 2011; MATTOS, 2013).

No século XVIII, em um período de fortes disputas entre Portugal e Espanha pela região da bacia do Prata, várias fortificações foram construídas na ilha. Com fins de sustentar a tecnologia militar e de povoar a localidade, houve o incentivo à vinda de casais açorianos - das ilhas Açores e Madeira, especialmente, por decisão do Conselho Ultramarino, entre 1747 e 1754 para essa região. A primeira leva de imigrantes chegou em 1748, totalizando cerca de 6.000 pessoas, que se juntou a uma paisagem demográfica de 4.194 habitantes. Em 1797, a população da capitania contava com 23.865 habitantes, entre os quais 5.191 eram escravizados (FERREIRA, 2005). Os imigrantes eram pessoas pobres e pouco letradas a quem foram oferecidas promessas de dinheiro, terras, ferramentas; tais promessas, contudo, não foram cumpridas (ZIMMERMANN, 2011).

A presença dos imigrantes açorianos motivou uma nova configuração administrativa, com a criação das primeiras freguesias na ilha, como Nossa Senhora da Lagoa da Conceição, Nossa Senhora da Lapa do Ribeirão da Ilha e Nossa Senhora das Necessidades e Santo Antônio, todas organizadas arquitetonicamente em torno de uma igreja e de uma praça (SANTOS, 2004). A freguesia de Santo Antônio, mais especificamente, foi fundada em 1750, no período da intensa imigração açoriana para a região. Entre as primeiras freguesias fundadas na ilha de Santa Catarina, Santo Antônio de 
Lisboa centrou-se na produção de farinha de mandioca e foi a freguesia que mais fielmente seguiu o modelo colonial português, com a construção da praça e da igreja viradas para o mar (JESUS, 2011). A Tabela 2.1 registra a presença preponderante de açorianos na freguesia, no período entre $1780 \mathrm{e}$ 1799, conforme uma análise dos registros de casamentos da época.

Tabela 2.1 - Origem da população de Nossa Senhora das Necessidades e Santo Antônio (1780-1799)

\begin{tabular}{l|c|c}
\multicolumn{1}{c|}{ Local } & Absoluto & Relativo \\
\hline Açores & 1.154 & $74,35 \%$ \\
\hline Outros estados do Brasil & 89 & $5,7 \%$ \\
\hline Santa Catarina - ilha & 76 & $4,89 \%$ \\
\hline Portugal Continental & 71 & $4,5 \%$ \\
\hline Santo Antônio de Lisboa & 69 & $4,44 \%$ \\
\hline Santa Catarina - continente & 45 & $2,89 \%$ \\
\hline Espanha & 44 & $2,8 \%$ \\
\hline Itália & 3 & $0,1 \%$ \\
\hline Alemanha & 1 & $0,1 \%$ \\
\hline Total & 1.552 & $100 \%$ \\
\hline
\end{tabular}

Fonte: Ferreira (2005, p. 545).

Sobre a presença massiva de açorianos na freguesia de Santo Antônio, há que se pontuar a origem diversificada desses imigrantes, oriundos de mais de 11 localidades diferentes e distribuídos entre as diferentes freguesias existentes na época. Com isso, o termo "açoriano", utilizado para designar as pessoas oriundas do arquipélago dos Açores, oculta a heterogeneidade dos povoados que constituíam esse agrupamento de ilhas. Apenas para exemplificar, na freguesia de Santo Antônio, a procedência dos imigrantes variava entre diferentes ilhas do arquipélago: cerca de 34\% eram oriundos da ilha Terceira, 19\% da ilha Graciosa, 16\% da ilha de São Jorge, 12\% do Pico, 11\% do Faial, 6,5\% de São Miguel e menos de 1\% das ilhas de Flores, Santa Maria e Corvo (FERREIRA, 2005).

Tal presença massiva de açorianos teria influenciado alguns discursos sobre as origens do português catarinense litorâneo, conforme se 
percebe na avaliação feita pelo viajante francês Saint-Hilaire, em sua visita à província, sobre a forma de falar dos catarinenses: "Tornaram dura e nasalada a língua, acentuando longamente a penúltima sílaba e articulando rapidamente as outras, sendo possível que essa pronúncia venha da ilha dos Açores" (SAINT-HILAIRE apud FURLAN, 1989, p. 43). Com isso, as buscas historiográficas pelas "origens açorianas" de Florianópolis contribuíram para atribuir "uma homogeneidade cultural a grupos que tiveram as mais diversas experiências e que ressignificaram, ou mesmo construíram, sua cultura em ambientes e embates distintos" (FERREIRA, 2005, p. 548). Já na região continental, foi criada, em 1752, a freguesia de São Miguel da Terra Firme, atual Biguaçu, local que foi habitado pela primeira leva de açorianos vindos para a região, além de alguns paulistas vicentistas.

Mais especificamente sobre a presença de escravizados em Desterro, muitos deles atuaram na produção de mandioca e na produção de óleo a partir da caça das baleias. Dados revelam que em 1789 havia na ilha de Santa Catarina 350 engenhos de farinha; em 1810, a população escravizada somava 1.869 cativos que, se comparada aos 5.250 homens livres, totalizava cerca de $30 \%$ da população da época (CARDOSO, 2007). No Ribeirão da Ilha, dados do registro de matrícula revelam que, em 1843, cerca de $40 \%$ das famílias possuíam entre um e dez escravizados (ESPÍNDOLA, 2013). No início do século XIX, na mesma freguesia de Nossa Senhora da Lapa do Ribeirão da Ilha, por exemplo, a Armação Baleeira da Lagoinha contava com 582 escravizados (MATTOS, 2013). A Tabela 2.2 ilustra numericamente a forte presença de escravizados africanos na freguesia do Ribeirão da Ilha.

Tabela 2.2 - Relação entre a população livre e escravizada no Ribeirão da Ilha (1776-1872)

\begin{tabular}{c|c|c|c|c|c|c|c}
\hline & $\mathbf{1 7 7 6}$ & $\mathbf{1 8 1 0}$ & $\mathbf{1 8 2 0}$ & $\mathbf{1 8 4 3}$ & $\mathbf{1 8 5 3}$ & $\mathbf{1 8 6 6}$ & $\mathbf{1 8 7 2}$ \\
\hline Livres & $71 \%$ & $71 \%$ & $69 \%$ & $72 \%$ & $76 \%$ & $81 \%$ & $91 \%$ \\
\hline Escravizados & $29 \%$ & $29 \%$ & $31 \%$ & $27 \%$ & $24 \%$ & $19 \%$ & $9 \%$ \\
\hline
\end{tabular}

Fonte: Adaptada de Espíndola (2013, p. 22).

Tais dados contradizem a forte ideia de que a presença de africanos ou afro-brasileiros negros na formação sociodemográfica de Florianópolis tenha sido mínima. O apagamento dos negros pelos discursos histo- 
riográficos atuou como uma prática ideológica de invisibilização desses sujeitos, conforme apontado por Leite (1991, p. 14-15):

na literatura científica, o negro é invisibilizado, seja porque não intencionam revelar a efetiva contribuição destes, seja porque os textos vão se deter na sua ausência, na reafirmação de uma suposta inexpressividade. [...] Ou seja, não é que o negro não seja visto, mas sim que ele é visto como não existente.

Os escravizados trazidos para Santa Catarina saíram, em grande parte, do porto do Rio de Janeiro, fato que evidencia origens linguísticas bantu entre os escravizados presentes em ambas as capitanias, com pessoas (com suas línguas e culturas) oriundas de Angola, Congo, Benguela e Moçambique.

No embalo das práticas coloniais, com a finalidade missionária e pedagógica de atender os imigrantes açorianos, indígenas e soldados, em 1748 foram enviados para a vila do Desterro dois padres jesuítas. Dois anos depois, foi criada a primeira casa-colégio (protótipo de um colégio) jesuítica na localidade, vinculada à Companhia de Jesus. Tratou-se da primeira iniciativa formal de ensino de escrita e leitura para os filhos dos imigrantes açorianos, na vila do Desterro, totalizando 50 alunos em 1750 (DALLABRIDA, 2008). Tal iniciativa durou até 1758, quando os jesuítas foram chamados de volta para o Rio de Janeiro, já em um movimento que culminou com a expulsão da Companhia de Jesus do Brasil pelo Decreto do Marquês de Pombal, em 1759. A expulsão dos jesuítas levou à substituição das aulas escolares por aulas régias, fazendo com que o diagnóstico do início do século XIX em Desterro tenha sido o de que

não há colégios, nem seminários; apenas um Professor Régio de Gramática Latina na Vila Capital e algumas escolas de primeiras letras são os únicos meios de instrução que couberam em partilha a estes desgraçados povos, que pela maior parte fora das vilas não sabem ler, nem escrever. (BRITO apud DALLABRIDA, 2008, p. 531).

Essa citação fornece um indício das práticas linguísticas da época, centradas, sobretudo, na oralidade e nos contextos cotidianos e informais, o que caracteriza a existência de uma variedade do português menos 
sujeita às regulamentações impostas pela norma escrita. Contudo, algumas iniciativas foram feitas em 1799, no contexto da empreitada pombalina, de letrar ("instruir") os habitantes da ilha, conforme a descrição a seguir da primeira remessa de livros feita pela Secretaria de Estado da Marinha e Ultramar ao governador da província de Santa Catarina:

Não eram cartilhas, livros de primeiras letras, para desemburrar - mas obras mais avançadas, algumas técnicas, outras literárias, que, de graça, os moradores seriam capazes de aceitar, para calçar algum pé de mesa mais curto, em chão desnivelado, mas, pagas, nem para ver as figuras, se é que as tinham, seriam capazes de adquirir. (CABRAL apud MATOS, 2007, p. 311).

Os livros enviados tiveram, evidentemente, poucos leitores na província, considerando o baixo número de sujeitos letrados (MATOS, 2007). O episódio da remessa de livros se enquadrou em um movimento iluminista e positivista das reformas políticas portuguesas, o que se evidencia pelos temas de natureza técnica dos livros, com a finalidade de racionalizar as práticas agrícolas e econômicas. As práticas letradas na vila do Desterro centraram-se, sobretudo, em alguns gêneros específicos, como os gêneros administrativos - vinculados à esfera governamental - e gêneros epistolares, como cartas pessoais ou formais. Evidentemente, os sujeitos letrados que ocupavam cargos administrativos constituíam uma pequena elite branca. As práticas letradas de forma geral, como lugares de estabilização de uma norma do português no Brasil, se tornaram mais frequentes e formalizadas a partir do século XIX, com a chegada da família real em 1808 e a consequente instalação da tipografia da Impressão Régia no Rio de Janeiro.

2.3.2 De Desterro a Florianópolis: o novo cenário políticocultural e o surgimento de uma elite

Em termos políticos, tem-se cronologicamente: em 1822, Santa Catarina passou a ser considerada uma província do Império do Brasil; em 1823, Desterro recebeu o status de cidade; em 1834, a organização administrativa pública instituiu a Assembleia Legislativa Provincial, formada por 20 deputados; e em 1891, Santa Catarina passou a integrar o 
Estado Federado da República dos Estados Unidos do Brasil. Florianópolis nasceu juridicamente pela Lei $\mathrm{n}^{\circ}$ 111, de $1^{\circ}$ de outubro de 1894. Antes disso, chamava-se Desterro, ou vila de Nossa Senhora do Desterro. A alteração de nome ocorreu no governo de Hercílio Pedro da Luz, que rebatizou a cidade em homenagem ao marechal Floriano Peixoto, após o assassinato dos integrantes do movimento revolucionário contra o marechal.

A situação demográfica de Desterro na segunda metade do século XIX tinha a configuração descrita a seguir. Em 1866, Desterro totalizava uma população de 6.474 pessoas; o censo da República de 1890 apresentava uma população de 11.400 pessoas; e o censo de 1900 indicava 13.474 habitantes em Florianópolis. Esse índice de crescimento populacional tão pequeno no século XIX é explicado pela ausência de um novo ciclo colonizador (após a vinda de casais açorianos no século XVIII), pela presença de epidemias e da cólera que atacaram a população local e pelo ritmo lento de expansão econômica - a primeira grande fábrica instalada na ilha foi uma firma de pregos, apenas em 1896 (PELUSO JÚNIOR, 1991). A partir de meados do século XIX, a economia começou a crescer devido à presença de alguns imigrantes alemães.

No século XIX, Desterro caracterizou-se por um processo de estruturação política, cultural e social. Foi o período em que uma elite se constituiu paralelamente às disputas políticas que caracterizavam o cenário nacional: primeiramente, o processo de Independência e, em seguida, a República. Tais processos foram, também, atravessados por movimentos a favor e contra o regime de escravização. Esse cenário político alimentou alguns posicionamentos ideológicos que passavam a ecoar nos primeiros jornais criados a partir de 1830 em Desterro, quando se tem uma produção de textos com a finalidade de divulgação de temas políticos, históricos, culturais e sociais locais e nacionais, grande parte deles de forte vinculação partidária às ideologias políticas, como ideais liberais em defesa do "povo brasileiro" e antilusitanos. Esse vínculo pode ser percebido pelo perfil do fundador do primeiro jornal de Desterro: Jerônimo Francisco Coelho era militar, foi deputado provincial, fundou a loja maçônica Concórdia e a Sociedade Patriótica Catarinense (DIONÍSIO, 2005). Salienta-se que, até 1843, os jornais publicados na província catarinense estavam vinculados ao poder público; após isso, a tipografia provincial foi aberta aos interesses particulares, fato que motivou uma intensa proliferação de jornais (FERNANDES, 2007). 
Importante frisar que a variedade linguística presente nos jornais da primeira parte do século XIX não poder ser tomada como representativa de uma suposta "variedade linguística catarinense", pois muitos dos escritores não eram considerados "locais", mas originários de grandes centros onde teriam buscado sua formação intelectual:

Todos os 13 jornais editados na cidade de Desterro, ao longo da década de 1850, foram escritos por homens que estudaram ou eram oriundos de outros centros. Este insurgente cosmopolitismo de seus redatores aliado às precariedades da realidade local criavam os dois polos fundamentais que mantinham em tensão o jornalismo catarinense e o ambiente a ele referido: a polêmica política e o processo civilizador. (SIEBERT apud GONÇALVES; HOLLER, 2009, p. 366).

A norma linguística presente nesses jornais, portanto, deve ser analisada à luz do "processo civilizador" mencionado na citação. Tratava-se de veicular não apenas ideologias políticas de época, mas também padrões de comportamento (cívico, cultural) que incluíam, além de regras de etiqueta para as mulheres, o uso de uma dada variedade linguística condizente com o tal "processo civilizador". Nesse contexto histórico e político emergiu e se consolidou uma classe burguesa defensora dos princípios civilizatórios. Além disso, há que se considerar que o público leitor na época incluía os funcionários públicos, militares, comerciantes locais, políticos, literatos e mulheres pertencentes à elite letrada; ou seja, tratava-se de uma elite.

As primeiras escolas públicas surgiram de forma tímida: em 1836 havia 18 escolas primárias com 533 alunos matriculados na província de Santa Catarina; as escolas privadas tinham 448 alunos matriculados. O ensino secundário teria iniciado apenas em 1837, com as disciplinas de Filosofia e Retórica. Assim, a taxa de crescimento dos alfabetizados foi igualmente lenta: em 1872 quase $20 \%$ da população era alfabetizada (5.073 pessoas); em 1890 esse percentual subiu para 22,84\% (7.011 pessoas); em 1903 havia 13.474 alfabetizados, totalizando $22.26 \%$ da população. Esse número grande de analfabetos teve causas e efeitos políticos, uma vez que eles estavam excluídos do sistema eleitoral (FERNANDES, 2007). Tais dados revelam que as práticas letradas eram reduzidas a uma pequena elite administrativa e política. Disso resulta a ideia de que a Desterro do 
século XIX apresentava um cenário linguístico heterogêneo e bifurcado: entre os letrados e os iletrados, entre a modalidade escrita e a modalidade oral, entre a variedade do português falada por descendentes de açorianos e a variedade falada pelos (ex-)escravizados, entre as modalidades escritas formais (jornais) e as modalidades informais (cartas pessoais).

\subsubsection{Urbanização e turismo em Florianópolis: as novas configurações sociodemográficas}

No século XX, ocorreram mudanças no panorama de Florianópolis, em sintonia com um processo de urbanização e de ampliação da expectativa de vida da população, que afetaram o país de forma geral. Em 1926, foi inaugurada a ponte Hercílio Luz, que liga a ilha ao continente, fazendo desaparecer o tráfego de lanchas e balsas pelo canal. A cidade assumiu a condição de polo regional e reforçou significativamente seu contato com o interior do estado. No fim da década de 1950, início da de 1960, houve a implantação da Universidade Federal de Santa Catarina, gerando um deslocamento populacional que foi facilitado pela abertura da BR-101. No início dos anos 1970, instalou-se a indústria turística, delineando novos ramos para a economia local e atraindo novos contingentes populacionais.

A heterogeneidade cultural que passou a demarcar o cenário de Florianópolis intensificou algumas tensões simbólicas entre os sujeitos locais e os imigrantes. De acordo com Farias (2000), o contato dos descendentes ítalo-germânicos com a cultura açoriana gerou certos preconceitos, ainda hoje existentes na comunidade catarinense. O homem do litoral era visto como malandro e preguiçoso, pois os ítalo-germânicos costumavam trabalhar durante todo o período diurno, já que vinham de centros urbanos acostumados aos horários comerciais-industriais, o que não era o caso dos luso-açorianos. Os descendentes ítalo-germânicos também viam os lusoaçorianos como "um povo ignorante, atrasado, que não tem ambição, se conformando com o que tem, por isso é que é pobre” (FARIAS, 2000, p. 106).

Já os luso-açorianos não tinham essa mentalidade capitalista; pelo contrário, sua economia era de subsistência, trabalhavam o necessário para sobreviver, sem ambicionar acumular riquezas. Os descendentes lusoaçorianos passaram a sentir certa pressão em função dos valores culturais 
dessas sociedades tecnologicamente mais qualificadas e competitivas que passaram a mostrar "um outro universo de bens de consumo, técnicas de produção e visões de vida [que os chamados] manezinhos, mocorongos, atrasados" (FARIAS, 2000, p. 108) não conheciam. Para reverter essa sensação de desprestígio cultural que os descendentes dos luso-açorianos passaram a ter - procurando se desfazer de todos os traços caracterizadores dessa cultura, inclusive os linguísticos -, alguns movimentos importantes começaram a surgir. Em 1992, criou-se o Núcleo de Estudos Açorianos da UFSC, com o objetivo de "devolver ao povo litorâneo o conhecimento de suas raízes históricas e culturais, despertando seu orgulho pelos valores culturais que praticava" (FARIAS, 2000, p. 108).

Esse núcleo passou a oferecer cursos de cultura açoriana, além de divulgar atividades culturais regionais de origem açoriana na mídia. Construiu-se o Monumento ao Povoamento Açoriano em Santa Catarina, criaram-se também o troféu Açorianidade, a Festa da Cultura Açoriana e o Encontro Sul-Brasileiro de Comunidades LusoAçorianas. A parceria com o Governo Regional dos Açores também contribuiu para a revitalização da cultura açoriana, viabilizando a ida de pessoas engajadas no projeto para os Açores a fim de realizarem cursos. Também não poderíamos deixar de lembrar que a mídia passou a destacar Florianópolis como uma das capitais com melhor qualidade de vida, assim como a ascensão do tenista Gustavo Kuerten, que sempre fez questão de enfatizar sua naturalidade e, juntamente com a criação do troféu Manezinho da Ilha, fez com que o ilhéu se sentisse de alguma forma prestigiado com o status de manezinho.

Por fim, pode-se afirmar que o cenário simbólico de Florianópolis foi atravessado por tensões e disputas entre culturas e identidades, o que respingava na língua e nas práticas linguísticas. Ainda hoje, o dito "manezês", modo de falar do nativo de Florianópolis, é alvo de estetização em diversas instâncias, seja para fins de produção de humor, seja para fins de valorização ou reconhecimento. A identidade do manezinho da ilha ainda está fortemente atrelada a uma dada representação linguística que agrupa uma série de elementos linguísticos, discursivos e prosódicos. ${ }^{4}$

4 Uma visão panorâmica desses traços linguístico-identitários pode ser conferida no trabalho de Severo e Souza (2015). 


\subsection{Lages: percurso sócio-histórico-cultural e aspectos linguísticos}

Para falar de Lages é preciso antes situarmos brevemente o leitor no contexto sócio-histórico e político do atual estado de Santa Catarina a partir do século XVII, contrapondo as regiões litorânea e serrana e seus respectivos ciclos de ocupação. Na sequência, focalizamos Lages, enfatizando: dados relativos à sua localização e fundação e ao perfil da população; aspectos geográficos e socioculturais associados à ligação entre Lages e o Rio Grande do Sul; e aspectos dialetológicos envolvidos em variedades linguísticas em conflito: paulista e açoriana.

\subsubsection{A região litorânea e a região serrana: ciclos de ocupação}

Do ponto de vista do povoamento, ao longo do século XVII, aos poucos foram se fixando no litoral catarinense vicentistas (provenientes da capitania paulista de São Vicente) que vinham à caça de índios e em busca da exploração de minas de ouro e prata, resultando em três fundações vicentistas no litoral catarinense entre as décadas de 1660 e 1680: Manoel Lourenço de Andrade instalou-se na ilha de São Francisco; Francisco Dias Velho, na ilha de Santa Catarina/Desterro; e Domingos de Brito Peixoto, em Laguna. Tais povoações, mais o forte Jesus, Maria, José (atual cidade de Rio Grande-RS), foram as bases para a conquista portuguesa do Sul (SANTOS, 2004). Como parte de seu projeto político-militar expansionista, em meados do século XVIII Portugal promoveu a emigração de açorianos e de madeirenses para a ilha de Santa Catarina, o litoral fronteiro e Rio Grande (cf. Seção 2.1), contingente que, somado à população litorânea constituída por vicentistas, portugueses, negros e índios (cerca de 4.000 habitantes) -, aumentou a população em torno de 150\%. Tem-se, assim, dois ciclos de ocupação: o vicentista e o açoriano.

Ao século XVIII, remonta o início da ocupação de Lages, na região serrana, quando a exploração de minas levou ao estabelecimento de uma rede de transportes ligando cidades e vilarejos. Os paulistas desviaram o foco do litoral e se voltaram à busca de gado, normalmente criado à solta nas pastagens do Rio Grande do Sul, para ser levado e vendido para abastecer a 
região das minas (atual estado de Minas Gerais). Três diferentes caminhos foram criados e percorridos nesse período: i) de início, o gado era trazido do Rio Grande do Sul pelo litoral até Laguna e então enviado em barcos para São Vicente e São Paulo, transporte com ônus de frete marítimo; ii) mais tarde, foi aberto um novo caminho que, subindo pelo Rio Araranguá, chegava a Lages e seguia, daí, diretamente para Curitiba e Sorocaba, intensificando-se assim o comércio por terra; e iii) por fim, o caminho do Araranguá foi substituído por outro que atravessava os campos de Vacaria e então chegava a Lages. O trajeto compreendido entre a campanha gaúcha (Cruz Alta, Passo Fundo e Vacaria), passando pelo planalto catarinense (Lages, Campos Novos e Curitibanos) e pelos campos do Paraná (Palmas, Guarapuava, Palmeira e Curitiba) até Sorocaba, ficou conhecido como o "caminho das tropas"; 5 por esse caminho se formou um longo curso de fazendas de criação de gado. A presença de tropas tornou-se comum no caminho entre o Rio Grande do Sul e São Paulo, e foram aparecendo moradores permanentes, muitos deles paulistas (SANTOS, 2004; MACHADO, 2001).

\subsubsection{Lages: fundação e povoamento}

Foi no contexto descrito na seção precedente que o governador da capitania de São Paulo enviou Antônio Correa Pinto com a missão de fundar uma vila no caminho das tropas. Em 22 de novembro de 1766, ele se fixa inicialmente no local denominado Taipas, fundando o povoado de Nossa Senhora dos Prazeres do Sertão das Lagens, mas apenas em 22 de maio de 1771 o povoado é elevado à categoria de vila, já em outra localização próxima (PEIXER, 2002). Portanto, a vila não brotou espontaneamente como outras povoações que surgiram ao longo do caminho dos tropeiros. O povoamento de Lages foi movido por uma dupla motivação: política (proteção das fronteiras) e econômica (interesse de fazendeiros e comerciantes).

O termo "tropas" remete tanto a gado muar, bovino e equino conduzido à venda pelos tropeiros como a mulas condutoras que faziam o transporte de mercadorias e correspondências. 
Do ponto de vista político, Lages é

uma das cidades do período colonial brasileiro com fundação planejada e cuja construção obedeceu a um objetivo claro: o de colocar em posição estratégica um núcleo de população que, além de marcar a ocupação portuguesa, constituísse, quando necessário, um ponto de dissuasão ou resistência a uma possível tentativa castelhana de invasão do território que Lisboa considerava de sua propriedade. (COSTA, 1982, p. 19).

Do ponto de vista econômico, houve duas levas de fazendeiros dedicados prioritariamente à criação de gado: uma mais antiga, constituída por paulistas e paranaenses, e outra mais tardia, constituída por gaúchos oriundos principalmente de Vacaria e Passo Fundo (MACHADO, 2001). Nas palavras de Bloemer, "o fazendeiro tornou-se um verdadeiro 'caudilho', que contava com sua gente na defesa do território e não hesitava, se necessário, em usar a violência, independente das circunstâncias" (BLOEMER, 2000, p. 50).

Lages surgiu como povoado (depois vila) pertencente à capitania de São Paulo e assim permaneceu por meio século. Somente em 1820 o rei de Portugal, Dom João VI, determinou a incorporação de Lages ao território de Santa Catarina, o que ocorreu no dia 9 de setembro daquele ano. Mesmo assim, as ligações econômicas, culturais e demográficas, por um longo período, permaneceram mais intensas com os paulistas e os gaúchos do que com a população do litoral catarinense, em virtude da barreira geográfica da Serra Geral (MACHADO, 2001).

De acordo com Santos (2004), tanto na ilha de Santa Catarina e arredores litorâneos como em Lages, escravos negros e índios faziam parte dos grupos que participavam da fundação das novas vilas, tendo como consequência imediata a miscigenação entre brancos, índios e negros, originando-se o chamado "caboclo". Os escravos, que acompanhavam as famílias paulistas ou que eram comprados nas vilas de Santa Catarina, destinavam-se basicamente a trabalhos domésticos ou a pequenas atividades de lavoura, e não a uma economia de exportação, como acontecia no Nordeste. A Tabela 2.3 apresenta a evolução da população de Lages nos séculos XVIII e XIX, evidenciando que a população negra e indígena em Lages era representativa nesse período. 
Tabela 2.3 - Evolução da população de Lages $(1777-1864)^{6}$

\begin{tabular}{c|c|c|c|c|c}
\hline População & $\mathbf{1 9 7 7}$ & $\mathbf{1 7 8 9}$ & $\mathbf{1 7 9 4}$ & $\mathbf{1 8 3 3}^{\mathbf{7}}$ & $\mathbf{1 8 6 4}$ \\
\hline Brancos e pardos & 372 & 363 & 456 & 1.688 & $7.942^{8}$ \\
\hline Agregados e índios & 94 & 84 & 136 & 97 & - \\
\hline Pretos forros & 10 & 8 & - & 422 & - \\
\hline Pretos cativos & 191 & 93 & 125 & 260 & 1.405 \\
\hline Total & 667 & 548 & 717 & 2.467 & 9.347 \\
\hline
\end{tabular}

Fonte: Mosimann (2010, p. 166).

É interessante observar que em 1833 o número de índios cai em relação ao final do século XVIII. Provavelmente isso de deva à determinação de Dom João, em 1808, de "guerra aos índios bugres que matam cruelmente todos os fazendeiros", referindo-se ao caminho entre Lages e Desterro, habitado por Xokleng, "em razão dos quais Lages vivia em estado de sobressalto e em plena decadência" (MOSIMANN, 2010, p. 195, grifo do autor).

Outro aspecto digno de nota, ainda em relação ao ano de 1833, diz respeito ao número de pardos e pretos livres. Entre os 1.688 brancos e pardos constantes na tabela, 564 são pardos; estes, somados aos pretos forros, perfazem um total de 986 pardos e pretos livres, número quatro vezes superior à população escrava nesse período. Daí a interessante observação de Machado acerca da "historiografia catarinense, que sempre considerou o contingente populacional negro pouco significativo no povoamento do planalto serrano, baseando esta assertiva unicamente nos censos estritos da população escrava" (MACHADO, 2001, p. 18-19). Essa observação pode ser estendida a 1864, pois junto aos brancos estão computados também os pardos e os pretos livres (cf. nota 9).

Note-se que a população de Lages, um século depois de sua fundação, ainda era relativamente pequena: 9.347 habitantes. Já em 1890 somava 14.348 habitantes, correspondendo à metade da população de Florianópolis à época (MOSIMANN, 2010, p. 319).

Em 1853, São Paulo desmembrou-se, dando origem à província do Paraná. A nova província pretendia manter seu domínio sobre a região

\footnotetext{
6 Anais do Museu Paulista, tomo XIV. Imprensa Oficial do Estado, São Paulo, 1950.

7 Os dados de 1833 são do Arquivo Histórico de Florianópolis.

8 Inclui pretos livres.
} 
meridional que atravessava Santa Catarina e alcançava parte do Rio Grande do Sul (cuja área contestada era de aproximadamente $48.000 \mathrm{~km}^{2}$ ), tendo Lages como um dos pontos dessa pretensa dominação. A pendência foi se arrastando e culminou com a Guerra do Contestado, que durou de 1912 a 1916. O território que estava em disputa foi então dividido entre os dois estados e o governo de Santa Catarina logo tratou de criar os municípios de Mafra, Porto União, Joaçaba e Chapecó (SANTOS, 2004).

Conforme Peixer (2002), ao longo do século XIX, Lages passava aos viajantes uma imagem de vila (casas com cercados irregulares e criação de animais, por exemplo), a despeito da posição geográfica estratégica e da importância regional - imagem que se procurou desfazer durante a primeira metade do século XX. A região, cuja economia até 1940 se concentrava prioritariamente nas grandes fazendas, com a exploração da pecuária e em menor escala com a produção agrícola para o consumo interno, a partir dessa data passa a ter o seu cenário reconfigurado, com significativo crescimento da população. Esse aumento populacional coincide com o início da exploração comercial da araucária. O ciclo da madeira compreende o período de 1940 a 1970, intensificando a mão de obra na cidade, caracterizada como polo regional centralizador de diversas atividades no comércio e em serviços (cf. PIMPÃO, 2012).

Encontram-se registros de imigrantes alemães em Lages desde a segunda metade do século XIX (CASTELLO BRANCO, 2001) e de italianos a partir do século XX (BLOEMER, 2000). Trata-se não só de imigrantes oriundos diretamente dos respectivos países de origem, mas principalmente de descendentes desses imigrantes que se deslocavam do Rio Grande do Sul e de outras colônias de Santa Catarina - período em que a população aumentou consideravelmente com o desenvolvimento de atividades madeireiras. Dessa forma, migrando já de outras colônias brasileiras, esses diferentes grupos traziam consigo uma mescla de costumes e cultura.

É interessante observar como se dá o movimento migratório em Lages: em um primeiro momento, o contingente humano move-se em direção às serrarias, situadas em grande parte no interior do município. Com a crise madeireira, também desencadeada pelo fim das reservas naturais, opera-se um novo deslocamento: os trabalhadores, agora desempregados, dirigem-se para a periferia da cidade de Lages. A população urbana, que em 1960 já ultrapassava a população rural, chega no início do século XXI a 97\%, segundo Peixer (2002). 
Do ponto de vista demográfico, a população de Lages dobra entre 1950 e 1980, com crescimento mais significativo a partir de 1970, provavelmente em consequência do término da BR-282 em 1980. O índice demográfico da cidade, porém, fica praticamente estacionário de 1980 a 2018, apontando para uma estabilização da cidade em termos de migração.

Tabela 2.4 - População de Lages (1950-2018) ${ }^{9}$

\begin{tabular}{c|c}
\hline Décadas & População \\
\hline 1950 & 77.234 \\
\hline 1970 & 99.910 \\
\hline 1980 & 155.295 \\
\hline 1991 & 151.235 \\
\hline 2000 & 157.682 \\
\hline 2010 & 156.727 \\
\hline 2018 & 157.743 (estimativa)
\end{tabular}

Fonte: Elaboração própria (com base em informações da nota 9).

Como já visto, a posição geográfica de Lages foi peça fundamental no estabelecimento da rota dos tropeiros. Esse caminho, construído para a passagem das tropas de comércio, é prova concreta de que "Lages, apesar de sempre integrada em Santa Catarina, esteve, por motivo da estrada das tropas, muito ligada ao Rio Grande; até parecia uma sobrecarga arreatada ao cargueiro da história" (CAON, 1978, p. 10 apud MARCON, 2009, p. 39).

\subsubsection{Lages e sua ligação com o Rio Grande do Sul}

A relação de Lages com o Rio Grande do Sul é um ponto discutível na literatura. Marcon (2009) apresenta duas perspectivas que ilustram essa

9 Os dados de 1950 foram obtidos em Mosimann (2010, p. 474). O indicador populacional de 1970 baseia-se em uma informação registrada no jornal Correio Lageano de 13/10/1970. Os indicadores referentes ao censo de 1980 e 1991 foram retirados do site www.sebrae-sc.com.br/scemnumero/arquivo/Lages.pdf. Os dados relativos a 2000 e 2010/2018 foram extraídos, respectivamente, dos sites (acessados em 10 de outubro de 2018): http://www.ibge.gov.br/home/estatistica/populacao/censo2000/universo.php?tipo=31o/tabela13_1.shtm\&paginaatual=1\&uf=42\&letra $=\mathrm{L}$ e http://www.ibge.gov.br/ cidadesat/link.php?uf=sc. 
discussão: Caon (1978), por exemplo, defende que o caboclo do planalto serrano (uma mistura de português, índio e negro) se sente atraído pelo estilo e temperamento agauchados, pelo amor à terra e ao campo; Santos (1971), por outro lado, nega a origem gaúcha dos lageanos, apostando nas raízes paulistas, mas admite que a cultura pastoril é a responsável pela aproximação dos valores e tradições gaúchas no planalto serrano de Santa Catarina. Segundo Santos:

As bombachas, o barbicacho, as botas, o chimarrão, o churrasco são alguns itens do vestuário e da alimentação que caracterizam a gente de Lages, aproximando-a da população gaúcha. Mas as origens desta gente estão em São Paulo, e não no Rio Grande. (SANTOS, 2004, p. 46).

Fato é que o caminho dos tropeiros constitui um forte ponto de contato entre Lages e o Rio Grande do Sul, não só do ponto de vista geográfico, mas também sociocultural, seja essa relação decorrente da afeição ao estilo gaúcho, seja decorrente da cultura pastoril. É inegável que o tropeirismo "tornou-se um forte símbolo da formação da cidade, constituindo um conjunto de práticas celebradas em momentos festivos, como o aniversário de Lages, a Festa Nacional do Pinhão e a Sapecada ${ }^{10}$ da Canção Nativa" (MARCON, 2009, p. 44). As duas últimas, fortemente associadas à cultura do Centro de Tradição Gaúcha (CTG), ocorrem no período de final de maio e início de junho.

A ligação de Lages com o Rio Grande do Sul também está presente na Revolução Farroupilha no Rio Grande do Sul, caracterizada como um levante contra o governo imperial em defesa de um ideal republicano e separatista, cujo marco inicial é o dia 20 de setembro de 1835 . Três anos depois, a então vila de Lages é invadida pelos revolucionários farroupilhas, que encontram demonstrações de simpatia e acolhimento do povo lageano (GUEDES, 1979). Segundo Mosimann, os revolucionários gaúchos, a chamado dos lageanos, decidiram tomar Lages,

10 Trata-se de um festival de música nativista cujo nome é homenagem a um traço cultural da cidade de Lages: o pinhão. Sapecada constitui uma forma de preparar o pinhão (ligeiramente assado). 
a vila mais próxima física e sentimentalmente, escala obrigatória do caminho das tropas. [...] Em 7 de março de 1838, [...] a imensidão de adeptos lageanos facilitava a missão farroupilha, tangidos pelas arbitrariedades e pela violência praticada pelos legalistas e estimulada pelos vínculos que os uniam aos gaúchos. (MOSIMANN, 2010, p. 217, grifo do autor).

Em 11 de março de 1838, os farroupilhas proclamam a República em Lages, passando o território lageano a integrar a República Rio-Grandense, ainda que por apenas dez dias. Uma das figuras marcantes durante a Revolução Farroupilha é Anita Garibaldi, personagem histórica cuja naturalidade envolve polêmica: seria ela natural de Lages (região serrana) ou de Laguna (região litorânea)? A origem lageana da heroína é defendida por alguns, com base no argumento de que ela

só poderia ser lageana, pois sua personalidade guerreira e corajosa a identificava prontamente com o temperamento da mulher lageana - que, na época da Revolução Farroupilha, tinha que aprender a se defender tanto de intempéries da natureza quanto de forasteiros. Nesse sentido, segundo tal argumentação, Anita não poderia ser lagunense, pois a mulher do litoral teria uma vida mais ligada ao mundo privado, menos hostil. (MARCON, 2009, p. 37).

Conforme Santos (2004), os pais de Anita moraram em Lages antes de se mudarem para Laguna, cidade em que Anita viveu. Como destaca Pimpão (2012), o relevante da discussão acerca da naturalidade dessa revolucionária, porém, reside na identificação do povo lageano com o perfil de uma heroína mais do que propriamente na precisão de sua cidade natal.

\subsubsection{Aspectos linguísticos}

Retomando alguns pontos: ao longo do século XVIII, havia em Santa Catarina dois movimentos praticamente simultâneos, porém sem comunicação entre si: enquanto no planalto catarinense a expansão interiorana se dava em torno do comércio de gado com a vinda de paulistas, no litoral a expansão do povoamento devia-se principalmente à política expansionista da Coroa portuguesa, com a chegada de um 
grande contingente de açorianos. Esses movimentos correspondem respectivamente aos ciclos paulista/vicentista e açoriano de ocupação do território catarinense.

Oliveira ilustra essa dualidade territorial com a seguinte passagem:

[...] Que tendo sido annexada há quatro annos a Villa de / Lages, e seu Districto, outrora pertencentes a São Paulo, / a esta Provincia, ainda hoje lhe He tão estranho aquelle / Disctricto, como d'antes, por falta de meyos de communi= / cação; pois que tendo se deixado obstruir, $\mathrm{e}$ fexar, senão / de propósito, ao menos pelo mais criminoso desleixo o $\mathrm{ca}=/$ minho que d'aquella Villa guiava ao Continente fronteiro / a esta Ilha; o qual tendo sido aberta em 1789 s[o se conser= / vou vadeável até 1806; as mui raras communicações q. / há entre aquelle Districto, e esta Provincia são com direção / pela Villa de Laguna, através d'espessas mattas ainda / virgens, infestadas de gentio indômito, e por hum caminho / asperíssimo, sendo preciso [ilegível] penoso trajecto atravessar / vinte vezes hum só Rio sem que haja Pontes, nem meyos / de passagem [...] (CORREA, A. R. C.; GESSER, M. S.; SILVA, L. C., 1995, doc. 22 apud OLIVEIRA, 2004, p. 69-70).

Os paulistas, também chamados de portugueses de São Paulo, traziam consigo a variedade paulista do português, difundindo-a pela região do planalto serrano catarinense, por Vacaria dos Pinhais e daí para o noroeste gaúcho (Passo Fundo, Carazinho, Cruz Alta (Santo Ângelo). Os açorianos, por sua vez, traziam a variedade açoriana, que, em Santa Catarina, ficou circunscrita ao litoral ${ }^{11}$ - variedades que influenciaram as expansões populacionais no Sul, mesmo as dos imigrantes alemães e italianos que vieram posteriormente e ajudaram a propagar essas variedades oriundas dos ciclos de penetração sobre a Região Sul, particularmente Santa Catarina. Oliveira se refere a essas variedades como "variedades em conflito" (OLIVEIRA, 2004, p. 63).

Seria, então, a variedade falada em Lages uma extensão da variedade paulista? A resposta a essa pergunta não é simples. Vejamos alguns aspectos envolvidos nessa questão. Do ponto de vista histórico, Lages se caracteriza

11 Segundo Oliveira (2004), os açorianos do Rio Grande do Sul, que tinham vindo para ocupar as Missões (região que passou a ser ocupada pelos paulistas), acabaram se estabelecendo no Porto dos Casais (hoje Porto Alegre), em Triunfo, Viamão, Rio Pardo, 
pelo povoamento paulista e, consequentemente, pelo uso da variedade linguística paulista, que circulava no caminho dos tropeiros (Sorocaba-SP, Curitiba-PR, Lages-SC, Vacaria e Passo Fundo-RS), no final do século XVIII e no século XIX. Considere-se também que houve uma leva representativa de gaúchos que se instalaram em Lages ainda à época dos tropeiros. Temos ainda notícia da presença de colonos alemães e italianos na região já a partir do final do século XIX e início do XX, respectivamente. Assim, nos termos de Reinecke: "A formação da variedade lageana esteve sujeita a influências de mistura de variedades brasileiras catarinenses, gaúchas, paulistas e até mineiras (pela influência tropeira), e também, [...] ao contato de línguas entre, principalmente, o português, o alemão e o italiano com outras variedades do Sul” (REINECKE, 2006, p. 80). Isso sem contar com a presença de índios e de negros na história do povoamento de Lages.

Ainda, como vimos na Tabela 2.4, a população de Lages dobra na segunda metade do século XX. Naturalmente, esses fatores de natureza sócio-histórica devem ter impactado a variedade linguística usada ao longo do tempo em Lages, especialmente se considerarmos a forte influência que a cultura gaúcha exerce na região.

Exemplifiquemos essa discussão de natureza linguística com o uso das formas de tratamento tu e você e respectiva concordância verbal na região litorânea e na região serrana.

Furlan $(1989$, p. 36) comenta que os açorianos que povoaram Santa Catarina possivelmente eram analfabetos e trouxeram uma cultura vinculada a práticas e valores dos séculos XV e XVI. Entende-se que, junto dos valores culturais conservadores, trouxeram também formas linguísticas como o /s/ palatalizado e os pronomes tu (para tratamento íntimo) e vós e vossa mercê (para tratamento respeitoso). [...]

Segundo os historiadores, até por volta de 1500, as duas únicas

Cachoeira e Santa Maria, expandindo-se ainda para o leste, ocupando Santo Antônio da Patrulha, Camaquã, Tramandaí, Mostardas e São José do Norte. Ainda de acordo com o autor, embora tanto os açorianos de Santa Catarina como os do Rio Grande do Sul tenham a mesma origem (o arquipélago dos Açores), eles têm pouca semelhança entre si: os primeiros são pequenos e magros, têm tez amarelada, alimentam-se de peixe e farinha de mandioca e vivem da pesca ou do trabalho da terra; os últimos são grandes e corpulentos, são mais brancos, alimentam-se de carne e vivem a cavalo, fazendo exercícios violentos (SAINT-HILAIRE, 1974 apud BERGER, 1990). 
maneiras de se dirigir ao interlocutor no português arcaico eram o tuteamento familiar $(t u)$ e o voseamento respeitoso (vós). Só por volta do final do século XVI é que as formas de vossa mercê começam a aparecer nos registros e já se encontram as variantes vocemecê, vancussê, vancê. Segundo Teyssier (1997, p. 89), "vossa mercê, ao mesmo tempo que passava a você por erosão fonética (vossa mercê > voacê $>$ você), perdia, por erosão semântica, o seu valor de tratamento respeitoso, para assumir o de tratamento familiar. O você familiar aparece desde o século XVII". Pelo que tudo indica, parece que essa mudança de tratamento não tinha afetado os açorianos quando vieram para o Brasil.

Por outro lado, paulistas que percorreram o caminho das tropas também deixaram suas marcas linguísticas no falar do catarinense, pela transmissão de traços como, por exemplo, o /r/ retroflexo e formas morfossintáticas como o pronome você. (COELHO; GÖRSKI, 2011, p. 268).

Menon e Loregian-Penkal (2002) registram que a implantação de você no sul do Brasil se deve à entrada dos paulistas a partir da segunda metade do século XVIII, atingindo primeiro Curitiba, passando pelo planalto catarinense (Lages) e chegando a parte do Rio Grande do Sul (Vacaria).

Oliveira defende que se trata de variedades trazidas por quem ocupou o território, descartando a hipótese de que a aquisição dessas formas pronominais tenha se propagado posteriormente em decorrência de outros fatores sociolinguísticos, e aponta para a possibilidade de uma estrutura de transição marcada por $t u f e z$ separando as áreas de vocêfez e tu fizeste. De acordo com o autor, o tu fez seria um fenômeno historicamente mais tardio e "o $t u$ foi levado a essas regiões, inclusive para o oeste catarinense, nos últimos anos do século XIX e já no século XX pelos imigrantes alemães e italianos que se deslocaram das já então esgotadas 'Colônias Velhas' em busca de novas terras para sua agricultura familiar” (OLIVEIRA, 2004, p. 84). Assim, o tu teria se expandido para regiões antes ocupadas por você, assim como tem avançado mais recentemente em algumas regiões do Mato Grosso, em áreas de colonização sulista. Oliveira (2004) estabelece, portanto, uma correlação estreita entre ciclos históricos de ocupação do território e variedades linguísticas. ${ }^{12}$

12 Para uma visão detalhada do uso de tu e você na Região Sul, conferir Loregian-Penkal (2004), que analisou o banco de dados de fala do VARSUL. Conferir também Koch; 
Voltando ao século XVIII: a colonização açoriana nas regiões litorâneas (especialmente Florianópolis) e a colonização paulista do planalto catarinense (especialmente Lages) começaram na mesma época - em meados do século XVIII. Como aponta Furlan (1989), junto dos valores culturais conservadores, os açorianos trouxeram também as formas pronominais $t u$ (para tratamento íntimo) e vós, Vossa Mercê (para tratamento respeitoso). Já a influência paulista pode ser verificada, por exemplo, no uso do pronome você por falantes catarinenses do planalto serrano. Assim, temos, de um lado, o uso típico de tu nas regiões litorâneas; e de outro, o uso de você, que ainda é encontrado majoritariamente na região do planalto serrano.

Mas questões ficam em aberto: será que o que se verificou em relação ao uso de tu e você também se verifica com outros fenômenos linguísticos? $\mathrm{Ou}$ seja, em que medida a participação de outras etnias na formação populacional de Lages ao longo do tempo influenciou a constituição da variedade linguística lageana?

\subsection{Blumenau: percurso sócio-histórico-cultural e aspectos linguísticos}

Tratamos, nesta seção, dos seguintes tópicos: a chegada dos alemães a Santa Catarina; a fundação e povoamento da colônia Blumenau; a inserção da língua portuguesa em Blumenau, considerando tanto fatores que favorecerem o uso do alemão como fatores que favoreceram o uso da língua portuguesa; e programas de nacionalização do ensino em áreas coloniais, focalizando a Reforma Orestes Guimarães e a Campanha de Nacionalização do ensino instituída por Getúlio Vargas.

\subsubsection{A chegada dos alemães a Santa Catarina}

O recurso à imigração estrangeira para ocupar o imenso território brasileiro já vinha sendo discutido desde 1808, na corte de Dom João VI, no Rio de Janeiro, e, com o casamento de Dom Pedro com a princesa

Altenhofen; Klassmann (2011), que analisaram dados do ALERS. As amostras datam do final do século XX. 
Leopoldina, da dinastia dos Habsburgos, começaram efetivamente as tratativas para trazer imigrantes alemães ao Brasil. Várias famílias alemãs que faziam parte da comitiva da princesa, a maioria associada a uma legião militar estrangeira, somadas a outras que vieram nos anos seguintes, deram início às cidades fluminenses de Petrópolis, Teresópolis e Nova Friburgo. Em julho de 1824, iniciou-se efetivamente a colonização alemã no Brasil, com a colônia (hoje cidade) de São Leopoldo-RS.

Santa Catarina, como vimos em seções precedentes, contava, no início do século XIX, com duas áreas de ocupação por falantes de português: i) o litoral - que era efetivamente governado pela província de Santa Catarina, abarcava, inicialmente, os povoados de São Francisco (1658), Desterro (1675) e Laguna (1676), tendo recebido depois um grande reforço demográfico com os imigrantes açorianos (chegados entre 1748 e 1756) que fundaram novas freguesias e cidades ao longo do litoral e nos estuários dos rios; e ii) o planalto serrano - que era governado, até 1820, pela província de São Paulo, responsável pela fundação de Lages em 1771. Entre o litoral e o planalto serrano, uma vasta área montanhosa, coberta por exuberante mata atlântica e habitada por índios decididos a defender seu território, dificultava a mobilidade e a comunicação entre Desterro e Lages.

Quando, em 1828, o governo imperial determinou à província de Santa Catarina que demarcasse uma área para instalar colonos alemães, a escolha recaiu em terras situadas ao longo do caminho São José-Lages, no vale do Rio Maruí (embora fosse uma área montanhosa, imprópria para a agricultura), pois o interesse primordial era melhorar esse caminho, a fim de integrar o planalto à província de Santa Catarina.

A colônia de São Pedro de Alcântara recebeu 694 imigrantes: 523 colonos embarcados em Bremen e 171 soldados (e familiares) da legião militar do Rio de Janeiro. Ainda nos primeiros meses de instalação da colônia, assumiu sua direção o ex-tenente João Henrique Soechting (casado com uma luso-brasileira do Rio de Janeiro), que tentou resolver o problema de lotes muito íngremes, levando algumas famílias de imigrantes ao alto vale do Rio Biguaçu, em áreas que hoje pertencem ao município de Antônio Carlos. Outro grupo de famílias foi realocado, alguns anos depois, em Vargem Grande, próximo a Santo Amaro da Imperatriz, às margens do Rio Cubatão e de um novo traçado da estrada para Lages. Em 1835, outras famílias foram realocadas em Pocinhos e Belchior, hoje 
Gaspar, no Vale do Itajaí, incluindo militares da legião estrangeira que vieram a integrar a Companhia de Pedestres sob o comando do major Henrique Etur.

O governo provincial continuou seu programa de povoamento estabelecendo novas colônias na região. Em 1847, fundou a colônia Santa Izabel, ao longo do novo caminho para Lages, passando por Rancho Queimado e Taquaras. Seguiu-se a instalação da colônia militar de Santa Teresa, no atual município de Alfredo Wagner, em 1853 e da colônia de Teresópolis em 1860, no alto vale do Rio Cubatão.

\subsubsection{A colônia Blumenau: fundação e povoamento}

Em 1846, Hermann Bruno Otto Blumenau embarcou para o Brasil com o objetivo de visitar as colônias alemãs do Rio Grande do Sul e de Santa Catarina e de selecionar uma área para implantar uma colônia de imigrantes alemães. Em 1848, conseguiu uma concessão de terras às margens do Rio Itajaí-Açu a partir da foz do Rio Garcia. Somente em 2/9/1850 chegaram os primeiros 17 imigrantes, a bordo de um veleiro que levou 72 dias para fazer a travessia.

Até o final da década, em 1860, somente 947 imigrantes tinham se estabelecido na colônia Blumenau, cujo diretor estava passando por sérios problemas financeiros devido aos altos custos das passagens, à demarcação de lotes e aos adiantamentos para os imigrantes até a primeira colheita. Em viagem ao Rio de Janeiro, ele conseguiu junto ao governo imperial um novo contrato: devolvia a concessão de terras, ficava na direção da colônia e recebia subsídios para custear a vinda de novos imigrantes - condições que lhe permitiram aumentar sensivelmente a entrada de novos imigrantes. No final da segunda década, em 1870, a colônia Blumenau já contava com mais de 6.000 habitantes, distribuídos em 1.230 famílias.

A partir de 1870, com a unificação alemã após a Guerra FrancoPrussiana, houve restrições para a emigração de cidadãos alemães para o Brasil, o que ocasionou uma diminuição drástica na entrada de imigrantes na colônia e levou seu diretor a escrever ao imperador austríaco solicitando imigrantes, com a expectativa de receber falantes de alemão. O imperador, contudo, enviou trentinos, falantes de italiano (Trento pertenceu à Áustria até a Primeira Guerra Mundial), e poloneses da Silésia, também parte de seu império. Os poloneses foram instalados em áreas ainda não colonizadas 
do Rio Benedito e os trentinos e outros italianos chegados a partir de 1875, nos atuais municípios catarinenses de Rodeio, Ascurra, Rio dos Cedros e Rio do Sul.

Com o retorno de Hermann Blumenau à Alemanha em 1880, sua colônia passou ao regime comum, deixando de receber subsídios para a fixação de imigrantes. Paralelamente, a colônia Blumenau foi elevada a município, desmembrando-se de Itajaí, tendo como território toda a área da colônia e o distrito de Belchior (hoje Gaspar). Apenas em 1882 foram realizadas eleições para a Câmara Municipal, sendo que seu governo só se instalou em janeiro de 1883 - atraso devido à grande enchente de 1880, que trouxe enormes prejuízos a toda a área do Vale do Itajaí.

Blumenau e seu enorme território com $12.181 \mathrm{~km}^{2}$ contava, à época, com 16.380 habitantes. Tinha recebido até então 10.256 imigrantes: 7.491 alemães, 79 suíços, 262 austríacos (sendo ao todo 7.836 falantes de alemão), 2.240 trentinos e italianos, além de belgas, poloneses, húngaros e irlandeses. Segundo o historiador José Ferreira da Silva, em 1882 apenas 1.567 lusobrasileiros são mencionados. Do total de habitantes, 8.475 eram homens e 7.905 eram mulheres; $61,5 \%$ dos habitantes se declararam evangélicoluteranos e 38,5\%, católicos (SILVA, 1972). Os dados estatísticos desse ano apresentam também uma descrição da economia da colônia: 12\% da população já estava engajada em atividades industriais, incluindo oito cervejarias, malharias, fábricas de carroças, móveis etc. Os 152 engenhos de farinha, copiados da cultura açoriana, evoluíram para estabelecimentos industriais movidos a água, com diversificação de matéria-prima (araruta e batata), produzindo farinha de mandioca, polvilho, fécula, sagu etc. e passando a ser chamados "fecularias", na primeira metade do século $\mathrm{XX}$.

A área da colônia Blumenau (sem considerar o distrito de Gaspar, colonizado por colonos de São Pedro de Alcântara) já contava, em 1882, com $6.481 \mathrm{~km}^{2}$ colonizados, restando ainda $5.700 \mathrm{~km}^{2}$ para serem demarcados no Alto Vale do Itajaí. O estado de Santa Catarina passou, então, a contratar companhias de colonização nacionais ou estrangeiras para povoar aquelas terras. Dessa forma, desde 1882 (data da criação do município) até 1934 (término da imigração estrangeira organizada), Blumenau recebeu 20.733 imigrantes estrangeiros, sendo 11.858 alemães (SILVA, 1972). Blumenau foi por muitos anos o município mais populoso do estado. Em 1920, contava com 72.213 habitantes, seguido de Joinville, com 42.852, de Florianópolis, 
com 41.338, e de Lages, com 31.500 habitantes (dados do IBGE). Hoje, Blumenau é o terceiro município mais populoso do estado, com mais de 300.000 habitantes.

\subsubsection{A inserção da língua portuguesa em Blumenau}

A aprendizagem do português pelos imigrantes alemães e seus descendentes foi um caminho longo e difícil. Inúmeros fatores sociais foram responsáveis pela manutenção do alemão e pelo fraco desempenho no uso do português nas primeiras décadas. $\mathrm{O}$ alemão falado pelos blumenauenses foi enriquecido com empréstimos do português para se adaptar às novas situações culturais. Exemplos desses empréstimos podem ser encontrados nos estudos pioneiros de Willems (1946) e de Fausel (1959).

Um diagnóstico acerca da competência linguística em língua portuguesa no recém-criado município de Blumenau foi obtido na eleição da Câmara de Vereadores em 1882. Somente 49 blumenauenses se consideraram falantes de português, preenchendo os requisitos para votar e ser votado: "Os poucos com direito de exercer a cidadania política, uma elite de eleitores blumenauenses, formada de 49 senhores que sabiam falar o português elegeram os primeiros vereadores" (SIMÃO, 2000, p. 19). Deve-se observar, entretanto, que a maior parte da população urbana de Blumenau conseguia se comunicar em português, quando necessário, mas com problemas de interferência fonológica. Na história da inserção da língua portuguesa em Blumenau, devem ser considerados diferentes fatores sociais que atuaram ora a favor da manutenção do alemão, ora a favor da aprendizagem do português.

2.5.3.1 Fatores que favoreceram o uso da língua alemã

O isolamento geográfico das comunidades de imigrantes dificultava contatos com falantes de português. A colônia transformou-se em uma ilha linguística, com redes de comunicação quase exclusivas em língua alemã. As lideranças religiosas (com pastores e padres alemães) incentivavam o uso do alemão na família, nas escolas e nos encontros sociais. Da mesma forma, os imigrantes recém-chegados criticavam falares com empréstimos e alternâncias entre alemão e português. 
A língua do sistema escolar era o alemão. Mesmo nas escolas públicas abertas em Blumenau em 1855 e 1864, os professores eram alemães e o ensino era feito "simultaneamente" em alemão e português. Em 1903, na administração de Alvin Schrader, das 112 escolas existentes no município, somente quatro eram públicas e supostamente ministravam o ensino em português; cinco estabelecimentos particulares ministravam aulas em alemão e português, quatro em alemão e polonês, um em italiano e alemão, 17 em áreas de colonização italiana ou polonesa não tinham ensino em alemão e os outros 81 ensinavam exclusivamente em alemão.

O primeiro estabelecimento de ensino médio, o Colégio São Paulo, foi criado em 1877 pelo vigário de Blumenau e era também frequentado pela comunidade luterana. A língua de ensino era o alemão, mas as disciplinas de Língua Portuguesa, Geografia e História do Brasil faziam parte do currículo. Em 1892, padres franciscanos da Ordem dos Frades Menores assumiram a paróquia, e o colégio passou a chamar-se Colégio Santo Antônio. Além de criarem novos cursos no colégio, os padres fundaram um seminário para a formação de padres brasileiros. A partir de 1911, mantiveram um curso complementar e um curso normal para a formação de professores bilíngues a fim de prover as escolas paroquiais das áreas de colonização estrangeira da diocese de Florianópolis de profissionais habilitados. Em 1889, a comunidade luterana também fundou sua escola confessional de ensino médio: a "Neue Schule" ou Escola Nova, dirigida pelo pastor Hermann Faulhaber. Essa escola tinha em seu corpo docente os professores Fritz Müller, Rudolf Damm, Georg August Büchler e Carlos Jürgens, que se envolveram na produção de materiais didáticos em língua alemã para uso nas escolas particulares. Oferecendo um currículo e programas semelhantes aos da escola alemã, essa escola conseguiu a equivalência com cursos congêneres da Alemanha, o que dava a seus alunos possibilidades de acesso ao sistema universitário alemão.

Em 1895, foi fundado o Colégio Sagrada Família pelas Irmãs da Divina Providência, de Münster, Alemanha, ofertando ensino primário, ginasial e normal, bem como internato para moças do interior do município e também do litoral e do planalto. Oferecia, inicialmente, ensino em alemão, depois de 1911 em alemão e português e somente em português a partir de 1937. 
Até 1911, o ensino usando o alemão como língua de instrução foi dominante em Blumenau. Entre 1911 e 1937 o português fez um enorme avanço como língua de instrução, mas o alemão ainda era a língua em que os blumenauenses tinham maior competência.

Outro fator importante em relação à língua foi o papel da imprensa. Os jornais, até 1926, eram escritos em língua alemã: Blumenaer Zeitung, fundado em 1881, e Immigrant, fundado em 1883 (que passou a chamarse Urwaldsbote em 1893, sob nova direção). Merece menção a revista pedagógica ligada à Associação de Escolas Alemãs de Santa Catarina: Mitteilungen $($ de mit teilen $=$ compartilhar = compartilhamentos), com publicações mensais de 1906 a 1918. O progresso econômico e a produção literária e pedagógica veiculada por esses meios de comunicação deram a Blumenau o status de centro da cultura germânica no estado nas primeiras décadas do século XX.

2.5.3.2 Fatores que favoreceram a inserção definitiva da língua portuguesa

A participação em atividades políticas a partir de 1882 fez com que mais blumenauenses procurassem aperfeiçoar seu português para poderem se candidatar à Câmara Municipal. Com o crescimento comercial e industrial e a passagem a comarca, Blumenau atraiu advogados, médicos e funcionários estaduais que começaram a interagir com as lideranças locais, mudando atitudes e valores em relação ao uso do português.

A política linguística do episcopado católico era favorável a um ensino esmerado do português na formação de seus padres e mesmo ao ensino do português e seu uso pelos padres estrangeiros. Também priorizava o ensino do português nas escolas paroquiais criadas depois da proclamação da República. Em Blumenau, os padres católicos atendiam falantes de diferentes línguas em suas paróquias: de alemão, italiano, polonês e português. Se todos os fiéis soubessem a língua nacional, o atendimento poderia ser facilitado. Tanto Dom João Becker, primeiro bispo de Santa Catarina, como Dom Joaquim Domingues de Oliveira, seu sucessor, defendiam o ensino do português nos seminários e em todas as escolas e colégios confessionais.

As mudanças no sistema de ensino, a partir de 1911, começam a direcionar o vento a favor do português, quando o governo provincial passa 
a investir na educação, com um plano objetivo de inserção do português nas áreas de colonização estrangeira, através de programas de nacionalização do ensino.

\subsubsection{Programas de nacionalização do ensino nas áreas coloniais}

Como vimos na seção precedente, a presença do governo na educação nas áreas de colonização era mínima. E é preciso salientar que não era discriminatória em relação aos filhos de imigrantes. O litoral e o planalto também eram mal atendidos, com poucas escolas e altos índices de analfabetismo. Houve muitas promessas nos primeiros governos republicanos e tentativas de reformas em governos estaduais. A primeira reforma que efetivamente teve resultados ocorreu somente em 1911, no governo de Vidal Ramos, que trouxe de São Paulo uma equipe de especialistas em educação.

\subsubsection{A Reforma Orestes Guimarães}

Em 1911, o diretor da Instrução Pública, professor Orestes Guimarães, introduziu o ensino obrigatório do português nas escolas étnicas, através de reforma educacional que leva seu nome - Decreto $\mathrm{n}^{\circ}$ 585, de 19 de abril de $1911 .{ }^{13}$ Além disso, essa reforma propunha a criação de escolas públicas nas áreas de colonização estrangeira, recomendando medidas que levariam os descendentes de imigrantes a uma assimilação gradual da língua portuguesa, entre elas: i) introdução do ensino obrigatório de Língua Portuguesa nas escolas étnicas e o ensino das disciplinas de Geografia e História do Brasil obrigatoriamente em língua portuguesa; ii) preparação de professores para as áreas de colonização estrangeira, tornando o alemão ou o italiano disciplinas obrigatórias no currículo das escolas normais para quem quisesse atuar nessas áreas (AURAS, 2005); iii) criação de grupos escolares e escolas públicas com professores bilíngues, especialmente para as séries iniciais; e iv) aplicação de exames de habilitação aos professores de escolas particulares para a

13 Os decretos citados ao longo do capítulo são da Coleção de decretos, leis e portarias, publicada pela Imprensa Oficial de Santa Catarina, nos respectivos anos. 
comprovação de conhecimento da língua portuguesa, feitos por autoridades educacionais.

Por outro lado, a reforma deixava certa liberdade às escolas particulares, como verificamos no Art. 129 do Decreto no 794/1914: "O ensino particular poderá ser exercido livremente, salvo quando for subsidiado pelos cofres públicos, quer estaduais, quer municipais. Neste caso, deve ser ministrado sempre em língua vernácula”. Em vários pronunciamentos e relatórios, Orestes Guimarães reafirmou a necessidade de que os professores em escolas coloniais conhecessem a língua materna dos alunos, especialmente nas classes de alfabetização. A introdução da língua alemã ou italiana como disciplinas da Escola Normal ou em cursos complementares visava sanar essa dificuldade (AURAS, 2005). Apesar dos esforços de seu idealizador, o número de professores habilitados ficou muito aquém das necessidades. Como as limitações financeiras não permitiam expandir o ensino público para substituir as escolas particulares que dominavam as áreas coloniais, a solução encontrada foi oferecer subsídios a essas escolas, em troca da habilitação dos professores (através de exames) e da oferta das disciplinas exigidas na legislação. Não obstante as fortes críticas que o plano de reforma do ensino recebeu a partir de 1917 - época em que o Brasil declarou guerra à Alemanha e Áustria -, Orestes Guimarães manteve-se convicto de que sua estratégia não podia sofrer com o clima de agitação patriótica que criava animosidade contra os alemães e que levou ao fechamento de escolas e à prisão de professores. No prefácio de seu relatório de 1918, rebate críticas e comentários maldosos da imprensa e defende sua política de manter o ensino de alemão e italiano nas escolas normais e cursos complementares:

O estado de guerra actual não modificou o problema pedagógico: a língua, as tendências e os hábitos continuam a ser os mesmos nos aludidos centros. [...] Si, para ensinar o portuguez a quem só fala o alemão, o professor tem necessidade de conhecer esta última língua, bem é que se conserve nos programas da escola normal e escolas complementares o ensino do alemão, não obstante o jacobino modo de pensar dos que entendem que apprender uma certa e determinada língua é homenagear a nação que a fala! (GUIMARÃES, 1918 apud LUNA, 2000, p. 45). 
Percebe-se que a nacionalização do ensino proposta em 1911 estava voltada para a assimilação linguística dos filhos de imigrantes, através do ensino gradual e sistemático em língua portuguesa. Com um maior domínio dessa língua, os alunos, em poucos anos, apresentariam preferência pelo uso do português, principalmente aqueles que desejassem ampliar sua escolaridade.

A Reforma Orestes Guimarães apresentou resultados positivos para a inserção da língua portuguesa em Blumenau. A cidade recebeu o novo Grupo Escolar Luiz Delfino, inaugurado em 1913, algumas escolas nos distritos do interior do município e sediou a Inspetoria-Geral de Escolas Subvencionadas pelo Governo. Essa inspetoria fiscalizava as escolas particulares que recebiam subsídios governamentais e se obrigavam a ensinar português (com mestre habilitado) e a ministrar, em língua portuguesa, as disciplinas de História, Geografia, Educação Cívica e Música e Cantos Patrióticos. Em 1925, mais de 50\% das escolas particulares de Blumenau recebiam subsídios do governo e seguiam o currículo e as diretrizes das leis estaduais. O governo distribuiu livros para incentivar a leitura em língua portuguesa e assim fazer concorrência aos jornais, revistas e livros em língua alemã. Em 1926, começou a ser editado o primeiro jornal em língua portuguesa - Cidade de Blumenau -, oferecendo material diário de leitura aos aprendizes de português.

A legislação que amparava essa política linguística vigorou formalmente até 1936, mas perdeu força com o afastamento de Orestes Guimarães da Diretoria de Instrução Pública em 1930 (início do governo revolucionário de Getúlio Vargas) e com a sua morte no ano seguinte. Os resultados positivos dessa reforma são apontados, entre outros, por Fiori (1991), mas uma avaliação específica de seus resultados nas áreas de colonização estrangeira, em diferentes comunidades, ainda precisa ser feita.

\subsubsection{A Campanha de Nacionalização (1937-1947)}

O segundo programa de nacionalização do ensino foi a Campanha de Nacionalização instituída por Getúlio Vargas após o golpe de 1937, que levou o Brasil à ditadura do Estado Novo. O Decreto-Lei de 31 de março de 1938, baseado na Constituição de 1937 e na legislação federal, estabeleceu, entre outras, as seguintes medidas que afetaram a situação 
linguística das comunidades de imigrantes, incluindo Blumenau: i) uso exclusivo do português em todas as aulas dos cursos pré-primários, primários e complementares; ii) adoção de livros didáticos e de leitura aprovados oficialmente e organização de bibliotecas com obras nacionais; iii) uso exclusivo da língua nacional na escrituração de tabuletas, placas, cartazes, avisos, instruções e dísticos; iv) proibição de circulação de revistas, livros e jornais em língua estrangeira; v) proibição de ensino de línguas estrangeiras a menores de 14 anos; vi) exigência de nacionalidade brasileira e de habilitação pela autoridade educacional para professores; e vii) hasteamento e homenagem à bandeira nacional nas salas de aula, com declamação de textos patrióticos e canto de hinos oficiais.

Com essas medidas legais, as escolas particulares étnicas - alemãs, italianas, polonesas etc. - foram fechadas e nem sempre substituídas por escolas públicas, dada a dificuldade de encontrar professores habilitados. De acordo com a legislação em vigor, em todos os grupos escolares deveriam funcionar associações escolares consideradas complementares e auxiliares no processo de nacionalização do ensino: Biblioteca Escolar, Jornal Escolar, Clube Agrícola, Pelotão de Saúde e Liga Pró-Língua Nacional. Esta última era formada pelos alunos de classes mais avançadas que se ocupavam em ensinar português aos iniciantes contando pequenas histórias, traduzindo vocábulos e levando-os a tentarem a comunicação em língua portuguesa. Em entrevista a Jaecyr Monteiro, o inspetor escolar José dos Santos Areão apontou os seguintes benefícios das Ligas Pró-Língua Nacional:

a) Os alunos do curso complementar e das quartas séries do curso primário foram inseridos no contexto, responsabilizando-se por uma tarefa, dentro da política nacionalizadora do Estado novo. b) Os alunos líderes puderam ter uma maior participação na vida da escola, despertando o senso de responsabilidade e o amor pelas coisas do Brasil. c) Os alunos do Primeiro Ano Primário foram mais facilmente integrados à vida da escola. Estas crianças eram acompanhadas nos recreios com carinho e dedicação pelos alunos mais velhos e isso teve grande influência no aprendizado da língua nacional. d) Despertou-se o gosto pela leitura nos alunos, estimulando-os a escreverem cartas aos colegas de outras cidades e conhecerem vultos de nossa história e a valorizá-los por tudo aquilo que fizeram pelo Brasil. (MONTEIRO, 1983, p. 101). 
Nas escolas isoladas, que serviam a comunidades onde o português era menos usado, as associações não puderam ser criadas e, consequentemente, a inserção do português teve menor sucesso. Mas, em áreas onde a Reforma Orestes Guimarães já havia colhido seus frutos, a intensificação do ensino do português foi bem-sucedida, pois os alunos já conseguiam se comunicar nessa língua.

Na colônia Hammonia - área do Vale do Itajaí que recebeu imigrantes de língua alemã até 1934 -, registraram-se grandes dificuldades, conforme analisado nas pesquisas de Albersheim (1962) e de Wiese (2003). Principalmente após a entrada do Brasil na Segunda Guerra Mundial contra a Alemanha, Itália e Japão, o clima de tensão social criado pela repressão ao uso do alemão, com a presença de tropas do Exército, não favorecia a aprendizagem do português pelas crianças, segundo os referidos autores. Em entrevistas com alunos daquela época, são descritas dificuldades por que passaram. Apenas para ilustrar, vejamos o que disse I. Z., entrevistada em julho de 2001:

Meu pai R. me tirou da escola. Eu não aguentei as humilhações impostas a nós. Eu não compreendia o que o professor falava. Se eu não compreendia como eu poderia aprender a língua brasileira? Nós até queríamos aprender, mas não era possível. Eu chorava todo o dia. $\mathrm{Na}$ escola alemã eu era uma aluna estudiosa e inteligente. Como eu não compreendia o brasileiro, não podia aprender. Então, meu pai me tirou da escola. (WIESE, 2002, p. 134).

Os depoimentos de outros entrevistados mostram a angústia de ficar quatro horas ouvindo o professor falar sem nada entenderem. É muito estranho que toda a pregação de Orestes Guimarães sobre a necessidade de professores bilíngues, principalmente em classes de alfabetização, tivesse sido esquecida.

Com o fim da guerra e da ditadura do Estado Novo, foram cessando, pouco a pouco, as tensões criadas nas áreas de colonização estrangeira. A liberdade de expressão permitiu a volta ao uso das línguas minoritárias, principalmente no ambiente familiar. Dessa forma, os dialetos alemães ou italianos passaram a funcionar nos contextos informais e o português assumiu o importante papel de uso em todos os contextos formais. Com a reforma do ensino de 1969, que elevou a escolaridade obrigatória para oito 
anos, a competência comunicativa em língua portuguesa passou a superar a competência nas línguas minoritárias, na maioria dos contextos sociais. Com a "nucleação de escolas" - concentração dos alunos do interior em escolas da sede dos municípios, através de transporte escolar -, o fator de isolamento geográfico que favorecia a manutenção das línguas minoritárias foi rompido, dando igual oportunidade de aprendizagem do português a todos os alunos.

\subsubsection{Revisitando os fatores sociais}

Um dos fatores apontados para a preservação do alemão em Blumenau foi o isolamento geográfico e a formação de uma ilha linguística em que o contato com o português era escasso e insuficiente para sua aprendizagem. Principalmente a partir da década de 1950, com um aumento notável no processo de industrialização, Blumenau recebeu trabalhadores do litoral, do planalto e de outros estados do Brasil. As redes de comunicação em português não só se tornaram possíveis, mas se tornaram obrigatórias nos contextos com os novos interlocutores que vieram morar em Blumenau.

Até a década de 1930, vários jornais eram editados em alemão porque essa era a língua de instrução da colônia, mas na Campanha de Nacionalização do ensino esses jornais foram fechados e boa parte dos livros em línguas minoritárias foi confiscada e destruída. Em seu lugar vão surgindo os jornais Cidade de Blumenau, A Nação e Jornal de Santa Catarina, entre outros, e sendo organizadas bibliotecas com livros majoritariamente em língua portuguesa. Emissoras de rádio e depois os canais de TV, exclusivamente em português, colocaram todos os blumenauenses e outros descendentes de imigrantes em contato constante com o português, ampliando a cada dia sua competência nessa língua.

Assinalamos que as lideranças religiosas - católicas e protestantes -, até por serem em sua maioria nascidas na Europa, estimulavam a manutenção das línguas maternas dos imigrantes. Com a formação de padres e pastores de nacionalidade brasileira, a posição em relação à manutenção do alemão se tornou menos radical entre os pastores protestantes e, com relação aos padres católicos, passou a haver um cuidado especial em sua formação para um bom desempenho na língua portuguesa. Atualmente, o Colégio Santo Antônio, dos padres franciscanos, é o que tem o melhor desempenho nos exames do ENEM no estado, há pelo menos três anos, 
mantendo sua liderança na cidade, mas agora usando somente o português como língua de instrução.

Todo o Vale do Itajaí é servido por boas escolas e instituições universitárias em que o português é a língua de instrução e é nessa língua que a quase totalidade da população tem o maior domínio na fala e na escrita, mostrando que ela está definitivamente inserida e é dominante na comunidade blumenauense.

O português falado na região de Blumenau apresenta ainda interferências do alemão e do italiano. A mais comum, tanto em descendentes de alemães como de italianos, é a falta de oposição entre a vibrante múltipla e o flap (vibrante simples), já analisada com dados de falantes de Blumenau do projeto VARSUL/SC (REINECKE, 2006). Em alguns falantes mais idosos ou de áreas rurais isoladas, encontramos ainda problemas na distinção entre consoantes surdas e sonoras e na realização fonética dos ditongos nasais. Com o aprimoramento do ensino da língua portuguesa, tais interferências das línguas minoritárias tendem a desaparecer.

\subsection{Chapecó: percurso sócio-histórico-cultural e aspectos linguísticos}

Nesta seção, apresentamos, de forma breve, uma síntese dos limites político-administrativos do Velho Chapecó passando pelo que hoje se constitui a região Oeste de Santa Catarina até chegar no atual município de Chapecó. Na sequência, traçamos o perfil da população chapecoense e sumarizamos um estudo que investigou um aspecto característico da língua falada na região, resultado do contato português com a língua de imigrantes europeus que colonizaram especialmente a Região Sul do Brasil.

\subsubsection{Do Velho Chapecó à região Oeste Catarinense: limites político-administrativos}

A presença humana na região Oeste Catarinense pode ser observada muito antes da Era das Grandes Navegações. Contudo, até a primeira metade do século XVIII, a definição dos limites político-administrativos da região passou por diversas disputas de fronteiras desde o Brasil Colônia. 
O território foi motivo de embate em, pelo menos, três momentos: primeiro entre as coroas espanhola e portuguesa, depois entre Brasil e Argentina e por fim entre Paraná e Santa Catarina, quando só então se definiu que a área pertencia ao estado catarinense.

A primeira disputa territorial se deu entre as colônias portuguesa e espanhola. A resolução do conflito ocorreu com a execução do Tratado de Madri, assinado em 1750, quando uma comissão mista transitou a região, nos anos de 1775 a 1777, e redesenhou os contornos geográficos que pertenciam às coroas portuguesa e espanhola. A demarcação reivindicada levou em conta rios ${ }^{14}$ e montanha para a definição das áreas de domínio de Portugal e da Espanha.

Posteriormente, após a declaração da Independência da Argentina e do Brasil, outra disputa pela demarcação de limites territoriais foi travada entre os dois países. Para segurança e garantia da posse brasileira da região contra o governo platino, foram instaladas duas colônias militares: “[...] o Decreto $\mathrm{n}^{\mathrm{0}}$ 2.502, de 6 de novembro de 1859, criava as Colônias Militares de Xapecó e do Chopim" (WAGNER, 2005, p. 19).

Em 1889, com a assinatura, em Buenos Aires, do Tratado de Arbitramento, mediante o juízo arbitral dos Estados Unidos, ficou definido que a fronteira entre os dois países seria fixada entre os rios PeperiGuaçu (que nasce no município de Dionísio Cerqueira, no extremo oeste catarinense, na fronteira Brasil-Argentina) e Santo Antônio (que nasce no município de Santo Antônio, no sudoeste paranaense, na fronteira Brasil-Argentina). Assim, grande parte do que hoje abrange todo o Oeste Catarinense incorporou-se ao território brasileiro definitivamente.

Já no início do século XX, o estado do Paraná, durante a Guerra do Contestado (1912-1916), também reivindicou os territórios pertencentes ao estado de Santa Catarina, que se estendiam por todo o planalto basáltico (Serra). Porém, em 3 de agosto de 1917, o então presidente do Brasil, Venceslau Brás Pereira Gomes, por meio do Decreto no 3.304, homologou o encerramento das disputas territoriais entre Paraná e Santa Catarina.

14 Os limites do que hoje abrange parte da região Oeste de Santa Catarina foram estabelecidos a partir do Rio Peperi-Guaçu (localizado na fronteira do Brasil com a Argentina), passando pelo Rio Chapecó (localizado na região do meio oeste de Santa Catarina) e pelo Rio Jangada (que banha os estados de Santa Catarina e do Paraná). 
A Lei $\mathrm{n}^{\mathrm{o}}$ 1.147, de 25 de agosto de 1917, definiu os limites entre os estados de Santa Catarina e do Paraná, passando definitivamente os municípios de Mafra (com $1.404 \mathrm{~km}^{2}$ ), Porto União (com 845,3 km²), Joaçaba (com 232,2 $\mathrm{km}^{2}$ ) e Chapecó (com $14.053 \mathrm{~km}^{2}$, à época) $)^{15}$ para a jurisdição catarinense.

Em 7 de setembro de 1917, Santa Catarina toma posse do seu território e o Velho Chapecó passa a ser oficialmente parte do estado. $\mathrm{Na}$ primeira metade do século XX, Chapecó representava 14,74\% do território de Santa Catarina, constituindo-se no maior município do estado, visto que abrangia toda a área do que é hoje a região Oeste Catarinense. A partir de 30 de dezembro de 1953, iniciaram-se os desmembramentos, criando-se os municípios de Dionísio Cerqueira, Itapiranga, Mondaí, Palmitos, São Carlos, Xanxerê e Xaxim.

Outras emancipações ocorreram no território de Chapecó de 1953 a 1992: "Em 1958, São Lourenço do Oeste e Campo Erê. Em 1961, [...] Coronel Freitas e Quilombo. Caxambu do Sul e Águas de Chapecó se emanciparam em 1962 [...]" (WAGNER, 2005, p. 72). Em 1991, ocorreu o desmembramento de Guatambu e de Itaberaba. Por último, em 1992, houve a emancipação de Cordilheira Alta. Assim, Chapecó ficou com um território de $626,06 \mathrm{~km}^{2}$, tendo desmembrado 17 municípios do Velho Chapecó; desses, "55 novos municípios foram desmembrados da $2^{\mathrm{a}}$ e $3^{\text {a }}$ geração, totalizando 72 dos 293 municípios de Santa Catarina que tiveram como origem Chapecó" (WAGNER, 2005, p. 72).

O espaço que hoje se estende de Dionísio Cerqueira (fronteira com a Argentina) a Joaçaba (antigo Cruzeiro) constituía um único município e foi conhecido, até 1917, como Velho Chapecó. Após os vários desmembramentos ocorridos a partir da década de 1950, passou a ser nomeado como a região Oeste de Santa Catarina, altualmente constituída por 118 municípios. Chapecó exerce hoje o papel de capital do Oeste Catarinense.

\subsubsection{Perfil da população chapecoense}

O perfil da população chapecoense tem sofrido transformações significativas decorrentes da história da ocupação da região ao longo dos

15 Os dados relativos à extensão territorial são do IBGE. 
séculos. Tem-se notícia de que as populações indígenas dos Xokleng e dos Kaingang foram os primeiros grupos nativos a se instalarem na região Oeste do estado. Segundo vestígios arqueológicos encontrados na bacia do Rio Uruguai, os Kaingang teriam chegado na região por volta de 5.500 a.C.

Até o fim do século XVII, o Oeste de Santa Catarina e o sudoeste do Paraná eram habitados por povos indígenas Guarani. Após a destruição das missões jesuíticas de Guaíra pelos bandeirantes paulistas, instalaram-se os Kaingang. Porém, Silva e Rosa destacam que

não se tem notícia de que tenha havido ali [no Oeste de Santa Catarina] aldeamentos indígenas organizados pela Companhia de Jesus nos séculos XVII e XVIII. Todavia, pode-se dizer que esse espaço territorial constituía-se senão como área de atuação (extração da erva-mate e criação de gado, por exemplo) pelo menos como área de influência das missões que existiram no seu entorno - Guaírá, Tapes, Sete Povos e outras estabelecidas a ocidente dos rios Paraná e Uruguai -, todas vinculadas à Diocese de Assunção no Paraguai. Ao longo do século XVII, atraídos por essas aldeias, vieram também os bandeirantes paulistas para capturar os indígenas e vendê-los como escravos nos mercados coloniais americanos. (SILVA; ROSA, 2011, p. 2).

Além da presença indígena na região Oeste, nos anos de 1552 e 1553, Ulrich Schmidl, militar alemão, percorreu a área seguindo o caminho indígena Peabiru ${ }^{16}$ a serviço do governo paraguaio e chegou ao Rio Peperi-Guaçu. Nessa época, jesuítas provenientes do Paraguai também incursionaram pela região. No século XVII, entre os anos de 1628 e 1630, grupos de bandeirantes paulistas estiveram na região à procura de minas de ouro e de índios. Há notícias de que mais de 60 mil índios foram capturados e levados para serem vendidos como escravos em São Paulo. No século XVIII, em 1720, a região foi percorrida pelo bandeirante paulista Zacarias Dias Cortes e, em 1736, pelo major José de Andrade Pereira.

Mais tarde, em 1838, outra expedição de bandeirantes seguiu a oeste para a colonização da região, tendo chegado até os Campos do Erê, onde

16 Trata-se de uma antiga trilha de cerca de três mil quilômetros, utilizada pelos povos nativos que viviam no continente americano. Servia de ligação entre a cidade de Cusco, no Peru, e a região da antiga capitania de São Vicente-SP, no Brasil (ARAÚJO, 2011). 
atualmente está localizado o município de Campo Erê. Num primeiro momento, houve a ocupação dos chamados Campos de Palmas, ${ }^{17}$ com a formação de 37 fazendas, cujo centro era a vila de Palmas. Porém, num segundo momento, devido ao número elevado de pessoas interessadas na ocupação de Palmas, muitos decidiram se instalar na região Oeste.

Além da ocupação de bandeirantes, o processo de colonização do Oeste Catarinense também implicou, entre outros aspectos, "[...] o desalojamento de caboclos ${ }^{18}$ e dos indígenas das terras que por longos anos ocuparam" (RADIN, 2003, p. 22).

Após a assinatura do Acordo de Limites entre os Estados de Santa Catarina e do Paraná, em 1916, os indígenas e caboclos que habitavam a região Oeste foram, aos poucos, expropriados de suas terras pelas companhias colonizadoras, a partir da década de 1920 (RENK, 2006).

A chegada dos colonos brancos imigrantes, hoje conhecidos como "Pioneiros" ou "Desbravadores" (BELLANI, 2006, p. 74), “[...] é um fenômeno relativamente recente [...]” (RADIN, 2003, p. 21).

A migração de descendentes de imigrantes italianos e alemães vindos, principalmente, das velhas colônias do Rio Grande do Sul para o Oeste de Santa Catarina se intensificou a partir das primeiras décadas do século XX. Mais especificamente com a assinatura do Acordo de Limites entre os Estados de Santa Catarina e do Paraná, em 1916, é iniciada uma política sistemática de incentivos do governo estadual para a colonização imediata de grandes áreas no Oeste Catarinense.

A extração da madeira da região por migrantes oriundos do estado gaúcho também impulsionou o processo de colonização do Oeste Catarinense. As cheias constantes do Rio Uruguai serviram de caminho para o escoamento de madeira, por meio de balsas, para a Argentina, o que, de um lado, resultou em "[...] um desbravamento, ao mesmo tempo intensivo e extensivo, de toda a região" (ROSSETTO, 1989, p. 261). Por outro lado, a cultura do milho, associada à criação de suínos, abriu perspectivas definitivas para a região se firmar como área fornecedora de alimentos. Nesse sentido, em 1950, ocorreu a formação das primeiras agroindústrias

17 Os documentos oficiais referem-se, de fato, a toda a região Oeste Catarinense quando mencionam Palmas.

18 O termo "caboclo" designa a população mestiça luso-brasileira existente na região no contexto da colonização (RADIN, 2003, p. 22). 
- a Indústria e Comércio Chapecó (Saic) foi uma das primeiras -, atraindo vários imigrantes. Em 1956, com o objetivo de industrializar a carne suína, surgiu o frigorífico Indústria e Comércio Marafon Ltda., atual Cooperativa Central Oeste Catarinense (Aurora).

Em termos populacionais, antes do Acordo de 1916, “a população de Santa Catarina era de 560.000 habitantes; após o Acordo, passou para 600.000 habitantes, segundo Piazza (1982). Ou seja, estimava-se a população da área incorporada ao estado, em 1916, de aproximadamente 40.000 pessoas" (SILVA; ROSA, 2011, p. 148).

O recém-criado município de Chapecó foi incluído no censo demográfico de 1920 estimando sua população em 11.315 habitantes, entre os quais 543 eram estrangeiros (441 argentinos, 68 paraguaios, 12 italianos, 8 uruguaios, 5 alemães, 3 turcos, 3 poloneses, 1 austríaco, 1 espanhol e 1 suíço). Esse contingente de argentinos e paraguaios na região evidencia "não só a permeabilidade das fronteiras entre o Brasil e os países vizinhos, mas também os interesses econômicos (principalmente a erva-mate e a madeira) desses grupos na região" (SILVA; ROSA, 2011, p. 149).

A evolução populacional de Chapecó pode ser conferida na Tabela 2.5.

Tabela 2.5 - Evolução populacional de Chapecó (1980-2010)

\begin{tabular}{c|c|c|c}
\hline Ano & Chapecó & Santa Catarina & Brasil \\
\hline 1980 & 83.772 & 3.627 .933 & 119.002 .706 \\
\hline 1991 & 123.050 & 4.541 .994 & 146.825 .475 \\
\hline 1996 & 129.794 & 4.844 .212 & 156.032 .944 \\
\hline 2000 & 146.967 & 5.356 .360 & 169.799 .170 \\
\hline 2007 & 164.803 & 5.866 .252 & 183.987 .291 \\
\hline 2010 & 183.530 & 6.248 .436 & 190.755 .799 \\
\hline
\end{tabular}

Fonte: IBGE: Censo Demográfico 1980, 1991, 2000, 2010 e Contagem Populacional 1996, 2007.

\subsubsection{Chapecó: aspectos linguísticos}

A reconstrução do contexto sócio-histórico revela que Chapecó, desde a sua constituição, vivenciou intensos fluxos migratórios, formando redes de contato linguístico diversificadas, em que se destacam diferentes 
formações étnicas, como as populações indígenas Guarani e Kaingang, os paulistas em sua marcha rumo ao sul do Brasil e os descendentes de imigrantes ítalo-brasileiros e alemães vindos de antigas colônias do Rio Grande do Sul, bem como os de poloneses provenientes de colônias do Paraná. Também no Oeste Catarinense, evidencia-se o contato do português e do espanhol na região de fronteira do Brasil com a Argentina. Chapecó configura-se, portanto, como área rica em dados linguísticos não só do português, mas também de línguas faladas por diferentes grupos étnicos que se instalaram na região ao longo dos séculos.

As comunidades monolíngues e bilíngues na região de fronteira com a Argentina assim como as áreas de manutenção das línguas de matrizes indígenas, africanas e europeias se constituem em campo bastante fértil para a realização de estudos linguísticos. Contudo, relativamente poucos trabalhos de descrição linguística com dados de fala ou de escrita de sujeitos do município de Chapecó têm sido realizados. A título de ilustração, levantamos algumas dissertações de mestrado concluídas concernentes à descrição e análise de fenômenos em variação de diferentes níveis linguísticos (HAUSEN, 2000; DAL MAGO, 2001; SPESSATTO, 2001, 2003; TAMANINE, 2001; MARTINS, 2003; ARDUIN, 2005; WIEDEMER, 2008) e três teses de doutorado (MARGOTTI, 2004; LOREGIAN-PENKAL, 2004; ROST SNICHELOTTO, 2009). ${ }^{19}$ A instalação da Universidade Federal da Fronteira Sul na cidade de Chapecó em 2010 e a criação do Programa de Pós-Graduação em Estudos Linguísticos (Mestrado) em 2012 já impulsionaram, até o momento, a produção de seis novas dissertações e um trabalho de conclusão de curso com base em amostras de fala e de escrita da região.

Spessatto $(2001,2003)$ aponta que também em Chapecó o sistema escolar foi o grande fator social para levar a população local à aprendizagem e uso do português. A comunidade de descendentes de italianos residente no município, assim como os demais imigrantes estrangeiros que viviam no Brasil na década de 1930, enfrentou a Campanha de Nacionalização (cf. 2.5.4.2), que punia rigorosamente os falantes de outras línguas que não o português. Dessa forma, sob imposição governamental, os descendentes

19 As dissertações e as teses de Loregian-Penkal e de Rost Snichelotto foram realizadas com amostras do VARSUL e a tese de Margotti, com amostras de fala coletadas pelo próprio autor. 
de italianos assimilaram a língua portuguesa, sem deixar de lado os dialetos trazidos pelos antepassados, que tiveram algumas especificidades fonológicas mantidas na fala em português.

No capítulo seguinte, Spessatto et al. retomam e ampliam a contextualização de Chapecó e exploram aspectos do contato linguístico do italiano com o português.

\subsection{Considerações finais}

Neste capítulo, apresentamos uma visão panorâmica do contexto sócio-histórico, geográfico, político e cultural do estado de Santa Catarina a partir do século XVI, focalizando as cidades de Florianópolis, Lages, Blumenau e Chapecó. Foram considerados, entre outros, os seguintes aspectos: a localização, fundação e povoamento dessas localidades; a diversidade étnica que as constitui (indígenas, portugueses/açorianos, africanos, alemães, italianos e também poloneses); a configuração sociodemográfica atual; e aspectos linguísticos, incluindo a influência das variedades paulista e açoriana, a inserção da língua portuguesa nas regiões de colonização alemã e italiana e políticas linguísticas associadas a isso, bem como menção a fenômenos linguísticos variáveis particulares. Abrindo esta coletânea, as informações aqui reunidas funcionam como pano de fundo para contextualizar os capítulos a seguir.

\section{Referências}

ALBA, R. S. Espaço urbano: os agentes da produção em Chapecó. Chapecó: Argos, 2002.

ALBERTSHEIM, U. Uma comunidade teuto-brasileira (Jarim). Rio de Janeiro: INEP, 1962.

ARAÚJO, F. Caminho do Peabiru. Disponível em: http://www.historiabrasileira. com/brasil-pre-colonial/caminho-do-peabiru/. Acesso em: 4 set. 2020.

ARDUIN, J. A variação dos pronomes possessivos de segunda pessoa do singular teu/seu na Região Sul do Brasil. 2005. 124 f. Dissertação (Mestrado em Linguística) - Programa de Pós-Graduação em Linguística, Universidade Federal de Santa Catarina, Florianópolis, 2005. 
AURAS, G. M. T. “Uma vez normalista sempre normalista”. A presença do método de ensino intuitivo ou lições de coisas na construção de um habitus pedagógico (Escola Normal Catarinense 1911-1939). 2005. 290 f. Tese (Doutorado em Educação) - Programa de Pós-Graduação em Educação, Universidade Federal do Paraná, Curitiba, 2005.

BAVARESCO, P. R. Ciclos econômicos regionais: modernização e empobrecimento no extremo oeste catarinense. Chapecó: Argos, 2005.

BELLANI, E. M. Balsas e balseiros no Rio Uruguai (1930-1950). Cadernos do CEOM: 20 anos de memórias e histórias no oeste de Santa Catarina, Chapecó, v. 19, n. 23, p. 73-97, 2006. Disponível em: http://bell.unochapeco.edu.br/revistas/ index.php/rcc/issue/view/141. Acesso em: 14 mar. 2021.

BLOEMER, N. M. S. Brava gente brasileira: migrantes italianos e caboclos nos Campos de Lages. Florianópolis: Cidade Futura, 2000.

BOITEUX, L. A. Notas para a história catharinense. Florianópolis: Livraria Moderna, 1912.

BRANCHER, A.; AREND, S. M. F. (org.). História de Santa Catarina: séculos XVI a XIX. Florianópolis: Editora da UFSC, 2004.

CABRAL, O. R. História de Santa Catarina. Florianópolis: Lunardelli, 1970.

CARDOSO, P. de J. F. Em busca de um fantasma: as populações de origem africana em Desterro, Florianópolis, de 1860 a 1888. PADÊ: estudos em filosofia, raça, gênero e direitos humanos - UniCEUB, v. 2, n. 1, 2007. Disponível em: http://publicacoesacademicas.uniceub.br/index.php/pade/article/ viewFile/143/132. Acesso em: 18 ago. 2020.

CASTELLO BRANCO, J. de S. Alemães em Lages: uma trajetória de conflitos e alianças guardadas pela memória. 2001. 177 f. Dissertação (Mestrado em História) - Programa de Pós-Graduação em História, Universidade Federal de Santa Catarina, Florianópolis, 2001.

COELHO, I. L.; GÖRSKI, E. M. A variação no uso dos pronomes tu e você em Santa Catarina. In: COUTO, L. R.; LOPES, C. R. dos S. (org.). As formas de tratamento em português e em espanhol: variação, mudança e funções conversacionais. Niterói: Editora da UFF, 2011. p. 263-287.

COSTA, A. F. da; BOITEUX, J. A. A viagem de 1929: oeste de Santa Catarina documentos e leituras. Chapecó: Argos, 2005.

COSTA, L. O continente das Lagens: sua história e influência no sertão da terra firme. v. 1, 2, 3 e 4. Florianópolis: Fundação Catarinense de Cultura, 1982.

DALLABRIDA, N. O colégio jesuítico da vila do Desterro e a expansão portuguesa no Atlântico Sul. Revista Lusófona de Ciência das Religiões, Lisboa, ano 7, n. 13/14, p. 527-538, 2008. 
DAL MAGO, D. Quer dizer: percurso de mudança via gramaticalização e discursivização. 2001. 142 f. Dissertação (Mestrado em Linguística) - Programa de Pós-Graduação em Linguística, Universidade Federal de Santa Catarina, Florianópolis, 2001.

DE HARO, M. A. P. (org.). Ilha de Santa Catarina: relato de viajantes estrangeiros nos séculos XVIII e XIX. 4. ed. Florianópolis: Editora da UFSC, Lunardelli, 1996. DIONÍSIO, A. C. Litterarios e recreativos: as primeiras reportagens sobre cultura nos jornais de Desterro (1850-1890). In: SIMPÓSIO NACIONAL DE HISTÓRIA, 23., 2005, Londrina. Anais [...]. Londrina: ANPUH, 2005. CD-ROM.

ESPÍNDOLA, A. M. Domingos e Domingas: escravidão e liberdade na Freguesia de Nossa Senhora da Lapa do Ribeirão da Ilha (1830-1880). Trabalho de Conclusão de Curso (Graduação em História) - Universidade Federal de Santa Catarina, Florianópolis, 2013.

FARIAS, V. F. de. Dos Açores ao Brasil meridional: uma viagem no tempo povoamento, demografia, cultura - Açores e litoral catarinense. Florianópolis: Edição do Autor, 1998.

FARIAS, V. F. de. Dos Açores ao Brasil meridional: uma viagem no tempo - 500 anos, litoral catarinense. 2. ed. Florianópolis: Edição do Autor, 2000.

FAUSEL, E. Die deutsch brasilianische Sprachmischung: Probleme, Vorgang und Wordbestant. Berlin: Schmidt, 1959.

FERNANDES, M. L. República de penas e espadas: o discurso da imprensa republicana catarinense (1885-1889). 2007. 263 f. Tese (Doutorado em Comunicação Social) - Pontifícia Universidade Católica do Rio Grande do Sul, Porto Alegre, 2007.

FERREIRA, S. L. A “açorianização" do litoral catarinense nos setecentos, 2005, p. 540-552. Disponível em: http://www.humanas.ufpr.br/portal/cedope/ files/2011/12/A-a\%C3\%A7orianiza\%C3\%A7\%C3\%A3o-do-litoral-catarinenseno-Setecentos-S\%C3\%A9rgio-Luiz-Ferreira.pdf. Acesso em: 4 set. 2020.

FIORI, N. de A. Aspectos da evolução do ensino público. Florianópolis: Editora da UFSC, 1991.

FLORES, M. B. R. Povoadores da fronteira: os casais açorianos rumo ao Sul do Brasil. Florianópolis: Editora da UFSC, 2000.

FUNDAÇÃO FRANKLIN CASCAES. Florianópolis: uma síntese histórica. 2. ed. Florianópolis: Secretaria Municipal de Turismo, 1995.

FURLAN, O. A. Influência açoriana no português do Brasil em Santa Catarina. Florianópolis: Editora da UFSC, 1989.

GONÇALVES, P. L.; HOLLER, M. T. A atuação de compositores em Desterro no 
século XIX. Revista do Centro de Artes da UDESC, Florianópolis, n. 7, p. 363-371, 2009.

GUEDES, A. Lages: história, atualidade, símbolos. Lages: Müller Editora, 1979. HAUSEN, T. A. P. Concordância verbal do pronome tu no interior do estado de Santa Catarina. 2000. 131 f. Dissertação (Mestrado em Letras) - Programa de Pós-Graduação em Letras, Universidade Federal do Paraná, Curitiba, 2000.

HEINSFELD, A. (org.). Economia, espaço e sociedade. Passo Fundo: Méritos, 2010.

JESUS, G. V. de. A importância dos açorianos em Santo Antônio de Lisboa e Sambaqui: marcando o processo de urbanização. Florianópolis: UFSC, 2011. Disponível em: http://nea.ufsc.br/files/2011/04/GISELLI.pdf. Acesso em: 4 set. 2020.

KNORST, P. A. R. Repensando alguns traços históricos de Santa Catarina. Unoesc \& Ciência - ACHS, Joaçaba, v. 2, n. 2, p. 198-205, jul./dez. 2011.

KOCH, W.; ALTENHOFEN, C. V.; KLASSMANN, M. (org.). Atlas LinguísticoEtnográfico da Região Sul do Brasil (ALERS): introdução, cartas fonéticas e morfossintáticas. 2. ed. Porto Alegre: Editora da UFRGS; Florianópolis: Editora da UFSC, 2011.

LEITE, I. B. Descendentes de africanos em Santa Catarina: invisibilidade histórica e segregação. Textos e Debates - NUER, Florianópolis, ano 1, n. 1, p. 5-42, 1991. LOHN, R. L. O náufrago e o sonho: Aleixo Garcia e o imaginário da conquista. In: BRANCHER, A.; AREND, S. M. F. (org.). História de Santa Catarina: séculos XVI a XIX. Florianópolis: Editora da UFSC, 2004. p. 27-59.

LOREGIAN-PENKAL, L. (Re)análise da referência de segunda pessoa na fala da Região Sul. 2004. 261 f. Tese (Doutorado em Letras) - Programa de PósGraduação em Letras, Universidade Federal do Paraná, Curitiba, 2004.

LUNA, J. M. de F. O português na escola alemã: da formação à extinção de uma prática. Blumenau: Editora da FURB, 2000.

MACHADO, P. P. Bugres, tropeiros e birivas: aspectos do povoamento do planalto serrano. In: BRANCHER, A.; AREND, S. M. F. (org.). História de Santa Catarina no século XIX. Florianópolis: Editora da UFSC, 2001. p. 11-29.

MARCO, B. H de. Os oestinos: quem são e como vivem os habitantes do oeste catarinense. Joaçaba: Unoesc - Universidade do Oeste de Santa Catarina, 2004. MARCON, F. Música de festival: uma etnografia da produção de música nativista no festival Sapecada da Canção Nativa em Lages-SC. 2009. 175 f. Dissertação (Mestrado em Antropologia Social) - Programa de Pós-Graduação em Antropologia Social, Universidade Federal de Santa Catarina, Florianópolis, 2009. 
MARGOTTI, F. W. Difusão sócio-geográfica do português em contato com o italiano no sul do Brasil. 2004. 332 f. Tese (Doutorado em Letras) - Programa de Pós-Graduação em Letras, Universidade Federal do Rio Grande do Sul, Porto Alegre, 2004.

MARTINS, L. Bem e bom e suas multifunções na fala da Região Sul do Brasil. 2003. 106 f. Dissertação (Mestrado em Linguística) - Programa de Pós-Graduação em Linguística, Universidade Federal de Santa Catarina, Florianópolis, 2003.

MATOS, F. A circulação dos livros da Tipografia do Arco do Cego em Nossa Senhora do Desterro (Florianópolis, século XVIII), 2007, p. 307-317. Disponível em: http://www.humanas.ufpr.br/portal/cedope/files/2011/12/A-circulacao-doslivros-da-Tipografia-do-Arco-do-Cego-em-Felipe-Matos.pdf. Acesso em: 4 set. 2020

MATTOS, F. A imigração açoriana na Grande Florianópolis: características e desdobramentos. Revista Maiêutica, v. 1, n. 1, 2013. Disponível em: https:// publicacao.uniasselvi.com.br/index.php/HID/issue/current. Acesso em: 4 set. 2020.

MENON, O. P. da S.; LOREGIAN-PENKAL, L. Variação no indivíduo e na comunidade: tu/você no sul do Brasil. In: VANDRESEN, P. (org.). Variação e mudança no português falado da Região Sul. Pelotas: EDUCAT, 2002. p. 147-188.

MIRANDA, A. L. Os espanhóis na ilha de Santa Catarina em 1777. In:

BRANCHER, A.; AREND, S. M. F. (org.). História de Santa Catarina: séculos XVI a XIX, 2004. p. 93-109.

MONTEIRO, J. Nacionalização do ensino. Florianópolis: Editora da UFSC, 1983.

MOSIMANN, J. C. Catarinenses: gênese e história. Florianópolis: Edição do Autor, 2010.

OLIVEIRA, D. R. M. de. O cotidiano das populações pré-coloniais na ilha de Santa Catarina. Revista Santa Catarina em História, Florianópolis, v. 1, n. 2, 2007. Disponível em: http://seer.cfh.ufsc.br/index.php/sceh/issue/view/26. Acesso em: 4 set. 2020 .

OLIVEIRA, G. M. de. Política linguística, política historiográfica: epistemologia da história da(s) língua(s) a propósito da língua portuguesa no Brasil Meridional (1754-1830). 2004. 222 f. Tese (Doutorado em Linguística) - Instituto de Estudos da Linguagem, Universidade Estadual de Campinas, Campinas, 2004.

PEIXER, Z. I. A cidade e seu tempo. Lages: Editora da UNIPLAC, 2002.

PELUSO JÚNIOR, V. A. Estudos de geografia urbana de Santa Catarina. Florianópolis: Editora da UFSC, Secretaria de Estado da Cultura e do Esporte, 1991. 
PEREIRA, R. N. O patrimônio cultural do Ribeirão da Ilha: lugar de múltiplas memórias. Trabalho de Conclusão do Curso - Departamento de História, Universidade do Estado de Santa Catarina, Florianópolis, 2003.

PIMPÃO, T. S. Uso variável do presente no modo subjuntivo: uma análise de amostras de fala e escrita das cidades de Florianópolis e Lages nos séculos XIX e XX. 2012. 350 f. Tese (Doutorado em Linguística) - Programa de Pós-Graduação em Linguística, Universidade Federal de Santa Catarina, Florianópolis, 2012.

RADIN, J. C. (org.). Cultura e identidade italiana no Brasil: algumas abordagens. Joaçaba: Unoesc - Universidade do Oeste de Santa Catarina, 2005.

RADIN, J. C.; BENEDET, J. H.; MILANI, M. L. Facetas da colonização italiana: planalto e oeste catarinense. Joaçaba: Unoesc - Universidade do Oeste de Santa Catarina, 2003.

RADIN, J. C. Italianos e ítalo-brasileiros na colonização do oeste catarinense. 2. ed. rev. e amp. Joaçaba: Unoesc - Universidade do Oeste de Santa Catarina, 2001.

RADIN, J. C. Representações da colonização. Chapecó: Argos, 2009.

REINECKE, K. Os róticos intervocálicos na gramática individual de falantes de Blumenau e Lages. 2006. 241 f. Tese (Doutorado em Linguística) - Programa de Pós-Graduação em Linguística, Universidade Federal de Santa Catarina, Florianópolis, 2006.

RENK, A. A luta da erva: um ofício étnico da nação brasileira no oeste catarinense. 2. ed. Chapecó: Argos, 2006.

ROST SNICHELOTTO, C. A. Olha e vê: caminhos que se entrecruzam. 2009. 411 f. Tese (Doutorado em Linguística) - Programa de Pós-Graduação em Linguística, Universidade Federal de Santa Catarina, Florianópolis, 2009.

ROSSETTO, S. Síntese histórica da região Oeste. Cadernos do CEOM, Chapecó, v. 4, 1989.

SANTA CATARINA. Coleção de decretos, leis e portarias de 1911. Florianópolis: Imprensa Oficial.

SANTA CATARINA. Coleção de decretos, leis e portarias de 1914. Florianópolis: Imprensa Oficial.

SANTA CATARINA. Coleção de decretos-leis de 1938. Florianópolis. Imprensa Oficial.

SANTOS, S. C. dos. Nova história de Santa Catarina. Florianópolis: Editora da UFSC, 2004.

SALOMON, M. O exílio da desordem na ilha de Santa Catarina no século XVIII. In: BRANCHER, A.; AREND, S. M. F. (org.). História de Santa Catarina: séculos XVI a XIX. Florianópolis: Editora da UFSC, 2004. p. 79-92. 
SEVERO, C. G.; SOUZA, C. M. N. de. Identidade e língua na ilha de Santa Catarina. In: SAVEDRA, M. M. G.; MARTINS, M. A.; HORA, D. (org.). Identidade social e contato linguístico no português brasileiro. Rio de Janeiro: Editora da UERJ: FAPERJ, 2015. p. 13-36.

SILVA, A. L. da. Fazendo cidade: memória e urbanização no extremo oeste catarinense. Chapecó: Argos, 2010.

SILVA, A. da; ROSA, A. da. Antes do Oeste Catarinense: aspectos da vida econômica e social de uma região. Fronteiras: Revista Catarinense de História, Florianópolis, n. 18, p. 139-160, 2010. (Edição em 2011). Disponível em: http:// www.anpuh-sc.org.br/rev\%20front\%2018\%20vers\%20fin/artigo3_antes_do_ oeste_catarinense_asilva_arosa.pdf. Acesso em: 4 set. 2020.

SILVA, J. F. da. História de Blumenau. Blumenau: Fundação Casa Dr. Blumenau, 1972.

SILVA, J. W. O oeste catarinense: memórias de um pioneiro. Florianópolis: Edição do Autor, 1987.

SIMÃO, V. M. Da hegemonia passiva à hegemonia ativa. In: THEIS, I. M.; ATTEDI, M. A. (org.). Nosso passado (in)comum. Blumenau: Editora da FURB, 2000.

SPESSATTO, M. B. Marcas da história: características dialetais dos imigrantes italianos na fala Chapecó. 2001. 93 f. Dissertação (Mestrado em Linguística) - Programa de Pós-Graduação em Linguística, Universidade Federal de Santa Catarina, Florianópolis, 2001.

SPESSATTO, M. B. Linguagem e colonização. Chapecó: Argos, 2003.

TAMANINE, A. M. B. A alternância de nós/a gente no interior de Santa Catarina. 2002. 222 f. Dissertação (Mestrado em Estudos Linguísticos) - Programa de PósGraduação em Letras, Universidade Federal do Paraná, Curitiba, 2002.

VICENZI, R. Mito e história na colonização do oeste catarinense. Chapecó: Argos, 2008.

WAGNER, A. Chapecó levantou voo. Florianópolis: De Letras, 2005.

WERLANG, A. Disputas e ocupação do espaço no oeste catarinense: a atuação da Companhia Territorial Sul Brasil. Chapecó: Argos, 2006.

WIEDEMER, M. L. A regência variável do verbo ir de movimento na fala de Santa Catarina. 2008. 141 f. Dissertação (Mestrado em Linguística) - Programa de Pós-Graduação em Linguística, Universidade Federal de Santa Catarina, Florianópolis, 2008.

WIESE, H. A inserção da língua portuguesa na colônia Hammonia. Ibirama: Edigrave, 2003. 
WILLEMS, E. Aculturação dos alemães no Brasil. São Paulo: Companhia Editora Nacional, 1946.

ZIMMERMANN, F. De armação baleeira a engenhos de farinha: fortuna e escravidão em São Miguel da Terra Firme-SC: 1800-1860. 2011. 142 f. Dissertação (Mestrado em História) - Programa de Pós-Graduação em História, Universidade Federal de Santa Catarina, Florianópolis, 2011. 


\section{Capítulo 3}

\section{Aspectos do contato linguístico do vêneto no português escrito de Chapecó no século XX}

Marizete Bortolanza Spessatto Loremi Loregian-Penkal Ana Lívia Agostinho Ivelã Pereira

\subsection{Introdução}

Os imigrantes italianos que cruzaram o oceano em direção ao Sul do Brasil trouxeram na bagagem bem mais do que os poucos pertences acumulados ao longo da vida. Para cá vieram hábitos e costumes, receitas da culinária e manifestações de fé. Esses sujeitos e suas famílias reconfiguraram as relações de trabalho e a organização de vilas e cidades, em um processo de interação algumas vezes visto como inovador e, outras, como opressivo em relação a outros grupos étnicos. 
Neste capítulo, ${ }^{1}$ vamos retomar brevemente o movimento interno de migração dos italianos, que do Rio Grande do Sul seguiram para o Oeste de Santa Catarina, no começo do século XX e as relações que estabeleceram nesse espaço. No estudo específico da presença desse grupo na cidade de Chapecó, focamos a análise no contato linguístico do vêneto ${ }^{2}$ (também chamado de "talian"3) no português escrito do século XX. A análise toma por base os documentos escritos pertencentes ao corpus do projeto Para a História do Português Brasileiro (PHPB) e analisa a interferência desse contato linguístico nos textos escritos nos gêneros textuais definidos pelo projeto. O principal objetivo de nossa investigação foi verificar a existência de elementos escritos - em variados domínios linguísticos (lexical/ semântico, fonético-fonológico, morfológico, morfossintático, sintático e discursivo-pragmático) - que revelem a influência do contato linguístico ${ }^{4}$ na cidade selecionada. ${ }^{5}$

1 Gostaríamos de agradecer aos colegas do grupo VARSUL que estiveram presentes na apresentação de nossos resultados parciais no "Seminário PHPB-SC", ocorrido no dia 2 de maio de 2018, e que nos deram sugestões significativas para o encaminhamento do trabalho.

2 Optamos por tratar apenas do vêneto e não dos demais dialetos trazidos ao Sul do Brasil pelos imigrantes do Norte da Itália, considerando ser este o predominante entre o grupo.

3 De acordo com o Instituto do Patrimônio Histórico e Artístico Nacional (IPHAN), "o Talian é uma das autodenominações para a língua de imigração falada no Brasil na região de ocupação italiana direta e seus desdobramentos desde 1875, em especial no nordeste do Rio Grande do Sul, Paraná, Santa Catarina, Mato Grosso e Espírito Santo. Sua origem linguística é o italiano e os dialetos falados, principalmente, nas regiões do Vêneto, Trentino-Alto e Friuli-Venezia Giulia e Piemontes, Emilia-Romagna e Ligúria". Disponível em: http://portal.iphan.gov.br/pagina/detalhes/183/. Acesso em: 3 set. 2018.

4 Sobre "contato linguístico", tomamos por base os estudos de Ferguson (1959), Fishman (1967), Heye (2003) e Weinreich (1953).

5 Das quatro cidades selecionadas para a constituição do corpus do projeto VARSUL Variação Linguística na Região Sul do Brasil - em Santa Catarina (Florianópolis, Blumenau, Lages e Chapecó), esta última foi definida tomando-se por base a forte presença dos italianos e seus descendentes, muito embora a mesorregião à qual pertence também tenha recebido outros grupos de imigrantes europeus, como os alemães, por exemplo. O mesmo critério foi adotado para a constituição do corpus do PHPB-SC (ver Capítulo 1 desta obra), por isso a análise dos dados linguísticos coletados para este capítulo centra-se no contato linguístico do português com a língua trazida ao Brasil por esse grupo étnico. 
A contribuição dos imigrantes para a constituição da história linguística brasileira e a necessidade de serem feitas pesquisas sobre o tema são pontos ressaltados por Faraco (2016):

Não temos ainda muitos estudos sistemáticos de eventuais influências das línguas dos imigrantes sobre o português do Brasil. A prosseguir investigações nesse sentido, será importante distinguir os diferentes contextos de inserção dos imigrantes na sociedade brasileira. (FARACO, 2016, p. 159).

Em se tratando da interferência do vêneto na fala em português no Oeste catarinense, os dados coletados pelo projeto VARSUL, nas décadas de 1980 e 1990, contribuíram de forma significativa para o levantamento de dados em estudos de diferentes pesquisadores, com análises sistemáticas da fala desses sujeitos. O ineditismo oportunizado pelo PHPB-SC está em possibilitar o estudo das manifestações dessa interferência linguística na escrita, mais resistente a mudanças e na qual são maiores as exigências de proximidade com a norma culta.

Para dar conta da proposta, apresentamos, na sequência, um breve apanhado do contexto sócio-histórico-geográfico da cidade de Chapecó, focalizando a presença dos imigrantes italianos e o contato linguístico resultante desse processo migratório. Na seção subsequente, descrevemos e analisamos os dados de contato linguístico do vêneto no português escrito encontrados no corpus de investigação. Por fim, trazemos as considerações finais, retomando os objetivos e as hipóteses iniciais, com o apontamento de limitações da pesquisa e possíveis encaminhamentos futuros para pesquisadores que se interessarem pelo tema.

\subsection{Breve contexto sócio-histórico-geográfico de Chapecó}

A história da região à qual nos dedicamos neste capítulo é marcada por inúmeros conflitos e constituída por múltiplos sujeitos. Dessa forma, não há como pensar na trajetória do português brasileiro nela falado sem iniciar por discorrer, mesmo que brevemente, sobre a história política de sua constituição.

Cenário de disputas entre Argentina e Brasil e depois entre os estados brasileiros do Paraná e de Santa Catarina, a mesorregião passou a 
ser chamada de Oeste Catarinense a partir do Estado Novo. "Anteriormente nos mapas constava zona desconhecida, zona despovoada. Ora era o sertão nacional, contrapondo-se aos Campos de Palmas, ora era sinônimo de área inóspita e limítrofe (com fronteira internacional em disputa)" (RENK, 2004, p. 2).

Figura 3.1 - Mesorregiões de Santa Catarina

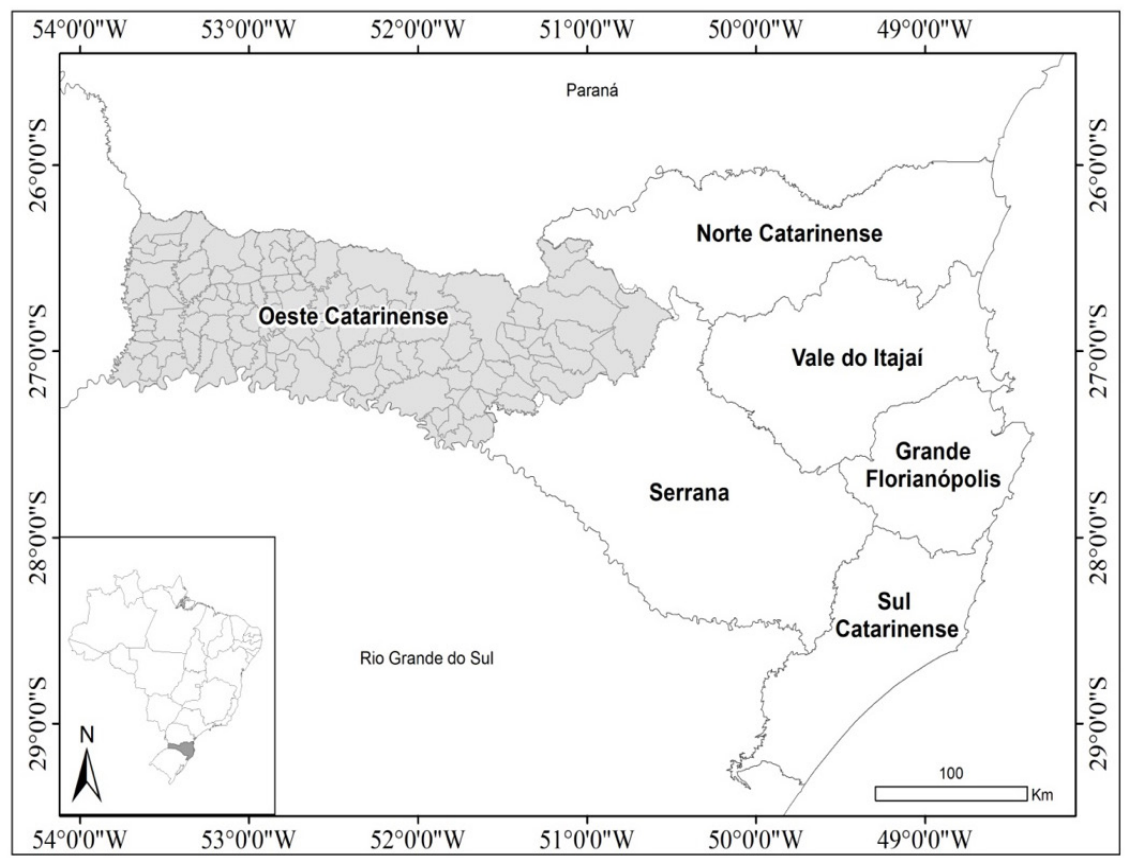

$\mathrm{Na}$ preocupação em assegurar o território, ao longo dos anos em disputa, o governo federal brasileiro deu às empresas colonizadoras o direito de venda de terras que atraíram a atenção de imigrantes que já povoavam o estado vizinho do Rio Grande do Sul. Grande parte desse contingente deu origem ao município de Chapecó, cujo primeiro centenário foi comemorado em 2017, e cujas marcas da constituição histórica estão expressas no principal monumento da cidade, chamado "O Desbravador".

6 O monumento ocupa espaço central na cidade e ao redor dele cresce um aglomerado de casas, prédios e estabelecimentos comerciais. Foi inaugurado em 25 de agosto de 1981, 
Figura 3.2 - Localização da cidade de Chapecó em Santa Catarina

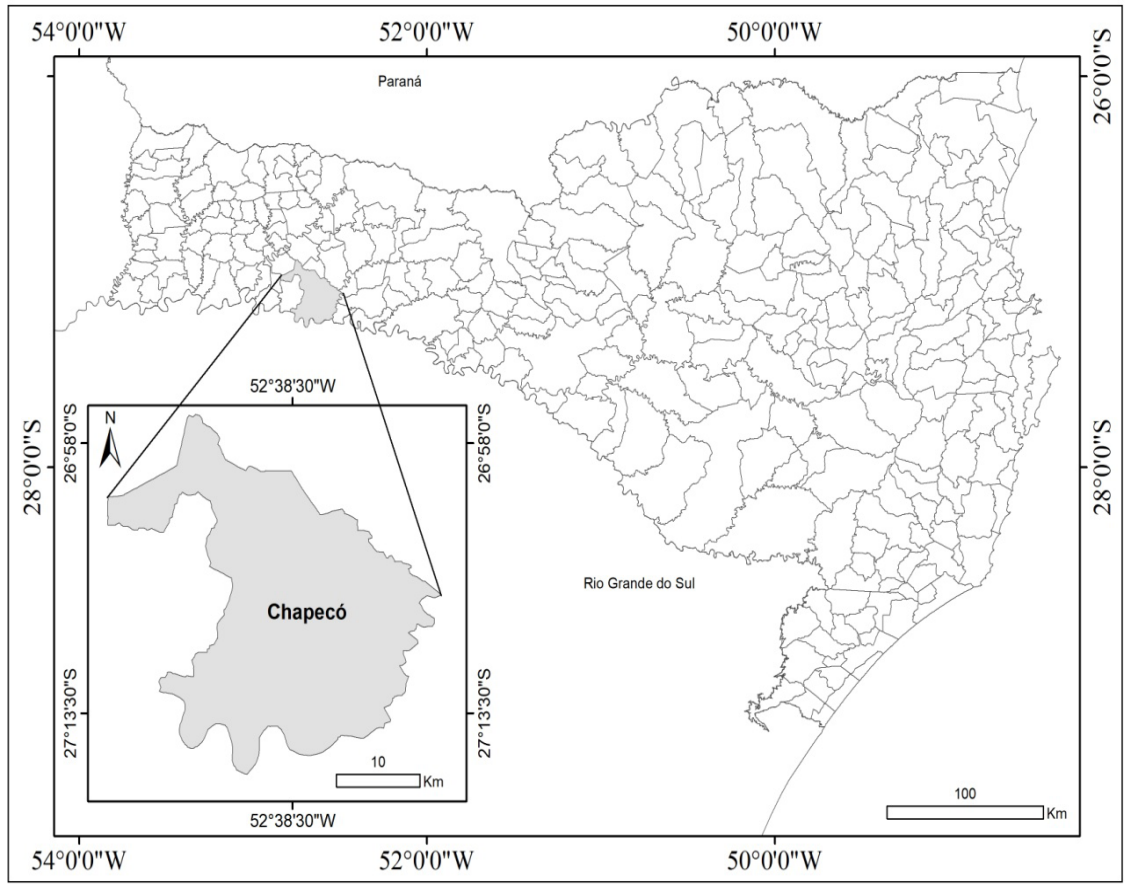

Nesse movimento migratório interno (do Rio Grande do Sul para Santa Catarina), vieram se juntar aos então chamados brasileiros, em uma relação de oposição identitária, - índios e caboclos que habitavam a região - os imigrantes europeus chegados ao Sul do país no final dos anos 1800 , entre os quais os italianos ${ }^{7}$ formaram um grande contingente.

com o objetivo de homenagear os primeiros "desbravadores" que colonizaram e construíram o município. Criado pelo artista plástico Paulo de Siqueira, mostra a figura de um gaúcho empunhando um machado, simbolizando o trabalho. Na mão esquerda há um louro, símbolo da conquista e da vitória. O monumento tem 14 metros de altura, 5,70 metros de largura e pesa nove toneladas.

7 Mesmo não ocupando uma posição prioritária no processo de imigração italiana, o Brasil acolheu um número significativo de imigrantes: o país recebeu, do final dos anos 1800 até 1914, de acordo com Balhana (1987), 1.356.398 italianos. E, ao contrário do que ocorreu com o processo migratório dentro do território europeu, a imensa maioria desse grupo de imigrados jamais retornou à Itália. Eles deixaram o país em condições 
A influência italiana na colonização de Chapecó foi registrada pelos órgãos oficiais, que denominam o município como "área de colonização italiana" e chamam a rota turística regional de "Rota de colonização italiana". Também há uma série de eventos que fazem uso do fato de a região ter nos imigrantes italianos a constituição de sua história, muitos deles ligados aos "Círculos italianos", que se desenvolveram de forma considerável no Sul do país nas últimas duas décadas.

No aspecto econômico regional, as famílias de italianos estão associadas à implantação de fábricas em diversas áreas de produção, sobretudo de grandes agroindústrias. A formação e o crescimento de Chapecó, de acordo com Facco et al. (2014), estão fortemente ligados a esses setores. De acordo com os autores,

Chapecó é fortemente influenciada pelas agroindústrias, desde 1950. $\mathrm{O}$ desenvolvimento e a expansão agroindustrial têm transformado os espaços, não só da cidade, mas também da região. [...] Das mais de 130 indústrias chapecoenses 12 delas são exportadoras e duas estão entre as 600 maiores indústrias brasileiras (Sadia em 63ํe Cooperalfa em 511º). (FACCO et al., 2014, p. 188).

Essa relação entre a colonização europeia e o desenvolvimento econômico das regiões de imigração marca a leitura feita do processo por pesquisadores italianos que estudaram a história da imigração em terras brasileiras. Em solo brasileiro, os imigrantes compraram terras, abriram estradas e contribuíram de forma significativa para o desenvolvimento socioeconômico do país, como afirma Franzina (1978). Lo Cascio (1987) destaca a presença dos imigrantes italianos como um fator que levou ao crescimento econômico do Sul do Brasil:

Resulta sempre importante, por exemplo, a contribuição italiana ao desenvolvimento e à vida comercial do Sul do Brasil, isto é, da parte mais ativa do país sul-americano. As cifras apresentadas revelam não apenas uma massiva imigração, mas também uma grande atividade

precárias: eram pequenos agricultores e trabalhadores que perderam o emprego nas indústrias, com a segunda revolução industrial.

8 Conforme consta no site da Secretaria de Turismo de Santa Catarina (SANTUR, 2018). Disponível em: http://turismo.sc.gov.br/cidade/chapeco/. Acesso em: 13 abr. 2018. 
e presença em nível empresarial e de gestão. (LO CASCIO, 1987, p. 90 , tradução nossa). ${ }^{9}$

Tal presença dos imigrantes italianos deixou marcas linguísticas na constituição histórica do português brasileiro falado na região, sobretudo pela presença, entre esses imigrantes, do vêneto, a mais expressiva língua de imigração na região de colonização italiana do Sul do Brasil. Frosi e Mioranza (1983) traçam um mapa com os índices da representatividade da proveniência regional dos imigrantes italianos que imigraram para o Rio Grande do Sul que também caracteriza as línguas de imigração faladas por eles: vênetos, $54 \%$; lombardos, $33 \%$; trentinos, $7 \%$; friulanos, $4,5 \%$; outros, $1,5 \% .^{10}$

Em cerca de 150 anos desde a imigração em massa, os vênetos enfrentaram, junto com os demais grupos étnicos que constituem o Brasil, muitos momentos de dificuldades gerados pelas mudanças no campo político. O mais severo foi a Campanha de Nacionalização, implementada pelo governo do presidente Getúlio Vargas, na década de 1930. Nesse período, falar línguas estrangeiras, mesmo aquelas que eram línguas maternas para muitos grupos, como o vêneto, era motivo de prisão. Consoante Altenhofen (2013, p. 109), tais práticas consistiram em "políticas de silenciamento linguístico e incriminação dos falantes de línguas minoritárias, em especial das línguas de imigração alemã e italiana, no período nacionalista entre as duas Guerras Mundiais". Disso, resultaram consequências duplamente nocivas aos sujeitos imigrantes, uma vez que foi proibido o uso da língua minoritária, sem que a eles fosse facilitado o acesso ao português.

Nesse contexto, os indivíduos que conseguiram manter suas línguas de origem, ainda que em contextos restritos (como o familiar), após “o cerco

9 Importante risulta per esempio il contributo italiano allo sviluppo e alla vita commerciale del Sud del Brasile, cioè della parte più attiva del paese sudamericano. Le cifre presentate non soltanto rivelano una massiccia immigrazione ma anche una grande attività e presenza a livello aziendale e imprenditoriale (LO CASCIO, 1987, p. 90).

10 Dessa forma, para tratar da interferência linguística dos italianos e seus descendentes na escrita em português, no corpus aqui em análise, consideramos as diferenças entre a escrita em italiano standard e aquelas provenientes do vêneto, conforme será tratado de forma detalhada na seção seguinte. De acordo com De Mauro (2008), a variedade dialetal italiana é resultado da diversidade de correntes inovadoras que levaram a alterações no latim falado nas diversas regiões, ao longo dos séculos. 
às línguas de imigrantes" (MAHER, 2013, p. 123), podem ser considerados "ecos de resistência" na história brasileira de discriminação linguística.

Os imigrantes e os descendentes nascidos na nova pátria sofreram as consequências do período e muito do capital cultural e linguístico foi perdido nessa época. Embora distantes da terra natal e obrigados pelas condições sociais e políticas a se incorporarem à nova realidade, os ítalobrasileiros, entretanto, sempre mantiveram o imaginário de uma identidade italiana: "Mi son taliàn de qua [eu sou um italiano daqui]", como afirma um morador das campanhas do Rio Grande do Sul (CORRÀ, 2001, p. 282), ou "Nós somos italianos", como afirma uma estudante de 14 anos, moradora do Oeste de Santa Catarina (SPESSATTO, 2011, p. 87).

Entretanto, mesmo considerando essas manifestações de pertencimento a uma identidade italiana mantida por elementos como a cultura e a gastronomia, presentes no cotidiano desses grupos, o falar dialetal foi sendo deixado de lado ao longo das gerações. Frosi (2001) destaca o estigma de ignorância atribuído ao uso das línguas de imigração em um cenário transformado pelos reflexos da Campanha de Nacionalização na vida dessas comunidades. A autora caracteriza desta forma as consequências do processo:

O estigma sociolinguístico que se forma nesse período é um embrião que se delineia de modo definitivo na fase sucessiva à evolução da RCI [Região de Colonização Italiana do Rio Grande do Sul] e dá origem ao sentimento de vergonha do ítalo-brasileiro em relação ao seu modo de falar, seja em língua italiana ou em português regional. O sentimento de vergonha do seu próprio modo de falar constitui um estigma sociolinguístico que passa a fazer parte da história de vida de muitos ítalo-brasileiros. (FROSI, 2001, p. 256).

Esse sentimento de vergonha é confirmado em depoimentos que constituem o banco de dados VARSUL. Quando os informantes mais velhos são questionados sobre o porquê de não terem ensinado as línguas de imigração aos filhos, apontam razões que revelam um sentimento de inferioridade: "Quando eles [filhos] eram pequenos, falar italiano era assim um pouco estranho, cafona, né?" (Informante 16/banco de dados VARSUL apud SPESSATTO, 2001, p. 35).

Se, por um lado, as (poucas) pesquisas existentes no Oeste Catarinense confirmam um significativo abandono do vêneto, mesmo na fala 
em contextos familiares, sua interferência na fala em português, por outro lado, é bastante evidente. Seja em casos de manutenção de parte do léxico dialetal, seja na transposição de elementos da fonologia de uma língua (no caso o vêneto) para a outra (o português brasileiro), percebem-se claramente características linguísticas parecidas entre as comunidades com antecedentes italianos. Nesse sentido, a preservação das línguas de imigração e sua história como um patrimônio importante para as duas nações é essencial. "Propõe-se a defesa de um patrimônio de origem italiana sem empobrecer o patrimônio cultural brasileiro" (PETRONE, 1991, p. 328, tradução nossa). ${ }^{11}$

Em pesquisa realizada na década de 1980 na comunidade de descendentes de italianos da região de colonização italiana do Rio Grande do Sul, Frosi e Mioranza (1983) observaram que, entre esses falantes, a língua portuguesa era usada alternadamente com as línguas de imigração italianas, havendo nos centros urbanos o predomínio do português. Os autores observaram, ainda, serem essas variedades "um sistema linguístico uno opondo-se à língua portuguesa” (FROSI; MIORANZA, 1983, p. 329). A análise das interferências da língua portuguesa quando do uso das línguas de imigração mostrou que elas se caracterizam como empréstimos tanto lexicais quanto de segmentos fônicos. Esses empréstimos foram sendo usados pelo falante de forma tão automática que ele, segundo os autores:

[...] tinha certeza de que determinados léxicos da língua portuguesa, por ele utilizados em sua fala dialetal italiana, não eram empréstimos do sistema lingüístico português, com os quais se familiarizara pelo uso dialetal italiano, através do tempo; exteriorizava, sim, a conviç̧ão de que tais palavras sempre haviam pertencido à sua língua de origem. (FROSI; MIORANZA, 1983, p. 331).

Os autores afirmam que os empréstimos lexicais da língua portuguesa na fala dialetal italiana foram incorporados pela necessidade de designar coisas novas, correspondentes à realidade brasileira, como "gaúcho", "chimarrão", "churrasco" e "tatu". Ainda, foram incorporados termos para designar objetos novos não existentes na época da imigração, como “televisão" (televisore), pronunciada pelo bilíngue como [televi’zõ] e pelo

11 Si propone la difesa di un patrimonio di origine italiana affinché non si impoverisca lo stesso patrimonio culturale brasiliano (PETRONI, 1991, p. 328). 
monolíngue do português como [televi'zãw]. Assim sendo, os empréstimos lexicais da coiné vêneta aparecem na fala em português, como demonstram as pesquisas desenvolvidas tanto na região de colonização italiana do Rio Grande do Sul quanto no Oeste de Santa Catarina.

Por outro lado, a preservação de termos do léxico da língua materna, assim como a incorporação de novos termos, parece estar relacionada com o uso em situações do dia a dia. Nesse sentido, Corrà (2006) aponta que as palavras usadas para indicar objetos e situações do cotidiano são as que mais se mantêm quando da sobrevivência de uma língua de imigração. A conclusão veio de uma pesquisa desenvolvida com estudantes de Lamon, uma cidade do norte da Itália. Mesmo não falando mais a variedade local, que foi substituída pelo italiano standard, no caso em análise pela pesquisadora, os estudantes não abandonaram muitos dos termos usados cotidianamente, na variedade em questão. Em depoimentos a Corrà (2006), eles empregaram termos classificados pelos dialetólogos como formas arcaicas. Um exemplo são os termos din (para giorno - dia) e doman (para domani - amanhã). Essas palavras, com forte valor identitário, foram recentemente definidas como "palavras-bandeira" (IANNACCARO, 2002 apud CORRÀ, 2006, p. 192).

Ainda de acordo com Corrà (2006), é o controle social da comunidade que permite a sobrevivência das formas dialetais. Fenômeno parecido também se dá na comunidade em estudo neste trabalho (a cidade de Chapecó). Em pesquisa anterior, desenvolvida por Spessatto (2011), em contexto de sala de aula, foram identificadas expressões e palavras de origem vêneta entre falantes jovens (último ano do ensino fundamental e com idade entre 12 e 15 anos), sendo a maioria deles monolíngues falantes de português: "Tem gente passando fome e gente jogando bolacha no chão. Pelo amor de Dio" (Elvis, 16/5/2008); “Ma co'Diona! Quanta conta!” (Diana, 7/4/2009); "Ai, Dio, por que estudar? (Eduarda, 7/4/2009); "Ma co'Dione, não termina mais! (Diana, 8/4/2009); "Poareta!” (Diana, 8/10/2008); "Porco can” (Elvis, 8/4/2009); “Sporcacciona!” (Eduarda, 9/4/2009).

O uso de expressões em língua italiana também foi razão para brincadeiras, ao longo do período de observação realizado em sala de aula, na pesquisa citada: “Eu não posso ir, vou pousar na minha vó, hoje!”, afirma uma estudante. O colega responde, rindo: "Vai na nona!" (Informante "Leandro", 24/8/2009). O uso de expressões dialetais igualmente apareceu durante as aulas nas quais os estudantes preparavam uma apresentação que 
teve como tema as diferentes identidades étnicas para a "Festa das etnias". Durante a preparação das atividades, surgiram os seguintes registros: "Mas a Jana é negri? Nós aqui somos negri (Informante "Marcos", 9/10/2009); "Os negri dançam funk (Informante "Alex", 9/10/2009); "O M. [nome do estudante] é um negri moderno!" (Informante "Denis", 9/10/2009)12 (SPESSATTO, 2011).

Os exemplos de contato linguístico em Chapecó revelam que, contemporaneamente e também entre sujeitos mais jovens, o léxico é marcado pelo vêneto, que é fruto da imigração italiana ao Brasil no século XIX. A partir disso, supomos que, se dados atuais (século XXI) de falantes da região ainda mostram elementos de contato linguístico, possivelmente textos mais antigos (do começo do século XX em diante) também poderiam trazer à vista, talvez até com maior força, dados dessa influência dialetal, mesmo em se tratando da modalidade escrita da língua.

Na seção que segue, fazemos a descrição e a análise de dados de contato linguístico, considerando o acervo de cartas (pessoais e de leitores) do PHPBChapecó, no qual constam documentos escritos do século XX (distribuídos em décadas), disponibilizados para consulta até a presente data.

\subsection{Análise dos dados do PHPB-SC em Chapecó}

A análise ora apresentada tem como base a coleta de dados realizada pela equipe do $\mathrm{PHPB}-\mathrm{SC}$ em Chapecó, sendo que a fonte documental foi o Centro de Organização da Memória do Oeste de Santa Catarina, mantido pela Universidade Comunitária da Região de Chapecó.

A coleta de dados do projeto está assim distribuída conforme gêneros textuais/discursivos e décadas do século XX.13

12 Os estudantes, autores dos depoimentos transcritos, foram identificados por pseudônimos criados para preservar a identidade.

13 Até o momento, contudo, nem todos os documentos elencados no Quadro 3.1 encontram-se transcritos e disponíveis para análise. 
Quadro 3.1 - Total de documentos coletados em Chapecó

\begin{tabular}{|l|c|c|c|c|c|c|c|c|}
\hline Gênero/Década & 1920 & 1930 & 1940 & 1950 & 1960 & 1970 & 1980 & 1990 \\
\hline Anúncios & - & 29 & 55 & 60 & 15 & 48 & 11 & 11 \\
\hline Cartas de leitores & - & - & 10 & 35 & 4 & 10 & 4 & 1 \\
\hline Cartas pessoais & 1914 a $1929=284$ & 22 & 28 & - & 2 & 5 & - & - \\
\hline
\end{tabular}

Fonte: Projeto PHPB-SC.

Considerando as características linguísticas da comunidade de Chapecó, de acordo com a contextualização feita na seção anterior, tomaremos como foco de análise, nos dados coletados no PHPB-SC, 11 cartas pessoais (CP), escritas no período de 1914 a 1970, e 14 cartas de leitores (CL), publicadas em jornais locais entre os anos de 1940 e 1990. ${ }^{14}$

De modo geral, as interferências do vêneto na fala no português da região, no corpus analisado, caracterizam-se pelo emprego de termos do léxico dialetal na fala em português; pelo uso de morfemas do vocabulário vêneto - como "solo" no lugar de "somente" ou "só"; e pelas interferências fônicas na escrita em português (exemplos: aborecido por aborrecido; troca de "g" por " $\mathrm{z}$ ", no caso de zenro por genro). Identificamos, ainda, no corpus investigado, a interferência da grafia do italiano standard, no uso de consoantes duplas. Na sequência, tratamos de cada um desses aspectos. Nas cartas, eles se encontram em construções ${ }^{15}$ que trazem outras variações em relação ao padrão do português brasileiro. Entretanto, esses aspectos não serão considerados, observando-se os elementos priorizados nesta investigação, relacionados à interferência do vêneto na escrita em português.

A análise dos dados permitiu identificar a presença de vocábulos (léxico) do vêneto na escrita no português da região, em construções como:

14 Selecionamos esse material por acreditarmos que há mais registros das interferências do vêneto na fala em português da comunidade em análise, considerando a livre autoria nas cartas pessoais e o menor controle sobre a escrita nas cartas de leitores, em oposição ao gênero anúncios, também catalogado na pesquisa.

15 Exemplo: vide nota 18 que remete à interferência da estrutura sintática do italiano na escrita em português. 
(1) $\left[20,2 \mathrm{CP}\right.$ SC ${ }^{16}[\ldots]$ mais uma cosa vo pedirte de se informava tenente da junta militar de xapeco. ${ }^{17}$

(2) [20,2 CP SC] Não bem de de saude a qui solo saude Eliza que andava sempre não muito boa. ${ }^{18}$

(3) $[20,2$ CP SC] [...] nao podemos ir a a Casamento de Celia pois a nona teve outro ataque veio a meliorar mas ficou variada da cabeça não sabe o que dis e muitas ves o que faz.

(4) [20,2 CL SC] Entretanto, fiquei sorpreso com a declaração que também esta abaixo transcrita na integra e assinada pelo maquiavélico e incompetente gerente da Radio Chapecó.

(5) [20,2 CL SC] Quero adiantar também, que ésta publicação é o presente de Natal, que os prometi, e que, o homem pode viver sem glórismos, morrer sem ela, nunca! VENDETA. ${ }^{19}$

Nos dados acima, temos a ocorrência dos itens lexicais "cosa", "solo", "nona", "sorpreso" e "vendeta". Os exemplos (1) e (4) não demonstram a interferência linguística de uma forma tão evidente quanto os demais exemplos pelo fato de haver apenas a modificação de um segmento fônico (acréscimo ou troca), em que "cosa" aparece no lugar de "coisa" e "sorpreso" no lugar de "surpreso". No entanto, não podemos ignorar que, apesar da similaridade entre os vocábulos na língua portuguesa e no italiano, a opção (consciente ou não) de utilizar um termo no lugar do outro é um ponto a se considerar.

16 Os códigos que precedem os dados do PHPB codificam o período - primeira ou segunda metade dos séculos XIX e XX; o gênero textual e o estado brasileiro (identificado por sigla). As seguintes abreviações são usadas para a indicação do gênero textual: $\mathrm{CL}$ - cartas de leitores; $\mathrm{CR}$ - cartas de redatores; A - anúncios; e CP - cartas pessoais.

17 Marcamos em negrito os termos em análise e utilizamos colchetes para indicar a tradução do termo estrangeiro empregado pelo informante na escrita do texto em português.

18 Observa-se, no fragmento, também a interferência da estrutura sintática do italiano na escrita em português. A tradução seria "Noi qui stiamo tutti bene, solo Eliza che spesso non sta bene".

19 Do italiano vendetta, esse termo já se encontra dicionarizado em português, mantendo a forte relação da origem do termo, significando "Espírito de hostilidade entre famílias e clãs inimigos, com atos de vingança recíproca, geralmente criminosos, como sucede na Córsega e em algumas regiões de Itália", de acordo com o Dicionário Priberam. Disponível em: https://www.priberam.pt/dlpo/vendeta. Acesso em: 23 abr. 2018. 
Já no caso dos dados (2), (3) e (5), observa-se a escolha de itens lexicais significativos no vêneto, como "solo" no lugar de "somente" ou "só"; além de "nona" para se referir à "avó" e "vendeta" como uma palavra um tanto intraduzível para o português, mas que é usada em contextos de exaltação, xingamento ou reclamação. Esses foram alguns exemplos da presença do contato linguístico em âmbito lexical, o qual se apresenta como o mais significativo e aparente quando se trata de contato linguístico em documentos escritos.

Já no que se refere às interferências fônicas identificadas nas cartas pessoais analisadas, está a neutralização da consoante vibrante múltipla (registrada, ortograficamente, no português, com dupla utilização do grafema $<$ rr $>$ ), substituída pelo uso do tepe (FROSI; MIORANZA, 1983) - o qual é registrado ortograficamente pelo grafema $<\mathrm{r}>$. Como exemplo de tal uso linguístico, mostramos uma carta ${ }^{20} \mathrm{em}$ que o informante se utiliza do termo "aborecida" em vez de "aborrecida":

Figura 3.3 - Carta pessoal (Data: 29/9/1920)

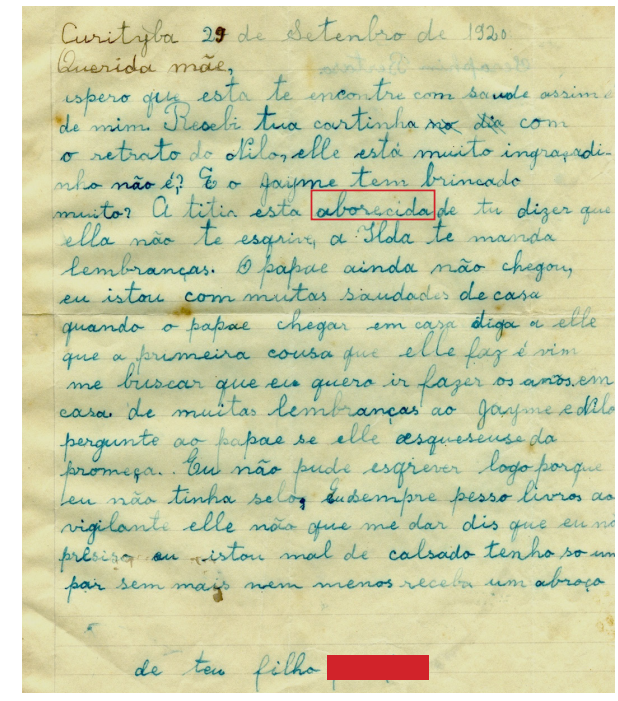

Fonte: Projeto PHPB-SC.

20 Esta carta ainda não havia sido transcrita. Além dessa razão, trouxemos a versão original (com o nome do informante omitido), a fim de que o leitor possa entrar em contato com algum documento original do corpus. 
Outros exemplos localizados em cartas do mesmo informante, que apresentam dados de tal natureza, mostram-se a seguir: "A despesa que ocorer pague e depois nóis resolvemos o problema"; "aroz" para "arroz"; "aramge" para "arrange" e "eterremos" para "e teremos".

Quando se trata da oralidade, muitos estudos têm mostrado a presença desse fenômeno em variação, não apenas entre imigrantes e descendentes de italianos residentes em solo brasileiro, mas entre falantes de dialetos em oposição ao italiano standard. Conforme estudos desenvolvidos por Gerhard Rohlfs, na década de 1960, as variedades do norte da Itália não possuem a vibrante geminada. "Conforme as características gerais do desenvolvimento fonético setentrional, em toda a Itália setentrional rr sofre a lenização em r (tèra, guèra)" (ROHLFS, 1966, p. 336 apud FROSI; MIORANZA, 1983, p. 347).

Em um estudo sobre as variedades do vêneto, Zamboni (1974) afirma que "no que diz respeito, enfim, a /r/, tem-se, em geral, uma vibrante simples apicodental, enquanto o standard possui uma vibrante múltipla" (ZAMBONI, 1974, p. 14 apud FROSI; MIORANZA, 1983, p. 347).

A inexistência da vibrante múltipla como fonema do dialeto e, por outro lado, a existência da mesma no sistema fonológico da língua portuguesa, estabelecendo oposição distintiva com a vibrante simples, acarreta, do ponto de vista fonêmico, o uso inadequado das duas vibrantes nos empréstimos do português. Tomando-se os empréstimos garrafa e cerração, por exemplo, observa-se que a vibrante múltipla foi sistematicamente substituída, quer pela vibrante simples, quer pela vibrante que se caracteriza como um tipo intermediário entre a múltipla e a simples. (FROSI; MIORANZA, 1983, p. 347).

Margotti (2004) também indica como uma das características da interferência das línguas de imigração na fala em português dos descendentes de italianos que vivem no Sul do Brasil a não produção do /R/ em contextos esperados no português do Brasil. O autor cita essa característica como um dos estereótipos mais comuns do contato do português com o italiano. De acordo com o autor,

[c]omo na coiné vêneta inexiste o $[\mathrm{r}$ ] forte, a influência do italiano no português faz com que os falantes bilíngues português-italiano, 
ou mesmo falantes monolíngues nas áreas de contato do português com o italiano, usem $[\mathrm{r}]$ fraco (tepe) em lugar de $[\mathrm{r}]$ forte (vibrante ou fricativa). (MARGOTTI, 2004, p. 10).

Voltando-se para o português brasileiro, segundo Bisol (1999), no contexto intervocálico (o mais favorável ao aparecimento de consoantes), há a oposição fonêmica do /r/ 'r forte' e do / $\mathrm{r} /$ ' $\mathrm{r}$ fraco' (carro:caro, erra:era, ferre:fere), enquanto na posição não intervocálica (pré-vocálica ou pósvocálica) ocorre a neutralização dessa oposição, havendo uma distribuição complementar (' $r$ forte' em início de palavra e depois de consoante e 'r fraco' em coda).

Por outro lado, Mateus e D’Andrade (2000) argumentam que o rótico é apenas um fonema / $\mathrm{f} /$ em português que pode ser realizado como [ $\mathrm{f}$ ou [r]. Segundo os autores, a distribuição dos róticos é previsível em fronteiras de palavra. Na posição intervocálica, os autores postulam que é possível ter dois róticos, um na coda na primeira sílaba e outro no onset, na forma subjacente. Dessa forma, teríamos 'caro' / karo/ e 'carro' /karro/. De acordo com essa análise, como o segundo / / / ocorre após uma consoante, o outro $/ \mathrm{r} /$, ele é realizado como [r], enquanto o primeiro é apagado da coda silábica. Bisol argumenta que palavras com [r] intervocálico nunca podem ser proparoxítonas, já que se trata de uma sílaba com coda e, portanto, pesada. Um argumento contrário a essa proposta é o fato de que a silabificação é previsível e possivelmente não está na estrutura subjacente, já que pares mínimos apenas com silabificação são muito raros e normalmente não ocorrem (BLEVINS, 1995), como é o caso do português. Além disso, palavras com $[\mathrm{r}]$ intervocálico podem ser oxítonas, tal como pierrô e forró, o que não deveria acontecer caso o peso silábico sempre determinasse o acento.

Tendo em vista esses dois argumentos e o fato de a proposta de Bisol (1999) ser a mais aceita na fonologia do português brasileiro, assumiremos aqui a distinção fonêmica de 'r forte' e ' $r$ fraco' intervocálicos para o português brasileiro e europeu em variedades que apresentam tal distinção semântica. Monteiro (2008) apresenta um quadro (adaptado abaixo) com desvios ortográficos feitos por alunos da $2^{a}$ série do ensino fundamental (com cerca de 7, 8 anos) de uma escola particular da cidade de Pelotas. 
Quadro 3.2 - Contextos de /R/ e desvios

\begin{tabular}{|c|c|}
\hline Contexto & Desvios encontrados \\
\hline 'r fraco' & - \\
\hline 'r forte' inicial & rriu, rratu, rrádio, rraiva \\
\hline 'r forte' pós-consonantal & enrrolou \\
\hline 'r forte' & corendo, varia, arumando, caregando \\
\hline
\end{tabular}

Fonte: Adaptado de Monteiro (2008, p. 87).

Segundo a autora, “a grafia do 'r' nos diferentes contextos tem uma regra bem definida e, se percebida pela criança, desde o início do processo de escrita ortográfica, pode levar à diminuição de desvios relacionados a essa grafia" (MONTEIRO, 2008, p. 87). Podemos observar que não houve desvios com $<$ rr $>$ no lugar de $<\mathrm{r}>$ correspondentes ao fonema ' $r$ fraco', ou seja, não foi possível encontrar algo como <parra $>$. Já em contextos em que o ' $r$ forte' é grafado com $<\mathrm{r}>$ (início de palavra e antecedendo outra consoante), aparece a troca por $<\mathrm{rr}>$, o que é explicado pela relação que a criança faz com o grafema $<$ rr $>$ e o fonema 'r forte'. Uma vez que a criança percebe que nem sempre o 'r forte' é grafado com $<\mathrm{rr}>$, ela hipercorrige palavras com fonema ' $r$ forte' e grafema $<$ rr $>$ para o grafema $<\mathrm{r}>$. Em relação aos dados contidos no Quadro 3.2, a autora argumenta ainda que

[o] 'r' inicial, por ter som forte, foi grafado com 'rr', desconsiderando o contexto inicial que determina a grafia de ' $r$ ' para representar $o$ som forte nessa posição. Erros relacionados à grafia do ' $r$ ' fraco não aparecem nos dados de escrita das crianças estudadas, confirmando a tendência já verificada nos estudos de Melo e Rego (1998), Guimarães (2005) e Araújo, Garcia e Miranda (2007) segundo os quais, desde o início do processo de aquisição da escrita, elas já percebem a diferença entre o ' $r$ ' forte e fraco, o que torna mais fácil a grafia do 'r' fraco. Esses estudos também mostram que a utilização do 'rr' intervocálico é facilmente aprendida pela criança e, consequentemente, os erros relacionados a esse contexto não aparecem com frequência em seus dados de escrita. (MONTEIRO, 2008, p. 87). 
Em estudo desenvolvido com descendentes de italianos residentes em Chapecó, a partir da coleta de dados desenvolvida pelo projeto VARSUL nas décadas de 1980 e 1990 (SPESSATTO, 2001), foi constatada a presença significativa desse fenômeno do uso do / $\mathrm{R} /$ em variação na oralidade. Do total de ocorrências em contextos de vibrante múltipla (início de palavra e posição intervocálica) registradas e analisadas pela pesquisa, $46 \%$ das ocorrências foram de tepe, 35\% de intermediária e apenas 19\% de vibrante múltipla em contextos esperados.

Em pesquisa desenvolvida com sujeitos jovens, estudantes do ensino fundamental, controlando-se os mesmos contextos linguísticos, os percentuais de tepe em contextos de vibrante múltipla foram ainda mais significativos: $75 \%$ das ocorrências foram de tepe, em $1 \%$ empregou-se a intermediária e apenas $23 \%$ das ocorrências foram de vibrante múltipla (SPESSATTO, 2011). Dessa forma, os dados encontrados nas cartas ("aborecida" por "aborrecida"; "ocorer" por "ocorrer"; "aroz" por "arroz", entre outros) vêm reforçar a constatação, na oralidade, de Spessatto (2011), bem como podem ser considerados como reflexos das altas incidências de tepe em contextos de vibrante múltipla.

Passando-se para outro elemento de contato linguístico identificado, a respeito do uso das consoantes geminadas, tal utilização, ao longo das cartas, marca a interferência da grafia do italiano standard na escrita em português. Alguns dos dados encontrados podem ser conferidos em (6) a (9).

(6) [20,1 CP SC] Nesta viagem não irá a Florianópolis, mas consolem-se porque antes do fim do anno irá fazer-vos uma visita.

(7) [20,1 CP SC] Mamãe disse que VAE te escrever uma cartinha, porque SINÃO não te lembras mais della. Plinio como VAE?

(8) [20,2 CP SC] não podeis immaginar quanta saudade tenho de vos todos quantas veses me allembro de voceis e mi parece de istar tão perto, mas muitos quilometros nos separa.

(9) [20,2 CP SC] Hoje termina a meu mal escrita enviando vos um abbraço a todos, Adeus de longe vosa irman e Cunhata Elisa e Luiz.

As consoantes geminadas não fazem parte do sistema linguístico do vêneto, diferentemente do que ocorre com o italiano standard. Essa característica também é apontada no estudo do vêneto como língua de 
estudo em território brasileiro, denominado de vêneto sul-rio-grandense (STAWINSKI, 1987) e talian (LUZZATTO, 1985, 2000), no Sul do país.

O Dizionario Italiano-Veneto aponta como característica do vêneto "la mancanza delle doppie [a falta das geminadas]" (NARDO, 2010, p. 11). Stawinski cita que "as consoantes têm, de modo geral, a mesma pronúncia que na língua portuguesa. Nunca, porém, aparecem geminadas, à exceção de 'ss"' (STAWINSKI, 1987, p. VI). Luzzatto explica que "o vêneto, por não usar a letra dupla como o italiano, se vale dos acentos (') grave e (') agudo para identificar a sílaba tônica com som aberto ou fechado, respectivamente" (LUZZATTO, 1985, p. 20).

Assim, os dados coletados das consoantes geminadas revelam, à primeira vista, certa estranheza, considerando-se o fato de, à época da imigração, a maioria dos italianos que vieram ao Brasil serem analfabetos. Em torno de $75 \%$ a $80 \%$ da população adulta italiana era analfabeta ao final do século XIX (TRIFONI, 2006; DE MAURO, 2008). As altas taxas de analfabetismo atingiam especialmente as classes baixas da população. Desse modo, a maioria dos imigrantes deixou o país portando na bagagem apenas o domínio oral das variedades da região de origem. Além disso, deve-se considerar que, no Brasil da época, a maioria da população era, também, analfabeta. ${ }^{21}$ Por outro lado, não temos informações sobre a possibilidade de os informantes analisados terem tido contato com a escrita de um italiano standard, o que poderia justificar esse uso. ${ }^{22}$

21 Muito embora se tenha optado, em estudos recentes, pela substituição dos conceitos de analfabeto/alfabetizado por iletrado/letrado, mantemos o emprego de analfabetismo e seus derivados, considerando a fidelidade aos termos empregados nas pesquisas de referência quanto à própria condição dos sujeitos aos quais nos referimos, que não tinham acesso, efetivamente, ao sistema de escrita alfabética. Sobre os dados, mesmo que, aqui, não tenha sido feita uma investigação acerca das condições sociais dos sujeitos analisados, supomos que o acesso à escrita tenha se dado em escolas de comunidades de imigração, que ensinavam em línguas maternas dos imigrantes, antes da Campanha de Nacionalização, o que pode ter se dado com os casos registrados em (7) e (8); quanto aos exemplos (9) e (10), consideramos a possibilidade de os sujeitos terem sido enviados pelos pais para estudarem em escolas bilíngues.

22 Cabe lembrar que as consoantes geminadas não são encontradas apenas em textos do Sul do Brasil do século XIX e início do XX, mas são casos muito frequentes na escrita desse período em todo o território brasileiro. No entanto, fazemos o destaque por causa da coincidência desse uso com o italiano padrão. 
Passando-se a outra interferência do vêneto encontrada nas cartas analisadas, citamos a substituição de $<\mathrm{g}>$ por $<\mathrm{z}>$, como em (10).

(10) [20,1 CP SC] agora eu tambem terminei as construssão e tirei um mes de folga para logo enfrentar otros trabalhos mandovos fotografias e o anel da Erminia mais saudassão nossas senfim muitas lembrassa â todos os vossos e meus amigos nada mais so aseita muitas lembranssa e um forte a brasso deste teu Zenro e tua Filha.

O uso do grafema $<\mathrm{z}>$ nesse caso sugere que há interferência na produção fonética relacionada com o ponto de articulação da fricativa pós-alveolar [3] (palatal) produzindo-a como alveolar ou dental [z], o que ocorre com frequência na oralidade dos descendente ${ }^{23}$ de vênetos da região pesquisada. Outras ocorrências bastante comuns na oralidade são estas: jeito/zeito; girar/zirare; janta/zanta. O Dicionário Vêneto sul-rio-grandensePortuguês (STAWINSKI, 1987, p. 319-322) registra esses e alguns outros verbetes em que tal interferência se faz presente no falar vêneto.

A análise dos dados nos permite afirmar que, assim como ocorre na oralidade, as marcas da interferência da língua de imigração trazida para o Oeste Catarinense se fizeram presentes também na escrita desse grupo, ao longo dos anos. Ao olharmos para os dados, percebemos que é preciso considerar fatores sociais, como a não escolarização dos imigrantes, a maioria analfabeta à época da imigração, e de seus descendentes, que viveram em áreas com poucas escolas, especialmente na primeira metade do século XX.

Como se pode perceber, os dados que encontramos (até o momento) se concentraram nos âmbitos lexical, fonético-fonológico e ortográfico, que parecem ser os mais propícios para evidenciar o contato linguístico na escrita, haja vista que o contexto escrito é sempre mais monitorado que a fala - na qual as evidências de contato geralmente se mostram muito mais significativas. O uso do tepe em contexto de /R/ forte e a utilização de determinados itens lexicais muito empregados no cotidiano dos ítalobrasileiros foram os aspectos que se destacaram em nossa pesquisa. Há,

${ }^{23}$ Como atestam duas das autoras deste capítulo, Spessatto e Loregian-Penkal, ambas naturais da região pesquisada e cujas famílias são falantes de vêneto como língua materna. 
porém, muito ainda a ser estudado a partir da transcrição dos documentos do corpus do PHPB-Chapecó e também da sua ampliação ao longo dos anos.

\subsection{Considerações finais}

Antes de tratarmos das considerações finais deste capítulo em si, cabe-nos fazer alguns comentários que perpassaram o domínio textual e se referem ao nosso processo de coleta de dados. Ao iniciarmos esta pesquisa, tínhamos por objetivo fazer um estudo qualitativo que observasse elementos de contato linguístico de línguas de imigração europeia na escrita em português a partir do corpus do PHPB-SC. A princípio, nossa ideia era trabalhar não apenas com a cidade de Chapecó (com a interferência vêneta), mas também com Blumenau, com forte influência da imigração italiana, na mesorregião do Vale do Itajaí - que contempla, em seu corpus, o século XIX (além do XX).

Deparamo-nos, entretanto, com quase inexistentes dados de contato linguístico nos documentos do corpus de Blumenau aos quais tivemos acesso. Acreditamos que isso tenha ocorrido por alguns motivos, como: (i) a extrema formalidade dos textos, em sua maioria cartas e documentos oficiais de figuras ilustres, o que pressupõe um uso bastante monitorado da língua; (ii) o alto nível de escolaridade desses sujeitos que escreviam os documentos, fator que também propicia um maior monitoramento da escrita; (iii) o fato de que muitos textos eram escritos em alemão e traduzidos para o português, havendo uma separação bastante nítida ${ }^{24}$ entre português e alemão; (iv) o plano de nacionalização, que teve repercussões bastante violentas na cidade de Blumenau - como mostram Oliveira (2008), Altenhofen (2013), Maher (2013), entre outros pesquisadores.

Diante dessa realidade, optamos por focar a cidade de Chapecó, pelo fato de termos encontrado dados dessa natureza nos textos de que dispúnhamos. Não poderíamos, no entanto, deixar de registrar essa questão da discrepância entre as duas cidades de Santa Catarina - Blumenau e Chapecó - nas quais o contato linguístico é bastante representativo.

${ }^{24}$ Alguns jornais da cidade, como o Blumenauer Beitung, publicavam suas colunas nas duas versões, lado a lado: português e alemão. 
É provável que esse fato possa indicar caminhos a pesquisadores sobre as peculiaridades existentes em cada uma dessas localidades no que se refere ao uso das línguas minoritárias.

Apesar disso, restringindo nosso foco, cumprimos nosso objetivo de descrever e analisar elementos de contato linguístico em dados escritos do corpus do PHPB-SC. Encontramos dados que puderam nos dar indícios da presença, ao longo da história, do multilinguismo em tal município do Oeste Catarinense, não obstante os processos de incriminação e silenciamento linguísticos sofridos pelos imigrantes no Brasil. É possível que, em documentos não analisados, ainda sejam encontrados mais dados dos fenômenos linguísticos aqui apontados, além de outros não descritos por nós neste capítulo. Muito ainda pode ser estudado e trazido à tona, mas desde já podemos vislumbrar que o registro dessa trajetória contribui para descrever e valorizar a presença desse grupo étnico no vasto mosaico linguístico que constitui o Brasil.

\section{Referências}

ALTENHOFEN, C. V. Bases para uma política linguística de línguas minoritárias no Brasil. In: NICOLAIDES, C.; SILVA, K. A. da; TILIO, R.; ROCHA, C. H. (org.). Política e políticas linguísticas. Campinas: Pontes Editores, 2013. p. 93-116. BALHANA, A. P. Presenza di comunità dialettali italiane in Brasile: aspetti sociali, economici e demografici. In: LO CASCIO, V. (ed.). Litaliano in America Latina. Firenze: Felice le Monnier, 1987. p. 97-130.

BISOL, L. A sílaba e seus constituintes. In: NEVES, M. H. de M. (org.). Gramática do português falado. v. 7: Novos estudos. Campinas: Editora da UNICAMP, 1999. p. 701-742.

BLEVINS, J. The Syllable in Phonological Theory. In: GOLDSMITH, J. (ed.). Handbook of Phonological Theory. London: Blackwell, 1995. p. 206-244.

CORRÀ, L. I veneti in Brasile: koinè dialettale come superamento dei confini? In: MARCATO, G. (ed.). I confini del dialetto. Padova: Unipress, 2001. p. 279-288.

CORRÀ, L. Osservazioni metalinguistiche sull'uso del dialetto e dell'italiano da parte di giovani lamonesi. In: TEMPESTA, I.; MAGGIO, M. (ed.). Lingue in contatto a scuola - tra italiano, dialetto e italiano L2. Milano: FrancoAngeli, 2006. p. 186-193. 
DE MAURO, T. Storia linguistica dell'Italia Unita. 10. ed. Roma: Laterza, 2008. FACCO, J. et al. Agroindustrialização e urbanização de Chapecó-SC (1950-2010): uma visão sobre os impactos e conflitos urbanos e ambientais. REDES - Revista do Desenvolvimento Regional, Santa Cruz do Sul, v. 19, n. 1, p. 187-215, jan./abr. 2014.

FARACO, C. A. História sociopolítica da língua portuguesa. São Paulo: Parábola, 2016.

FERGUSON, C. A. Diglossia. Word, v. 15, n. 2, p. 325-340, 1959.

FISHMAN, J. Bilingualism With and Without Diglossia, Diglossia With and Without Bilingualism. Jornal of Social Issues, v. 2, n. 23, p. 29-38, 1967.

FRANZINA, E. L'America degli emigranti: dal Veneto ai "nuovi mondi" latinamericani (1876-1924). In: ZILIO, G. M. (ed.). Presenza, cultura, lingua e tradizioni dei veneti nel mondo. Parte I: America Latina. Prime inchieste e documenti. Venezia: Guinta Regionale Veneto, 1987. p. 17-59.

FROSI, V.; MIORANZA, C. Dialetos italianos: um perfil linguístico dos ítalobrasileiros do Nordeste do Rio Grande do Sul. Caxias do Sul: Educs, 1983.

FROSI, V. L'italiano standard e i dialetti italiani in Brasile. In: MARCATO, G. (ed.). I confini del dialetto. Padova: Unipress, 2001. p. 253-264.

HEYE, J. Considerações sobre bilinguismo e bilingualidade. Palavra, n. 11, p. 3038, 2003.

LO CASCIO, V. (ed.). Litaliano in America Latina. Firenze: Felice le Monnier, 1987.

LUZZATTO, D. L. Ghenavemo fato arquante. Porto Alegre, 1985.

LUZZATTO, D. L. Dissionàrio Talian Véneto Brasilian Portoghese. Porto Alegre: Sagra Luzzatto, 2000.

MAHER, T. M. Ecos de resistência: políticas linguísticas e línguas minoritárias no Brasil. In: NICOLAIDES, C.; SILVA, K. A. da; TILIO, R.; ROCHA, C. H. (org.). Política e políticas linguísticas. Campinas: Pontes Editores, 2013. p. 117-134.

MARGOTTI, F. W. Difusão sócio-geográfica do português em contato com o italiano no sul do Brasil. 2004. 332 f. Tese (Doutorado em Letras) - Programa de Pós-Graduação em Letras, Universidade Federal do Rio Grande do Sul, Porto Alegre, 2004.

MATEUS, M. H. M.; D’ANDRADE, E. The Phonology of Portuguese. Oxford: Oxford University Press, 2000.

MONTEIRO, C. R. A aprendizagem da ortografia e o uso de estratégias metacognitivas. 2008. 171 f. Dissertação (Mestrado em Educação) - Programa de Pós-Graduação em Educação, Universidade Federal de Pelotas, Pelotas, 2008. 
NARDO, L. Dizionario Italiano-Veneto: a sercar parole. Padova: Editoriale Programma, 2010.

OLIVEIRA, G. M. de. Plurilinguismo no Brasil, 2008, p. 1-11. Disponível em: http://www.lacult.unesco.org/docc/Plurilinguismo_no_Brasil.pdf. Acesso em: 30 jun. 2018.

PETRONE, P. Italiani e discendenti di italiani in Brasile: le scuole e la lingua. In: COSTA, R.; DE BONI, L. A. (ed.). La presenza italiana nella storia e nella cultura del Brasile. Torino: Fondazione Giovanni Agnelli, 1991.

RENK, A. Identidade comunitária. Chapecó: Argos, 2004.

ROHLFS, G. Grammatica Storica della Lingua Italiana e dei suoi dialetti. Torino: Einaudi, 1966.

SPESSATTO, M. B. Marcas da história: características dialetais na fala dos descendentes de italianos de Chapecó. 2001. 93 f. Dissertação (Mestrado em Linguística) - Programa de Pós-Graduação em Linguística, Universidade Federal de Santa Catarina, Florianópolis, 2001.

SPESSATTO, M. B. Variação linguística e ensino: por uma educação linguística democrática. 2011. 237 f. Tese (Doutorado em Educação) - Programa de PósGraduação em Educação, Universidade Federal de Santa Catarina, Florianópolis, 2011.

STAWINSKI, A. Dicionário Vêneto sul-rio-grandense-Português. Porto Alegre: Escola Superior de Tecnologia; Caxias do Sul: Educs, 1987.

TRIFONI, P. (org.). Lingua e identità: una storia sociale dell'italiano. Roma: Carroci, 2006.

WEINREICH, U. Languages in contact: findings and problems. New York: De Gruiter, 1953.

ZAMBONI, A. Veneto: profilo dei dialetti italiani. Pisa: Pacini, 1997. 


\section{Capítulo 4}

\section{Variação nós e a gente em Santa Catarina: do presente para o passado}

Isabel de Oliveira e Silva Monguilhott Raquel Gomes Chaves Ana Kelly Borba da Silva Brustolin Juliana Flores das Chagas

\subsection{Introdução}

Neste capítulo, abordaremos dois fenômenos variáveis no português brasileiro (doravante $\mathrm{PB}$ ), os quais se encontram intimamente relacionados: (a) o de expressão da primeira pessoa do plural (nós gostamos $\sim$ a gente gosta $\varnothing)$ e (b) o de marcação explícita da concordância verbal de primeira pessoa do plural (nós gostamos nó(i)s gosta $\varnothing$; a gente vai $~ \sim$ a gente vamos). A variação verificada entre as formas pronominais nós e a gente 
(P4), ${ }^{1}$ bem como a variação na marcação explícita de concordância verbal de P4 (CVP4), ${ }^{2}$ com esses pronomes, vem sendo investigada em amostras catarinenses sincrônicas. Entre os trabalhos, podemos aludir aos estudos de Brustolin (2009) e de Silvano (2016), os quais indicaram alto grau de variabilidade dos fenômenos, tanto na modalidade escrita como na modalidade oral catarinense.

A partir do tema já introduzido, objetivamos, neste trabalho, revisar os estudos sincrônicos mencionados anteriormente (BRUSTOLIN, 2009; SILVANO, 2016) e, em seguida, apresentar uma análise de dados diacrônicos dos dois fenômenos em questão. $\mathrm{Na}$ Seção 4.2, apresentamos a metodologia e os resultados das duas pesquisas. Em seguida, com o intuito de observar o comportamento diacrônico da variação entre nós e a gente e da variação na marcação explícita de CVP6, analisamos, na Seção 4.3, amostras de cartas pessoais dos séculos XIX e XX que compõem o corpus do projeto $\mathrm{PHPB}-\mathrm{SC}$.

\subsection{Panorama dos estudos variacionistas sobre nós e a gente em Florianópolis}

Nesta seção, apresentamos uma breve revisão de literatura acerca dos dois estudos que versaram tanto sobre o fenômeno variável de primeira pessoa do plural (alternância entre nós e a gente) como sobre o da concordância variável de primeira pessoa do plural (nós falamos $\sim$ nós falaØ; a gente vai a gente vamos) em dados de fala, no estudo de Brustolin (2009), e de escrita, nos trabalhos de Brustolin (2009) e de Silvano (2016), de Florianópolis.

Brustolin (2009) estudou a variação no uso dos pronomes nós e a gente na escrita e na fala de alunos nos anos finais do ensino fundamental (do 6ㅜ ao 9a ano) de escolas da rede estadual localizadas na cidade de Florianópolis. Quanto à variação na concordância verbal de primeira pessoa, embora a autora não tenha se dedicado especificamente a esse

1 Adotamos, neste texto, a nomenclatura de Camara Jr., para o qual a primeira pessoa do plural equivaleria à quarta pessoa do discurso (P4).

2 Utilizamos a sigla CV para concordância verbal e P4 para a primeira pessoa do plural do discurso (nós e a gente). 
fenômeno, a flexão verbal explícita foi controlada, no estudo da alternância pronominal, por meio da variável linguística marca morfêmica do verbo que acompanha o pronome.

$\mathrm{Na}$ etapa de coleta de dados, os alunos foram solicitados a narrar uma experiência vivida juntamente a outras pessoas para que fosse possível resgatar preferencialmente dados de primeira pessoa do plural em um texto escrito. O mesmo procedimento foi realizado com vistas à coleta de dados de fala. No entanto, vale ressaltar que as entrevistas foram realizadas apenas em uma das escolas investigadas.

A amostra constituiu-se de 393 produções escritas, nas quais a autora encontrou 1.284 dados de nós e a gente, e 85 produções orais, as quais computaram 383 dados de nós e a gente. Do resultado total de uso dos pronomes nós e a gente (1.667), incluindo-se dados tanto de escrita como de fala, obtiveram-se $25 \%$ de presença do pronome a gente e $75 \%$ do pronome nós. Considerando o pronome a gente como aplicação da regra, os seguintes grupos de fatores foram indicados como relevantes: marca morfêmica (morfema zero - a gente vaiØ); preenchimento do sujeito (sujeito preenchido - a gente fala); fala/escrita (o pronome a gente foi verificado de forma mais efetiva na escrita dos alunos do que na fala). A seguir, apresentamos alguns exemplos encontrados pela autora.

(1) Nós + P3

"[...] foi passando o tempo assim, nós tinha bastante comida pra comê..."

(2) Nós + P4

"[...] bateu o recreio nós fomos pro recreio e depois nóis demo a mochila pra ele."

(3) A gente + P3

"Quase sempre a gente vai um monte de vezes no shoppi, no circo também."

(4) A gente + P4

"[...] a gente ficamo um pouco no restaurante e depois voltamo pra casa."

Se levarmos em conta apenas os dados de fala, em todos os anos escolares, o pronome a gente suplanta o pronome nós, sendo mais usado pelos alunos do $8^{\circ}$ ano $(70 \%)$. As variáveis apontadas como relevantes para 
o uso do pronome referido foram: paralelismo formal - paralelismo sujeitosujeito (ex.: Um dia de manhã eu acordei e fui na minha amiga que o nome dela é Fran a gente foi passear no Chopin e paquerar os minino porque lá sempre vai uns gato") e paralelismo sujeito-objeto (ex.: No outro dia quando nós acordamos a gente montou barracos por que tinha muitas pessoas e passamos o dia se divertindo.); saliência fônica - menor grau de saliência fônica (ex.: Às vezes a gente brinca de boneco, um monte de coisa.), sexo sexo feminino e ano escolar - alunos do $6^{\circ}$ e $7^{\circ}$ anos.

No que tange à concordância, Brustolin (2009) realizou um cruzamento entre as variáveis fala/escrita e marca morfêmica do verbo que acompanha o pronome a gente para verificar o percentual da combinação de a gente, tanto na escrita quanto na fala, e de a gente com a marca morfêmica -mos e a marca morfêmica $\varnothing$ (zero). Os resultados indicaram mais ocorrências do pronome a gente com a marca morfêmica $\varnothing$ do que com a marca morfêmica - mos tanto na fala quanto na escrita (89\% e $83 \%$, respectivamente). Vale destacar que a ocorrência de a gente +- mos foi maior na escrita (17\%) do que na fala (11\%). Apesar de o índice percentual não ser muito superior, a autora indagou sobre a possibilidade de esse resultado retratar um caso de hipercorreção, ${ }^{3}$ já que, na escrita, há um monitoramento maior do que na fala.

A autora ainda ressalta que a concordância do pronome a gente com a marca morfêmica $\varnothing$ mostra que formas gramaticalizadas não perdem inteiramente as suas propriedades originais, mantendo, nesse caso, a possibilidade de $\mathrm{CV}$ com $\mathrm{P}^{4}$ e a pluralidade inerente ao nome coletivo gente (LOPES, 1999; VIANNA, 2006; BRUSTOLIN, 2009). Os resultados de Brustolin (2009) corroboram os resultados de Vianna (2006), autora que constatou maior produtividade de a gente na fala e de nós na escrita, em seu estudo a respeito da concordância de nós e a gente em estruturas predicativas na fala e na escrita carioca.

Brustolin (2009) efetuou, ainda, análises estatísticas somente com os dados de escrita dos alunos de uma das escolas investigadas com o

3 O termo "hipercorreção" indica a aplicação equivocada de uma regra aprendida imperfeitamente por desejo do falante de se expressar corretamente, como, por exemplo, pronunciar "previlégio" por privilégio. Também chamada de "hiperurbanismo" ou "ultracorreção" (CALVET, 2002).

4 Assim como empregamos P4 para a primeira pessoa do plural, utilizamos P3 para a terceira pessoa do singular do discurso (ele/ela), assim como propõe Camara Jr. (1970). 
intuito de comparar dados de escrita com dados de fala. ${ }^{5}$ Nessa rodada, os grupos de fatores selecionados como relevantes foram: marca morfêmica, paralelismo formal e saliência fônica. Assim como na primeira análise, a autora estipulou como aplicação da regra o uso de a gente, e a CV de a gente com verbos com morfema $\emptyset$ (zero) ou em P3 apresentou índice percentual superior, correspondente a $94 \%$ contra $5 \%$ de a gente com morfema -mos.

Quanto ao paralelismo formal (sujeito-sujeito), a autora entendeu que, quando o pronome a gente inicia uma série na escrita, a tendência é que a escolha influencie o uso do verbo $+\varnothing$ nas formas subsequentes (OMENA, 1998, 2003; LOPES, 1993; BRUSTOLIN, 2009). Brustolin (2009) ressalta que embora não pareça haver nenhuma avaliação negativa atrelada ao uso do pronome a gente, verifica-se estigma quanto à concordância verbal de P4: a gente vai/a gente vamos; nós vai/nós vamos.

Silvano (2016), por sua vez, investigou a variação na concordância verbal de primeira pessoa do plural em uma amostra coletada pela própria autora, constituída de 160 produções escritas do gênero relato de experiência pessoal $^{6}$ de alunos do $6^{\circ}$ e $9^{\circ}$ anos do ensino fundamental de duas escolas da rede pública de ensino de Florianópolis. O objetivo da autora também consistiu em analisar questionários sociais aplicados aos alunos e aos professores, além de avaliação/correção dirigida aos professores de Língua Portuguesa das turmas investigadas de um dos textos produzidos por um aluno do $9^{\circ}$ ano adaptado para a atividade.

Do total de textos considerados, a autora levantou 1.113 dados de variação na concordância verbal de primeira pessoa do plural, dos quais $78,3 \%$ apresentaram sujeito pronominal nós (nós fomos no cinema), $13 \%$ sujeito pronominal SN + eu (Eu e a Sofia fomo fazer pipoca) e 8,6\%

5 Foram feitas entrevistas orais nas quatro escolas, mas foram analisadas apenas as da escola 3, por não haver tempo hábil para a análise das quatro escolas.

6 A autora descreve, em sua dissertação, as etapas do trabalho com o gênero "relato de experiência pessoal", pensadas para $4 \mathrm{~h} / \mathrm{a}$ compreendendo quatro momentos, apresentados aqui de forma resumida: $\left(1^{\circ}\right)$ os alunos leram e discutiram um texto do gênero relato de experiência pessoal; $\left(2^{\circ}\right)$ a pesquisadora estimulou a turma a relatar, inicialmente de forma oral, suas experiências de vida envolvendo episódios que aconteceram em viagens, passeios, jogos, festas, reuniões familiares, brincadeiras com amigos etc.; (3o) a pesquisadora pediu que cada aluno relembrasse e contasse um episódio de sua vida que envolvesse sua participação e de outra(s) pessoa(s) como um "relato de aventura" para um colega; $\left(4^{\circ}\right)$ cada aluno escreveu a aventura que relatou ao colega. 
sujeito pronominal a gente (A gente tinha levado um pote de minhocas). Os resultados indicaram, portanto, ampla preferência dos alunos, nos seus textos escritos, pelo uso do sujeito pronominal nós em detrimento dos sujeitos pronominais $S N+e u$ e a gente, o que era esperado pela autora, em função do maior monitoramento da modalidade escrita, em especial no ambiente escolar.

Silvano empreendeu análises estatísticas separadas para o sujeito pronominal nós, para o sujeito pronominal $S N+e u$ e para o sujeito pronominal a gente, relacionando-as às variáveis linguísticas forma verbal, realização do sujeito, vogal temática, posição do acento, saliência fônica, conjugação do verbo e estrutura verbal e às variáveis extralinguísticas escolaridade, sexo e escola.

No que se refere à análise relativa ao sujeito nós, os resultados indicam que dos 872 dados, a maioria deles, 852 (97,7\%), apresentou concordância padrão com -mos (Todos nós achamos muito engraçado), oito dados $(0,9 \%)$ apresentaram concordância com -mo (e depois nois fomo) jogar baralho e 12 dados $(1,4 \%)$ apresentaram marca zero (Um dia nós estava $\varnothing$ com o meus amigos saltado pipa).

A análise considerando -mos/-mo versus zero selecionou um único grupo de fatores como estatisticamente relevante, a variável sexo. De acordo com a autora, o fato de as outras variáveis linguísticas e extralinguísticas não terem sido selecionadas, contrariando suas expectativas, pode ser reflexo do baixo número de dados de sua amostra e da alta frequência de uso de concordância padrão do sujeito pronominal nós e da desinência -mos. Os resultados indicam que os informantes do sexo masculino utilizaram mais a concordância não padrão (nós + zero), enquanto os informantes do sexo feminino utilizaram mais a concordância padrão. Além de utilizarem mais a marcação de CV, os informantes do sexo feminino também utilizaram mais o pronome nós.

No que se refere ao sujeito $S N+e u$ (Eu e meu primo tivemos a ideia de andar de bicicleta), dos 145 dados, 133 (91,7\%) apresentaram concordância padrão com -mos, dez dados (6,9\%) com desinência zero e apenas dois dados $(2,1 \%)$ com - mo. Na análise com o sujeito $S N+e \mathfrak{u}$, a única variável selecionada foi a forma verbal: os verbos no pretérito perfeito preservaram mais as marcas de concordância do que os verbos no pretérito imperfeito. 
Em relação ao sujeito pronominal a gente, a concordância padrão com zero (A gente tinha $\varnothing$ levado um pote de minhocas) foi registrada em $94,8 \%$, isto é, de forma quase categórica. A desinência -mos foi verificada em apenas cinco dados $(5,2 \%)$ e não se registrou nenhum dado com -mo. Nessa análise, nenhuma variável foi apontada como significativa.

Como dissemos anteriormente, Silvano (2016) também analisou questionários sociais aplicados aos alunos, nos quais foram registradas informações sobre moradia, escolaridade dos pais, deslocamento dos alunos até a escola, grau de acesso à internet e hábito de leitura, com o objetivo de traçar o perfil dos alunos das duas escolas investigadas. A autora, na tentativa de correlacionar os diferentes perfis ao condicionamento da variação da concordância verbal, atestou que o perfil social dos alunos é semelhante, a não ser no que se refere à escolaridade do pai e à escolaridade da mãe.

Em linhas gerais, os resultados dessa análise indicaram que há influência da escolaridade dos pais e das mães dos alunos no uso da CVP4, já que as ocorrências padrão se deram com mais frequência entre os alunos da escola em que a maioria dos pais e mães tinha ensino médio/superior/ pós-graduação, em contraste com a outra escola em que a maioria dos pais e mães tinha apenas ensino fundamental/médio. Dessa forma, os resultados parecem indicar que a escolaridade dos pais se correlaciona à realidade econômica e cultural dos alunos, como, por exemplo, a valorização do estudo e o acesso a bens culturais

Por fim, em relação à avaliação/correção de uma produção textual dirigida aos professores investigados, a autora observou que todos os docentes privilegiaram o conteúdo do texto, a coesão e a coerência em detrimento das questões gramaticais, uma vez que se tratava de uma primeira versão e que não ficaram claros alguns comandos ao aluno, como seu interlocutor e a esfera de circulação do gênero produzido. Silvano (2016) constata que mesmo os profissionais com mais formação (os professores com pós-graduação) demonstraram certo rigor na avaliação da variação da concordância verbal de primeira pessoa do plural na modalidade escrita, destacando que o uso do pronome a gente seria mais adequado na modalidade oral e que a concordância não padrão deveria ser corrigida para a versão final do texto, o que corrobora as conclusões de Brustolin (2009) de que o processo de escolarização influencia o uso e a escolha 
desses pronomes, bem como o uso e a escolha da relação de concordância estabelecida entre esses pronomes e as marcas verbais que os acompanham.

\subsection{A variação entre nós e a gente em Santa Catarina: comparando sincronias}

Com vistas à delineação de um panorama dos fenômenos de variação de nós e a gente e da marcação explícita de CVP4 investigados no PB, no estado de Santa Catarina, nos séculos XIX e XX, apresentamos, a seguir, a análise qualitativa ${ }^{7}$ para os casos (variáveis) inerentes à primeira pessoa do plural. Apresentamos, primeiramente, uma análise relativa à alternância entre os pronomes de primeira pessoa $(\mathrm{P} 4)$. Logo a seguir, nos detemos à variação da marcação da concordância (CVP4).

Em ambas as análises, foram levadas em conta amostras que compõem o PHPB-SC, a saber: (i) Amostra Cruz e Sousa, constituída das missivas Araújo Figueiredo para Cruz e Sousa (1888 a 1897); Cruz e Sousa para Gavita (1892); Virgílio Várzea para Cruz e Sousa (1888 a 1890) - século XIX; (ii) Amostra José Boiteux (1927 a 1933), Amostra do Vale (1965 a 1970), Amostra Tia Ciça (1980 a 1996), Amostra Medeiros (1980 a 1983) e Amostra Monguilhott (1989 a 1998) - século XX.

Foi analisado um total de 142 ocorrências das formas pronominais nós e a gente explícitas (plenas) e não explícitas (desinenciais ou nulas). Desse número geral, no século XIX, todos os casos, correspondentes a 13, foram casos de nós. No século XX, por seu turno, foram computados 129 casos (9,2\%) de nós e oito casos $(0,8 \%)$ de a gente. Podemos verificar, portanto, considerando-se as ocorrências obtidas nas amostras do PB (séculos XIX e $\mathrm{XX}$ ), o predomínio da forma nós sobre a forma a gente independentemente do século. Os resultados apontam que a forma inovadora a gente aparece mesmo que em número menor - apenas na escrita do século XX, ao passo que a forma pronominal conservadora nós prevalece independentemente do século.

Comparamos os resultados obtidos neste estudo aos resultados evidenciados por Brustolin (2009) e por Silvano (2016), com amostras

Embora tenhamos apresentado, na seção anterior, um detalhamento das variáveis investigadas nos estudos sincrônicos, não nos deteremos a uma análise quantitativa, em função do baixo número de dados. 
de fala e de escrita de Florianópolis do século XXI, a fim de verificar as possíveis aproximações e distâncias entre a frequência de uso relativas a cada uma das formas pronominais de $\mathrm{P} 4$.

Brustolin (2009) registrou 14\% de uso do pronome a gente na escrita dos alunos e $65 \%$ de a gente na fala dos alunos do segundo segmento do ensino fundamental de Florianópolis. Os resultados de Silvano (2016), que dizem respeito apenas à escrita, conforme apresentado na seção anterior, revelaram 78,3\% de sujeito nós (expresso ou nulo), $13 \%$ de sujeito $S N+e u$ (expresso ou nulo) e apenas $8 \%$ de sujeito a gente. Sendo assim, constatamos uma diferença bastante expressiva no uso dos pronomes nós e a gente a depender da modalidade falada ou escrita.

Embora sejam análises de gêneros textuais distintos nas três amostras investigadas (Brustolin e Silvano - relato de experiência; PHPB-SC - cartas pessoais); em épocas diferentes (séculos XIX, XX e XXI); com informantes e missivistas com diferentes perfis sociais e ainda com número de dados não equilibrado, percebemos que, ao longo dos séculos, houve crescimento do uso do pronome a gente no registro escrito: de $0 \%$ no século XIX para 5,8\% no século XX, entre 8,6\% (SILVANO, 2016) e 14\% (BRUSTOLIN, 2009), respectivamente, no século XXI. Apesar de vislumbrarmos esse aumento, não observamos índices altos de uso da forma inovadora na escrita como observamos na fala.

No que diz respeito à variação na marcação da concordância verbal de P4, nos dados de escrita de Santa Catarina do século XX em que se verifica o emprego de a gente, constatamos a predominância de um padrão: a gente + marca morfêmica $\emptyset$. Os dados a seguir ilustram esses casos.

(5) [20,2 CP SC] Este amor que sinto por ti é o nutriente da minha vida, ele faz a gente sentir-se num estado de espírito bom. (Amostra Medeiros)

(6) $[20,2$ CP SC] Com o tempo a gente vai aprendendo as malandragens do trabalho. (Amostra Medeiros)

(7) [20,2 CP SC] Realmente é cansativo, mas vale a pena, a gente sente que esta se realizando. (Amostra Medeiros)

(8) [20,2 CP SC] [...] enfim só assim os sentimentos crescem e a gente vive. (Amostra Medeiros)

(9) [20,2 CP SC] É tão bom $\underline{a}$ gente receber comunicação da pessoa que gosta. (Amostra Medeiros) 
(10) [20,2 CP SC] E a gente pensa tanto nela. (Amostra Medeiros)

(11) [20,2 CP SC] Como é bom saber que a gente tem um amor, que nos dá tanta força. (Amostra Medeiros)

(12) [20,2 CP SC] Espero que a gente consiga atingir esse nível. (Amostra Medeiros)

Conforme observamos nos exemplos supracitados, a combinação de a gente com a marca morfêmica $\varnothing$ (verbo em P3) mostrou-se dominante, o que vai ao encontro do que os estudos dessa área atestam, tanto em amostras sincrônicas (SILVANO, 2016) quanto em amostras diacrônicas. ${ }^{8}$

Brustolin (2009) já havia denunciado que a combinação de $a$ gente com a marca morfêmica $\varnothing$ (a gente compra $\varnothing$ ) e de nós com a marca morfêmica -mos (nós compramos) ainda se apresenta majoritária. Em seu estudo, houve, na escrita, mais ocorrências de a gente com a marca morfêmica -mos do que com a marca morfêmica $\varnothing$, o que a autora apontou como um fato que poderia caracterizar um fenômeno de "hipercorreção". Esse aspecto já fora evidenciado no PB, como mostram os trabalhos de Omena ${ }^{9}$ (1998), Menon ${ }^{10}$ (1995) e Naro et al. ${ }^{11}$

8 Como não temos estudos diacrônicos acerca do fenômeno ora investigado, recorremos a estudos com amostras distintas.

9 Omena (1998) trabalhou com uma amostra de fala de 48 informantes cariocas integrantes do projeto Censo Linguístico do Rio de Janeiro, distribuídos em três faixas etárias (15 a 25 anos, 26 a 49 anos e 50 anos ou mais), três graus de escolaridade ( $1^{\text {a }}$ a $4^{\text {a }}$ série do ensino fundamental, $5^{\underline{a}}$ a $8^{\underline{a}}$ série do ensino fundamental e ensino médio) e sexos masculino e feminino. Sua proposta buscava conferir por que o falante se vale de uma das formas pronominais nós/a gente em substituição à outra nos mesmos contextos, bem como analisar os empregos de a gente e nós que compreendam traços comuns, como $\left[+1^{\underline{a}}\right.$ pessoa gramatical] e/ou [+pluralidade]. A autora também procurou explicar a preferência que o falante vem dando ao pronome a gente em detrimento de nós, desvendando e avaliando a ação dos condicionadores linguísticos estruturais e a ação das características sociais do falante sobre esse uso.

10 Menon (1995) mostrou um aspecto evidenciado no PB que se refere ao fato de o pronome a gente estar associado semanticamente com morfema do verbo no plural, ou seja, podemos encontrar esse uso na língua.

11 Naro et al. (1999) discutiram uma mudança na distribuição dos pronomes de primeira pessoa do plural, bem como mudanças nos padrões de uso do verbo e suas correspondentes flexões em quatro gerações de falantes do Rio de Janeiro. Os autores trataram do tema em relação à fala do Rio de Janeiro na década de 1980, na variante popular carioca de informantes pouco escolarizados e com baixo nível socioeconômico. No início dos 
(1999), com exemplos de fala como: a gente dançamos, a gente fomos, entre outros.

Já em Silvano (2016), os dados de a gente apresentaram um percentual bem maior de concordância com $\varnothing(94,8 \%)$ do que com -mos $(5,2 \%)$, o que não corresponde ao que Brustolin (2009) encontrou em seus dados de escrita. Com relação ao nós, Silvano também encontrou altos índices percentuais de concordância padrão, nesse caso com -mos $(97,7 \%)$, e baixos índices com -mo $(0,9 \%)$ e com $\varnothing(1,4 \%)$.

Com relação às estratégias "não padrão", Vianna (2006), em seu estudo no Rio de Janeiro, encontrou baixos índices de combinação de $a$ gente com verbo em $\mathrm{P} 4$ (a gente fomos). Já entre falantes não cultos, a autora, baseada nas amostras do projeto Censo/Peul-RJ, constatou predominância da combinação de a gente com verbo em P3 (a gente foi $)$ e de nós com verbo em $\mathrm{P} 4$ (nós fomos), como no presente estudo.

De acordo com o estudo de Vianna (2011, p. 109) sobre a representação da primeira pessoa do plural do discurso no português europeu (PE): "pode-se dizer que, entre falantes portugueses, a opção primeira na indicação da $1^{\text {a }}$ pessoa do plural acontece por meio da desinência verbal -mos", o que também confirmamos nos nossos dados do $\mathrm{PB}$, dos séculos XIX e XX, a saber:

(13) [19,2 CP SC] Pela minha honra e pelo dia em que nos vimos pela primeira vez. (Amostra Cruz e Sousa)

(14) [19,2 CP SC] Tornemo-nos mais praticos. (Amostra Cruz e Sousa)

(15) [19,2 CP SC] Verdade, e despedindo-nos de todas as illusões, pudemos dizer, não ha, jamais haverá, para nós prosperidade [...] (Amostra Cruz e Sousa)

anos 1980, foram realizadas, gravadas e transcritas 64 entrevistas individuais, cada uma com cerca de 45 minutos de duração. A escolha dos informantes em função do local de residência foi feita aleatoriamente em todo o município do Rio de Janeiro. Pelo menos duas reuniões foram realizadas com cada falante: a primeira foi uma sessão preliminar destinada a obter dados sociais relevantes e a familiarizar o informante com a situação de entrevista; a segunda foi a entrevista propriamente dita, realizada de acordo com um questionário e modificada para atender a interesses pessoais de cada pessoa. Aos informantes foi dito que o objetivo da pesquisa era estudar o carioca (Rio de Janeiro) e as opiniões sobre o modo de vida carioca. Nenhuma menção específica à linguagem foi feita. 
(16) [20,2 CP SC] [...] que já somos mais, e por teres me aturado todo este tempo [...] (Amostra Medeiros)

(17) $[20,2$ CP SC] [...] acho que devemos formar um pensamento. (Amostra Medeiros)

(18) [20,2 CP SC] Senão mais tarde iremos sofrer e [...] (Amostra Medeiros)

Por meio da observação da amostra investigada, verificamos que as combinações de nós com verbo em $\mathrm{P} 4$ (nós queremos) e de a gente com verbo em P3 (a gente quer) - quando surgem - prevalecem nos dados. Tais resultados também servem para inferirmos que a concordância de a gente com P3 evidencia que formas gramaticalizadas não perdem inteiramente as suas propriedades originais. Assim, a gente mantém a possibilidade de concordância verbal com a terceira pessoa do singular e a pluralidade inerente ao nome coletivo gente, como já delinearam Lopes (1999), Vianna (2006) e Brustolin (2009).

No que diz respeito a uma correlação entre as variáveis controladas nos estudos sincrônicos de Brustolin (2009) e de Silvano (2016), observamos que, ao considerarmos a forma a gente, no estudo de Silvano (2016), nenhuma das variáveis controladas mostrou-se significativa. Já no estudo de Brustolin (2009), na amostra de escrita, a autora observou a influência da marca morfêmica, o que parece ir ao encontro dos resultados da nossa amostra diacrônica aqui investigada por indicar forte correlação entre expressão do pronome de $\mathrm{P} 4 \mathrm{e}$ marcação de concordância.

\subsection{Algumas considerações}

Buscamos, neste capítulo, analisar, em dados de escrita catarinense, a variação entre dois fenômenos variáveis interrrelacionados: a variação na expressão de P4, nós e a gente, e a variação na marcação da CVP4. Para isso, levamos em conta uma amostra de 21 cartas pessoais do século XIX e de 136 cartas do século XX, todas pertencentes ao corpus do PHPB-SC. Além disso, apresentamos um panorama geral dos estudos de Brustolin (2009) e de Silvano (2016), buscando estabelecer, sempre que possível, paralelos entre as análises.

Verificamos, na amostra diacrônica investigada, que os resultados, assim como defende a literatura, indicam que a gente é uma forma 
pronominal inovadora no século XX, sendo verificada em apenas oito casos em nossos dados. Desse modo, no que diz respeito à expressão de P4, nós mostrou-se categórico no século XIX e praticamente categórico no século XX. Já em relação à CVP4, observamos a prevalência da variante marcada (nós + CVP4).

Ao compararmos os resultados encontrados na análise diacrônica com os trabalhos de Brustolin (2009) e de Silvano (2016), observamos também, em dados de escrita, um padrão semelhante no que toca às duas variáveis. Podemos esboçar um percurso tanto do uso dos pronomes quanto do da marcação de concordância, que vai do uso categórico de nós e de concordância canônica, no século XIX, passando pelo uso variável entre nós e a gente e de concordância canônica com ambos os pronomes, no século XX, chegando, por fim, a um uso variável entre nós e a gente e a um uso também variável na concordância com ambos os pronomes no século XXI.

\section{Referências}

AGOSTINHO, S. R. N. A variação na concordância verbal de primeira pessoa do plural na escrita de alunos do ensino fundamental. 2013. 318 f. Dissertação (Mestrado em Linguística) - Programa de Pós-Graduação em Linguística, Universidade Federal de Santa Catarina, Florianópolis, 2013.

AMARAL, L. I. C. A concordância verbal de segunda pessoa do singular em Pelotas e suas implicações linguísticas e sociais. 2003. $181 \mathrm{f}$. Tese (Doutorado em Letras) Programa de Pós-Graduação em Letras, Universidade Federal do Rio Grande do Sul, Porto Alegre, 2003.

BORGES, P. R. S. A gramaticalização de a gente no Português Brasileiro: análise histórico-social-linguística da fala das comunidades gaúchas de Jaguarão e Pelotas. 2004. 227 f. Tese (Doutorado em Letras) - Programa de Pós-Graduação em Letras, Universidade Federal do Rio Grande do Sul, Porto Alegre, 2004.

BORTONI-RICARDO, S. M. Educação em língua materna: a sociolinguística na sala de aula. São Paulo: Parábola, 2004.

BORTONI-RICARDO, S. M. Nós cheguemu na escola, e agora? 2. ed. São Paulo: Parábola, 2006.

BORTONI-RICARDO, S. M. The urbanization of rural dialect speakers: a sociolinguistic study in Brazil. Cambridge: Cambridge University Press, 1985. 
BRUSTOLIN, A. K. B. da S. Itinerário do uso e variação de nós e a gente em textos escritos e orais de alunos do ensino fundamental da rede pública de Florianópolis. 2009. 245 f. Dissertação (Mestrado em Linguística) - Programa de Pós-Graduação em Linguística, Universidade Federal de Santa Catarina, Florianópolis, 2009.

CALVET, L. J. As políticas linguísticas. Florianópolis: IPOL; São Paulo: Parábola, 2006.

CALVET, L. J. Sociolinguística: uma introdução crítica. Tradução de Marcos Marcionilo. São Paulo: Parábola, 2002.

CAMARA JR., J. M. Estrutura da língua portuguesa. Petrópolis: Vozes, 1970.

GARCIA, S. O. A concordância verbal em redações de vestibular. 2005. $130 \mathrm{f}$. Dissertação (Mestrado em Linguística) - Programa de Pós-Graduação em Linguística, Universidade de Brasília, Brasília, 2005.

LOPES, C. R. dos S. Nós e a gente no português falado culto do Brasil. 1993.

Dissertação (Mestrado em Letras Vernáculas) - Faculdade de Letras, Universidade Federal do Rio de Janeiro, Rio de Janeiro, 1993.

LOPES, C. R. dos S. A inserção de a gente no quadro pronominal do português: percurso histórico. 1999. Tese (Doutorado em Letras Vernáculas) - Faculdade de Letras, Universidade Federal do Rio de Janeiro, Rio de Janeiro, 1999.

LOPES, C. R. dos S. A gramaticalização de a gente em português em tempo real de longa e de curta duração: retenção e mudança na especificação dos traços intrínsecos. Fórum Linguístico, Florianópolis, v. 4, n. 1, p. 47-80, jul. 2004.

LOPES, C. R. dos S. A inserção de "a gente" no quadro pronominal do português. Frankfurt am Main: Vervuert; Madri: Iberoamericana, 2003. v. 18.

LOPES, C. R. dos S. Nós e a gente no português falado culto do Brasil. DELTA, São Paulo, v. 14, n. 2, p. 405-422, 1998.

MENON, O. P. da S. A gente, eu, nós: sintomas de uma mudança em curso no português do Brasil? In: ENCONTRO NACIONAL DE LÍNGUA FALADA E ESCRITA, 2., 1995, Maceió. Anais [...]. Maceió: UFAL, 1995. p. 397-403.

MENON, O. P. da S. et al. Alternância nós/a gente nos quadrinhos: análise em tempo real. In: RONCARATI, C.; ABRAÇADO, J. (org.). Português brasileiro: contato linguístico, heterogeneidade e história. Rio de Janeiro: 7Letras, 2003. p. 397-403.

NARO, A. J. A referência à primeira pessoa do discurso no plural. In: OLIVEIRA E SILVA, G. M.; SCHERRE, M. M. P. (org.). Padrões sociolinguísticos: estudos de fenômenos variáveis do português falado na cidade do Rio de Janeiro. 2. ed. Rio de Janeiro: Tempo Brasileiro, 1998. p. 185-215. 
NARO, A. J. The social and structural dimensions of a syntatic change. Language, v. 57, n. 1, p. 63-98, 1981.

NARO, A. J.; GÖRSKI, E. M.; FERNANDES, E. Change without Change. Language Variation and Change, New York, v. 11, n. 2, p. 197-211, 1999.

NARO, A. J.; SCHERRE, M. M. P. Variação e mudança linguística: fluxos e contrafluxos na comunidade de fala. Cadernos de Estudos Linguísticos, Campinas, v. 20, p. 9-16, 1991.

OMENA, N. P. de. A referência à primeira pessoa do plural: variação ou mudança? In: PAIVA, M. da C.; DUARTE, M. E. L. (org.). Mudança linguística em tempo real. Rio de Janeiro: Contra Capa: FAPERJ, 2003. p. 63-80.

OMENA, N. P. de. A referência à primeira pessoa do discurso no plural. In: OLIVEIRA E SILVA, G. M.; SCHERRE, M. M. P. (org.). Padrões sociolinguísticos: estudos de fenômenos variáveis do português falado na cidade do Rio de Janeiro. 2. ed. Rio de Janeiro: Tempo Brasileiro, 1998. p. 185-215.

OMENA, N. P. de; BRAGA, M. L. A gente está se gramaticalizando? In: MACEDO, A. T. et al. (org.). Variação e discurso. Rio de Janeiro: Tempo Brasileiro, 1996. p. 75-83.

SILVA, I. da. De quem nós/a gente está(mos) falando afinal?: uma investigação sincrônica da variação entre nós e a gente como estratégias de designação referencial. 2004. 145 f. Dissertação (Mestrado em Linguística) - Programa de Pós-Graduação em Linguística, Universidade Federal de Santa Catarina, Florianópolis, 2004.

SILVA, J. A. A. da. A concordância verbal no português afro-brasileiro: um estudo sociolinguístico de três comunidades rurais do estado da Bahia. 2003. $323 \mathrm{f}$. Dissertação (Mestrado em Letras e Linguística) - Programa de Pós-Graduação em Letras e Linguística, Universidade Federal da Bahia, Salvador, 2003.

SILVANO, G. L. P. A concordância verbal de primeira pessoa do plural em textos escritos por alunos do ensino fundamental da rede pública de Florianópolis. 2016. 244 f. Dissertação (Mestrado em Linguística) - Programa de Pós-Graduação em Linguística, Universidade Federal de Santa Catarina, Florianópolis, 2016.

SPESSATTO, M. B. Formas linguísticas inovadoras não conhecem fronteiras: nós/a gente na fala da população da Costa da Lagoa. Working Papers em Linguística, Florianópolis, n. esp., p. 82-93, 2011.

VIANNA, J. B. de S. A concordância de nós e a gente em estruturas predicativas na fala e na escrita carioca. 2006. 141 f. Dissertação (Mestrado em Letras Vernáculas) - Faculdade de Letras, Universidade Federal do Rio de Janeiro, Rio de Janeiro, 2006. 
VIANNA, J. B. de S. Semelhanças e diferenças na implementação de a gente em variedades do português. 2011. 255 f. Tese (Doutorado em Letras Vernáculas) - Faculdade de Letras, Universidade Federal do Rio de Janeiro, Rio de Janeiro, 2011.

ZILLES, A. M. S. A concordância verbal com a primeira pessoa do plural em Panambi e Porto Alegre, RS. Organon, Porto Alegre, v. 14, n. 28/29, p. 195-219, 2000.

ZILLES, A. M. S. O que a fala e a escrita nos dizem sobre a avaliação social do uso de a gente. Letras de Hoje, Porto Alegre, v. 42, n. 2, p. 27-44, jun. 2007. 


\section{Capítulo 5}

\section{A concordância verbal de terceira pessoa do plural em Santa Catarina: um olhar diacrônico}

Raquel Gomes Chaves Isabel de Oliveira e Silva Monguilhott

Patrícia Corrêa Ferminio

\subsection{Introdução}

A presença ou ausência de marcas explícitas de concordância verbal na terceira pessoa do plural (eles bebem $\sim$ eles bebeØ, eles falaram $\sim$ eles falou $\varnothing$ ) é fenômeno variável sincrônico vislumbrado em praticamente todas as regiões do Brasil. No que tange a dados de Santa Catarina, foco de nosso interesse particular neste capítulo, o fenômeno em questão foi investigado pelos estudos de Monguilhott (2001, 2009), Chaves (2017) e Ferminio (2017), os quais levaram em consideração dados de fala e, por vezes, de escrita. 
A variação na marcação da concordância verbal de terceira pessoa do plural (doravante CVP6), ${ }^{1}$ nos estudos supracitados, mostrou-se bastante produtiva, entendendo produtividade aqui como alta frequência de aplicação do fenômeno, tanto em dados de fala florianopolitana (MONGUILHOTT, 2001, 2009; CHAVES, 2017) quanto em dados de escrita catarinense - dialeto de Florianópolis e de Itajaí (MONGUILHOTT, 2009; FERMINIO, 2017).

Partindo dos estudos referidos, procuramos, neste capítulo, apresentar um panorama geral dos resultados encontrados pelas três autoras no decorrer de quase duas décadas de investigação. Apresentamos, em seguida, uma análise diacrônica de amostras de cartas pessoais dos séculos XIX e XX que compõem o corpus do projeto PHPB-SC. Por fim, a partir dos resultados referentes à variação na sincronia e na diacronia, expomos uma análise comparativa no que toca especificamente ao fenômeno de marcação explícita de CVP6.

O capítulo está organizado como se segue. Na Seção 5.2, revisamos os trabalhos que trataram da marcação da concordância de P6 em dados de fala e de escrita catarinenses. Na Seção 5.3, exibimos uma análise dos dados de CVP6 nas amostras que compõem o corpus do projeto PHPB-SC. Na Seção 5.4, estabelecemos uma análise comparativa entre o que observamos no passado da língua e o que os estudos mostram no presente no que se refere a esse fenômeno em específico. Por fim, tecemos as considerações finais deste estudo.

\subsection{A marcação explícita de CVP6 em dados sincrônicos de fala/escrita catarinenses}

Nesta seção, revisamos os trabalhos acerca do fenômeno variável de marcação explicitada CVP6 em dados de fala de Florianópolis

\footnotetext{
Adotamos, neste capítulo, a nomenclatura de Camara Jr. (2013 [1970]) para nos referirmos às pessoas do discurso. Segundo o autor, "[...] há seis sufixos número-pessoais, para indicarem como sujeito o falante $\mathrm{P}$ (essoa) 1, o falante e mais alguém ou $\mathrm{P}$ (essoa) 4, um ouvinte ou $\mathrm{P}$ (essoa) 2, mais de um ouvinte ou $\mathrm{P}$ (essoa) 5, um ser ou mais de um ser distintos do falante e do ouvinte, ou seja, respectivamente, $\mathrm{P}$ (essoa) 3 e $\mathrm{P}$ (essoa) 6”. Desse modo, adotamos a sigla CVP6 para representar, ao longo do texto, concordância verbal (CV) com a sexta pessoa do discurso (P6).
} 
(MONGUILHOTT, 2001, 2009; CHAVES, 2017) e de escrita de Florianópolis (MONGUILHOTT, 2009; FERMINIO, 2017) e de Itajaí (FERMINIO, 2017). Antes de apresentar individualmente os trabalhos, exibimos, no Quadro 5.1, o corpus investigado em cada um dos estudos, a fim de que, no decorrer da leitura, seja possível estabelecer comparações entre as pesquisas.

Quadro 5.1 - Corpora investigados pelos estudos acerca do fenômeno variável de terceira pessoa do plural em dados de Santa Catarina

\begin{tabular}{|c|c|c|c|}
\hline Estudo & Localidade & Corpus & $\begin{array}{c}\text { Natureza } \\
\text { dos dados }\end{array}$ \\
\hline $\begin{array}{c}\text { Monguilhott } \\
(2001)\end{array}$ & $\begin{array}{c}\text { Florianópolis - região } \\
\text { urbana }\end{array}$ & $\begin{array}{c}\text { 24 entrevistas do banco } \\
\text { VARSUL }\end{array}$ & Fala \\
\hline $\begin{array}{c}\text { Monguilhott } \\
(2009)\end{array}$ & $\begin{array}{c}\text { Florianópolis - região } \\
\text { urbana (Ingleses e } \\
\text { Centro) e região não } \\
\text { urbana (Ribeirão da Ilha } \\
\text { e Costa da Lagoa) }\end{array}$ & $\begin{array}{c}\text { Amostra Monguilhott } \\
(2006 / 2007) \text { - Amostra } \\
\text { Complementar banco } \\
\text { VARSUL }\end{array}$ & Fala \\
\hline $\begin{array}{c}\text { Monguilhott } \\
(2009)\end{array}$ & Santa Catarina & $\begin{array}{c}\text { 14 peças de teatro: cinco } \\
\text { peças do século XIX e nove } \\
\text { do século XX }\end{array}$ & Escrita \\
\hline $\begin{array}{c}\text { Chaves } \\
(2017)\end{array}$ & $\begin{array}{c}\text { Florianópolis - região } \\
\text { não urbana da Costa da } \\
\text { Lagoa }\end{array}$ & $\begin{array}{c}\text { Amostra Chaves (2016) } \\
\text { Amostra Complementar } \\
\text { banco VARSUL }\end{array}$ & Fala \\
\hline $\begin{array}{c}\text { Ferminio } \\
(2017)\end{array}$ & Florianópolis & $\begin{array}{c}\text { Amostra Brustolin (2009), } \\
\text { Amostra Agostinho (2013), } \\
\text { Amostra Silvano (2016) } \\
\text { Amostra Complementar } \\
\text { banco VARSUL }\end{array}$ & Fala/ \\
Escrita \\
\hline
\end{tabular}

Conforme exposto no Quadro 5.1, os quatro estudos que tratam do fenômeno variável de marcação explícita de CVP6 em dados catarinenses fizeram uso de amostras de fala e de escrita diferenciadas. Monguilhott (2001) investigou os 24 inquéritos de fala referentes à localidade de 
Florianópolis que compõem o banco VARSUL. ${ }^{2}$ Já em seu estudo posterior (MONGUILHOTT, 2009), analisou 16 entrevistas que compuseram seu próprio banco de fala (amostra Monguilhott - 2006/2007) e 14 peças teatrais catarinenses (cinco datadas do século XIX e nove do século $\mathrm{XX}){ }^{3}$

Chaves (2017), por seu turno, investigou um conjunto de entrevistas compilado pela própria autora (amostra Chaves, 2016), relativo à região não urbana da Costa da Lagoa, em Florianópolis. Por fim, Ferminio analisou dados de fala e de escrita de alunos dos anos finais do ensino fundamental de escolas públicas de Florianópolis e de Itajaí, a partir de produções pertencentes à amostra Brustolin (2009), amostra Agostinho (2013) e amostra Silvano (2016).

Apesar de os estudos se diferenciarem no que diz respeito às amostras investigadas, buscaremos, nesta seção, explorar as semelhanças verificadas nos resultados relativos a dados de fala e de escrita. Não apresentamos uma extensa revisão, elencando todos os grupos de fatores que se mostraram relevantes em cada uma das análises, mas sim um panorama geral daquilo que a nosso ver é mais significativo.

\subsubsection{Estudos centrados na análise de fala sincrônica catarinense}

Os quatro estudos referenciados fizeram uma análise de dados de fala sincrônica e investigaram dados de fala exclusivamente de Florianópolis. As amostras, como podemos observar no Quadro 5.1, foram coletadas em períodos distintos e estratificadas de forma diferenciada também. No entanto, os resultados, mesmo com essas diferenças em termos de estratificação amostral, mostram-se bastante coesos. Na tabela a seguir, exibimos o índice de aplicação total de marcação de CVP6 em cada um dos estudos.

2 O projeto Variação Linguística na Região Sul do Brasil (VARSUL) é um projeto interinstitucional (UFSC, UFPR, UFRGS, PUC-RS) que reúne um banco de dados de fala da Região Sul do país. Mais informações em www.varsul.org.br.

3 Além de estudar dados de Florianópolis, Monguilhott (2009) investigou dados de fala e de escrita da região de Lisboa/Portugal. 
Tabela 5.1 - Valores de aplicação da marcação de CVP6 nos quatro estudos

\begin{tabular}{c|c}
\hline Estudo & Marcação de CVP6 \\
\hline Monguilhott (2001) & $79 \%$ \\
\hline Monguilhott (2009) & $81,6 \%$ \\
\hline Chaves (2017) & $79,8 \%$ \\
\hline Ferminio (2017) & $81,8 \%$ \\
\hline
\end{tabular}

No que diz respeito aos grupos de fatores que se mostraram relevantes à marcação de CVP6, os estudos relativos à modalidade de fala também apresentaram semelhanças. Em função de o número de dados levados em conta na análise de Ferminio (2017) ser equivalente a 100 , não nos deteremos nos fatores apontados como condicionadores do fenômeno nesse trabalho. Nos estudos de Monguilhott $(2001,2009)$ e de Chaves (2017) praticamente os mesmos grupos foram apontados como estatisticamente significativos na manifestação da variante marcada. As seguintes variáveis independentes se mostraram relevantes em ao menos duas das três pesquisas: saliência fônica, posição do sujeito em relação ao verbo, ${ }^{4}$ paralelismo formal, animacidade/traço humano do sujeito e tipo de verbo.

No que se refere ao grupo de fatores saliência fônica, controlada segundo a proposta de Naro (1981), ${ }^{5}$ as oposições entre formas verbais singulares e formas verbais plurais mais salientes (é/são, disse/disseram) favoreceram de forma mais expressiva a marcação explícita de CVP6 nos verbos em todos os estudos. Em outros termos, segundo Naro (1981), quanto maior a diferença entre formas verbais singulares e plurais, maior a probabilidade da presença de marcas nos verbos. Essa diferença, medida pelo autor por meio de dois critérios - diferenciação material (diferença

4 No estudo de Chaves (2017), essa variável foi rotulada de presença e localização do SN sujeito.

5 De acordo com Naro (1981), a variável saliência fônica é estabelecida em função de dois critérios: (1) presença ou ausência de acento na desinência e (2) quantidade de material fônico que diferencia a forma singular da forma plural. Formas verbais salientes, dentro dessa proposta, seriam, portanto, aquelas em que há tonicidade em uma das terminações verbais e alta distinção em termos de material fônico, como, por exemplo, o par fez/ fizeram. 
entre os elementos fônicos na oposição singular/plural) e acentuação (verificação ou não de acento na terminação na forma singular, na forma plural ou em ambas) -, mostrou relevância tanto nos estudos de Monguilhott (2001, 2009) como no estudo de Chaves (2017), no quesito acento.

A seleção da variável posição do sujeito nos trabalhos, assim como tem mostrado uma série de outros estudos acerca do fenômeno de marcação explícita de CVP6 em dados de fala do português brasileiro (LEMLE; NARO, 1977; PONTES, 1986; RODRIGUES, 1987; BERLINCK, 1988; SCHERRE; NARO, 1997; SILVA, 2003; CARDOSO, 2005), confirmou a hipótese de que sujeitos antepostos aos verbos (Eles fizeru churrasco) favoreceriam muito a marcação da concordância.

O outro grupo apontado como forte favorecedor da variante marcada foi o paralelismo formal. O paralelismo é tratado, pela literatura, como um princípio que prediz que quanto mais marcas estiverem presentes no sintagma nominal (doravante, $\mathrm{SN}$ ) sujeito, maior a probabilidade de verificarmos marcas também na forma verbal (Todas as minhas amigas namoravam). Os três trabalhos confirmaram a expectativa, portanto, de que, por um lado, quando o último ou único elemento do SN apresentasse marca explícita de plural, o verbo também apresentaria tendência à pluralização e de que, por outro lado, quando houvesse a presença de zero no último elemento (Os homi $\varnothing \underline{\text { ia } \varnothing}$ assim tarrafear), haveria o não favorecimento da forma de plural no verbo.

O grupo de fatores animacidade/traço humano do sujeito também foi selecionado como relevante à ocorrência da marca explícita da concordância verbal nos estudos que se dedicaram à análise de dados de fala florianopolitana. Sujeitos que apresentaram traços [+humano] e/ou [+animado] (As criança $\emptyset$ não são cachorro; traço) mostraram índices percentuais e probabilísticos superiores de marcação de CVP6.

Por fim, no que toca ao grupo de fatores tipo de verbo, os verbos cópula (E o meus dois irmão sempre foru meio pacatos, assim, né?) e os verbos inacusativos (Aí todos os barco vão atrás da Santa, né?!) mostraramse favorecedores da marcação.

No que tange aos grupos de fatores extralinguísticos controlados no estudo de Monguilhott $(2001,2009)$ e de Chaves (2017), os resultados apontaram que, para o fenômeno em estudo, esses condicionadores mostraram-se menos decisivos do que os fatores linguísticos. A escolaridade, 
entre os fatores controlados, foi a variável que se mostrou mais relevante. Em todos os trabalhos, verificou-se, em conformidade com a literatura que trata do fenômeno nas mais diversas regiões do Brasil, que quanto maior o nível de escolaridade, maior a probabilidade de o falante utilizar a regra de concordância verbal.

Sendo assim, podemos afirmar, com base nos resultados relativos à influência das variáveis linguísticas sobre o fenômeno variável de marcação explícita de CVP6 que, assim como temos vislumbrado em muitos estudos em diferentes variedades do PB (SCHERRE; NARO, 1993, 1997; RODRIGUES, 1987; SILVA, 2003; PEREIRA, 2004; CARDOSO, 2005), os grupos de fatores que favorecem a marcação são essencialmente os mesmos. Desse modo, podemos destacar a forte influência das variáveis saliência fônica, posição do sujeito em relação ao verbo, paralelismo formal, animacidade/traço humano do sujeito e tipo de verbo sobre a marcação da CVP6 em dados de fala florianopolitana.

\subsubsection{Estudos centrados na análise de escrita sincrônica/ diacrônica catarinense}

Monguilhott (2009) realizou, além de um estudo sincrônico de dados de fala, uma análise diacrônica do fenômeno de marcação explícita de CVP6 em dados de escrita catarinense, a partir da análise de peças teatrais dos séculos XIX e XX. Para essa investigação, foi levado em conta um total de 14 peças de teatro escritas por autores catarinenses, sendo cinco peças do século XIX e nove do século XX. No total, 549 situações em que a marcação da CVP6 poderia ou não ser constatada foram levantadas pela autora. Desse número, 197 corresponderam a contextos encontrados em peças do século XIX e 352, em peças do século XX. A Tabela 5.2 ilustra os valores totais de aplicação de marcação computados em cada um dos séculos por Monguilhott (2009). 
Tabela 5.2 - Valores de aplicação da marcação de CVP6

\begin{tabular}{c|c|c}
\hline \multirow{2}{*}{ Século } & \multicolumn{2}{|c}{ Marcação de CVP6 } \\
\cline { 2 - 3 } & Apl./Total & $\%$ \\
\hline Séc. XIX & $195 / 197$ & $99 \%$ \\
\hline Séc. XX & $340 / 352$ & $96,6 \%$ \\
\hline
\end{tabular}

Fonte: Adaptado de Monguilhott (2009, p. 184).

Conforme constatado por Monguilhott (2009), observamos um leve declínio na marcação da concordância se compararmos o índice de aplicação do fenômeno nas peças analisadas do século XIX, taxa praticamente categórica (99\%), ao índice das peças do século XX (96,6\%). Em função dos altos percentuais de aplicação em ambos os séculos, Monguilhott (2009) dedica-se, então, a uma análise qualitativa dos casos em que não se verificou a marcação da concordância.

Em relação aos dois dados datados do século XIX em que não houve marcação de concordância, a autora destaca que ambos são casos de verbos inacusativos. Além disso, nas duas ocorrências o sujeito encontrava-se posposto ao verbo e apresentava o traço [-humano]. A seguir, em (1) e (2), expomos os dados da autora.

(1) João André: Eu te conheço; ficarias vermelho. Olha Raimundo, nós marinheiros, nós que nos criamos sobre o convés, não devemos abaixar a cabeça diante dessa súcia de biltres que não nos valem, nem no corpo, nem n’alma: não nos misturemos, Raimundo; sejamos, sempre, francos marujos, e bons camaradas. E com um milhão de diabos, quando alguém se engrilar mostra-se-lhe os dez mandamentos. [Raimundo, 1868, p. 40] (MONGUILHOTT, 2009, p. 186, grifo do autor).

(2) D. Manoel: É o que acontece sempre que se vive em contato imediato com o povo; toma-se amizades... relações, e esquece a gente o que deve ao seu nome. [Raimundo, 1868, p. 58] (MONGUILHOTT, 2009, p. 186, grifo do autor).

Já no que se refere aos 12 dados relativos ao século XX, Monguilhott (2009) identifica três casos em que a não marcação é vislumbrada, aos quais denominamos, neste texto, de casos (1), (2) e (3). O caso (1), que 
compreende um terço dos dados (quatro casos dos 12, portanto), seria aquele já verificado nos dados do século XIX, em que a não marcação estaria circunscrita ao seguinte ambiente linguístico: verbos inacusativos seguidos de sujeitos pospostos com o traço semântico [-humano]. O dado em (3) ilustra um desses casos.

(3) Walfrides: Elle è pobre, mas existe tantos pobres que julgam-se felizes no mundo. [Waltrudes, o nauta veneziano, 1918, p. 67] (MONGUILHOTT, 2009, p. 187, grifo do autor).

O caso (2) seria aquele em que haveria a presença de verbos inacusativos, no entanto com sujeitos antepostos ou nulos, como expresso em (4).

(4) Moambeiro: Eles pensam que é assim. Sai por aí atropelando a mãe dos outros e não dão a mínima satisfação. [Stradivarius, 1993, p. 15] (MONGUILHOTT, 2009, p. 187, grifo do autor).

Por fim, o caso (3) foi caracterizado por Monguilhott (2009) como característico de situações em que se verifica a presença de verbos inacusativos com baixo grau de saliência fônica, como podemos verificar em (5).

(5) Curió: E se o meu nome e a minha cara aparece no jornal, eles logo pensam que eu tenho grana. [Stradivarius, 1993, p. 24] (MONGUILHOTT, 2009, p. 186, grifo do autor).

Como podemos vislumbrar, quatro variáveis linguísticas apontadas como extremamente relevantes na marcação da concordância em dados de fala florianopolitana (cf. Seção 5.2.1) foram apontadas como relevantes na análise diacrônica de Monguilhott (2009), a saber: tipo de verbo, posição do sujeito, traço humano do sujeito e saliência fônica. Ao mesmo tempo, assim como já concluído por Monguilhott (2009), vemos que, apesar de a não marcação ter aumentado nos dados diacrônicos de escrita catarinense do século XIX para o XX, a não marcação fica restrita a determinados contextos bastante limitados.

O estudo de Ferminio (2017), por seu turno, também analisou a modalidade escrita catarinense, no entanto de uma perspectiva sincrônica. A autora buscou identificar os grupos de fatores linguísticos e 
extralinguísticos que influenciavam a marcação da CVP6 na modalidade escrita de alunos dos anos finais do ensino fundamental da rede pública de ensino de Florianópolis e de Itajaí, oriundos da amostra Brustolin (2009), ${ }^{6}$ amostra Agostinho $(2013)^{7}$ e amostra Silvano (2016). ${ }^{8}$

Ferminio (2017) realizou três etapas de análises. Na primeira delas, foram considerados todos os dados de escrita das três amostras; na segunda, foram separados os dados de escrita referentes às localidades de Florianópolis - amostra Brustolin (2009) e amostra Silvano (2016) - e de Itajaí, amostra Agostinho (2013), e na terceira etapa foram efetuadas rodadas estatísticas individuais. Os valores de presença de marcas nas três amostras conjuntas, análise à qual daremos ênfase aqui, encontram-se expostos na Tabela 5.3.

Tabela 5.3 - Valores de aplicação da marcação de CVP6 nos quatro estudos

\begin{tabular}{c|c|c}
\hline \multirow{2}{*}{ Amostra } & \multicolumn{2}{|c}{ Marcação de CVP6 } \\
\cline { 2 - 3 } & Apl./Total & $\%$ \\
\hline Todas as amostras & $1.226 / 1.411$ & $87 \%$ \\
\hline
\end{tabular}

Os grupos de fatores que se mostraram significativos, levando-se em conta os dados das três amostras, foram: posição do sujeito, ${ }^{9}$ saliência fônica, forma de representação do sujeito e traço humano no sujeito.

6 A amostra Brustolin (2009) consiste em coletas realizadas em quatro escolas da rede pública de ensino de Florianópolis. Foram realizadas coletas de escrita nas quatro escolas e entrevistas orais realizadas apenas em uma das escolas. A metodologia do trabalho consistiu na solicitação de que os alunos narrassem uma experiência vivida juntamente com outras pessoas, primeiramente em um texto escrito e, depois, de forma oral (em apenas uma das escolas). A amostra constituiu-se de 393 produções escritas e 85 produções orais.

7 A amostra Agostinho (2013) é constituída por produções textuais oriundas dos alunos do ensino fundamental estratificados por sexo (masculino e feminino), escolaridade dos alunos nos anos finais ( $5^{\underline{a}}$ série; $6^{\underline{a}}$ série; $7^{\underline{a}}$ série e $8^{\underline{a}}$ série), atuais $6^{\circ}$ ano, $7^{\circ}$ ano, $8^{\circ}$ ano e 9o ano (de acordo com a Lei no $11.274 / 06$ ) em duas escolas.

8 A amostra Silvano (2016) constitui-se de 160 produções escritas do gênero relato de experiência pessoal de alunos do 6ㅇ e 9o anos do ensino fundamental de duas escolas da rede pública de ensino de Florianópolis: uma delas municipal e outra federal.

9 Ferminio (2017), assim como Chaves (2017), utiliza a nomenclatura presença e localização do SN sujeito para essa variável. 
O grupo de fatores posição do sujeito foi o que se mostrou mais relevante. Os resultados corroboram os dos estudos anteriores, relacionados à marcação da concordância na fala (LEMLE; NARO, 1977; RODRIGUES, 1987; SCHERRE; NARO, 1998; VIEIRA, 1995; MONGUILHOTT, 2001, 2009; GAMEIRO, 2009; CHAVES, 2017) e os do estudo de Monguilhott (2009), relativos à marcação da concordância em dados de escrita diacrônica, de que o sujeito anteposto ao verbo tende a apresentar mais marcação flexional no verbo do que o sujeito posposto ao verbo.

No que se refere à variável saliência fônica, os resultados atestaram, também, o que outros estudos apontam (LEMLE; NARO, 1977; RODRIGUES, 1987; VIEIRA, 1995; SCHERRE; NARO, 1998; MONGUILHOTT, 2001, 2009; PEREIRA, 2004; CARDOSO, 2005; SCHERRE; NARO, 2006, 2007; GAMEIRO, 2009; CHAVES, 2017). As formas verbais em que a oposição entre plural e singular é menos saliente seria um contexto que restringe a aplicação da regra de concordância verbal. Em contraposição, quanto mais o verbo no plural se distingue, em termos de diferenciação acentual, da forma no singular, maiores índices de marcação de concordância verificaram-se. Todavia, é necessário ressaltar, com base nos resultados da autora e nos de Monguilhott $(2001,2009)$ e de Chaves (2017), que a escala hierárquica esperada por Naro (1981), no que diz respeito ao critério distinção material, também não foi atestada nessa análise da modalidade escrita. ${ }^{10}$

Quanto ao grupo de fatores forma de representação do sujeito, os resultados confirmaram algumas das hipóteses formuladas com base em outros estudos (MONGUILHOTT, 2001, 2009; GAMEIRO, 2009; CHAVES, 2017) de que as formas de representação do sujeito com SN [+humano], que normalmente estão antepostas ao verbo (Ela e a Bruna foram andar de bicicleta), influenciam a marcação de concordância verbal, diferentemente das formas de representação do sujeito com SN [-humano] (Começou as aulas), que normalmente se posicionam pospostas ao verbo, influenciando a não marcação de concordância verbal.

Os resultados referentes ao grupo de fatores traço humano do sujeito, também apontado como estatisticamente significativo, confirmam

10 Chaves (2014) desenvolve uma longa discussão problematizando a escala de saliência fônica de Naro (1981). 
a hipótese de que o SN [+humano] é um importante condicionador da marcação de plural nos verbos (90\%). Em contrapartida, em construções com SN [-humano] a probabilidade de concordância mostrou-se bastante inferior $(65 \%)$.

Com base nos estudos relativos à modalidade escrita, é possível estabelecer uma comparação entre os resultados dos estudos de Monguilhott (2009) e de Ferminio (2017), apesar de estarmos cientes de que os estudos se diferenciam em muitos aspectos: um analisa dados diacrônicos, enquanto o outro investiga dados sincrônicos; além disso, em um se analisa o gênero peças teatrais, enquanto no outro o foco está voltado a redações escolares. No que toca à escrita, o fenômeno de marcação de CVP6, em dados catarinenses, como apontam ambos os estudos, é favorecido basicamente pelos mesmos grupos de fatores: posição do sujeito, saliência fônica e traço humano do sujeito.

\subsection{A concordância verbal no passado: um olhar para o gênero cartas pessoais}

Exploramos, nesta seção, a análise dos dados de variação na concordância verbal de CVP6, do corpus do PHPB-SC, de escritores florianopolitanos no período compreendido entre os séculos XIX e XX. A amostra investigada neste trabalho reuniu 21 cartas do século XIX e 136 cartas do século XX. A diferença quantitativa no material analisado entre os dois séculos resulta do que temos disponível no corpus do PHPB-SC nesses diferentes períodos de tempo.

O gênero carta pessoal é um dos gêneros textuais selecionados para a composição do corpus do PHPB-SC por ser um dos gêneros privilegiados para o estudo diacrônico, já que em tempos anteriores era uma das formas mais utilizadas para a comunicação interpessoal. Além disso, por ser um gênero que apresenta um interlocutor bem definido, os missivistas se entregam à comunicação de maneira íntima e espontânea, o que faz com que se aproxime, portanto, do gênero entrevista sociolinguística com o qual tecemos comparações neste trabalho, por exemplo.

As cartas que compõem a amostra investigada neste trabalho foram selecionadas a partir do material disponível no corpus do PHPB-SC para a 
cidade de Florianópolis, dos séculos XIX e XX, já que objetivávamos fazer uma comparação com amostras sincrônicas da mesma localidade e de regiões litorâneas, como Itajaí (MONGUILHOTT, 2001, 2009; CHAVES, 2017; FERMINIO, 2017).

Assim, contamos com as seguintes amostras: (i) século XIX, Amostra Cruz e Sousa, constituída das missivas Araújo Figueiredo para Cruz e Sousa (1888 a 1897); Cruz e Sousa para Gavita (1892); Virgílio Várzea para Cruz e Sousa (1888 a 1890); (ii) século XX, Amostra José Boiteux (1927 a 1933); Amostra do Vale (1965 a 1970); Amostra Tia Ciça (1980 a 1996); Amostra Medeiros (1980 a 1983) e Amostra Monguilhott (1989 a 1998).

Com base no estudo de Monguilhott (2009), resenhado na Seção 5.2.2, trabalho que julgamos estar mais próximo deste, apesar de estarmos analisando o gênero cartas pessoais e não o gênero peças teatrais como fez a autora, esperávamos: (a) diminuição da taxa de marcação de CVP6 (Séc. XIX > Séc. XX); (b) verificação de não marcação de concordância em contextos específicos (verbos inacusativos, sujeitos pospostos, verbos menos salientes e sujeitos com traço semântico [-humano]). No que toca a esta última hipótese, nos baseamos em todos os estudos revisados (MONGUILHOTT, 2001, 2009; CHAVES, 2017; FERMINIO, 2017), haja vista que, independentemente da modalidade (fala/escrita) e da dimensão de análise (sincrônica/diacrônica), os grupos de fatores que colaboram com a variante não marcada foram praticamente os mesmos em todos os trabalhos.

Nas 21 cartas do século XIX, encontramos um total de 42 contextos de marcação de CVP6. Já nas 136 cartas do século XX, foi computado um total de 162 contextos. No que se refere à primeira amostra (cartas do século XIX), todos os 42 dados apresentaram marcação explícita de concordância. Já no que toca à segunda amostra (cartas do século XX), do total de 162 dados, sete não apresentaram marcação de CV. A Tabela 5.4 expõe esses resultados. 
Tabela 5.4 - Valores de aplicação da marcação de CVP6 em cartas pessoais de escritores catarinenses (séculos XIX e XX)

\begin{tabular}{c|c|c}
\hline \multirow{2}{*}{ Século } & \multicolumn{2}{|c}{ Marcação de CVP6 } \\
\cline { 2 - 3 } & Apl./Total & $\%$ \\
\hline Séc. XIX & $42 / 42$ & $100 \%$ \\
\hline Séc. XX & $7 / 135$ & $94,8 \%$ \\
\hline
\end{tabular}

De forma semelhante aos resultados na análise diacrônica de Monguilhott (2009), na qual foi computado um percentual de 99\% de marcação de CVP6 para dados de escrita catarinense nos séculos XX e XXI, mesmo em contextos favoráveis à não verificação da marcação de CVP6 em dados de fala sincrônica (verbos eram inacusativos e o sujeito encontravase posposto às formas verbais), na análise de dados de escrita de cartas pessoais temos índices categóricos de marcação da concordância no século XIX. Tal achado vai ao encontro do que os estudos diacrônicos sobre a ordem do sujeito no PB atestam (BERLINCK, 1989, 1995; COELHO, 2008), como podemos observar no exemplo (6), em que há relação de concordância entre o verbo passavam e o sujeito posposto rapazes.

(6) [19,2 CP SC] Das bandas de lá da praia passavam rapazes vindos da venda com seus grandes cigarros de palha atraz da orêlha, explodindo gargalhadas de aço e fallando á respeito das belíssimas e tradicionais fogueiras de São Pedro. (Amostra Cruz e Sousa)

A ordem posposta, no século XIX, assim como no século XVIII, ainda era produtiva, apresentando "[...] frequências de VSO em todos os tipos de construções verbais e com todos os tipos de SNs" (COELHO; MONGUILHOTT; MARTINS, 2008, p. 136), fato que sofreu alterações ao longo do século seguinte. No século XX, a ordem SVO foi se enrijecendo, e a ordem posposta passou a ser pouco produtiva, fazendo com que os falantes do $\mathrm{PB}$ já não reconhecessem o elemento à direita do verbo como sujeito.

Os dados de escrita do século XX, por seu turno, confirmam, em alguma medida, nossa hipótese inicial de que haveria um aumento nas taxas de não marcação de CVP6. Nas cartas investigadas, registramos valor 
aproximado de 5\% de não marcação, o que já faz com que o fenômeno seja classificado como variável. A seguir apresentamos, em (7), um exemplo de não verificação de marcação de CVP6.

(7) [20,2 CP SC] E, na cartola, as 3 bonecas: Júlia, Carola e Marieta. Peço a Deus, que surjaØ tambem, de alguma cartola, salários justos e vida digna pra todos. (Amostra Tia Ciça)

No caso expresso em (7), conforme podemos observar, atestamos nossa segunda hipótese: a de que a não marcação estaria circunscrita a contextos específicos. Em (7), o verbo inacusativo surja não estabelece relação de concordância com o sujeito posposto salários justos e vida digna pra todos. Sendo assim, temos nesse exemplo dois fatores que, em consonância com os estudos resenhados, se mostram favorecedores da variante não marcada.

No que se refere à variável saliência fônica, outro grupo de fatores relevante para a não marcação da concordância, observamos, na amostra referente ao século XX, que os dados das cartas pessoais analisadas seguem a mesma tendência verificada nos estudos acerca da marcação explícita de CVP6 na fala/escrita dos séculos XIX e XX. É exatamente nas formas verbais menos salientes que observamos menos marcas de concordância. Conforme podemos vislumbrar no exemplo (8), o verbo passasse/passassem, com baixo grau de saliência fônica de Naro (1981) - nível 1a, não apresenta consoante nasal $m$, que seria a única marca ortográfica de marcação de concordância nesse caso.

(8) [20,2 CP SC] Gostaria que passasse ligeiro êstes dois anos de me faltam. (Amostra do Vale)

Diferentemente do que se observa nos dados de escrita do século $\mathrm{XX}$, no século XIX, mesmo em contextos de verbos com baixa saliência fônica, como no par escorre/escorrem, no exemplo (9), temos a marcação da concordância na relação com o sujeito olhos ardentes.

(9) [19,2 CP SC] Unjo-me, portanto, de olios puríssimos, como os que [...] olhos ardentes escorrem, e aromatiso-me de nardo e myrra como um templo que se voe abrir em festas do Agnus Dei. (Amostra Cruz e Sousa) 
Cabe ressaltar, no entanto, que na amostra de escrita relativa ao século XX, encontramos, igualmente, um caso, exemplo (10), com alto nível de saliência fônica, conforme escala hierárquica proposta por Naro (1980), com variação na marcação da concordância verbal - deixará/deixarão na relação com o sujeito estas palavras.

(10) [20,2 CP SC] Pelo que vejo, você esta sendo muito romantico para comigo espero que estas palavras não deixará de se repetir por muito tempo, apesar o que você esteja sentindo não sei se estou sendo meio pessimista penso que seja $80 \%$ um amor meio materialista desculpe se não é. (Amostra do Vale)

Os estudos que investigam a fala indicam uma forte correlação entre a saliência fônica e a escolaridade dos informantes (NARO, 1981; SCHERRE; NARO, 1997; MONGUILHOTT, 2009). Embora não tenhamos controlado a escolaridade dos missivistas, em virtude de não dispormos de informações suficientes para traçar seus perfis sociais, percebemos que a missivista do exemplo (10) parece não apresentar um alto grau de letramento, porque, na sua missiva, indicada no exemplo apresentado, encontramos algumas palavras com acentuação inadequada (esta/está, romantico/romântico), bem como algumas inadequações em relação à coesão e à coerência textuais.

Já na amostra do século XIX, percebemos que os verbos mais salientes, como esperado, apresentam marcação da concordância verbal em todos os casos, como no exemplo (11), a seguir. ${ }^{11}$

(11) $[19,2$ CP SC] Foi dessa primeira cidade que te escrevi as cartas das quaes já te fallei, e que até hoje não tiveram a menor resposta, pelo que, entretanto, não me zango, visto lembrar-me que talvez nem as tivesses recebido, e que acontecesse com ellas o que acontecia com as que eu mandava para minha familia e vice-versa. (Amostra Cruz e Sousa)

11 Essa informação não se faz tão relevante, haja vista que como computamos marcação categórica nos dados da amostra do século XIX, todos os contextos, de certo modo, mostraram-se colaboradores do fenômeno. No entanto, cabe destacar que, em nossos dados, dispúnhamos de contextos como o exposto em (6). 
Para finalizar nossa discussão em torno da variável saliência fônica, apresentamos o exemplo (12), retirado de uma missiva do século XX, em que não há relação de concordância entre o verbo é/são, com alto nível de saliência, e seu sujeito os notáveis (Ulisses no caso).

(12) [20,2 CP SC] Aliás, os notáveis (Ulisses no caso) é como negro. (Amostra Tia Ciça)

Percebemos semelhança entre esse exemplo e alguns dados do português europeu (PE) analisados em Monguilhott (2009). ${ }^{12}$ A autora sugeriu que o sujeito, em dados desse tipo, está em posição de tópico, “[...] como se tivéssemos um pronome nulo neutro (como um isso) na posição do sujeito" (MONGUILHOTT, 2009, p. 171). De acordo com Monguilhott, poderíamos reanalisar o dado como em (12'):

(12’) [20,2 CP SC] Aliás, os notáveis (Ulisses no caso) (isso) é como negro. (Amostra Tia Ciça)

Outro grupo de fatores observado nos dados das missivas do século $\mathrm{XX}$ que também corrobora nossa hipótese é o traço humano do sujeito. Podemos ressaltar, nos exemplos (13), (14) e (15), que não há marcação de concordância entre os verbos e locução verbal era, passa e deixa calar na relação com seus respectivos sujeitos, todos com o traço [-humano]: os meus finais de semana, estes dias e seus lábios lindos.

(13) [20,2 CP SC] Quando eu recebi a sua 1aㅗ carta (que adorei), o meu pai foi para o hospital, ficou 1 mês lá, os meus finais de semana era só no hospital. (Amostra Monguilhott)

(14) [20,2 CP SC] Ja la que se passa estes dias [apois] de minha ultima víagem. (Amostra do Vale)

(15) [20,2 CP SC] Termino esta cartinha enviando abraços e beijos em seus lábios lindos que deixa calar nos meus lábios. (Amostra do Vale)

Sendo assim, apesar do baixo número de ocorrências de não marcação de CVP6 nas cartas pessoais analisadas tanto do século XIX

${ }_{12}$ Monguilhott (2009) realizou também análise diacrônica de peças de teatro do PE. 
como do século $\mathrm{XX}$, houve, de forma semelhante ao constatado por Monguilhott (2009), na análise de peças teatrais catarinenses, um aumento na variação da CVP6. Esse fato, a nosso ver, encontra-se diretamente ligado ao enrijecimento da ordem SVO no PB a partir do século XX. Além disso, confirmamos também que os casos em que a marcação da concordância não foi verificada restringiam-se a contextos específicos.

Por fim, estabelecendo uma comparação entre os estudos que abordaram a modalidade de fala (MONGUILHOTT, 2001, 2009; CHAVES, 2017, FERMINIO, 2017) e aqueles que investigaram a modalidade escrita (MONGUILHOTT, 2009; FERMINIO, 2017) catarinense, podemos constatar que a escrita se mostrou mais conservadora do que a fala, se levarmos em conta a comparação entre os índices percentuais de marcação de concordância nas duas modalidades. De forma mais clara, em dados de fala, os índices de marcação de CVP6, independentemente da época (década de 1990 ou década de 2010), apresentaram valores de marcação de concordância superiores, se comparados aos índices verificados em dados de escrita (diacrônicos ou sincrônicos), como pudemos verificar nos trabalhos apresentados na Seção 5.2.

\subsection{Considerações finais}

Neste capítulo, buscamos apresentar um panorama de quatro estudos que abarcaram o fenômeno variável de marcação explícita de terceira pessoa do plural em dados de fala e de escrita em duas comunidades de fala catarinense e analisar o comportamento da variação na concordância verbal de terceira pessoa do plural em Santa Catarina em amostras de cartas pessoais dos séculos XIX e XX que compõem o corpus do PHPB-SC.

$\mathrm{Na}$ análise qualitativa conduzida neste capítulo, em alguma medida, mostramos correlações entre os resultados apresentados nas amostras de fala e de escrita, em diferentes épocas, e entre as amostras investigadas neste trabalho. Essas correlações foram traçadas mais especificamente entre o fenômeno de marcação de CVP6 e as variáveis tipo de verbo, ordem do sujeito, saliência fônica e traço mais ou menos humano do sujeito, principalmente nos dados relativos à amostra do século $\mathrm{XX}$, na qual encontramos alguns casos de variação. As comparações feitas contrastam, de forma genérica, fala/escrita, sem levar em conta as particularidades das amostras. 


\section{Referências}

BERLINCK, R. de A. A ordem V SN no português do Brasil: sincronia e diacronia. 1988. 265 f. Dissertação (Mestrado em Linguística) - Instituto de Estudos da Linguagem, Universidade Estadual de Campinas, Campinas, 1988.

BERLINCK, R. de A. A construção V SN no português do Brasil: uma visão diacrônica no fenômeno da ordem. In: TARALLO, F. (org.). Fotografias sociolinguísticas. Campinas: Pontes Editores, 1989. p. 95-112.

CAMARA JR., J. M. Estrutura da língua portuguesa. 4. ed. Petrópolis: Vozes, 2003 [1970].

CARDOSO, C. R. Variação da concordância verbal no indivíduo: um confronto entre o linguístico e o estilístico. 2005. 126 f. Dissertação (Mestrado em Linguística) - Programa de Pós-Graduação em Linguística, Universidade de Brasília, Brasília, 2005.

COELHO, I. L.; MONGUILHOTT, I. de O. e S.; MARTINS, M. A. Estudo diacrônico da inversão sujeito-verbo no português brasileiro: fenômenos correlacionados. In: RONCARATI, C.; ABRAÇADO, J. (org.). Português brasileiro II: contato linguístico, heterogeneidade e história. Niterói: Editora da UFF, 2008. p. 137-157.

CHAVES, R. G. Princípio de saliência fônica: isso não soa bem. Letrônica, Porto Alegre, v. 7, n. 2, p. 522-550, 2014.

CHAVES, R. G. A redução/desnasalização de ditongos nasais átonos e a marcação explícita de CVP6: um estudo de correlação. 2017. 359 f. Tese (Doutorado em Linguística) - Programa de Pós-Graduação em Linguística, Universidade Federal de Santa Catarina, Florianópolis, 2017.

FERMINIO, P. C. A variação na concordância verbal de terceira pessoa do plural em textos escritos e orais de alunos das séries finais do ensino fundamental da rede pública de ensino de Florianópolis e Itajaí. 2017. 211 f. Dissertação (Mestrado em Linguística) - Programa de Pós-Graduação em Linguística, Universidade Federal de Santa Catarina, Florianópolis, 2017.

GAMEIRO, M. B. A variação da concordância verbal na terceira pessoa do plural em redações escolares do ensino fundamental e médio. 2009. $222 \mathrm{f}$. Tese (Doutorado em Língua Portuguesa) - Programa de Pós-Graduaçao em Língua Portuguesa, Universidade Estadual Paulista, São Paulo, 2009.

GUY, G. Linguistic variation in Brazilian Portuguese: aspects of the phonology, syntax, and language history. 1981. 406 f. Tese (Doutorado em Linguística) University of Pennsylvania, Philadelphia, 1981. 
GUY, G. Form and function in linguistic variarion. In: LABOV, W. (ed.). Variation and change in language and society. Amsterdam/Philadelphia: John Benjamins, 1996. p. 221-252.

LEMLE, M.; NARO, A. J. Competências básicas do português. Relatório final de pesquisa apresentado às instituições patrocinadoras Fundação Movimento Brasileiro de Alfabetização (Mobral) e Fundação Ford, Rio de Janeiro, 1977. $151 \mathrm{p}$.

MONGUILHOTT, I. de O. e S. Variação na concordância verbal de terceira pessoa do plural na fala dos florianopolitanos. 2001. 109 f. Dissertação (Mestrado em Linguística) - Programa de Pós-Graduação em Linguística, Universidade Federal de Santa Catarina, Florianópolis, 2001.

MONGUILHOTT, I. de O. e S. Estudo sincrônico e diacrônico da concordância verbal de terceira pessoa do plural no PB e no PE. 2009. 229 f. Tese (Doutorado em Linguística) - Programa de Pós-Graduação em Linguística, Universidade Federal de Santa Catarina, Florianópolis, 2009.

MONGUILHOTT, I. de O. e S; COELHO, I. L. Um estudo da concordância verbal de terceira pessoa em Florianópolis. In: VANDRESEN, P. (org.). Variação e mudança no português falado na Região Sul. Pelotas: EDUCAT, 2002. p. 189-216.

NARO, A. J. The social and structural dimensions of a syntatic change. Language, v. 57, n. 1, p. 63-98, 1981.

NARO, A. J.; GÖRSKI, E. M.; FERNANDES, E. Change without Change. Language Variation and Change, New York, v. 11, n. 2, p. 197-211, 1999.

NARO, A. J.; SCHERRE, M. M. P. Variação e mudança linguística: fluxos e contrafluxos na comunidade de fala. Cadernos de Estudos Linguísticos, Campinas, v. 20, p. 9-16, 1991.

PEREIRA, D. C. Concordância verbal na língua falada nas trilhas das bandeiras paulistas. 2004. 116 f. Dissertação (Mestrado em Filologia e Língua Portuguesa) - Faculdade de Filosofia, Letras e Ciências Humanas, Universidade de São Paulo, São Paulo, 2004.

PONTES, E. S. L. Sujeito: da sintaxe ao discurso. São Paulo: Ática, 1986.

RODRIGUES, Â. C. de S. A concordância verbal no português popular em São Paulo. 1987. 323 f. Tese (Doutorado em Filologia e Língua Portuguesa) Faculdade de Filosofia, Letras e Ciências Humanas, Universidade de São Paulo, São Paulo, 1987.

SCHERRE, M. M. P. Paralelismo linguístico. Revista de Estudos da Linguagem, Belo Horizonte, v. 7, n. 2, p. 29-59, jul./dez.1998. 
SCHERRE, M. M. P.; NARO, A. J. Duas dimensões do paralelismo formal na concordância verbal no português popular do Brasil. DELTA, São Paulo, v. 9, n. 1, p. 1-14, 1993.

SCHERRE, M. M. P.; NARO, A. J. A concordância de número no português do Brasil: um caso de variação inerente. In: HORA, D. (org.). Diversidade linguística no Brasil. João Pessoa: Idéia, 1997. p. 93-114.

SCHERRE, M. M. P.; NARO, A. J. Restrições sintáticas e semânticas no controle da concordância verbal em português. Fórum Linguístico, Florianópolis, v. 1, p. 45-71, 1998.

SCHERRE, M. M. P.; NARO, A. J. Mudança sem mudança: a concordância de número no português brasileiro. Scripta, Belo Horizonte: PUC Minas, v. 9, n. 18, p. 109-131, 2006.

SCHERRE, M. M. P.; NARO, A. J.; CARDOSO, C. R. O papel do tipo de verbo na concordância verbal no português brasileiro. DELTA, São Paulo, v. 23, n. esp., p. 283-317, 2007.

SILVA, J. A. A. da. A concordância verbal no português afro-brasileiro: um estudo sociolinguístico de três comunidades rurais do estado da Bahia. 2003. $323 \mathrm{f}$. Dissertação (Mestrado em Letras e Linguística) - Programa de Pós-Graduação em Letras e Linguística, Universidade Federal da Bahia, Salvador, 2003.

SILVANO, G. L. P. A concordância verbal de primeira pessoa do plural em textos escritos por alunos do ensino fundamental da rede pública de Florianópolis. 2016. 244 f. Dissertação (Mestrado em Linguística) - Programa de Pós-Graduação em Linguística, Universidade Federal de Santa Catarina, Florianópolis, 2016. 


\section{Capítulo 6}

\section{A trajetória da mudança na sintaxe do sujeito e do objeto direto em cartas pessoais catarinenses e cariocas}

Izete Lehmkuhl Coelho Silvia Regina de Oliveira Cavalcante

Cecília Augusta Vieira Pinto Anna Lyssa Machado Anna Beatriz Cruz Gésyka Mafra

\subsection{Introdução}

Este capítulo se propõe a investigar a trajetória da mudança na sintaxe do sujeito e do objeto direto em duas amostras de cartas pessoais, uma de cartas catarinenses e outra de cartas cariocas, escritas ao longo dos séculos XIX e XX. Para tanto, pretendemos analisar três fenômenos linguísticos variáveis: ordem do DP sujeito, preenchimento do sujeito 
pronominal e objeto direto anafórico em contextos de terceira pessoa, no entendimento de que os três fenômenos de mudança estejam relacionados entre si, tal como proposto por Tarallo (1993). Mudança linguística aqui é entendida como uma consequência inevitável da dinâmica interna das línguas naturais.

A análise desses três fenômenos sintáticos se ancora nos problemas de transição, de encaixamento e de implementação, postulados por Weinreich, Labov e Herzog (1968). Nesse sentido, estamos adotando a ideia de que (i) uma mudança não ocorre de forma abrupta. Há estágios intermediários que podem ser identificados entre os sistemas transicionais; (ii) algumas mudanças estão encaixadas a outras mudanças de modo que não são acidentais por criarem condições linguísticas adequadas para que outras mudanças aconteçam; (iii) as explicações sobre as formas como as mudanças estão se implementando nos diferentes contextos estruturais podem ser oferecidas por meio dos fatores condicionantes.

Nesse sentido, acreditamos que a rigidez da ordem SV transitiva no português brasileiro (já constatada ao longo do tempo) cria condições necessárias para a realização do sujeito pronominal e para a manifestação do objeto direto nulo. Essa proposta de um possível encaixamento entre as mudanças sintáticas já foi tratada na década de 1990 por Fernando Tarallo (1993), ao correlacionar a mudança da ordem VS para SV à mudança do objeto direto anafórico. Segundo o autor, uma língua com um sistema de clítico produtivo deveria permitir uma maior liberdade de ordenação de seus constituintes na sentença, uma vez que sua função sintática ficaria evidente. Já em uma configuração SVO rígida, os DPs na função de sujeito e de objeto só poderiam ser reconhecidos em sua posição (à direita ou à esquerda do verbo). Essa análise de correlação parece fazer algum sentido quando olhamos para outros trabalhos que analisaram o percurso de mudança do português escrito no Brasil ao longo do tempo (cf. KATO; TARALLO, 1988; TARALLO; KATO, 1989; TORRES MORAIS, 1993; RIBEIRO, 1995, 2001; KATO et al., 2006; BERLINCK et al., 2016; COELHO et al., 2017; COELHO; VIEIRA-PINTO, 2018; CAVALCANTE, 2018; entre outros).

Essa proposta abre algumas questões que queremos investigar neste trabalho: Como essas três mudanças estão encaixadas nas amostras catarinense e carioca ao longo do tempo? Quais as condições linguísticas necessárias que uma mudança cria para que outras mudanças se efetivem? 
Como as variantes novas se implementam na escrita catarinense e carioca ao longo do tempo?

Para responder a essas questões, pretendemos verificar, nas duas amostras escritas no curso dos séculos XIX e XX, pertencentes ao projeto Para a História do Português Brasileiro (PHPB), qual a correlação entre os fenômenos da ordem do DP sujeito e do preenchimento do sujeito pronominal e objeto direto anafórico, em contextos de terceira pessoa. Os exemplos a seguir ilustram as variáveis do estudo: (1) com sujeito pósverbal, (2) a (5) exemplos da representação do objeto direto anafórico:

(1) $[19,2$ CP SC] [...] logo que eu aqui cheguei, fez BELLARMINO questão da minha pessôa para ir dirigir o Mercantil, cuja redacção tencionava então deixar ficando só com a propriedade. (Período 1)

(2) [19,2 CP SC] Tencionava enviar-te Gazetas de Noticias por este correio, mas esqueci-as em casa, e por isso só t’as remette rei pelo vapor de 12 do de-corrente. (Período 1)

(3) $[20,1$ CP SC] Estranho achei ao receber tua cartinha porque como havia te dito eu não esperava que me escrevesses $\varnothing$. Enfim cumpriste com o que prometeste. No momento em que a recebi fiquei satisfeitíssima mas quando abri $\varnothing$ e comecei a lê-la fiquei muito triste porque notei que o que me dedicas não é amor mas apenas amizade. (Período 2)

(4) [19,2 CP RJ] Vi a planta da casa que mandaraõ a Theodosia: ainda naõ tive tempo de examinal-a, o que farei logo. (Período 1)

(5) [20,1 CP RJ] Está em minhas mãos a tua carta de 2 de Outubro Desculpa custar a responder $\varnothing$. (Período 2)

Com base nas ocorrências utilizadas neste trabalho e nos resultados de estudos que já investigaram esses fenômenos, levantamos duas hipóteses gerais:

Acreditamos que o português do século XIX ainda manifeste resquícios do sistema do português clássico (séculos XVI e XVII), com propriedades do grupo das línguas românicas (como o italiano e o espanhol), com índices produtivos de ordem VS, sujeito nulo e clítico acusativo. Já para os dados do século XX, espera-se que outro sistema esteja 
se implementando, o que vem sendo chamado de gramática do PB: ordem preferencialmente SV em contextos com verbos transitivos, uso majoritário de sujeito pronominal expresso e de objeto direto nulo.

Podemos supor que a mudança na direção da perda da liberdade de ordenação do sujeito, da perda do sujeito nulo e da perda de clíticos (mais especificamente os acusativos de terceira pessoa) progrida numa direção muito parecida nos três casos: de sujeito [+animado] e [+específico] para sujeito [-animado] e [-específico] e de objeto direto [+animado] e [+específico] para objeto [-animado] e [-específico].

Com o propósito de aferir nossas hipóteses, organizamos este capítulo da seguinte maneira. A Seção 6.2 traz a descrição das cartas pessoais catarinenses e cariocas e dos grupos de fatores que serão utilizados para a análise dos fenômenos sintáticos em investigação. A Seção 6.3 está voltada para a caracterização dos fenômenos em investigação e para a apresentação dos resultados estatísticos mais significativos. A Seção 6.4 é destinada à discussão sobre a trajetória da mudança desses três fenômenos em correlação. Por último, trazemos as referências.

\subsection{Aspectos metodológicos}

Para a análise dos três fenômenos em variação e mudança, escolhemos cartas pessoais de amor e de amizade por acreditar que são textos "que transpõem, para o meio escrito, intercâmbios comunicativos que ocorreram ou poderiam ocorrer no meio oral" (CONDE SILVESTRE, 2007, p. 45). A fim de compreendermos um pouco mais as cartas catarinenses e cariocas utilizadas, apresentamos, no início desta seção, o perfil dos missivistas que escreveram essas cartas e, na sequência, descrevemos a metodologia variacionista utilizada, com as informações a respeito das variáveis linguísticas e extralinguísticas controladas.

\subsubsection{Perfil das amostras}

Para a análise que ora propomos, consideramos duas amostras de cartas pessoais, uma catarinense e outra carioca, escritas ao longo dos séculos XIX e XX, por missivistas que adquiriram o vernáculo em diferentes épocas. As amostras estão descritas nas seções 6.2.1.1 e 6.2.1.2, a seguir. 


\subsubsection{Amostra de cartas pessoais catarinenses'}

A amostra catarinense é constituída por quatro grupos formados por missivistas que mantêm laços familiares, de amizade ou de amor entre si, compondo quatro períodos distintos de tempo:

Período 1 (1870-1895): Esse grupo é constituído por 35 cartas de amor e de amizade escritas no decorrer das décadas de 1870, 1880 e 1890. As cartas, extraídas da Amostra Cruz e Sousa, giram em torno do poeta, ora remetente, ora destinatário. Há cartas de amor de Cruz e Sousa para sua noiva e cartas de amizade a ele endereçadas, escritas pelos amigos Virgílio Várzea e Araújo Figueiredo, também escritores e nascidos em Desterro. Os três escritores, além de amigos, tinham forte atuação política em Desterro.

Período 2 (1905-1945): Esse grupo contém 19 cartas escritas entre os anos de 1905 e 1941 extraídas da Amostra Virgílio Várzea. Ele era escritor, jornalista e político catarinense. Parte das missivas (10 delas) foi endereçada ao escritor por amigos políticos e escritores. Outras seis cartas foram escritas por ele a seu filho. Por fim, há mais três cartas enviadas pelo escritor a seu amigo José Boiteux, que também era escritor e político catarinense.

Período 3 (1955-1975): Esse grupo é formado por 41 cartas de amor e de amizade extraídas da Amostra do Vale. São cartas escritas por 15 jovens, endereçadas a um mesmo destinatário, que era músico e professor do Vale do Itajaí, na década de 1960. A temática das cartas versa sobre assuntos do cotidiano e de relacionamentos amorosos, a partir da qual se infere que algumas remetentes eram namoradas do músico e outras, amigas ou pretendentes.

Período 4 (1980-1990): Esse grupo é composto por 42 cartas de amizade extraídas da Amostra Harry Laus. São cartas remetidas pelo escritor catarinense a sua tradutora e amiga Claire Cayron, durante as décadas de 1980 e 1990. O escritor escreveu essas cartas quando tinha entre 60 e 70 anos, o que sinaliza para um falante que adquiriu a língua no início do século XX (período correspondente a 1901-1925). Suas cartas a Claire envolvem tanto assuntos profissionais quanto assuntos pessoais. ${ }^{2}$

1 As amostras de cartas pessoais catarinenses estão descritas detalhadamente no Capítulo 1 deste volume.

2 Grando, no Capítulo 9 deste volume, descreve detalhadamente a relação escritor-tradutora (Harry-Claire) ao longo dos 20 anos de correspondência. Segundo o autor, é possível 


\subsubsection{Amostra de cartas pessoais cariocas}

A amostra carioca é constituída de 200 cartas escritas por sete famílias, cujos membros estão divididos por data de nascimento e cujas cartas estão divididas por período de tempo:

Período 1 (1876-1900): O grupo é composto por 40 cartas pessoais escritas entre os anos de 1876 e 1900. As cartas são escritas por membros de quatro famílias, os casais CO e BO, AP e MGP, PF e seu genro JM e OC. $\mathrm{CO}$ foi senador do Império e também senador federal, com a proclamação da República. AP, formado em direito, assim como CO, foi uma figura importante no cenário político brasileiro, chegando a ocupar o cargo de vicepresidente e, posteriormente, de presidente da República. Já PF, o patriarca da família, era advogado e trabalhou como secretário do Supremo Tribunal, enquanto seu genro, JM, era engenheiro civil. Por fim, OC, que era médico e cientista reconhecido internacionalmente, promotor de uma importante campanha sanitária no país. As cartas, trocadas entre os membros das famílias, relatam o cotidiano dos remetentes e os acontecimentos recentes.

Período 2 (1901-1950): Esse grupo é composto por 80 cartas pessoais escritas ao longo da primeira metade do século XX por membros de três das famílias já abordadas no primeiro período. As cartas são escritas por MTP, filha de PF, ZFM, também filha de PF e esposa de JM, e seus oito filhos, todos religiosos. Também há cartas de MGP, AnP, sua irmã, MP, seu cunhado, e de seus filhos AlP e AP Jr, assim como de sua nora MP. Escrevem também EC e LC, esposa e filha de OC. Por fim, há cartas trocadas entre um casal de namorados, J e M, que, diferentemente dos outros missivistas, não são considerados ilustres. As cartas trocadas entre os missivistas apresentam relatos do cotidiano e fornecem notícias aos entes queridos além de, no caso dos casais, expressar também as saudades e o amor pelo companheiro distante.

Período 3 (1951-1975): Essa amostra é formada por 40 cartas pessoais da família carioca FB, escritas entre os anos de 1951 e 1975. Grande parte das missivas foi escrita por $\mathrm{AB}$, uma jovem que sempre mandava notícias sobre sua rotina na Europa aos pais EB e WB. Outras missivas foram escritas

notar que, com o passar dos anos, a relação entre escritor-tradutora fica mais estreita, e essa mudança fica muito evidente na temática das cartas, que vai de questões voltadas à tradução e à publicação de livros a questões intimistas. 
pela matriarca da família, RB (mãe de WB), um amigo da família CB e algumas (cinco cartas) por tios e primos. De um modo geral, o assunto das cartas gira em torno de relatos sobre a vida dos familiares.

Período 4 (1976-1994): Essa amostra é composta por 40 cartas pessoais escritas entre os anos de 1976 e 1994. Dessas, 28 foram escritas por membros e amigos da família mineira SL. A missivista principal é ML, visto que a maioria das cartas foi ou escrita por ela ou endereçada a ela. Nascida em Minas Gerais, mas morando nos Estados Unidos, ML destinava suas cartas principalmente a sua mãe para contar em detalhes sua experiência como estudante no exterior. Escrevia também para ACM, com quem, segundo informações das missivas, manteve um relacionamento amoroso. Algumas cartas foram escritas por ACM, CL e BL, irmãos de ML, e LL, seu pai. As outras 12 missivas foram escritas por membros da família carioca FB.

\subsubsection{Análise estatística}

Para a análise estatística dos três fenômenos variáveis, levantamos todas as ocorrências de sujeitos pré-verbais e pós-verbais (nominais e pronominais), de sujeitos pronominais (expressos ou nulos) e de objetos diretos anafóricos (clíticos, pronomes tônicos e objetos nulos) em contextos de terceira pessoa na escrita das referidas cartas pessoais catarinenses e cariocas.

Optamos por controlar cinco variáveis linguísticas comuns aos três fenômenos: transitividade do verbo, estrutura da sentença, forma de realização do DP sujeito, animacidade do DP sujeito e definitude e especificidade do DP sujeito; e três variáveis extralinguísticas: região, grupos de cartas que correspondem ao período em que as cartas foram escritas e missivistas.

Após o levantamento das ocorrências, os dados foram rodados por variável dependente (posição do sujeito, sujeitos pronominais e objeto direto anafórico), por região, por grupos de cartas e por amostra, utilizando-se das ferramentas do Excel e do pacote estatístico Goldvarb X (SANKOFF, TAGLIAMONTE, SMITH, 2005).

A seguir apresentamos nossos resultados mais significativos. 


\subsection{A descrição dos fenômenos em estudo nas amostras catarinense e carioca}

Nesta seção, apresentamos a descrição dos três fenômenos em estudo: ordem do DP sujeito, preenchimento do sujeito pronominal e preenchimento do objeto direto anafórico. Partimos da caracterização das variáveis controladas com respeito a cada um desses fenômenos e, em seguida, descrevemos os resultados estatísticos, fazendo algumas correlações. A descrição dos três fenômenos é importante para que possamos falar em encaixamento e implementação da mudança linguística na sintaxe do português catarinense e carioca, tema da Seção 6.4 deste capítulo.

\subsubsection{A ordem do DP sujeito}

\subsubsection{Caracterização do fenômeno e hipótese}

Resgatamos nesta seção alguns resultados acerca da posição do DP sujeito no português escrito no Brasil no curso dos séculos XIX e XX, com o objetivo geral de traçar a trajetória de mudança da ordem VS para a ordem SV, especialmente em contextos com verbos transitivos. Desde a década de 1980, muitos pesquisadores brasileiros (cf. LIRA, 1986; KATO; TARALLO, 1988; BERLINCK, 1988, 1989; FIGUEIREDO SILVA, 1996; COELHO, 2000, 2006; ZILLES, 2000; PILATI, 2006, 2017; SPANO, 2008; SANTOS, 2008; SANTOS; SOARES DA SILVA, 2012; CAVALCANTE, 2014, 2018; GRAVINA, 2014; entre outros) se debruçaram sobre o estudo da ordem do DP sujeito.

Dos estudos citados acima, duas constatações são importantes: (i) nas primeiras fases históricas do português, até mais ou menos o século XIX, o português teria mantido um padrão semelhante ao de outras línguas românicas, como o espanhol e o italiano, com possibilidades relativamente livres de VS transitiva; e (ii) a ordem VS no português atual é extremamente baixa, vinculada apenas a contextos de verbos inacusativos e de inversão locativa.

Essa tendência ao enrijecimento da ordem VS foi mostrada percentualmente em diversos trabalhos variacionistas que utilizaram corpora de língua escrita de diferentes épocas. O primeiro deles, que teve uma 
importância ímpar para os estudos que se seguiram, foi o de Berlinck (1988). Utilizando dois corpora, um composto por cartas de cunho pessoal dos séculos XVIII (1751-1768) e XIX (1848-1851) e outro composto por conversações gravadas com 20 jovens de Curitiba na faixa etária dos 20 aos 30 anos (1987), a autora mostra uma queda acentuada da ordem VS(O) ao longo dos últimos séculos no português escrito no Brasil: de $42 \%$ de VS(O) no século XVIII para 31\% no século XIX. No final do século XX (em 1987), a autora observou apenas $21 \%$ de VS. De acordo com a análise da autora, essa queda estaria relacionada principalmente à transitividade do verbo da construção sintática.

A força da transitividade do verbo foi também constatada em estudo diacrônico de Coelho (2006) a partir de amostras de peças de teatro escritas por catarinenses no curso dos séculos XIX e XX. Os resultados a que a autora chegou revelam que entre 1859 e 1881 a ordem VS(O) ficava na faixa de $15 \%$, caindo para 8\% no período de 1948 a 1992.

Com base nesses resultados, algumas questões teóricas também foram suscitadas a partir de 1980. Nos textos de Coelho e Martins (2009, 2012) e de Berlinck e Coelho (2018), buscou-se compreender se havia nas amostras investigadas indícios dos padrões de inversão germânica e de inversão românica, como observaram Kato et al. (2006).

Os resultados do trabalho de Berlinck e Coelho revelam, com base em um panorama das construções encontradas em amostras do projeto Para a História do Português Brasileiro, os seguintes padrões de VS:

Resquícios de inversão germânica ([XP]VS), com verbo transitivo em segunda posição e DP sujeito pós-verbal, encontrada no Português Antigo e no Português Clássico, convivendo com uma sintaxe do PB atual, manifestada através de construções transitivas majoritariamente SVO;

Resquícios de construções de inversão românica (V[XP]S) com foco informacional recaindo sobre o DP sujeito pós-verbal, como resquício de uma língua de sujeito nulo, com possibilidades relativamente livres de VS;

Produtividade de construções VS inacusativas com ou sem sintagma locativo projetado pelo verbo. Nesse tipo de construção VS o que está em jogo é a natureza do verbo e o efeito de definitude sobre o DP pós-verbal. (BERLINCK; COELHO, 2018, p. 377-378). 
Com base nos resultados desses trabalhos, nossa expectativa é de que as mudanças gramaticais relacionadas à posição do DP sujeito são observadas notadamente a partir do século XIX e compreendem o enrijecimento gradativo da ordem SV, com perda dos padrões de VS com verbos transitivos e estabilidade dos padrões de construção VS inacusativa no curso do século XX.

Além da significância da transitividade verbal na restrição à ordem VS no português brasileiro, outros estudos tentam associar o estatuto informacional do sujeito com a ordem VS, como o de Berlinck (1989) e mais recentemente o de Cavalcante (2018). Berlinck (1989) mostra que a ordem VS era favorecida pelo estatuto informacional do sujeito (informação nova) na amostra do século XVIII, e isso muda no século XIX, quando a transitividade verbal passa a ser o fator predominante na influência da ordem VS. Cavalcante (2018), analisando dados de uma amostra de cartas pessoais, confirma os resultados de Berlinck (1989), na medida em que na amostra de missivistas nascidos no século XIX o fator mais favorecedor para a ordem VS era o estatuto informacional do sujeito, ao passo que na amostra dos missivistas nascidos a partir do século XX a transitividade verbal passa a ser o fator mais favorecedor da ordem VS, justamente em construções inacusativas e de inversão locativa.

Os resultados de Cavalcante (2018) mostram que fatores de ordem discursiva eram importantes para o aparecimento de sujeitos pós-verbais, ao passo que com a mudança - diminuição progressiva de sujeitos pósverbais ao longo do tempo - somente fatores de ordem morfossintática é que passam a ter importância. Daí, temos um quadro de ordem VS restrita.

Neste capítulo, estamos focando nos fatores de ordem sintática e semântica, a fim de verificar a implementação e o encaixamento da mudança nas escritas catarinenses e cariocas. Passemos aos resultados da ordem VS.

\subsubsection{Resultados e discussão}

Os resultados que são apresentados nesta seção em cada uma das variedades investigadas, a catarinense e a carioca, estão relacionados a duas análises estatísticas, uma geral e outra por período investigado. Começamos pela rodada estatística geral. No total, a amostra catarinense apresentou 692 dados, em que 562 (82\%) foram de ordem SV e 130 (18\%) de ordem 
VS. Na amostra carioca, do total de 3.052 dados, 2.749 foram de SV (90\%) e 303 (10\%) de VS.

Tabela 6.1 - Percentual geral de SV e de VS, segundo as amostras catarinense e carioca

\begin{tabular}{l|c|c}
\hline \multirow{2}{*}{ Ordem do DP sujeito } & Ordem SV & Ordem VS \\
\cline { 2 - 3 } & Apl./Total & $\begin{array}{c}\text { Apl./Total } \\
\%\end{array}$ \\
\hline \multirow{2}{*}{ Amostra catarinense } & $562 / 692$ & $130 / 692$ \\
& $82 \%$ & $18 \%$ \\
\hline \multirow{2}{*}{ Amostra carioca } & $2.749 / 3.052$ & $303 / 3.052$ \\
& $90 \%$ & $10 \%$ \\
\hline
\end{tabular}

Os resultados separados por período de tempo estão expostos na Tabela 6.2.

Tabela 6.2 - Percentual de SV e de VS, segundo os períodos investigados nas amostras catarinense e carioca

\begin{tabular}{|c|c|c|c|c|c|}
\hline \multirow{2}{*}{\multicolumn{2}{|c|}{$\begin{array}{l}\text { Ordem do DP } \\
\text { sujeito }\end{array}$}} & $\begin{array}{c}\text { Período } 1 \\
1870-1895\end{array}$ & $\begin{array}{c}\text { Período } 2 \\
1905-1935\end{array}$ & $\begin{array}{c}\text { Período } 3 \\
1955-1975\end{array}$ & $\begin{array}{c}\text { Período } 4 \\
1980-1995\end{array}$ \\
\hline & & $\begin{array}{c}\text { Apl./Total } \\
\%\end{array}$ & $\begin{array}{c}\text { Apl./Total } \\
\%\end{array}$ & $\begin{array}{c}\text { Apl./Total } \\
\%\end{array}$ & $\begin{array}{c}\text { Apl./Total } \\
\%\end{array}$ \\
\hline \multirow{2}{*}{$\begin{array}{l}\text { Amostra } \\
\text { catarinense }\end{array}$} & SV & $\begin{array}{c}98 / 126 \\
78 \%\end{array}$ & $\begin{array}{c}47 / 61 \\
77 \%\end{array}$ & $\begin{array}{c}167 / 212 \\
78 \%\end{array}$ & $\begin{array}{c}250 / 293 \\
86 \%\end{array}$ \\
\hline & VS & $\begin{array}{c}28 / 126 \\
22 \% \\
\end{array}$ & $\begin{array}{c}14 / 61 \\
23 \% \\
\end{array}$ & $\begin{array}{c}45 / 212 \\
22 \% \\
\end{array}$ & $\begin{array}{c}43 / 293 \\
14 \% \\
\end{array}$ \\
\hline \multirow{2}{*}{$\begin{array}{l}\text { Amostra } \\
\text { carioca }\end{array}$} & SV & $\begin{array}{c}337 / 421 \\
80 \%\end{array}$ & $\begin{array}{c}1.052 / 1.162 \\
91 \%\end{array}$ & $\begin{array}{c}518 / 574 \\
90 \%\end{array}$ & $\begin{array}{c}842 / 895 \\
94 \%\end{array}$ \\
\hline & VS & $\begin{array}{c}84 / 421 \\
20 \%\end{array}$ & $\begin{array}{c}110 / 1.162 \\
9 \%\end{array}$ & $\begin{array}{c}56 / 518 \\
10 \%\end{array}$ & $\begin{array}{c}53 / 895 \\
6 \%\end{array}$ \\
\hline
\end{tabular}

Conforme vemos nos resultados das tabelas 6.1 e 6.2, os índices de ordem VS são mais baixos na amostra carioca, no cômputo geral e em todos os períodos de tempo, nesse caso, especialmente nos três últimos períodos, os quais estão relacionados a missivistas do século XX. Para compreendermos a trajetória da mudança em cada uma das amostras 
investigadas, observamos os índices gerais do condicionamento da ordem VS e, em seguida, os resultados por período de tempo.

De modo geral, podemos dizer que a ordem VS em cartas catarinenses é condicionada pelas seguintes variáveis, por ordem de relevância: 'definitude e especificidade do DP sujeito', 'transitividade do verbo', 'forma de representação do DP sujeito', 'período em que as cartas foram escritas' e 'animacidade do DP sujeito'. Já a ordem VS na escrita carioca é condicionada pelas variáveis: 'transitividade do verbo', 'forma de representação do DP sujeito', 'estrutura da sentença', 'período em que as cartas foram escritas', 'local em que as cartas foram escritas' e 'definitude e especificidade do DP sujeito', conforme indicam os índices percentuais e de peso relativo (PR) expostos na Tabela 6.3.

Tabela 6.3 - Percentual geral de VS, de acordo com as variáveis selecionadas, nas amostras catarinense e carioca

\begin{tabular}{|c|c|c|c|c|c|c|}
\hline \multicolumn{7}{|c|}{ Variáveis independentes } \\
\hline \multicolumn{3}{|c|}{ Santa Catarina ${ }^{3}$} & \multicolumn{4}{|c|}{ Rio de Janeiro } \\
\hline & $\begin{array}{c}\text { Apl./Total } \\
\%\end{array}$ & PR & & & $\begin{array}{l}\text { l./Total } \\
\% \\
\end{array}$ & PR \\
\hline \multicolumn{3}{|c|}{ Definitude do DP SUJ } & \multicolumn{4}{|c|}{ Verbo } \\
\hline [-def, -esp] & $\begin{array}{c}39 / 84 \\
46 \% \\
\end{array}$ & 0.813 & Inacusativo & & $\begin{array}{l}76 / 173 \\
44 \% \\
\end{array}$ & 0.908 \\
\hline [-def, +esp] & $\begin{array}{c}47 / 188 \\
25 \% \\
\end{array}$ & 0.634 & Predicativas & & $\begin{array}{l}10 / 877 \\
13 \% \\
\end{array}$ & 0.575 \\
\hline [+def, +esp] & $\begin{array}{c}43 / 383 \\
11 \%\end{array}$ & 0.388 & Transitivo & & $\begin{array}{l}6 / 1.785 \\
6 \%\end{array}$ & 0.442 \\
\hline [ genérico] & $\begin{array}{l}1 / 37 \\
2 \% \\
\end{array}$ & 0.185 & Inergativo & & $\begin{array}{c}1 / 101 \\
1 \% \\
\end{array}$ & 0.103 \\
\hline \multicolumn{3}{|c|}{ Verbo } & \multicolumn{4}{|c|}{ Forma do DP SUJ } \\
\hline Inacusativo & $\begin{array}{c}73 / 193 \\
38 \% \\
\end{array}$ & 0.776 & $\begin{array}{r}\text { Sintagm } \\
\text { quantifica }\end{array}$ & & $\begin{array}{c}34 / 141 \\
24 \% \\
\end{array}$ & 0.698 \\
\hline Cópula & $\begin{array}{c}36 / 256 \\
14 \% \\
\end{array}$ & 0.443 & Sintagma def & & $\begin{array}{c}216 / 1.519 \\
14 \%\end{array}$ & 0.619 \\
\hline
\end{tabular}

3 A variável "estrutura da sentença" não foi significativa em nenhuma das rodadas da ordem do sujeito na amostra de cartas catarinenses. 


\begin{tabular}{|c|c|c|c|c|c|}
\hline Transitivo & $\begin{array}{c}20 / 222 \\
9 \%\end{array}$ & 0.338 & Sintagma indefinido & $\begin{array}{c}11 / 58 \\
19 \% \\
\end{array}$ & 0.546 \\
\hline Inergativo & $\begin{array}{c}1 / 21 \\
5 \% \\
\end{array}$ & 0.171 & Pronome pessoal & $\begin{array}{c}42 / 1.334 \\
3 \% \\
\end{array}$ & 0.344 \\
\hline \multicolumn{3}{|c|}{ Forma do DP SUJ } & \multicolumn{3}{|c|}{ Estrutura da sentença } \\
\hline Pronome & $\begin{array}{l}10 / 43 \\
23 \% \\
\end{array}$ & 0.795 & $\begin{array}{l}\text { Interrogativa } \\
\text { cristalizada }\end{array}$ & $\begin{array}{c}25 / 35 \\
71 \% \\
\end{array}$ & 0.960 \\
\hline DP complexo & $\begin{array}{c}21 / 65 \\
32 \%\end{array}$ & 0.603 & Interrogativa & $\begin{array}{l}7 / 39 \\
18 \% \\
\end{array}$ & 0.606 \\
\hline DP simples & $\begin{array}{c}84 / 419 \\
20 \% \\
\end{array}$ & 0.506 & Subordinada & $\begin{array}{c}77 / 913 \\
8 \% \\
\end{array}$ & 0.504 \\
\hline Nome próprio & $\begin{array}{c}8 / 125 \\
6 \% \\
\end{array}$ & 0.392 & Matriz & $\begin{array}{c}171 / 1.706 \\
10 \%\end{array}$ & 0.493 \\
\hline DP indefinido & $\begin{array}{l}7 / 40 \\
17 \% \\
\end{array}$ & 0.268 & 2를 Coordenada & $\begin{array}{c}23 / 359 \\
6 \% \\
\end{array}$ & 0.435 \\
\hline \multicolumn{3}{|c|}{ Período de tempo } & \multicolumn{3}{|c|}{ Período de tempo } \\
\hline Período 2 & $\begin{array}{c}14 / 61 \\
23 \%\end{array}$ & 0.756 & Período 1 & $\begin{array}{c}84 / 421 \\
20 \%\end{array}$ & 0.735 \\
\hline Período 1 & $\begin{array}{c}28 / 126 \\
22 \%\end{array}$ & 0.582 & Período 2 & $\begin{array}{c}110 / 1.162 \\
9 \%\end{array}$ & 0.528 \\
\hline Período 3 & $\begin{array}{c}45 / 212 \\
21 \% \\
\end{array}$ & 0.459 & Período 3 & $\begin{array}{c}56 / 574 \\
10 \% \\
\end{array}$ & 0.453 \\
\hline Período 4 & $\begin{array}{c}43 / 293 \\
15 \% \\
\end{array}$ & 0.436 & Período 4 & $\begin{array}{c}53 / 895 \\
6 \% \\
\end{array}$ & 0.376 \\
\hline \multicolumn{3}{|c|}{ Animacidade do DP SUJ } & \multicolumn{3}{|c|}{ Local da carta } \\
\hline Inanimado & $\begin{array}{c}107 / 443 \\
24 \%\end{array}$ & 0.572 & Despedida & $\begin{array}{l}10 / 16 \\
63 \%\end{array}$ & 0.954 \\
\hline Animado & $\begin{array}{c}23 / 242 \\
9 \% \\
\end{array}$ & 0.373 & $\begin{array}{c}\text { Captação da bene- } \\
\text { volência }\end{array}$ & $\begin{array}{l}1 / 24 \\
29 \% \\
\end{array}$ & 0.771 \\
\hline Divindade & $\begin{array}{l}0 / 7 \\
0 \%\end{array}$ & - & Corpo do texto & $\begin{array}{c}286 / 3.012 \\
9 \%\end{array}$ & 0.494 \\
\hline & & & \multicolumn{3}{|c|}{ Definitude do DP SUJ } \\
\hline & & & [-def, -esp] & $\begin{array}{c}19 / 77 \\
25 \% \\
\end{array}$ & 0.723 \\
\hline & & & {$[-$ def, + esp $]$} & $\begin{array}{c}35 / 133 \\
26 \%\end{array}$ & 0.692 \\
\hline
\end{tabular}




\begin{tabular}{|c|c|c|c|}
\hline & {$[+\mathrm{def},+\mathrm{esp}]$} & $\begin{array}{c}246 / 2.736 \\
9 \% \\
\end{array}$ & 0.492 \\
\hline & [+genérico] & $\begin{array}{c}3 / 79 \\
4 \%\end{array}$ & 0.232 \\
\hline $\begin{array}{l}\text { Rodada significativa } \\
\text { Input: } 0.119 \\
\text { Log likelihood: }-256,34 \\
\text { Significance: } 0.045\end{array}$ & \multicolumn{3}{|c|}{$\begin{array}{c}\text { Rodada significativa } \\
\text { Input: } 0.056\end{array}$} \\
\hline
\end{tabular}

Os resultados gerais apresentados na Tabela 6.3 apontam que na amostra catarinense a ordem VS é condicionada (i) pela natureza do DP sujeito: DP [-definido] e [-específico] (0.813), em oposição à DP [-definido] e [+específico] (0.634); DP: [-animado] (0.572); DP pronominal (0.795); DP complexo (0.603); (ii) pela natureza do verbo: inacusativo (0.776) e (iii) pelos fatores externos ligados ao período em que as cartas foram escritas: período 2 (0.756) e período 1 (0.583). Em grande medida, esses resultados atestam os estudos anteriores, o que revela que, para além das forças internas, há indicativo de mudança em curso quando a variável período em que as cartas foram escritas se mostra relevante na determinação de VS, indicando os primeiros dois períodos favorecedores de VS (período 2: 0.756 > período 1: 0.582) e os terceiro e quarto períodos inibidores de VS (período 3: 0.459 > período 4: 0.436) e, portanto, favorecedores de SV.

Os resultados apresentados na Tabela 6.3 sugerem que, na amostra carioca, a ordem VS é condicionada, principalmente, por fatores de natureza gramatical, como (i) o tipo de verbo: inacusativo (0.908); (ii) a forma do sujeito: sintagma quantificado (0.698), sintagma definido (0.619) e sintagma indefinido (0.546); (iii) estrutura da sentença: interrogativa cristalizada (0.960). Outros fatores, como (iv) período de tempo: período 1 (0.735) e (v) local em que as cartas foram escritas: despedida (0.954), também parecem condicionar a ordem VS na amostra carioca. Destacamos também a influência de outro fator gramatical sobre a ordem VS nessa amostra, (vi) a natureza do sujeito: sujeitos [-definido] e [-específico] (0.723) e sujeitos [-definido] e [+específico] (0.692). Os resultados obtidos, em especial para o período de escrita das cartas, são interessantes, pois, assim como na amostra catarinense, indicam uma mudança em curso, já que podemos observar que o primeiro período é aquele que mais favorece a ordem VS, enquanto os períodos seguintes vão, lentamente, se tornando 
menos favorecedores dessa ordem (que vai sendo inibida nos períodos seguintes (período 1: $0.735>$ período 2: $0.528>$ período 3: $0.453>$ período 4: 0.376).

Duas circunstâncias chamam a atenção nesses resultados gerais apresentados na Tabela 6.3: (i) as semelhanças de contextos internos favorecedores de VS nas duas amostras investigadas, relacionados aos traços de definitude e de especificidade do sujeito e ao verbo inacusativo, atestando o que a literatura tem apontado, o que permite assim algumas generalizações; (ii) as particularidades encontradas nas escritas catarinense e carioca, como os pronomes e os sintagmas indefinidos, respectivamente, revelando índices de VS não esperados na literatura. Com relação às generalizações, podemos dizer que tanto as cartas catarinenses quanto as cariocas apresentam a implementação da mudança em direção a uma ordem VS restrita a contextos inacusativos, o que já foi mostrado por pesquisas anteriores. As particularidades dizem respeito aos maiores índices de VS com determinado tipo de sujeito: os sujeitos pronominais apresentaram maior índice de VS nas cartas catarinenses em comparação com as cartas cariocas (23\% versus $3 \%$ ), que apresentam maior índice de VS com sujeitos pronominais, ao passo que os sujeitos quantificados apresentaram maior índice de VS na amostra carioca.

Vejamos agora como se dão os resultados por período de tempo. Nessa nova análise, trazemos os resultados percentuais de VS por período de tempo para compreender o curso da mudança da ordem VS para a ordem SV.

$\mathrm{Na}$ amostra catarinense, a ordem VS foi condicionada em cada período investigado pelas seguintes variáveis, por ordem de relevância:

- Primeiro período: definitude e especificidade do DP, animacidade do DP e forma de representação do DP;

- Segundo período: não houve variável selecionada;

- Terceiro período: transitividade do verbo;

- Quarto período: transitividade do verbo, definitude e especificidade do DP e animacidade do DP.

A Tabela 6.4 apresenta os resultados percentuais de todas as variáveis que foram selecionadas pelo menos em algum dos períodos, bem como os resultados do PR em cada uma das rodadas selecionadas para que se possa 
estabelecer alguma comparação sobre a força interna dos fatores na atuação da ordem VS.

Tabela 6.4 - Resultados estatísticos de VS, segundo os grupos de fatores investigados na amostra catarinense

\begin{tabular}{|c|c|c|c|c|c|c|c|c|}
\hline \multirow{2}{*}{$\begin{array}{c}\text { Variáveis } \\
\text { independentes }\end{array}$} & \multicolumn{2}{|c|}{$\begin{array}{c}\text { Período } 1 \\
1870-1895\end{array}$} & \multicolumn{2}{|c|}{$\begin{array}{l}\text { Período } 2 \\
1905-1935\end{array}$} & \multicolumn{2}{|c|}{$\begin{array}{l}\text { Período } 3 \\
1955-1975\end{array}$} & \multicolumn{2}{|c|}{$\begin{array}{c}\text { Período } 4 \\
1980-1995\end{array}$} \\
\hline & \begin{tabular}{|c|} 
Apl./Total \\
$\%$
\end{tabular} & PR & \begin{tabular}{|c|} 
Apl./Total \\
$\%$
\end{tabular} & PR & $\begin{array}{c}\text { Apl./Total } \\
\%\end{array}$ & PR & $\begin{array}{c}\text { Apl./Total } \\
\%\end{array}$ & PR \\
\hline \multicolumn{9}{|c|}{ Traços de definitude e de especificidade do sujeito } \\
\hline [-def.] e [-esp.] & $\begin{array}{l}8 / 16 \\
50 \% \\
\end{array}$ & 0.902 & $\begin{array}{c}2 / 4 \\
50 \% \\
\end{array}$ & - & $\begin{array}{l}8 / 29 \\
27 \% \\
\end{array}$ & - & $\begin{array}{c}21 / 35 \\
60 \% \\
\end{array}$ & 0.919 \\
\hline [-def.] e [+esp.] & $\begin{array}{c}11 / 31 \\
35 \%\end{array}$ & 0.801 & $\begin{array}{c}1 / 3 \\
33 \%\end{array}$ & - & $\begin{array}{c}25 / 103 \\
24 \%\end{array}$ & - & $\begin{array}{c}10 / 51 \\
19 \%\end{array}$ & 0.678 \\
\hline [+def.] e [+esp.] & $\begin{array}{l}9 / 77 \\
11 \% \\
\end{array}$ & 0.265 & $\begin{array}{c}11 / 54 \\
20 \% \\
\end{array}$ & - & $\begin{array}{l}11 / 53 \\
20 \% \\
\end{array}$ & - & $\begin{array}{c}12 / 201 \\
5 \% \\
\end{array}$ & 0.352 \\
\hline Genérico & $\begin{array}{l}0 / 2 \\
0 \%\end{array}$ & - & sem dados & & $\begin{array}{c}1 / 27 \\
3 \%\end{array}$ & - & $\begin{array}{l}0 / 6 \\
0 \%\end{array}$ & - \\
\hline \multicolumn{9}{|c|}{ Transitividade do verbo } \\
\hline Inacusativo & $\begin{array}{c}13 / 29 \\
44 \%\end{array}$ & - & $\begin{array}{l}3 / 10 \\
30 \% \\
\end{array}$ & - & $\begin{array}{c}24 / 64 \\
37 \% \\
\end{array}$ & 0.741 & $\begin{array}{c}33 / 90 \\
36 \%\end{array}$ & 0.850 \\
\hline Cópula & $\begin{array}{l}5 / 34 \\
14 \% \\
\end{array}$ & - & $\begin{array}{l}6 / 25 \\
24 \% \\
\end{array}$ & - & $\begin{array}{c}17 / 79 \\
21 \%\end{array}$ & 0.566 & $\begin{array}{c}8 / 118 \\
6 \%\end{array}$ & 0.334 \\
\hline Transitivo & $\begin{array}{c}10 / 59 \\
16 \% \\
\end{array}$ & - & $\begin{array}{l}5 / 24 \\
20 \% \\
\end{array}$ & - & $\begin{array}{c}3 / 61 \\
4 \% \\
\end{array}$ & 0.198 & $\begin{array}{c}2 / 78 \\
2 \% \\
\end{array}$ & 0.278 \\
\hline Inergativo & $\begin{array}{l}0 / 4 \\
0 \%\end{array}$ & - & $\begin{array}{l}0 / 2 \\
0 \%\end{array}$ & - & $\begin{array}{c}1 / 8 \\
12 \% \\
\end{array}$ & 0.405 & $\begin{array}{l}0 / 7 \\
0 \% \\
\end{array}$ & - \\
\hline \multicolumn{9}{|c|}{ Traço de animacidade do sujeito } \\
\hline Inanimado & $\begin{array}{c}20 / 68 \\
29 \% \\
\end{array}$ & 0.710 & $\begin{array}{l}6 / 20 \\
30 \% \\
\end{array}$ & - & $\begin{array}{c}40 / 161 \\
25 \% \\
\end{array}$ & - & $\begin{array}{c}39 / 185 \\
21 \% \\
\end{array}$ & 0.653 \\
\hline Animado & $\begin{array}{l}8 / 56 \\
14 \%\end{array}$ & 0.367 & $\begin{array}{l}8 / 40 \\
20 \%\end{array}$ & - & $\begin{array}{l}5 / 48 \\
10 \%\end{array}$ & - & $\begin{array}{c}4 / 107 \\
3 \%\end{array}$ & 0.251 \\
\hline Divindade & $\begin{array}{l}0 / 2 \\
0 \%\end{array}$ & - & $\begin{array}{l}0 / 1 \\
0 \%\end{array}$ & - & $\begin{array}{l}0 / 3 \\
0 \%\end{array}$ & - & $\begin{array}{l}0 / 1 \\
0 \%\end{array}$ & - \\
\hline \multicolumn{9}{|c|}{ Forma de representação do DP sujeito } \\
\hline Pronome & $\begin{array}{l}7 / 24 \\
29 \%\end{array}$ & 0.878 & $\begin{array}{l}2 / 10 \\
20 \%\end{array}$ & - & $\begin{array}{l}1 / 10 \\
10 \%\end{array}$ & - & $\begin{array}{c}1 / 59 \\
1 \%\end{array}$ & - \\
\hline
\end{tabular}




\begin{tabular}{|c|c|c|c|c|c|c|c|c|}
\hline DP complexo & $\begin{array}{l}6 / 26 \\
23 \% \\
\end{array}$ & 0.438 & $\begin{array}{c}1 / 4 \\
25 \% \\
\end{array}$ & - & $\begin{array}{c}14 / 35 \\
40 \% \\
\end{array}$ & - & $\begin{array}{l}4 / 19 \\
21 \% \\
\end{array}$ & - \\
\hline DP simples & $\begin{array}{c}10 / 49 \\
20 \% \\
\end{array}$ & 0.417 & $\begin{array}{c}10 / 27 \\
37 \% \\
\end{array}$ & - & $\begin{array}{c}25 / 140 \\
18 \%\end{array}$ & - & $\begin{array}{c}34 / 124 \\
27 \%\end{array}$ & - \\
\hline Nome próprio & $\begin{array}{l}2 / 19 \\
10 \% \\
\end{array}$ & 0.310 & $\begin{array}{c}1 / 13 \\
7 \% \\
\end{array}$ & - & $\begin{array}{c}1 / 2 \\
50 \% \\
\end{array}$ & - & $\begin{array}{c}4 / 91 \\
4 \% \\
\end{array}$ & - \\
\hline DP indefinido & $\begin{array}{c}3 / 8 \\
37 \% \\
\end{array}$ & 0.239 & $\begin{array}{l}0 / 7 \\
0 \% \\
\end{array}$ & - & $\begin{array}{c}4 / 25 \\
0 \% \\
\end{array}$ & - & \multicolumn{2}{|c|}{ sem dados } \\
\hline $\begin{array}{c}\text { Rodadas } \\
\text { significativas }\end{array}$ & \multicolumn{2}{|c|}{$\begin{array}{c}\text { Input: } 0,129 \\
\text { Log likelihood = } \\
-51675 \\
\text { Significance }= \\
0,027\end{array}$} & \multicolumn{2}{|l|}{$\mathrm{n} / \mathrm{a}$} & \multicolumn{2}{|c|}{$\begin{array}{c}\text { Input: } 0,173 \\
\text { Log likelihood }= \\
-98,455 \\
\text { Significance }= \\
0,000\end{array}$} & \multicolumn{2}{|c|}{$\begin{array}{c}\text { Input: } 0,045 \\
\text { Log likelihood }= \\
-90,210 \\
\text { Significance = } \\
0,000\end{array}$} \\
\hline
\end{tabular}

Os resultados da análise por período investigado sinalizam forças sintáticas e semânticas distintas no favorecimento de VS. No período 1 (século XIX), a ordem VS era condicionada especialmente pela natureza do DP, ligada à variável 'definitude e especificidade do DP', com peso de 0.902 para o fator DP [-definido] e [-específico] e peso de 0.801 para o fator DP [-definido] e [+específico], e à variável 'animacidade do DP sujeito', com 0.710 para o fator DP inanimado. Já no terceiro e quarto períodos analisados, apesar de apresentar índices gerais distintos (22\% e $14 \%$, respectivamente), a ordem VS passa a ser fortemente condicionada pelo tipo de verbo, sendo os verbos transitivos inibidores de VS, com pesos de 0.198 (período 3) e de 0.278 (período 4), enquanto os verbos inacusativos aparecem como os contextos fortemente favorecedores dessa mesma ordem, como os pesos de 0.741 (período 3) e de 0.850 (período 4) revelam. Vale registrar que, no período 4, a natureza do DP também se mostrou significativa, uma vez que a variável 'definitude e especificidade do DP sujeito' foi o segundo grupo selecionado com pesos de 0.919 e 0.678 para os fatores DP [-definido] e [-específico] e DP [-definido] e [+específico], respectivamente, e a variável 'animacidade do DP sujeito' foi o terceiro grupo selecionado, com peso de 0.653 para o fator DP inanimado.

Esses resultados corroboram os estudos de Berlinck (1989) e de Cavalcante (2018), os quais mostram que a ordem VS nos séculos XVIII e XIX são fortemente condicionadas pela natureza do DP, enquanto no século 
XX a transitividade verbal passa a ser o fator predominante na influência da ordem VS, justamente em construções inacusativas.

Os exemplos a seguir dão rosto a esses resultados da escrita catarinense:

(6) [19,2 CP SC] A principio uma nostalgia lhe invadirá a alma, vindo essa da quietude de uma pequena cidade de provincia, mas não será ella mais profundamente pesada e esmagadora do que a do recanto da Affrica [...] (Período 1)

(7) $[19,2$ CP SC] [...] comquanto passassemos tanto tempo sem nos communicar por meio da escripta, continúas a ser meu maior amigo, o mais altamente sincero e dedicado; porque vive junto de mim, habitando o mesmo castello de esperanças, a doce eleita dos meus sonhos, achada entre as mais procuradas. (Período 1)

(8) [20,2 CP SC] Não podes imaginar a alegria que me causou o recebimento de teu bilhête. (Período 3)

(9) [20,2 CP SC] [...] por teres feito com que em horas de labuta diária me viesse a mente uma linda recordação como a de certas horas que a seu lado eu passei! (Período 3)

(10) [20,2 CP SC] Em carta, diz ele que será publicado em fins de junho na revista "Lâne" que não conheço. (Período 4)

Vejamos agora os resultados para a amostra carioca. Os fatores selecionados foram diferentes em cada período de tempo, conforme veremos a seguir, por ordem de seleção:

- Primeiro período: tipo de verbo e forma do sujeito;

- Segundo período: forma do sujeito, tipo de verbo, estrutura da sentença, local na carta;

- Terceiro período: local na carta, tipo de verbo e tipo de sentença;

- Quarto período: nenhum grupo de fatores foi selecionado.

A Tabela 6.5 mostra os índices percentuais e de PR (para os grupos que foram selecionados como favorecedores de VS) para cada um dos períodos na amostra carioca. 
Tabela 6.5 - Resultados estatísticos de VS, segundo os grupos de fatores investigados na amostra carioca

\begin{tabular}{|c|c|c|c|c|c|c|c|}
\hline \multirow{3}{*}{$\begin{array}{c}\text { Variáveis } \\
\text { independentes }\end{array}$} & \multirow{2}{*}{\multicolumn{2}{|c|}{\begin{tabular}{|c|} 
Período 1 \\
$1870-1895$ \\
\end{tabular}}} & \multirow{2}{*}{\multicolumn{2}{|c|}{$\begin{array}{l}\text { Período } 2 \\
1905-1935\end{array}$}} & \multirow{2}{*}{\multicolumn{2}{|c|}{$\begin{array}{l}\text { Período } 3 \\
1955-1975\end{array}$}} & \multirow{3}{*}{\begin{tabular}{|c|} 
Período 4 \\
$1976-1995$ \\
$\begin{array}{c}\text { Apl./Total } \\
\%\end{array}$ \\
\end{tabular}} \\
\hline & & & & & & & \\
\hline & \begin{tabular}{|c|} 
Apl./Total \\
$\%$
\end{tabular} & PR & \begin{tabular}{|c|} 
Apl./Total \\
$\%$ \\
\end{tabular} & $\mathbf{P R}$ & \begin{tabular}{|c|} 
Apl./Total \\
$\%$ \\
\end{tabular} & PR & \\
\hline \multicolumn{8}{|c|}{ Verbo } \\
\hline Inacusativo & $\begin{array}{c}17 / 26 \\
65 \% \\
\end{array}$ & 0.883 & $\begin{array}{c}26 / 45 \\
58 \% \\
\end{array}$ & 0.926 & $\begin{array}{c}16 / 44 \\
36 \% \\
\end{array}$ & 0.893 & $\begin{array}{c}17 / 58 \\
29 \% \\
\end{array}$ \\
\hline Cópula & $\begin{array}{c}25 / 95 \\
26 \% \\
\end{array}$ & 0.570 & $\begin{array}{c}39 / 279 \\
14 \% \\
\end{array}$ & 0.552 & $\begin{array}{c}21 / 230 \\
9 \% \\
\end{array}$ & 0.515 & $\begin{array}{c}25 / 273 \\
9 \% \\
\end{array}$ \\
\hline Transitivo & $\begin{array}{c}42 / 293 \\
14 \% \\
\end{array}$ & 0.443 & $\begin{array}{c}45 / 811 \\
6 \% \\
\end{array}$ & 0.447 & $\begin{array}{c}42 / 293 \\
14 \% \\
\end{array}$ & 0.443 & $\begin{array}{c}11 / 525 \\
2 \% \\
\end{array}$ \\
\hline Inergativo & \multicolumn{2}{|c|}{ sem dados } & \multicolumn{2}{|c|}{ sem dados } & $\begin{array}{c}1 / 28 \\
4 \% \\
\end{array}$ & 0.212 & sem dados \\
\hline \multicolumn{8}{|c|}{ Forma do SUJ } \\
\hline $\begin{array}{c}\text { Sintagma } \\
\text { quantificado }\end{array}$ & $\begin{array}{l}6 / 21 \\
29 \% \\
\end{array}$ & 0.667 & $\begin{array}{c}10 / 28 \\
36 \% \\
\end{array}$ & 0.909 & $\begin{array}{l}6 / 51 \\
12 \% \\
\end{array}$ & - & $\begin{array}{c}12 / 41 \\
29 \% \\
\end{array}$ \\
\hline $\begin{array}{c}\text { Sintagma } \\
\text { determinado }\end{array}$ & $\begin{array}{c}65 / 179 \\
36 \% \\
\end{array}$ & 0.610 & $\begin{array}{c}80 / 585 \\
14 \% \\
\end{array}$ & 0.664 & $\begin{array}{c}35 / 300 \\
12 \% \\
\end{array}$ & - & $\begin{array}{c}36 / 390 \\
9 \% \\
\end{array}$ \\
\hline $\begin{array}{l}\text { Sintagma } \\
\text { indefinido }\end{array}$ & $\begin{array}{c}1 / 6 \\
17 \% \\
\end{array}$ & 0.372 & $\begin{array}{c}10 / 26 \\
38 \% \\
\end{array}$ & 0.905 & \multicolumn{2}{|c|}{ sem dados } & sem dados \\
\hline Pronome & $\begin{array}{c}12 / 150 \\
8 \% \\
\end{array}$ & 0.309 & $\begin{array}{c}10 / 523 \\
2 \% \\
\end{array}$ & 0.269 & $\begin{array}{c}15 / 205 \\
7 \% \\
\end{array}$ & - & $\begin{array}{c}/ 456 \\
1 \% \\
\end{array}$ \\
\hline \multicolumn{8}{|c|}{ Estrutura da sentença } \\
\hline $\begin{array}{c}\text { Interrogativa } \\
\text { cristalizada }\end{array}$ & - & - & $\begin{array}{c}13 / 17 \\
76 \% \\
\end{array}$ & 0.973 & $\begin{array}{c}4 / 7 \\
57 \% \\
\end{array}$ & 0.959 & - \\
\hline Interrogativa & $\begin{array}{l}5 / 10 \\
50 \% \\
\end{array}$ & $\mathrm{n} / \mathrm{a}$ & $\begin{array}{l}4 / 20 \\
20 \% \\
\end{array}$ & 0.666 & $\begin{array}{c}1 / 3 \\
33 \% \\
\end{array}$ & 0.810 & $\begin{array}{l}5 / 17 \\
29 \% \\
\end{array}$ \\
\hline Subordinada & $\begin{array}{c}27 / 161 \\
17 \% \\
\end{array}$ & $\mathrm{n} / \mathrm{a}$ & $\begin{array}{c}31 / 378 \\
8 \% \\
\end{array}$ & 0.572 & $\begin{array}{c}8 / 167 \\
5 \% \\
\end{array}$ & 0.428 & $\begin{array}{c}11 / 207 \\
5 \% \\
\end{array}$ \\
\hline Matriz & $\begin{array}{c}41 / 206 \\
20 \% \\
\end{array}$ & $\mathrm{n} / \mathrm{a}$ & $\begin{array}{c}59 / 648 \\
9 \% \\
\end{array}$ & 0.486 & $\begin{array}{c}42 / 310 \\
14 \% \\
\end{array}$ & 0.645 & $\begin{array}{c}29 / 542 \\
5 \% \\
\end{array}$ \\
\hline $2^{-}$Coordenada & $\begin{array}{c}11 / 44 \\
25 \%\end{array}$ & $\mathrm{n} / \mathrm{a}$ & $\begin{array}{c}3 / 99 \\
3 \%\end{array}$ & 0.183 & $\begin{array}{c}1 / 87 \\
1 \%\end{array}$ & 0.133 & $\begin{array}{c}8 / 129 \\
6 \%\end{array}$ \\
\hline
\end{tabular}




\begin{tabular}{|c|c|c|c|c|c|c|c|}
\hline \multicolumn{8}{|c|}{ Local na carta } \\
\hline Despedida & \multicolumn{2}{|c|}{ sem dados } & $\begin{array}{c}3 / 6 \\
50 \%\end{array}$ & 0.943 & \multicolumn{2}{|c|}{ sem dados } & - \\
\hline $\begin{array}{l}\text { Captação da } \\
\text { benevolência }\end{array}$ & $\begin{array}{c}3 / 6 \\
50 \%\end{array}$ & $\mathrm{n} / \mathrm{a}$ & $\begin{array}{l}2 / 18 \\
11 \%\end{array}$ & 0.430 & $\begin{array}{l}9 / 10 \\
90 \%\end{array}$ & 0.993 & - \\
\hline Corpo do texto & $\begin{array}{c}81 / 415 \\
20 \% \\
\end{array}$ & $\mathrm{n} / \mathrm{a}$ & \begin{tabular}{|c|}
$105 / 1.138$ \\
$9 \%$ \\
\end{tabular} & 0.497 & $\begin{array}{c}47 / 564 \\
8 \% \\
\end{array}$ & 0.478 & - \\
\hline \multirow{3}{*}{$\begin{array}{c}\text { Rodadas } \\
\text { significativas }\end{array}$} & \multicolumn{2}{|c|}{ Input: 0.170} & \multicolumn{2}{|c|}{ Input: 0.049} & \multicolumn{2}{|c|}{ Input: 0.055} & \multirow{3}{*}{$\mathrm{n} / \mathrm{a}$} \\
\hline & \multicolumn{2}{|c|}{$\begin{array}{c}\text { Log likelihood }= \\
-184.953\end{array}$} & \multicolumn{2}{|c|}{$\begin{array}{c}\text { Log likelihood }= \\
-263.268\end{array}$} & \multicolumn{2}{|c|}{$\begin{array}{c}\text { Log likelihood }= \\
-135.557\end{array}$} & \\
\hline & \multicolumn{2}{|c|}{$\begin{array}{c}\text { Significance }= \\
0.001\end{array}$} & \multicolumn{2}{|c|}{$\begin{array}{c}\text { Significance }= \\
0.012\end{array}$} & \multicolumn{2}{|c|}{$\begin{array}{c}\text { Significance }= \\
0.000\end{array}$} & \\
\hline
\end{tabular}

Os resultados da amostra carioca indicam que a implementação da mudança em direção a uma ordem VS restrita pode ser capturada na amostra de cartas pessoais de forma diferente do que acontece na amostra catarinense. Notemos que os índices de VS em todos os contextos selecionados diminuem ao longo do tempo, mas algumas variáveis demonstram ter um peso maior na manutenção de VS na escrita, como o tipo de verbo e o tipo de sentença.

Podemos perceber que as variáveis selecionadas em todas as rodadas foram o tipo de verbo, o que corrobora a hipótese de que a ordem VS é restrita no PB, e os índices na Tabela 6.5 apontam para isso: as construções verbais com maior índice de ordem VS são as construções inacusativas, incluídas aí as construções de inversão locativa. Os índices de VS nessas construções diminuem ao longo do tempo, mas permanecem bem mais altos do que nos outros tipos de verbo. Chamam a atenção também os índices percentuais e de PR de VS em contextos específicos, como nas chamadas interrogativas cristalizadas ou em contextos de captação da benevolência ou despedida, o que indica que o uso de VS está, nesses contextos, relacionado ao uso frequente de expressões ou construções formulaicas, isto é, construções fixas em que não ocorre variação na ordem dos constituintes.

Vejamos alguns exemplos com os principais fatores condicionadores de VS da amostra carioca: 
(11) [19,2 CP RJ] Ainda não chegou o vapor com presentes teus. Convem que o Jeronimo mande saber qual o motivo da demora. (Período 1)

(12) [19,2 CP RJ] Estimei muito as boas noticias, que estaõ passando bem e que estaõ muito adiantados eque tem sempre boas notas. Naõ te posso dizer nada daqui pois cheguei á 8 dias e ainda naõ sahi e aqui tem vindo poucas pessoas. (Período 1)

(13) [20,1 CP RJ] E como vae o querido amigo Senhor Doutor Anistides José da Gama Vieira Machado? (Período 2)

(14) [20,2 CP RJ] Foi resolvido algo como esperavas em agôsto? (Período 3)

(15) [19,2 CP RJ] Com muitas saudades os abraça Sua avó Amiga. (Período 1).

Passemos agora aos resultados do sujeito nulo nas duas amostras a fim de testar a hipótese de Kato e Tarallo (2001) sobre a relação entre a ordem VS restrita e a preferência pelos sujeitos pronominais plenos.

\subsection{2 $\bigcirc$ preenchimento sujeito pronominal \\ 6.3.2.1 Caracterização do fenômeno e hipótese}

O português brasileiro $(\mathrm{PB})$ sofreu uma mudança no seu sistema pronominal intimamente relacionada ao Parâmetro do Sujeito Nulo (PSN): na posição de sujeito pronominal, há a preferência pelo preenchimento do sujeito tanto de referência definida - exemplos (16a, b, c) de Duarte (1995) - quanto indeterminada - exemplos (17a, b, c) e (18a, b, c) de Kato e Tarallo (1986) e de Duarte (1995), respectivamente.

(16) a. Mesmo que eu não fizesse o pré-vestibular, eu acho que eu passaria por causa da base que eu tinha.

b. Aí vocês vão entrar em atrito porque vocês vão começar a brigar.

c. Essa minha tia que mora aqui, ela é solteirona e eu acho que ela é super feliz, sabe? Eu não acho que ela seria feliz assim... Ela é uma pessoa que ajuda os outros pra caramba. Ela não 
ficou solteira porque não apareceu pretendente. Ela ficou solteira porque ela quis.

(17) a. Depois que você termina o comércio, você vai na área residencial.

b. Em primeiro lugar nós temos identificado claramente uma nova consciência crítica da classe média.

c. E se a gente falar que não tem?

d. E se eu pego aquela rua ali, então eu chego mais rápido.

(18) a. Você quando você viaja, você passa a ser turista. Então você passa a fazer coisas que você nunca faria no Brasil.

b. Quando eles querem, eles fazem. Quando eles querem eles acham dinheiro.

c. Hoje em dia quando a gente levanta as coisas é que a gente vê tudo o que aconteceu. Mas na época a gente não podia acreditar. A gente não acreditava nisso, primeiro porque a gente era novo.

Segundo Duarte $(1995,2000)$, a preferência pelo pronome pleno no $\mathrm{PB}$ se deve principalmente a uma mudança na morfologia flexional verbal e inserção de novas formas pronominais de primeira e segunda pessoas, como a gente e você. Duarte apresenta exemplos em que há o preenchimento do sujeito de referência definida mesmo quando seu antecedente é um elemento com traço [-animado], o que não ocorre nas outras línguas românicas de sujeito nulo, como podemos ver em (19a, b) com dados da fala culta carioca:

(19) a. A casa virou filme quando ela teve que ir abaixo.

b. Nova Trento é do tamanho da rua São Clemente de Botafogo. Ela é desse tamanho. Ela não tem paralela.

Os resultados de pesquisas quantitativas (DUARTE, 1995, 2000) revelam que o PB se distancia das demais línguas românicas de sujeito nulo não só na interpretação da categoria vazia, mas também no comportamento estatístico, como podemos ver na Tabela 6.6, a seguir, com resultados das pesquisas de Duarte (1995), Soares da Silva (2006) e Marins (2009) de 
fala culta do PE, do espanhol de Buenos Aires, do espanhol de Madri e do italiano.

Tabela 6.6 - Frequência de sujeito nulo em línguas românicas (România Nova/ România Velha) por pessoa gramatical

\begin{tabular}{|c|c|c|c|c|}
\hline & $\begin{array}{c}\text { PE } \\
\text { (Duarte, } \\
\text { 1995) }\end{array}$ & $\begin{array}{c}\text { Espanhol de } \\
\text { Buenos Aires } \\
\text { (Soares da Silva, } \\
\text { 2006) } \\
\end{array}$ & $\begin{array}{c}\text { Espanhol de } \\
\text { Madri } \\
\text { (Soares da Silva, } \\
\text { 2006) } \\
\end{array}$ & $\begin{array}{c}\text { Italiano } \\
\text { (Marins, 2009) }\end{array}$ \\
\hline & $\begin{array}{c}\text { Apl./Total } \\
\%\end{array}$ & $\begin{array}{c}\text { Apl./Total } \\
\%\end{array}$ & $\begin{array}{c}\text { Apl./Total } \\
\%\end{array}$ & $\begin{array}{c}\text { Apl./Total } \\
\%\end{array}$ \\
\hline 1PS & $\begin{array}{c}248 / 421 \\
59 \% \\
\end{array}$ & $\begin{array}{c}330 / 527 \\
63 \% \\
\end{array}$ & $\begin{array}{c}336 / 517 \\
65 \% \\
\end{array}$ & $\begin{array}{c}179 / 239 \\
75 \% \\
\end{array}$ \\
\hline $1 \mathrm{PP}$ & $\begin{array}{c}86 / 140 \\
61 \% \\
\end{array}$ & $\begin{array}{c}40 / 65 \\
62 \% \\
\end{array}$ & $\begin{array}{c}90 / 101 \\
89 \% \\
\end{array}$ & $\begin{array}{c}34 / 41 \\
83 \% \\
\end{array}$ \\
\hline 2PS & $\begin{array}{c}82 / 110 \\
75 \% \\
\end{array}$ & $\begin{array}{c}78 / 100 \\
78 \% \\
\end{array}$ & $\begin{array}{c}13 / 144 \\
78 \% \\
\end{array}$ & $\begin{array}{c}104 / 133 \\
78 \% \\
\end{array}$ \\
\hline $2 \mathrm{PP}$ & $\begin{array}{c}18 / 28 \\
68 \% \\
\end{array}$ & - & $\begin{array}{c}6 / 6 \\
100 \% \\
\end{array}$ & $\begin{array}{c}25 / 26 \\
96 \% \\
\end{array}$ \\
\hline $\begin{array}{c}\text { 2PS } \\
\text { indireta }\end{array}$ & - & $\begin{array}{c}101 / 168 \\
60 \% \\
\end{array}$ & $\begin{array}{c}80 / 116 \\
69 \% \\
\end{array}$ & - \\
\hline $\begin{array}{c}2 \mathrm{PP} \\
\text { indireta }\end{array}$ & - & $\begin{array}{c}12 / 19 \\
63 \% \\
\end{array}$ & $\begin{array}{l}6 / 9 \\
67 \% \\
\end{array}$ & - \\
\hline $3 P S$ & $\begin{array}{c}205 / 285 \\
72 \% \\
\end{array}$ & $\begin{array}{c}208 / 258 \\
81 \% \\
\end{array}$ & $\begin{array}{c}213 / 242 \\
88 \% \\
\end{array}$ & $\begin{array}{c}250 / 272 \\
92 \% \\
\end{array}$ \\
\hline $3 P P$ & $\begin{array}{c}98 / 132 \\
74 \% \\
\end{array}$ & $\begin{array}{c}65 / 84 \\
77 \% \\
\end{array}$ & $\begin{array}{c}99 / 109 \\
91 \% \\
\end{array}$ & $\begin{array}{c}38 / 40 \\
95 \% \\
\end{array}$ \\
\hline Total & $\begin{array}{c}738 / 1.116 \\
66 \% \\
\end{array}$ & $\begin{array}{c}843 / 1.221 \\
68 \% \\
\end{array}$ & $\begin{array}{c}943 / 1.244 \\
76 \% \\
\end{array}$ & $\begin{array}{c}630 / 751 \\
84 \% \\
\end{array}$ \\
\hline
\end{tabular}

Podemos ver que há certa variação nos índices de sujeito nulo nas línguas apresentadas que as fazem ser muito próximas. Ao olharmos, entretanto, para os dados do português brasileiro, os índices de sujeito nulo são muito mais baixos, como se pode ver na Tabela 6.7 com dados da fala culta carioca. 
Tabela 6.7 - Frequência de sujeito nulo na fala culta carioca por pessoa gramatical e desinência

\begin{tabular}{|c|c|c|}
\hline \multicolumn{2}{|c|}{ Pessoa } & Apl. $/$ Total $=\%$ \\
\hline 1PS & $\begin{array}{l}-o(-i) \\
\text { zero }\end{array}$ & $\begin{array}{c}138 / 479=29 \% \\
37 / 153=24 \%\end{array}$ \\
\hline $1 \mathrm{PP}$ & $\begin{array}{l}\text {-mos } \\
\text { zero }\end{array}$ & $\begin{aligned} 15 / 53 & =28 \% \\
3 / 67 & =9 \%\end{aligned}$ \\
\hline \multicolumn{2}{|c|}{ 2PS indireta } & $13 / 119=11 \%$ \\
\hline \multicolumn{2}{|c|}{$2 \mathrm{PP}$ indireta } & $0 / 8=0 \%$ \\
\hline \multicolumn{2}{|c|}{ 3PS } & $165 / 419=39 \%$ \\
\hline \multicolumn{2}{|c|}{$3 \mathrm{PP}$} & $44 / 127=35 \%$ \\
\hline \multicolumn{2}{|c|}{ Total } & $415 / 1.425=29 \%$ \\
\hline
\end{tabular}

Fonte: Adaptada de Duarte (1995, Tabelas 3.1, 3.2 e 3.3, p. 57-60).

Comparando os resultados, agora com a Tabela 6.8, adaptada de Duarte e Soares da Silva (2016), em que consideramos os índices de sujeito nulo da fala culta e da fala popular brasileiras com as falas cultas do italiano, espanhol de Madri e português europeu, vemos que aparece quase uma inversão nos valores: os índices de sujeito nulo no PB (20\% e 29\%) se aproximam dos índices de sujeito pleno das outras línguas românicas.

Tabela 6.8 - Sujeitos nulos e plenos na fala

\begin{tabular}{c|c|c|c}
\hline \multirow{2}{*}{ Línguas românicas } & Nulo & Pleno & \multirow{2}{*}{ Total } \\
\cline { 2 - 3 } & Apl. $=\%$ & Apl. $=\%$ & \\
\hline Italiano & $746=86 \%$ & $121=14 \%$ & 867 \\
\hline Espanhol (Madri) & $937=76 \%$ & $422=26 \%$ & 1.359 \\
\hline PE & $738=66 \%$ & $378=34 \%$ & 1.116 \\
\hline PB (ensino superior) & $415=29 \%$ & $1.009=71 \%$ & 1.424 \\
\hline PB (ensino médio) & $843=20 \%$ & $3.421=80 \%$ & 4.264 \\
\hline
\end{tabular}

Fonte: Adaptada de Duarte e Soares da Silva (2016). 
A mudança atestada na fala já se encontra implementada na escrita, principalmente se consideramos a amostra de peças portuguesas e brasileiras: Duarte (1993), analisando a implementação da mudança no Parâmetro do Sujeito Nulo em peças brasileiras escritas ao longo dos séculos XIX e XX, mostra uma curva ascendente do sujeito pleno em todas as pessoas do discurso, como vemos com a Tabela 6.9.

Tabela 6.9 - Evolução do sujeito pleno em peças brasileiras

\begin{tabular}{c|c|c|c|c|c|c|c}
\hline & $\mathbf{1 8 4 5}$ & $\mathbf{1 8 8 2}$ & $\mathbf{1 9 1 8}$ & $\mathbf{1 9 3 7}$ & $\mathbf{1 9 5 5}$ & $\mathbf{1 9 7 5}$ & $\mathbf{1 9 9 0}$ \\
\hline $1^{\mathrm{a}}$ pessoa & $31 \%$ & $22 \%$ & $17 \%$ & $39 \%$ & $44 \%$ & $68 \%$ & $82 \%$ \\
\hline $2^{2 \mathrm{a}}$ pessoa & $7 \%$ & $21 \%$ & $31 \%$ & $75 \%$ & $79 \%$ & $80 \%$ & $78 \%$ \\
\hline $3^{\text {a }}$ pessoa & $17 \%$ & $35 \%$ & $34 \%$ & $28 \%$ & $41 \%$ & $48 \%$ & $45 \%$ \\
\hline
\end{tabular}

Fonte: Adaptada de Duarte (1993).

Com relação aos sujeitos de referência indeterminada/arbitrária, a mudança atestada na fala já aparece implementada na escrita, como mostram os resultados de Cavalcante (1999) com textos de jornais dos séculos XIX e XX. Os índices de sujeito pleno não são superiores aos de sujeito nulo, mas já se encontram dados de você e a gente na escrita jornalística dos séculos XIX e XX:

(20) a. Você não fala de igual para igual com um político europeu se não souber encher um sobretudo. (1824)

b. A gente sempre encontra velhas e novas assombrações que assustam o nosso cotidiano.

c. Quando você pensa que já pode escolher com certeza o seu favorito, eles lançam, só para confundi-lo, uma tolice nova.

d. Este governo tem se esforçado para nos convencer de que o Brasil que a gente vê não é o Brasil de verdade, é outro país.

Utilizando uma amostra de cartas pessoais, Coelho, Silva e Zibetti (2016) fazem uma relação entre a ordem VS e o sujeito nulo. As autoras observam que há um aumento na expressão do sujeito pronominal em 
cartas pessoais dos séculos XIX e XX, como mostram os resultados por pessoa gramatical na Tabela 6.10.

Tabela 6.10 - Percentual de sujeitos nulos e plenos por pessoa em cartas pessoais de SC

\begin{tabular}{c|c|c|c|c}
\hline \multirow{2}{*}{ Sujeito } & \multicolumn{2}{|c|}{ Século XIX } & \multicolumn{2}{c}{ Século XX } \\
\cline { 2 - 5 } & nulo & pleno & nulo & pleno \\
\cline { 2 - 5 } & $\begin{array}{c}\text { Apl./Total } \\
\%\end{array}$ & $\begin{array}{c}\text { Apl./Total } \\
\%\end{array}$ & $\begin{array}{c}\text { Apl./Total } \\
\%\end{array}$ & $\begin{array}{c}\text { Apl./Total } \\
\%\end{array}$ \\
\hline \multirow{2}{*}{$\mathrm{Eu}$} & $204 / 245$ & $41 / 245$ & $112 / 228$ & $116 / 228$ \\
& $84 \%$ & $16 \%$ & $49 \%$ & $51 \%$ \\
\hline \multirow{2}{*}{$\mathrm{Tu}$} & $55 / 68$ & $13 / 68$ & $61 / 72$ & $11 / 72$ \\
& $81 \%$ & $19 \%$ & $85 \%$ & $15 \%$ \\
\hline \multirow{2}{*}{ Você(s) } & $1 / 1$ & $0 / 1=0 \%$ & $4 / 93=4 \%$ & $89 / 93$ \\
& $100 \%$ & & $96 \%$ \\
\hline \multirow{2}{*}{ Ele/Ela } & $3 / 12$ & $9 / 12$ & $0 / 9$ & $9 / 9$ \\
& $25 \%$ & $75 \%$ & $0 \%$ & $100 \%$ \\
\hline
\end{tabular}

Fonte: Adaptada de Coelho, Silva e Zibetti (2016, p. 53).

Vemos que, na amostra de cartas de Santa Catarina, um contexto de "resistência" do sujeito nulo é a segunda pessoa "tu": enquanto há um aumento significativo dos índices de sujeito pleno para "você" e para a primeira e a terceira pessoas, o índice de sujeito pleno para a forma "tu" permanece estável.

Neste capítulo, vamos explorar a relação entre a ordem VS restrita e o sujeito nulo e analisar o comportamento do sujeito pronominal nas cartas pessoais, considerando somente os sujeitos de terceira pessoa, a fim de comparar com os resultados dos sujeitos nominais. Por hipótese, esperamos encontrar um aumento nos índices de sujeito pleno, como encaixamento da mudança na ordem VS.

\subsubsection{Resultados e discussão}

Nesta seção, apresentamos os resultados estatísticos do sujeito pronominal nulo e pleno de terceira pessoa nas amostras catarinense 
e carioca. Inicialmente, observamos os resultados gerais e por período de tempo apresentados na Tabela 6.11. Das 448 ocorrências de sujeito pronominal encontradas nas missivas catarinenses, 69\% são de sujeitos nulos e $31 \%$ de sujeitos plenos. O sujeito nulo predomina em todos os períodos investigados, inclusive com um leve aumento dessa variante no último período $(53 \%, 60 \%, 52 \%$ e $80 \%)$. Já na amostra carioca, das 535 ocorrências, $36 \%$ são de sujeito nulo e $64 \%$ de sujeito pleno. Desse número geral, o sujeito nulo apresenta índices bem mais baixos do que os índices do pleno em todos os períodos: $38 \%, 53 \%, 32 \%$ e $8 \%$.

Tabela 6.11 - Ocorrência das variantes do preenchimento do sujeito, por amostra e por período

\begin{tabular}{|c|c|c|c|c|c|c|}
\hline \multirow{2}{*}{\multicolumn{2}{|c|}{$\begin{array}{c}\text { Sujeito } \\
\text { pronominal }\end{array}$}} & $\begin{array}{c}\text { Período 1 } \\
1870-1895\end{array}$ & $\begin{array}{c}\text { Período } 2 \\
\text { 1905-1935 }\end{array}$ & $\begin{array}{c}\text { Período } 3 \\
1955-1975\end{array}$ & $\begin{array}{c}\text { Período } 4 \\
1980-1995\end{array}$ & Total \\
\hline & & Apl./Total & Apl./Total & Apl./Total & Apl./Total & Apl./Total \\
\hline \multirow{2}{*}{$\begin{array}{c}\text { Amostra } \\
\text { catarinense }\end{array}$} & Nulo & $\begin{array}{c}62 / 116 \\
53 \% \\
\end{array}$ & $\begin{array}{c}31 / 51 \\
60 \% \\
\end{array}$ & $\begin{array}{c}22 / 42 \\
52 \% \\
\end{array}$ & $\begin{array}{c}193 / 239 \\
80 \% \\
\end{array}$ & $\begin{array}{c}308 / 448 \\
69 \% \\
\end{array}$ \\
\hline & Pleno & $\begin{array}{c}54 / 116 \\
47 \%\end{array}$ & $\begin{array}{c}20 / 51 \\
40 \%\end{array}$ & $\begin{array}{c}20 / 42 \\
48 \%\end{array}$ & $\begin{array}{c}46 / 239 \\
20 \%\end{array}$ & $\begin{array}{c}140 / 448 \\
31 \%\end{array}$ \\
\hline \multirow{2}{*}{$\begin{array}{l}\text { Amostra } \\
\text { carioca }\end{array}$} & Nulo & $\begin{array}{c}25 / 65 \\
38 \%\end{array}$ & $\begin{array}{c}135 / 253 \\
53 \%\end{array}$ & $\begin{array}{c}22 / 69 \\
32 \%\end{array}$ & $\begin{array}{c}12 / 148 \\
8 \%\end{array}$ & $\begin{array}{c}194 / 535 \\
36 \%\end{array}$ \\
\hline & Pleno & $\begin{array}{c}40 / 65 \\
62 \% \\
\end{array}$ & $\begin{array}{c}118 / 253 \\
47 \%\end{array}$ & $\begin{array}{c}47 / 69 \\
68 \%\end{array}$ & $\begin{array}{c}136 / 148 \\
92 \%\end{array}$ & $\begin{array}{c}341 / 535 \\
64 \%\end{array}$ \\
\hline
\end{tabular}

Esses resultados já sinalizam que na variedade carioca, diferentemente da catarinense, há indicativo de mudança de um sistema de sujeito nulo para um sistema de sujeito pleno. Vejamos, agora, os resultados da análise multivariada do sujeito nulo, considerando as mesmas variáveis controladas para a ordem do sujeito, nas duas amostras investigadas.

Podemos dizer que o sujeito nulo nas cartas catarinenses é condicionado pelas seguintes variáveis, por ordem de relevância: 'período de tempo', 'construção sintática' e 'animacidade do sujeito pronominal'. $\mathrm{Na}$ escrita carioca todas as variáveis controladas foram selecionadas na seguinte ordem de seleção: 'período de tempo', 'definitude e especificidade do sujeito pronominal,' 'tipo de verbo', 'animacidade do sujeito pronominal' 
e 'construção sintática', conforme os índices expostos na Tabela 6.12, a seguir.

Tabela 6.12 - Ocorrência de sujeito nulo, segundo os grupos de fatores investigados nas amostras catarinense e carioca

\begin{tabular}{|c|c|c|c|c|c|}
\hline \multicolumn{6}{|c|}{ Variáveis independentes para sujeito nulo } \\
\hline \multicolumn{3}{|c|}{ Santa Catarina } & \multicolumn{3}{|c|}{ Rio de Janeiro } \\
\hline & $\begin{array}{c}\text { Apl./Total } \\
\%\end{array}$ & PR & & $\begin{array}{c}\text { Apl./Total } \\
\%\end{array}$ & PR \\
\hline \multicolumn{3}{|c|}{ Período de tempo } & \multicolumn{3}{|c|}{ Período de tempo } \\
\hline Período 4 & $\begin{array}{c}193 / 239 \\
81 \% \\
\end{array}$ & 0.639 & Período 1 & $\begin{array}{c}25 / 65 \\
38 \% \\
\end{array}$ & 0.646 \\
\hline Período 2 & $\begin{array}{c}31 / 51 \\
61 \% \\
\end{array}$ & 0.460 & Período 2 & $\begin{array}{c}135 / 253 \\
53 \% \\
\end{array}$ & 0.751 \\
\hline Período 1 & $\begin{array}{c}62 / 116 \\
53 \%\end{array}$ & 0.313 & Período 3 & $\begin{array}{c}22 / 69 \\
32 \%\end{array}$ & 0.456 \\
\hline Período 3 & $\begin{array}{c}22 / 42 \\
52 \% \\
\end{array}$ & 0.292 & Período 4 & $\begin{array}{c}12 / 148 \\
8 \%\end{array}$ & 0.112 \\
\hline \multicolumn{3}{|c|}{ Construção sintática } & \multicolumn{3}{|c|}{ Definitude do SUJ pronominal } \\
\hline Substantiva & $\begin{array}{l}52 / 66 \\
79 \% \\
\end{array}$ & 0.595 & [+genérico] & $\begin{array}{c}19 / 21 \\
90 \% \\
\end{array}$ & 0.978 \\
\hline 2 Coordenada & $\begin{array}{c}90 / 117 \\
77 \% \\
\end{array}$ & 0.592 & [-def, -esp] & $\begin{array}{c}8 / 9 \\
89 \% \\
\end{array}$ & 0.955 \\
\hline $\begin{array}{l}\text { 1 }{ }^{\text {a }} \text { Coordenada/ } \\
\text { Absoluta }\end{array}$ & $\begin{array}{c}77 / 107 \\
72 \% \\
\end{array}$ & 0.530 & {$[-$ def, + esp $]$} & $\begin{array}{c}3 / 4 \\
75 \% \\
\end{array}$ & 0.761 \\
\hline Adverbial & $\begin{array}{c}26 / 39 \\
67 \% \\
\end{array}$ & 0.485 & [+def, +esp] & $\begin{array}{c}164 / 501 \\
33 \%\end{array}$ & 0.445 \\
\hline $2^{\mathrm{a}}$ Coordenada & $\begin{array}{c}90 / 117 \\
77 \% \\
\end{array}$ & 0.592 & \multicolumn{3}{|c|}{ Tipo de verbo } \\
\hline \multicolumn{3}{|c|}{ Animacidade do SUJ pronominal } & Intransitivo & $\begin{array}{c}16 / 34 \\
47 \% \\
\end{array}$ & 0.722 \\
\hline Inanimado & $\begin{array}{l}74 / 98 \\
76 \%\end{array}$ & 0.609 & Cópula & $\begin{array}{c}52 / 114 \\
46 \% \\
\end{array}$ & 0.617 \\
\hline Animado & $\begin{array}{c}230 / 346 \\
66 \% \\
\end{array}$ & 0.469 & $\begin{array}{c}\text { Transitivo } \\
\text { direto }\end{array}$ & $\begin{array}{c}93 / 310 \\
30 \% \\
\end{array}$ & 0.435 \\
\hline Divindade & $\begin{array}{c}4 / 4 \\
100 \% \\
\end{array}$ & - & $\begin{array}{l}\text { Transitivo } \\
\text { indireto }\end{array}$ & $\begin{array}{c}15 / 45 \\
33 \%\end{array}$ & 0.324 \\
\hline
\end{tabular}




\begin{tabular}{|c|c|c|c|c|}
\hline \multicolumn{5}{|c|}{ minal } \\
\hline & & Inanimado & $\begin{array}{c}24 / 39 \\
62 \%\end{array}$ & 0.767 \\
\hline & & Humano & $\begin{array}{c}168 / 483 \\
35 \%\end{array}$ & 0.487 \\
\hline & & Divindade & $\begin{array}{l}2 / 13 \\
15 \%\end{array}$ & 0.167 \\
\hline & & \multicolumn{3}{|c|}{ Construção sintática } \\
\hline & & Interrogativa & $\begin{array}{l}6 / 11 \\
55 \% \\
\end{array}$ & 0.606 \\
\hline & & Principal & $\begin{array}{c}115 / 301 \\
38 \%\end{array}$ & 0.549 \\
\hline & & Relativa & $\begin{array}{c}10 / 22 \\
45 \% \\
\end{array}$ & 0.538 \\
\hline & & Absoluta & $\begin{array}{c}14 / 27 \\
52 \%\end{array}$ & 0.524 \\
\hline & & Substantiva & $\begin{array}{c}37 / 133 \\
28 \%\end{array}$ & 0.483 \\
\hline & & Adverbial & $\begin{array}{c}11 / 40 \\
28 \% \\
\end{array}$ & 0.180 \\
\hline \multirow{3}{*}{$\begin{array}{c}\text { Rodadas } \\
\text { significativas }\end{array}$} & Input: 0.711 & \multicolumn{3}{|c|}{ Input: 0.307} \\
\hline & $\begin{array}{c}\text { Log likelihood }= \\
-246.566\end{array}$ & \multicolumn{3}{|c|}{ Log likelihood $=-254.781$} \\
\hline & Significance $=0.040$ & \multicolumn{3}{|c|}{ Significance $=0.008$} \\
\hline
\end{tabular}

Os resultados da amostra catarinense não revelam mudança em curso. Apontam que no período 4 há índice significativo de PR para o sujeito nulo. Essa talvez seja uma idiossincrasia da própria amostra, escrita por um missivista mais velho, nascido no começo do século XX. De qualquer forma, quando comparamos os percentuais dos quatro períodos de tempo, observamos certa instabilidade, indicando a seguinte trajetória para o sujeito nulo: período 4: $81 \%$ e PR de 0.639; período 2: $61 \%$ e PR de 0.460; período 1: 53\% e PR de 0.313; e período 3: 52\% e PR de 0.292. Em todos os períodos, os percentuais de sujeito nulo são altos. Outras duas variáveis selecionadas pelo programa estatístico foram 'construção sintática' e 'animacidade do sujeito pronominal. Os resultados nesses dois casos 
mostram que os contextos favorecedores do sujeito nulo são estruturas coordenadas ( $1^{\mathrm{a}}$ e $2^{\mathrm{a}}$ ) e subordinadas substantivas e sujeito inanimado, atestando o que a literatura tem apontado.

A amostra carioca, por outro lado, já apresenta uma implementação dos sujeitos plenos mais avançada do que a amostra catarinense, e isso pode ser comprovado com o primeiro grupo de fatores selecionado como o mais favorecedor do sujeito nulo: o período de tempo. Podemos ver que os índices de sujeito nulo diminuem ao longo do tempo, apresentando uma curva de mudança, com índices de sujeito nulo mais altos nos períodos 1 e $2(38 \%$ e $53 \%$, com PR de 0.646 e 0.751$)$ e mais baixos nos períodos 3 e 4 (32\% e $8 \%$, com PR de 0.456 e 0.112 ). Em segundo lugar, foi selecionado como fator relevante o traço de especificidade e de definitude do sujeito: sujeitos genéricos ou menos específicos favorecem o sujeito nulo, ao passo que sujeitos com traço [+definido, +específico] não favorecem. Isso pode indicar, de certo modo, que a propriedade de sujeito nulo parcial pode estar aparecendo nas missivas dos cariocas, em que o sujeito nulo é licenciado, mas sua interpretação é diferente do sujeito nulo das outras línguas românicas de sujeito nulo.

O traço de animacidade, terceiro grupo selecionado como favorecedor do sujeito nulo, parece ser um contexto de resistência para o sujeito nulo, pois é com os sujeitos com traço [-animado] que os índices de sujeito nulo são mais altos, como ocorre nas línguas de sujeito nulo canônico, como italiano ou português europeu.

Passemos agora para os resultados da amostra catarinense e, em seguida, da amostra carioca com relação aos fatores mais relevantes para condicionar o sujeito nulo por período de tempo. Metodologicamente, separamos as amostras por período de tempo e fizemos rodadas separadas para cada período para saber os fatores mais relevantes em cada período, a fim de detectar mudança linguística.

Vejamos, primeiramente, os resultados da amostra catarinense e, em seguida, veremos os resultados da amostra carioca. Na amostra catarinense, os seguintes grupos de fatores foram selecionados por ordem de significância:

- Primeiro período: construção sintática e animacidade do sujeito pronominal;

- Segundo período: não houve variável selecionada; 
- Terceiro período: não houve variável selecionada;

- Quarto período: construção sintática e animacidade do sujeito pronominal.

Consideremos os resultados da Tabela 6.13 relativos aos índices percentuais e de PR dos grupos que foram selecionados como favorecedores do sujeito nulo em cada um dos períodos na amostra catarinense.

Tabela 6.13 - Ocorrência de sujeito nulo, segundo os grupos de fatores investigados na amostra catarinense

\begin{tabular}{|c|c|c|c|c|c|c|c|c|}
\hline \multirow{2}{*}{$\begin{array}{c}\text { Variáveis } \\
\text { independentes }\end{array}$} & \multicolumn{2}{|c|}{$\begin{array}{l}\text { Período } 1 \\
1870-1895 \\
\end{array}$} & \multicolumn{2}{|c|}{$\begin{array}{l}\text { Período } 2 \\
1905-1935\end{array}$} & \multicolumn{2}{|c|}{$\begin{array}{l}\text { Período } 3 \\
1955-1975\end{array}$} & \multicolumn{2}{|c|}{$\begin{array}{l}\text { Período } 4 \\
1980-1995\end{array}$} \\
\hline & \begin{tabular}{|c|} 
Apl./Total \\
$\%$
\end{tabular} & PR & \begin{tabular}{|c|} 
Apl./Total \\
$\%$ \\
\end{tabular} & $\mathbf{P R}$ & $\begin{array}{c}\text { Apl./Total } \\
\%\end{array}$ & PR & $\begin{array}{c}\text { Apl./Total } \\
\%\end{array}$ & PR \\
\hline \multicolumn{9}{|c|}{ Construção sintática } \\
\hline $2^{\underline{a}}$ Coordenada & $\begin{array}{c}23 / 30 \\
80 \% \\
\end{array}$ & 0.805 & $\begin{array}{c}\text { sem } \\
\text { dados }\end{array}$ & - & $\begin{array}{l}6 / 14 \\
42 \% \\
\end{array}$ & - & $\begin{array}{c}58 / 71 \\
81 \% \\
\end{array}$ & 0.477 \\
\hline $\begin{array}{c}1^{\underline{a}} \text { Coordenada/ } \\
\text { Absoluta }\end{array}$ & $\begin{array}{l}16 / 26 \\
61 \%\end{array}$ & 0.603 & $\begin{array}{l}12 / 16 \\
75 \%\end{array}$ & - & $\begin{array}{c}6 / 8 \\
75 \%\end{array}$ & - & $\begin{array}{l}45 / 59 \\
76 \%\end{array}$ & 0.398 \\
\hline Principal & $\begin{array}{c}12 / 28 \\
42 \%\end{array}$ & 0.412 & $\begin{array}{c}12 / 23 \\
52 \%\end{array}$ & - & $\begin{array}{l}4 / 8 \\
50 \% \\
\end{array}$ & - & $\begin{array}{c}29 / 41 \\
70 \% \\
\end{array}$ & 0.336 \\
\hline Adverbial & $\begin{array}{l}6 / 16 \\
37 \% \\
\end{array}$ & 0.276 & $\begin{array}{c}2 / 6 \\
33 \% \\
\end{array}$ & - & $\begin{array}{l}2 / 4 \\
50 \% \\
\end{array}$ & - & $\begin{array}{l}16 / 17 \\
94 \%\end{array}$ & 0.683 \\
\hline Substantiva & $\begin{array}{l}4 / 12 \\
33 \%\end{array}$ & 0.216 & $\begin{array}{l}5 / 7 \\
71 \%\end{array}$ & - & $\begin{array}{l}5 / 6 \\
66 \%\end{array}$ & - & $\begin{array}{c}39 / 41 \\
95 \%\end{array}$ & 0.801 \\
\hline Relativa & $\begin{array}{c}1 / 5 \\
20 \%\end{array}$ & 0.074 & $\begin{array}{c}\text { sem } \\
\text { dados }\end{array}$ & - & $\begin{array}{c}1 / 3 \\
33 \%\end{array}$ & - & $\begin{array}{l}6 / 10 \\
60 \%\end{array}$ & 0.247 \\
\hline \multicolumn{9}{|c|}{ Animacidade do sujeito pronominal } \\
\hline Inanimado & $\begin{array}{c}16 / 32 \\
50 \% \\
\end{array}$ & 0.473 & $\begin{array}{c}5 / 7 \\
71 \% \\
\end{array}$ & - & $\begin{array}{l}9 / 13 \\
69 \% \\
\end{array}$ & - & $\begin{array}{c}45 / 47 \\
95 \% \\
\end{array}$ & 0.806 \\
\hline $\begin{array}{l}\text { Humano/ } \\
\text { animado }\end{array}$ & $\begin{array}{c}42 / 81 \\
52 \%\end{array}$ & 0.511 & $\begin{array}{c}26 / 45 \\
57 \%\end{array}$ & - & $\begin{array}{c}14 / 30 \\
46 \%\end{array}$ & - & $\begin{array}{c}148 / 192 \\
77 \%\end{array}$ & 0.414 \\
\hline Divindade & $\begin{array}{c}4 / 4 \\
100 \%\end{array}$ & - & $\begin{array}{c}\text { sem } \\
\text { dados }\end{array}$ & - & sem dados & - & $\begin{array}{c}\text { sem } \\
\text { dados }\end{array}$ & - \\
\hline $\begin{array}{c}\text { Rodadas } \\
\text { significativas }\end{array}$ & $\begin{array}{r}\text { Input: } 0 \\
\text { Log likelih } \\
-67,11 \\
\text { Significance }\end{array}$ & $\begin{array}{l}553 \\
\text { ood }= \\
5 \\
=0.018\end{array}$ & $\mathrm{n} / \mathrm{a}$ & & $\mathrm{n} / \mathrm{a}$ & & $\begin{array}{r}\text { Input: } 0 \\
\text { Log likelih } \\
-105.1 \\
\text { Significance }\end{array}$ & $\begin{array}{l}851 \\
\text { ood }= \\
7 \\
=0.025\end{array}$ \\
\hline
\end{tabular}


Novamente, na escrita catarinense os índices percentuais e de PR dos quatro períodos em separado mostram que o sujeito nulo é ainda bastante resistente. Comparando os PR dos períodos 1 e 4, que se mostraram significativos para o sujeito nulo, observamos certa instabilidade de fatores na variável 'estrutura da sentença': no período 1 , os fatores $2^{2}$ coordenada e $1^{\text {a }}$ coordenada foram significativos, o que sinaliza para um contexto de resistência já atestado na literatura. No entanto, quando observamos a seleção que o programa faz para o quarto período, notamos que os fatores $2^{\text {a }}$ coordenada e 1a coordenada não foram relevantes, mas sim os fatores substantiva e adverbial. Quanto à variável 'animacidade do sujeito pronominal', no período 1 há pouca diferença entre os contextos inanimados e animados no condicionamento do sujeito nulo, com uma preferência para nulos com sujeito humano/animado e sujeito divindade. Já no período 4 o fator sujeito inanimado é um forte condicionador do sujeito nulo (ou da preservação do sujeito nulo) nessa amostra, com índices percentuais de 95\% e de PR de 0.806. É nesse contexto em específico que o sujeito nulo apresenta forte resistência em Santa Catarina. Os exemplos a seguir ilustram a variação entre nulos e plenos em diferentes períodos de tempo.

(21) [19,2 CP SC] Agora, meu Crus, pensa: si estes homens, que são meus adversarios politicos, segundo elles julgam, me fasem essas coisas, o que não farão aquelles que, soffrendo como eu soffri; sendo perseguidos como eu fui, acham que deverão faser muito mais por mim? (Período 1)

(22) [20,2 CP SC] Destinatário N, espliquei o assunto à minha mãe, ela mandou que eu levasse ao teu conhecimento e pedisse uma opinião! (Período 3)

(23) [20,2 CP SC] O homem montou veículos que o tornam o super homem! Inventou computadores, que pensam por êle, que agem por êle, conquistou espaços! (Período 3)

(24) [20,2 CP SC] Celeste ainda não voltou do passeio. Agora está em Joinville. Deve voltar esta semana, e rezará para que vocês encontrem o apartamento em Paris. (Período 4)

$\mathrm{Na}$ amostra carioca, não houve seleção dos mesmos fatores em todos os períodos de tempo, o que pode indicar uma implementação da mudança nas cartas. Nos períodos 1 e 3, não houve fatores selecionados 
como relevantes, mas inserimos na tabela os índices dos fatores que mais foram selecionados nos outros períodos. No período 2, os fatores relevantes foram traço de animacidade do sujeito, pessoa do sujeito, tipo de verbo, estrutura da sentença e definitude do sujeito. Podemos ver que os traços de animacidade e definitude do sujeito são os mais favorecedores do sujeito nulo: os maiores índices de sujeito nulo estão nos sujeitos com traço [-animado] e [+genérico], o que pode indicar para o contexto de resistência do sujeito nulo, tal como ocorre nas línguas românicas de sujeito nulo.

Tabela 6.14 - Ocorrência de sujeito nulo, segundo os grupos de fatores investigados na amostra carioca

\begin{tabular}{|c|c|c|c|c|c|c|c|}
\hline \multirow{3}{*}{$\begin{array}{c}\text { Variáveis } \\
\text { independentes }\end{array}$} & Período 1 & \multicolumn{2}{|c|}{ Período 2} & \multicolumn{2}{|c|}{ Período 3} & \multicolumn{2}{|c|}{ Período 4} \\
\hline & $1870-1895$ & \multicolumn{2}{|c|}{ 1905-1935 } & \multicolumn{2}{|c|}{$1955-1975$} & \multicolumn{2}{|c|}{ 1976-1995 } \\
\hline & $\begin{array}{c}\text { Apl./Total } \\
\% \\
\end{array}$ & $\begin{array}{c}\text { Apl./Total } \\
\% \\
\end{array}$ & PR & $\begin{array}{c}\text { Apl./Total } \\
\% \\
\end{array}$ & PR & $\begin{array}{c}\text { Apl./Total } \\
\% \\
\end{array}$ & PR \\
\hline \multicolumn{8}{|c|}{ Animacidade do SUJ } \\
\hline Inanimado & $\begin{array}{l}3 / 5 \\
60 \% \\
\end{array}$ & $\begin{array}{l}19 / 20 \\
95 \%\end{array}$ & 0.936 & $\begin{array}{c}1 / 3 \\
33 \% \\
\end{array}$ & - & $\begin{array}{c}1 / 11 \\
9 \%\end{array}$ & - \\
\hline $\begin{array}{c}\text { Humano/ } \\
\text { animado }\end{array}$ & $\begin{array}{c}22 / 60 \\
37 \% \\
\end{array}$ & $\begin{array}{c}114 / 222 \\
51 \% \\
\end{array}$ & 0.461 & $\begin{array}{c}21 / 65 \\
32 \% \\
\end{array}$ & - & $\begin{array}{c}11 / 137 \\
8 \% \\
\end{array}$ & - \\
\hline Divindade & $\begin{array}{c}\text { sem } \\
\text { dados }\end{array}$ & $\begin{array}{l}2 / 11 \\
18 \%\end{array}$ & 0.152 & $\begin{array}{c}\text { sem } \\
\text { dados }\end{array}$ & - & $\begin{array}{c}\text { sem } \\
\text { dados }\end{array}$ & - \\
\hline \multicolumn{8}{|c|}{ Pessoa do SUJ } \\
\hline 3PPL & $\begin{array}{l}7 / 15 \\
47 \% \\
\end{array}$ & $\begin{array}{c}30 / 35 \\
86 \%\end{array}$ & 0.872 & $\begin{array}{l}8 / 21 \\
38 \% \\
\end{array}$ & - & $\begin{array}{l}6 / 34 \\
18 \% \\
\end{array}$ & - \\
\hline 3PSG & $\begin{array}{c}18 / 50 \\
36 \% \\
\end{array}$ & $\begin{array}{c}105 / 218 \\
48 \% \\
\end{array}$ & 0.424 & $\begin{array}{c}14 / 48 \\
29 \% \\
\end{array}$ & - & $\begin{array}{c}6 / 114 \\
5 \% \\
\end{array}$ & - \\
\hline \multicolumn{8}{|c|}{ Estrutura da sentença } \\
\hline Principal & $\begin{array}{c}11 / 20 \\
55 \%\end{array}$ & $\begin{array}{c}88 / 145 \\
61 \% \\
\end{array}$ & 0.578 & $\begin{array}{c}10 / 33 \\
30 \%\end{array}$ & - & $\begin{array}{c}6 / 103 \\
6 \%\end{array}$ & - \\
\hline Absoluta & $\begin{array}{l}2 / 5 \\
40 \% \\
\end{array}$ & $\begin{array}{c}12 / 22 \\
55 \%\end{array}$ & 0.535 & - & - & - & - \\
\hline Relativa & $\begin{array}{c}3 / 6 \\
50 \% \\
\end{array}$ & $\begin{array}{l}6 / 15 \\
40 \% \\
\end{array}$ & 0.509 & - & - & - & - \\
\hline Substantiva & $\begin{array}{l}6 / 19 \\
32 \%\end{array}$ & $\begin{array}{c}23 / 48 \\
48 \%\end{array}$ & 0.495 & $\begin{array}{c}12 / 36 \\
33 \%\end{array}$ & - & $\begin{array}{l}6 / 45 \\
13 \%\end{array}$ & - \\
\hline
\end{tabular}




\begin{tabular}{|c|c|c|c|c|c|c|c|}
\hline Adverbial & $\begin{array}{l}2 / 14 \\
14 \% \\
\end{array}$ & $\begin{array}{l}6 / 23 \\
26 \% \\
\end{array}$ & 0.109 & - & - & - & - \\
\hline \multicolumn{8}{|c|}{ Tipo de verbo } \\
\hline Intransitivo & $\begin{array}{r}2 / 6 \\
33 \% \\
\end{array}$ & $\begin{array}{l}8 / 11 \\
73 \% \\
\end{array}$ & 0.843 & $\begin{array}{l}6 / 8 \\
75 \% \\
\end{array}$ & 0.886 & $\begin{array}{c}\text { sem } \\
\text { dados }\end{array}$ & - \\
\hline Inacusativo & $\begin{array}{c}\text { sem } \\
\text { dados }\end{array}$ & $\begin{array}{l}9 / 10 \\
90 \% \\
\end{array}$ & 0.703 & \multicolumn{2}{|c|}{$\begin{array}{c}\text { sem } \\
\text { dados }\end{array}$} & $\begin{array}{l}3 / 9 \\
33 \% \\
\end{array}$ & 0.832 \\
\hline Cópula & $\begin{array}{r}4 / 9 \\
44 \% \\
\end{array}$ & $\begin{array}{c}38 / 57 \\
67 \% \\
\end{array}$ & 0.556 & $\begin{array}{l}6 / 16 \\
38 \% \\
\end{array}$ & 0.608 & $\begin{array}{l}4 / 32 \\
13 \% \\
\end{array}$ & 0.695 \\
\hline Transitivo direto & $\begin{array}{c}16 / 41 \\
39 \% \\
\end{array}$ & $\begin{array}{c}67 / 140 \\
48 \% \\
\end{array}$ & 0.474 & $\begin{array}{l}6 / 36 \\
17 \% \\
\end{array}$ & 0.341 & $\begin{array}{c}4 / 93 \\
4 \% \\
\end{array}$ & 0.388 \\
\hline Transitivo indireto & $\begin{array}{l}3 / 7 \\
43 \% \\
\end{array}$ & $\begin{array}{l}9 / 16 \\
56 \% \\
\end{array}$ & 0.273 & $\begin{array}{l}2 / 7 \\
29 \% \\
\end{array}$ & 0.509 & $\begin{array}{l}1 / 5 \\
20 \% \\
\end{array}$ & 0.582 \\
\hline \multicolumn{8}{|c|}{ Definitude do SUJ } \\
\hline [+genérico] & $\begin{array}{c}\text { sem } \\
\text { dados }\end{array}$ & $\begin{array}{c}11 / 12 \\
92 \% \\
\end{array}$ & - & - & - & $\begin{array}{l}2 / 3 \\
67 \% \\
\end{array}$ & 0.958 \\
\hline$[+$ def, + esp $]$ & $\begin{array}{c}21 / 59 \\
36 \% \\
\end{array}$ & $\begin{array}{c}119 / 236 \\
50 \% \\
\end{array}$ & - & - & - & $\begin{array}{c}9 / 144 \\
6 \% \\
\end{array}$ & 0.484 \\
\hline [-def, +esp] & $\begin{array}{l}2 / 3 \\
67 \% \\
\end{array}$ & $\begin{array}{c}\text { sem } \\
\text { dados }\end{array}$ & - & - & - & - & - \\
\hline [-def, -esp] & $\begin{array}{l}2 / 3 \\
67 \% \\
\end{array}$ & $\begin{array}{c}\text { sem } \\
\text { dados }\end{array}$ & - & - & - & - & - \\
\hline \multirow{3}{*}{$\begin{array}{c}\text { Rodadas } \\
\text { significativas } \\
\text { n/a }\end{array}$} & & \multicolumn{2}{|c|}{ Input: 0.572} & Input: 0 . & 279 & \multicolumn{2}{|c|}{ Input: 0.061} \\
\hline & $\begin{array}{r}\text { Log lil } \\
-1 \\
\end{array}$ & $\begin{array}{l}\text { lihood }= \\
.558\end{array}$ & $\begin{array}{r}\text { Log lik } \\
-3 \\
\end{array}$ & $\begin{array}{l}\text { lihood }= \\
.778\end{array}$ & $\begin{array}{r}\text { Log li } \\
-\end{array}$ & $\begin{array}{l}\text { lihood }= \\
1.164\end{array}$ & - \\
\hline & Signi & $\begin{array}{l}\text { cance }= \\
16\end{array}$ & $\begin{array}{r}\text { Signi } \\
0 \\
\end{array}$ & $\begin{array}{l}\text { cance }= \\
13\end{array}$ & Sign & $\begin{array}{l}\text { icance }= \\
050\end{array}$ & - \\
\hline
\end{tabular}

A amostra carioca apresentou índices muito baixos de sujeito nulo nas cartas do período 4, o que pode indicar uma implementação da mudança mais forte do que ocorre nas cartas de Santa Catarina. De fato, podemos associar isso ao fato de as cartas pessoais do Rio de Janeiro terem sido escritas, em sua maioria, entre membros da mesma família: marido e mulher, filhos e pais, irmãos etc. Isso sugere um grau de intimidade maior entre os missivistas, o que pode significar uma amostra que permite que marcas da gramática brasileira apareçam na escrita. 


\subsection{3 $\bigcirc$ objeto direto anafórico}

\subsubsection{Caracterização do fenômeno e hipótese}

Passemos agora à descrição do terceiro fenômeno sintático a ser estudado neste capítulo: o objeto direto anafórico. Diversos autores que analisaram dados do português brasileiro atestam uma mesma tendência relacionada à variação desse fenômeno (cf. OMENA, 1978; DUARTE, 1986, 1989; CYRINO, 1994, 1997; MARAFONI, 2004; FREIRE, 2005; COSTA, 2011; VIEIRA-PINTO, 2015; MARQUES DE SOUSA, 2017; entre outros). Esses estudos mostram que, até o século XVIII, há uma grande preferência pelo uso do pronome clítico, quase sem restrições linguísticas. Com o passar do tempo, essa variante vai dividindo seu espaço com o objeto nulo até que, ao final do século XX, os percentuais se invertem e as análises sincrônicas do PB apontam para uma alta frequência de objeto nulo, o uso de pronome reto na função acusativa e a quase extinção do clítico de terceira pessoa na fala.

O trabalho de Cyrino $(1994,1997)$ ilustra muito bem essa mudança. A autora analisa textos brasileiros dos séculos XVI ao XX e atesta que, na primeira sincronia, o percentual de objeto preenchido, que era de $89,3 \%$, cai para $20,9 \%$ na última. Enquanto isso, a ocorrência de objeto nulo vai crescendo no decorrer dos tempos: o percentual que era de $10,7 \%$ no século XVI passa a 79,1\% no século XX. Esse aumento expressivo de objeto nulo se dá a partir do século XIX, período em que se verificam evidências claras de uma "gramática brasileira" propriamente dita, que se diferencia da gramática portuguesa predominante até então (TARALLO, 1993).

Cyrino também verifica que forças linguísticas passam a condicionar a variação do objeto direto anafórico, principalmente aquelas relacionadas aos traços semânticos do referente. A categoria nula com referente [+específico] começa a surgir com frequência no século XIX e esse aumento se dá em contextos de objeto nulo com antecedente [-animado] (49,3\% no século XIX e 86,5\% no XX). A frequência de objeto nulo com referente [-específico] é bem alta somente no século XX e, combinado com o traço [-animado], o percentual de objeto nulo chega aos 93,1\%. Os referentes [+animado] e [+específico] se mantêm estáveis em todos os períodos, favorecendo fortemente o uso de pronome clítico.

A hierarquia da referencialidade, proposta por Cyrino, Duarte e Kato (2000), leva em conta essa combinação de traços semânticos em 
um continuum e propõe que tanto sujeitos como objetos sejam mais preenchidos quanto mais referenciais eles forem. Assim, a tendência é a de que referentes com traços [-animado] e [-específico] influenciem o uso de objeto nulo. Em contrapartida, referentes com traços [+animado] e [+específico] condicionam o pronome clítico.

A transitividade verbal e estrutura projetada pelo verbo é também uma importante variável estudada em alguns trabalhos sobre o objeto direto, que identificaram as estruturas simples de um ou de dois complementos como condicionadoras do objeto nulo. Já as estruturas complexas influenciam o uso de objeto preenchido (cf. DUARTE, 1986, 1989; MARAFONI, 2004; VIEIRA-PINTO, 2015; MARQUES DE SOUSA, 2017). Duarte $(1986,1989)$ atesta, na fala de informantes de São Paulo, que, quando a estrutura é simples, seja de um complemento $(76,2 \%)$ ou de dois (93\%), o uso de objeto nulo supera o preenchimento tanto pelo clítico quanto pelo pronome reto. Já quando a estrutura é complexa, o quadro é diferente: na estrutura com predicativo, o maior percentual ainda é de nulo $(52,9 \%)$, mas percebe-se que o preenchimento também tem peso, principalmente com a variante pronome reto $(40,4 \%)$; nas estruturas com complementos sentenciais, o objeto nulo perde força e o preenchimento é o mais frequente (com $23,8 \%$ de clítico e $42,9 \%$ de pronome reto nas estruturas bitransitivas com complemento relativo oracional e $77,4 \%$ de pronome reto nas estruturas completivas reduzidas).

Coelho e Vieira-Pinto (2018) verificam a mesma tendência nas cartas catarinenses dos séculos XIX e XX e, além disso, percebem que sentenças simples com verbos bitransitivos que apresentam um complemento circunstancial se comportam de maneira parecida com as sentenças complexas, condicionando o uso de objeto preenchido em vez de objeto nulo. Nossa hipótese, portanto, é a de que objetos nulos sejam frequentes em estruturas simples e objetos preenchidos sejam favorecidos por estruturas complexas e por sentenças bitransitivas com complemento circunstancial.

A variável 'construção sintática' foi estudada em trabalhos como os de Costa (2011) e de Marques de Sousa (2017), que compararam dados de peças teatrais brasileiras e portuguesas, e em que foram identificadas as orações coordenadas, absolutas e principais como condicionadoras do uso de objeto nulo e as orações subordinadas como influenciadoras do 
preenchimento do objeto. Nos resultados de Costa relacionados ao PE, as orações absolutas e principais tiveram 0.55 de peso relativo, enquanto as substantivas apresentaram mais resistência para a ocorrência de nulo, com 0.26. As coordenadas e as adverbiais também são contextos de restrição, com 0.38 e 0.31 de peso relativo, respectivamente. Nossa hipótese, então, é a de que haja mais objetos nulos quando a oração for absoluta ou coordenada e mais objetos preenchidos quando a oração for subordinada.

Levando em conta essa breve caracterização, nossa expectativa neste capítulo é a de que atestaremos, nas cartas pessoais cariocas e catarinenses dos séculos XIX e XX, a trajetória de mudança de um sistema muito produtivo de pronomes clíticos para um sistema em variação em que duas formas (ou mais, se houver dados de pronome reto) são utilizadas para a função de objeto direto anafórico. Temos por hipótese que o objeto nulo será condicionado pelos traços [-animado] e [-específico] do referente e ocorrerá com mais frequência em estruturas simples e em sentenças que sejam absolutas ou coordenadas.

\subsubsection{Resultados e discussão}

Apresentamos a seguir os resultados estatísticos da ocorrência de objeto direto anafórico nas amostras de cartas catarinenses e cariocas.

No total, a amostra catarinense apresentou 218 dados, em que 140 (64\%) eram pronome clítico e 78 (36\%) eram objeto nulo. Na amostra carioca, o total também foi de 218 dados, dos quais 139 (64\%) eram pronome clítico, 73 (33\%) objeto nulo e ainda seis dados (3\%) pronome reto na função acusativa. Sobre os dados de pronome reto na função acusativa, podemos observar a implementação na escrita missivista carioca de formas frequentes na fala, principalmente em contextos de predicados complexos, como construções com verbos causativos ("mandou ele fazer") ou perceptivos ("viu ele sair").

Os resultados separados por período de tempo estão expostos na Tabela 6.15 a seguir. 
Tabela 6.15 - Ocorrência das variantes do objeto direto anafórico, por amostra e por período

\begin{tabular}{c|c|c|c|c|c}
\hline \multirow{2}{*}{$\begin{array}{c}\text { Objeto direto } \\
\text { anafórico }\end{array}$} & $\begin{array}{c}\text { Período 1 } \\
1870-1895\end{array}$ & $\begin{array}{c}\text { Período 2 } \\
1905-1935\end{array}$ & $\begin{array}{c}\text { Período 3 } \\
1955-1975\end{array}$ & $\begin{array}{c}\text { Período 4 } \\
1980-1995\end{array}$ \\
\cline { 3 - 6 } \multicolumn{2}{c}{} & $\begin{array}{c}\text { Apl./Total } \\
\%\end{array}$ & $\begin{array}{c}\text { Apl./Total } \\
\%\end{array}$ & $\begin{array}{c}\text { Apl./Total } \\
\%\end{array}$ & $\begin{array}{c}\text { Apl./Total } \\
\%\end{array}$ \\
\hline \multirow{4}{*}{ Amostra } & Pronome & $52 / 71$ & $23 / 26$ & $18 / 42$ & $47 / 79$ \\
catarinense & clítico & $73 \%$ & $88 \%$ & $43 \%$ & $59 \%$ \\
\cline { 2 - 6 } & Objeto & $19 / 71$ & $3 / 26$ & $24 / 42$ & $32 / 79$ \\
& nulo & $27 \%$ & $12 \%$ & $57 \%$ & $41 \%$ \\
\hline \multirow{4}{*}{ Amostra } & Pronome & $33 / 57$ & $42 / 58$ & $38 / 52$ & $26 / 51$ \\
& clítico & $58 \%$ & $72 \%$ & $73 \%$ & $51 \%$ \\
\cline { 2 - 6 } & Pronome & $1 / 57$ & $1 / 58$ & $1 / 52$ & $3 / 51$ \\
& reto & $2 \%$ & $2 \%$ & $2 \%$ & $6 \%$ \\
\cline { 2 - 6 } & Objeto & $23 / 57$ & $15 / 58$ & $13 / 52$ & $22 / 51$ \\
& nulo & $40 \%$ & $26 \%$ & $25 \%$ & $43 \%$ \\
\hline
\end{tabular}

Em relação aos períodos de tempo, na amostra catarinense percebemos uma frequência maior do pronome clítico nas duas primeiras sincronias, enquanto há variação com o objeto nulo nas duas últimas, conforme esperávamos.

Com respeito à amostra carioca, os resultados do período 1 surpreendem. Os índices baixos de clíticos e os índices altos de objetos nulos - comparáveis aos do período 4 - podem estar relacionados a alguma particularidade das cartas (talvez à escolaridade, ou à idade dos missivistas). Nos períodos 2 e 3 , há um uso maior de pronome clítico em relação ao objeto nulo.

Sobre o pronome reto na função acusativa, os contextos em que esses dados ocorreram na amostra carioca eram estruturas complexas, com verbos causativos, em que há marcação excepcional de caso acusativo. Além disso, o referente era [+animado], como no exemplo:

(25) [20,1 CP RJ] Octavio tirou 400\$ em Dezembro no Oliveira Valle pa mim. Ja mandei elle pagar a sua conta no Ramires. (Período 2) 
Quando agrupamos todos os períodos em uma mesma rodada, os resultados das amostras catarinense e carioca são muito parecidos, conforme a tabela que vem em seguida. Nas duas amostras, foram apenas duas as variáveis selecionadas pelo programa estatístico como condicionadoras do objeto nulo: a 'animacidade do referente' e o 'período de tempo'.

Tabela 6.16 - Ocorrência de objeto nulo, segundo os grupos de fatores investigados nas amostras catarinense e carioca

\begin{tabular}{|c|c|c|c|c|}
\hline \multirow{2}{*}{$\begin{array}{c}\text { Variáveis } \\
\text { independentes }\end{array}$} & \multicolumn{2}{|c|}{ Amostra catarinense } & \multicolumn{2}{|c|}{ Amostra carioca } \\
\hline & $\begin{array}{c}\text { Apl./Total } \\
\% \\
\end{array}$ & PR & $\begin{array}{c}\text { Apl./Total } \\
\% \\
\end{array}$ & PR \\
\hline \multicolumn{5}{|c|}{ Transitividade verbal e estrutura projetada pelo verbo } \\
\hline Estruturas simples & $\begin{array}{c}70 / 188 \\
37,2 \% \\
\end{array}$ & - & $\begin{array}{c}63 / 174 \\
36,2 \% \\
\end{array}$ & - \\
\hline $\begin{array}{l}\text { Estruturas } \\
\text { complexas }\end{array}$ & $\begin{array}{c}8 / 30 \\
26,7 \% \\
\end{array}$ & - & $\begin{array}{l}10 / 44 \\
22,7 \%\end{array}$ & - \\
\hline \multicolumn{5}{|c|}{ Construção sintática } \\
\hline $\begin{array}{c}\text { Coordenadas, } \\
\text { absolutas e principais }\end{array}$ & $\begin{array}{l}36 / 94 \\
38,3 \% \\
\end{array}$ & - & $\begin{array}{l}36 / 107 \\
33,6 \% \\
\end{array}$ & - \\
\hline Subordinadas & $\begin{array}{l}42 / 124 \\
33,9 \% \\
\end{array}$ & - & $\begin{array}{l}37 / 111 \\
33,3 \% \\
\end{array}$ & - \\
\hline \multicolumn{5}{|c|}{ Animacidade do referente } \\
\hline Inanimado & $\begin{array}{c}73 / 161 \\
45,3 \% \\
\end{array}$ & 0.61 & $\begin{array}{l}65 / 135 \\
48,1 \% \\
\end{array}$ & 0.70 \\
\hline Humano/animado & $\begin{array}{l}5 / 57 \\
8,8 \% \\
\end{array}$ & 0.20 & $\begin{array}{l}8 / 83 \\
9,6 \% \\
\end{array}$ & 0.19 \\
\hline \multicolumn{5}{|c|}{ Especificidade do referente } \\
\hline [-específico] & $\begin{array}{l}18 / 38 \\
47,4 \% \\
\end{array}$ & - & $\begin{array}{l}29 / 59 \\
49,2 \% \\
\end{array}$ & - \\
\hline [+específico] & $\begin{array}{l}60 / 180 \\
33,3 \% \\
\end{array}$ & - & $\begin{array}{l}44 / 159 \\
27,7 \% \\
\end{array}$ & - \\
\hline \multicolumn{5}{|c|}{ Período de escrita } \\
\hline Período 1 & $\begin{array}{l}19 / 71 \\
26,8 \%\end{array}$ & 0.42 & $\begin{array}{l}23 / 57 \\
40,4 \% \\
\end{array}$ & 0.52 \\
\hline
\end{tabular}




\begin{tabular}{c|c|c|c|c}
\hline Período 2 & $\begin{array}{c}3 / 26 \\
11,5 \%\end{array}$ & 0.27 & $\begin{array}{c}15 / 58 \\
25,9 \%\end{array}$ & 0.44 \\
\hline Período 3 & $\begin{array}{c}24 / 42 \\
57,1 \%\end{array}$ & 0.65 & $\begin{array}{c}13 / 52 \\
25 \%\end{array}$ & 0.36 \\
\hline Período 4 & $\begin{array}{c}32 / 79 \\
40,5 \%\end{array}$ & 0.56 & $\begin{array}{c}22 / 51 \\
43,1 \%\end{array}$ & 0.66 \\
\hline \multirow{2}{*}{ Rodadas significativas } & \multicolumn{2}{|c|}{$\begin{array}{c}\text { Input: } 0.313 \\
\text { Log likelihood }=-123.635 \\
\text { Significance }=0.041\end{array}$} & $\begin{array}{c}\text { Input: } 0.282 \\
\text { Log likelihood }=-115.780 \\
\text { Significance }=0.047\end{array}$ \\
\hline
\end{tabular}

Em relação à animacidade, conforme nossa hipótese, os referentes [-animado] são os grandes condicionadores do objeto nulo, com 0.61 de peso relativo na amostra catarinense e 0.70 na amostra carioca.

Sobre o período de tempo, também atestamos nossa expectativa. $\mathrm{Na}$ amostra catarinense, o objeto nulo é mais frequente nos períodos 3 e 4 , com 0.65 e 0.56 de peso relativo, respectivamente. Na amostra carioca, nossa hipótese foi igualmente atestada, porém apenas em relação ao período 4 , que teve 0.66 de peso relativo para o objeto nulo. Não esperávamos uma frequência tão alta dessa variante no período 1 , que apresentou 0.52 de peso relativo. As amostras de cartas desse período merecem uma atenção especial, pois são cartas escritas por casais ilustres: os homens foram pessoas influentes na sociedade carioca (senador do Império e da República, médico sanitarista, engenheiro civil) e suas esposas eram senhoras da sociedade carioca, que receberam ensino domiciliar, e figuravam como protagonistas no âmbito familiar, diferentemente de seus maridos. Esse fato indica uma diferença entre os missivistas, tendo em vista seus papéis sociais no final do século XIX: os homens "ilustres" atuantes na sociedade e as mulheres "anônimas" restritas ao ambiente doméstico. Outros trabalhos com a mesma amostra sobre fenômenos linguísticos distintos mostram um comportamento linguístico diferente entre os homens e as mulheres desse período, como se vê em Pagotto e Duarte (2005) e em Cavalcante (2014). As mulheres apresentam comportamento linguístico muito mais próximo do PB do final do século XX do que os homens.

Focando apenas na amostra catarinense e separando os períodos, vemos os resultados em relação às variáveis independentes mais de perto. 
Tabela 6.17 - Ocorrência de objeto nulo, segundo os grupos de fatores investigados na amostra catarinense

\begin{tabular}{|c|c|c|c|c|c|c|c|c|}
\hline \multirow{2}{*}{$\begin{array}{c}\text { Variáveis } \\
\text { independentes }\end{array}$} & \multicolumn{2}{|c|}{$\begin{array}{c}\text { Período } 1 \\
1870-1895\end{array}$} & \multicolumn{2}{|c|}{$\begin{array}{l}\text { Período } 2 \\
1905-1935\end{array}$} & \multicolumn{2}{|c|}{$\begin{array}{l}\text { Período } 3 \\
1955-1975\end{array}$} & \multicolumn{2}{|c|}{$\begin{array}{l}\text { Período } 4 \\
1980-1995\end{array}$} \\
\hline & $\begin{array}{c}\text { Apl./Total } \\
\%\end{array}$ & PR & $\begin{array}{c}\text { Apl./Total } \\
\%\end{array}$ & PR & $\begin{array}{c}\text { Apl./Total } \\
\%\end{array}$ & PR & $\begin{array}{c}\text { Apl./Total } \\
\%\end{array}$ & PR \\
\hline
\end{tabular}

Transitividade verbal e estrutura projetada pelo verbo

\begin{tabular}{|c|c|c|c|c|c|c|c|c|}
\hline $\begin{array}{c}\text { Estruturas } \\
\text { simples }\end{array}$ & $\begin{array}{l}17 / 60 \\
28,3 \% \\
\end{array}$ & & $\begin{array}{l}2 / 22 \\
9,1 \% \\
\end{array}$ & - & $\begin{array}{l}22 / 39 \\
56,4 \% \\
\end{array}$ & - & $\begin{array}{l}29 / 67 \\
43,3 \% \\
\end{array}$ & - \\
\hline $\begin{array}{l}\text { Estruturas } \\
\text { complexas }\end{array}$ & $\begin{array}{c}2 / 11 \\
18,2 \% \\
\end{array}$ & - & $\begin{array}{c}1 / 4 \\
25 \% \\
\end{array}$ & - & $\begin{array}{c}2 / 3 \\
66,7 \% \\
\end{array}$ & - & $\begin{array}{l}3 / 12 \\
25 \% \\
\end{array}$ & - \\
\hline \multicolumn{9}{|c|}{ Construção sintática } \\
\hline $\begin{array}{c}\text { Coordenadas, } \\
\text { absolutas e } \\
\text { principais }\end{array}$ & $\begin{array}{c}6 / 33 \\
18,2 \%\end{array}$ & - & $\begin{array}{c}2 / 13 \\
15.4 \%\end{array}$ & - & $\begin{array}{l}7 / 14 \\
50 \%\end{array}$ & - & $\begin{array}{l}21 / 34 \\
61,8 \%\end{array}$ & 0.76 \\
\hline Subordinadas & $\begin{array}{l}13 / 38 \\
34,2 \% \\
\end{array}$ & - & $\begin{array}{l}1 / 13 \\
7,7 \% \\
\end{array}$ & - & $\begin{array}{l}17 / 28 \\
60,7 \% \\
\end{array}$ & - & $\begin{array}{l}11 / 45 \\
24,4 \% \\
\end{array}$ & 0.29 \\
\hline \multicolumn{9}{|c|}{ Animacidade do referente } \\
\hline Inanimado & $\begin{array}{l}16 / 48 \\
33,3 \%\end{array}$ & - & $\begin{array}{c}2 / 11 \\
18,2 \%\end{array}$ & - & $\begin{array}{l}24 / 41 \\
58,5 \%\end{array}$ & - & $\begin{array}{l}31 / 61 \\
50,8 \%\end{array}$ & 0.68 \\
\hline $\begin{array}{l}\text { Humano/ } \\
\text { animado }\end{array}$ & $\begin{array}{l}3 / 23 \\
13 \%\end{array}$ & - & $\begin{array}{l}1 / 15 \\
6,7 \%\end{array}$ & - & $\begin{array}{l}0 / 1 \\
0 \%\end{array}$ & - & $\begin{array}{l}1 / 18 \\
5,6 \%\end{array}$ & 0.06 \\
\hline
\end{tabular}

Especificidade do referente

\begin{tabular}{|c|c|c|c|c|c|c|c|c|}
\hline [-específico] & $\begin{array}{c}5 / 11 \\
45,5 \%\end{array}$ & - & $\begin{array}{l}0 / 1 \\
0 \%\end{array}$ & - & $\begin{array}{l}4 / 10 \\
40 \%\end{array}$ & - & $9 / 1656,2 \%$ & - \\
\hline [+específico] & $\begin{array}{l}14 / 60 \\
23,3 \%\end{array}$ & - & $\begin{array}{l}3 / 25 \\
12 \%\end{array}$ & - & $\begin{array}{l}20 / 32 \\
62,5 \%\end{array}$ & - & $\begin{array}{l}23 / 63 \\
36,5 \%\end{array}$ & - \\
\hline $\begin{array}{c}\text { Rodadas } \\
\text { significativas }\end{array}$ & $\mathrm{n} / \mathrm{a}$ & & $\mathrm{n} / \mathrm{a}$ & & $\mathrm{n} / \mathrm{a}$ & & \multicolumn{2}{|c|}{$\begin{array}{c}\text { Input: } 0.334 \\
\text { Log likelihood }= \\
-39.018 \\
\text { Significance = } \\
0.000\end{array}$} \\
\hline
\end{tabular}


No geral, a variável mais significativa para a ocorrência do objeto nulo foi a animacidade. Os referentes [-animado] influenciaram o uso de objeto nulo, atestando nossa hipótese. O período 4 foi o único em que essa variável foi selecionada pelo programa estatístico, com 0.68 de peso relativo para o objeto nulo quando o referente é [-animado], mas vemos que os percentuais nos outros períodos seguem a mesma tendência, conforme os exemplos.

(26) [20,2 CP SC] Perguntas a idade do Chico. Não sei Ø e não tive como descobrir $\varnothing$, mas acho que deve ter pouco mais de 40 . (Período 4)

(27) [20,2 CP SC] Desculpa me por não ter escrito antes a você por falta de ter esquecido a sua caixa postal na casa que aparava antes E não avia tempo para buscar $\varnothing$. (Período 3)

Outra variável selecionada pelo Goldvarb no período 4 foi a construção sintática. O objeto nulo é condicionado pelas orações coordenadas, absolutas e principais, com 0.76 de peso relativo, conforme havíamos previsto. Porém, essa mesma tendência não é atestada nos outros períodos catarinenses. Os exemplos do período 4 estão a seguir.

(28) [20,2 CP SC] Não gosto muito da pequena novela que escrevi em Ibiza, "Fábula da Vida Dupla”. Pretendo mexer nela. Um dia talvez mande $\varnothing$ para a senhora dar uma olhada. (Período 4)

(29) [20,2 CP SC] Ontem de noite, quando voltei do Museu, encontrei dois envelopes me esperando. Abri $\varnothing$ pelas datas dos carimbos: primeiro a de 27 de janeiro, com tua carta e a tradução para Jagot; segundo, carimbo 30.1.89, com o iceberg! (Período 4)

Passemos a observar os dados da amostra carioca, separando os períodos de tempo, conforme a Tabela 6.18. 
Tabela 6.18 - Ocorrência de objeto nulo, segundo os grupos de fatores investigados na amostra carioca

\begin{tabular}{|c|c|c|c|c|c|c|c|c|}
\hline \multirow{2}{*}{$\begin{array}{c}\text { Variáveis } \\
\text { independentes }\end{array}$} & \multicolumn{2}{|c|}{$\begin{array}{l}\text { Período } 1 \\
1870-1895 \\
\end{array}$} & \multicolumn{2}{|c|}{$\begin{array}{c}\text { Período } 2 \\
1905-1935 \\
\end{array}$} & \multicolumn{2}{|c|}{$\begin{array}{l}\text { Período } 3 \\
1955-1975 \\
\end{array}$} & \multicolumn{2}{|c|}{$\begin{array}{c}\text { Período } 4 \\
1980-1995 \\
\end{array}$} \\
\hline & $\begin{array}{c}\text { Apl./Total } \\
\%\end{array}$ & PR & $\begin{array}{c}\text { Apl./Total } \\
\%\end{array}$ & PR & \begin{tabular}{|c|} 
Apl./Total \\
$\%$
\end{tabular} & PR & $\begin{array}{c}\text { Apl./Total } \\
\%\end{array}$ & PR \\
\hline
\end{tabular}

Transitividade verbal e estrutura projetada pelo verbo

\begin{tabular}{|c|c|c|c|c|c|c|c|c|}
\hline $\begin{array}{c}\text { Estruturas } \\
\text { simples }\end{array}$ & $\begin{array}{l}20 / 44 \\
45,5 \%\end{array}$ & - & $\begin{array}{l}13 / 43 \\
30,2 \%\end{array}$ & - & $\begin{array}{l}12 / 43 \\
27,9 \%\end{array}$ & - & $\begin{array}{l}18 / 44 \\
40,9 \%\end{array}$ & - \\
\hline $\begin{array}{l}\text { Estruturas } \\
\text { complexas }\end{array}$ & $\begin{array}{c}3 / 13 \\
23,1 \%\end{array}$ & - & $\begin{array}{c}2 / 15 \\
13,3 \%\end{array}$ & - & $\begin{array}{c}1 / 9 \\
11,1 \%\end{array}$ & - & $\begin{array}{c}4 / 7 \\
57,1 \% \\
\end{array}$ & - \\
\hline \multicolumn{9}{|c|}{ Construção sintática } \\
\hline $\begin{array}{c}\text { Coordenadas, } \\
\text { absolutas e } \\
\text { principais }\end{array}$ & $\begin{array}{c}6 / 21 \\
28,6 \%\end{array}$ & - & $\begin{array}{c}7 / 30 \\
23,3 \%\end{array}$ & - & $\begin{array}{c}5 / 23 \\
21,7 \%\end{array}$ & - & $\begin{array}{l}18 / 33 \\
54,5 \%\end{array}$ & 0.65 \\
\hline Subordinadas & $\begin{array}{l}17 / 36 \\
47,2 \%\end{array}$ & - & $\begin{array}{c}8 / 28 \\
28,6 \%\end{array}$ & - & $\begin{array}{c}8 / 29 \\
27,6 \%\end{array}$ & - & $\begin{array}{c}4 / 18 \\
22,2 \%\end{array}$ & 0.23 \\
\hline \multicolumn{9}{|c|}{ Animacidade do referente } \\
\hline Inanimado & $\begin{array}{l}20 / 42 \\
47,6 \% \\
\end{array}$ & - & $\begin{array}{c}12 / 30 \\
40 \% \\
\end{array}$ & - & $\begin{array}{l}12 / 35 \\
34,3 \% \\
\end{array}$ & 0.66 & $\begin{array}{c}21 / 28 \\
75 \% \\
\end{array}$ & 0.87 \\
\hline $\begin{array}{l}\text { Humano/ } \\
\text { animado }\end{array}$ & $\begin{array}{l}3 / 15 \\
20 \%\end{array}$ & - & $\begin{array}{c}3 / 28 \\
10,7 \%\end{array}$ & - & $\begin{array}{l}1 / 17 \\
5,9 \%\end{array}$ & 0.19 & $\begin{array}{l}1 / 23 \\
4,3 \%\end{array}$ & 0.08 \\
\hline \multicolumn{9}{|c|}{ Especificidade do referente } \\
\hline [-específico] & $\begin{array}{c}6 / 17 \\
35,3 \%\end{array}$ & - & $\begin{array}{c}9 / 17 \\
52,9 \%\end{array}$ & 0.79 & $\begin{array}{l}2 / 10 \\
20 \%\end{array}$ & - & $\begin{array}{c}12 / 15 \\
80 \%\end{array}$ & - \\
\hline [+específico] & $\begin{array}{l}17 / 40 \\
42,5 \%\end{array}$ & - & $\begin{array}{c}6 / 41 \\
14,6 \%\end{array}$ & 0.36 & $\begin{array}{l}11 / 42 \\
26,2 \%\end{array}$ & - & $\begin{array}{l}10 / 36 \\
27,8 \%\end{array}$ & - \\
\hline $\begin{array}{c}\text { Rodadas } \\
\text { significativas }\end{array}$ & $\mathrm{n} / \mathrm{a}$ & & $\begin{array}{r}\text { Input: } \\
\text { Log likeli } \\
-28.8 \\
\text { Significa } \\
0.00\end{array}$ & $\begin{array}{l}229 \\
\text { ood }= \\
3 \\
\text { ce }=\end{array}$ & $\begin{array}{r}\text { Input: } 0 \\
\text { Log likelih } \\
-26.30 \\
\text { Significar } \\
0.016\end{array}$ & $\begin{array}{l}207 \\
\text { ood }= \\
5 \\
1 \mathrm{ce}=\end{array}$ & $\begin{array}{r}\text { Input: } \\
\text { Log likelil } \\
-17.6 \\
\text { Significa } \\
0.03\end{array}$ & $\begin{array}{l}299 \\
\text { ood }= \\
4 \\
c e=\end{array}$ \\
\hline
\end{tabular}


No geral, a animacidade foi a mais significativa em todos os períodos. Essa variável foi selecionada pelo programa estatístico como condicionadora do objeto nulo nos períodos 3 e 4: o referente [-animado] teve 0.66 e 0.87 de peso relativo, respectivamente. Nos períodos 1 e 2 , vemos que os percentuais também favorecem o referente [-animado]. Alguns exemplos vêm a seguir.

(30) [20,2 CP RJ] Está em minhas mãos a tua carta de 2 de Outubro Desculpa custar a responder $\varnothing$. (Período 3)

(31) [20,2 CP RJ] Mando aqui um retrato meu para voce queimar $\varnothing$, jogar $\varnothing$ fora, desenhar bigode, ..., e até guardar $\varnothing$. (Período 4)

Assim como na amostra catarinense, a variável 'construção sintática' foi selecionada na amostra carioca apenas no período 4. Atestando nossa hipótese, as orações coordenadas, absolutas e principais condicionam o objeto nulo, com 0.65 de peso relativo, conforme os exemplos.

(32) [20,2 CP RJ] Mano, há algum tempo eu soube que tu vinhas mandando para Bela um generoso auscílio financeiro. [...] Acontece porém, que por ela, pela Bela, tive conhecimento de que desde o mês e julho não recebe dito auscilio. Tu tens enviado $\varnothing$ ? (Período 4)

(33) [20,2 CP RJ] O Denis ligou novamente [...] isto é mau, porq. o telefonema aquí é caro e fica para o Denis pagar $\varnothing$. Eu não queria, mas ele insistiu, q. fazer! (Período 4)

Outra variável selecionada na amostra carioca (apenas no período 2) foi a especificidade do referente. Conforme tínhamos imaginado, os referentes [-específico] condicionam o objeto nulo, com 0.79 de peso relativo. Todavia, a mesma tendência só ocorre igualmente no período 4 e não nos períodos 1 e 3 . Alguns exemplos dessa ocorrência estão a seguir.

(34) [20,1 CP RJ] [...] estou ouvindo dizer que o Fernando foi ahi e quiz comprar a casa, mas não sei se estão em negocio, caso o João Ladeira não queira vender tudo, pode-se ver se elle vende um pedaço do terreno. Vossé querendo me favoreçer, compra $\varnothing$ para vossé e só será meu quando eu te pagar $\emptyset$; (Período 2) 
(35) [20,2 CP RJ] Ontem fiquei na clí- nica até às $15 \mathrm{hs,} \mathrm{ela} \mathrm{mandou}$ vir comida na clínica para mim, eu não queria $\emptyset$, mas qdo ela quer. Tem q. ser, por isso aceitei $\varnothing$. (Período 4)

\subsection{A trajetória de mudança dos fenômenos em correlação: generalizações}

Reunindo os resultados apresentados na Seção 6.3, vamos tentar responder às três questões postas na Introdução deste capítulo: (i) Como essas três mudanças estão encaixadas nas amostras catarinense e carioca ao longo do tempo? (ii) Quais as condições linguísticas necessárias que uma mudança cria para que outras mudanças se efetivem? (iii) Como as variantes novas se implementam na escrita catarinense e carioca ao longo do tempo?

Observamos, inicialmente, os resultados encontrados nas duas regiões investigadas, por período. Os gráficos expostos nas figuras 6.1 e 6.2, a seguir, sinalizam a seguinte trajetória de mudança na escrita catarinense e carioca.

Figura 6.1 - Trajetória de mudança na escrita catarinense

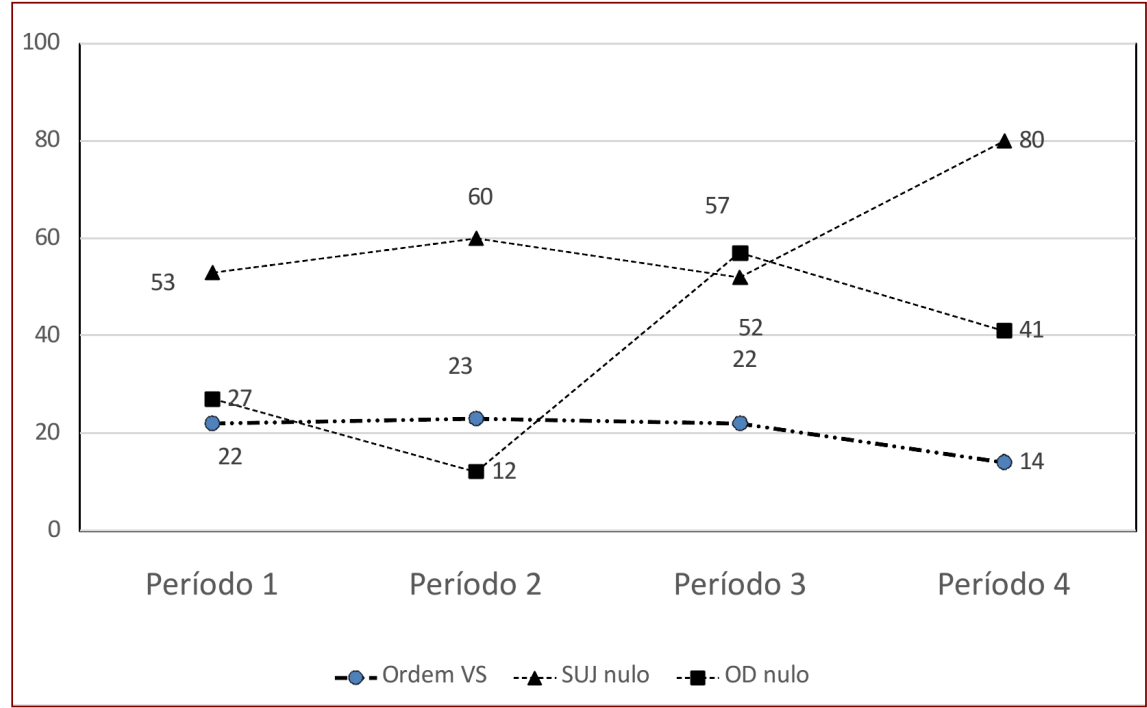


Figura 6.2 - Trajetória de mudança na escrita carioca

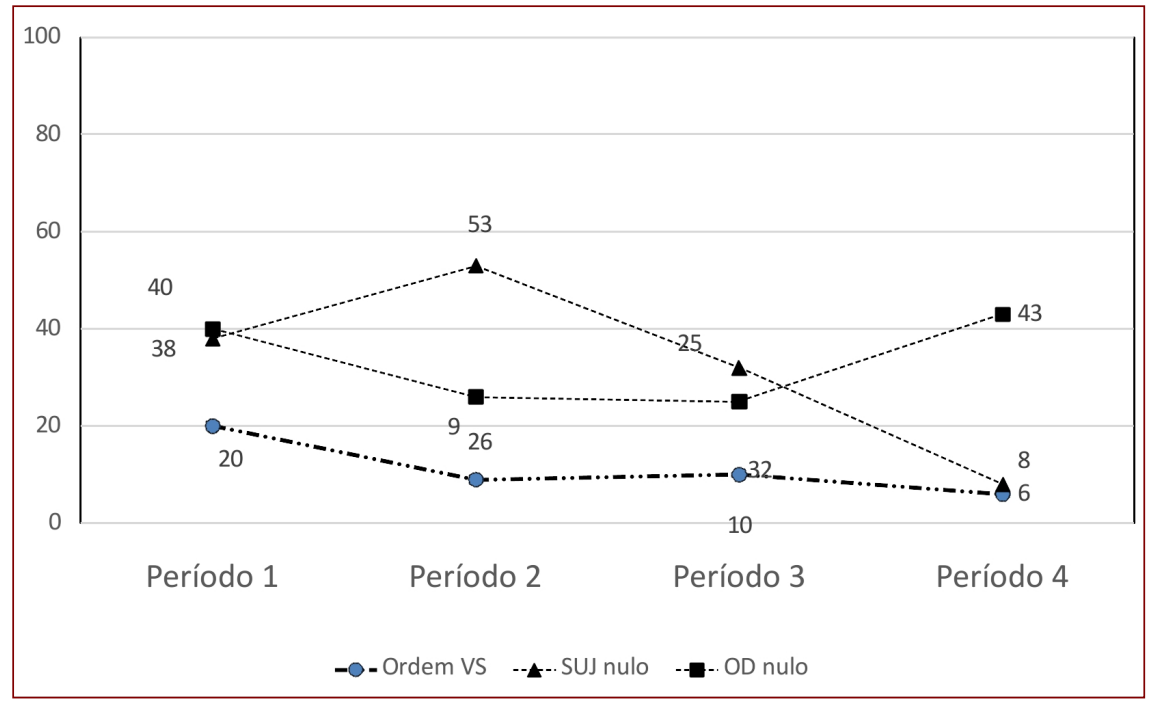

Quando comparamos cada um dos fenômenos na linha do tempo, notamos que (i) nas duas amostras a ordem VS cai do primeiro para o quarto período: de $22 \%>23 \%>22 \%>14 \%$ na amostra catarinense e de $20 \%>9 \%>10 \%>6 \%$ na amostra carioca; (ii) os índices de objeto nulo crescem no mesmo curso do tempo: de $27 \%>12 \%>57 \%>41 \%$ na amostra catarinense e de $40 \%>26>25 \%>43 \%$ na amostra carioca; (iii) os índices de mudança de sujeito nulo para sujeito pleno não seguem a mesma direção nas duas variedades aqui investigadas: nos quatro períodos, os índices de sujeito nulo são de $53 \%>60 \%>52 \%>80 \%$ na amostra catarinense e de $38 \%>53 \%>32 \%>8 \%$ na amostra carioca. Dos três fenômenos, portanto, a mudança de sujeito nulo para sujeito pleno é a menos implementada na escrita catarinense, que se mostra mais conservadora do que a escrita carioca.

Os índices da escrita carioca corroboram os resultados encontrados na década de 1980 por Tarallo e Kato (1989) e por Tarallo (1993), indicando que a queda acentuada da ordem VS para SV e do sujeito nulo do período 3 para o período 4 coincide com a expansão do objeto nulo. É como se, com a cristalização da ordem SVO, o português preferisse manter apenas uma posição nula, alternando substancialmente um sistema que preserva 
sujeitos pospostos ao verbo (VS) ou sujeitos nulos numa configuração ØVO para um sistema de sujeitos antepostos ao verbo numa configuração preferencialmente SVØ. Para entendermos melhor esses resultados nas duas amostras, observamos cada fenômeno isoladamente.

$\mathrm{Na}$ trajetória da ordem do sujeito, observa-se uma mudança de ordem variável (SV/VS) para uma ordem rígida SVO em contextos com verbos transitivos, como o gráfico da Figura 6.3 sinaliza. Essa mudança atinge igualmente as duas variedades estudadas.

Figura 6.3 - VS em contextos com verbos transitivos

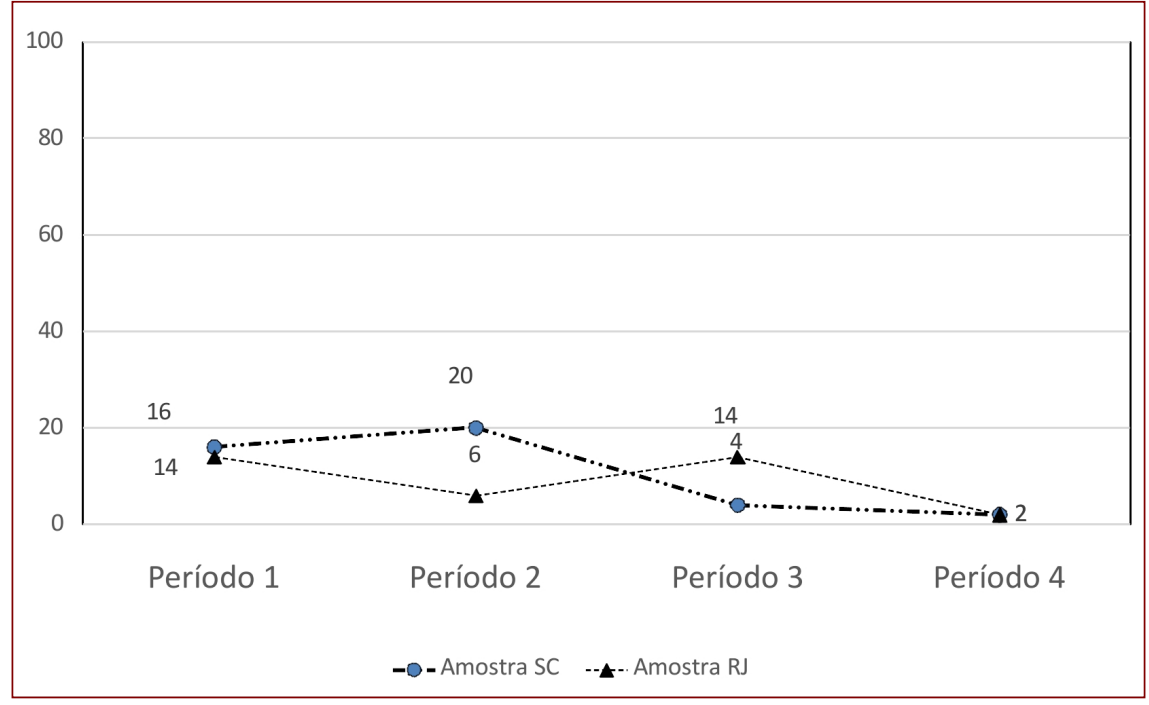

Quando se observam os contextos resistentes à mudança de sujeito nulo para sujeito pleno e de clítico para objeto direto nulo, os resultados das duas variedades não seguem a mesma direção. É especialmente em contextos em que o sujeito pronominal é inanimado que o sujeito nulo ainda resiste na variedade catarinense. Entretanto, na escrita carioca, a mudança de um sistema de sujeito pronominal nulo para um sistema de sujeito pleno atinge, inclusive, esse contexto de resistência, como a Figura 6.4 ilustra. 
Figura 6.4 - Sujeitos nulos em contextos de sujeitos pronominais inanimados nas amostras catarinense e carioca

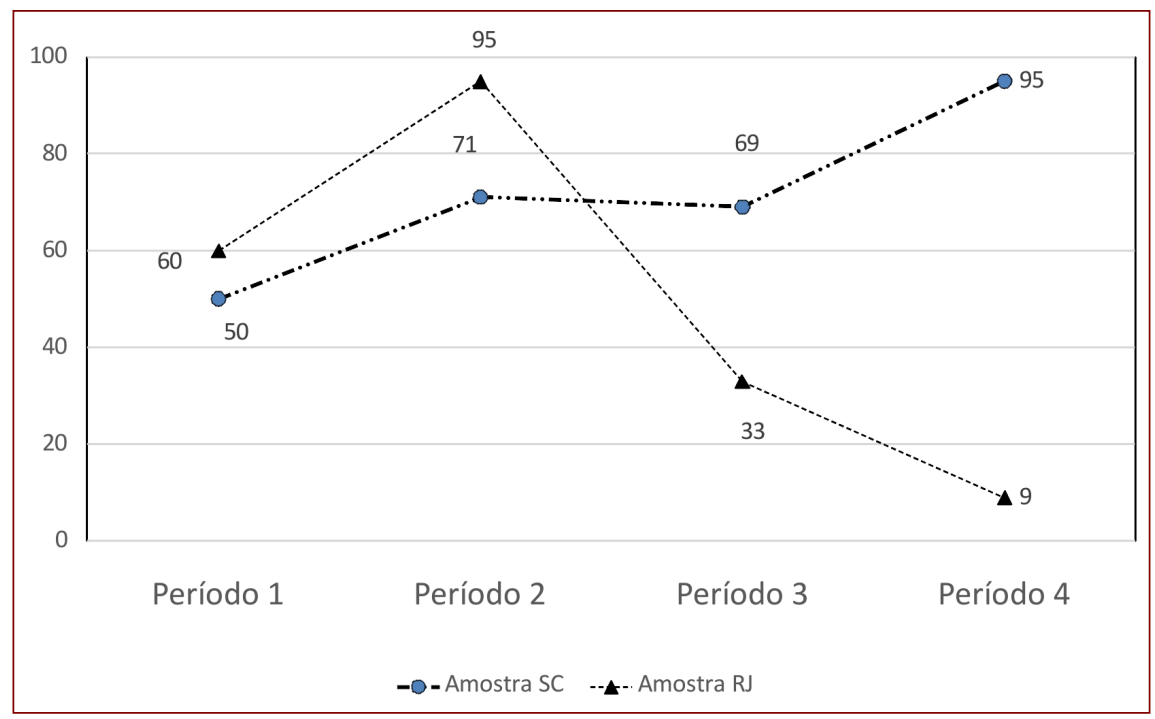

Quando observamos a atuação da variável 'animacidade do referente' sobre o objeto nulo, notamos que os primeiros contextos de queda dos clíticos - os referentes inanimados - são os mesmos que se apresentam favorecedores de objetos nulos nas duas amostras investigadas, como o gráfico da Figura 6.5 sinaliza. 
Figura 6.5 - Objetos nulos em contextos com referentes inanimados nas amostras catarinense e carioca

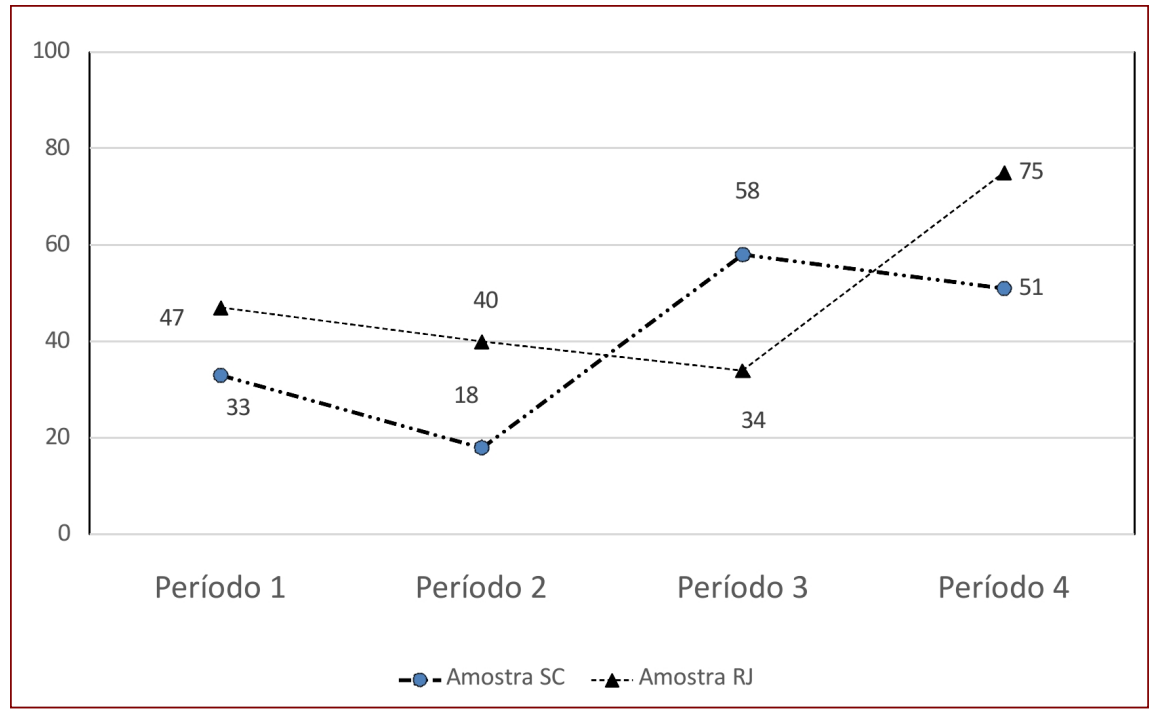

Como os resultados percentuais apontam, a implementação do objeto nulo nas amostras catarinense e carioca segue a mesma curva de mudança. Do terceiro para o quarto período, crescem os índices de objetos nulos quando os referentes são inanimados.

Finalmente, retomando os resultados dos gráficos expostos nas figuras 6.3, 6.4 e 6.5, podemos responder à nossa segunda questão: Quais as condições linguísticas necessárias que uma mudança cria para que outras mudanças se efetivem? Há condições linguísticas para que as três mudanças se implementem nas duas amostras investigadas: transitividade do verbo e traços de animacidade do DP (sujeito ou objeto). Se Tarallo (1993) estiver correto, a cristalização da ordem SVO em contextos com verbos transitivos é acompanhada de uma mudança em que o clítico não é mais produtivo e o sujeito passa a ser cada vez mais preenchido. Resta saber, então, por que o PB prefere uma língua de sujeito pronominal expresso a uma língua de objeto direto anafórico expresso. Nossa hipótese é a de que essa mudança possa estar atrelada ao enfraquecimento da concordância verbal. Com a subespecificação de traços de pessoa e número das formas verbais que acompanham os novos pronomes do $\mathrm{PB}$ você e a gente, como em 'você vai' e 
'a gente vai', o sujeito pronominal passa a ser predominantemente expresso e localizado à esquerda do verbo para não gerar ambiguidade (SVO). Essa exigência dá condições para que o objeto direto seja um argumento nulo.

Com respeito à nossa terceira questão, Como as variantes novas se implementam na escrita catarinense e carioca ao longo do tempo?, os resultados apresentados nos gráficos das figuras 6.1 e 6.2 mostram que nos três fenômenos investigados há mudança em curso na escrita carioca: de um sistema de ordem VS para SV, de sujeito nulo para sujeito pleno e de clítico para objeto nulo. Entretanto, a escrita catarinense é mais conservadora do que a escrita carioca, principalmente no que se refere à implementação do sujeito pronominal pleno. Precisamos entender o contexto social de Santa Catarina para explicar esse conservadorismo.

A região litorânea do estado catarinense preserva em grande medida o pronome $t u$, acompanhado de verbo com marca morfêmica distintiva de segunda pessoa, como em 'tu vais', 'tu foste/fosse'. Já o pronome você é pouco produtivo nessa região, estando atrelado em geral a contextos de impessoalidade e de formalidade, conforme apontam os trabalhos de Coelho e Görski (2011), Nunes de Souza e Coelho (2015), Nunes de Souza (2015), entre outros. A história social, geográfica e linguística do estado catarinense nos permite fazer uma associação entre aspectos da sócio-história catarinense e "etnia colonizadora", uma vez que (i) as cartas pessoais catarinenses aqui investigadas são escritas predominantemente por missivistas nascidos na Grande Florianópolis, região colonizada por açorianos em meados do século XVIII, os quais trouxeram na bagagem o sistema de tuteamento; (ii) a ilha de Santa Catarina ficou isolada do continente até as primeiras décadas do século XX, quando foi construída a primeira ponte que ligou a ilha ao continente.

\section{Referências}

BERLINCK, R. de A. A ordem V SN no português do Brasil: sincronia e diacronia. 1988. 265 f. Dissertação (Mestrado em Linguística) - Instituto de Estudos da Linguagem, Universidade Estadual de Campinas, Campinas, 1988.

BERLINCK, R. de A. A construção V SN no português do Brasil: uma visão diacrônica do fenômeno da ordem. In: TARALLO, F. (org.). Fotografias sociolinguísticas. Campinas: Pontes Editores, 1989. p. 95-112. 
BERLINCK, R. de A.; COELHO, I. L.; CYRINO, S.; DUARTE, M. E. L.; MARTINS, M. A. Mudança sintática e a história do português brasileiro nos séculos XIX e XX. In: DE SÁ JÚNIOR, L. A.; MARTINS, M. A. (org.). Rumos da linguística brasileira no século XXI: historiografia, gramática e ensino. São Paulo: Blucher, 2016. v. 1, p. 155-188.

CAVALCANTE, S. R. de O. Posição do sujeito e posição social: um caso de competição de gramáticas em cartas dos séculos XIX e XX. Filologia e Linguística Portuguesa, São Paulo, v. 16, n. 1, p. 147-170, 2014.

CAVALCANTE, S. R. de O. Mudança na posição do sujeito em cartas pessoais brasileiras: a ordem VS e o estatuto informacional do sujeito. Diadorim, Rio de Janeiro, v. 20, n. esp., p. 101-121, 2018.

CAVALCANTE, S. R. de O.; GALVES, C.; PAIXÃO DE SOUSA, M. C. Topics, Subjects and Grammatical Change: from Classical to Modern European Portuguese. LaborHistórico, Rio de Janeiro, v. 1, n. 2, p. 97-107, jul./dez. 2015. COELHO, I. L. A ordem V DP em construções monoargumentais: uma restrição sintático-semântica. 2000. 245 f. Tese (Doutorado em Linguística) - Programa de Pós-Graduação em Linguística, Universidade Federal de Santa Catarina, Florianópolis, 2000.

COELHO, I. L. Variação na sintaxe: estudo da ordem do sujeito no PB. In: RAMOS, J. M. (org.). Estudos sociolinguísticos: quatro vértices do GT da ANPOLL. Belo Horizonte: FALE: Editora da UFMG, 2006. p. 84-99.

COELHO, I. L.; GÖRSKI, E. M. A variação no uso dos pronomes tu e você em Santa Catarina. In: COUTO, L. R.; LOPES, C. R. dos S. (org.). As formas de tratamento em português e em espanhol: variação, mudança e funções conversacionais. Niterói: Editora da UFF, 2011. p. 263-287.

COELHO, I. L.; SILVA, G. M.; ZIBETTI, E. M. de O. Correlação entre ordem verbo-sujeito e sujeito nulo: a trajetória da mudança no português de Santa Catarina. In: FREITAG, R. K.; SEVERO, C. G.; GÖRSKI, E. M. (org.). Sociolinguística e política linguística: olhares contemporâneos. São Paulo: Blucher, 2016. v. 1, p. 35-57.

COELHO, I. L.; VIEIRA-PINTO, C. A.; ZIBETTI, E. M. de O.; SILVA, G. M. e. Ordem SV, sujeito expresso e objeto nulo: a trajetória da mudança no português de Santa Catarina. In: CONGRESSO INTERNACIONAL ALFAL, 18., 2017, Bogotá. Actas [...]. Bogotá: Universidade de Bogotá, 2017. v. 1. Disponível em: https://www.mundoalfal.org/es/pt_actas. Acesso em: 16 mar. 2021.

COELHO, I. L.; VIEIRA-PINTO, C. A. O encaixamento da mudança sintática em cartas pessoais de Santa Catarina: ordem do sujeito e objeto direto anafórico. 
Veredas - Revista de Estudos Linguísticos, Juiz de Fora, v. 22, n. 2, p. 114-133, 2018.

CONDE SILVESTRE, J. C. Sociolingüística histórica. Madrid: Gredos, 2007. COSTA, S. O (não) preenchimento do objeto anafórico na língua portuguesa: análise diacrônica do PB e do PE dos séculos XIX e XX. 2011. 268 f. Tese (Doutorado em Linguística) - Programa de Pós-Graduação em Linguística, Universidade Federal de Santa Catarina, Florianópolis, 2011.

CYRINO, S. M. L. O objeto nulo no português do Brasil: um estudo sintáticodiacrônico. 1994. 217 f. Tese (Doutorado em Linguística) - Instituto de Estudos da Linguagem, Universidade Estadual de Campinas, Campinas, 1994.

CYRINO, S. M. L. O objeto nulo no português do Brasil: um estudo sintáticodiacrônico. Londrina: Editora da UEL, 1997.

CYRINO, S. M. L.; DUARTE, M. E. L.; KATO, M. A. Visible subjects and invisible clitics in brasilian portuguese. In: KATO, M. A.; NEGRÃO, E. V. (ed.). Brazilian Portuguese and the Null Subject Parameter. Frankfurt am Main: Vervuert; Madrid: Iberoamericana, 2000. p. 55-73.

DUARTE, M. E. L. Variação e sintaxe: clítico acusativo, pronome lexical e categoria vazia no português do Brasil. 1986. 73 f. Dissertação (Mestrado em Linguística Aplicada e Estudos da Linguagem) - Pontifícia Universidade Católica de São Paulo, São Paulo, 1986.

DUARTE, M. E. L. Clítico acusativo, pronome lexical e categoria vazia no português do Brasil. In: TARALLO, F. (org.). Fotografias sociolinguísticas. Campinas: Pontes Editores, 1989. p. 19-34.

DUARTE, M. E. L. A evolução na representação do sujeito pronominal em dois tempos. In: PAIVA, M. da C.; DUARTE, M. E. L. (org.). Mudança linguística em tempo real. Rio de Janeiro: Contra Capa: FAPERJ, 2003. p. 115-128.

DUARTE, M. E. L.; SOARES DA SILVA, H. Microparametric variation in Spanish and Portuguese: the null subject parameter and the role of the verb inflectional paradigm. In: KATO, M. A.; ORDOÑEZ, F. (org.). The morphosyntax of Portuguese and Spanish in Latin America. New York: Oxford University Press, 2016. v. 1, p. 1-26.

FIGUEIREDO SILVA, M. C. A posição sujeito no português brasileiro: frases finitas e infinitivas. Campinas: Editora da UNICAMP, 1996.

FREIRE, G. C. A realização do acusativo e do dativo anafóricos de terceira pessoa na escrita brasileira e lusitana. 2005. $204 \mathrm{f}$. Tese (Doutorado em Letras Vernáculas) - Faculdade de Letras, Universidade Federal do Rio de Janeiro, Rio de Janeiro, 2005. 
GRAVINA, A. P. Sujeito Nulo e a Ordem VS no Português Brasileiro: um estudo diacrônico-comparativo baseado em corpus. 2014. $251 \mathrm{f}$. Tese (Doutorado em Linguística) - Instituto de Estudos da Linguagem, Universidade Estadual de Campinas, Campinas, 2014.

KATO, M. A.; TARALLO, F. Restrictive VS syntax in Brazilian Portuguese: its correlation with invisible clitics and visible subjects. In: GEORGETOWN ROUND TABLE IN LANGUAGES AND LINGUISTICS, Georgetown, 1988. Trabalho apresentado.

KATO, M. A.; DUARTE, M. E. L.; CYRINO, S. M. L.; BERLINCK, R. de A. Português brasileiro no fim do século XIX e na virada do milênio. In: CARDOSO, S. A. M.; MOTA, J. A.; MATTOS E SILVA, R. V. (org.). Quinhentos anos de história linguística do Brasil. Salvador: Secretaria da Cultura e Turismo do Estado da Bahia, 2006. p. 413-438.

LIRA, S. de A. Subject postposition in Portuguese. DELTA, São Paulo, v. 2, n. 1, p. 17-36, 1986.

MARAFONI, R. L. A realização do objeto direto anafórico: um estudo em tempo real de curta duração. 2004. 112 f. Dissertação (Mestrado em Letras Vernáculas) - Faculdade de Letras, Universidade Federal do Rio de Janeiro, Rio de Janeiro, 2004.

MARQUES DE SOUSA, A. A. As realizações do acusativo anafórico no português europeu e brasileiro: um estudo diacrônico. 2017. 127 f. Dissertação (Mestrado em Letras Vernáculas) - Faculdade de Letras, Universidade Federal do Rio de Janeiro, Rio de Janeiro, 2017.

NUNES DE SOUZA, C. M. A alternância entre tu e você na correspondência de florianopolitanos ilustres no decorrer de um século. 2015. 210 f. Tese (Doutorado em Linguística) - Programa de Pós-Graduação em Linguística, Universidade Federal de Santa Catarina, Florianópolis, 2015.

NUNES DE SOUZA, C. M.; COELHO, I. L. Caminhos para a investigação da alternância de pronomens de segunda pessoa em Santa Catarina. Laborhistórico: História dos Pronomes de Tratamento no Português Brasileiro, Rio de Janeiro, v. 1, n. 1, p. 49-61, 2015.

OMENA, N. P. Pronome pessoal de terceira pessoa: suas formas variantes em função acusativa. 1978. 139 f. Dissertação (Mestrado em Língua Portuguesa) Pontifícia Universidade Católica do Rio de Janeiro, Rio de Janeiro, 1978.

PAGOTTO, E. G.; DUARTE, M. E. L. Gênero e norma: avós e netos, classes e clíticos no final do século XIX. In: LOPES, C. R. dos S. A norma brasileira em construção: fatos linguísticos em cartas pessoais do século 19. Rio de Janeiro: UFRJ, Pós-Graduação em Letras Vernáculas: FAPERJ, 2005. p. 67-81. 
PILATI, E. Aspectos sintáticos e semânticos da ordem verbo-sujeito no português. 2006. 242 f. Tese (Doutorado em Linguística) - Programa de Pós-Graduação em Linguística, Universidade de Brasília, Brasília, 2006.

PILATI, E. Sobre a ordem verbo-sujeito no português brasileiro: 30 anos em mirada crítica. Revista Linguística, Rio de Janeiro, v. 12, p. 183-205, 2017.

RIBEIRO, I. A sintaxe da ordem do português arcaico: o efeito V2. 1995. 286 f. Tese (Doutorado em Linguística) - Instituto de Estudos da Linguagem, Universidade Estadual de Campinas, Campinas, 1995.

RIBEIRO, I. Sobre a perda da inversão do sujeito no português brasileiro. In: MATTOS E SILVA, R. V. (org.). Para a história do português brasileiro. São Paulo: Humanitas, 2001. p. 91-126. v. II, tomo I - Primeiros estudos.

SANKOFF, D.; TAGLIAMONTE, S. A.; SMITH, E. Goldvarb X: a variable rule application for Macintosh and Windows, 2005. Disponível em: http://individual. utoronto.ca/tagliamonte/goldvarb.html. Acesso em: 16 ago. 2019.

SANTOS, D. de R. A ordem VS/SV com verbos inacusativos: um estudo diacrônico. 2008. 110 f. Dissertação (Mestrado em Letras Vernáculas) Faculdade de Letras, Universidade Federal do Rio de Janeiro, Rio de Janeiro, 2008.

SANTOS, D. de R.; SOARES DA SILVA, H. A ordem V-DP/DP-V com verbos inacusativos. In: DUARTE, M. E. L. (org.). O sujeito em peças de teatro (18331992): estudos diacrônicos. São Paulo: Parábola, 2012. p. 121-142.

SPANO, M. A ordem verbo-sujeito no português brasileiro e europeu: um estudo sincrônico da escrita padrão. 2008. 191 f. Tese (Doutorado em Letras Vernáculas) - Faculdade de Letras, Universidade Federal do Rio de Janeiro, Rio de Janeiro, 2008.

TARALLO, F. Diagnosticando uma gramática brasileira: o português d’aquém e d’além-mar ao final do século XIX. In: ROBERTS, I.; KATO, M. A. (org.). Português brasileiro: uma viagem diacrônica. Campinas: Editora da UNICAMP, 1993. p. 69-105.

TARALLO, F.; KATO, M. A. Harmonia Trans-sistêmica: variação intra- e interlinguística. Preedição 5, Campinas, p. 13-42, 1989.

TORRES MORAIS, M. A. Aspectos diacrônicos do movimento do verbo, estrutura da frase e caso nominativo no português do Brasil. In: ROBERTS, I.; KATO, M. A. (org.). Português brasileiro: uma viagem diacrônica. Campinas: Editora da UNICAMP, 1993. p. 263-306.

VIEIRA-PINTO, C. A. Variação do objeto anafórico acusativo na fala de Florianópolis. 2015. 164 f. Dissertação (Mestrado em Linguística) - Programa 
de Pós-Graduação em Linguística, Universidade Federal de Santa Catarina, Florianópolis, 2015.

WEINREICH, U.; LABOV, W.; HERZOG, M. I. Empirical foundations for a theory of language change. In: LEHMANN, W. P.; MALKIEL, Y. (ed.). Directions for Historical Linguistics. Austin: University of Texas Press, 1968.

ZILLES, A. M. S. A posposição do sujeito ao verbo no português falado no Rio Grande do Sul. Letras de Hoje, Porto Alegre, v. 35, n. 1, p. 75-96, 2000. 


\section{Capítulo 7}

\section{Análise diatópico-diacrônica dos clíticos em jornais brasileiros dos séculos XIX e XX e especificidades da escrita em Santa Catarina}

Marco Antonio Rocha Martins Aroldo Andrade Grazielle Helena Scheidt Juliana Regina da Silva

\subsection{Introdução'}

Estudos diversos em sintaxe diacrônica sobre a escrita brasileira dos séculos XVIII, XIX e XX mostraram que significativas mudanças gramaticais envolvendo o sistema pronominal estão na origem da gramática

Neste artigo, Marco Antonio Rocha Martins apresenta resultados do projeto de pesquisa "Position of the subject and proclisis in neutral contexts [XP]V in $19^{\text {th }}$ century Brazilian writing: reflexes of a parametric change in BP", financiado por uma bolsa de estudos do 
do português brasileiro (PB) e, de modo particular, que essas mudanças afetaram a sintaxe dos pronomes pessoais clíticos (GALVES, 1996; TORRES MORAIS, 1996; PAGOTTO, 1992; LOBO, 1992, 2001; CARNEIRO, 2005; MARTINS, 2009, 2018). No que se refere à implementação (no sentido laboviano) dessas mudanças no contínuo diacrônico em diferentes regiões do Brasil, estudos em sociolinguística histórica têm mostrado que a escrita na Região Sul é mais conservadora que a escrita em demais regiões, como mostram Lopes et al. (2018) sobre a implementação das formas do pronome você no $\mathrm{PB}$ e Martins (2018) sobre a sintaxe dos pronomes clíticos (ver, ainda, Martins, Moura e Costa da Silva, 2019).

Considerando esse quadro, a proposta deste capítulo é apresentar uma descrição e análise da sintaxe dos pronomes pessoais clíticos em uma amostra constituída de textos da imprensa brasileira dos séculos XIX e XX em diferentes estados de três regiões do Brasil: Ceará, Pernambuco e Bahia no Nordeste; Rio de Janeiro no Sudeste; e Santa Catarina no Sul. Os dados aqui analisados foram extraídos de cartas de leitores, cartas de redatores e anúncios dos corpora do projeto Para a História do Português Brasileiro (PHPB). ${ }^{2}$ Uma primeira análise com dados das regiões Nordeste e Sudeste fora apresentada em Martins (2018) e, para esta versão do trabalho, dados do estado de Santa Catarina foram incluídos, esperando que se confirme a hipótese de que a implementação das mudanças na sintaxe dos clíticos apresenta uma evolução diatópico-diacrônica no território brasileiro segundo a qual formas mais inovadoras da gramática do $\mathrm{PB}$ se implementam primeiro da Região Nordeste, e evoluem diatópico e diacronicamente para o Sudeste e para o Sul, de modo que a escrita nesta última região deve se mostrar mais conservadora.

Além de apresentar um mapeamento diatópico-diacrônico do sistema de clíticos pronominais no português escrito nos séculos XIX e XX em diferentes regiões, buscaremos enfocar a escrita catarinense, contribuindo, assim, com a descrição da história do português escrito em

Instituto Humboldt/CAPES (Processo número 88881.145464/2017-01), durante o período em que esteve como professor visitante na Universidade de Colônia/Alemanha. Esta pesquisa está integrada ao projeto "A posição do sujeito pré-verbal e das estruturas [XP-clitic-Verb] na escrita brasileira do século XIX", financiado pelo CNPq com a bolsa de estudos de produtividade PQ-2 (Processo número 310094/2017-8).

2 Os textos dos corpora do PHPB estão disponíveis em https://sites.google.com/site/corpo raphpb/. 
Santa Catarina e com os objetivos do projeto Para a História do Português Brasileiro em Santa Catarina (PHPB-SC).

O capítulo está organizado em mais três seções, além desta Introdução. Na Seção 7.2, apresentamos um breve panorama do sistema dos pronomes clíticos na diacronia do português no Brasil entre os séculos XIX e XX. Na Seção 7.3, apresentamos os resultados da análise de regra variável da posição e da colocação dos pronomes clíticos em sentenças finitas com um verbo e em predicados complexos no corpus. Na Seção 7.4, sistematizamos as conclusões às quais a análise nos permitiu chegar até o momento.

\subsection{Aspectos gerais do sistema pronominal clítico na diacronia do português escrito no Brasil nos séculos XIX e XX}

O panorama da sintaxe dos pronomes pessoais clíticos apresentado em Martins (2018) com base num corpus de cartas de leitores, cartas de redatores e anúncios de jornais brasileiros dos estados do Rio de Janeiro, da Bahia, de Pernambuco e do Ceará confirma, em parte, resultados de estudos anteriores sobre os padrões de posição e de colocação dos clíticos na escrita do Brasil nos séculos XIX e XX (PAGOTTO, 1992; LOBO, 1992, 2001; CARNEIRO, 2005; MARTINS, 2009, 2012, 2013). O autor mostra que o padrão proclítico da gramática do $\mathrm{PB}$ se manifesta em diferentes contextos sintáticos na escrita brasileira de forma bastante uniforme, mas destaca que usos de formas inovadoras de colocação e de posição dos pronomes clíticos estão fortemente associados a questões diatópicas: a escrita no Nordeste é mais inovadora e a do Sudeste, representada pelo estado do Rio de Janeiro, é mais conservadora.

Como evidência de um quadro inovador da escrita na Região Nordeste, Martins (2018) mostra que:

a. A interpolação de constituintes diferentes do marcador frásico de negação não, característica do português clássico $(\mathrm{PCl})$, está restrita à escrita no Brasil do século XIX, com uma queda de 57 para 11 dados em textos desse período, como ilustra o dado em (1). 
(1) $[19,1$ CL CE] ME muito AFOÍTESA, senhor redactor pedirem se taes attestados: os dois primeiros senhores ja lhe diceraõ abertamente, que naõ lhe davaõ atestados

b. A contração de clíticos, ainda frequente no português europeu moderno (PE), desaparece em textos do século XX, sendo encontrada no corpus de textos do século XIX, em sua maioria do estado do Rio de Janeiro, como em (2).

(2) [19,1 CL RJ] Parece-me incrivel; e entretanto m'o affirma pessôa que tem rasão para saber do facto.

c. A colocação inovadora característica do PB com a próclise em posição absoluta na oração e no período aparece timidamente, com três dados na amostra analisada pelo autor, na primeira metade do século XIX na escrita impressa da Região Nordeste, nos estados do Ceará e de Pernambuco, como nos dados em (3), fato também observado em Carneiro (2005) e em Carneiro e Galves (2010) com base num corpus de cartas pessoais da Bahia.

(3) a. [19,1 CLPE] OSenhor Rangelprocurou saberseappareceraõ essas noticias nos Afogados? Estou que não. se indagou. Constou-lhe que nunca se desse tal cousa? Duvido.

b. [19,1 CL PE] Na rua d'Agoas-Verdes. numero 46. se dirá quem vende um excellente moleque de idade de 17 annos, muito proprio para servir a uma casa, pois é muito fiel, bom comprador, e não tem vicio nem achaque, o que se afiança, um escravo bom canoeiro e pescador, sem vicio nem achaque, um dito idade de 20 annos, proprio para armazem de assucar,

c. [20,2 CL CE] O que se questiona é quem colocaremos novamente no poder? Pois, sabemos que nosso País foi colonizado por meliantes oriundos de Portugal, onde ao chegarem aqui, encontraram índios e escravos africanos, que dessa miscigenação resultou no produto final - o brasileiro. nos resta, somente aguardar o próximo furo de reportagem da revista Veja, e logo em seguida, a matéria 
detalhada nos jornais de grande circulação, para sabermos a quem será atribuída a nova falcatrua ou patifaria.

d. Em predicados complexos, diminui significativamente a subida de clítico para o verbo auxiliar e essa diminuição parece ser sensível à região. $\mathrm{O}$ fenômeno de subida de clíticos consiste no posicionamento de um pronome pessoal clítico fora do domínio verbal do qual depende em estruturas com predicados complexos, considerando que esse elemento se move (sobe) para um domínio funcional (temporal, aspectual ou modal) da estrutura oracional ou para um verbo superior, a depender da proposta de representação adotada. Das quatro posições possíveis em sentenças com predicados complexos, aquelas com subida de clíticos, como em (4c/d), são construções conservadoras, apresentando subida de clítico, assim como a variante sem subida e com ênclise ao verbo temático, como em (4b), opções que se contrapõem à construção inovadora do $\mathrm{PB}$, sem subida e com próclise ao verbo temático, como em (4a).

(4) a. [19,1 CR CE] Uma vez que os Cearenses naõ podem se ligar em um só pensamento politico

b. [19,2 CL RJ] Sob estas condições, ninguém pode surpreender-se da violência produzida, cuja origem é evidente.

c. [20,2 CL CE] Não se pode conceber que este tipo de abuso continue a acontecer, sem que nada de concreto se faça para coibir estes desmandos

d. [20,2 CR CE] pode-se afirmar que, em linhas gerais, a economia oferece perspectiva favorável para 1982.

As construções sem subida e com ênclise ao verbo temático estão fortemente associadas a uma gramática com as formas clíticas átonas acusativas de terceira pessoa $o / a$. As formas com subida de clíticos são variantes conservadoras na escrita no Brasil de um modo geral, e Martins (2018) mostra que há uma diferença diatópico-diacrônica significativa no condicionamento do alçamento, numa análise multivariada com peso relativo, na amostra que analisa: há uma diferença de peso relativo de 
0.62 para os textos do Rio de Janeiro, na Região Sudeste, enquanto nos textos da Região Nordeste os pesos relativos encontrados são de 0.45 para Pernambuco, 0.43 para o Ceará e 0.42 para a Bahia, conforme dados na Tabela 7.1 a seguir.

Tabela 7.1 - Frequências de usos e pesos relativos de subida de clíticos por Estado

\begin{tabular}{c|c|c}
\hline & N/Total $=\%$ & PR \\
\hline Rio de Janeiro & $101 / 150=67 \%$ & 0.62 \\
\hline Pernambuco & $183 / 262=69 \%$ & 0.45 \\
\hline Ceará & $81 / 128=63 \%$ & 0.43 \\
\hline Bahia & $131 / 226=57 \%$ & 0.42 \\
\hline TOTAL & $496 / 766=64 \%$ & - \\
\hline
\end{tabular}

Fonte: Martins (2018, p. 206).

Considerando a relação entre o uso dos pronomes clíticos e a evolução do objeto nulo característico do $\mathrm{PB}$, do ponto de vista geográfico em relação às singularidades de aspectos da sintaxe inovadora do $\mathrm{PB}$ que se revelam na escrita da Região Nordeste em relação às demais regiões do Brasil, é importante destacar o trabalho de Cyrino (2018), que analisa a evolução do objeto nulo em cartas de leitores, cartas de redatores e anúncios de jornais e cartas particulares de diferentes estados brasileiros (Bahia, Minas Gerais, Pernambuco, Rio de Janeiro, Paraná e São Paulo). Os resultados da autora mostram que o estado do Rio de Janeiro é também o mais conservador em relação aos usos de objeto nulo nas cartas de leitores.

\subsection{Novos dados para uma descrição diatópico- diacrônica do português escrito no Brasil dos séculos XIX e XX}

Nesta seção, consideramos textos da imprensa brasileira, mais especificamente cartas de leitores, cartas de redatores e anúncios, dos séculos XIX e XX, com ênfase naqueles de Santa Catarina (SC), em contraposição 
com os dados discutidos anteriormente, dos estados do Rio de Janeiro (RJ), da Bahia (BA), de Pernambuco (PE) e do Ceará (CE). Numa análise geral dos dados da imprensa de Santa Catarina, encontramos o seguinte quadro, que segue as tendências apresentadas acima: (a) a perda dos grupos clíticos - foi encontrado um dado apenas, como mostra (5); (b) a perda da mesóclise - foram encontrados cinco dados em textos da primeira metade do século XIX, conforme dados em (6); e (c) a perda da interpolação foram encontrados três dados também em textos da primeira metade do século XIX, conforme dados em (7).

(5) [19,2 CR SC] Muita gente as attribue exclusivamente a politica dominante que mui-|to influe naquelle que os nomèa, e eu á acompanho nesta parte: o que se segue d'ahi é o nosso atrazo, porque um commandante, posto que animado de bons desejos de nos fazer o bem que precisamos, não contando com a commandancia ao menos por dous annos, desanima, e pouco se lhe dá que as cousas sigão nas vias do progresso, ou fiquem no statu quo.

(6) a. [19,1 A SC] Número 23. SOBRADO Encarrega-se o agente abaixo assig|nado de toda e qualquer transacção commercial, como causa forense Recebe objetos para serem vendidos, tanto em leilao, como particularmente. Empresta dinheiro sobre objectos de valor. Encarrega-se de expedir tanto para fora da provincia como do império qualquer objectos, assim como de mandar vir; de tirar passaportes, titulos de residencia, etc. encontrar-se-há finalmente nesta agencia todos os recursos, que desejar-se possa com toda a segurança e brevidade, e mediante huma mui modi|ca porcentagem.

b. [19,1 A SC] DOMINGOS Gonsalves, faz publico que tem de accresentar seu nome o apellido - Leitão;- e por isso chamarse-há, d’ora em diante, Domingos Gonsalves Leitão.

c. [19,1 CL SC] Quem é o Senhor Major Antunes? Diga todo o povo da Laguna e o Senhor Marechal Antero, e ver-se-ha os relevantes serviços a favo da Legalidade, já com seu pessoal já com sua fortuna, inveja dos cains judaicos; logo é assassino. 
Senhor Bessa, esteja certo que suas alicantinas servirião para outro tempo, mas não para o d'agora, por que Vossa Mercê é já bem conhecido na historia: culpado é o Senhor Doutor Severo que quiz ter complacencia com Vossa Mercê; do contrario Vossa Mercê tinha bem pago os altos feitos de seu Pernambuco, quero dizer seu Tubarão. Espero ainda, Senhor Editor, que não seja esta a ultima vez de o incommodar, por que ainda sou $\mathrm{O}$ Veritas.

d. [19,1 A SC] Francisco Ignacio residente na rua do Menino Deos, caza número 7 , tem sua loja de penteeiro na mesma casa, faz pentes de tartaruga, concerta-os, e limpa: As pessôas que se Quizerem utilizar do seu prestimo achal-o-hao na indicada caza. Encarrega-se de fazer qualquer obra da mesma materia, e tambem as compra.

e. [19,2 CR SC] Em abono da verdade dir-te-ei que os tres anteriores, e o interino portarão-se satisfatoriamente. Não sabemos a causa que concorreo para tão successivas mudanças.

(7) a. [19,1 CL SC] Nem um Antunes esteve em armas nunca, nem agredirão ninguem. Estavao recolhidos ás suas fazendas e habitações, esperando a maligna pronuncia do club da Banca Jeromista para se apresentarem ás authoridades competentes, e o não fizerao a mais tempo por serem ameaçados de morte, logo que fossem vistas, por quanto todo o Tubarão estava, por ordem do tal Teixeirinha que commandava a força em chefe, em armas e agitado.

b. [19,1 CL SC] Quando quizesse considerar como escripto pelo Editor do Conciliador esse interessante artigo, nao posso fazel-o quanto a ultima parte, que me parece lembrança de certo Juiz, que se nao cançara em escrever contra mim, pois que tem, talvez, á sua disposição os processos.

c. [19,1 CL SC] Queira, Senhor Editor, lançar nas columnas de seo, muito lido, jornal estas poucas linhas, aconselhadas pelo meo ainda não arrefecido patriotismo. E cá do retiro onde vivo, peço-lhe que se não esqueça de continuar a sientificar 
a justiceira Administração do Excelentíssimo Senhor Doutor Coutinho, dos males que soffre a nossa bella Provincia, causados pelo Conciliador e mais sucia;

Desconsiderados os poucos casos de mesóclise e de interpolação encontrados, procedemos à análise de regra variável considerando os dois fenômenos numa amostra retirada dos corpora impressos do projeto PHPB: (A) a colocação do pronome pessoal clítico em próclise ou ênclise em sentenças matrizes afirmativas com um único verbo e (B) a colocação com ou sem alçamento do clítico em predicados complexos, ilustrados em (4) acima. Foram observados os seguintes contextos sintáticos: sentenças finitas afirmativas com um verbo em posição inicial - cf. (8); verbo precedido de oração subordinada ou de oração coordenada - cf. (9); e sentenças com o verbo em segunda posição superficial precedido de um ou mais constituintes, porém sem atratores de próclise; mais especificamente, foram considerados dados com sujeitos pré-verbais - cf. (10), com sintagmas preposicionais - cf. (11), com advérbios - cf. (12) - no contexto $([\mathrm{XP}])[\mathrm{XP}] \mathrm{V}$.

(8) Verbo em primeira posição na sentença

a. [20,2 CL CE] Nos resta, somente aguardar o próximo furo de reportagem da revista Veja, e logo em seguida, a matéria detalhada nos jornais de grande circulação, para sabermos a quem será atribuída a nova falcatrua ou patifaria.

b. [20,2 CR CE] referimo-nos ao reiterado compromisso, do Governo, de devolver, no prazo estipulado, os cruzados retidos pelo Plano Collor 1.

(9) Verbo precedido de oração subordinada

[20,1 CL SC] Scientes agora o seu pensamento em relação a "greve" com a qual Vossa senhoria não poderá concordar, attendendo ao seu longo passado, todo dedicado a ordem, as industrias e ao progressão da terra brasileira, pensamento do qual nos não podemos discordar, cumpre nos todavia levar ao conhecimento de Vossa senhoria que não podemos mais evitar a explosão do nosso OPERARIADO que esta se manifestando profundamente desgostoso com a attitude do Senhor Neitsch. 
(10) Verbo precedido de sujeito

a. [20,2 CL SC] Vocês se lembram daquela musiquinha que diz assim: Choveu, choveu Choveu Canasvieiras encheu Quando chove

b. [19,1 CL SC] Dito e feito. A pirataria poz-se em actividade; e muitas embarcações nacionaes forão tomadas a pretexto de reprezalia! Alem de outras violencias praticadas contra a soberania da Nação. O governo não se acobardou, convenceo-se da justiça que lhe assistia, e insistio em não acceder as pretenções da altiva legação.

(11) Verbo precedido de sintagma preposicional

a. [19,1 A SC] No armazem de Henrique Schutel vende-se milho a 1:280 réis o saco

b. [19,1 A SC] Precisa-se de um menino para caixeiro de uma casa de molhados qne tenha alguma prataica deste negocio. Nesta Typogra|phia se dirá com quem deve tratar.

(12) Verbo precedido de advérbio

[19,2 CL SC] Minha filha tomou 18 frascos [de] Peitoral de Cambará e hoje acha-[se] completamente restabelecida.

Foram tabulados 2.827 dados, e a análise de regra variável para os fenômenos A e B está apresentada nas subseções que seguem.

7.3.1 Sentenças matrizes afirmativas finitas com um verbo (fenômeno $A$ ): a dinâmica da mudança em direção à próclise do PB

Foram categorizadas 1.993 ocorrências do fenômeno A, sentenças matrizes com o verbo em primeira posição (absoluta ou não) e com um ou mais constituintes não ativadores de próclise em posição pré-verbal (sujeito, sintagma preposicional, advérbio ou oração). Esses dados foram submetidos à análise multivariada com os programas do pacote estatístico Goldvarb 2001 (cf. ROBINSON; LAWRENCE; TAGLIAMONTE, 2001). Elegemos como regra variável a colocação em próclise correlacionada aos 
possíveis condicionadores (extra)linguísticos: (a) a posição superficial do verbo, (b) a natureza do constituinte que antecede imediatamente o verbo em contextos ([XP])[XP]V, (c) a natureza do sujeito em contextos SV, (d) a forma do pronome pessoal clítico, (e) o gênero do texto, e (f) o estado onde foi escrito o texto. Num primeiro momento da análise, tomamos por referência rodadas separadas com os dados de cada século; ou seja, foram feitas rodadas separadas com os dados do século XIX e com os dados do século XX. Essa primeira análise mostrou como estatisticamente relevante o período de escrita dos textos: a primeira metade do século XIX foi selecionada como um condicionador da próclise, em contraposição à segunda metade do XIX e ao século XX. Considerando essa significância obtida com a primeira rodada nos programas do Goldvarb e o fato de análises anteriores mostrarem particularidades dos textos escritos no Brasil da primeira metade do século XIX (ver, por exemplo, Martins $(2009,2012)$ e Carneiro (2005)), no sentido de os textos desse período refletirem propriedades da gramática do português clássico $(\mathrm{PCl})$, foram feitas mais duas rodadas separadas: uma com os dados da primeira metade do século XIX e outra em que juntamos dados da segunda metade do século XIX e do século XX. Nessa etapa da análise, o período já não foi selecionado como uma variável relevante e os resultados estão descritos no que segue.

\subsubsection{Dados da primeira metade do século XIX}

Os dados da primeira metade do século XIX somaram 463 ocorrências e das variáveis independentes controladas, numa rodada multivariada com Log likelihood -376.092 e Significance 0.000, foram selecionadas nessa ordem de relevância estatística: (a) a natureza do constituinte que antecede imediatamente o verbo em contextos $([\mathrm{XP}])[\mathrm{XP}] \mathrm{V}$, (b) a posição superficial do verbo, e (c) a localidade/o estado onde fora escrito o texto.

Os resultados obtidos para a primeira variável selecionada mostram que, no contexto $([\mathrm{XP}])[\mathrm{XP}] \mathrm{V}$, advérbios $(0.94$ de peso relativo, $34 / 41=85 \%)$ e sujeitos $(0.78,38 / 54=70 \%)$ favorecem a próclise, em oposição a sintagmas preposicionais PP $(0.50,22 / 44=50 \%)$ e a orações $(0.18,9 / 96=9 \%)$ em posição imediatamente antecedente ao verbo, como mostra a Tabela 7.2 a seguir. 
Tabela 7.2 - Frequências de usos e pesos relativos de próclise, por natureza do constituinte que antecede imediatamente o verbo no contexto ([XP]) [XP]V

\begin{tabular}{c|c|c}
\hline & N/Total $=\%$ & PR \\
\hline Advérbio & $34 / 41=85 \%$ & 0.94 \\
\hline Sujeito & $38 / 54=70 \%$ & 0.78 \\
\hline PP & $22 / 44=50 \%$ & 0.50 \\
\hline Oração & $9 / 96=9 \%$ & 0.18 \\
\hline TOTAL & $235=100 \%$ & - \\
\hline
\end{tabular}

Esses resultados evidenciam que advérbios em posição pré-verbal condicionam a próclise, em oposição a sujeitos, PPs e orações, o que era esperado, pois incluímos aqui todos os advérbios por considerar estudos anteriores sobre o português escrito no Brasil do século XIX que mostram a variação na posição com todos os advérbios (MARTINS, 2009, 2012, 2018; CARNEIRO, 2005). Os resultados mostram, ainda, que sujeitos préverbais condicionam a próclise com peso relativo de 0.78 , em oposição a PPs e orações. Esse resultado contrasta com aqueles encontrados na análise de textos da segunda metade do século XIX e do século XX nessa mesma amostra, como mostraremos mais adiante, e com aqueles atestados em Martins (2018). Nossa hipótese é de que o condicionamento da próclise no contexto de sujeitos pré-verbais nos dados da primeira metade do século XIX pode refletir o padrão predominantemente proclítico da gramática do PCl.

Em relação à segunda variável, também como esperado, há um condicionamento da próclise quando o verbo não está em primeira posição absoluta no período e na sentença, como mostram os resultados sistematizados na Tabela 7.3. 
Tabela 7.3 - Frequências de usos e pesos relativos de próclise, por posição superficial do verbo

\begin{tabular}{c|c|c}
\hline & N/Total $=\%$ & PR \\
\hline$[\mathrm{XP}][\mathrm{XP}] \mathrm{V}$ & $30 / 40=75 \%$ & 0.85 \\
\hline$[\mathrm{XP}] \mathrm{V}$ & $75 / 206=36 \%$ & 0.77 \\
\hline V1 em primeiras coordenadas & $15 / 56=27 \%$ & 0.62 \\
\hline V1 absoluto & $2 / 46=1 \%$ & 0.08 \\
\hline TOTAL & $348=100 \%$ & - \\
\hline
\end{tabular}

A terceira variável selecionada traz um resultado bastante interessante para a hipótese elaborada neste capítulo: há uma especificidade diatópica quando comparados os dados de Santa Catarina com os demais estados na história do português escrito no Brasil. Os textos de Santa Catarina, com peso relativo de $0.27(10 / 102=10 \%)$, inibem a próclise nesses contextos em relação aos textos do Rio de Janeiro, com peso relativo de $0.64(45 / 119=38 \%)$, da Bahia, com peso relativo de $0.58(18 / 80=20 \%)$, de Pernambuco, com peso relativo de $0.56(27 / 99=27 \%)$, e do Ceará, com peso relativo de $0.41(24 / 63=38 \%)$, como sistematizam os dados na Tabela 7.4 a seguir.

Tabela 7.4 - Frequências de usos e pesos relativos de próclise, por posição região/ estado

\begin{tabular}{c|c|c}
\hline & N/Total $=\%$ & PR \\
\hline Santa Catarina & $10 / 102=10 \%$ & 0.27 \\
\hline Rio de Janeiro & $45 / 119=38 \%$ & 0.64 \\
\hline Bahia & $18 / 80=20 \%$ & 0.58 \\
\hline Pernambuco & $27 / 99=27 \%$ & 0.56 \\
\hline Ceará & $24 / 63=38 \%$ & 0.41 \\
\hline TOTAL & $463=100 \%$ & - \\
\hline
\end{tabular}

Nesse sentido, a escrita de Santa Catarina se mostra mais conservadora em relação ao uso da próclise nesse contexto, quando comparada à dos demais estados das regiões Sudeste e Nordeste. 
7.3.1.2 Dados da segunda metade do século XIX e do século XX

Em relação aos dados da segunda metade do século XIX e do século XX, somaram-se 1.531 ocorrências e, numa rodada com Log likelihood -376.092 e Significance 0.000, aquelas selecionadas pelo programa foram, nessa ordem de relevância, a posição superficial do verbo, a natureza do constituinte que antecede imediatamente o verbo em contextos ([XP])[XP] $\mathrm{V}$ e a natureza do sujeito no contexto SV. Primeiro, quando o verbo está em primeira posição absoluta na sentença, em V1 inicial (0.09 de peso relativo, $2 / 829=0,2 \%)$, há um desfavorecimento da próclise em oposição a V1 não inicial e com um ou mais constituintes antes do verbo, como mostram os dados na Tabela 7.5.

Tabela 7.5 - Frequências de usos e pesos relativos de próclise, por posição superficial do verbo

\begin{tabular}{c|c|c}
\hline & N/Total $=\%$ & PR \\
\hline V1 inicial & $2 / 829=0,2 \%$ & 0.09 \\
\hline V1 em primeiras coordenadas & $19 / 160=12 \%$ & 0.84 \\
\hline$[\mathrm{XP}] \mathrm{V}$ & $143 / 430=33 \%$ & 0.95 \\
\hline$[\mathrm{XP}][\mathrm{XP}] \mathrm{V}$ & $66 / 112=59 \%$ & 0.97 \\
\hline TOTAL & $230 / 1.531=16 \%$ & - \\
\hline
\end{tabular}

Segundo, em sentenças em que o verbo não está na primeira posição absoluta, advérbios em posição contígua ao verbo favorecem a próclise, em oposição a sujeitos, sintagmas preposicionais e orações, como mostram os dados na Tabela 7.6 a seguir.

Tabela 7.6 - Frequências de usos e pesos relativos de próclise, por natureza do constituinte que antecede imediatamente o verbo no contexto ([XP]) [XP]V

\begin{tabular}{c|c|c}
\hline & N/Total $=\%$ & PR \\
\hline Advérbio & $68 / 94=74 \%$ & 0.81 \\
\hline Sujeito & $87 / 203=43 \%$ & 0.55 \\
\hline PP & $44 / 150=29 \%$ & 0.44 \\
\hline Oração & $10 / 95=10 \%$ & 0.19 \\
\hline TOTAL & $542=100 \%$ & - \\
\hline
\end{tabular}


Sujeitos e PPs, em oposição a orações subordinadas pré-verbais, também favorecem a próclise nesse contexto. É importante registrar que, nos dados da segunda metade do século XIX e do século XX, sujeitos deixam de ser um dos fatores mais relevantes no condicionamento da próclise.

A terceira variável selecionada mostra que sentenças em que $o$ verbo é imediatamente antecedido por um sujeito, sujeitos pronominais pessoais $(0.79,25 / 33=76 \%)$ e demonstrativos $(0.68,3 / 5=68 \%)$, favorecem a próclise, em oposição a sujeitos nominais (DP: 0.43, 56/153 = 37\%) e sujeitos complexos (DP + relativa: $0.33,3 / 12=25 \%$ ), conforme dados na Tabela 7.7 a seguir.

Tabela 7.7 - Frequências de usos e pesos relativos de próclise, por natureza do sujeito

\begin{tabular}{c|c|c}
\hline & N/Total $=\%$ & PR \\
\hline Pronome pessoal & $25 / 33=76 \%$ & 0.79 \\
\hline Pronome demonstrativo & $3 / 5=68 \%$ & 0.68 \\
\hline DP & $56 / 153=37 \%$ & 0.43 \\
\hline DP + relativa & $3 / 12=25 \%$ & 0.33 \\
\hline TOTAL & $240=100 \%$ & - \\
\hline
\end{tabular}

7.3.1.3 $\bigcirc$ que podemos interpretar desses resultados?

Consideradas as rodadas I e II, que incluem dados de diferentes sincronias, observamos que as forças que atuam no condicionamento da próclise na primeira metade do século XIX não são as mesmas que atuam no condicionamento da próclise em textos da segunda metade do século XIX e do século XX. Os resultados relevantes estão sistematizados no Quadro 7.1 que segue. 
Quadro 7.1 - Ordem e seleção de variáveis que condicionam a próclise na amostra, Rodada I: primeira metade do século XIX e Rodada II: segunda metade do século XIX e século XX

\begin{tabular}{|l|l|}
\hline $\begin{array}{l}\text { (a) Rodada I: textos da primeira meta- } \\
\text { de do século XIX }\end{array}$ & $\begin{array}{r}\text { (b) Rodada II: textos da segunda me- } \\
\text { tade do século XIX e do século XX }\end{array}$ \\
\hline $\begin{array}{l}\text { 1. natureza do constituinte que ante- } \\
\text { cede imediatamente o verbo em } \\
\text { contextos }([\mathrm{XP}])[\mathrm{XP}] \mathrm{V} \text { (advérvios e } \\
\text { sujeitos) }\end{array}$ & $\begin{array}{l}\text { 1. posição superficial do verbo } \\
\text { 2. natureza do constituinte que antece- } \\
\text { de imediatamente o verbo em con- } \\
\text { textos ([XP]) [XP]V (advérbios) }\end{array}$ \\
$\begin{array}{ll}\text { 2. posição superficial do verbo } \\
\text { 3. a localidade/o estado }\end{array}$ & 3. natureza do sujeito \\
\hline
\end{tabular}

Os resultados encontrados evidenciam, por um lado, que em textos da primeira metade do século XIX a "natureza do constituinte pré-verbal" foi a primeira variável selecionada no condicionamento da próclise; a "posição superficial do verbo" foi a segunda variável selecionada como estatisticamente relevante; "a localidade/o estado" foi a terceira e mostrou que a escrita de Santa Catarina em oposição à dos demais estados é mais conservadora, não favorecendo a próclise. Por outro lado, em textos da segunda metade do século XIX e do século XX a primeira variável selecionada foi a "posição superficial do verbo", seguida da "natureza do constituinte pré-verbal”, em que sujeitos deixam de ser relevantes para o condicionamento da próclise; a localidade deixa de ser selecionada e outra variável linguística, a "natureza do sujeito", foi selecionada pelos programas do pacote estatístico Goldvarb.

Esse quadro evidencia que há forças linguísticas e diatópicas diferentes que atuam no condicionamento (i.e., no licenciamento) da próclise nesse contexto nos diferentes períodos, o que nos leva a interpretar que os dados da primeira metade do século XIX ainda refletem propriedades da gramática do $\mathrm{PCl}$, em que sujeitos pronominais e DP, indistintamente, motivam a próclise. Além disso, o quadro evidencia que o conservadorismo da escrita em Santa Catarina se mostra um fator inibidor da próclise nesses contextos de variação diacrônica na escrita brasileira do primeiro período, ou seja, da escrita da primeira metade do século XIX. 
7.3.2 Sentenças com predicados complexos: a dinâmica da mudança em direção à próclise do PB

A soma dos dados coletados dos impressos dos cinco estados brasileiros em análise - RJ, BA, PE, CE e SC - totaliza 788 ocorrências em sentenças com predicados complexos que serviram de base para a análise estatística com os pacotes do programa Goldvarb apresentada a seguir. Para a análise dos predicados complexos nos orientamos pela descrição de variação e mudança da subida de clíticos em Andrade (2010), considerando construções com dois verbos (aparecendo o segundo no gerúndio, no particípio ou no infinitivo) formadas por (i) construções de reestruturação que formam predicados complexos com um ou mais verbos auxiliares ou semiauxiliares (modal ou aspectual) e um verbo lexical e (ii) construções de união de orações que formam predicados complexos com um verbo causativo/perceptivo e um verbo infinitivo não flexionado.

Seguindo a metodologia adotada em Martins (2018), a análise que apresentamos neste capítulo toma por regra variável a possibilidade de o clítico estar ou não alçado no domínio encaixado, isto é, no qual é gerado como argumento (interno ou externo). O fenômeno de subida de clítico é uma nomenclatura assumida na literatura gerativista que faz alusão ao movimento do clítico para uma categoria funcional alta na estrutura da sentença, contrapondo-se à não subida, em que se observa a ausência desse movimento, permanecendo o clítico no domínio encaixado (em outras visões da estrutura da sentença, como a cartográfica, o domínio encaixado é simplesmente apresentado como projeção lexical). Em estruturas com predicados complexos formados por dois verbos, o clítico pode figurar alçado em próclise ou ênclise ao verbo flexionado, como dados em (13c) e (13d), retomados de (4) acima, ou não alçado em próclise ou ênclise ao verbo do qual depende sintática e semanticamente, como dados em (13a) e (13b).

(13) a. [19,1 CR CE] Uma vez que os Cearenses naõ podem se ligar em um só pensamento politico

b. [19,2 CL RJ] Sob estas condições, ninguém pode surpreender-se da violência produzida, cuja origem é evidente. 
c. [19,2 CL CE] Não se pode conceber que este tipo de abuso continue a acontecer, sem que nada de concreto se faça para coibir estes desmandos.

d. [20,2 CR CE] pode-se afirmar que, em linhas gerais, a economia oferece perspectiva favorável para 1982.

Considerando a variação na colocação do pronome clítico na estrutura com predicados complexos, com ou sem alçamento, os dados foram organizados de acordo com a natureza do complexo verbal em construções com (a) auxiliares temporais (14), (b) verbos ir e vir de movimento (15), (c) aspectuais (16), (d) modais (17); (e) verbos de controle (18); e (f) causativos e perceptivos (19).

(14) [19,1 A SC] vae publicar-se uma obra intitulada O Homem de Côrte vertida do original francez.

(15) [19,2 CL SC] Vamos, senhor Constantino, tome coragem, venha justificar-se perante o nosso chefe supremo o senhor conselheiro Vianna e perante o partido federal

(16) [20,2 CR PE] Esse tipo de confromto político pela televisão está se tornando de certo modo comum.

(17) $[19,1$ A SC] Os dentes muito arruinados e doloridos podem-se curar, e conservar por muito tempo Offerece-se tambem para collocar dentes artificiaes de porcelana, os quaes não se podem distinguir dos naturaes: cara a dôr de dentes sem tiral-os, e os tira sem dôr, pela applicação do choroformeo, tudo por preços comnodos.

(18) [20,2 CL SC] Porto Bello 4 de Janeiro de 1860. Meu amigo e Senhor Visto que nos achamos em anno novo, quero lhe transmittir o que por nqui ha de mais moderno.

(19) $[19,2$, CL SC] Os nossos Lycurgos que despunhão de um casebre, estão aquartelados desde o anno passado, e no actual terão dese reunir na enfermaria dos bexiguentos!... E então, é ou não é regresso?... Ainda outro exemplo: tenho ouvido dizer que esses sabios costumão receber subsidio, porque a constituição do paiz manda dar-lhes, mas parte de taes subsidios da ultima reunião não lhes quizeram pagar, (caso raro nesta terra) sob 
pretexto de falta daquillo com que se comprão os melões!!... Tú bem me entendes.

Muitos estudos sobre a colocação pronominal em predicados complexos têm sido realizados em diferentes amostras do português escrito no Brasil, e diferentes são as possibilidades de agrupamento dessas construções (CAVALCANTE; DUARTE; PAGOTTO, 2011; ANDRADE; CARNEIRO, 2014; THOMAZ, 2017). A motivação para o agrupamento que assumimos aqui foi motivada por entendermos que a natureza do complexo verbal é um fator determinante na implementação de diferentes padrões de colocação do clítico na diacronia do português, conforme resultados já apresentados em Andrade (2010), Reis (2011) e, mais especificamente para a implementação de padrões associados à gramática do português brasileiro, Martins $(2009,2018)$ e Carneiro (2005). A natureza do predicado complexo será, pois, uma variável independente controlada para a análise multivariada do alçamento ou não do clítico na amostra.

Além da variável (a) natureza do predicado complexo, acima detalhada, foram consideras para as rodadas estatísticas com os programas do pacote Goldvarb (b) a posição superficial do verbo, (c) a forma do pronome pessoal clítico, (d) o gênero textual, (e) o período e (f) a localidade/o estado onde fora escrito o texto.

Assim como para a análise das construções com um único verbo, numa primeira rodada a variável "período" foi selecionada com relevância estatística para o alçamento do clítico em textos da primeira metade do século XIX, motivo pelo qual optamos por realizar duas rodadas separadas, considerando primeiro os dados da primeira metade do século XIX (Rodada I) e em separado os dados da segunda metade do século XIX e do século XX (Rodada II). Essa especificidade da análise se diferencia dos procedimentos assumidos em Martins (2018).

\subsubsection{Dados da primeira metade do século XIX}

Para a Rodada I, com os textos da primeira metade do século XIX, 258 dados foram submetidos aos programas do pacote estatístico Goldvarb com o valor de aplicação da regra variável alçamento do clítico versus não alçamento e as variáveis independentes acima elencadas. Para esse passo da análise foi necessário excluir os poucos dados com 
os verbos ir e vir de movimento e com os aspectuais da amostra. No melhor passo da rodada, com Likelihood-127.280 e Significance 0.008 na análise multivariada, o programa selecionou as variáveis (a) natureza do predicado complexo e (b) a localidade/o estado onde fora escrito o texto, nessa ordem de relevância.

Ratificando os resultados obtidos em outros estudos (MARTINS, 2009, 2018; CARNEIRO, 2005; REIS, 2011), a natureza do predicado complexo é um contexto muito relevante no condicionamento da subida do pronome pessoal clítico no português escrito no Brasil na primeira metade do século XIX: as construções com verbos causativos e perceptivos, com peso relativo de 0.76 , e com verbos auxiliares temporais, com peso relativo de 0.77 , condicionam a subida de clítico em oposição às construções com modais, com peso relativo de 0.30 , e com verbos de controle, com peso relativo de 0.35 , que não se mostraram relevantes para a subida de clítico, conforme resultados sistematizados na Tabela 7.8 abaixo.

Tabela 7.8 - Frequências de usos e pesos relativos de subida de clíticos, por natureza do predicado complexo

\begin{tabular}{c|c|c}
\hline & N/Total $=\%$ & PR \\
\hline Causativos e perceptivos & $17 / 19=89 \%$ & 0.76 \\
\hline Auxiliares temporais & $66 / 72=91 \%$ & 0.77 \\
\hline Modais & $52 / 85=61 \%$ & 0.30 \\
\hline Verbos de controle & $44 / 71=62 \%$ & 0.35 \\
\hline TOTAL & $728=100 \%$ & - \\
\hline
\end{tabular}

A análise binomial selecionou ainda o estado como relevante no condicionamento do alçamento, opondo os estados do Rio de Janeiro (peso relativo de 0.63), da Bahia (0.55) e de Pernambuco (0.52) com o favorecimento do alçamento, em oposição aos estados do Ceará (0.39) e de Santa Catarina (0.25), como mostram os dados na Tabela 7.9 a seguir. 
Tabela 7.9 - Frequências de usos e pesos relativos de subida de clíticos, por estado

\begin{tabular}{c|c|c}
\hline & N/Total $=\%$ & PR \\
\hline Rio de Janeiro & $64 / 77=83 \%$ & 0.63 \\
\hline Bahia & $39 / 51=76 \%$ & 0.55 \\
\hline Pernambuco & $36 / 47=76 \%$ & 0.52 \\
\hline Ceará & $34 / 50=68 \%$ & 0.39 \\
\hline Santa Catarina & $17 / 33=51 \%$ & 0.25 \\
\hline TOTAL & $264=100 \%$ & - \\
\hline
\end{tabular}

No entanto, é necessário relativizar esses resultados, pois são poucos os dados referentes à primeira metade do século XIX (264) e se faz necessário aumentar a amostra, o que pretendemos fazer em trabalhos futuros, com o desdobramento do projeto citado na nota 2. De Santa Catarina, por exemplo, foram considerados aqui 33 dados, 17 com alçamento e $16 \mathrm{sem}$ alçamento, sendo que destes últimos todas as ocorrências foram com ênclise ao verbo temático, como em (20) a seguir, uma estrutura igualmente conservadora na história do português, portanto. É importante referir que não foi encontrada na escrita catarinense da primeira metade do século XIX nenhuma ocorrência com próclise ao verbo temático, construção inovadora da gramática do $\mathrm{PB}$, o que reforça o caráter conservador da escrita no sul do Brasil em relação às demais regiões.

(20) [19,1 A SC] O traductor levado do desejo de ser util, e certo de que esta obra merecerá grande conceito do publico ilustrado, pretende dal-a brevemente ao prélo.

É importante registrar, ainda, que as construções sem alçamento com ênclise ao verbo temático não são estruturas inovadoras da gramática do PB; muito pelo contrário, são construções encontradas na história do português escrito.

7.3.2.2 Dados da segunda metade do século XIX e do século XX

Para a Rodada II, com os dados da segunda metade do século XIX e do século XX, foram analisadas 532 ocorrências com o mesmo valor de aplicação da regra variável alçamento do clítico versus não alçamento 
e as variáveis independentes acima elencadas. Para esse passo da análise foi necessário excluir uma única ocorrência com o clítico "te". No melhor passo da rodada, com Likelihood -327.001 e Significance 0.001 na análise multivariada, o programa selecionou em primeira posição a variável (a) natureza do predicado complexo, mais uma vez, e em segundo lugar (b) a forma do pronome pessoal clítico.

Em relação aos resultados com a variável natureza do predicado complexo, os resultados são muito parecidos com aqueles obtidos na análise da primeira metade do século XIX, com o acréscimo da informação de que os aspectuais e os verbos de movimento, assim como os modais e os verbos de controle, em oposição aos causativos e perceptivos e os temporais, inibem construções com alçamento de clítico.

Tabela 7.10 - Frequências de usos e pesos relativos de subida de clíticos, por natureza do predicado complexo

\begin{tabular}{c|c|c}
\hline & N/Total $=\%$ & PR \\
\hline Causativos e perceptivos & $22 / 29=75 \%$ & 0.70 \\
\hline Auxiliares temporais & $118 / 151=78 \%$ & 0.70 \\
\hline Verbos de controle & $51 / 105=51 \%$ & 0.39 \\
\hline Modais & $88 / 178=49 \%$ & 0.40 \\
\hline Aspectuais & $11 / 27=40 \%$ & 0.29 \\
\hline Verbos de movimento (ir e vir) & $3 / 13=23 \%$ & 0.17 \\
\hline TOTAL & $293 / 503=58 \%$ & -
\end{tabular}

Nessa rodada, a variável forma do clítico foi selecionada para o alçamento na escrita da segunda metade do século XIX e do século XX: sequências de clíticos favorecem o alçamento e construções com os clíticos acusativos de terceira pessoa $o / a$ inibem o alçamento. 
Tabela 7.11 - Frequências de usos e pesos relativos de subida de clíticos, por tipo de clítico

\begin{tabular}{c|c|c}
\hline & N/Total $=\%$ & PR \\
\hline Dois clíticos & $2 / 4=75 \%$ & 0.74 \\
\hline se & $195 / 311=62 \%$ & 0.53 \\
\hline me & $28 / 43=65 \%$ & 0.56 \\
\hline nos & $26 / 36=72 \%$ & 0.56 \\
\hline lhe & $33 / 54=59 \%$ & 0.59 \\
\hline vos & $2 / 4=50 \%$ & 0.41 \\
\hline o/a(s) & $34 / 78=43 \%$ & 0.32 \\
\hline TOTAL & $761=100 \%$ & - \\
\hline
\end{tabular}

Esses resultados mostram que a mudança atestada na escrita brasileira da segunda metade do século XIX e do século XX em relação à subida de clítico parece estar fortemente associada ao tipo de complexo, apesar de, em quase todas as construções, com exceção daquelas com verbos causativos e perceptivos, perder-se gradativamente o movimento do clítico para um domínio funcional temporal, modal e aspectual da estrutura oracional. O que se observa nesses contextos é a implementação na escrita brasileira de uma variante inovadora da gramática do $\mathrm{PB}$, com próclise ao verbo do qual o clítico depende sintática e semanticamente, conforme dados em (21).

(21) a. [20,1 CL BA] O meu Carnaval está a se extinguir!

b. [21,1 A BA] Se V. vai se casar ou quer renovar o mobiliário de sua casa, visite antes| as exposições de O LAR

c. $[20,2 \mathrm{CR}$ PE] queremos nos referir ao abastecimento e ao saneamento.

d. [20,2 CR PE] Evidentemente, estamos nos referindo ao projeto do Código Tributário | enviado pelo Governo do Estado à deliberação de nossa Assembléia Legislativa.

e. [20,2 A SC] precisamos nos mobilizar, escrever, fazer manifestações, pressionar autoridades, etc... 
f. [19,2 CL SC] Porto Bello 4 de Janeiro de 1860. Meu amigo e Senhor Visto que nos achamos em anno novo, quero lhe transmittir o que por nqui ha de mais moderno.

\subsubsection{3 $\bigcirc$ que podemos interpretar desses resultados?}

Comparando os resultados obtidos com as duas rodadas, podemos constatar que há uma mudança na seleção dos condicionadores de construções com alçamento. Primeiro, em ambas as rodadas, a variável mais relevante foi de caráter formal - a natureza do predicado complexo -, em que construções com verbos causativos e perceptivos - cf. (22) e com auxiliares temporais - cf. (23) condicionam o alçamento, em oposição a construções com verbos de controle, modais, aspectuais e verbos de movimento cf. (24), que inibem o alçamento. Segundo, nos dados da primeira metade do século XIX, uma variável extralinguística - a localidade - foi selecionada, que nos dados do segundo período deixa de ser selecionada, enquanto uma segunda variável formal passa a ser selecionada - a forma do clítico. Em dados da segunda metade do século XIX e do século XX, o alçamento é condicionado por construções com sequências de clíticos, que a gramática do $\mathrm{PB}$ perdeu, e o alçamento é fortemente inibido pelos clíticos acusativos de terceira pessoa $o / a$.

(22) [19,2 A SC] A pedra que se acumula nos dentes, causando mao halito e vista desagradavel, e em fim os fez cahir, pode evitar somente com a operação de os limpar e polir com os instrumentos do dentista.

(23) a. [19,2 CL SC] Será por que não temos illuminação publica? Não, porque esta desde meiados do anno passado foi suspensa por falta de dinheiro. Será por ter-se reduzido a força policial?

b. [19,1 CL SC] "O QUE - E PARA QUE - ME SERVE HONRAS, OU MELHOR, GALÃO COMO ORNAMENTO, SI NÃO PRETENDO ME ESTABELECER COM CASA FUNERARIA"?

(24) [19,2 CL SC] O Monarcha Brazileiro não se fez esperar, foi o primeiro a comparecer no Paço da cidade, e em seu transito por 
entre a multidão de seus fieis subditos teve a bondade de dirigirlhes palavras animadoras, cheias de verdadeiro patriotismo que forão recebidas com estrepitosos applausos. Desde logo as manifestações populares forão successivas no sentido de coadjuvar o governo á manter-se na alta e digna posição que havia assumido em semelhante emergência. Innumeraveis felicitações forão dirigidas ao Monarcha Brazileiro que se tornára cidadão como qualquer dos que via ante si.

O Quadro 7.2 a seguir sistematiza esses resultados.

Quadro 7.2 - Ordem e seleção de variáveis que condicionam o alçamento na amostra, Rodada I: primeira metade do século XIX e Rodada II: segunda metade do século XIX e século XX

\begin{tabular}{|c|c|}
\hline $\begin{array}{l}\text { (a) Rodada I: textos da primeira me- } \\
\text { tade do século XIX }\end{array}$ & $\begin{array}{l}\text { (b) Rodada II: textos da segunda meta- } \\
\text { de do século XIX e do século XX }\end{array}$ \\
\hline $\begin{array}{l}\text { 1. natureza do predicado complexo } \\
\text { (verbos causativos e perceptivos e } \\
\text { verbos auxiliares temporais) } \\
\text { 2. a localidade/o estado }\end{array}$ & $\begin{array}{l}\text { 1. natureza do predicado complexo (ver- } \\
\text { bos causativos e perceptivos e verbos } \\
\text { auxiliares temporais) } \\
\text { 2. forma do clítico }\end{array}$ \\
\hline
\end{tabular}

A evolução na frequência geral da próclise ao verbo temático, construção inovadora do $\mathrm{PB}$, considerando os tipos de predicados complexos no curso da segunda metade do século XIX para o século XX, é de $5 \%(16 / 306)$, sobe para $16 \%$ (17/107) na primeira metade do século XX e para $20 \%$ (19/95) na segunda metade do século XX. A distribuição por predicado complexo no curso temporal, sem os causativos, está descrita na Figura 7.1 a seguir.

Há um significativo aumento na frequência de uso de próclise ao verbo temático, principalmente em sentenças com aspectuais, o que mostra ser este o ambiente em que a mudança associada à gramática do PB mais se implementa na escrita brasileira dos séculos XIX e XX. 
Figura 7.1 - A dinâmica da mudança em direção à próclise ao verbo temático em predicados complexos na escrita brasileira dos séculos XIX e XX, de acordo com o tipo de verbo de reestruturação.

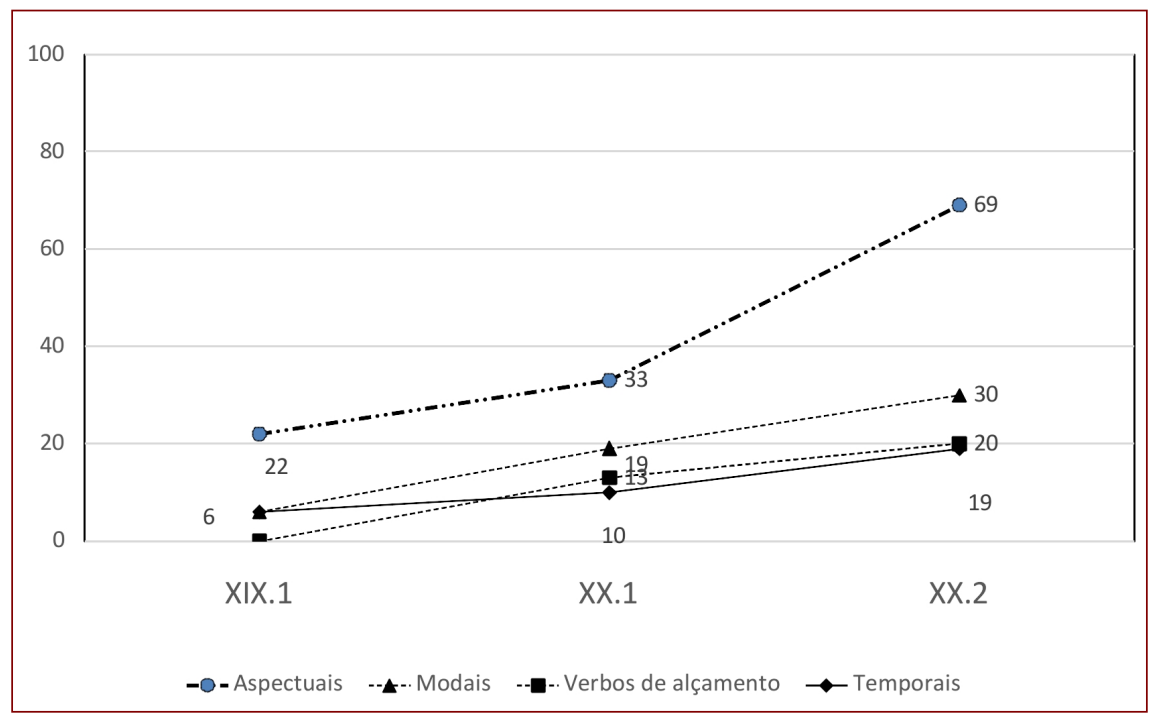

\subsection{Conclusões}

Apresentamos neste texto uma análise da posição e da colocação de clíticos na escrita brasileira dos séculos XIX e XX em cartas de leitores, cartas de redatores e anúncios de jornais escritos em cinco estados brasileiros: Santa Catarina, Rio de Janeiro, Bahia, Pernambuco e Ceará. Os resultados nos permitem chegar às seguintes conclusões.

Em relação à posição dos pronomes clíticos em sentenças matrizes com um único verbo, há um quadro bastante interessante em que a escrita brasileira da primeira metade do século XIX evidencia que advérbios e sujeitos pré-verbais condicionam a próclise em oposição a PPs e orações. Esse resultado contrasta com aqueles encontrados na análise de textos da segunda metade do século XIX e do século XX nessa mesma amostra. Nossa hipótese é de que o condicionamento de sujeitos pré-verbais nos dados da primeira metade do século XIX pode ser o reflexo do padrão de próclise da gramática do $\mathrm{PCl}$ na escrita desse período. E há uma interessante 
especificidade diatópico-diacrônica quando comparados os dados de Santa Catarina com os dos demais estados na história do português escrito no Brasil: os textos de Santa Catarina, com peso relativo de 0.27 $(10 / 102=10 \%)$, são mais conservadores e inibem a próclise em sentenças com um único verbo em relação aos textos do Rio de Janeiro, com peso relativo de $0.64(45 / 119=38 \%)$, da Bahia, com peso relativo de 0.58 $(18 / 80=20 \%)$, de Pernambuco, com peso relativo de $0.56(27 / 99=27 \%)$, e do Ceará, com peso relativo de $0.41(24 / 63=38 \%)$.

Consideradas as duas rodadas dos dois períodos, mostramos que as forças que atuam no condicionamento da próclise em textos da primeira metade do século XIX não são as mesmas que atuam no condicionamento da próclise em textos da segunda metade do século XIX e do século XX. Em textos do primeiro período, a natureza do constituinte que antecede imediatamente o verbo no contexto ([XP])[XP]V (advérbios e sujeitos em oposição a PPs e orações), a posição superficial do verbo (V1 absoluto em relação às demais) e a localidade/o estado (estados do Nordeste e do Sudeste em oposição a Santa Catarina) condicionam a próclise. Em textos do segundo período, a posição superficial do verbo (V1 absoluto em relação às demais), a natureza do constituinte que antecede imediatamente o verbo no contexto ([XP]) [XP]V (advérbios em oposição a sujeitos, PPs e orações) e a natureza do sujeito (pronomes pessoais e demonstrativos em oposição a $\mathrm{DP}$ e DP + relativas) condicionam a próclise.

Em relação à colocação dos pronomes clíticos em predicados complexos, a natureza do predicado condiciona fortemente o alçamento, de modo que construções com verbos causativos e perceptivos e com temporais favorecem o alçamento, em oposição a construções com verbos de controle, modais, aspectuais e verbos de movimento. A escrita de Santa Catarina pode ser mais conservadora, pois não foi encontrada na escrita catarinense da primeira metade do século XIX nenhuma ocorrência com próclise ao verbo temático, construção inovadora da gramática do $\mathrm{PB}, \mathrm{o}$ que reforça o caráter conservador da escrita no sul do Brasil em relação às demais regiões.

Esses resultados evidenciam que há forças diferentes que atuam no condicionamento da próclise em sentenças matrizes com um único verbo e do alçamento nos predicados complexos nas diferentes sincronias, o que nos leva a interpretar que os dados da primeira metade do século XIX ainda refletem propriedades da gramática do PCl (cf. MARTINS, 2009). Como 
resposta à hipótese apresentada no início deste capítulo, aventamos que a implementação das mudanças na sintaxe dos pronomes clíticos apresenta uma evolução diatópico-diacrônica bastante heterogênea no vasto território brasileiro no curso dos séculos XIX e XX, de modo que formas inovadoras se implementam primeiro da Região Nordeste, e evoluem para o Sudeste e para o Sul, mostrando ser a escrita de Santa Catarina mais conservadora, em comparação com a de outras regiões do país.

\section{Referências}

ANDRADE, A. L. de. A subida de clíticos em português: um estudo sobre a variedade europeia dos séculos XVI a XX. 2010. 344 f. Tese (Doutorado em Linguística) - Instituto de Estudos da Linguagem, Universidade Estadual de Campinas, Campinas, 2010.

ANDRADE, A. L. de; CARNEIRO, Z. de O. N. A posição e a colocação de clíticos em predicados complexos: o português brasileiro visto a partir de duas vertentes. Filologia e Linguística Portuguesa, São Paulo, v. 16, n. esp., p. 125-161, 2014.

CARNEIRO, Z. de O. N. Cartas brasileiras (1809-1904): um estudo linguístico-filológico. 2005. 2360 f. Tese (Doutorado em Linguística) Instituto de Estudos da Linguagem, Universidade Estadual de Campinas, Campinas, 2005.

CARNEIRO, Z. de O. N.; GALVES, C. Variação e gramática: colocação de clíticos na história do português brasileiro. Revista de Estudos da Linguagem, Belo Horizonte, v. 18, n. 2, p. 7-38, jul./dez. 2010.

CAVALCANTE, S. R. de O.; DUARTE, M. E. L.; PAGOTTO, E. G. Clíticos no século 19: uma questão de posição social? In: CALLOU, D.; BARBOSA, A. (org.). A norma brasileira em construção: cartas a Rui Barbosa (1866 a 1899). Rio de Janeiro: Fundação Casa de Rui Barbosa, 2011. p. 167-217.

CYRINO, S. O objeto nulo. In: CYRINO, S.; TORRES MORAIS, M. A. (coord.). História do português brasileiro. v. 6: Mudança sintática do português brasileiro: perspectiva gerativista. São Paulo: Contexto, 2018. p. 210-251.

GALVES, C. O enfraquecimento da concordância no português brasileiro. In: ROBERTS, I.; KATO, M. A. (org.). Português brasileiro: uma viagem diacrônica. Campinas: Editora da UNICAMP, 1996. p. 387-408. 
LOBO, T. A colocação dos clíticos em português: duas sincronias em confronto. 1992. 170 f. Dissertação (Mestrado em Linguística Portuguesa e Histórica) - Faculdade de Letras, Universidade de Lisboa, 1992.

LOBO, T. Para uma sociolinguística histórica do português do Brasil: edição filológica e análise linguística de cartas particulares do recôncavo da Bahia, século XIX. 2001. 324 f. Tese (Doutorado em Filologia e Língua Portuguesa) - Faculdade de Filosofia, Letras e Ciências Humanas, Universidade de São Paulo, São Paulo, 2001.

LOPES, C. R. dos S. et al. A reorganização do sistema pronominal de $2^{\text {a }}$ pessoa na história do português brasileiro: a posição de sujeito. In: LOPES, C. R. dos S. (coord.). História do português brasileiro. v. 4: Mudança sintática das classes de palavra: perspectiva funcionalista. São Paulo: Contexto, 2018. p. 7-105.

MARTINS, M. A. A sintaxe dos pronomes pessoais clíticos na história do português brasileiro. In: CYRINO, S.; TORRES MORAIS, M. A. (coord.). História do português brasileiro. v. 6: Mudança sintática do português brasileiro: perspectiva gerativista. São Paulo: Contexto, 2018. p. 150-209. MARTINS, M. A. Competição de gramáticas do português na escrita catarinense dos séculos 19 e 20. 2009. 326 f. Tese (Doutorado em Linguística) - Programa de Pós-Graduação em Linguística, Universidade Federal de Santa Catarina, Florianópolis, 2009.

MARTINS, M. A. Para o estudo da propagação da mudança na colocação de clíticos no Português Brasileiro. In: LIMA, M. A. F.; ALVES FILHO, F.; COSTA, C. de S. M. da (org.). Linguística e literatura: percorrendo caminhos. Teresina: EDUFPI, 2013. v. 1, p. 83-98.

MARTINS, M. A. Reflexos da gramática do PC na escrita brasileira do século 19: uma análise das construções XclV. In: LOBO, T. et al. (org.). ROSAE: linguística histórica, história das línguas e outras histórias. Salvador: EDUFBA, 2012. p. 333-356.

MARTINS, M. A.; MOURA, K. K.; COSTA DA SILVA, F. Análise diatópico-diacrônica dos complementos pronominais de verbos na escrita brasileira dos séculos XIX e XX. Working Papers em Linguística, Florianópolis, v. 20, n. 2, p. 196-216, 2019.

PAGOTTO, E. G. A posição dos clíticos em português: um estudo diacrônico. 1992. 157 f. Dissertação (Mestrado em Linguística) - 
Instituto de Estudos da Linguagem, Universidade Estadual de Campinas, Campinas, 1992.

PAGOTTO, E. G. Norma e condescendência, ciência e pureza. Línguas e Instrumentos Linguísticos, Campinas, n. 2, p. 49-68, 1998.

REIS, F. E. de B. A perda da subida de clíticos no português brasileiro: séculos XIX e XX. 2011. 164 f. Dissertação (Mestrado em Linguística) Instituto de Estudos da Linguagem, Universidade Estadual de Campinas, 2011.

ROBINSON, J.; LAWRENCE, H.; TAGLIAMONTE, S. J. GoldVarb: a multivariate analysis application for Windows. Department of Language and Linguistic Science, University of York, 2001. Disponível em: http:// www.york.ac.uk/depts/lang/webstuff/goldvarb/. Acesso em: 4 set. 2020. THOMAZ, D. S. A colocação pronominal em cartas pessoais da família Pedreira Ferraz - Abreu Magalhães: um caso de competição de gramáticas. 2017. 185 f. Dissertação (Mestrado em Letras Vernáculas) - Faculdade de Letras, Universidade Federal do Rio de Janeiro, 2017.

TORRES MORAIS, M. A. Aspectos diacrônicos do movimento do verbo, estrutura da rase e Caso nominativo no português do Brasil. In: ROBERTS, I.; KATO, M. A. (org.). Português brasileiro: uma viagem diacrônica. Campinas: Editora da UNICAMP, 1996. p. 263-306. 


\section{Capítulo 8}

\section{Convergências e divergências na expressão do dativo de segunda pessoa: análise de cartas pessoais catarinenses e cariocas dos séculos XIX e XX}

Thiago Laurentino de Oliveira Bruna Brasil Albuquerque de Carvalho

Thaissa Frota Teixeira Araujo Silva

\subsection{Palavras iniciais}

Neste capítulo, objetivamos analisar a variação pronominal de segunda pessoa do singular na função de dativo/objeto indireto com base em cartas pessoais escritas por remetentes catarinenses e cariocas. Diferentes estudos (SOUZA, 2012; RUMEU, 2013; LOPES et al., 2018) destacam que a forma nominal Vossa Mercê teria sofrido um intenso processo de 
gramaticalização, que resultou no pronome você. Durante o século XIX, essa forma começa a concorrer com o pronome tu em algumas variedades do português brasileiro (PB). Com a inserção e difusão gradual de você no sistema de tratamento, emergem diferentes estratégias de representação da segunda pessoa do singular.

Outros estudos realizados a partir de cartas pessoais e peças teatrais escritas nos séculos XIX eXX (DUARTE, 1995; MACHADO, 2011; SOUZA, 2012) sinalizam que a forma você, em função de sujeito, teria suplantado o emprego de tu por volta da década de 1930. Em outras funções sintáticas, todavia, você tem uma difusão mais complexa e irregular, sendo "freado" pela forte produtividade de formas pronominais do paradigma de $t u$, como, por exemplo, o clítico te nas funções de objeto direto e objeto indireto do verbo (cf. OLIVEIRA, 2014; SOUZA, 2014).

No presente trabalho, optamos por focalizar especificamente a dinâmica dessa variação entre tu e você no contexto sintático de objeto indireto (dativo), contexto esse que conta, até então, com poucas investigações acerca do fenômeno de tratamento. Examinamos os dados de objeto indireto produzidos na língua escrita de fins do século XIX e da segunda metade do século XX. Para tanto, comparamos dois conjuntos de cartas pessoais produzidas por indivíduos de Santa Catarina e do Rio de Janeiro. Utilizamos, para a nossa análise e discussão, os pressupostos da sociolinguística variacionista laboviana (WEINREICH; LABOV; HERZOG, 2006 [1968]; LABOV, 1994) e os da sociolinguística histórica (CONDE SILVESTRE, 2007; HERNÁNDEZ-CAMPOY; CONDE SILVESTRE, 2012).

Dentro da proposta comparativa de análise do corpus, pretendemos discutir as seguintes questões: (i) Quais eram as formas variantes de dativo de segunda pessoa do singular utilizadas na escrita pessoal catarinense e carioca do final do século XIX e da segunda metade do século XX? (ii) As variantes empregadas são as mesmas nas duas localidades? (iii) Que fatores linguísticos e extralinguísticos condicionavam o emprego dessas variantes? (iv) Como esses fatores atuavam em ambas as variedades? (v) É possível verificar um processo de difusão das formas relacionadas ao pronome você na função dativa ao confrontar os dados do século XIX com os dados do século XX? (vi) Essa possível difusão ocorreria de igual modo em Santa Catarina e no Rio de Janeiro? 
Com o intuito de viabilizar a apresentação dos nossos resultados, estruturamos este capítulo da seguinte maneira: na Seção 8.2, descrevemos o fenômeno em análise; revisitamos brevemente, na Seção 8.3, alguns estudos que exploram a variação entre tu e você nas variedades catarinense e carioca; apresentamos os pressupostos teóricos e a metodologia utilizada na Seção 8.4; analisamos e discutimos, na Seção 8.5, os resultados encontrados; por fim, na Seção 8.6, tecemos as considerações finais deste estudo.

\subsection{Delimitando o objeto de estudo: os complementos dativos}

Desde a língua latina, o dativo é marcado pela hibridez e multiplicidade de contextos morfossintáticos e de sentidos que pode veicular. Isso tem dificultado a formulação de uma definição razoavelmente precisa para essa posição sintática. Utilizamos como referência, neste capítulo, a definição proposta por Mateus et al., segundo a qual o dativo (Dat)/objeto indireto (OI) é "o argumento interno de verbos de dois ou três lugares com o papel semântico de Alvo ou Fonte" (MATEUS et al., 2003, p. 289).

As autoras mencionam ainda outras propriedades típicas do Dat/ OI: a sua animacidade, uma vez que o constituinte OI é, na maioria dos casos, semanticamente [+animado]; a possibilidade de substituição por um clítico, sendo a forma lhe sua marca principal (p. ex., "Ela enviou um livro $\underline{a \text { você" }}$ > "Ela lhe enviou um livro"); a utilização das preposições $a$ ou para ${ }^{1}$ nos casos de forma tônica (p. ex., deu o doce ao João; pediu ajuda a/para ele; contou a verdade a/para você) .

De um ponto de vista semântico, Van Hoecke (1996) e Berlinck (1996) descrevem o argumento dativo como o polo de orientação para o qual se dirigem as ações e os processos expressos pela predicação da sentença. Esse é um traço comum a todos os constituintes dativos; de maneira mais ou menos explícita (dependendo da semântica do elemento predicador em questão), o dativo sempre instancia o sentido de estágio final, de ponto terminal de uma transferência ou de um movimento.

1 É possível, em alguns casos, que o argumento dativo seja introduzido por preposições diferentes de a e para. Isso é comum no $\mathrm{PB}$ quando o dativo recebe o papel semântico de Fonte: "João tomou o lápis de você" > "João lhe tomou o lápis"; "Paula roubou um beijo $\underline{\text { de } t i "}>$ > "Paula te roubou um beijo". 
Quanto às possibilidades formais de representação da segunda pessoa do singular, o dativo pode se manifestar através dos clíticos te (associado a tu) e lhe (associado a você), e dos sintagmas preposicionados a/para ti e al para você. Há ainda o dativo nulo, isto é, quando o argumento verbal não é realizado grafo-foneticamente. Em (1-3), apresentamos exemplos dessas estratégias de realização, atestados em cartas pessoais escritas no Rio de Janeiro: ${ }^{2}$

(1) pronome clítico:

a. [20,2 CP RJ] Não te conto a maior, quero dizer te conto sim. Teu pai me chamou para voltar à sua casa quando eu pudesse.

b. [19,2 CP RJ] Eu não apressei-me em escrever lhe falando no seu novo despacho porque a falar a verdade não fiquei contente com o lugar que the deram [...].

(2) sintagmas preposicionais:

a. [19,2 CP RJ] [...] diz-se que Você é quem influe para que a revolução continue, enfim attribuem $a$ ti tudo, nunca vi maior injustiça, espero que tudo isto desapareça e que venha a verdade.

b. [20,1 CP RJ] São 11 horas preciso dormir, se não fosse isso seria capaz de ficar a noite toda escrevendo para ti, dizendo tudo quanto sinto por ti, porque quando estou junto de ti a emoção embarga-me a voz, faz-me fugir as palavras, e fico mudo.

c. [20,2 CP RJ] Maria e eu enviamos um afetuoso abraço a Yolanda e a você.

d. [20,2 CP RJ] Bia vou mandar prá você, como presente de aniversário, uma fita do grupo 'Balão Mágico'. Espero que você a curta bastante, ok?

(3) objeto nulo:

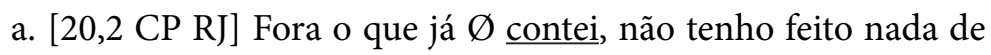
extraordinariamente interessante.

2 Todos os exemplos da presente seção foram retirados de Oliveira (2014). 


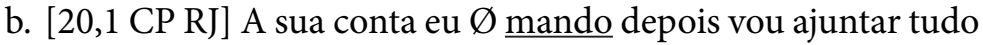
o que você me deve não tenho pressa do cobre, enquanto estiver na sua mão não gasto eles [...]

Dando sequência à delimitação do objeto de estudo, revisitamos, na próxima seção, pesquisas recentes que se debruçaram sobre a variação entre tu e você nas variedades catarinense e carioca, que serão analisadas e confrontadas neste capítulo.

\subsection{Aspectos sócio-históricos das variedades catarinense e carioca e a variação tu/você}

Os estados de Santa Catarina e Rio de Janeiro tiveram processos de formação histórica bastante distintos entre si. De um lado, temos a ilha de Santa Catarina, que, mesmo após a chegada dos primeiros portugueses à região - durante o século XVI e parte do século XVII -, foi utilizada somente como porto de passagem de exploradores europeus por bastante tempo. O povoamento efetivo da antiga Desterro teria se iniciado por volta de 1673, e em 1726 a freguesia foi elevada à categoria de vila (cf. NUNES DE SOUZA, 2015). A região é marcada, inclusive, por uma considerável pluralidade étnica, contando com representantes europeus (açorianos, portugueses, alemães e italianos), indígenas (os Carijó) e africanos (sobretudo do grupo bantu). O progresso e a modernidade chegaram efetivamente a Florianópolis no princípio do século XX, tendo como marco principal a inauguração da ponte Hercílio Luz (1926). Apenas na década de 1970 a capital passa a se destacar como cidade turística e ocorre a abertura de estradas que ligam as cidades dentro e fora do estado.

De outro lado, encontramos a cidade do Rio de Janeiro, fundada oficialmente em 1565 como uma das ações da Coroa portuguesa para assegurar o domínio da região, invadida em 1555 pelos franceses. Apesar de a fundação datar da segunda metade do século XVI, o Rio de Janeiro foi por aproximadamente dois séculos uma pequena colônia pouco desenvolvida. Essa situação começa a se alterar a partir de 1763, com a transferência da capital do Brasil para a região, que se torna, ao longo do século XVIII, a principal cidade brasileira (cf. CALLOU, 2009). A vinda da família real portuguesa e sua corte para o Brasil (1808) acelera o processo 
de desenvolvimento, transformando o cenário do Rio de Janeiro, até então bastante rural, em uma cidade nos moldes europeus.

Apesar das diferenças assinaladas entre as duas localidades em questão, destacamos um aspecto da história de Santa Catarina (principalmente em relação a Florianópolis) e do Rio de Janeiro que, de certa forma, as aproxima: a presença maciça de portugueses em seus territórios. Segundo Nunes de Souza (2015), chegaram ao litoral catarinense, entre 1748 e 1756, cerca de 6.000 açorianos enviados pelo governo português. Essa leva migratória teria sido uma tentativa de solucionar dois problemas: a superpopulação nos Açores e o povoamento em Desterro. A capital catarinense foi fortemente influenciada pela colonização açoriana, com traços marcantes na arquitetura, na culinária, nas festas e na língua. Essa influência tem sido tomada como hipótese para explicar a variação dos pronomes de segunda pessoa do singular em Santa Catarina. Desde o trabalho de Loregian-Penkal (2004), os estudiosos da variedade catarinense (NUNES DE SOUZA; COELHO, 2013, 2015; NUNES DE SOUZA, 2015; LOPES et al., 2018) assumem que a maior preservação do pronome tu em Florianópolis é uma herança dos colonizadores açorianos, em contraste, por exemplo, com o uso majoritário de você na cidade de Lages, onde a influência de tropeiros paulistas teria sido mais decisiva.

Quanto ao Rio de Janeiro, certos aspectos linguísticos, sobretudo os de ordem fonética, são costumeiramente associados à instalação da corte portuguesa na cidade. Leite e Callou (2002) destacam, por exemplo as pronúncias do /R/ e do /S/ em coda silábica como heranças da imigração portuguesa ocorrida na segunda metade do século XIX. As autoras relatam que "há referências também ao fato de, por volta de 1860, os baianos poderem distinguir a fala 'bastante aportuguesada' do sotaque fluminense" (LEITE; CALLOU, 2002, p. 32). Apesar disso, a presença significativa da variante $t u$ no português falado no Rio de Janeiro não costuma ser correlacionada - ao menos, diretamente - com a influência lusitana pelos estudiosos do tema. Contudo, ao considerarmos os padrões de uso dos pronomes de segunda pessoa do singular verificados em localidades bastante próximas ao Rio de Janeiro (São Paulo, Minas Gerais e Espírito Santo), percebemos facilmente a "singularidade" do uso de tu no dialeto carioca em meio aos demais dialetos que compõem a Região Sudeste do Brasil (cf. SCHERRE et al., 2015). 
Se, por um lado, essa semelhança de ordem sócio-histórica entre Santa Catarina e Rio de Janeiro pode explicar a presença expressiva da variante $t u$, até os dias atuais, nessas localidades, por outro lado, constatamos, a partir de diferentes trabalhos, que a produtividade e o valor social desse pronome divergem na fala catarinense e carioca. Associada a essa divergência está o processo de difusão da variante inovadora você, cujo ritmo de implementação é bastante distinto nas duas localidades.

A variação entre tu e você em Santa Catarina constitui um traço que distingue diferentes localidades dentro do estado. Loregian-Penkal (2004), utilizando entrevistas coletadas pelo núcleo VARSUL, analisou a distribuição dos pronomes de segunda pessoa do singular na zona urbana de quatro cidades catarinenses: Florianópolis, Blumenau, Chapecó e Lages. Entre essas, a autora identificou Florianópolis como a localidade onde havia maior uso de tu em comparação com você. Nas outras cidades, a maioria dos informantes estudados alternava o uso dos dois pronomes. Adotando uma abordagem diacrônica, Nunes de Souza e Coelho (2013) analisam o fenômeno a partir de cartas pessoais escritas por florianopolitanos ilustres e não ilustres dos séculos XIX e XX e constatam, entre outros aspectos, que (i) nos dados do século XIX, não havia ocorrências de você e (ii) no século XX, embora tenha sido observada a inserção do novo pronome, não é possível reconhecer um processo de mudança sistemática.

Um panorama bastante distinto tem sido apresentado pelos trabalhos que analisam a variação tu/você na variedade do Rio de Janeiro. $\mathrm{O}$ português falado nessa área caracteriza-se pela coexistência de você e tu na posição de sujeito. Os estudos já realizados apontam que os índices do pronome $t u$, categoricamente combinado com uma forma verbal sem a concordância morfológica canônica ("tu vai", "tu foi" em vez de "tu vais", "tu foste"), são, em geral, inferiores aos de você. A depender do perfil da amostra e da situação interacional, as frequências podem ser bastante baixas, em torno de $5 \%$, ou atingirem patamares que ultrapassem $60 \%$ de frequência (cf. PAREDES SILVA, 2003). As análises já realizadas a partir de cartas pessoais têm mostrado que tal coexistência dessas formas variantes é bastante antiga. Na documentação analisada, verifica-se que os escreventes empregam, em uma mesma carta, somente você, somente tu ou as duas formas em variação.

Em síntese, podemos dizer que, embora a variação entre tu e você tenha sido atestada nas variedades de Santa Catarina e do Rio de Janeiro, 
aspectos sócio-históricos relativos à formação do português falado nessas localidades parecem influenciar a dinâmica do fenômeno. Enquanto Santa Catarina tem em seu histórico um relativo grau de isolamento em relação ao restante do país, associado a um desenvolvimento socioeconômico tardio, o Rio de Janeiro teve, em boa parte de sua história, posição de destaque no cenário nacional; foi capital da colônia (1763-1808), do Império português (1808-1822), da Monarquia brasileira (1822-1889) e da República (18891960). Esses fatos podem justificar certo "conservadorismo" linguístico catarinense (principalmente em Florianópolis), manifesto em um uso mais expressivo de $t u$ (herança açoriana) e mais restrito de você até os dias atuais, diante do "inovadorismo" carioca, notório na produtividade da variante você em alternância com tu (significativamente modificado, se levarmos em consideração a ausência categórica de concordância verbo-pronominal nesta variedade).

A partir dessas considerações gerais acerca da sócio-história do português catarinense e carioca, brevemente discutida e correlacionada com a variação $t u / v o c \hat{e}$, avançamos na exposição do capítulo pontuando, na próxima seção, os pressupostos teóricos e os aspectos metodológicos norteadores do nosso estudo.

\subsection{Pressupostos teóricos e metodologia utilizada}

Conjugamos, neste estudo, duas "modalidades" da sociolinguística: a chamada "sociolinguística laboviana" e o que tem sido denominado como "sociolinguística histórica". Ambas naturalmente compartilham vários pressupostos teóricos, a saber: a necessidade de observação e descrição da heterogeneidade linguística; o reconhecimento de que toda mudança linguística emerge de um processo anterior de variação; a relevância de análise dos fatores extralinguísticos que condicionam os processos de variação/mudança; a importância da construção de corpora de análise para registrar a atuação das variáveis linguísticas em dados reais de uso.

A diferença principal entre a sociolinguística laboviana e a sociolinguística histórica reside na metodologia e nos objetivos da investigação; enquanto a primeira preocupa-se majoritariamente com a sincronia atual, explorando dados da língua falada, identificando e analisando processos de variação em andamento, a última volta-se para as 
sincronias passadas, com base em dados da língua escrita, e, em muitos casos, investiga processos de variação do passado que já se consolidaram em mudança no presente. Dito de outro modo, a sociolinguística laboviana busca compreender a língua do passado a partir do que existe na língua do presente, ao passo que a sociolinguística histórica faz o caminho oposto, ao resgatar o(s) estágio(s) anterior(es) da língua para compreender a língua do presente.

Conforme assinala Conde Silvestre (2007), a sociolinguística histórica trabalha com um material enviesado, que sobreviveu "por acaso" à ação do tempo. $\mathrm{O}$ aspecto fragmentário desse tipo de corpus compromete a análise de variáveis extralinguísticas como sexo, faixa etária e escolaridade nos moldes de uma sociolinguística sincrônica. Além disso, existe a limitação imposta pelo corpus devido a sua natureza escrita: os estudiosos restringem-se a estudar o que estiver disponível no material encontrado.

Outro aspecto diz respeito aos informantes: Hernández-Campoy e Schilling (2012) destacam como problemas recorrentes a questão da autoria (quem são os verdadeiros autores dos documentos?), da autenticidade (que norma linguística é reproduzida no documento?) e da validade social e histórica (em que modelo de sociedade/comunidade o informante vivia?).

Diante desses problemas com que lidam os estudiosos da sociolinguística histórica, fica evidente a necessidade de o pesquisador elaborar uma metodologia de coleta e análise dos dados adequada ao objeto de estudo. É preciso considerar, entre outros tópicos, o gênero textual que favorece a ocorrência do fenômeno investigado, a disponibilidade de material para o recorte cronológico estudado e as informações disponíveis sobre os informantes e sobre a sociedade em que viveram.

Nesta investigação, adotamos o gênero carta pessoal como corpus porque ele favorece a ocorrência de formas pronominais com referência à segunda pessoa do singular, dado o seu caráter dialógico. Dessa forma, assumimos que o gênero epistolar representa um material bastante adequado para a obtenção de dados do nosso fenômeno. Além disso, a situação comunicativa construída no gênero carta pessoal se aproxima, de acordo com Koch e Oesterreicher (2007), das situações de interação mais imediata (reproduz uma "conversa a distância") e por isso é mais propensa a registrar fenômenos de variação linguística.

No Quadro 8.1, apresentamos sistematicamente as amostras selecionadas como corpus da nossa investigação: 
Quadro 8.1 - Amostras analisadas

\begin{tabular}{|c|c|c|}
\hline & Século XIX & Século XX \\
\hline Corpus SC & $\begin{array}{c}\text { Amostra Cruz e Sousa } \\
(1883-1898)-78 \text { documentos }\end{array}$ & $\begin{array}{c}\text { Amostra Harry Laus } \\
\text { (1984-1992) - } 35 \text { documentos } \\
\text { Amostra Do Valle } \\
\text { (1964-1970) - } 25 \text { documentos }\end{array}$ \\
\hline Corpus $\mathrm{RJ}^{3}$ & $\begin{array}{c}\text { Amostra OC } \\
(1889-1899)-21 \text { documentos } \\
\text { Amostra CA } \\
(1873-1895)-23 \text { documentos } \\
\text { Amostra FP } \\
\text { (1898) - } 6 \text { documentos } \\
\text { Amostra PFM } \\
\text { (1879-1897) - } 13 \text { documentos } \\
\text { Amostra RB } \\
(1893-1895)-5 \text { documentos }\end{array}$ & $\begin{array}{c}\text { Amostra FL } \\
(1977-1979)-12 \text { documentos } \\
\text { Amostra EC } \\
(1979-1985)-37 \text { documentos }\end{array}$ \\
\hline
\end{tabular}

A construção do corpus deste estudo foi orientada por parâmetros de ordem quantitativa e qualitativa. A fim de assegurarmos a comparabilidade entre os dados de ambas as localidades, analisamos, do corpus de Santa Catarina, apenas a documentação referente à capital, Florianópolis, visto que ainda não se encontra disponível a documentação produzida em outras cidades durante o século XIX. Além disso, optamos por confrontar dois recortes sincrônicos - as três últimas décadas do século XIX e a segunda metade do século XX - devido à indisponibilidade de material referente à primeira metade do século XX no corpus de Santa Catarina.

Quanto ao perfil sociolinguístico dos remetentes das cartas, todas as amostras são compostas por indivíduos com alto grau de domínio sobre os modelos de escrita (levando em consideração a época em que escreveram e o perfil do gênero carta pessoal). Há cartas escritas por políticos, comerciantes, religiosos, escritores e estudantes, trocadas, em sua maioria, entre amigos e familiares.

Após a leitura das cartas e coleta das ocorrências de dativos pronominais de segunda pessoa do singular, codificamos os dados e os

3 Para manter em sigilo a identidade dos escreventes das cartas pessoais do corpus do Rio de Janeiro que não se encontram em domínio público, identificamos as amostras por siglas. 
submetemos ao programa Goldvarb X. Com o auxílio dessa ferramenta estatística, calculamos as frequências das variantes em consonância com os fatores controlados e pudemos cruzar as variáveis independentes entre si, a fim de verificar a existência de correlações entre elas. Tendo em vista os limites deste capítulo, apresentaremos, na próxima seção, apenas os resultados referentes às variáveis século, forma pronominal utilizada na posição de sujeito, temática da carta e sexo dos interlocutores.

\subsection{Análise e discussão dos resultados}

\subsubsection{Resultados gerais}

Dos 255 documentos analisados, encontramos 648 dados de complemento dativo com referência à segunda pessoa do singular, sendo 291 ocorrências extraídas das missivas catarinenses e 357 das missivas fluminenses. Nos gráficos das figuras 8.1 e 8.2, ilustramos os percentuais registrados para cada variante.

Figura 8.1 - Distribuição de ocorrências das variantes dativas nas cartas de Santa Catarina

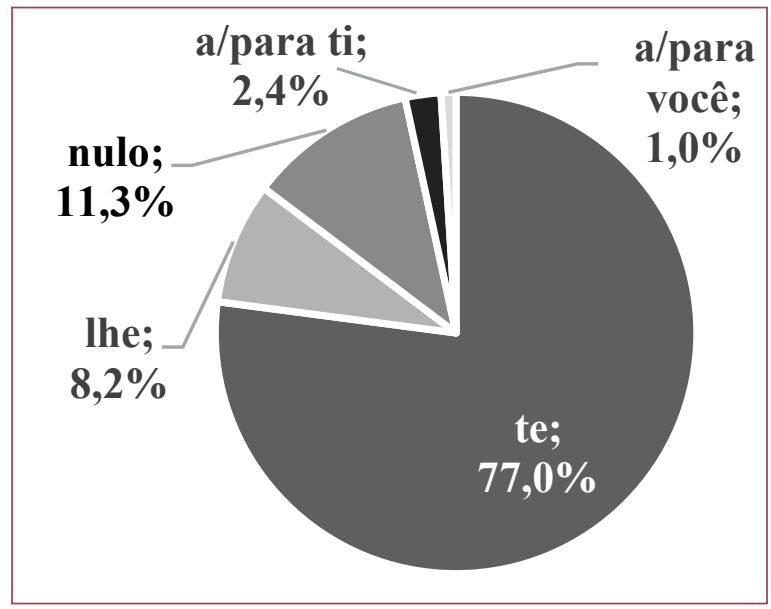


Figura 8.2 - Distribuição de ocorrências das variantes dativas nas cartas do Rio de Janeiro

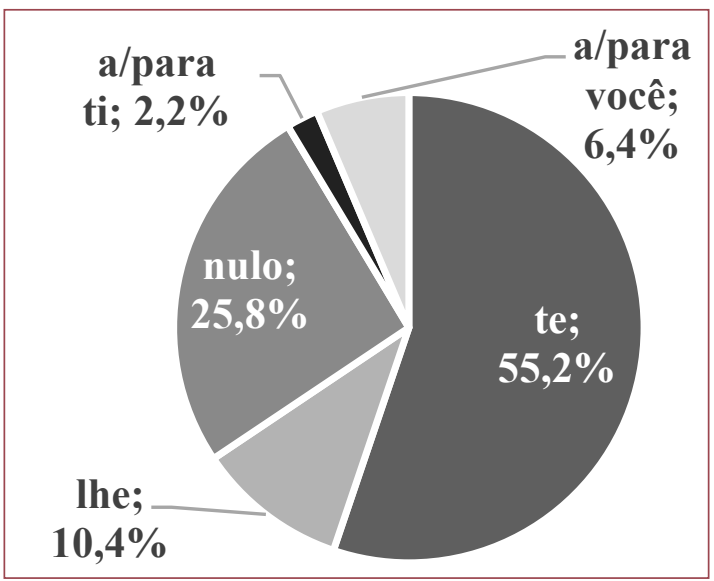

Primeiramente, podemos observar que as mesmas formas variantes estão presentes nos dados das duas localidades; encontramos ocorrências dos clíticos te e lhe, dos sintagmas preposicionados a/para ti e a/para você e do dativo nulo. Há, no entanto, diferenças notáveis quanto à frequência das variantes em cada amostra. O clítico te, por exemplo, apesar de ser a variante mais frequente nas duas cidades, apresenta um índice bem mais elevado nos dados de Santa Catarina (224 ocorrências, 77\%) do que nos dados do Rio de Janeiro (197 ocorrências, 55,2\%). Por sua vez, os dados de dativo nulo foram mais numerosos nas cartas cariocas (92 ocorrências, $25,8 \%$ ) do que nas cartas florianopolitanas (33 ocorrências, 11,3\%). A frequência de sintagmas preposicionados a/para você também foi mais expressiva no material do Rio de Janeiro: 6,4\% (23 ocorrências) diante de $1 \%$ (três ocorrências) no material de Santa Catarina. Os índices do clítico the e dos sintagmas preposicionados a/para ti foram bastante similares em ambas as amostras.

Após essa apreciação global dos dados extraídos das cartas, passemos a correlacioná-los com as variáveis independentes controladas. Iniciamos essa análise considerando a variável século. Como dissemos na Seção 8.3, a amostra em exame é formada por cartas escritas em duas sincronias distintas (finais do século XIX e segunda metade do século XX). Nos gráficos das figuras 8.3 e 8.4, distribuímos as ocorrências das variantes segundo esses dois períodos. 
Figura 8.3 - Distribuição de ocorrências dos dativos de segunda pessoa do singular na diacronia $(\mathrm{SC})$

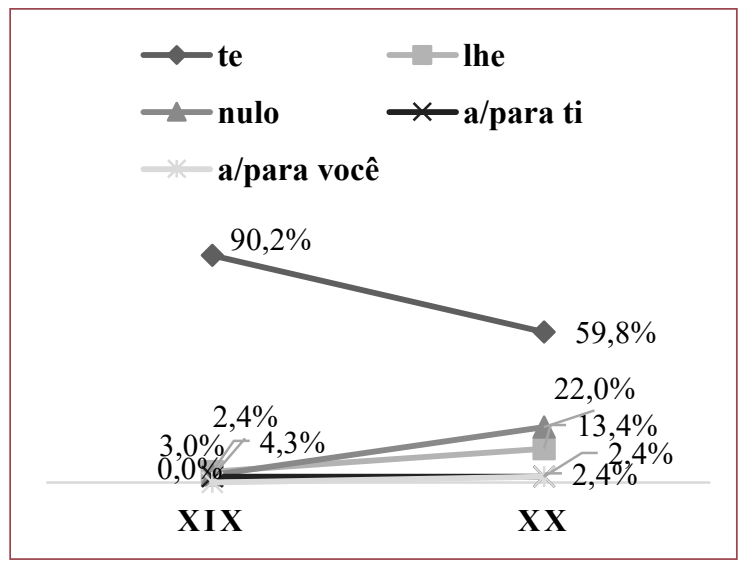

Figura 8.4 - Distribuição de ocorrências dos dativos de segunda pessoa do singular na diacronia $(\mathrm{RJ})$

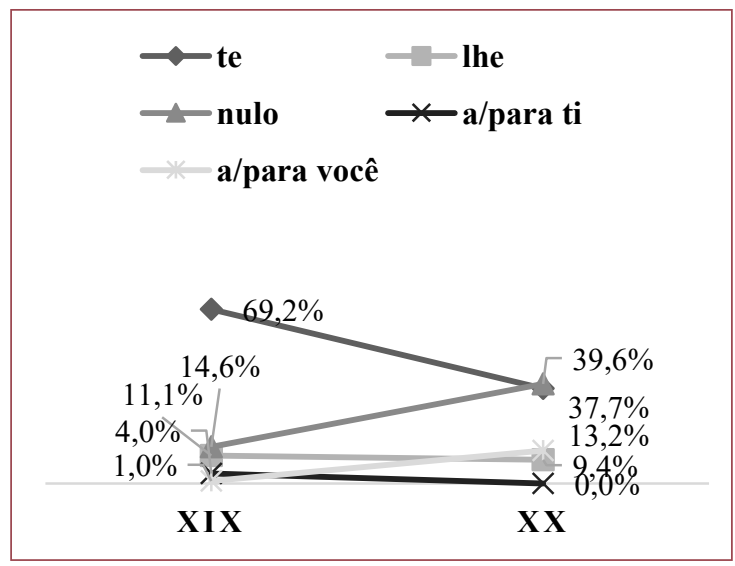

Ao confrontarmos os dados de cada século, percebemos que, em ambas as localidades, o processo de variação entre as formas dativas de segunda pessoa do singular se acirrou no século XX. Nas cartas catarinenses, embora o clítico te seja a forma mais produtiva nas duas sincronias, notamos que a frequência dessa variante se reduz bastante no século XX (76 ocorrências, 59,8\%) em comparação com o século XIX, no qual ela era altíssima (148 ocorrências, 90,2\%). Com exceção dos sintagmas 
preposicionados $a /$ para ti, todas as demais variantes registram um aumento na frequência na amostra catarinense: os índices do clítico lhe saltam de $4,3 \%$ para $13,4 \%$, o dativo nulo sobe de $3 \%$ para $22 \%$ e os sintagmas preposicionados a/para você vão de $0 \%$ para $2,4 \%$.

Entre os dados do Rio de Janeiro também podemos verificar alterações importantes na frequência das variantes dativas de um período para outro. Em primeiro lugar, destaca-se no gráfico da Figura 8.4 a redução no índice percentual do clítico te, que decresce de 69,2\% (137 ocorrências) no século XIX para 37,7\% (60 ocorrências) no século XX. Neste último período, vemos que a variante mais produtiva nas cartas cariocas é o dativo nulo, que salta de 14,6\% (29 ocorrências) para 39,6\% (63 ocorrências). Outra variante que sofre um aumento de frequência do século XIX para o século XX são os sintagmas preposicionados a/ para você: de $1 \%$ (duas ocorrências) para 13,2\% (21 ocorrências). As outras duas variantes, assim como te, também sofrem diminuição de frequência: o índice do clítico lhe se reduz de 11,1\% (22 ocorrências) para $9,4 \%$ (15 ocorrências), e os sintagmas preposicionados a/para ti, que contabilizavam 4\% (oito ocorrências) no século XIX, não registram nenhuma ocorrência no século XX.

Tendo em vista que a distribuição das variantes dativas é significativamente distinta nas cartas do século XIX em comparação com as cartas do século XX, passamos a examinar, nas subseções que seguem, as demais variáveis independentes controladas neste estudo, separando as ocorrências de acordo com o século em que as correspondências foram produzidas. Esperamos, desse modo, analisar como essas variáveis independentes influenciavam o uso das variantes dativas nos dois recortes temporais aqui considerados.

\subsubsection{A (as)simetria entre formas pronominais na função de sujeito e de dativo}

A primeira variável independente analisada é a forma pronominal utilizada na posição de sujeito. Essa variável vem sendo controlada sistematicamente pelos estudiosos do tema (LOPES; CAVALCANTE, 2011; OLIVEIRA, 2014; SOUZA, 2014; NUNES DE SOUZA, 2015; entre outros) e consiste em checar, em cada documento, todos os sujeitos pronominais 
de segunda pessoa do singular ${ }^{4}$ utilizados pelo remetente. $\mathrm{O}$ controle dessa variável é relevante, pois permite ao pesquisador verificar em que medida as estratégias adotadas na posição de sujeito (locus inicial da variação entre tu e você) influenciam as formas utilizadas em outras funções sintáticas.

Dessa forma, costuma-se admitir três níveis para essa variável: tu-exclusivo, quando o remetente utiliza categoricamente a forma $t u$ nos sujeitos da carta; você-exclusivo, quando o remetente só emprega o pronome você nos sujeitos; alternância tu/você, quando se registra a ocorrência dos pronomes tu e você na posição de sujeito dentro de uma mesma carta (ainda que seja uma única ocorrência de uma das duas variantes). Na Tabela 8.1, correlacionamos as ocorrências das variantes dativas com as formas encontradas nos sujeitos das cartas produzidas no século XIX, nas duas localidades em estudo.

Tabela 8.1 - Correlação entre as variantes dativas de segunda pessoa do singular e a forma pronominal utilizada na posição de sujeito - século XIX

\begin{tabular}{|c|c|c|c|c|c|c|}
\hline \multirow{2}{*}{$\begin{array}{c}\text { Século } \\
\text { XIX }\end{array}$} & & te & lhe & a/para ti & $\begin{array}{c}\text { a/para } \\
\text { você }\end{array}$ & nulo \\
\hline & & $\begin{array}{c}\text { Apl./Total } \\
\%\end{array}$ & $\begin{array}{c}\text { Apl./Total } \\
\%\end{array}$ & $\begin{array}{c}\text { Apl./Total } \\
\%\end{array}$ & $\begin{array}{c}\text { Apl./Total } \\
\%\end{array}$ & $\begin{array}{c}\text { Apl./Total } \\
\%\end{array}$ \\
\hline \multirow{2}{*}{$\begin{array}{c}\mathrm{Tu} \\
\text { (exclusivo) }\end{array}$} & SC & $\begin{array}{c}146 / 153 \\
95,4 \% \\
\end{array}$ & - & $\begin{array}{l}3 / 153 \\
2,0 \% \\
\end{array}$ & - & $\begin{array}{l}4 / 153 \\
2,6 \% \\
\end{array}$ \\
\hline & $\mathrm{RJ}$ & $\begin{array}{l}89 / 108 \\
82,4 \%\end{array}$ & $\begin{array}{l}1 / 108 \\
0,9 \%\end{array}$ & $\begin{array}{l}3 / 108 \\
2,8 \%\end{array}$ & $\begin{array}{l}1 / 108 \\
0,9 \%\end{array}$ & $\begin{array}{c}14 / 108 \\
13 \%\end{array}$ \\
\hline \multirow{2}{*}{$\begin{array}{c}\text { Você } \\
\text { (exclusivo) }\end{array}$} & SC & - & $\begin{array}{c}4 / 5 \\
80,0 \% \\
\end{array}$ & - & - & $\begin{array}{c}1 / 5 \\
20,0 \% \\
\end{array}$ \\
\hline & $\mathrm{RJ}$ & - & $\begin{array}{l}16 / 22 \\
72,7 \%\end{array}$ & - & $\begin{array}{l}1 / 22 \\
4,6 \% \\
\end{array}$ & $\begin{array}{c}5 / 22 \\
22,7 \% \\
\end{array}$ \\
\hline \multirow{2}{*}{ Tu/Você } & SC & $\begin{array}{c}2 / 6 \\
33,3 \% \\
\end{array}$ & $\begin{array}{c}3 / 6 \\
50,0 \% \\
\end{array}$ & $\begin{array}{c}1 / 6 \\
16,7 \% \\
\end{array}$ & - & - \\
\hline & $\mathrm{RJ}$ & $\begin{array}{l}48 / 68 \\
70,7 \%\end{array}$ & $\begin{array}{l}5 / 68 \\
7,3 \%\end{array}$ & $\begin{array}{l}5 / 68 \\
7,3 \%\end{array}$ & - & $\begin{array}{l}10 / 68 \\
14,7 \%\end{array}$ \\
\hline
\end{tabular}

4 Excluem-se, nesse caso, as formas imperativas, por se acreditar que a variação nesse contexto envolva fatores de ordem morfofonológica. 
Examinando de maneira geral a Tabela 8.1, percebemos que os remetentes de Santa Catarina e do Rio de Janeiro exibem usos pronominais bastante similares nas cartas produzidas nas últimas décadas do século XIX. Observamos uma forte correlação entre as formas utilizadas na posição de sujeito e de dativo: quando os missivistas empregavam apenas $t u$ na posição de sujeito, as formas dativas utilizadas eram aquelas pertencentes ao paradigma de $t u$ (o clítico te e os sintagmas preposicionados a/para $t i$ ), com destaque para a variante te; por outro lado, quando utilizavam apenas a forma você como sujeito pronominal, as variantes dativas empregadas eram o clítico lhe (principalmente) e os sintagmas preposicionados a/para você (uma ocorrência nos dados do Rio de Janeiro).

Nas cartas com variação entre tu e você na posição de sujeito, identificamos um comportamento diferente, a depender da localidade do escrevente. Nos dados catarinenses, ocorre um empate: metade das ocorrências correspondem ao clítico the e a outra metade, às formas relacionadas ao paradigma de $t u$ (duas ocorrências do clítico te e uma de a/para ti). Já nos dados cariocas, prevalecem as ocorrências do clítico te (70,7\%), sendo registrados, ainda, cinco dados do clítico the e cinco de $a /$ para ti. Quanto aos dados de dativo nulo, registramos ocorrências em todos os contextos e, aparentemente, o uso dessa variante não está relacionado com um contexto específico (isto é, com cartas de tu-exclusivo, vocêexclusivo ou de alternância tu/você). Passemos à apreciação da Tabela 8.2, que traz os dados do século XX.

Tabela 8.2 - Correlação entre as variantes dativas de segunda pessoa do singular e a forma pronominal utilizada na posição de sujeito - século XX

\begin{tabular}{c|c|c|c|c|c|c}
\hline \multirow{2}{*}{$\begin{array}{c}\text { Século } \\
\text { XX }\end{array}$} & te & lhe & a/para ti & $\begin{array}{c}\text { a/para } \\
\text { você }\end{array}$ & nulo \\
\cline { 3 - 7 } & & $\begin{array}{c}\text { Apl./Total } \\
\%\end{array}$ & $\begin{array}{c}\text { Apl./Total } \\
\%\end{array}$ & $\begin{array}{c}\text { Apl./Total } \\
\%\end{array}$ & $\begin{array}{c}\text { Apl./Total } \\
\%\end{array}$ & $\begin{array}{c}\text { Apl./Total } \\
\%\end{array}$ \\
\hline \multirow{2}{*}{$\begin{array}{c}\text { Tu } \\
\text { (exclusivo) }\end{array}$} & SC & $\begin{array}{c}52 / 66 \\
78,8 \%\end{array}$ & - & $3 / 66$ & $1 / 66$ & $10 / 66$ \\
& RJ & - & - & - & - & - \\
\hline
\end{tabular}




\begin{tabular}{|c|c|c|c|c|c|c|}
\hline \multirow{2}{*}{$\begin{array}{c}\text { Você } \\
\text { (exclusivo) }\end{array}$} & $\mathrm{SC}$ & $\begin{array}{l}1 / 15 \\
6,6 \% \\
\end{array}$ & $\begin{array}{c}7 / 15 \\
46,7 \% \\
\end{array}$ & - & - & $\begin{array}{c}7 / 15 \\
46,7 \% \\
\end{array}$ \\
\hline & $\mathrm{RJ}$ & $\begin{array}{c}49 / 134 \\
36,6 \% \\
\end{array}$ & $\begin{array}{c}15 / 134 \\
11,2 \% \\
\end{array}$ & - & $\begin{array}{c}19 / 134 \\
14,2 \% \\
\end{array}$ & $\begin{array}{c}51 / 134 \\
38,0 \% \\
\end{array}$ \\
\hline \multirow{2}{*}{ Tu/Você } & $\mathrm{SC}$ & $\begin{array}{l}23 / 41 \\
56,1 \% \\
\end{array}$ & $\begin{array}{c}6 / 41 \\
14,6 \% \\
\end{array}$ & - & $\begin{array}{l}2 / 41 \\
4,9 \% \\
\end{array}$ & $\begin{array}{l}10 / 41 \\
24,4 \% \\
\end{array}$ \\
\hline & RJ & $\begin{array}{r}11 / 24 \\
45,8 \% \\
\end{array}$ & - & - & $\begin{array}{l}1 / 24 \\
4,2 \% \\
\end{array}$ & $\begin{array}{l}12 / 24 \\
50,0 \% \\
\end{array}$ \\
\hline
\end{tabular}

Os dados do século XX nos trazem diferenças perceptíveis quanto à correlação que verificamos na Tabela 8.1. Em primeiro lugar, sublinhamos a inexistência de cartas com uso exclusivo de $t u$ na posição de sujeito na amostra carioca desse período. Nesse mesmo contexto, observamos que os escreventes de Santa Catarina preservam a simetria no tratamento ao interlocutor, utilizando as variantes te $(78,8 \%)$ e a/para ti $(4,5 \%)$. Nas cartas com uso exclusivo de você na posição de sujeito, constatamos uma divergência entre os missivistas catarinenses e cariocas: enquanto os primeiros utilizam majoritariamente o clítico lhe e o dativo nulo (46,7\% para ambos), os últimos empregam produtivamente quatro variantes (dativo nulo - $38 \%$, clítico te $36,6 \%$, a/para você $-14,2 \%$, clítico lhe $-11,2 \%)$.

Nas cartas em que havia alternância entre tu e você na posição de sujeito, podemos identificar semelhanças e diferenças entre os usos de dativo pelos missivistas de Santa Catarina e do Rio de Janeiro. Em ambas as amostras, nenhum escrevente utiliza a variante $a /$ para $t i$, sendo as variantes te, a/para você e dativo nulo as principais estratégias desse contexto. Em contrapartida, verificamos que a variante lhe é empregada apenas por remetentes catarinenses $(14,6 \%)$, não sendo computada nenhuma ocorrência dessa forma em cartas cariocas. Além disso, vemos que a variante mais frequente em contexto de alternância no sujeito não é a mesma nas duas amostras: nas cartas de Santa Catarina prevalece o clítico te $(56,1 \%)$, ao passo que nas cartas do Rio de Janeiro o dativo nulo é majoritário (50\%).

\subsubsection{A temática da carta pessoal}

A segunda variável independente que vamos discutir é a temática da carta pessoal. Essa variável também costuma ser investigada pelos 
estudiosos da variação pronominal na segunda pessoa do singular e aparece em alguns trabalhos identificada como subgênero da carta pessoal (cf. OLIVEIRA, 2014; SOUZA, 2014). Embora a documentação analisada nos trabalhos sobre o tema pertença a um mesmo gênero textual, os pesquisadores que lidam com esse tipo de corpus admitem que, dentro do gênero carta pessoal, há uma grande variabilidade temática. Sendo assim, o controle dessa variável visa a examinar se temáticas específicas podem influenciar a ocorrência de certas variantes pronominais.

Como dissemos, as cartas analisadas encerram em si grande diversidade temática. Com o intuito de estabelecer algum grau de generalização, que evitasse a criação de inúmeros níveis (o que poderia dificultar ou mesmo inviabilizar a análise dessa variável), consideramos a variável temática da carta a partir de três categorias: romântico-amorosa, familiar e amizade. Na Tabela 8.3, temos o cruzamento dessa variável com as ocorrências das variantes dativas registradas na documentação do século XIX.

Tabela 8.3 - Correlação entre as variantes dativas de segunda pessoa do singular e a temática da carta pessoal - século XIX

\begin{tabular}{|c|c|c|c|c|c|c|}
\hline \multirow{2}{*}{\multicolumn{2}{|c|}{$\begin{array}{l}\text { Século } \\
\text { XIX }\end{array}$}} & te & lhe & a/para ti & $\begin{array}{l}\text { a/para } \\
\text { você }\end{array}$ & nulo \\
\hline & & $\begin{array}{c}\text { Apl./Total } \\
\%\end{array}$ & $\begin{array}{c}\text { Apl./Total } \\
\%\end{array}$ & $\begin{array}{c}\text { Apl./Total } \\
\%\end{array}$ & $\begin{array}{c}\text { Apl./Total } \\
\%\end{array}$ & $\begin{array}{c}\text { Apl./Total } \\
\%\end{array}$ \\
\hline \multirow{2}{*}{$\begin{array}{l}\text { Romântico- } \\
\text { amorosa }\end{array}$} & SC & $\begin{array}{c}8 / 11 \\
72,7 \% \\
\end{array}$ & - & $\begin{array}{c}2 / 11 \\
18,2 \% \\
\end{array}$ & - & $\begin{array}{l}/ 11 \\
9,1 \% \\
\end{array}$ \\
\hline & $\mathrm{RJ}$ & $\begin{array}{l}54 / 60 \\
90,0 \% \\
\end{array}$ & - & $\begin{array}{l}2 / 60 \\
3,3 \% \\
\end{array}$ & - & $\begin{array}{l}4 / 60 \\
6,7 \% \\
\end{array}$ \\
\hline \multirow{2}{*}{ Familiar } & SC & $\begin{array}{l}42 / 54 \\
77,8 \%\end{array}$ & $\begin{array}{c}7 / 54 \\
13,0 \%\end{array}$ & $\begin{array}{l}1 / 54 \\
1,8 \%\end{array}$ & - & $\begin{array}{l}4 / 54 \\
7,4 \%\end{array}$ \\
\hline & $\mathrm{RJ}$ & $\begin{array}{l}29 / 66 \\
43,9 \%\end{array}$ & $\begin{array}{l}19 / 66 \\
28,8 \%\end{array}$ & $\begin{array}{l}1 / 66 \\
1,6 \%\end{array}$ & $\begin{array}{l}2 / 66 \\
3,0 \%\end{array}$ & $\begin{array}{l}15 / 66 \\
22,7 \%\end{array}$ \\
\hline \multirow{2}{*}{ Amizade } & SC & $\begin{array}{l}98 / 99 \\
99,0 \%\end{array}$ & - & $\begin{array}{l}1 / 99 \\
1,0 \%\end{array}$ & - & - \\
\hline & $\mathrm{RJ}$ & $\begin{array}{l}54 / 72 \\
75,0 \%\end{array}$ & $\begin{array}{l}3 / 72 \\
4,2 \%\end{array}$ & $\begin{array}{l}5 / 72 \\
6,9 \%\end{array}$ & - & $\begin{array}{l}10 / 72 \\
13,9 \%\end{array}$ \\
\hline
\end{tabular}


Ao contemplarmos a Tabela 8.3, chama a atenção o fato de que as variantes te e a/para ti tenham sido registradas nas três temáticas e nas cartas das duas cidades investigadas. Entre os dados de Santa Catarina, o clítico te predominou nas três temáticas, sendo de uso quase categórico nas cartas de amizade (99\%). Já os sintagmas preposicionados a/para ti foram mais frequentes nas cartas romântico-amorosas (18,2\%). No que tange aos dados do Rio de Janeiro, o clítico te também prevaleceu nas cartas das três temáticas (embora com índices percentuais inferiores àqueles registrados nos dados de Santa Catarina). Contudo, é nas cartas romântico-amorosas que essa variante alcança a maior frequência na amostra carioca (90\%). A variante $a /$ para ti contabilizou maior número de ocorrências nas cartas de amizade $(6,9 \%)$.

Outro ponto de convergência entre os remetentes catarinenses e cariocas se dá no uso da variante lhe. Essa estratégia aparece, nos dados do século XIX, associada às cartas de temática familiar. Na amostra de Santa Catarina, o clítico lhe só foi utilizado em cartas com essa temática. Já na amostra do Rio de Janeiro, lhe também foi empregado em cartas de amizade, porém com uma frequência bem menor do que nas cartas familiares: $4,2 \%$ contra $28,8 \%$. A variante a/para você só ocorreu na amostra carioca, contabilizando apenas duas ocorrências em cartas familiares. Dando prosseguimento, vejamos, na Tabela 8.4, a correlação entre a variável independente em questão e as formas dativas no material produzido na segunda metade do século XX.

Tabela 8.4 - Correlação entre as variantes dativas de segunda pessoa do singular e a temática da carta pessoal - século XX

\begin{tabular}{|c|c|c|c|c|c|c|}
\hline \multirow{2}{*}{\multicolumn{2}{|c|}{$\begin{array}{c}\text { Século } \\
\text { XX }\end{array}$}} & te & lhe & a/para ti & $\begin{array}{c}\text { a/para } \\
\text { você }\end{array}$ & nulo \\
\hline & & $\begin{array}{c}\text { Apl./Total } \\
\%\end{array}$ & $\begin{array}{c}\text { Apl./Total } \\
\%\end{array}$ & $\begin{array}{c}\text { Apl./Total } \\
\%\end{array}$ & $\begin{array}{c}\text { Apl./Total } \\
\%\end{array}$ & $\begin{array}{c}\text { Apl./Total } \\
\%\end{array}$ \\
\hline \multirow{2}{*}{$\begin{array}{c}\text { Romântico- } \\
\text { amorosa }\end{array}$} & SC & $\begin{array}{l}27 / 38 \\
71,0 \%\end{array}$ & - & $\begin{array}{l}1 / 38 \\
2,7 \%\end{array}$ & $\begin{array}{l}2 / 38 \\
5,3 \%\end{array}$ & $\begin{array}{c}8 / 38 \\
21,0 \%\end{array}$ \\
\hline & $\mathrm{RJ}$ & $\begin{array}{l}17 / 52 \\
32,7 \%\end{array}$ & $\begin{array}{l}1 / 52 \\
2,0 \%\end{array}$ & - & $\begin{array}{c}6 / 52 \\
11,5 \%\end{array}$ & $\begin{array}{l}28 / 52 \\
53,8 \%\end{array}$ \\
\hline
\end{tabular}




\begin{tabular}{c|c|c|c|c|c|c}
\hline \multirow{4}{*}{ Familiar } & SC & - & - & - & - & - \\
\cline { 2 - 7 } & \multirow{2}{*}{ RJ } & $6 / 26$ & $6 / 26$ & & $3 / 26$ & $11 / 26$ \\
& & $23,1 \%$ & $23,1 \%$ & - & $11,5 \%$ & $42,3 \%$ \\
\hline \multirow{5}{*}{ Amizade } & \multirow{2}{*}{ SC } & $49 / 89$ & $17 / 89$ & $2 / 89$ & $1 / 89$ & $20 / 89$ \\
& & $55,0 \%$ & $19,1 \%$ & $2,2 \%$ & $1,2 \%$ & $22,5 \%$ \\
\cline { 2 - 7 } & \multirow{2}{*}{ RJ } & $37 / 81$ & $8 / 81$ & & $12 / 81$ & $24 / 81$ \\
& & $45,7 \%$ & $9,9 \%$ & - & $14,8 \%$ & $29,6 \%$ \\
\hline
\end{tabular}

$\mathrm{Na}$ amostra do século XX, percebemos que, assim como na amostra do século XIX, o clítico te foi encontrado nos três tipos de temática, sendo a variante mais frequente nas cartas romântico-amorosas catarinenses (71\%) e nas cartas de amizade de ambas as localidades em estudo (SC: 55\%; RJ: $45,7 \%)$. Outra variante que se destaca na Tabela 8.4 é o dativo nulo, que se configura como a estratégia predominante nas cartas cariocas românticoamorosas $(53,8 \%)$ e familiares $(42,3 \%)$.

Apesar de apresentarem índices percentuais reduzidos, as variantes lhe e a/para você também apareceram nas três temáticas, sendo dignos de nota os $19,1 \%$ de lhe nas cartas catarinenses de amizade, os $23,1 \%$ de lhe nas cartas cariocas familiares e os $14,8 \%$ de a/para você nas cartas cariocas de amizade. A variante a/para ti aparece apenas nas cartas de Santa Catarina, tendo sido computada em missivas de temática romântico-amorosa (uma ocorrência) e de amizade (duas ocorrências).

\subsection{4 $\bigcirc$ sexo dos interlocutores}

Rotulamos a terceira variável independente a ser considerada como sexo dos interlocutores. Na realidade, tentamos dar conta, com essa variável, de dois aspectos bastante pertinentes para os estudos de formas de tratamento ao interlocutor: o sexo dos indivíduos e o tipo de relação entre os interlocutores. Sem entrarmos em maiores detalhes, lembramos que diversos trabalhos salientam o papel sociolinguístico das mulheres nos processos de variação e mudança. No que se refere especificamente às formas pronominais de segunda pessoa do singular, alguns estudos defendem a hipótese de que as mulheres seriam as responsáveis pelo processo de difusão de você no português brasileiro (cf. RUMEU, 2013). Paralelamente a esse fator, outros estudos afirmam que o tipo de interação 
estabelecida entre os interlocutores condiciona diretamente o uso de formas relacionadas ao pronome $t u$ ou ao pronome você. Em certos períodos históricos, o uso de $t u$ denotava elevado grau de intimidade entre os falantes, ao passo que você expressava um tratamento mais respeitoso (cf. SOUZA, 2012).

Diante disso, resolvemos controlar o sexo dos remetentes e dos destinatários das cartas, a fim de observar se a alteração nesses parâmetros (p. ex., um homem escrevendo para outro homem, uma mulher escrevendo para um homem etc.) condicionaria a maior ou menor utilização das variantes dativas de segunda pessoa do singular. Na Tabela 8.5, temos os resultados dessa distribuição para os dados coletados das cartas do século XIX.

Tabela 8.5 - Correlação entre as variantes dativas de segunda pessoa do singular e o sexo dos interlocutores - século XIX

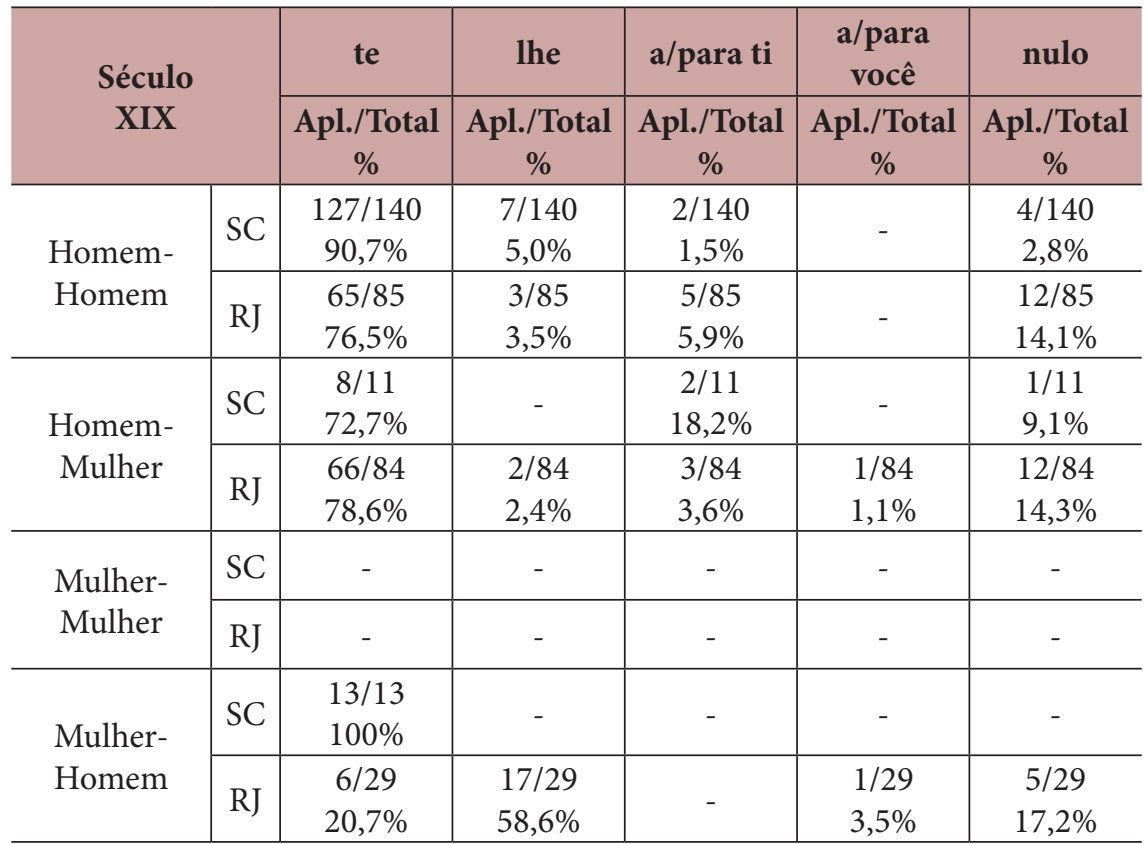


Um primeiro ponto a ser comentado diz respeito à inexistência, em nossa amostra, de cartas do século XIX trocadas entre mulheres. Tal fato pode ser justificado de diferentes formas, porém vamos nos restringir a lembrar que, por um longo período da história, o acesso à educação formal era algo bastante restrito para as mulheres, o que quase sempre dificulta, nas pesquisas sócio-históricas, a obtenção de materiais produzidos por mulheres em períodos mais antigos. Vale lembrar, no entanto, que os remetentes do nosso corpus detinham certo status social, e que, por essa razão, temos cartas produzidas por algumas mulheres, quase sempre destinadas a seus maridos, noivos, pais, irmãos etc.

Quanto ao uso dos pronomes dativos, percebemos que, mais uma vez, a variante te se destaca por figurar nos diferentes tipos de interação. Nas cartas escritas por homens e endereçadas tanto para homens quanto para mulheres, a frequência desse clítico está acima dos $70 \%$ na amostra das duas localidades, alcançando um índice de 90,7\% nas cartas produzidas por homens e endereçadas a homens de Santa Catarina. Nas cartas catarinenses escritas por mulheres e enviadas a homens, o uso de te dativo é categórico.

Outro aspecto a ser comentado nos dados do século XIX refere-se à variante lhe. Registramos a sua utilização, na amostra catarinense, apenas nas cartas escritas por homens e enviadas a homens (sete ocorrências). Já na amostra carioca, essa estratégia apareceu nos três tipos de interação, sendo mais frequente em cartas escritas por mulheres e enviadas a homens (58,6\%). A variante a/para ti ocorreu em cartas escritas por homens e endereçadas a homens e mulheres das duas cidades, tendo contabilizado um baixo número de ocorrências. A variante a/para você teve apenas duas ocorrências, sendo elas pertencentes a cartas cariocas (uma na interação homem-mulher e outra na interação mulher-homem). Vejamos, a seguir, a correlação entre as variantes e a variável em questão nas cartas escritas no século XX. 
Tabela 8.6 - Correlação entre as variantes dativas de segunda pessoa do singular e o sexo dos interlocutores - século XX

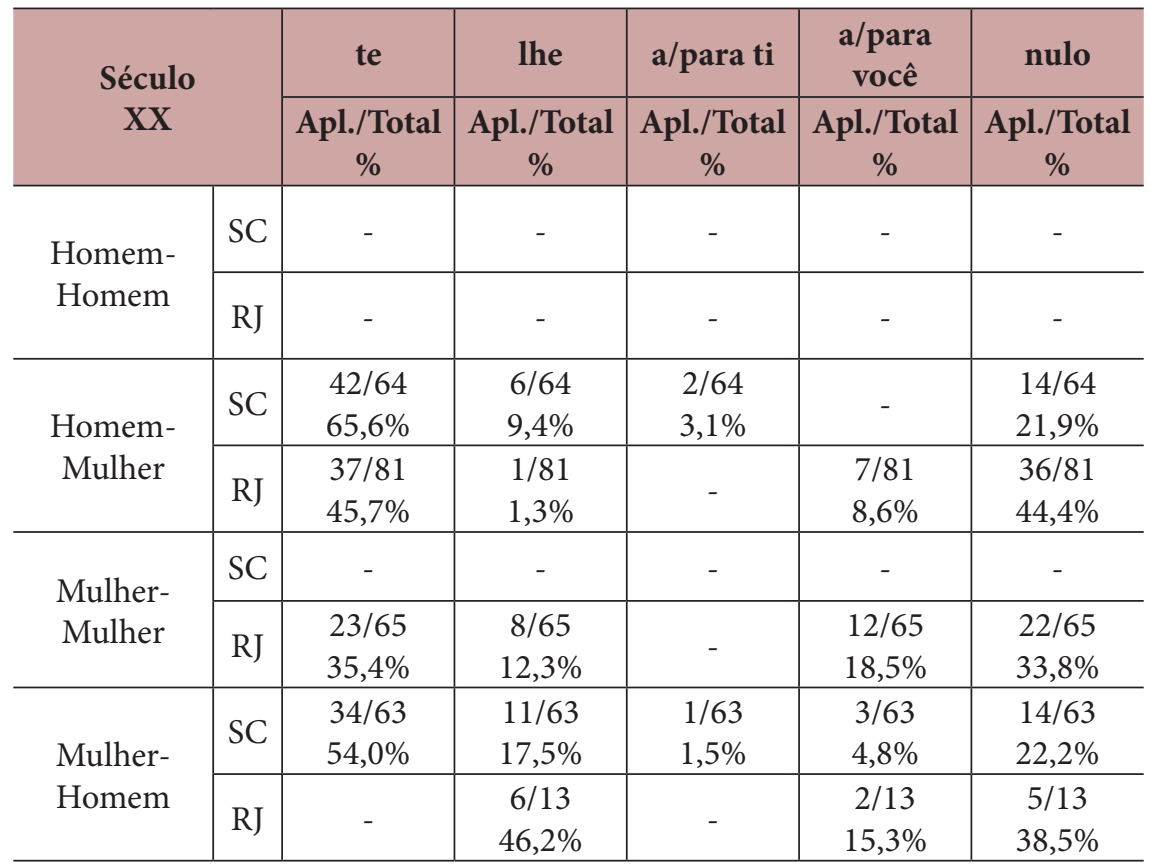

Nas cartas do século XX reunidas no corpus, não detectamos interação do tipo homem-homem, o que nos impossibilita de analisar (e sobretudo comparar com o século XIX) os usos dos dativos pronominais nessa categoria. Apesar disso, há outras observações relevantes que podem ser feitas a partir do exame da Tabela 7.6. Novamente, o clítico te aparece como a variante mais frequente nas cartas catarinenses escritas por homens e endereçadas a mulheres $(65,6 \%)$ e vice-versa (54\%). Entre as missivas cariocas, a variante te foi mais frequente nas interações do tipo homemmulher $(45,7 \%)$ e mulher-mulher $(35,4 \%)$.

A variante the registra maiores índices percentuais nas cartas em que mulheres escreviam para homens, tanto nos dados de Santa Catarina $(17,5 \%)$ quanto nos dados do Rio de Janeiro (46,2\%). Além disso, cabe ainda destacar a produtividade da variante $a /$ para você nas cartas cariocas escritas por mulheres (18,5\% nas interações mulher-mulher e 15,3\% 
nas interações mulher-homem) e do dativo nulo nas cartas cariocas em geral (homem-mulher: 44,4\%; mulher-mulher: 33,8\%; mulher-homem: $38,5 \%)$.

\subsection{Considerações finais}

Com base nos resultados apreciados na análise empreendida acerca da representação da segunda pessoa do singular na posição de dativo em cartas particulares escritas em fins do século XIX e na segunda metade do século XX por florianopolitanos e cariocas, podemos sumarizar alguns aspectos sobre o tema.

Primeiramente, reforçamos a importância da sociolinguística histórica para estudos dessa natureza. Dada a especificidade do corpus histórico, seria inviável explorar os dados obtidos a partir de uma perspectiva puramente laboviana, pois as amostras disponíveis e acessíveis para investigar os fenômenos linguísticos do passado são, em geral, incompletas, fragmentárias e escassas. Em contrapartida, a análise da variação em perspectiva histórica torna-se factível se levamos em consideração os procedimentos metodológicos propostos pela sociolinguística histórica. Assim, pudemos observar panorâmica e comparativamente a dinâmica das variantes de dativo de segunda pessoa do singular em dois recortes geográficos e cronológicos.

Verificamos que o clítico te foi a variante dativa mais frequente na escrita dos informantes analisados em ambas as localidades. Além disso, constatamos que, independentemente da forma pronominal utilizada na posição de sujeito ( $t u$ e/ou você), o clítico te é produtivo e registra uma frequência relativamente alta em quase todas as amostras apreciadas, podendo combinar-se com o pronome você.

O clítico lhe figurou no corpus como uma variante de frequência irregular, cujo uso parece estar condicionado a variáveis de ordem linguística e extralinguística. A referida estratégia apresenta um uso mais expressivo nas missivas em que se utiliza a forma você na posição de sujeito, sobretudo nas cartas catarinenses. Além disso, the parece estar associado a cartas escritas por mulheres e que trazem a temática familiar e de amizade.

Contabilizamos baixos índices de frequência dos sintagmas preposicionados na amostra analisada. Sublinhamos, no entanto, dois 
aspectos interessantes: a inexistência da variante a/para ti nos dados extraídos das cartas cariocas do século XIX e a escassa utilização da variante a/para você nas cartas catarinenses. Esses aspectos parecem estar relacionados ao estágio de implementação da variante você e ao índice de "permanência" da variante tu no sistema das duas variedades investigadas.

Para concluir, destacamos que, por meio deste estudo, pudemos encontrar pontos convergentes e divergentes acerca da variação pronominal de segunda pessoa do singular na função de dativo na escrita de informantes de Santa Catarina e do Rio de Janeiro. Apesar do número limitado de dados, ficou evidente que a entrada da forma você causou certo impacto no uso de formas pronominais das duas localidades, com reflexos na função dativa. Comparando os dados do século XIX com os do século XX, vimos que, nas duas variedades, a competição entre formas se acirrou, ainda que a variante te se mantenha como a mais frequente em alguns contextos. Paralelamente a isso, é incontestável que a intensidade desse processo de variação é bastante diferente nas duas cidades: enquanto identificamos usos mais conservadores na escrita florianopolitana, que respeitam em boa medida a alegada "uniformidade" de tratamento (sobretudo quanto ao uso das formas do paradigma de $t u$ ), percebemos uma dinâmica de variação mais acentuada na escrita carioca, fato que é, possivelmente, um reflexo do processo de implementação mais avançado da variante você nesse dialeto.

\section{Referências}

BERLINCK, R. de A. The Portuguese dative. In: VAN BELLE, W.; VAN LANGENDONCK, W. (ed.). Case and grammatical relations across languages: the dative. v. 1: Descriptive studies. Amsterdam/Philadelphia: John Benjamins, 1996. p. 119-151.

CALLOU, D. M. I. O impacto linguístico da chegada da Família Real ao Rio de Janeiro. Veröffentlichungsreihe des Studienbereiches Neue Romania des Instituts für Romanische Philologie der FU Berlin, v. 39, p. 7-22, 2009.

CONDE SILVESTRE, J. C. Sociolingüística histórica. Madrid: Gredos, 2007.

DUARTE, M. E. L. A perda do princípio "evite pronome" no português brasileiro.

1995. 151 f. Tese (Doutorado em Linguística) - Instituto de Estudos da Linguagem, Universidade Estadual de Campinas, Campinas, 1995. 
HERNÁNDEZ-CAMPOY, J. M.; CONDE SILVESTRE, J. C. The Handbook of Historical Sociolinguistics. Oxford: Wiley-Blackwell, 2012.

HERNÁNDEZ-CAMPOY, J. M.; SCHILLING, N. The Application of the Quantitative Paradigm to Historical Sociolinguistics: Problems with the Generalizability Principle. In: HERNÁNDEZ-CAMPOY, J. M.; CONDE SILVESTRE, J. C. The Handbook of Historical Sociolinguistics. Oxford: WileyBlackwell, 2012. p. 63-79.

KOCH, P.; OESTERREICHER, W. Oralidad y escrituralidad a la luz de la teoría del lenguaje. In: KOCH, P.; OESTERREICHER, W. Lengua hablada en la Romania: español, francés, italiano. Madrid: Gredos, 2007. p. 20-42.

LABOV, W. Principles of linguistic change. v. 1: Internal factors. Oxford/ Cambridge: Blackwell, 1994.

LEITE, Y.; CALLOU, D. M. I. Como falam os brasileiros. Rio de Janeiro: Jorge Zahar, 2002.

LOPES, C. R. dos S.; CAVALCANTE, S. R de O. A cronologia do voceamento no português brasileiro: expansão de você-sujeito e retenção do clítico-te. Revista Lingüística, Madrid, v. 25, p. 30-65, 2011. Disponível em: http://www.mundoalfal. org/sites/default/files/revista/25_linguistica_030_065.pdf. Acesso em: 4 set. 2020.

LOPES, C. R. dos S. et al. A reorganização do sistema pronominal de $2^{2}$ pessoa na história do português brasileiro: outras relações gramaticais. In: LOPES, C. R. dos S. (coord.). História do português brasileiro. v. 4: Mudança sintática das classes de palavra: perspectiva funcionalista. São Paulo: Contexto, 2018. p. 106-189.

LOREGIAN-PENKAL, L. Re(análise) da referência de segunda pessoa na fala da Região Sul. 2004. 261 f. Tese (Doutorado em Letras) - Programa de PósGraduação em Letras, Universidade Federal do Paraná, Curitiba, 2004.

MACHADO, A. C. M. As formas de tratamento no teatro brasileiro e português dos séculos XIX e XX. 2011. 237 f. Tese (Doutorado em Letras Vernáculas) - Faculdade de Letras, Universidade Federal do Rio de Janeiro, Rio de Janeiro, 2011.

MATEUS, M. H. M. et al. Gramática da língua portuguesa. 5. ed. Lisboa: Caminho, 2003.

NUNES DE SOUZA, C. M. A alternância entre tu e você na correspondência de florianopolitanos ilustres no decorrer de um século. 2015. 210 f. Tese (Doutorado em Linguística) - Programa de Pós-Graduação em Linguística, Universidade Federal de Santa Catarina, Florianópolis, 2015.

NUNES DE SOUZA, C. M.; COELHO, I. L. Caminhos para a investigação da alternância de pronomes de segunda pessoa em Santa Catarina. LaborHistórico, Rio de Janeiro, v. 1, n. 1, p. 49-61, jan./jun. 2015. 
NUNES DE SOUZA, C. M.; COELHO, I. L. O sistema de tratamento em Santa Catarina: uma análise de cartas pessoais dos séculos XIX e XX. Revista do GELNE, v. 15, n. 1/2, p. 213-243, 2013.

OLIVEIRA, T. L. Entre o linguístico e o social: complementos dativos de $2^{\mathrm{a}}$ pessoa em cartas cariocas (1880-1980). 2014. 166 f. Dissertação (Mestrado em Letras Vernáculas) - Faculdade de Letras, Universidade Federal do Rio de Janeiro, Rio de Janeiro, 2014.

PAREDES SILVA, V. L. O retorno do pronome tu à fala carioca. In: RONCARATI, C.; ABRAÇADO, J. (org.). Português brasileiro: contato linguístico, heterogeneidade e história. Rio de Janeiro: 7Letras, 2003. p. 160-169.

RUMEU, M. C. de B. Língua e sociedade: a história do pronome "Você" no português brasileiro. Rio de Janeiro: Ítaca, 2013.

SCHERRE, M. M. P. et al. Variação dos pronomes "tu" e "você". In: MARTINS, M. A.; ABRAÇADO, J. (org.). Mapeamento sociolinguístico do português brasileiro. São Paulo: Contexto, 2015. p. 133-172.

SOUZA, C. D. Eu te amo, eu the adoro, eu quero você: a variação das formas de acusativo de 2a pessoa em cartas pessoais (1880-1980). 2014. 156 f. Dissertação (Mestrado em Letras Vernáculas) - Faculdade de Letras, Universidade Federal do Rio de Janeiro, Rio de Janeiro, 2014.

SOUZA, J. P. F. de. Mapeando a entrada do você no quadro pronominal: análise de cartas familiares dos séculos XIX-XX. 2012. 148 f. Dissertação (Mestrado em Letras Vernáculas) - Faculdade de Letras, Universidade Federal do Rio de Janeiro, Rio de Janeiro, 2012.

VAN HOECKE, W. The Latin dative. In: VAN BELLE, W.; VAN LANGENDONCK, W. (ed.). Case and grammatical relations across languages: the dative. v. 1: Descriptive studies. Amsterdam/Philadelphia: John Benjamins, 1996. p. 3-37.

WEINREICH, U.; LABOV, W.; HERZOG, M. Fundamentos empíricos para uma teoria da mudança linguística. Tradução de Marcos Bagno. Revisão técnica de Carlos Alberto Faraco. São Paulo: Parábola, 2006 [1968]. 


\section{Capítulo 9}

\section{Formas de tratamento nas cartas do escritor catarinense Harry Laus para sua tradutora francesa}

Vanessa Grando

\subsection{Introdução'}

Com base em pesquisas do projeto Variação Linguística na Região Sul do Brasil (VARSUL) e do projeto Para a História do Português Brasileiro em Santa Catarina (PHPB-SC) e nos pressupostos da sociolinguística variacionista, este trabalho tem o compromisso de analisar as formas de tratamento nas cartas que Harry Laus escreveu para Claire Cayron.

As cartas selecionadas foram extraídas de Melo (2001), um trabalho de compilação e transcrição de todas as correspondências de Harry Laus. A dissertação contém o resumo de mais de 550 cartas que o autor escreveu,

1 Este capítulo é uma compilação do trabalho de conclusão de curso de Grando (2016). 
além da reprodução fac-similar das cartas que enviou para Claire Cayron. Os fac-símiles encontram-se no Núcleo de Literatura e Memória da Universidade Federal de Santa Catarina (nuLIME/UFSC).

Harry Laus catalogava suas cartas num arquivo pessoal, em sua residência, cujos assuntos variam entre pessoal e profissional, e além de arquivar as cartas que recebia, mantinha cópia das que enviava. Essa noção de arquivo deixa a impressão de que o autor sabia da importância posterior de todas as suas obras, que não eram apenas novelas e romances, mas também diários e cartas.

O objeto de estudo do presente artigo são as 93 cartas que Harry enviou a Claire, entre os anos de 1984 e 1992. Assim, a partir de pressupostos da teoria variacionista, este trabalho tem o objetivo de investigar as formas de tratamento utilizadas nas correspondências enviadas para a tradutora.

Com esse material em mãos, observamos os vocativos (formas nominais) e a variação entre tu e você - pronomes de segunda pessoa do singular ( $2^{\underline{a}}$ p.s.). Para analisá-los, olhamos para todas as formas associadas ao tu e para todas as formas associadas ao você, definindo-as como paradigmas de sujeito, de possessivo, de imperativo e de complemento.

A partir de uma perspectiva diacrônica, buscamos elucidar os seguintes objetivos específicos: (i) identificar, nas formas de tratamento, indícios mais formais ou menos formais; (ii) identificar os vocativos usados nas cartas; (iii) descrever os paradigmas de tu e você e os contextos sintáticos em que eles aparecem; (iv) analisar o assunto das cartas e relacioná-lo à categoria profissional, pessoal ou mista; (v) estabelecer uma correlação entre os paradigmas de $t u$ e você e o assunto das cartas, e entre esses paradigmas e o período em que as cartas foram escritas, para compreender melhor as diferenças tratamentais.

Ao analisar as cartas, surgiram algumas questões. As formas de tratamento utilizadas sofrem variação? Como os vocativos se apresentam? Qual a relação entre o vocativo em uso e as escolhas dos paradigmas de $t u$ e você? Entre os paradigmas de tu e você, qual prevalece nas cartas? Que relação há entre a forma de tratamento e o assunto da correspondência?

Levando em conta a literatura linguística respaldada em conhecimento científico, a hipótese era que Harry Laus usasse mais formas de tu do que de você em suas cartas e que, conforme a relação se estreitasse 
ao longo dos anos, os assuntos evoluíssem de profissional para pessoal, as formas de tratamento passariam de uma esfera mais formal (formas de você) para uma esfera mais íntima (formas de $t u$ ). ${ }^{2}$

O presente trabalho se estrutura da seguinte forma: a Seção 9.1 norteia os caminhos deste estudo; a Seção 9.2 apresenta os pressupostos teóricos, apontando as teorias usadas e a história dos pronomes de tratamento de segunda pessoa do singular; a Seção 9.3 descreve a relação autor/tradutora, trazendo um breve histórico do gênero epistolar, uma breve biografia e o contato entre os dois interlocutores; a amostra é apresentada na Seção 9.4, que contém alguns trechos das cartas e a discussão sobre vocativo; a Seção 9.5 desenvolve a análise variacionista dos grupos de fatores controlados; ${ }^{3}$ e, por fim, a Seção 9.6 encerra o artigo com as considerações finais.

Além da observação social lançada sobre o autor e as cartas, tratamos, neste trabalho, dos pressupostos teóricos arraigados na Teoria da Variação e Mudança - fundamentada elementarmente por Labov (2008 [1972]); da origem e evolução dos pronomes tu e você - substancialmente sob a luz dos estudos de Faraco (1996); da relação tu e você enquanto pronomes de segunda pessoa do singular, apresentada por Lopes e Marcotulio (2011); da função social dessa literatura epistolar ocorrida ao longo de oito anos (1984 a 1992); assim como da importância literário-histórica das correspondências como memória para a história do português brasileiro.

\subsection{Pressupostos teóricos}

A teoria em cujo estudo se baseia este trabalho é a sociolinguística variacionista, também conhecida como sociolinguística laboviana - por ter o linguista William Labov como principal teórico -, bem como sociolinguística quantitativa, por se tratar de análise estatística de dados, e, ainda, conhecida também como Teoria da Variação e Mudança Linguística, em que a variação e a mudança da língua são os principais fatores observados. Essa teoria se ampara em investigações com abordagem da sociolinguística,

2 Cf. pesquisas do projeto VARSUL.

3 Termo usado para contemplar os tipos de variáveis analisados no presente trabalho; neste caso, as variações de $t u$, de você e das demais formas nominais referentes à segunda pessoa do singular. 
"uma área da linguística que estuda a relação entre a língua que falamos e a sociedade em que vivemos" (COELHO et al., 2015, p. 14).

Partindo do pressuposto de que a língua está sujeita à variação diacrônica, em que sua história externa e interna evolui dentro de um espaço de tempo (ILARI; BASSO, 2007), que é um sistema heterogêneo, ordenado, e que existem diversos estudos de investigação sociolinguística laboviana (cf. COELHO et al., 2015), revisitamos trabalhos que mostram a história e a evolução da forma de tratamento Vossa Mercê > você, bem como a variação entre as formas de segunda pessoa do singular, tu e você.

A investigação diacrônica das formas de tratamento abre porta para o campo dos pronomes e, assim, adentramos um corredor que possibilitou consultarmos algumas gramáticas tradicionais (GTs). Cegalla (2008) afirma que os pronomes indicam a pessoa do discurso, substituindo ou determinando os substantivos. Para Bechara (2015), os pronomes reúnem unidades em número limitado e se referem a um objeto substantivo, considerado pessoa localizada no discurso: o falante (primeira pessoa) e o ouvinte (segunda pessoa).

Considerando o crescente interesse em estudos sociolinguísticos, pode-se dizer que há uma linha tênue que diferencia o pronome pessoal de $2^{\text {a }}$ p.s. tu do pronome de tratamento você. Alguns estudos, como os de Lopes $(2008,2014)$, contudo, já consideram você como pronome pessoal de $2^{\underline{a}}$ p.s. (competindo com o $t u$ ), mas conservando características de terceira pessoa do singular ( $3^{\text {a }}$ p.s.) - tu foste, você foi, embora, salvo poucas exceções, ainda seja julgado como um pronome de tratamento pela tradição gramatical (na mesma seção de Senhor, Vossa Senhoria, Vossa Magnificência etc.).

Para que se possa esclarecer o fenômeno em estudo, passamos a uma breve resenha dos trabalhos de Faraco (1996) e de Lopes e Marcotulio (2011).

\subsubsection{A evolução do você}

Significativo estudo sobre a evolução do você é apresentado por Faraco (1996), que se dedicou às pesquisas sobre a história dos pronomes de tratamento e sobre a história da sociedade portuguesa. De acordo com esse estudo, o você sofreu mudanças que deram em modificações nos paradigmas verbais e pronominais do português. Segundo o autor, 
o tratamento pronominal do português tem origem no sistema latino de tratamento, que usava os paradigmas de tu e vos para interlocutores do singular menos formais e para formalidades de referência singular ou plural, respectivamente, observados em textos do século XVI.

Das línguas românicas, a portuguesa herdou características que se combinaram com atuais reformulações: expressões herdadas do latim conjugadas em $2^{\mathrm{a}}$ p.s. e novas expressões combinadas com a $3^{\mathrm{a}}$ p.s. ${ }^{4}$ Assim, como herança do sistema latino, a língua portuguesa, inicialmente, registrava o tu para referência menos formal e o vos para referências formais. As mudanças no sistema linguístico apareciam a partir do uso tanto de $2^{\text {a }}$ p.s. quanto de $3^{\text {a }}$ p.s. Esse tipo de alteração causou certa instabilidade nos traços da língua, uma "revolução da terceira pessoa", segundo Marilina dos Santos Luz (1957 apud FARACO, 1996), considerando as grandes mudanças morfológicas e sintáticas pelas quais passou o sistema de tratamento.

Conferindo a história do sistema de tratamento do português e, ainda, expandindo o estudo para a história da sociedade portuguesa que viveu em fins da Idade Média, observa-se que a partir do século XIV foram introduzidas na língua portuguesa estruturas sob a forma Vossa + N: Vossa Mercê, Vossa Senhoria, Vossa Alteza, Vossa Excelência, Vossa Majestade (como ocorreu em outras línguas europeias, porém o destaque aqui é para a portuguesa). A partir dessas formas, Vossa Merce, ${ }^{5}$ estrutura mais antiga, evoluiu gerando um novo pronome de $2^{\mathrm{a}}$ p.s.: você. Cabe relembrar sobre a instabilidade repercutida na gramática:

O novo elemento gramatical, em razão de sua principal característica (pronome de segunda pessoa do discurso, mas estabelecendo concordância com a terceira pessoa verbal) - característica que o colocou em forte contraste com os pronomes antigos (que estabeleciam concordância com a segunda pessoa verbal), desencadeou diferentes rearranjos nos sistemas verbal e pronominal das línguas em questão, particularmente do português. (FARACO, 1996, p. 55).

${ }_{4}$ Algumas línguas neolatinas, como o francês, ainda guardam esses traços.

5 Mercê, do latim mercês, -edis: 'salário, prêmio', derivação de merx mercis. A palavra mercê significa favor, gosto, graça, paga. Merceeiro, 'indivíduo a quem se dava pensão ou casa, com certos encargos espirituais'. Mercearia, mercar, mercadoria (CUNHA, 2010, p. 421). 
O entendimento sobre a introdução de estruturas inovadoras de tratamento está no conhecimento da história e da economia da sociedade portuguesa, que, a partir do século XII, começou a adquirir características novas com o surgimento da burguesia, ${ }^{6}$ uma classe social emergente que desenvolveu formas alternativas de tratamento que competiam com as das camadas mais nobres da sociedade.

Para se diferenciarem das camadas menos nobres, os reis e o clero passaram a ter uma referenciação pronominal diferente daquelas, afinal a burguesia, aumentando sua riqueza, passou a ter representantes na corte e evoluiu para uma aristocracia burocrática que agora exigia suas próprias formas de tratamento. Essa nova vida social, com seus costumes e protocolos, alcançou o pico na transição do século XV para o século XVI.

Como reflexo de novas situações comunicativas que se desenvolvem através do tempo e da história e de relações sociais e interpessoais, está a língua, uma propriedade característica que acompanha as mudanças como indício de variação e adaptação linguística de uma sociedade; a língua "é o mais sensível indicador das mudanças sociais", como disse Bakhtin (1973 apud FARACO, 1996), é uma prova das mudanças que acontecem em uma sociedade dentro de um espaço de tempo. E no interior da língua, as formas inovadoras dos pronomes de tratamento são reflexo desses indicativos.

\subsubsection{Tu versus você}

A atenção lançada sobre as mudanças linguísticas tem raízes antigas: as ocorrências de tu e você em forma concomitante não são recentes. É através de análises das formas de tratamento encontradas em documentos escritos, como cartas pessoais ou oficiais, e mesmo em peças de teatro, que se pode investigar a variação desses dois agentes pronominais inseridos num determinado contexto.

Baseados em estudos sobre o português brasileiro (PB), Lopes e Marcotulio (2011) apresentam um panorama da amostra de cartas escritas a Rui Barbosa de 1866 a 1899, em que os pronomes tu e você fundiram-se

6 A burguesia aparece a partir do surgimento e desenvolvimento do comércio, centralizando poder nas mãos de comerciantes que passam a adquirir terras e, assim, enriquecer e conquistar espaço na corte nobre portuguesa. Para mais detalhes, consultar Faraco (1996). 
pela sua coexistência, gerando um novo paradigma pronominal: você continua com características de $2^{\underline{a}}$ p.s., mas concorda com a $3^{\underline{a}}$ p.s.

De acordo com estudos de diferentes amostras do século XIX, como afirmam os autores, $t u$ era usado em momentos de mais intimidade numa relação de simetria entre os interlocutores de classes mais populares ou em relações de assimetria de superior para inferior, enquanto você era menos frequente e usado como estratégia de prestígio pela elite brasileira. Segundo os autores, acredita-se que essa superposição do você ao tu, como forma prestigiada pela parcela de pessoas com maior instrução, esteja relacionada à história do processo de gramaticalização de Vossa Mercê > você, já que o primeiro era usado como forma de respeito à realeza (FARACO, 1996).

Koch (2008 apud LOPES; MARCOTULIO, 2011) argumenta que você teria vindo da tradição de distanciamento e respeito do Vossa Mercê e caracterizaria o ato como menos invasivo, enquanto tu invadiria o território do outro, numa relação solidariamente discursiva.

A forma pronominal você pode ter mantido algum valor de cortesia, formalidade, distanciamento ou indiretividade própria da expressão primitiva Vossa Mercê. Nesse sentido, o seu emprego no lugar do tratamento direto $t u$ poderia ser uma estratégia de polidez/cortesia que funciona pragmaticamente como um recurso mitigador que minimizaria um determinado ato, preservando as faces dos participantes da interação. (LOPES; MARCOTULIO, 2011, p. 271).

A observação das cartas pelos autores mostra que as formas de tratamento foram escolhidas de acordo com o assunto e com o nível da relação interpessoal entre os correspondentes (se mais ou menos íntimo, se mais ou menos formal, se mais ou menos distante). Em determinadas cartas formais, chegou-se à conclusão de que a posição social do remetente e o teor do documento influenciaram a escolha das formas de tratamento. Nas cartas escritas pelo então presidente da República Prudente de Morais a Rui Barbosa, segundo o estudo, prevaleceu o uso de Vossa Excelência, o que validou a hipótese de seleção de tratamento a uma posição social ilustre.

O estudo, contudo, salientou a análise das cartas escritas por Carlos Aguiar, correspondências de uma relação de amizade nas quais se apresenta a mescla de tu e você em uma mesma carta. Afirma-se ainda que diversos 
estudos já mostraram a tímida e aparente mescla dos pronomes em cartas de fins do século XIX da família Ottoni e de outros missivistas desse século, e ainda em dados de peças teatrais cariocas do século XX e em cartas de cariocas dos séculos XIX e XX. Os dados estão registrados, embora o ensino tradicional ainda condene tal tipo de uso híbrido. Os resultados acusaram o predomínio de um paradigma de você na função de sujeito e nas formas de imperativo, embora a forma $t u$ fosse de uso geral mais frequente.

As correlações entre paradigmas de tu e você inseridas num mesmo contexto indicam que este último está se inserindo no sistema pronominal, mas com taxas de frequência ainda menores que o antigo. Dessa forma, essa variação concomitante deu origem a um aparente pronome supletivo com formas de tu e de você.

Duas hipóteses se confirmaram com o estudo: a posição de sujeito foi o espaço de inserção do emergente você, ou seja, foi através da posição de sujeito que o você passou a concorrer com o antigo $t u$ (este enquanto sujeito nulo); e os resultados confirmam também a hipótese de que o você ainda carrega resquícios de distanciamento herdados do Vossa Mercê, deixando a cargo do novo pronome a seleção através do discurso sociopragmático, mesmo dentro de um contexto de solidariedade do $t u$.

Diante dessas ratificações, traçou-se um paralelo com a Teoria da Polidez de Brown e Levinson (1987), através da qual se defende que determinados pronomes de tratamento sobrevivem a um ambiente de interação em que os interactantes poderiam estar invadindo o espaço do outro num sentido de ameaça, e é nesse momento que se recorre a estratégias de polidez para garantir a harmonia entre os interlocutores (LOPES; MARCOTULIO, 2011).

O que se pode concluir é que (i) a escolha do tratamento você, como estratégia atenuante de distanciamento, demonstra respeito pelo espaço do interlocutor; e (ii) a noção de que tornar o discurso mais íntimo através da escolha da forma $t u$ invadiria o espaço particular do outro, a não ser que este o permita.

\subsection{A relação Harry-Claire}

Além da investigação linguística, a fim de que se pudesse analisar o tipo de relação (se profissional, pessoal ou ambas), e ainda o quanto esse 
resultado poderia influenciar a escolha entre os paradigmas de $t u$ e você, consideramos importante também olhar para o relacionamento entre os dois correspondentes através de cada uma das cartas. Apresentamos, então, a trajetória dos personagens, uma história sucinta de Harry Laus e de Claire Cayron, e da relação, que cresceu da de meramente profissional para a de zelosa amizade.

\subsection{1 $\bigcirc$ escritor catarinense}

Harry Laus (1922-1992) nasceu em Tijucas, litoral norte do estado de Santa Catarina, sul do Brasil. A situação humilde da grande família de descendentes de alemães levou-o ainda jovem (1941/43) a estudar na Escola Preparatória de Cadetes para ingressar na Escola Militar (BRUCHARD, 2012, p. 37). Órfão de mãe e homossexual, ${ }^{7}$ Harry foi morar com um de seus irmãos em Passo Fundo, Rio Grande do Sul, para terminar seus estudos colegiais (MUZART, 1992).

A carreira militar não limitou o seu trabalho de escritor. Mais tarde, tornou-se funcionário público e crítico de arte. Publicou diversos artigos e livros, entre eles As horas de Zenão das Chagas (1987), La Première Balle (1989), Jandira (1989), Os papéis do Coronel (1992), obras de pouco reconhecimento no Brasil e de maior repercussão na França por "culpa" das traduções de Claire Cayron, para quem dedica a publicação de obras e a quem se sente eternamente agradecido.

Várias honrarias foram feitas em deferência ao escritor catarinense. Uma sala no prédio do Centro Integrado de Cultura (CIC) e outra sala na Biblioteca Universitária Central da UFSC levam o seu nome. O SENAI da cidade de Tijucas-SC possui a Biblioteca Harry Laus. O blog Memorial Harry Laus, criado por Egeu Laus, comunica a inauguração da Travessa Harry Laus no centro da cidade de Florianópolis, uma pequena rua transversal à Avenida Beira-Mar Norte.

Harry Laus morava com sua irmã Celeste, na época em que se correspondia com Claire Cayron, no centro de Florianópolis e, de vez em quando, hospedava sua outra irmã que vinha do Rio de Janeiro, Ruth Laus.

\footnotetext{
"Não sei dar explicações convincentes para ti, mas posso vislumbrar algo na pobreza que caracterizou minha infância, na perseguição homossexual que sempre sofri na vida (família, igreja, exército, sociedade, eu próprio que não admito)” (27/2/1992).
} 
Tinha também uma residência em Porto Belo, como descreve nas cartas, para onde viajava frequentemente. Embora morasse em um apartamento no Centro, por causa de problemas de convívio, em 1991 compra uma casa no bairro Campeche, no sul da ilha de Santa Catarina, onde passa seus últimos meses de vida.

$\mathrm{Na}$ carta de 1\%/10/1991, Harry escreve contando sobre um câncer de pulmão diagnosticado por meio de uma bateria de exames, e a partir de então, além de assuntos profissionais, passa a tratar sobre o processo da doença. Em 22/5/1992, escreve a última carta para sua amiga e falece em 24/5/1992. Nesse mesmo ano, quando completaria 70 anos, foi homenageado in memoriam com a publicação do livro Tempo e andanças de Harry Laus: 1922-1992, organizado por Zahidé Muzart, com quem mantinha contato a propósito das vindas de Claire Cayron para eventos na UFSC.

\subsubsection{A tradutora francesa}

Claire Cayron (1935-2002) morava em Bordeaux, na França. Trabalhava como tradutora com exclusividade para a editora José Corti. Ficou conhecida por seu trabalho de tradução das obras do português Miguel Torga, ${ }^{8}$ ao qual se dedicou por mais de 25 anos. Do Brasil, traduziu obras de Harry Laus e de Caio Fernando Abreu, além de ser responsável por disseminar as obras dos dois na França. Conheceu Caio por sugestões de leitura enviadas por Harry Laus. Foi professora de Literatura Geral e Comparada no Institut Universitaire de Technologie (IUT) e membro da Association pour la promotion de la traduction littéraire ${ }^{9}$ (ATLAS).

Exprime sua modéstia e humildade quando responde como seria sua assinatura em trabalhos de tradução ou de orelha de publicação, como o fez para Fábio Brüggemann, escritor catarinense e um de seus correspondentes, em e-mail datado de agosto de 1999: "Da professora que fui, o texto da orelha fala, escritora não sou, fica o meu máximo título de glória presente (e pelo porvenir que me fica!): Tradutora (das obras de Miguel Torga, Harry Laus, Caio Fernando Abreu e vários outros)". Mais tarde, outro fato

8 Adolfo Correia da Rocha (1907-1995), conhecido por Miguel Torga, escritor português.

9 Associação para a Promoção da Tradução Literária. 
registra a sua autodenominação diante de um comentário chamando-a de "escritora francesa”: "[...] quero precisar que não me considero escritora. Simplesmente tradutora. Os escritores são criadores, eu não sou: para mim não há 'página branca"' (MELO, 2001). Faleceu em 2002, aos 67 anos, deixando família e uma vasta lista de obras traduzidas do português para o francês.

\subsection{3 $\bigcirc$ contato}

Harry Laus falava francês e tinha grande conhecimento literário. Conhecia a obra de Torga e, consequentemente, o trabalho de tradução para o francês de Claire Cayron. Por volta de 1983, enviou material para o editor da tradutora.

No artigo “Traduzir Harry Laus” (MUZART, 1992), Claire Cayron conta como teve contato com a obra e com o próprio autor. Em 1984, recebeu coletâneas, entre as quais se encontrava o conto "As horas de Zenão das Chagas", pelo qual muito se interessou. Assim, contando os motivos pelos quais não poderia traduzir a obra naquele ano, escreveu para Harry Laus, de quem recebeu a seguinte resposta: "Creio que ver esta obra traduzida para o francês por quem tão bem traduz Torga será uma honra para mim” $(10 / 3 / 1984)$. Ele esperaria o tempo que fosse pela tradução.

A resposta francesa veio em meados de 1986, quando Claire traduziria o primeiro conto que recebera do autor catarinense, por puro gosto pela tradução e pela literatura de língua portuguesa de cunho brasileiro. A partir de então, Harry e Claire passam a trocar frequentes cartas, telegramas, cartões-postais e hospedagem.

A leitura das cartas fica mais interessante quando se analisa a correlação entre os vocativos e as formas de tratamento e entre estes e o ano da escrita ou o assunto, e se percebe o resultado da relação entre os dois correspondentes.

\subsection{A amostra Harry Laus}

Ao ter contato com o objeto de estudo, veio à tona a importância do arquivamento, afinal é de um arquivo que vêm os documentos analisados, e se não fosse por ele, não teríamos acesso à troca de correspondências 
entre Harry e Claire. Mesmo que por simples curiosidade, fez-se necessário acessar os fac-símiles. Ter em mãos as cartas que o próprio Harry Laus escreveu e segurar o mesmo documento que o autor segurou é como entrar no túnel do tempo. São materiais que ele tocou e aos quais dispensou tempo para ali escrever de próprio punho sobre sua literatura, traduções, exposições, publicações, assuntos da sua vida ou do país em que vivia etc.

O acesso a essas cartas não se deu só pelo interesse nas conversas epistolares, mas também pela preocupação em manter o registro dessas memórias. Através do arquivamento, temos noção da trajetória dos documentos: de onde vieram, por onde andaram, onde estão, quem os guarda e por que são conservados. Segundo Gonzaga, o arquivo é "um lugar físico que acolhe um determinado rastro documental, e ainda, [...] trabalharia como um conservador da memória, ao resguardar aqueles documentos desviados [...] através do tempo" (GONZAGA, 2016, p. 66).

Isto posto, passamos à amostra Harry Laus, que engloba as cartas que o escritor catarinense enviou ${ }^{10}$ para sua tradutora Claire Cayron, contendo formas associadas ao $t u$, formas associadas ao você e formas mistas ( $t u e$ você), conforme apresenta a Tabela 9.1.

Tabela 9.1 - Quantidade de cartas com paradigmas de $t u$, de você e mistos

\begin{tabular}{c|c|c}
\hline $\begin{array}{c}\text { Cartas com formas } \\
\text { associadas ao } t u\end{array}$ & $\begin{array}{c}\text { Cartas com formas } \\
\text { associadas ao } \text { você }\end{array}$ & $\begin{array}{c}\text { Cartas com paradigmas } \\
\text { mistos }\end{array}$ \\
\hline $\begin{array}{c}\text { Apl./Total } \\
\%\end{array}$ & $\begin{array}{c}\text { Apl./Total } \\
\%\end{array}$ & $\begin{array}{c}\text { Apl./Total } \\
\%\end{array}$ \\
\hline $70 / 93$ & $8 / 93$ & $15 / 93$ \\
$75,27 \%$ & $8,6 \%$ & $16,13 \%$ \\
\hline
\end{tabular}

Fonte: Adaptada de Grando (2016, p. 37).

A Tabela 9.1 permite-nos observar a grande manifestação dos paradigmas de $t u$ distribuídos integralmente em 70 cartas, enquanto os paradigmas de você distribuem-se em oito. Já num contexto híbrido, os dois paradigmas aparecem num mesmo trecho, em cartas que denominamos

10 As cartas de Claire totalizam mais ou menos a mesma quantidade das escritas por Harry, e não foram consideradas nesta análise por estarem, em sua grande maioria, escritas em francês. 
“mistas" ou "paradigmas mistos", e estão representados em 16\% (15 cartas), ou seja, Harry Laus, nesses casos, usa tanto paradigma de tu quanto de você numa mesma carta, conforme (1).

(1) [20,2 CP SC] Gostei muito de tua conferência sobre os problemas da tradução. Acho que é perfeita para ser dita ou lida no Brasil. Confesso que sempre me admirou muito o quanto você consegue ser fiel ao escritor, inclusive ao ritmo da frase. $(22 / 11 / 1987)^{11}$

Matematicamente falando, os $16 \%$ de cartas mistas representam a intersecção entre o conjunto de cartas com os paradigmas de tu e o conjunto de cartas com os paradigmas de você. Mesmo que o terceiro conjunto (mistas) não exista, os paradigmas de tu prevalecem. No entanto, o destaque para essas cartas é justamente para entender por que tal mistura acontece.

Além dos estudos sociolinguísticos que atestam a variação de você e $t u$ no $\mathrm{PB}$, algumas gramáticas trazem informações sobre a coexistência desses dois tipos de paradigmas. Segundo Azeredo (2013), nas variedades coloquiais pode haver, num mesmo discurso, a coexistência dos pronomes você e tu e seus paradigmas, conforme aparece em (1). Bechara (2015) descreve você como uma "forma de tratamento indireto" de segunda pessoa que leva o verbo ao qual está ligado para a terceira pessoa, contudo ainda não o considera como pronome reto, assim como pactuam Cegalla (2012 [2008]), Cunha (2015) e Bezerra (2015).

Cunha (2015) inclui você junto ao tu e ao o senhor na lista de pronomes de tratamento empregados na segunda pessoa, e Cegalla (2012 [2008]) designa você para tratamento familiar ou informal. Bezerra (2015, p. 236-240) observa que você foi praticamente sendo substituído pelo tu na fala coloquial e descreve ainda, assim como Cunha (2015, p. 167), que o tu é falado em poucas regiões do Brasil (restringido ao extremo sul e a alguns pontos do norte), flexionando o verbo na terceira pessoa do singular.

Deixando um pouco de lado a versão tradicional das gramáticas, de acordo com o estudo de Duarte (1993), o sistema pronominal do PB vem se

11 Todos os exemplos mostrados são passagens coletadas das cartas de Harry Laus para Claire Cayron e seguirão com a data em que a carta foi escrita. As reproduções podem ser consultadas em Melo (2001). 
transformando de um quadro tradicional com seis formas (eu, tu, ele, nós, vós, eles) em um quadro com quatro formas (eu, tu/você/ele, nós/a gente, vocês/eles), em que, segundo a autora, a segunda pessoa direta (tu) passou a coexistir com um terceiro paradigma (você), o qual conserva propriedades de $3^{\text {a }}$ p.s., sendo a forma emergente. Vale aqui relacionar essa afirmação com o que Lopes e Marcotulio (2011) falam sobre "pronome supletivo", pois são conclusões semelhantes.

\subsection{1 $\bigcirc$ vocativo}

Como expressão que faz parte das formas de tratamento, o vocativo pode ser uma forma nominal, e/ou, segundo Monteiro (1994), um pronome de intenção respeitosa. Para Bechara (2015), o vocativo cumpre uma função apelativa de segunda pessoa através da qual chamamos ou pomos em evidência a pessoa a quem nos dirigimos, representada por substantivo ou pronome. Pode, assim, ser observado em (2):

(2) [20,2 CP SC] Prezada Senhora Claire Cayron:

Recebi sua carta de 17 com o xerox de "Livres-Hebdos" falando em nosso Zenão. Merci. Minha carta de 8 já deve estar em suas mãos. Nela eu lhe dava conta de que escrevi a Arcane 17, como me sugere. $(24 / 7 / 1987)$

Segundo Azeredo (2013), uma pessoa pode dirigir-se a seu interlocutor ou correspondente de diversas maneiras, usando as expressões de tratamento (você - forma pronominal característica da interlocução coloquial, tu, o/a senhor/a, prezado/a, caro/a colega, companheiro/a, senhor/a, gente, galera etc.) de acordo com a relação social ou afetiva que os relaciona no momento da interação.

Algumas são protocolares ou ritualizadas (prezado cliente, senhores e senhoras), usadas apenas como vocativos dirigidos a um público indiferenciado; outras revelam que o enunciador identifica o perfil social do interlocutor e o individualiza (doutor, colega). (AZEREDO, 2013, p. 264).

Através da leitura do vocativo podemos compreender se há aproximação ou distanciamento entre os dois correspondentes (BROWN; 
GILMAN, 2003). O objetivo dessa observação é saber que relação há entre a escolha do vocativo e o assunto das cartas que Harry escrevia para a tradutora e, sobretudo, entender a seleção dos pronomes de tratamento em consequência dessa escolha e como a variação dessas formas se manifesta à medida que o tempo passa.

O vocativo, nesta amostra, aparece no cabeçalho da carta e, conforme explica Bechara (2015), “[...] vem separado do resto do enunciado por vírgula, enquanto em textos de outra natureza costuma aparecer o emprego dos dois-pontos (:) ou do ponto de exclamação (!)”. Como demonstra o Quadro 9.1, os vocativos se distribuem numa relação entre assunto, data, formas de tratamento e paradigmas de tu e você. As datas representam o momento em que o vocativo foi citado pela primeira vez (a partir daí as escolhas não são categóricas, ou seja, Harry usa o novo sem, no entanto, deixar de citar outros que já tenha usado).

Quadro 9.1 - Relação entre vocativo, assunto, forma de tratamento e paradigmas.

\begin{tabular}{|c|c|c|c|}
\hline $\begin{array}{c}\text { Data da } \\
\text { carta }\end{array}$ & Vocativo & $\begin{array}{c}\text { Assunto da } \\
\text { carta }\end{array}$ & $\begin{array}{c}\text { Forma de tratamento } \\
\text { e paradigmas } \\
\text { predominantes }\end{array}$ \\
\hline $10 / 3 / 1984$ & Prezada Mme. Claire Cayron & Profissional & Você \\
\hline $25 / 11 / 1986$ & $\begin{array}{c}\text { Muito prezada senhora } \\
\text { Claire Cayron }\end{array}$ & Profissional & Você, senhora \\
\hline $29 / 1 / 1987$ & $\begin{array}{c}\text { Prezada senhora } \\
\text { Claire Cayron }\end{array}$ & Profissional & Você, Mme. \\
\hline $6 / 7 / 1987$ & $\begin{array}{c}\text { Muito prezada Mme. } \\
\text { Claire Cayron }\end{array}$ & Profissional & Você \\
\hline $22 / 11 / 1987$ & Minha cara Clara Claire & Profissional & Você \\
\hline $13 / 12 / 1987$ & Muito prezada e amiga Claire & Profissional & Você, tu \\
\hline $18 / 12 / 1987$ & Minha querida Claire & Misto & Você, tu \\
\hline $25 / 12 / 1987$ & Muito prezada Claire & Misto & Tu, dear \\
\hline $14 / 1 / 1988$ & Prezada Claire & Profissional & Tu \\
\hline $20 / 1 / 1988$ & Dona Claire & Misto & Tu \\
\hline $6 / 3 / 1988$ & Querida Claire & Profissional & Tu \\
\hline $15 / 4 / 1988$ & Dear Clarinha & Profissional & Você, tu \\
\hline $21 / 4 / 1988$ & Muito prezada Claire & Profissional & Tu, dona Clarinha \\
\hline $9 / 5 / 1988$ & Dear Claire & Pessoal & Tu, Clarinha \\
\hline
\end{tabular}




\begin{tabular}{|c|c|c|c|}
\hline $21 / 5 / 1988$ & $\begin{array}{c}\text { Minha cara Clarinha de } \\
\text { Bordeaux }\end{array}$ & Profissional & Você, tu, madame \\
\hline $15 / 1 / 1989$ & Prezada Claire & Misto & Você, tu, minha Clara \\
\hline $1 / 1 / 1990$ & Claire & Misto & $\mathrm{Tu}$ \\
\hline $1 / 3 / 1990$ & Chère Claire & Misto & $\mathrm{Tu}$ \\
\hline $20 / 5 / 1992$ & Claire, ma fleur & Misto & $\mathrm{Tu}$ \\
\hline
\end{tabular}

Fonte: Adaptada de Grando (2016, p. 41).

Refletindo sobre como o autor escolhia o vocativo, observamos uma peculiaridade na assinatura das cartas que não se limita às cartas de Harry; ela pode ser observada também nas cartas de Claire, embora não as consideremos neste trabalho. A forma como os dois assinam também nos dá a impressão de que o relacionamento se estreita carta após carta. Algumas escritas a máquina são assinadas de próprio punho. É a partir desse instante que, em vez de datilografar sua assinatura, o correspondente prefere tomar uma caneta para rubricar a carta, deixando sua marca pessoal. Nas primeiras correspondências, assinam o nome inteiro; depois passam a assinar apenas o primeiro nome e às vezes somente as iniciais.

Vale ainda comentar que, por pura curiosidade e acaso, ao analisar certas cartas de Claire em resposta, a tradutora assina um de seus postais como "Clarinha!". Será que Harry já a teria chamado dessa forma em postagem anterior (alguma que tenha se perdido)? Ou será que Claire usou sua assinatura para abrandar a impessoalidade? Isso nos leva a pensar que pode ter partido de Claire a aproximação através dessa aparente "permissão" registrada na assinatura.

A partir do Quadro 9.1, registramos a quantidade de ocorrências de vocativos e os relacionamos à época em que foram citados para saber qual deles predominou nas cartas. O vocativo mais mencionado é Querida Claire, registrado em mais da metade das cartas a partir de 1988, conforme se pode conferir na Tabela 9.2. 
Tabela 9.2 - Quantidade de vocativos versus data em que foram usados

\begin{tabular}{c|c|c}
\hline Vocativo & Ocorrência & Época \\
\hline Prezada Mme. Claire Cayron & $2 / 93(2 \%)$ & 1984,1987 \\
\hline Muito prezada Sra. Claire Cayron & $4 / 93(4 \%)$ & 1986,1987 \\
\hline Prezada senhora Claire Cayron & $2 / 93(2 \%)$ & 1987 \\
\hline Muito prezada Mme. Claire Cayron & $2 / 93(2 \%)$ & 1987 \\
\hline Muito prezada e amiga Claire & $1 / 93(1 \%)$ & 1987 \\
\hline Minha cara Clara Claire & $1 / 93(1 \%)$ & 1987 \\
\hline Muito prezada Claire & $5 / 93(5 \%)$ & $1987,1988,1989$ \\
\hline Dear Claire & $8 / 93(9 \%)$ & $1987,1988,1989$ \\
\hline Minha querida Claire & $2 / 93(2 \%)$ & 1987,1989 \\
\hline Querida Claire & $50 / 93(54 \%)$ & $1988,1989,1990,1991,1992$ \\
\hline Prezada Clarinha & $1 / 93(1 \%)$ & 1988 \\
\hline Prezada Claire & $8 / 93(9 \%)$ & 1988 \\
\hline Minha cara Clarinha de Bordeaux & $1 / 93(1 \%)$ & 1988 \\
\hline Dona Claire & $2 / 93(2 \%)$ & 1988 \\
\hline Dear Clarinha & $1 / 93(1 \%)$ & 1988 \\
\hline Claire & $1 / 93(1 \%)$ & 1990 \\
\hline Chère Claire & $1 / 93(1 \%)$ & 1990 \\
\hline Claire, ma fleur & $1 / 93(1 \%)$ & 1992 \\
\hline
\end{tabular}

Fonte: Adaptada de Grando (2016, p. 42).

Comparando o Quadro 9.1 com a Tabela 9.2, nota-se que, a partir de 1988, os assuntos das cartas transitam de profissionais a mistos e pessoais, ou seja, Harry Laus começa a ser menos formal e fala também sobre sua vida pessoal, passando a usar vocativos mais carinhosos. Nesse mesmo momento, começa a usar mais formas associadas ao $t u$, minimizando a impessoalidade. ${ }^{12}$ Ao longo do tempo, a forma de tratamento se transforma

12 No caso deste estudo, o tu tem característica de impessoalidade porque notamos assunto de teor pessoal no mesmo trecho em que aparece só paradigma de $t u$, e os relacionamos ao vocativo carinhoso usado. Concluímos a premissa quando percebemos que o autor usa 
de um status formal em uma categoria mais coloquial, íntima e carinhosa. Tudo indica que a relação formal se transforma em uma relação profissional imbuída de amizade.

\subsection{A análise variacionista}

Considerando que as formas de tratamento no $\mathrm{PB}$, um sistema organizado e heterogêneo, estão em constante variação; considerando ainda o comportamento social e a variação dos pronomes de $2^{\underline{a}}$ p.s.; e, tendo em vista estudos da sociolinguística variacionista realizados na Região Sul, em especial no litoral do estado de Santa Catarina, descrevemos a variação linguística das formas de tratamento nas cartas de Harry Laus para Claire Cayron.

É importante salientar que, embora não consideremos a variável diastrática na presente análise, Harry Laus era personalidade pública em Santa Catarina, com alto grau de letramento, o que nos faz acreditar que ele teve motivações que o levaram a escolher entre uma ou outra forma de tratamento. Leva-se em conta também que a variação na língua não é aleatória, pois existem fatores que condicionam a escolha de variantes (COELHO et al., 2015). Considera-se ainda que quando falamos fazemos escolhas que podem chamar a atenção, caso não sejam adequadas em determinada situação de comunicação (PAGOTTO, 2006), e que uma pessoa pode escolher uma forma de tratamento mais conservadora numa situação mais formal ou uma mais íntima numa conversa informal (NARO, 2013).

As correlações feitas entre o tema das cartas, o vocativo e as formas de tratamento, apresentadas nas tabelas 9.2 e 9.3, indicam que Harry Laus alternava as formas, considerando o nível de formalidade associado ao tema das cartas e à relação de mais ou menos intimidade que o autor foi estabelecendo com sua tradutora ao longo do tempo.

A amostra Harry Laus contém 93 cartas, escritas de 1984 até 1992, com 816 ocorrências de formas associadas ao tu e ao você. O ano de 1985 não foi considerado na estatística porque não houve troca de cartas. De posse dessas ocorrências, todos os dados foram categorizados e rodados

apenas paradigmas de você em cartas totalmente profissionais e ainda, numa mesma carta, mesmo usando paradigma de $t u$, seleciona o você quando fala de assunto profissional. 
no programa Goldvarb $2001^{13}$ para cruzamento das variáveis e geração de resultados.

\subsubsection{Descrição dos resultados}

Para analisar estatisticamente as formas de tratamento nas cartas de Harry Laus, foi considerada a variável dependente abstrata: formas associadas ao tu e formas associadas ao você. Essas formas foram analisadas à luz dos contextos morfossintáticos de: sujeito (nulo ou expresso), imperativo, possessivo e complemento; das variáveis extralinguísticas: tema da carta (profissional, pessoal ou mista) e ano em que a carta foi escrita.

Os resultados apresentados na Tabela 9.3 trazem os índices das formas associadas ao tu e das formas associadas ao você nos contextos morfossintáticos controlados. Como notamos, em todos os contextos as formas de $t u$ prevalecem sobre as formas de você.

Tabela 9.3 - Classificação dos contextos morfossintáticos e quantidade de ocorrências

\begin{tabular}{c|c|c}
\hline \multirow{2}{*}{$\begin{array}{c}\text { Contextos } \\
\text { morfossintáticos }\end{array}$} & $\begin{array}{c}\text { Formas associadas } \\
\text { ao tu }\end{array}$ & $\begin{array}{c}\text { Formas associadas } \\
\text { ao você }\end{array}$ \\
\cline { 2 - 3 } & $\begin{array}{c}\text { Apl./Total } \\
\%\end{array}$ & $\begin{array}{c}\text { Apl./Total } \\
\%\end{array}$ \\
\hline Sujeito pronominal & $316 / 345$ & $29 / 345$ \\
Formas do pronome & $92 \%$ & $8 \%$ \\
possessivo & $214 / 239$ & $25 / 239$ \\
Formas do modo imperativo & $90 \%$ & $10 \%$ \\
\hline Formas de complemento & $23 / 29$ & $6 / 29$ \\
& $80 \%$ & $20 \%$ \\
\hline
\end{tabular}

Fonte: Adaptada de Grando (2016, p. 48).

13 Programa de análise de variáveis usado no projeto VARSUL e desenvolvido em 1990 por David Rand e David Sankoff para o Departamento de Linguagem e Ciência Linguística da University of York. 
Com base na quantidade total das formas associadas ao tu e ao você em relação à diacronia das correspondências, o gráfico da Figura 9.1 mostra a prevalência dos paradigmas de $t u$ em relação aos paradigmas de você. Mostra ainda que inicialmente, nas cartas escritas por Harry Laus para sua tradutora, as formas associadas ao você eram categóricas e que, a partir de 1987, passa a ser o contrário.

Figura 9.1 - Paradigmas de tu versus paradigmas de você

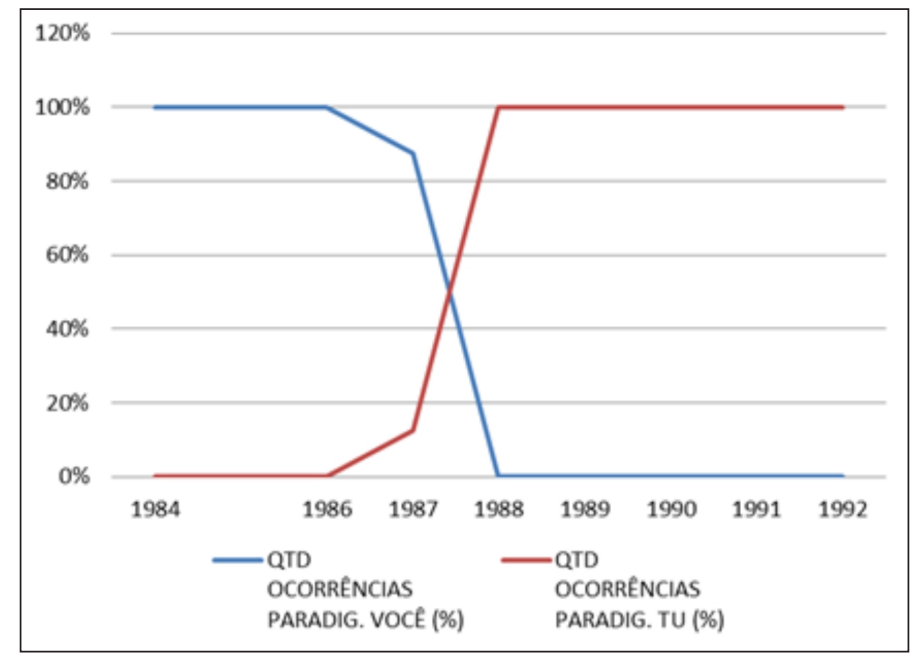

Fonte: Adaptado de Grando (2016, p. 48).

Observemos, a seguir, a distribuição dessas formas por variável de controle.

\subsubsection{Preenchimento do sujeito pronominal}

Para as GTs, o sujeito se apresenta em relação ao predicado como um sintagma nominal, por um pronome ou por uma palavra substantivada (CEGALLA, 2008), constituinte da oração, estando expresso ou oculto (BECHARA, 2015). Para Azeredo (2013), o lugar sintático do sujeito pode estar vazio quando sua existência é assinalada na flexão verbal. Complementa dizendo que a omissão de qualquer constituinte da frase é um fato gramatical relativo ao princípio da economia linguística e que a não marcação de sujeito nas construções é mais frequente na escrita. 
Cunha (2015) caracteriza o sujeito nulo como omissão do pronome sujeito, pois a desinência verbal basta para indicar a pessoa do discurso, ${ }^{14} \mathrm{e}$ descreve o sujeito expresso como "presença do pronome sujeito", empregado para enfatizar a pessoa do discurso.

Em teor reflexivo sobre os termos da oração, Duarte (2014) esclarece que as definições de sujeito e predicado das GTs são por vezes confundidas com definições de "tópico" e "comentário", podendo coincidir ou não com os elementos referentes ao sujeito e ao predicado, e chama o tradicional sujeito de "argumento externo" dentro de uma estrutura oracional constituída por predicadores (verbos) que "selecionam" os argumentos externo (sujeito) ou interno (complemento). Afirma ainda que só faz sentido o sujeito ser classificado como oculto se ele se opuser ao sujeito "expresso".

Em outros estudos, Duarte (1993) afirma a crescente preferência do sujeito pronominal expresso pelos falantes do $\mathrm{PB}$, resultante da entrada de novos pronomes (você/a gente) - que se combinam com formas verbais de $3^{\text {a }}$ p.s. - no quadro pronominal do $\mathrm{PB}$ e da perda da desinência de $2^{\mathrm{a}}$ p.s. “-s" (DUARTE et al., 2012), associando-se assim o pronome tu com verbos de terceira pessoa ( $t u$ foi). Nesse caso, há uma neutralização das formas verbais, passando os pronomes a serem os únicos indicadores da pessoa do discurso.

Para a variável preenchimento do sujeito pronominal foram considerados os fatores presença e ausência do sujeito tu e você. Como os resultados da Tabela 9.4 sinalizam, o pronome tu é usado preferencialmente com sujeito nulo (91\%) e o pronome você é variável, com uma maior tendência ao sujeito expresso (55\%). Independentemente de o sujeito ser nulo ou expresso, a quantidade de ocorrências de $t u$ na função de sujeito é superior à quantidade de ocorrências de você.

14 Em latim, nem existiam os pronomes de terceira pessoa. 
Tabela 9.4 - Quantidade de ocorrências de sujeito pronominal

\begin{tabular}{c|c|c}
\hline \multirow{3}{*}{ Sujeito } & Tu & Você \\
\cline { 2 - 3 } & Apl./Total & Apl./Total \\
$\%$ & $16 / 29$ \\
\hline \multirow{2}{*}{ Expresso } & $27 / 316$ & $55 \%$ \\
\hline \multirow{2}{*}{ Nulo } & $9 \%$ & $13 / 29$ \\
& $289 / 316$ & $45 \%$ \\
\hline
\end{tabular}

Fonte: Adaptada de Grando (2016, p. 50).

Os resultados são reflexo de construções conforme (3) a (6):

(3) [20,2 CP SC] Fiquei muito feliz por Øter gostado de minhas novelas e sobretudo pelo interesse em traduzir "As Horas de Zenão das Chagas". (10/3/1984)

(4) [20,2 CP SC] Gostaria de ter o endereço dela para mandar um cartão. Como Ødizes que virá um artigo dela, agradecerei ambos. (22/11/1987)

(5) [20,2 CP SC] Veio também o folheto do Encontro de Tradutores e agora é a vez de se falar nas traduções que você já fez. $(22 / 11 / 1987)$

(6) [20,2 CP SC] Caixa d'aço foi escrito a pedido, para uma antologia chamada Este Mar Catarina que eu pensei que tu tivesses porque, faz tempo, pedi ao Salim que te mandasse. (15/4/1988)

Conforme estudo de Grando (2016), nas primeiras cartas, de 1984 a 1986, Harry Laus usou somente você, e principalmente como sujeito nulo. Nas demais, o usou como sujeito expresso, e os vocativos e assuntos das cartas indicam que o uso de você na função de sujeito se deu no momento mais formal da relação. Quando usa $t u$, dá preferência ao sujeito nulo. Independentemente do preenchimento do sujeito, eis a importância do assunto da carta em relação ao pronome usado para compreender o seu "tutear" com Claire. 


\subsubsection{Assunto da carta}

Observando o assunto das correspondências, podemos relacioná-lo às datas para entender a possível razão que levou à seleção de uma ou outra forma de tratamento. Classificamos o assunto das cartas em profissional, pessoal e misto (Tabela 9.5).

Tabela 9.5 - Assunto da carta versus quantidade de ocorrências tu/você por ano

\begin{tabular}{|c|c|c|c|c|c|c|}
\hline & \multicolumn{2}{|c|}{ Profissional } & \multicolumn{2}{|c|}{ Misto } & \multicolumn{2}{|c|}{ Pessoal } \\
\hline & você & $t u$ & você & $t u$ & você & $t u$ \\
\hline 1984 & $\begin{array}{c}1 / 1 \\
100 \%\end{array}$ & $\begin{array}{l}0 / 1 \\
0 \%\end{array}$ & sem dados & sem dados & sem dados & sem dados \\
\hline 1986 & $\begin{array}{l}17 / 17 \\
100 \%\end{array}$ & $\begin{array}{c}0 / 17 \\
0 \% \\
\end{array}$ & sem dados & sem dados & sem dados & sem dados \\
\hline 1987 & $\begin{array}{c}40 / 58 \\
69 \% \\
\end{array}$ & $\begin{array}{c}18 / 58 \\
31 \% \\
\end{array}$ & $\begin{array}{l}4 / 23 \\
17 \% \\
\end{array}$ & $\begin{array}{c}19 / 23 \\
83 \% \\
\end{array}$ & sem dados & sem dados \\
\hline 1988 & $\begin{array}{c}3 / 109 \\
3 \%\end{array}$ & $\begin{array}{c}106 / 109 \\
97 \%\end{array}$ & $\begin{array}{c}3 / 100 \\
3 \%\end{array}$ & $\begin{array}{c}97 / 100 \\
97 \%\end{array}$ & $\begin{array}{c}0 / 26 \\
0 \%\end{array}$ & $\begin{array}{l}26 / 26 \\
100 \%\end{array}$ \\
\hline 1989 & sem dados & sem dados & $\begin{array}{c}3 / 163 \\
2 \% \\
\end{array}$ & $\begin{array}{c}160 / 163 \\
98 \% \\
\end{array}$ & $\begin{array}{l}0 / 8 \\
0 \%\end{array}$ & $\begin{array}{c}8 / 8 \\
100 \% \\
\end{array}$ \\
\hline 1990 & $\begin{array}{l}0 / 4 \\
0 \% \\
\end{array}$ & $\begin{array}{c}4 / 4 \\
100 \% \\
\end{array}$ & $\begin{array}{c}0 / 98 \\
0 \% \\
\end{array}$ & $\begin{array}{l}98 / 98 \\
100 \% \\
\end{array}$ & $\begin{array}{l}0 / 5 \\
0 \% \\
\end{array}$ & $\begin{array}{c}5 / 5 \\
100 \% \\
\end{array}$ \\
\hline 1991 & $\begin{array}{l}0 / 8 \\
0 \% \\
\end{array}$ & $\begin{array}{c}8 / 8 \\
100 \% \\
\end{array}$ & $\begin{array}{c}1 / 93 \\
1 \% \\
\end{array}$ & $\begin{array}{c}92 / 93 \\
99 \% \\
\end{array}$ & $\begin{array}{c}0 / 17 \\
0 \% \\
\end{array}$ & $\begin{array}{l}17 / 17 \\
100 \% \\
\end{array}$ \\
\hline 1992 & sem dados & sem dados & $\begin{array}{c}2 / 86 \\
2 \% \\
\end{array}$ & $\begin{array}{c}84 / 86 \\
98 \% \\
\end{array}$ & sem dados & sem dados \\
\hline
\end{tabular}

Fonte: Adaptada de Grando (2016, p. 58).

As primeiras cartas têm assunto estritamente profissional e somente paradigmas de você, quantidade que declina a partir de 1987, ao mesmo tempo que passam a apresentar muito mais paradigmas de $t u$ e mistura dos assuntos. 


\subsubsection{Formas do pronome possessivo}

Os pronomes possessivos, de acordo com definições de GTs, referemse às pessoas do discurso geralmente com atribuição de posse (CEGALLA, 2008; CUNHA, 2015). Contudo, os possessivos têm caráter complexo (AZEREDO, 2013) e podem ser usados também como tratamento ao interlocutor (você, o senhor) sob as formas seu/sua. Exemplos: (1) Bom dia, seu Pedro! - forma mais presente na língua falada; (2) Presente à cerimônia, Sua Majestade, a Rainha Elizabeth II.

Monteiro (1994) defende a ideia da eliminação do grupo dos possessivos para interpretá-los como pronomes pessoais, uma vez que aqueles são formas adjetivas destes. O autor chama a atenção para um fenômeno sintático de variação causado pela anteposição e posposição do possessivo em relação ao substantivo ao qual se liga: (a) espero a tua carta e (b) espero carta tua. Para o autor, há uma diferenciação referencial e atributiva, resultante de intuitos de natureza estilística ou expressiva, entre os exemplos (a) e (b), em que no primeiro supõe-se que existe uma carta a ser enviada e no segundo o indício é de que ainda não há uma carta.

Diante de tais esclarecimentos, a Tabela 9.6 apresenta o panorama de ocorrências das formas de possessivo, em que, a partir de 1988, passa a ter a prevalência de formas associadas ao tu até o fim, coincidindo com o assunto da carta, que varia entre misto e pessoal (cf. Tabela 9.5).

Tabela 9.6 - Formas do pronome possessivo

\begin{tabular}{c|c|c}
\hline Ano & $\begin{array}{c}\text { Formas associadas ao você } \\
\text { (seu, seus, sua, suas) }\end{array}$ & $\begin{array}{c}\text { Formas associadas ao } \boldsymbol{t} u \\
\text { (teu, teus, tua, tuas) }\end{array}$ \\
\hline \multirow{2}{*}{1984} & sem dados & sem dados \\
\hline \multirow{2}{*}{1986} & $6 / 6$ & $0 / 6$ \\
\hline \multirow{2}{*}{1987} & $100 \%$ & $0 \%$ \\
\hline \multirow{2}{*}{1988} & $19 / 30$ & $11 / 30$ \\
& $63 \%$ & $37 \%$ \\
\hline \multirow{2}{*}{1989} & $0 / 66$ & $66 / 66$ \\
& $0 \%$ & $100 \%$ \\
\hline
\end{tabular}




\begin{tabular}{c|c|c}
\hline \multirow{2}{*}{1990} & $0 / 36$ & $36 / 36$ \\
& $0 \%$ & $100 \%$ \\
\hline \multirow{2}{*}{1991} & $0 / 31$ & $31 / 31$ \\
& $0 \%$ & $100 \%$ \\
\hline \multirow{2}{*}{1992} & $0 / 23$ & $23 / 23$ \\
& $0 \%$ & $100 \%$ \\
\hline
\end{tabular}

Fonte: Adaptada de Grando (2016, p. 62).

Considerando as argumentações anteriores sobre sujeito e assunto das cartas, já podemos afirmar que quatro anos após o primeiro contato entre os correspondentes, com o predomínio de $t u$ e cartas de teor mais pessoal, "tutear", segundo este estudo, tem caráter informal.

\subsubsection{Formas do modo imperativo}

Da classificação tradicional das gramáticas, o imperativo é um modo pelo qual o verbo expressa ordem, proibição, conselho, pedido (CEGALLA, 2008). Em face da relação entre a ação verbal e seu agente, o imperativo, segundo Bechara (2015), é um ato exigido do agente na posição de interlocutor. As passagens (7) e (8) ilustram imperativos usados por Harry Laus.

(7) [20,2 CP SC] Esteja certa de que poderá ler o Diário entre as primeiras pessoas. $(24 / 8 / 1987)$

(8) [20,2 CP SC] Imagina que tua carta de 24 de jan. levou 20 dias para chegar aqui. (20/2/1989)

No imperativo, a $2^{a}$ p.s. deriva daquela correspondente ao presente do indicativo suprimindo-se o "s" final do verbo, conforme ilustra (8). Você é tomado do presente do subjuntivo, cf. (7). Cegalla (2008) esclarece que os casos de imperativo em que as formas verbais derivam de você revestem-se de aspecto de $3^{\mathrm{a}}$ p.s. embora refiram-se à segunda pessoa do discurso.

Assim, das cartas de Harry para Claire, coletamos dados de tu e você nas formas de imperativo, apresentados na Tabela 9.7. 
Tabela 9.7 - Formas do modo imperativo

\begin{tabular}{c|c|c}
\hline Ano & Formas associadas ao você & Formas associadas ao $\boldsymbol{u} u$ \\
\hline 1984 & sem dados & sem dados \\
\hline \multirow{2}{*}{1986} & $2 / 2$ & $0 / 2$ \\
& $100 \%$ & $0 \%$ \\
\hline \multirow{2}{*}{1987} & $4 / 7$ & $3 / 7$ \\
& $57 \%$ & $43 \%$ \\
\hline \multirow{2}{*}{1988} & $0 / 4$ & $4 / 4$ \\
& $0 \%$ & $100 \%$ \\
\hline \multirow{2}{*}{1989} & $0 / 8$ & $8 / 8$ \\
& $0 \%$ & $100 \%$ \\
\hline \multirow{2}{*}{1990} & $0 / 3$ & $3 / 3$ \\
& $0 \%$ & $100 \%$ \\
\hline \multirow{2}{*}{1991} & $0 / 5$ & $5 / 5$ \\
& $0 \%$ & $100 \%$ \\
\hline \multirow{2}{*}{1992} & sem dados & sem dados \\
\hline
\end{tabular}

Fonte: Adaptada de Grando (2016, p. 64).

Embora a quantidade de ocorrências de imperativo seja relativamente baixa, os resultados das tabelas de possessivos e imperativos são similares. O você se manifesta apenas em 1986 e 1987. A partir de 1988, há unanimidade de $t u$.

\subsubsection{Formas de complemento}

Partindo do pressuposto de que as GTs apresentam os clíticos em oposição aos pronomes retos, Cunha (2015) e Cegalla (2008) definem que, enquanto os pronomes retos funcionam como sujeitos de uma oração, os clíticos são empregados nela como objeto ou complemento. Já para Azeredo (2013), as formas de complemento podem desempenhar função acusativa (complemento de um verbo transitivo direto) ou função dativa (expressão de papel semântico de destinatário), cf. (10) e (11).

(9) [20,2 CP SC] Tudo de bom. Se não houver outra carta antes do Natal, votos de muita alegria pra ti. $(13 / 12 / 1987)$ 
(10) $[20,2$ CP SC] Desculpe se lhe escrevo tão longamente. $(25 / 11 / 1986)$

(11) [20,2 CP SC] A propósito, também queria te perguntar se em O Estivador não se poderia dizer "Regarde ce bateau lá" em vez de "regarde ce bateau"? (22/11/1987)

Categorizadas as formas dos complementos, apresentamos, na Tabela 9.8, as ocorrências das formas associadas ao tu e ao você coletadas nas cartas de Harry Laus para Claire Cayron.

Tabela 9.8 - Formas de complemento

\begin{tabular}{c|c|c}
\hline Ano & $\begin{array}{c}\text { Formas associadas ao você } \\
\text { (lhe, se, -la) }\end{array}$ & $\begin{array}{c}\text { Formas associadas ao } t u \\
\text { (te, ti, contigo) }\end{array}$ \\
\hline \multirow{2}{*}{1984} & sem dados & sem dados \\
\hline \multirow{2}{*}{1986} & $5 / 5$ & $0 / 5$ \\
& $100 \%$ & $0 \%$ \\
\hline \multirow{2}{*}{1987} & $8 / 21$ & $13 / 21$ \\
& $38 \%$ & $62 \%$ \\
\hline \multirow{2}{*}{1988} & $0 / 47$ & $47 / 47$ \\
& $0 \%$ & $100 \%$ \\
\hline \multirow{2}{*}{1989} & $1 / 46$ & $45 / 46$ \\
& $2 \%$ & $98 \%$ \\
\hline \multirow{2}{*}{1990} & $0 / 31$ & $31 / 31$ \\
& $0 \%$ & $100 \%$ \\
\hline \multirow{2}{*}{1991} & $0 / 29$ & $29 / 29$ \\
& $0 \%$ & $100 \%$ \\
\hline \multirow{2}{*}{1992} & $0 / 24$ & $24 / 24$ \\
& $0 \%$ & $100 \%$ \\
\hline
\end{tabular}

Fonte: Adaptada de Grando (2016, p. 67).

Com resultados semelhantes às formas de possessivo e imperativo, Harry Laus passa a usar mais formas de complemento associadas ao $t u$ quando a relação com Claire fica mais íntima. 


\subsubsection{Fechando a seção}

Olhando para os índices apresentados acima, podemos constatar semelhanças entre os resultados das tabelas, em que prevalece o uso de formas associadas ao $t u$. Relacionando os paradigmas de $2^{\mathrm{a}}$ p.s. com o ano e o assunto, observamos que é entre 1987 e 1988 que Harry Laus passa a misturar tanto os sujeitos pronominais em uma mesma carta quanto os assuntos, de profissionais a pessoais, com o passar do tempo. É nesse mesmo período que deixa de usar o você e passa a usar o tu. Nas cartas em que mescla o uso dos sujeitos pronominais, a quantidade de vocêé mínima em relação a $t u$, e o você é usado em casos bem específicos, chamando a atenção para assunto profissional. A mescla, da qual falam Lopes e Marcotulio (2011), é relativa somente aos sujeitos pronominais. Harry Laus faz concordância entre os paradigmas e o sujeito.

\subsection{Considerações finais}

No início do estudo, registramos algumas questões que esperávamos encontrar no desenvolvimento deste trabalho e às quais procuramos responder no decorrer da análise das cartas. Resenhamos textos teóricos relativos às questões levantadas e definimos a base teórica que sustenta esta pesquisa. Acessamos os arquivos de Harry Laus, visitamos sua história, classificamos as correspondências, coletamos as ocorrências relativas aos pronomes de tratamento, e, por fim, a metodologia foi concluída. Passamos, então, aos resultados que encontramos para as questões que levantamos inicialmente: Como os vocativos se apresentam? As formas de tratamento sofrem variação?

Os vocativos apresentados nas cartas de Harry Laus variam, segundo os pressupostos de variação e mudança propostos por Labov, de acordo com o ano e o estreitamento da relação atestado pela dimensão solidária proposta por Brown e Gilman (2003). Autor e tradutora passam de uma relação formal a uma relação de amizade, a qual é representada através de vocativos carinhosos.

Entre as formas você e $t u$, que paradigmas prevalecem nas cartas? Qual a relação entre o vocativo e as escolhas dos paradigmas? Que relação há entre a forma de tratamento e o assunto das cartas? Para responder às 
questões a que nos propúnhamos, lançamo-nos à descrição das formas associadas ao tu e das formas associadas ao você, classificamos as formas de tratamento e, a partir de então, categorizamos os paradigmas em sujeito pronominal, formas do pronome possessivo, formas do modo imperativo e formas de complemento. Consideramos também o ano em que a carta foi escrita e o assunto. Concluímos que além de tratar de temas profissionais e pessoais, o autor os mesclava.

Quando fala de assunto profissional, o autor usa predominantemente paradigmas de você e registra vocativo formal: a relação é estritamente profissional. Com o passar dos anos, destaca-se o uso abundante de paradigmas de $t u$. O autor volta a usar o você na forma de sujeito quando se refere a assunto de teor mais profissional, mesmo em cartas em que predominam paradigmas de $t u$.

Por fim, as escolhas de Harry Laus entre os paradigmas de tu e você, de acordo com o presente estudo, corroboram o fato de que "tutear", considerando estudos que envolvem o litoral de Santa Catarina e o extremo sul do Brasil, é tratar o correspondente de forma mais informal. Ou seja, com o passar do tempo, Harry passou a usar mais formas associadas ao $t u$, ao mesmo tempo que a relação entre ele e Claire ficou mais íntima. E assim acontece até o dia em que escreve a última carta para sua amiga francesa, em 22 de maio de 1992.

\section{Referências}

AZEREDO, J. C. de. Gramática Houaiss da língua portuguesa. 3. ed. São Paulo: Publifolha, 2013.

BECHARA, E. Moderna gramática portuguesa. 38. ed. Rio de Janeiro: Nova Fronteira, 2015.

BEZERRA, R. Nova gramática da língua portuguesa para concursos. 7. ed. Rio de Janeiro: Forense; São Paulo: Método, 2015.

BROWN, R.; GILMAN, A. The pronouns of power and solidarity. In:

PAULSTON, C. B.; TUCKER, G. R. Sociolinguistics: the essential readings. Oxford: Blackwell, 2003 [1960]. p. 156-176.

BRUCHARD, D. de (org.). Claire Cayron: profissão: traductrice, profession: tradutora. Tradução de Ana Carolina Corrêa da Silva et al. Florianópolis: DLLE/ UFSC: Escritório do Livro, 2012. 
CEGALLA, D. P. Novíssima gramática da língua portuguesa. 48. ed. São Paulo: Companhia Editora Nacional, 2012 [2008].

COELHO, I. L.; GÖRSKI, E. M.; NUNES DE SOUZA, C. M.; MAY, G. Para conhecer sociolinguística. São Paulo: Contexto, 2015.

CUNHA, A. G. da. Dicionário etimológico da língua portuguesa. 4. ed. Rio de Janeiro: Lexikon, 2010.

CUNHA, C. Gramática do português contemporâneo: edição de bolso. Rio de Janeiro: Lexikon; Porto Alegre: L\&PM, 2015.

DUARTE, M. E. L. Do pronome nulo ao pronome pleno: a trajetória do sujeito no português do Brasil. In: ROBERTS, I.; KATO, M. A. (org.). Português brasileiro: uma viagem diacrônica. Campinas: Editora da UNICAMP, 1993. p. 107-128.

DUARTE, M. E. L. Termos da oração. In: VIEIRA, S. R.; BRANDÂO, S. F. (org.). Ensino de gramática: descrição e uso. 2. ed. São Paulo: Contexto, 2014. p. 185-203. DUARTE, M. E. L.; MOURÃO, G. C.; SANTOS, H. M. Os sujeitos de 3a pessoa: revisitando Duarte 1993. In: DUARTE, M. E. L. (org.). O sujeito em peças de teatro (1833-1992): estudos diacrônicos. São Paulo: Parábola, 2012. p. 21-44.

FARACO, C. A. O tratamento "você" em português: uma abordagem histórica. Fragmenta, Curitiba, n. 13, p. 51-82, 1996.

GONZAGA, N. O cavaleiro biografado e outros ecos. 2016. 177 f. Dissertação (Mestrado em Literatura) - Programa de Pós-Graduação em Literatura, Universidade Federal de Santa Catarina, Florianópolis, 2016.

GRANDO, V. Formas de tratamento nas cartas de Harry Laus para Claire Cayron: uma análise sociolinguística. 2016. $71 \mathrm{f}$. Trabalho de Conclusão de Curso (Bacharelado em Letras-Língua Portuguesa) - Universidade Federal de Santa Catarina, Florianópolis, 2016.

ILARI, R.; BASSO, R. O português da gente: a língua que estudamos, a língua que falamos. São Paulo: Contexto, 2007.

LABOV, W. Padrões sociolinguísticos. Tradução de Marcos Bagno, Maria Marta Pereira Scherre e Caroline Rodrigues Cardoso. São Paulo: Parábola, 2008 [1972].

LOPES, C. R. dos S. Pronomes pessoais. In: VIEIRA, S. R.; BRANDÃO, S. F. (org.). Ensino de gramática: descrição e uso. 2. ed. São Paulo: Contexto, 2014. p. 103-119.

LOPES, C. R. dos S. Retratos da variação entre "você" e "tu" no português do Brasil: sincronia e diacronia. In: RONCARATI, C.; ABRAÇADO, J. (org.). Português brasileiro II: contato linguístico, heterogeneidade e história. Niterói: Editora da UFF, 2008. p. 55-71. 
LOPES, C. R. dos S.; MARCOTULIO, L. L. O tratamento a Rui Barbosa. In: CALLOU, D.; BARBOSA, A. (org.). A norma brasileira em construção: cartas a Rui Barbosa (1866 a 1899). Rio de Janeiro: Fundação Casa de Rui Barbosa, 2011. p. 265-292.

MELO, M. A. F. de. As cartas de Harry Laus e de sua tradutora francesa. 2001. 496 f. Dissertação (Mestrado em Literatura) - Programa de Pós-Graduação em Literatura, Universidade Federal de Santa Catarina, Florianópolis, 2001.

MONTEIRO, J. L. Pronomes pessoais: subsídios para uma gramática do português do Brasil. Fortaleza: Edições UFC, 1994.

MUZART, Z. L. (org.). Tempo e andanças de Harry Laus: 1922-1992.

Florianópolis: Editora da UFSC: Fundação Prometheus Libertus, 1992.

NARO, A. J. O dinamismo das línguas. In: MOLLICA, M. C.; BRAGA, M. L. (org.). Introdução à Sociolinguística: o tratamento da variação. 4. ed. São Paulo: Contexto, 2013. p. 43-50.

PAGOTTO, E. G. Sociolinguística. In: PFEIFFER, C. C.; NUNES, J. H. (org.). Introdução às ciências da linguagem: linguagem, história e conhecimento.

Campinas: Pontes Editores, 2006. p. 49-72. 


\section{Capítulo 10}

\section{A correlação tempo-modalidade e o uso variável do presente do modo subjuntivo em cartas ao redator de Lages e Florianópolis}

Tatiana Schwochow Pimpão

\subsection{Introdução'}

Tendo como fonte de coleta de dados o corpus do PHPB-SC, apresento e discuto resultados de uma investigação acerca do uso variável entre as formas verbais de presente do modo subjuntivo e presente do modo indicativo em quatro contextos linguísticos: orações com advérbio talvez; e orações subordinadas substantivas, adjetivas e adverbiais (PIMPÃO, 2012). Compõem a amostra cartas ao redator publicadas em jornais das cidades

1 Este capítulo consiste em retomada revisada de parte da tese de doutorado (PIMPÃO, 2012). 
de Florianópolis e de Lages, compreendendo as duas últimas décadas do século XIX e todo o século XX. Como referencial teórico, o trabalho está embasado em princípios da teoria funcionalista de vertente norteamericana, principalmente nas obras de Givón (1984, 1993, 1995, 2001, 2005).

O objetivo consiste em assinalar a relevância da projeção futura e da modalidade deôntica no condicionamento do uso variável do presente do modo subjuntivo, ${ }^{2}$ conforme previsto por Givón $(1993,1995,2001)$, já registrado em algumas gramáticas históricas do português (BARBOZA, 1830; BARROS, 1957 [1540]) e também apontado em pesquisas linguísticas com diferentes amostras (PIMPÃO, 1999; ALVES NETA, 2000; SANTOS, 2005; CARVALHO, 2007; FAGUNDES, 2007; VIEIRA, 2007; ALMEIDA, 2010).

Este capítulo parte de uma revisão teórica, considerando a abordagem do modo subjuntivo sob diferentes enfoques gramaticais e pressupostos teórico-conceituais funcionalistas, especialmente no que diz respeito à modalidade. Sempre que for pertinente, serão apresentados e discutidos exemplos que ilustram os contextos linguísticos investigados e pressupostos da teoria. Seguem-se a seção destinada à análise e discussão dos resultados quantitativos e as considerações finais.

\subsection{Revisão teórica}

A revisão teórica que fundamenta a discussão empreendida no tratamento do uso variável do presente do subjuntivo se organiza em duas subseções: a primeira enfoca o tratamento concedido ao modo subjuntivo em diferentes tipos de gramáticas (de caráter normativo, descritivo e histórico) e na literatura linguística; a segunda delineia os pressupostos

2 Tempo, modalidade e presente do subjuntivo são termos usados para designar tanto a categoria (a faceta estrutural gramaticalmente codificada) como a função (a faceta semântico-pragmática associada). No caso, tempo e modalidade são domínios mais amplos que recobrem, por exemplo, passado, presente e futuro - tempo; epistêmica e deôntica - modalidade. Já presente do subjuntivo remete tanto à forma verbal que codifica, com uma morfologia própria em português, o tempo presente do modo subjuntivo, quanto à referência temporal em que o tempo do evento/estado coincide com o tempo de fala, espraiando-se com valores de modalidade (GÖRSKI, inédito). 
teórico-conceituais em que se assenta a noção funcionalista de modalidade, mobilizada na análise realizada.

\subsubsection{Modo subjuntivo}

Os gramáticos normativos, de modo geral, concebem o modo como uma propriedade da forma verbal, tendo a marca morfológica o propósito de assinalar a oposição realidade/irrealidade. Nesse sentido, diz-se que o modo subjuntivo responde por valores de incerteza, dúvida, hipótese, eventualidade, irrealidade - em contraposição ao modo indicativo, que exprime certeza, realidade (LUFT, 1971; CUNHA, 1992; BECHARA, 2009). De acordo com Cunha, "chamam-se modos as diferentes formas que toma o verbo para indicar a atitude (de certeza, de dúvida, de suposição, de mando etc.) da pessoa que fala em relação ao fato que enuncia" (CUNHA, 1992, p. 368). Esses valores indicam uma perspectiva semântico-pragmática, uma vez que preveem um locutor que fala ${ }^{3}$ e, consequentemente, ainda que o autor não mencione, um interlocutor que ouve e um contexto comunicativo em que esses participantes interagem. Ressalva deve ser feita apenas para o fato de que a atitude do falante estaria expressa na morfologia verbal. À semelhança de Cunha (1992), Bechara concebe o modo verbal em conformidade com a posição do falante, porém a relação desse falante se dá "entre a ação verbal e seu agente" (BECHARA, 2009, p. 221).

Em outra direção, Mendes de Almeida (1973) considera que o modo subjuntivo é o modo da subordinação, uma vez que não possui sentido completo, necessitando, portanto, de um verbo ao qual esteja subordinado. O curioso é que o autor, na seção destinada ao modo verbal, ilustra apenas com exemplos de orações substantivas, em que o subjuntivo, na oração substantiva, está subordinado a determinados verbos na oração principal. Cunha reforça essa ideia ao dizer que o subjuntivo "denota que uma ação, ainda não realizada, é concebida como dependente de outra, expressa ou subentendida" (CUNHA, 1992, p. 443). Nessa ótica, o modo subjuntivo é compreendido em um escopo sintático.

Temos, pois, que tradicionalmente o modo subjuntivo é visto em sua dupla face - semântico-pragmática (associada a valores atitudinais)

3 Os termos locutor/falante e interlocutor/ouvinte não se restringem à modalidade oral, remetendo também a escrevente e leitor na modalidade escrita. 
e sintática (associada à relação de dependência e subordinação) -, ambas expressas na morfologia verbal. Verifica-se que há um deslizamento entre os níveis morfológico, sintático e semântico-pragmático, e que os autores ora focalizam mais um nível ora outro.

Azeredo, já no sumário de sua gramática - que tem caráter descritivo de usos da variedade padrão -, situa os modos do verbo no capítulo destinado à predicação e às categorias do verbo, o que denomina "Período Simples I" (AZEREDO, 2013, p. 10). Esse deslocamento do subjuntivo da morfologia (perspectiva dos gramáticos normativos) para a oração constitui um importante indicador de uma concepção mais abrangente do que seja modo verbal. Oportuna é a afirmação de Castilho de que "uma operação linguística tão importante quanto é a avaliação sobre o que estamos falando, ao mesmo tempo em que falamos, não poderia ser entregue apenas à morfologia do verbo" (CASTILHO, 2010, p. 438).

Nesse sentido, o modo constitui uma das estratégias para sinalizar a modalidade, estando esta mais claramente centrada no contexto comunicativo - em uma perspectiva distinta do que propõem Cunha (1992) e Bechara (2009), por exemplo. Azeredo define modalidade como "a atitude ou ponto de vista do enunciador relativamente ao objeto de sua comunicação" e, como recursos dessa modalidade, destaca, por exemplo, verbos como "duvidar" e "supor", o advérbio "talvez" e as formas verbais no subjuntivo (AZEREDO, 2013, p. 209).

Para Bagno (2011), o modo subjuntivo é duplamente redundante: pela modalização (o modo repete, na morfologia, um valor modal já expresso no verbo da oração principal) e pela subordinação (o modo exprime a subordinação sintática, já sinalizada pelo conector que introduz a oração subordinada). Diferente ponto de vista é o de Lyons, para quem parece ser mais adequado pensar em forma subjuntiva e não em modo subjuntivo, considerando que a morfologia do modo verbal "não carrega em si mesma nenhuma distinção de modalidade” (LYONS, 1984 apud BAGNO, 2011, p. 565). Esse esvaziamento modal é considerado por Camara Jr. uma "servidão gramatical" (CAMARA JR., 1986, p. 145). Segundo o autor, o subjuntivo no português é usado em certos tipos de frases. ${ }^{4}$ Isso, no entanto,

4 Alguns dos tipos de frases mencionados por Camara Jr.: "em oração independente depois do advérbio de dúvida talvez; em oração integrante subordinada a verbos de significação volitiva ou optativa; em oração relativa, para expressar apenas a possibilidade de qualifi- 
não pressupõe uma omissão da atitude do falante; na verdade, a atitude mantém-se, porém fora da estrutura mórfica (CAMARA JR., 1974).

Também para Perini (2010) o subjuntivo está subordinado a determinados verbos (no caso de orações substantivas), sintagmas nominais (no caso de orações adjetivas), conectores (no caso de orações adverbiais), bem como ao talvez. Essa previsão não se mostra, todavia, uniforme em todas as variedades do português brasileiro. Segundo o autor, uma observação informal aponta o Nordeste como a região do país em que o subjuntivo é mais atuante; nas regiões Sul e Sudeste, por outro lado, verifica-se uma expansão do uso do indicativo.

Da mesma forma, Mattos e Silva admite o uso do subjuntivo "a partir de características das frases em que se encaixa, por isso é considerado um padrão formal sem a marcação de valores semânticos independentes" (MATTOS E SILVA, 2006, p. 119). Como exemplos dessas características, citam-se os advérbios de dúvida e a subordinação a verbos de estado mental, quais sejam, pensar, crer etc. (CAMARA JR., 1986). Perini, de modo convergente, considera que há uma tendência de a oposição indicativo/subjuntivo no português brasileiro tornar-se essencialmente formal, e "os casos em que se pode ver um efeito semântico imputável ao modo são excepcionais e tendem a desaparecer na língua moderna" (PERINI, 1996, p. 257).

Como podemos notar na exposição acerca da perspectiva de diferentes autores, não há consenso entre eles sobre a natureza do modo subjuntivo. Há os que se inclinam para uma interpretação formal, com esvaziamento modal, e outros que consideram o modo intimamente associado à modalidade. Esse impasse talvez tenha origem na antiga distinção entre modo outativo e subjuntivo. De acordo com Barros (1957 [1540]), existem cinco modos verbais, entre os quais ele menciona o outativo e o subjuntivo: o primeiro é considerado o modo do desejo e o segundo, o modo da conexão de orações. Para o modo outativo, Barros indica alguns tempos verbais, como o futuro, cuja estrutura morfológica se confunde com o que conhecemos como presente do subjuntivo. Além disso, de acordo com Barboza (1830), todos os gramáticos admitem a incorporação do modo outativo ao modo subjuntivo.

cação expressa; em orações subordinadas finais; em orações subordinadas concessivas" (CAMARA JR., 1986, p. 225-226). 
O entrecruzamento de níveis (morfologia/sintaxe/semântica/ pragmática) mostrado nesta subseção, no que diz respeito a modo verbal, respalda a correlação entre modalidade deôntica, projeção futura e emprego do modo subjuntivo, conforme apresentado na Introdução deste capítulo.

\subsubsection{A modalidade em uma perspectiva funcionalista}

Nesta subseção, apresento inicialmente alguns postulados funcionalistas gerais para, em seguida, deter-me na modalidade e seus submodos deôntico e epistêmico (cf. GIVÓN, 1984, 1993, 1995, 2001, 2005).

Para Givón (1995), a teoria funcionalista está assentada no postulado da não autonomia do sistema linguístico, pressuposto que prevê uma intrínseca correlação entre a estrutura da língua e a função que ela desempenha no processo de comunicação, que necessariamente envolve, pelo menos, dois interlocutores. Dessa forma, a língua (e a gramática) não pode ser compreendida sem referência ao eixo comunicativo: propósito do evento de fala, seus participantes e seu contexto discursivo (NICHOLS, 1984).

Os participantes, interlocutores envolvidos no processo de interação social e comunicativa, dispõem de estratégias linguísticas que espelham e refletem o ato propriamente dito. Nesses termos, língua e discurso são dois lados da mesma moeda: a língua constitui o discurso e o discurso molda a língua. Assim sendo, a estrutura linguística está em constante ajuste de modo a satisfazer as necessidades comunicativas dos interlocutores que buscam, nos termos de Givón $(1995,2001)$, um discurso coerente.

E é no discurso que se faz presente o complexo subsistema denominado TAM (tempo, aspecto e modalidade), atuante em todas as sentenças produzidas (GIVÓN, 2001). No estudo da variação entre as formas verbais do presente do modo subjuntivo e presente do modo indicativo, cujos resultados estão apresentados adiante, emergem as noções de tempo e modalidade, esta última com muita força, tendo em vista que:

(i) a distinção entre esses modos verbais, prevista em gramáticas normativas, está assentada em valores atitudinais específicos e discretos - incerteza, irrealidade, hipótese, para o subjuntivo; e certeza, realidade, factualidade, para o indicativo - atrelados à morfologia do modo (de tempo-modo, de fato); 
(ii) na perspectiva funcionalista, a modalidade, diferentemente de (i), deve ser concebida no contexto comunicativo e no discurso multiproposicional; e

(iii) ainda na perspectiva funcionalista, a correlação entre valores temporais e valores modais deve ser considerada não somente pela presença do tempo e da modalidade em todas as sentenças como também pela articulação entre escopo da projeção temporal e valores atitudinais no condicionamento das formas verbais variáveis de expressão do presente do modo subjuntivo.

Especificamente tratando da modalidade, a literatura funcionalista norte-americana a situa no eixo comunicativo, no discurso multiproposicional. Para Givón, “a atitude do falante não é apenas - nem principalmente - sobre a proposição propriamente dita, mas sim sobre a atitude do ouvinte em relação à proposição assim como em relação ao falante" (GIVÓN, 2005, p. 149). ${ }^{5}$

A modalidade, na perspectiva givoniana, desdobra-se em dois submodos: o submodo deôntico, eixo da conduta, envolve valores de volição, obrigação, manipulação, tendo projeção futura; o submodo epistêmico, eixo do conhecimento, compreende valores de crença, probabilidade e verdade. Nesse sentido, o submodo deôntico difere do epistêmico, pois, sob este, "o falante pode se comprometer com a verdade da proposição no passado, presente ou futuro"6 (PALMER, 1986, p. 97). Vê-se, pois, quão imbricadas estão as noções de tempo e de modalidade, devendo, portanto, ser consideradas no tratamento do uso variável do presente do modo subjuntivo. Os dados ${ }^{7}$ a seguir ilustram os submodos deôntico e epistêmico, respectivamente, associados a perspectivas temporais.

5 "The speaker attitude is, in turn, never just - not even primarily - about the proposition itself, but rather about the hearer's attitude toward the proposition as well as toward the speaker" (GIVÓN, 2005, p. 149).

6 "[...] the speaker can commit himself to the truth of propositions in the past, present or future" (PALMER, 1986, p. 97).

7 Todos os dados foram retirados de cartas ao redator publicadas em jornais de Florianópolis (FLP) e de Lages (LGS). 
(1) $[20,1$ CR SC] [...] apresso-me a PEDIR-vos QUE no proximo numero d'O Ideal PUBLIQUEIS a corrigenda que ora vos remetto. (Florianópolis)

(2) [20,2 CR SC] Mas, sr. Dr. uma coisa esse conceituado jornal tem esquecido e TALVEZ essa SEJA de maior alcance político e social. (Florianópolis)

Em (1), o verbo pedir instaura um escopo deôntico sobre todo o contexto linguístico, envolvendo a manipulação do remetente para que sua carta seja publicada no jornal $O$ Ideal e podendo envolver, em certa medida, uma intimidação por parte do remetente acerca do anseio manifestado. Em (2), por sua vez, a modalidade epistêmica se faz presente por intermédio do advérbio talvez, que espalha um tom de incerteza acerca de uma situação que percorre passado, presente e futuro: a possibilidade de que a "coisa" que o jornal esqueceu seja de maior alcance político e social.

Seguindo a previsão givoniana, o presente do modo subjuntivo tem mais probabilidade de aparecer em contexto de submodo deôntico, que naturalmente pressupõe uma projeção temporal futura da situação codificada. Em (1), não há certeza de que a carta será publicada no jornal, ainda que seja do desejo do remetente. E, caso ocorra, sua publicação será posterior ao pedido do autor da carta. Dessa forma, há uma íntima relação entre submodo deôntico e projeção futura, contexto tido como ideal ao aparecimento do modo subjuntivo.

Em (2), a possibilidade de o autor da carta estar errado é, como já apontado, uma incerteza que abarca passado, presente e avança em direção ao futuro, o que ilustra uma projeção temporal espraiada. A incerteza, expressa pelo talvez, não se restringe ao momento exato do processo de escrita; inicia antes e se estende até, pelo menos, o fim da carta. Além do eixo epistêmico poder estar associado a um espectro temporal mais alargado, também é possível encontrar casos de projeção futura em contexto de submodo epistêmico, conforme pode ser observado no dado a seguir.

(3) [19,2 CR SC] Quando forem publicados esses quadros de que fallamos e examinados devidamente, terá então o publico occasião de verificar que não estamos phantasiando, CASO 
ENTENDA que foi com tal objectivo que viemos occupar uma columna deste jornal. (Lages)

Em (3), claramente o conector caso instaura um ambiente epistêmico, envolvendo toda uma situação sob o escopo da incerteza, da possibilidade. A eventualidade de o público vir a entender o objetivo de ocupar a coluna do jornal somente poderá ser verificada em um tempo futuro. Esse dado ilustra, portanto, a relação entre submodo epistêmico e projeção futura. Ainda, é possível encontrar situações em que a modalidade deôntica está associada à projeção espraiada, como pode ser observado no dado que segue.

(4) [19,2 CR SC] A elevação de vistas e o apurado criterio com que tem sido redigida a GAZETA, são motivos PARA QUE o FELICITEMOS de coração [...] (Lages)

Em (4), apresenta-se uma situação - a elevação de vistas e o apurado critério - que promove a necessidade de se manifestarem felicitações. Há, nesse caso, uma situação desencadeadora de uma outra, âmbito, portanto, do submodo deôntico. No dado em análise, a felicitação está ocorrendo no momento em que o autor da carta a escreve, não sendo, nesse sentido, projetada para o futuro.

Os dados de (1) a (4) ilustram, dessa forma, os dois submodos considerados por Givón (1995, 2001, 2005): o deôntico (eixo da manipulação, obrigação, e também do desejo, intenção) e o epistêmico (eixo da crença, probabilidade, verdade), ambos submodos da modalidade. Concebida por Givón (2005) como a atitude do falante sobre a proposição e, também, como a atitude do ouvinte sobre a proposição e sobre o próprio falante, a modalidade, na perspectiva givoniana, instaura-se na interação, recebendo, portanto, um contorno pragmático. Esse contorno pragmático pode ser observado na reinterpretação comunicativa da modalidade na tradição lógica.

Conforme Givón (2001), no eixo da pressuposição, uma proposição é admitida como verdadeira, seja por concordância prévia, seja pela ausência de contestação por parte do ouvinte. Na asserção do realis, a proposição é fortemente asserida como verdadeira e, ainda que haja contestação por parte do ouvinte, o falante tem condições de apresentar evidências consistentes para defender o conteúdo da proposição. Ao 
contrário, na asserção do irrealis, a proposição é fracamente asserida. Como o falante não dispõe de evidências que sustentem a proposição, a contestação pelo ouvinte é prontamente esperada. Por último, a asserção negativa revela uma proposição fortemente asserida como falsa, podendo contrariar crenças do ouvinte. Mesmo havendo contestações por parte do ouvinte, evidências podem ser apresentadas pelo falante em defesa do conteúdo da proposição.

Dessas quatro modalidades, três recebem atenção neste trabalho, a saber: irrealis, realis e pressuposição, articuladas aos submodos deôntico e epistêmico. Associados a esses submodos, estão os 'valores do submodo', quais sejam: volição, volição-manipulação, possibilidade-crença, certeza, manipulação, manipulação-avaliação, avaliação e situação desencadeadora de outra (PIMPÃO, 2012), respectivamente ilustrados nos dados a seguir.

(5) [20,2 CR SC] ESPERO, todavia, QUE depois a Prefeitura não RESOLVA inverter as prioridades. (Florianópolis)

Nesse dado, o autor da carta expressa um desejo, o desejo de que a Prefeitura não inverta as prioridades. Por essa razão, a volição, valor do submodo deôntico, faz-se presente, e a situação sobre a qual incide o verbo esperar está projetada para o futuro.

(6) [20,1 CR SC] [...] apresso-me a PEDIR-vos QUE no proximo numero d'O Ideal PUBLIQUEIS a corrigenda que ora vos remetto. (Florianópolis)

Nesse trecho, o verbo pedir expressa um desejo, uma vontade de que, no número seguinte da edição do jornal, a corrigenda apresentada pelo autor da carta seja publicada. A situação descrita em (6) não envolve apenas um desejo; abarca, ainda, certo grau de manipulação, na medida em que o autor da carta tenta persuadir, mesmo que de forma sutil, o redator do jornal a publicar a corrigenda em um futuro próximo.

(7) [20,2 CR SC] CREIO mesmo QUE os artefatos nucleares é que SÃO os responsáveis por esta grande confusão climática. (Florianópolis) 
Em (7), o verbo crer instaura, no contexto, o submodo epistêmico, especificamente valores de possibilidade, de crença. A situação expressa na oração subordinada - que os artefatos nucleares é que são os responsáveis por esta grande confusão climática - está sob o escopo desse verbo, portanto sob o escopo da incerteza. O autor da carta não afirma nem refuta a ideia de que os artefatos são responsáveis; antes, deixa margem a dúvidas. E essa dúvida já existia antes da redação da carta, continua no momento de sua escrita e avançará em direção ao futuro. Nesse sentido, o espectro temporal mostra-se mais alargado, compreendendo uma maior faixa de tempo.

(8) [20,2 CR SC] Nada contra os operadores, funcionários, gerentes MESMO QUE TEM alguns operadores de caixa que sinceramente era melhor operarem um Facit. (Lages)

O exemplo (8) ilustra um caso de certeza, valor vinculado ao submodo epistêmico, eixo do conhecimento. Nesse trecho, o autor da carta afirma existirem alguns operadores de caixa que não deveriam operar. A situação descrita articula, portanto, o valor de certeza a uma projeção temporal espraiada, compreendendo passado, presente e futuro.

(9) [20,1 CR SC] Não BASTA que o lançador DIGA. (Lages)

O dado (9) ilustra um contexto de manipulação, em que o autor da carta afirma, de forma categórica, que algo não é suficiente, sendo fortemente marcado pelo verbo bastar.

(10) $[19,1$ CR SC] É CONVENIENTE pois que lhe SAIA este apedido. (Lages)

Nesse trecho, o autor da carta avalia a publicação do seu texto, mediante o emprego de ser conveniente, ao mesmo tempo que manifesta, por meio dessa expressão, uma força manipulativa para persuadir o redator a publicá-la. Por sua vez, a publicação pode vir ou não a ser efetivada.

(11) [20,1 CR SC] Não é de ADMIRAR QUE o Snr. Ver.se OPPONHA ao uso livre da razão, porque a igreja romana sempre se oppoz a esta liberdade humana [...]. (Florianópolis) 
Em (11), o verbo admirar por si só instaura um contexto de avaliação acerca de uma situação que está em curso: a oposição de uma pessoa acerca do "uso livre da razão".

(12) [20,1 CR SC] Como sou proprietario e antigo morador desta cidade, pagando muitos impostos, acho-me no direito e no dever de também reclamar alguma cousa QUE me INCOMMODE e QUE não ESTEJA certa. (Lages)

No trecho (12), alguma situação que gere incômodo ao autor da carta pode incitá-lo a fazer uma reclamação. Esse caso ilustra dados que apresentam uma situação desencadeadora de uma ação, projetada, por sua vez, para o futuro.

\subsection{Procedimentos metodológicos}

Entre os diferentes documentos coletados, catalogados e editados, o projeto PHPB-SC, conforme descrito no Capítulo 1, reúne e disponibiliza cartas ao redator de quatro localidades do estado de Santa Catarina: Florianópolis, Blumenau, Chapecó e Lages. Para a descrição do uso variável de formas verbais do presente do modo subjuntivo e presente do modo indicativo, foram consideradas cartas ao redator publicadas em jornais de Florianópolis e de Lages do final do século XIX e de todo o século XX. ${ }^{8}$

Vale ressaltar que o pesquisador interessado na descrição de fenômenos linguísticos a partir de dados diacrônicos precisa, necessariamente, submeter-se à documentação (cartas, peças teatrais, anúncios, por exemplo) existente, não sendo possível constituir seu corpus exatamente como desejado (MATTOS E SILVA, 2006). Recorrer a registros de época significa tentar fotografar os usos linguísticos de um determinado período. Claro que documentos escritos, como cartas pessoais e algumas peças de teatro, por mais naturais que possam parecer, são afetados pela normatização que rege a modalidade escrita da língua em uma determinada época. Essas considerações não desqualificam um estudo, entretanto exigem do pesquisador certa cautela na interpretação de resultados decorrentes

8 O detalhamento da coleta dessa amostra de cartas ao redator encontra-se em Pimpão (2012). 
de uma amostra diacrônica (TARALLO, 1994). Paiva e Duarte (2003) destacam que esse tipo de amostra pode não representar a comunidade de fala da época e pode, ainda, preservar, na escrita, construções já em desuso na fala. Esses aspectos não podem ser ignorados pelo pesquisador.

No que diz respeito especificamente às cartas ao redator, não há como saber se o remetente é natural da cidade onde o jornal é publicado. Por exemplo, não há como saber se o remetente de uma carta publicada no jornal de Florianópolis é natural da cidade; o mesmo ocorre com a publicação de uma carta no jornal de Lages. Para esse tipo de amostra, também não se descarta a possibilidade de ter havido revisão das cartas pela redação do jornal ou mesmo por outras pessoas. O pesquisador, então, precisa submeter-se ao material disponível, como aponta Mattos e Silva (2006). Diante disso, ganha destaque a posição defendida por Labov (1994) segundo a qual se deve fazer o melhor uso de dados não ideais. $\mathrm{O}$ ideal seria haver uma carta por ano, porém, devido à baixa regularidade na publicação de jornais, especialmente no século XIX, e devido à ausência de seções específicas para cartas nos jornais florianopolitanos e lageanos, notadamente até 1960, não foi possível atingir essa expectativa.

Ainda, importa registrar a intenção de diversificar os jornais na tentativa de evitar uma relação entre os resultados alcançados para o uso variável do presente do subjuntivo e o estilo priorizado em determinados jornais. Também cartas enviadas de outras cidades, pertencentes ou não ao estado de Santa Catarina, não fizeram parte da amostra, a menos que o remetente se identificasse como natural de Florianópolis ou de Lages em algum momento da carta publicada.

Outra dificuldade com a qual o pesquisador se depara refere-se ao paradoxo da linguística histórica: "a tarefa da linguística histórica é explicar as diferenças entre o passado e o presente; porém não há meio de saber a extensão da diferença entre o passado e o presente" (LABOV, 1994, p. 21). ${ }^{9}$ Não havendo, portanto, meios de antecipar distinções entre passado e presente, como tentar indicar generalizações acerca de fenômenos linguísticos em um determinado período histórico? Labov $(1972,1994)$ propõe o 'princípio do uniformitarismo', originado das ciências históricas,

9 "The task of historical linguistics is to explain the difference between the past and the present; but to the extent that the past was different from the present, there is no way of knowing how different it was" (LABOV, 1994, p. 21). 
especialmente a geologia e a filologia. De acordo com esse princípio, "as forças que operam para produzir a mudança linguística hoje são do mesmo tipo e ordem de grandeza das que operaram no passado, há cinco ou dez mil anos" (LABOV, 1972, p. 317). Por essa razão, o "conhecimento de processos que operaram no passado pode ser inferido, observando os processos que ocorrem no presente"10 (LABOV, 1994, p. 21). É isso que se busca na seção seguinte.

\subsection{O binômio modalidade e projeção temporal}

Antes de discutir os resultados para as variáveis independentes (ou grupos de fatores) associadas à modalidade e à projeção temporal, importa apresentar a frequência geral das ocorrências na amostra investigada, tomando como aplicação da regra a variante forma verbal no presente do subjuntivo e considerando conjuntamente todos os contextos linguísticos (com talvez e os três tipos de oração subordinada). As rodadas estatísticas (com o programa Goldvarb X) foram realizadas em três etapas: a primeira reunindo dados das duas cidades, a segunda somente dados de Florianópolis (FLP) e a terceira somente dados de Lages (LGS), conforme ilustra a Tabela 10.1.

Tabela 10.1 - Frequência geral de uso da forma verbal presente do subjuntivo (versus presente do indicativo), nas amostras de cartas ao redator de Florianópolis e de Lages

\begin{tabular}{c|c|c}
\hline FLP/LGS & FLP & LGS \\
\hline Apl./Total & Apl./Total & Apl./Total \\
$\%$ & $\%$ & $232 / 269$ \\
\hline $427 / 499$ & $195 / 230$ & $86 \%$ \\
$85 \%$ & $84 \%$ & \\
\hline
\end{tabular}

Fonte: Adaptada de Pimpão (2012, p. 296).

Os resultados percentuais exibidos na Tabela 10.1 praticamente não diferem: apresentam uma diferença de um a dois pontos percentuais,

10 "[...] knowledge of processes that operated in the past can be inferred by observing ongoing process in the present" (LABOV, 1994, p. 21). 
o que, em princípio, exclui a cidade como um potencial grupo de fatores condicionadores do fenômeno variável em análise. A despeito da colonização e do movimento migratório bastante específicos que envolvem Florianópolis e Lages (cf. Capítulo 2), as cidades atingem um percentual bastante aproximado para o uso do presente do modo subjuntivo.

Não somente em termos percentuais há semelhança entre as cidades como também no que se refere às variáveis independentes estatisticamente selecionadas como significativas pelo Goldvarb X, conforme ilustra o Quadro 10.1.

Quadro 10.1 - Variáveis independentes selecionadas nas rodadas gerais de Florianópolis e Lages

\begin{tabular}{|c|c|c|}
\hline FLP/LGS & FLP & LGS \\
\hline $\begin{array}{l}\text { Valores do submodo } \\
\text { Projeção temporal } \\
\text { Tipo de contexto sintático } \\
\text { Periodização histórica } \\
\text { Submodo }\end{array}$ & \begin{tabular}{|c|} 
Submodo \\
Tipo de contexto sintático \\
Projeção temporal
\end{tabular} & $\begin{array}{c}\text { Projeção temporal } \\
\text { Valores do submodo } \\
\text { Periodização histórica } \\
\text { Tipo de contexto sintático }\end{array}$ \\
\hline
\end{tabular}

Fonte: Pimpão (2012, p. 296).

Como se observa no Quadro 10.1, na rodada com as duas cidades reunidas, cinco variáveis obtêm relevância estatística em termos probabilísticos, sendo apenas uma de natureza extralinguística: periodização histórica. Merece destaque a seleção das três variáveis concernentes à modalidade, quais sejam: valores do submodo, projeção temporal e submodo. Dentre essas, a 'projeção temporal' é selecionada também em cada uma das cidades, o 'submodo’ recebe significância em Florianópolis e, em Lages, os 'valores do submodo'. Das demais variáveis, o 'tipo de contexto sintático' é selecionado nos três tipos de rodada, e a 'periodização', única variável extralinguística controlada na amostra, obtém significância na rodada que reúne Florianópolis e Lages e na rodada individual de Lages.

Infere-se, a partir do Quadro 10.1, que há "forças muito semelhantes atuando no uso variável do presente do modo subjuntivo, essencialmente as referentes à modalidade, e, por conseguinte, pouca diferenciação entre Florianópolis e Lages no que diz respeito à atuação dos grupos de fatores" (PIMPÃO, 2012, p. 297). Como se verá adiante, esses resultados vão permitir a distribuição das formas verbais de presente do subjuntivo em 
um continuum de modalidade. A seguir, estão os resultados para as três variáveis independentes concernentes à modalidade: valores do submodo, projeção temporal e submodo.

Tabela $10.2-{ }^{11}$ Atuação das três variáveis independentes concernentes à modalidade sobre o uso da forma verbal de presente do modo subjuntivo (versus presente do modo indicativo) em cartas ao redator de Florianópolis e Lages

\begin{tabular}{|c|c|c|c|c|c|c|}
\hline \multirow[b]{2}{*}{ Modalidade } & \multicolumn{2}{|c|}{ FLP/LGS } & \multicolumn{2}{|c|}{ FLP } & \multicolumn{2}{|c|}{ LGS } \\
\hline & \begin{tabular}{|c|} 
Apl./Total \\
$\%$
\end{tabular} & PR & \begin{tabular}{|c|} 
Apl./Total \\
$\%$
\end{tabular} & PR & \begin{tabular}{|c|} 
Apl./Total \\
$\%$
\end{tabular} & $\mathbf{P R}$ \\
\hline \multicolumn{7}{|c|}{ Valor } \\
\hline Volição & $\begin{array}{l}31 / 31 \\
100 \% \\
\end{array}$ & - & $\begin{array}{c}7 / 7 \\
100 \% \\
\end{array}$ & - & $\begin{array}{l}24 / 24 \\
100 \% \\
\end{array}$ & - \\
\hline Avaliação & $\begin{array}{c}18 / 21 \\
85 \% \\
\end{array}$ & 0.450 & $\begin{array}{c}7 / 8 \\
87 \% \\
\end{array}$ & $(0.459)$ & $\begin{array}{c}11 / 13 \\
84 \% \\
\end{array}$ & 0.651 \\
\hline Manipulação & $\begin{array}{c}249 / 256 \\
97 \% \\
\end{array}$ & 0.415 & $\begin{array}{c}115 / 118 \\
97 \% \\
\end{array}$ & $(0.480)$ & $\begin{array}{c}134 / 138 \\
97 \% \\
\end{array}$ & 0.749 \\
\hline Certeza & $\begin{array}{c}59 / 73 \\
80 \%\end{array}$ & 0.723 & $\begin{array}{c}30 / 38 \\
78 \% \\
\end{array}$ & $(0.571)$ & $\begin{array}{c}29 / 35 \\
82 \% \\
\end{array}$ & 0.479 \\
\hline Probabilidade/Crença & $\begin{array}{c}70 / 118 \\
59 \% \\
\end{array}$ & 0.547 & $\begin{array}{c}36 / 59 \\
61 \% \\
\end{array}$ & $(0.500)$ & $\begin{array}{c}34 / 59 \\
57 \% \\
\end{array}$ & 0.067 \\
\hline \multicolumn{7}{|c|}{ Projeção temporal } \\
\hline Projeção futura & $\begin{array}{c}286 / 295 \\
96 \% \\
\end{array}$ & 0.715 & $\begin{array}{c}125 / 131 \\
95 \%\end{array}$ & 0.653 & $\begin{array}{c}161 / 164 \\
98 \%\end{array}$ & 0.788 \\
\hline Projeção espraiada & $\begin{array}{c}141 / 204 \\
69 \% \\
\end{array}$ & 0.210 & $\begin{array}{c}70 / 99 \\
70 \% \\
\end{array}$ & 0.302 & $\begin{array}{c}71 / 105 \\
67 \%\end{array}$ & 0.114 \\
\hline \multicolumn{7}{|c|}{ Submodo } \\
\hline Deôntico & $\begin{array}{c}298 / 308 \\
96 \% \\
\end{array}$ & 0.772 & $\begin{array}{c}129 / 133 \\
96 \% \\
\end{array}$ & 0.753 & $\begin{array}{c}169 / 175 \\
96 \% \\
\end{array}$ & $(0.788)$ \\
\hline Epistêmico & $\begin{array}{c}129 / 191 \\
67 \% \\
\end{array}$ & 0.122 & $\begin{array}{c}66 / 97 \\
68 \% \\
\end{array}$ & 0.179 & $\begin{array}{c}63 / 94 \\
67 \% \\
\end{array}$ & $(0.080)$ \\
\hline $\begin{array}{c}\text { Total } \\
\text { Significância }\end{array}$ & $\begin{array}{c}427 / 499 \\
85 \% \\
0,025 \\
\end{array}$ & $\begin{array}{l}0.964 \\
\text { Input }\end{array}$ & $\begin{array}{c}195 / 230 \\
84 \% \\
0,006 \\
\end{array}$ & $\begin{array}{l}0.880 \\
\text { Input }\end{array}$ & $\begin{array}{c}232 / 269 \\
86 \% \\
0,009 \\
\end{array}$ & $\begin{array}{l}0.977 \\
\text { Input }\end{array}$ \\
\hline
\end{tabular}

Fonte: Adaptada de Pimpão (2012, p. 298).

${ }_{11}$ Para as variáveis não selecionadas, os pesos relativos foram extraídos do nível 1 do stepdown, estando tais resultados entre parênteses. 
De acordo com a Tabela 10.2, os resultados para a primeira variável independente mostram que a forma verbal de presente do subjuntivo atinge percentuais mais elevados nos valores do submodo associados à modalidade deôntica, quais sejam: volição, avaliação e manipulação, tanto na rodada que reúne dados de Florianópolis e de Lages quanto nas rodadas por cidade. Dentre esses valores, a 'volição' desponta como o contexto de uso categórico dessa forma variante, conforme previsão givoniana. Em termos de peso relativo, os fatores 'avaliação' e 'manipulação' configuram um contexto condicionador ao uso da forma verbal de presente do subjuntivo em Lages.

Observa-se que os valores probabilísticos para 'avaliação' e 'manipulação' destoam entre as rodadas individuais por cidade, ficando Florianópolis com resultados abaixo do esperado devido à sobreposição de grupos de fatores: valores do submodo e submodo. ${ }^{12}$ Essa sobreposição pode ser observada na seleção estatística: Florianópolis seleciona 'submodo' e Lages, 'valores do submodo'. Nesse sentido, apenas em Lages há uma boa paridade entre os pesos relativos e os resultados percentuais.

Ainda na primeira variável independente, no que diz respeito aos valores do submodo epistêmico, o fator 'probabilidade/crença' apresenta os percentuais mais baixos nas rodadas em conjunto e por cidade, revelandose como contexto que não promove o uso do presente do subjuntivo. Diferentemente do esperado, o valor 'certeza' evidencia percentuais altos para o uso do presente do subjuntivo, ainda que com peso relativo mais baixo em Lages. Os dados de 'certeza' enquadram-se, em geral, em um ambiente sintático denominado por Bybee, Perkins e Pagliuca (1994) como 'modo subordinante', à semelhança da 'servidão gramatical' nos termos de Camara Jr. (1986) (cf. dado 22 adiante).

As outras duas variáveis independentes (projeção temporal da situação codificada e submodo) apresentam resultados que se alinham à previsão givoniana: a 'projeção futura' favorece o uso do presente do subjuntivo, com os respectivos pesos para Florianópolis/Lages, Florianópolis e Lages:

12 "Na rodada em conjunto de Florianópolis e Lages, a alteração nos pesos decorre da interação dos grupos de fatores 'valores do submodo' e 'submodo'. Até então, nos níveis de interação com as demais variáveis selecionadas nessa rodada, os pesos para 'manipulação' e 'avaliação' eram os mais elevados. Era esperado que a sobreposição de fatores pudesse interferir nos resultados obtidos" (PIMPÃO, 2012, p. 297). 
0.715; 0.653 e 0.788 . Também o 'submodo deôntico' condiciona o uso dessa variante, conforme os seguintes pesos: $0.772 ; 0.753$ e (0.788).

Sintetizando a análise,

a estreita relação entre as variáveis referentes à modalidade está marcada por essa disputa pela relevância estatística no condicionamento do presente do subjuntivo. $\mathrm{Na}$ rodada em conjunto entre as cidades, 'valores do submodo' assume a primeira posição; em Florianópolis, o grupo de fatores 'submodo' e, em Lages, 'projeção temporal'. Ainda que haja sobreposição de fatores, o controle dessas três variáveis mostra-se significativo e explicita a complexidade que envolve a modalidade: ora aspectos mais modais ganham expressão, ora aspectos mais ligados à projeção temporal de uma situação. (PIMPÃO, 2012, p. 299).

Os resultados discutidos nesta seção, que apontam para a associação entre submodo deôntico e projeção futura, encontram eco nas gramáticas históricas de Barros (1957 [1540]) e Barboza (1830), que destacam o modo outativo como o modo do desejo. O tempo futuro desse modo apresenta, como estrutura morfológica, morfes do presente do subjuntivo como conhecemos na atualidade. Esse modo outativo, posteriormente, foi incorporado ao modo subjuntivo. Também diferentes pesquisas conduzidas com dados de fala têm evidenciado, a partir de resultados estatísticos, a relevância do binômio submodo deôntico e projeção futura: Pimpão (1999), Alves Neta (2000), Santos (2005), Carvalho (2007), Fagundes (2007) e Vieira (2007). Conjugando dados sincrônicos e diacrônicos, Almeida (2010) também integra essa lista de pesquisadores.

Buscando um refinamento no tratamento dos dados, as variáveis independentes 'submodo', 'valores do submodo' e 'projeção temporal da situação codificada' são articuladas de modo a comporem uma variável complexa, cujos fatores são distribuídos em um continuum de modalidade, que percorre o irrealis, o realis e a pressuposição. De tal correlação, despontam os graus descritos a seguir.

Grau 1 - irrealis 1: Manifestado pela modalidade deôntica associada à projeção futura, envolvendo desejo, intenção ou preferência.

(13) [20,2 CR SC] ESPERO, todavia, QUE depois a Prefeitura não RESOLVA inverter as prioridades. (Florianópolis) 
Grau 2 - irrealis 2: Manifestado pela modalidade deôntica associada à projeção futura, envolvendo, ainda, certo grau de manipulação.

(14) [20,1 CR SC] [...] apresso-me a PEDIR-vos QUE no proximo numero d'O Ideal PUBLIQUEIS a corrigenda que ora vos remetto. (Florianópolis)

Grau 3 - irrealis 3: Manifestado pela modalidade deôntica associada à projeção futura, envolvendo avaliação.

(15) [20,1 CR SC] - Pois bem, mulher louca dos meus peccados, PREFIRO QUE CORTES as saias, isto é, QUE as FAÇAS curtas daqui por diante, com um palmo acima do tornozello somente [...] (Lages)

Grau 4 - irrealis 4: Manifestado pela modalidade epistêmica de incerteza associada à projeção futura.

(16) [19,2 CR SC] Quando forem publicados esses quadros de que fallamos e examinados devidamente, terá então o publico occasião de verificar que não estamos phantasiando, CASO ENTENDA que foi com tal objectivo que viemos occupar uma columna deste jornal. (Lages)

Grau 5 - irrealis-realis 1: Manifestado pela modalidade deôntica de volição associada à projeção espraiada.

(17) [19,2 CR SC] Atribulados pelo preço que a vida moderna impõe no nosso dia-a-dia e ansiosos para QUE o final de semana CHEGUE rapidamente [...] (Lages)

Grau 6 - irrealis-realis 2: Manifestado pela modalidade deôntica de manipulação acerca de uma situação atemporal, que se espraia em um eixo temporal que contempla passado, presente e futuro.

(18) [20,1 CR SC] Nestas condições, a não ser por ignorancia ou má fé ninguem terá o direito de AFFIRMAR QUE a elevação de entrancia de uma comarca POSSA concorrer para a elevação de impostos. (Lages) 
Grau 7 - irrealis-realis 3: Manifestado pela modalidade epistêmica de probabilidade/crença associada a uma situação atemporal, que se espraia em um eixo temporal que contempla passado, presente e futuro.

(19) [20,2 CR SC] Mas, sr. Dr. uma coisa esse conceituado jornal tem esquecido e TALVEZ essa SEJA de maior alcance político e social. (Florianópolis)

Grau 8 - realis-pressuposição 1: Manifestado pela certeza epistêmica associada à projeção futura.

(20) [20,1 CR SC] Tendo eu dito que a minha poesia era na mesma metrificação da do sr. Lessa, e havendo n'ella um verso errado, não faltará QUEM JULGUE que na Surdina dos infelizes o verso correspondente está errado tambem, quando está perfeito, completo em todas as suas partes. (Florianópolis)

Grau 9 - realis-pressuposição 2: Manifestado pela modalidade deôntica de avaliação acerca de uma situação atemporal dada como certa pelo falante e não contestada pelo ouvinte.

(21) [20,1 CR SC] Não é de ADMIRAR QUE o Snr. Ver.se OPPONHA ao uso livre da razão, porque a igreja romana sempre se oppoz a esta liberdade humana [...]. (Florianópolis)

Grau 10 - realis-pressuposição 3: Manifestado por uma situação atemporal, dada como certa pelo falante e não contestada pelo ouvinte.

(22) [20,2 CR SC] EMBORA o Nordeste brasileiro FIQUE a muitos quilômetros de Santa Catarina, alguns fenômenos característicos daquela região podem ser vistos claramente em nosso estado. (Florianópolis)

A expectativa associada a esse gradiente é de que a forma verbal de presente do subjuntivo seria mais provável de ocorrer em contexto de submodo deôntico, no valor volitivo, da modalidade irrealis, associado à projeção futura. Valores associados ao submodo epistêmico e com projeção espraiada, por outro lado, situados na interface realis-pressuposição, 
constituiriam o ambiente propício ao uso da forma verbal de presente do indicativo. A Tabela 10.3 exibe os resultados referentes à variável complexa, que envolve um continuum de modalidade.

Tabela 10.3 - Atuação da 'variável complexa' ('valores do submodo' e 'projeção temporal') sobre o uso da forma verbal de presente do modo subjuntivo (versus presente do modo indicativo) em cartas ao redator de Florianópolis e Lages

\begin{tabular}{|c|c|c|c|c|c|c|}
\hline \multirow{2}{*}{$\begin{array}{l}\text { Variável } \\
\text { complexa }\end{array}$} & \multicolumn{2}{|c|}{ FLP/LGS } & \multicolumn{2}{|l|}{ FLP } & \multicolumn{2}{|l|}{ LGS } \\
\hline & $\begin{array}{c}\text { Aplic./Total } \\
\%\end{array}$ & PR & $\begin{array}{c}\text { Aplic./Total } \\
\%\end{array}$ & PR & $\begin{array}{c}\text { Aplic./Total } \\
\%\end{array}$ & PR \\
\hline Irrealis 1 & $\begin{array}{l}30 / 30 \\
100 \% \\
\end{array}$ & - & $\begin{array}{c}7 / 7 \\
100 \% \\
\end{array}$ & - & $\begin{array}{l}23 / 23 \\
100 \% \\
\end{array}$ & - \\
\hline Irrealis 3 & $\begin{array}{c}3 / 3 \\
100 \% \\
\end{array}$ & - & $\begin{array}{c}1 / 1 \\
100 \% \\
\end{array}$ & - & $\begin{array}{c}2 / 2 \\
100 \% \\
\end{array}$ & - \\
\hline $\begin{array}{c}\text { Realis- } \\
\text { pressuposição } 1\end{array}$ & $\begin{array}{c}3 / 3 \\
100 \% \\
\end{array}$ & - & $\begin{array}{c}1 / 1 \\
100 \% \\
\end{array}$ & - & - & - \\
\hline Irrealis-realis 1 & $\begin{array}{c}1 / 1 \\
100 \% \\
\end{array}$ & - & - & - & $\begin{array}{c}1 / 1 \\
100 \% \\
\end{array}$ & - \\
\hline Irrealis 2 & $\begin{array}{c}214 / 216 \\
99 \% \\
\end{array}$ & 0.899 & $\begin{array}{c}97 / 99 \\
97 \% \\
\end{array}$ & 0.858 & $\begin{array}{c}117 / 117 \\
100 \% \\
\end{array}$ & - \\
\hline $\begin{array}{c}\text { Realis- } \\
\text { pressuposição } 2\end{array}$ & $\begin{array}{l}15 / 18 \\
83 \%\end{array}$ & 0.412 & $\begin{array}{c}6 / 7 \\
85 \% \\
\end{array}$ & 0.547 & $\begin{array}{l}9 / 11 \\
81 \% \\
\end{array}$ & 0.681 \\
\hline Irrealis-realis 2 & $\begin{array}{c}35 / 40 \\
87 \%\end{array}$ & 0.313 & $\begin{array}{c}18 / 19 \\
94 \%\end{array}$ & 0.592 & $\begin{array}{c}17 / 21 \\
80 \%\end{array}$ & 0.709 \\
\hline Irrealis 4 & $\begin{array}{c}36 / 43 \\
83 \%\end{array}$ & 0.232 & $\begin{array}{c}17 / 21 \\
80 \%\end{array}$ & 0.235 & $\begin{array}{c}19 / 22 \\
86 \%\end{array}$ & 0.688 \\
\hline $\begin{array}{c}\text { Realis- } \\
\text { pressuposição } 3\end{array}$ & $\begin{array}{c}56 / 70 \\
80 \% \\
\end{array}$ & 0.089 & $\begin{array}{c}27 / 35 \\
77 \% \\
\end{array}$ & 0.105 & $\begin{array}{c}29 / 35 \\
82 \% \\
\end{array}$ & 0.629 \\
\hline Irrealis-realis 3 & $\begin{array}{c}34 / 75 \\
45 \%\end{array}$ & 0.051 & $\begin{array}{c}19 / 38 \\
50 \%\end{array}$ & 0.092 & $\begin{array}{c}15 / 37 \\
40 \%\end{array}$ & 0.155 \\
\hline $\begin{array}{c}\text { TOTAL } \\
\text { Significância }\end{array}$ & $\begin{array}{c}427 / 499 \\
85 \% \\
0,000\end{array}$ & $\begin{array}{l}0.966 \\
\text { Input }\end{array}$ & $\begin{array}{c}195 / 230 \\
84 \% \\
0,000\end{array}$ & $\begin{array}{l}0.883 \\
\text { Input }\end{array}$ & $\begin{array}{c}232 / 269 \\
86 \% \\
0,000\end{array}$ & $\begin{array}{l}0.750 \\
\text { Input }\end{array}$ \\
\hline
\end{tabular}

Fonte: Adaptada de Pimpão (2012, p. 301). 
Para melhor visualização, a Figura 10.1 apresenta a distribuição da variável complexa no continuum de modalidade. De forma geral, os resultados indicam que quanto mais à esquerda, mais submodo deôntico e projeção temporal futura - ambiente que promove o uso de formas verbais do presente do modo subjuntivo. Quanto mais à direita, menos o presente do subjuntivo se mostra atuante, devido à associação entre submodo epistêmico e projeção espraiada - ambiente mais favorável ao uso de formas do presente do indicativo.

Figura 10.1 - Continuum de modalidade no uso de formas verbais do presente do subjuntivo a partir da associação entre submodo, valores do submodo e projeção temporal

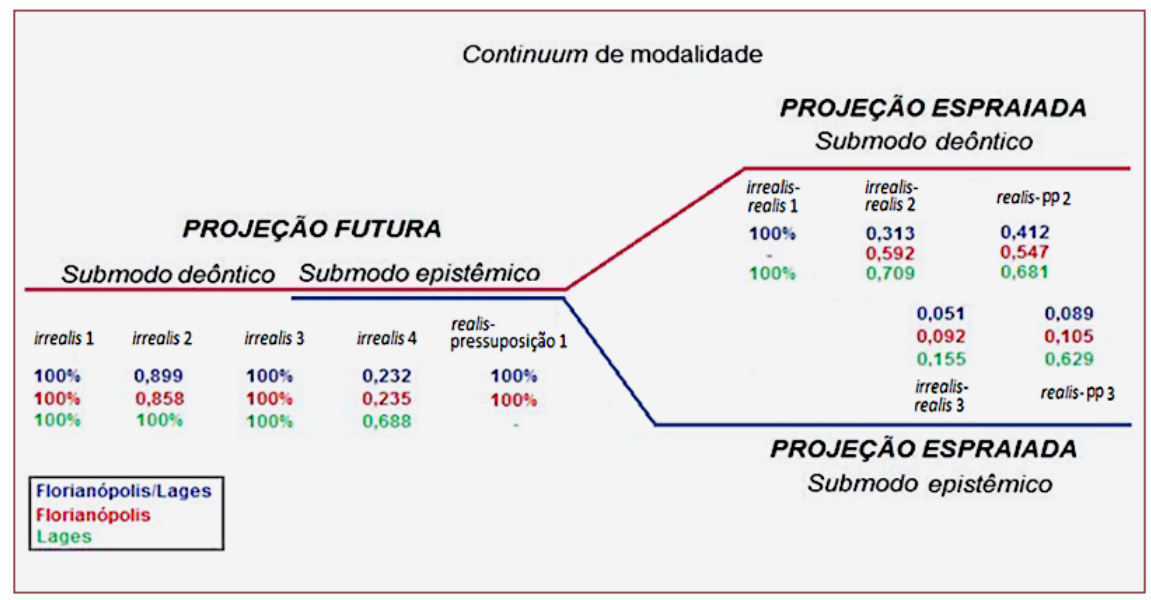

Fonte: Pimpão (2012, p. 301).

Conforme a expectativa embasada em Givón (1995, 2001, 2005), o uso de formas verbais do presente do modo subjuntivo seria mais esperado no ponto do gráfico em que a modalidade deôntica se encontra com a projeção futura, hipótese essa atestada na análise dos dados e evidenciada na Figura 10.1. Nos contextos irrealis 1 e irrealis 3, o presente do modo subjuntivo apresenta usos categóricos, atingindo o percentual de $100 \%$ tanto na rodada estatística que reúne as duas cidades quanto nas rodadas por cidade. No irrealis 2 , o uso categórico alterna com pesos relativos altos para o uso do presente do subjuntivo. 
Usos categóricos também são encontrados em contextos realispressuposição 1 e irrealis-realis 1: o primeiro associando submodo epistêmico e projeção futura e o segundo, submodo deôntico e projeção espraiada, o que evidencia a força da projeção futura e do submodo deôntico, respectivamente.

No lado oposto, e conforme esperado, os valores mais baixos estão na combinação do submodo epistêmico e da projeção espraiada: irrealispressuposição 3 e realis-pressuposição 3. Alguma diferença entre os resultados para Florianópolis e Lages é encontrada nos contextos irrealisrealis 2 e realis-pressuposição 2 , e um pouco mais acentuada no ambiente irrealis 4 .

\subsection{Considerações finais}

Nas palavras de Mattos e Silva, o pesquisador "não constituirá seu corpus, de acordo com os objetivos de sua pesquisa, mas terá de condicionar a seleção de seus dados à documentação remanescente" (MATTOS E SILVA, 2006, p. 34). Essa busca no passado pode apresentar, portanto, alguns obstáculos ao pesquisador, como os encontrados durante a coleta das cartas: baixa frequência de publicação e disposição variada nas páginas dos jornais. $\mathrm{O}$ vocativo, nesse caso, constituiu a referência para a seleção do material: Sr. Redactor e Illmo. Redactor, por exemplo.

Das coletas realizadas, observou-se que: (i) de 1880 , período em que inicia a coleta, até meados da década de 1960, a publicação de cartas ao redator se caracterizava pela baixa regularidade e pela falta de um espaço fixo no jornal; (ii) a partir de meados da década de 1960, os jornais já dispõem de uma seção destinada especificamente à publicação de cartas, o que não necessariamente dispensa o uso de vocativos. Nesse sentido, a constituição da amostra ficou condicionada à documentação existente e buscou-se diversificar a amostra com vistas a não associar o uso variável do presente do subjuntivo a um determinado jornal.

A despeito das dificuldades encontradas, os resultados apontam algumas tendências, como a importância das variáveis independentes concernentes à modalidade, selecionadas em todas as rodadas estatísticas, e a pouca atuação das demais variáveis no condicionamento do uso de formas verbais de presente do subjuntivo. $\mathrm{Na}$ análise dos dados, a modalidade 
parece constituir uma motivação importante na retenção dessa variante. A conjugação de submodo deôntico, volição e projeção futura constitui o ambiente propício ao uso da forma de presente do subjuntivo. Os resultados percentuais e probabilísticos, bem como o continuum de modalidade (cf. Figura 10.1), evidenciam essa correlação, já prevista em Givón (1995, 2001, 2005), assinalada na gramática de Barros (1957 [1540]) e de Barboza (1830) e constatada em estudos a partir de dados sincrônicos de Pimpão (1999), Alves Neta (2000), Santos (2005), Carvalho (2007), Fagundes (2007) e Vieira (2007), e de dados diacrônicos de Almeida (2010).

\section{Referências}

ALMEIDA, E. S. de. Variação de uso do subjuntivo em estruturas subordinadas: do século XIII ao XX. 2010. 294 f. Tese (Doutorado em Letras Vernáculas) Faculdade de Letras, Universidade Federal do Rio de Janeiro, Rio de Janeiro, 2010.

ALVES NETA, A. O uso de formas do indicativo por formas do subjuntivo no português brasileiro. 2000. 114 f. Dissertação (Mestrado em Letras: Linguística) - Faculdade de Letras, Universidade Federal de Minas Gerais, Belo Horizonte, 2000.

AZEREDO, J. C. de. Gramática Houaiss da língua portuguesa. 2. ed. São Paulo: Publifolha, 2013.

BAGNO, M. Gramática pedagógica do português brasileiro. São Paulo: Parábola, 2011.

BARBOZA, J. S. Grammatica philosophica da lingua portugueza. Lisboa:

Tipographia da Académia Real das Sciencias, 1830.

BARROS, J. de. Gramática da língua portuguesa. 3. ed. Organizado por José Pedro Machado. Lisboa: [s.n.], 1957 [1540].

BECHARA, E. Moderna gramática portuguesa. 37. ed. rev. e amp. Rio de Janeiro: Lucerna, 2009.

BYBEE, J.; PERKINS, R.; PAGLIUCA, W. The evolution of grammar: tense, aspect, and modality in the languages of the world. Chicago: The University of Chicago Press, 1994.

CAMARA JR., J. M. Dicionário de linguística e gramática. 13. ed. Petrópolis: Vozes, 1986.

CAMARA JR., J. M. Princípios de linguística geral. 4. ed. Rio de Janeiro: Acadêmica, 1974. 
CARVALHO, H. M. de. A alternância indicativo/subjuntivo nas orações substantivas em função dos tempos verbais presente e imperfeito na língua falada do Cariri. 2007. 158 f. Tese (Doutorado em Linguística) - Departamento de Letras Vernáculas, Universidade Federal do Ceará, Fortaleza, 2007.

CASTILHO, A. T. de. Nova gramática do português brasileiro. São Paulo: Contexto, 2010.

CUNHA, C. Gramática da língua portuguesa. Rio de Janeiro: FAE, 1992.

FAGUNDES, E. D. As ocorrências do modo subjuntivo nas entrevistas do VARSUL no estado do Paraná e as possibilidades de variação com o modo indicativo. 2007. 220 f. Tese (Doutorado em Letras) - Programa de Pós-Graduação em Letras, Universidade Federal do Paraná, Curitiba, 2007.

GÖRSKI, E. M. Variação verbal no domínio funcional tempo-aspecto-modalidade (TAM). (inédito)

GIVÓN, T. Context as other minds: the pragmatics of sociality, cognition and communication. Amsterdam/Philadelphia: John Benjamins, 2005.

GIVÓN, T. English grammar. Amsterdam/Philadelphia: John Benjamins, v. I e II, 1993.

GIVÓN, T. Functionalism and grammar. Amsterdam/Philadelphia: John Benjamins, 1995.

GIVÓN, T. Syntax: a functional-typological introduction. Amsterdam/ Philadelphia: John Benjamins, 1984.

GIVÓN, T. Syntax: an introduction. Amsterdam/Philadelphia: John Benjamins, v. I e II, 2001.

LABOV, W. Principles of linguistic change. v. 1: Internal factors. Oxford/ Cambridge: Blackwell, 1994.

LABOV, W. Sociolinguistic patterns. Philadelphia: University of Pennsylvania Press, 1972.

LUFT, C. P. Gramática resumida. Porto Alegre: Globo, 1971.

MATTOS E SILVA, R. V. O português arcaico: fonologia, morfologia e sintaxe. São Paulo: Contexto, 2006.

MENDES DE ALMEIDA, N. Gramática metódica da língua portuguesa. 45. ed. São Paulo: Saraiva, 1973.

NICHOLS, J. Functional theories of grammar. Annual Review of Anthropology, n. 13, p. 97-117, 1984.

PAIVA, M. da C.; DUARTE, M. E. L. (org.). Mudança linguística em tempo real. Rio de Janeiro: Contra Capa: FAPERJ, 2003. 
PALMER, F. Mood and modality. Cambridge: Cambridge University Press, 1986. PERINI, M. Gramática descritiva do português. São Paulo: Ática, 1996.

PERINI, M. Gramática do português brasileiro. São Paulo: Parábola, 2010. PIMPÃO, T. S. Uso variável do presente no modo subjuntivo: uma análise de amostras de fala e escrita das cidades de Florianópolis e Lages nos séculos XIX e XX. 2012. 350 f. Tese (Doutorado em Linguística) - Programa de Pós-Graduação em Linguística, Universidade Federal de Santa Catarina, Florianópolis, 2012. PIMPÃO, T. S. Variação no presente do modo subjuntivo: uma abordagem discursivo-pragmática. 1999. 129 f. Dissertação (Mestrado em Linguística) Programa de Pós-Graduação em Linguística, Universidade Federal de Santa Catarina, Florianópolis, 1999.

SANTOS, R. M. A. dos. O uso variável do modo subjuntivo em estruturas complexas. 2005. 170 f. Dissertação (Mestrado em Estudos Linguísticos) Instituto de Biociências, Letras e Ciências Exatas, Universidade Estadual Paulista, São José do Rio Preto, 2005.

TARALLO, F. A pesquisa sociolinguística. São Paulo: Ática, 1994.

VIEIRA, M. M. M. Alternância no uso dos modos indicativo e subjuntivo em orações subordinadas substantivas: uma comparação entre o português do Brasil e o francês do Canadá. 2007. 106 f. Dissertação (Mestrado em Letras) Departamento de Letras, Universidade Federal do Rio Grande do Norte, Natal, 2007. 


\section{Capítulo 11}

\section{Estratégias de interação em cartas pessoais íntimas em amostras do PHPB-SC}

Carla Regina Martins Valle Cláudia Andrea Rost Snichelotto

Érica Marciano de Oliveira

\subsection{Introdução}

Neste capítulo, propomos uma análise qualitativa de estratégias de interação em cartas pessoais íntimas, considerando: (i) o continuum falaescrita (cf. MARCUSCHI, 2001; SILVA, 2002; KOCH; OESTERREICHER, 2007) e (ii) a perspectiva da sociolinguística histórica (cf. CONDE SILVESTRE, 2007), que prevê que materiais históricos sejam estudados a partir da relação comunicativa entre os participantes em um determinado evento de fala, levando em conta fatores pessoais (locutor, interlocutor e tipo de relação entre eles) e fatores não pessoais (elementos discursivos e contextuais). 
Foram observadas três estratégias de interação, a saber: sequências injuntivas; marcadores interacionais (MDIs); e formas de tratamento nominal (FTNs), em três amostras do corpus do PHPB-SC - cartas da Tia Ciça, cartas do Vale e cartas de Elza Bertaso.

Um exame preliminar desse material escrito apontava presença significativa de estratégias de interação que se caracterizam pela sua multifuncionalidade, contribuindo para o estabelecimento e a manutenção do contato íntimo entre missivistas e destinatários. Para levar a cabo uma análise dos tipos de estratégias nas amostras mencionadas, mantivemos em mente algumas questões que nortearam a investigação: (i) Quais as características do gênero "cartas" e dos conjuntos de cartas das amostras? (ii) Como estabelecer contato com o interlocutor por meio de cartas pessoais? (iii) Quais são as estratégias usadas para marcar o contato entre os interlocutores? (iv) Que funções cumprem esses elementos interacionais?

O presente capítulo organiza-se em cinco seções. Na seção seguinte lançamos os apontamentos teóricos que orientam a análise e, logo após, na Seção 11.3, apresentamos a metodologia do trabalho. Na Seção 11.4, por causa de diferenças e especificidades das amostras, analisamos em cada uma delas uma estratégia de interação que pareceu mais evidente naquele conjunto de cartas. Por fim, na Seção 11.5, apresentamos nossas considerações finais sobre os achados da análise.

\subsection{Apontamentos teóricos}

Esta seção é organizada em duas subseções: uma dedicada à sociolinguística histórica e outra que versa sobre o gênero carta pessoal e sobre o continuum fala-escrita inerente a esse gênero.

\subsubsection{Sociolinguística histórica}

A sociolinguística histórica (cf. CONDE SILVESTRE, 2007) surgiu na década de 1980, através de estudos que propuseram unir os métodos de análise da sociolinguística variacionista (centrada em dados de fala) com os da linguística histórica (focada em dados de escrita), para pesquisar fenômenos linguísticos em textos escritos antigos. 
Um dos pressupostos dessa disciplina é "vislumbrar as diferenças substanciais, comunicativas ou estruturais [da escrita], sem supor que o material escrito é isento de variabilidade"1 (CONDE SILVESTRE, 2007, p. 44). Embora nem todos os textos escritos apresentem o mesmo grau de variabilidade, os que têm maior variação são aqueles que transferem para o meio escrito trocas comunicativas que poderiam ter ocorrido no meio oral, tal como é o caso do gênero cartas pessoais.

Para a sociolinguística histórica (cf. CONDE SILVESTRE, 2007), os materiais históricos que sobreviveram ao tempo (como as cartas pessoais, por exemplo) devem ser estudados a partir da relação comunicativa entre os participantes em um determinado evento de fala, considerando fatores pessoais (locutor, interlocutor e tipo de relação entre eles) e fatores não pessoais (elementos discursivos e contextuais), tal como elencados no seguinte trecho:

1 Fatores pessoais, que incluem: (a) o falante e o controle que este exerce sobre sua produção linguística, além das restrições histórico-geográficas e sociolinguísticas às quais está submetido; (b) os interlocutores, a quantidade dos que participam na interação (estabelecendo com o falante relações bilaterais ou multilaterais), e a atenção que, como audiência, prestam à mensagem (monitorada ou casual segundo o tratamento dos interlocutores investigados diretamente ou não); e (c) o tipo de relação que se estabelece entre eles (íntima, formal, casual etc.), manifestada, por exemplo, no exercício de poder e/ou de solidariedade.

2 Fatores não pessoais, que compreendem: (a) elementos discursivos como o tema (formal ou informal, pessoal ou não), o tipo de comunicação (monólogo, conversa dirigida, conversa livre) e o gênero discursivo (narrativo, expositivo, argumentativo); e (b) elementos contextuais, como o lugar (familiar ou não), o momento em que ocorre a interação comunicativa (adequada ou não), e o

1 "[...] vislumbrar que la existencia de diferencias sustanciales, comunicativas o estructurales, no supone que el material linguístico escrito esté exento de variabilidade" (CONDE SILVESTRE, 2007, p. 44). Todas as traduções de citações ao longo deste capítulo são de responsabilidade das autoras. 
tipo de atividade pública ou privada que com ela se desenvolve. ${ }^{2}$ (CONDE SILVESTRE, 2007, p. 59, grifo do autor).

Nem sempre é possível recuperar todas as informações relevantes para o estudo dos registros escritos que permaneceram no tempo. Muitos materiais apresentam-se parcialmente deteriorados pelas condições de armazenamento e pela própria passagem dos anos. A falta de organização do material escrito também é um complicador para a análise, já que no processo de garimpagem dos arquivos históricos disponíveis é comum encontrarmos muito material sem a devida sistematização e registro. Muitas vezes o material escrito está misturado em pastas sem catalogação detalhada, carecendo também de informações sobre o ano de produção, a autoria e os propósitos do texto.

Nesse sentido, a carta pessoal apresenta-se como fonte frutífera de análise, pois possibilita a reconstrução do contexto histórico por conter informações necessárias, como o nome dos missivistas e dos destinatários (muitas vezes encontramos também os envelopes com dados completos de remetente e destinatário), as possíveis relações entre seus interlocutores (depreendidas a partir do conteúdo das cartas), o local e a data de produção, além de dados sobre o contexto social da época em que se escreve.

Ademais, cartas pessoais, quando não são de figuras ilustres, são guardadas em arquivos de familiares (geralmente do destinatário) e, quando disponibilizadas para a pesquisa, vêm acompanhadas de relatos pessoais de seu curador ou do próprio destinatário ou missivista (quando doadas ainda

2 “1) Factores personales, que incluyen: (a) el hablante y el control que éste ejerce sobre su producción linguística, además de las restricciones histórico-geográficas y sociolinguísticas a las que está sometido; (b) los interlocutores, la cantidad de ellos que participan en la interacción (estableciendo con el hablante relaciones bilaterales o multilaterales), y la atención que, como audiencia, prestan al mensaje (plena o casual según se trate de interlocutores interpelados diretamente o no); y (c) el tipo de relación que se estabelece entre ellos (íntima, formal, casual etc.), manifestada, por ejemplo, en el ejercicio del poder $y / o$ la solidaridad. 2) Factores no personales, que compreenden: (a) elementos discursivos como el tema (formal o informal, personal o no), el tipo de comunicación (monólogo, conversación dirigida, conversación libre) y el género discursivo (narrativo, expositivo, argumentativo); y (b) elementos contextuales, como el lugar (familiar o no), el momento en el que ocorre la interación comunicativa (adecuado o no), y el tipo de actividad pública o privada que con ella se desarrolla" (CONDE SILVESTRE, 2007, p. 59, grifo do autor). 
em vida), o que auxilia sobremaneira a recuperação dos fatores pessoais e não pessoais.

\section{1.2.2 Gênero carta pessoal e o continuum fala-escrita}

Bakhtin, de uma perspectiva dialógica, considera que o uso da língua está relacionado às diversas esferas da atividade humana, materializadas nos diversos gêneros do discurso, que refletem as condições específicas de cada uma das esferas comunicativas, por seu conteúdo temático, seu estilo verbal e sua estrutura composicional. Para o autor, o uso da língua se realiza em forma de enunciados (orais e escritos) e "cada enunciado particular é individual, mas cada campo de utilização da língua elabora seus tipos relativamente estáveis de enunciados, os quais denominamos gêneros do discurso" (BAKHTIN, 2011 [1979], p. 262). Apesar de sua natureza preditiva, os gêneros não são estanques, pelo contrário, são passíveis de modificação pela ação criativa dos sujeitos envolvidos na situação comunicativa que se instaura por meio deles: são dinâmicos, maleáveis, plásticos (MARCUSCHI, 2002, 2008).

Estudos mostram que a escrita de cartas existe há 4.000 anos. As primeiras missivas foram produzidas pela civilização egípcia e pelas civilizações da antiga Mesopotâmia com o intuito de estabelecer a comunicação com alguém que não está próximo (cf. BOUVET, 2006). Ao longo do tempo, essa comunicação epistolar passou a garantir a convivência e o estreito relacionamento a distância entre familiares e pessoas com certa intimidade. Nesse caso, a escrita possibilita o diálogo por superar obstáculos temporais e espaciais que impedem a comunicação presencial entre missivista e destinatário.

A temática das cartas pessoais normalmente envolve assuntos da vida cotidiana e "[...] há uma sobreposição de propósitos, entre eles o de informar sobre a vida cotidiana, agradecer por um presente, ou mesmo reclamar da falta de notícias, sendo que algum pode se destacar como predominante" (GALVÃO; SILVA, 2012, p. 313). Contudo, muitas vezes, a troca de cartas, para além da finalidade de compartilhar conteúdo específico, ocorre simplesmente para ativar e manter a interação entre missivista e destinatário. Ainda segundo os autores, a configuração das cartas pessoais envolve elementos fixos, embora nem sempre presentes, organizados em 
seções, tais como: local e data, endereçamento, abertura, desenvolvimento, fechamento, assinatura e post scriptum.

A interação e o envolvimento entre os interlocutores são características fundamentais desse gênero, por isso aqueles que escrevem usam estratégias linguísticas que dão ao leitor a impressão de que estão em uma interação face a face (GALVÃO; SILVA, 2012). Sendo assim, cabe ressaltar que

[...] a dimensão interativa envolve e caracteriza toda e qualquer produção discursiva, na qual se pressupõe a (inter)ação dos participantes sobre (e entre) si mesmos, sobre os saberes partilhados que abrangem os conhecimentos ditos enciclopédicos, os relativos ao gênero textual atualizado, as representações da situação comunicativa em que estão engajados, o(s) assunto(s) em questão. (SILVA, 2002, p. 23).

Essa interação recorrente que permeia o diálogo entre missivista e destinatário evidencia que a ambivalência oralidade-escrita é inerente às cartas pessoais. Nesse sentido, Koch e Oesterreicher caracterizam a relação entre oralidade e escrita em dois aspectos: meio (fônico/gráfico) e concepção (fala/escrita). Além disso, os autores estabelecem alguns valores paramétricos prototípicos do gênero carta pessoal:

a) privacidade, b) familiaridade entre os interlocutores; c) envolvimento emocional relativamente forte; d) ausência de fixação na situação, talvez uma fixação limitada na ação; e) impossibilidade, em princípio, de dêixis focada na origem do falante, exceto em relação ao eu; f) distância física; g) impossibilidade de cooperação na produção; h) dialogicidade rigorosamente regulada (intercâmbio de correspondência); i) relativa espontaneidade; j) desenvolvimento temático livre. ${ }^{3}$ (KOCK; OESTERREICHER, 2007, p. 27, grifo do autor).

3 “a) privacidad, b) familiaridad entre los interlocutores; c) implicación emocional relativamente fuerte; d) ausencia de anclaje en la situación, quizá un anclaje limitado en la acción; e) imposibilidad, en principio, de deíxis centrada en el origo del hablante, excepto con respecto al ego; $f$ ) distancia fisica; $g$ ) imposibilidad de cooperación en la producción; $h$ ) dialogicidad estrictamente regulada (intercambio de correspondencia); i) espontaneidad relativa; $j$ ) desarrollo temático libre" (KOCH; OESTERREICH, 2007, p. 26-27, grifo do autor). 
Tais valores paramétricos são situados, pelos autores, entre dois eixos comunicativos, inmediatez (oralidade) e distancia (escrita), o que resulta na configuração explicitada na Figura 11.1.

Figura 11.1 - Valores paramétricos da carta pessoal

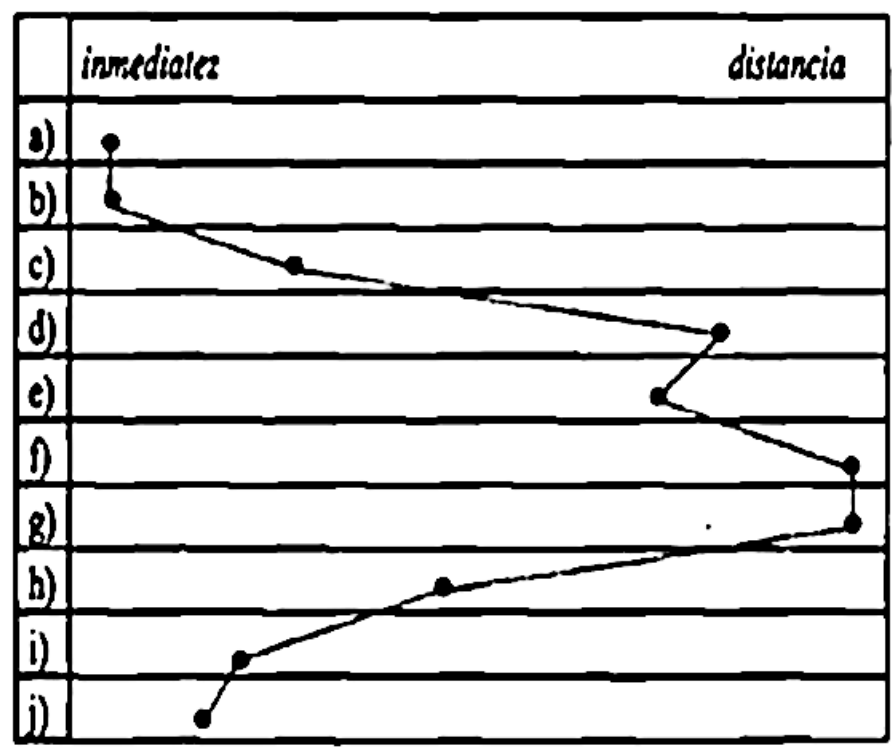

Fonte: Koch e Oesterreicher (2007, p. 28-29).

Nota-se que os valores paramétricos (a) privacidade e (b) familiaridade entre os interlocutores estão no eixo inmediatez (oralidade), enquanto os valores paramétricos (f) distância física e (g) impossibilidade de cooperação na produção estão no eixo distancia (escrita). No entanto, o que nos chama a atenção é o valor paramétrico $(\mathrm{h})$ dialogicidade rigorosamente regulada, que está situado ao meio do continuum entre oralidade e escrita. Observe-se que, enquanto no eixo inmediatez (oralidade), a dialogicidade corresponderia às respostas aos estímulos e à típica alternância de turnos entre os interlocutores que interagem face a face, no eixo distancia (escrita), a dialogicidade refere-se ao intercâmbio de correspondências entre missivista e destinatário. Nesse sentido, o parâmetro dialogicidade rigorosamente regulada evidencia como a interação é característica desse gênero epistolar. 
Ao final desta seção, cabe pontuar que a troca de cartas pessoais dáse em esfera privada, entre interlocutores que, distanciados no tempo e no espaço, constroem sentidos por compartilharem conhecimentos, crenças, pontos de vista e histórias em comum. Sendo assim, na maioria das vezes, é possível recuperar o grau de intimidade entre os interlocutores (amigos, pai/mãe e filho(a), namorados, entre outros) pelo conteúdo das missivas, por uma série de pistas linguísticas que estão presentes nas cartas e também pelos relatos adicionais dos curadores ou proprietários das cartas. Vale destacar ainda que o gênero cartas pessoais, apesar de ter assegurado a comunicação privada ao longo de séculos, tem seu uso reduzido nos dias atuais, já que suportes mais modernos como o e-mail e os aplicativos de comunicação online, como o Whatsapp, viabilizam outros gêneros que assumem a finalidade sociocomunicativa que um dia foi restrita às cartas pessoais.

\subsection{Metodologia}

A fim de analisarmos algumas das estratégias de interação entre missivistas e destinatários que ocorrem em cartas pessoais que compõem o corpus do PHPB-SC, realizamos observação em três amostras de regiões representativas do estado (Florianópolis, Vale do Itajaí e Oeste Catarinense): amostra cartas da Tia Ciça, amostra cartas do Vale e amostra cartas de Elza Bertaso, respectivamente, já apresentadas brevemente no Capítulo 1. Percebemos que cada amostra apresentava suas particularidades e em cada uma havia estratégias diferentes que chamavam a atenção.

$\mathrm{Na}$ amostra cartas da Tia Ciça, foram analisadas as sequências injuntivas (formas de imperativo de segunda pessoa e algumas perguntas diretas do locutor para o interlocutor como marca de interação). Na amostra cartas do Vale, foram examinados marcadores discursivos interacionais (MDIs), que têm o papel de colocar foco, cumprindo funções relacionadas com o interlocutor e com a organização discursiva, tais como sabe? e tá certo?. E na amostra cartas de Elza Bertaso, foram investigadas as formas de tratamento nominal (FTNs), expressões utilizadas para se dirigir a outra pessoa participante do discurso.

A seguir, descrevemos cada uma das amostras e, na seção seguinte, passamos à análise de cada um dos fenômenos na respectiva amostra. 


\section{1.3.1 Amostra cartas da Tia Ciça}

Para este trabalho foram analisadas 50 das 125 cartas que compõem a amostra cartas da Tia Ciça. Essas cartas foram escritas por uma missivista catarinense a sua sobrinha T, entre os anos de 1988 e 2014. A missivista é filha de imigrantes poloneses, nasceu no ano de 1934 em Itajaí-SC, cidade portuária que recebeu os primeiros grupos de imigrantes poloneses no estado de Santa Catarina, no final do século XIX (ZANELATTO, 2011). Em Itajaí, a missivista cresceu e permaneceu até ir para a Escola Normal. Aos 19 anos foi trabalhar como professora em Florianópolis, onde conheceu A, com quem se casou e teve quatro filhos.

A sobrinha T, também professora, nasceu e cresceu em Lages-SC. Na década de 1980, passa a viver e a trabalhar na ilha de Santa Catarina. Vivendo na mesma cidade, tia e sobrinha continuaram a trocar correspondências. A tia mora no bairro Estreito, lado continental da capital, e a sobrinha no centro da cidade, lado ilhéu, separadas geograficamente pela Baía Norte.

Os assuntos das cartas são os mais variados, há conversas ontológicas sobre a vida e a morte, a partir da contemplação de uma planta ou de uma letra de música ouvida enquanto a carta é escrita; há desabafos sobre os problemas familiares, como crise no casamento e educação dos filhos; há, também, críticas sobre o governo da época, sobre a inflação e sobre programas de televisão. As telenovelas são muito comentadas nas cartas, a missivista reconta histórias de alguns personagens e analisa a direção e as atuações de atores famosos para a sobrinha.

\section{1.3.2 Amostra cartas do Vale}

A amostra cartas do Vale conta com 25 cartas de missivistas (mulheres jovens) da região do Vale do Itajaí para um mesmo destinatário (namorado ou pretendente das missivistas), que foram escritas na década de 1960. O doador da amostra e destinatário das cartas é nascido em Nova TrentoSC, cidade que recebeu grande fluxo migratório da península itálica no final do século XIX e início do século XX. As cerca de 11 mil pessoas que se estabeleceram na colônia, a partir de 1875, vinham de regiões distintas do norte da Itália, da Valsugana, no alto vale do Brenta, no Trentino e de Monza. Esses imigrantes trouxeram consigo línguas distintas e defrontaram-se com as outras línguas já existentes no contexto brasileiro: no convívio com os 
falantes de português, com os falantes de origem germânica que chegaram no mesmo período e com os povos indígenas que já habitavam a região (MUNICÍPIO DE NOVA TRENTO, 2014).

O destinatário, jovem na faixa dos 20 anos de idade na época em que as cartas foram escritas, trabalhava como professor de Língua Portuguesa e era integrante de uma banda de música da região.

As cartas que compõem a amostra são de 11 missivistas que escreviam das cidades de Nova Trento, Blumenau, Angelina, Guabiruba, Itajaí, São João Batista e Florianópolis. Sabe-se que todas eram mulheres jovens, mas não foi possível recuperar informações específicas sobre cada uma delas. Percebe-se, a partir do conteúdo das cartas, que há variação no grau de proximidade entre as missivistas e o destinatário, já que há: (i) aquelas que já estavam em relacionamento amoroso com o rapaz (tratando de ciúmes, saudades, encontros e desencontros); e (ii) aquelas que almejavam um relacionamento amoroso ou de amizade (discorrendo sobre a banda do rapaz, falando de si, de seus hábitos etc.).

\subsubsection{Amostra cartas de Elza Bertaso}

A amostra cartas de Elza Bertaso é constituída por correspondências pessoais escritas por Elza Bertaso ${ }^{4}$ dirigidas à mãe Zenaide Bertaso no período de 1914 a $1926 .{ }^{5}$ Elza remeteu nesse período 82 cartas à sua mãe Zenaide.

Essa amostra compõe o acervo de correspondências da família do coronel Ernesto Bertaso, um dos proprietários da empresa colonizadora Bertaso, Maia e Cia. ${ }^{6}$ Esse arquivo documental foi doado pela família para

4 Essa amostra de cartas integra o projeto "Práticas de escrita no oeste catarinense: uma história da escrita epistolar a partir do acervo da família Bertaso", coordenado pelo professor Fernando Vojniak, integrante do Grupo de Pesquisa Historiografia, Linguagens e Memória (GP-HLM) e do Laboratório Escrita, Memória e Arte (LEMA) da Universidade Federal da Fronteira Sul.

5 Não há, no arquivo epistolar doado ao Centro de Memória do Oeste de Santa Catarina (CEOM), cartas de Elza à mãe correspondentes ao ano de 1924.

6 A Companhia Colonizadora Bertaso, Maia e Cia iniciou suas atividades no município de Chapecó em 1918. A colonizadora, que mais tarde passou a ser apenas Bertaso, incentivava os migrantes gaúchos a adquirir títulos de propriedade de pequenos e médios lotes rurais no Oeste de Santa Catarina (VICENZI, 2014). 
o Centro de Memória do Oeste de Santa Catarina (CEOM) e tombado pelo município de Chapecó em 9 de agosto de 1993 por meio do Decreto no 3.202. O acervo contém documentos relativos não só à companhia colonizadora, mas também à vida privada da família Bertaso (SCHAPUIS WENDLING; VOJNIAK, 2018).

Elza Bertaso nasceu em 15 de julho de 1905 em Bento Gonçalves-RS e lá morou na casa dos avós maternos até 1915, quando foi encaminhada a Porto Alegre-RS, com 9 anos de idade, para estudar no Colégio Nossa Senhora do Bom Conselho, onde ficou sob regime de internato até 1918. Depois, foi para o Colégio Nossa Senhora de Sion, em Curitiba-PR, e, em 1920, foi para São Paulo, capital, onde estudou até 1923 na sede da mesma instituição. Em 22 de abril de 1924, Elza se casa com Paulo Pasquali e volta a residir em Bento Gonçalves.

Do conjunto de correspondências escritas por Elza Bertaso, selecionamos aquelas que ocorrem em um único tipo de interação: a díade mãe e filha. A maior parte das cartas desse período (1914 a 1926) foi escrita num ambiente institucionalizado e passava por supervisão antes de ser postada. A supervisão das cartas, de certa forma, desagradava Elza, que manifestou o seguinte em carta à mãe no dia 20 de junho de 1922: “[...] Serafim esteve aqui [São Paulo] domingo, e me prometeu que viria amanha para buscar esta carta. Porque o que eu mais detesto é mandar carta pelo collegio [...]". Porém, há, também, na amostra, a sinalização de que algumas cartas não tenham sido escritas na escola: "Esta carta não estou escrevendo no collegio estou escrevendo-a em casa" (Porto Alegre, 6/8/1916).

Em geral, as cartas que Elza encaminhou à mãe relatam, de modo recorrente, sua condição de saúde, o cotidiano e seu desempenho escolar, além de demonstrarem afeto e preocupação com o pequeno núcleo familiar de que vivia afastada (SIMON, 2015).

\subsection{Estratégias de interação em cartas pessoais}

Nesta seção é apresentada a análise de algumas estratégias de interação - aquelas que se mostraram mais evidentes nos conjuntos de cartas examinadas: (i) na amostra cartas da Tia Ciça, o foco recai sobre as sequências injuntivas; (ii) na amostra cartas do Vale, são analisados os marcadores discursivos interacionais (MDIs); e (iii) na amostra cartas 
de Elza Bertaso, são examinadas as formas de tratamento nominal (FTNs).

\subsubsection{As sequências injuntivas como estratégias de interação na amostra cartas da Tia Ciça}

No gênero carta pessoal é possível destacar diversas estratégias de interação entre remetente e destinatário, uma delas é a sequência tipológica injuntiva. Conforme Marcuschi, a sequência tipológica, ${ }^{7}$ ou o tipo textual, "designa uma espécie de construção teórica (em geral uma sequência subjacente aos textos) definida pela natureza linguística de sua composição (aspectos lexicais, sintáticos, tempos verbais, relações lógicas, estilo)" (MARCUSCHI, 2008, p. 154).

Ao analisar as sequências tipológicas em uma carta pessoal, Marcuschi (2002) encontrou as variedades tipológicas mais frequentes de forma integrada (narração, descrição, argumentação, exposição e injunção), com predominância das sequências descritivas e expositivas. As sequências injuntivas apareceram mais em momentos em que o remetente incita uma ação do destinatário. De acordo com Werlich (1973 apud MARCUSCHI, 2002, p. 27), os traços linguísticos do tipo textual injuntivo são, geralmente, representados por um verbo no imperativo e por enunciados incitadores à ação. Na perspectiva pragmática, o tipo injuntivo - ou os atos de fala exercitivos (AUSTIN 1990 [1962]) ou diretivos (SEARLE, 1995 [1979]) se caracteriza pelo fato de o locutor tentar direcionar, orientar, levar o interlocutor a fazer algo.

Koch explica que as sequências injuntivas "apresentam prescrições de comportamentos ou ações sequencialmente ordenadas, tendo como principais marcas os verbos no imperativo, infinitivo ou futuro do presente e articuladores adequados ao encadeamento sequencial das ações prescritas" (KOCH, 2009, p. 68). Para Travaglia, o tipo textual injuntivo pode ser dividido em seis subtipos: "a ordem, o pedido, a súplica, o conselho, a prescrição e a optação ou volição” (TRAVAGLIA, 2012, p. 365).

7 Nos termos de Koch, as sequências tipológicas, também conhecidas por sequências textuais, são "esquemas linguísticos básicos que entram na constituição de diversos gêneros [...]” (KOCH, 2009, p. 62-63). 
De forma semelhante aos subtipos do tipo textual injuntivo apresentados por Travaglia (2012), Zibetti (2018), ao propor um estudo sobre a alternância estilística na amostra cartas da Tia Ciça na perspectiva da sociolinguística variacionista, encontrou na amostra analisada alguns contextos estilísticos com características injuntivas - como pergunta e resposta explícita à interlocutora, pergunta retórica, conselho e pedido explícito à interlocutora - que foram agrupados pela autora em contextos estilísticos interacionais.

Com base nesses estudos, mapeamos as sequências injuntivas em 50 missivas da referida amostra, considerando a estrutura do gênero epistolar, e encontramos três subtipos de sequências injuntivas distribuídos em um total de 40 ocorrências, conforme mostra a Tabela 11.1.

Tabela 11.1 - Subtipos de sequências injuntivas encontrados na amostra cartas da Tia Ciça

\begin{tabular}{c|c|c}
$\begin{array}{c}\text { Partes constitutivas do } \\
\text { gênero epistolar }\end{array}$ & $\begin{array}{c}\text { Subtipos de sequências } \\
\text { injuntivas }\end{array}$ & $\begin{array}{c}\text { Número de } \\
\text { ocorrências }\end{array}$ \\
\hline Encabeçamento & Pedido & 3 \\
(data e saudações iniciais) & Conselho & 2 \\
\hline \multirow{2}{*}{ Núcleo } & Pedido & 2 \\
& Conselho & 7 \\
\hline \multirow{2}{*}{ Fechamento (saudações finais, } & Pergunta & 1 \\
\hline assinatura e possível post scriptum) & Pedido & 17 \\
& Conselho & 5 \\
\hline
\end{tabular}

É interessante observar que esses subtipos injuntivos aparecem nas diferentes partes constitutivas do gênero epistolar, com mais frequência no fechamento da carta (em 25 das 40 ocorrências), permitindo, dessa forma, perceber um elo de interação entre a remetente, que incita sua interlocutora à ação, e a destinatária, que, possivelmente, realiza a ação solicitada em uma futura carta de resposta àquela.

$\mathrm{Na}$ parte encabeçamento, os subtipos injuntivos encontrados nas cartas foram pedido e conselho. Para ilustrar tais subtipos, selecionamos excertos de algumas cartas, como a do dia 3/11/2009, em que a missivista dá as boas-vindas à $T$, que, supostamente, volta de uma viagem. Nessa carta, a missivista mostra o quanto sentia falta da sobrinha, por meio do 
pedido "preciso de ti". Considerando que a sobrinha é uma interlocutora de confiança da missivista - porque Tia Ciça conversa os mais variados assuntos com T, sobretudo assuntos muito íntimos -, esse pedido foi feito à sobrinha com a intenção de manter o diálogo, mesmo que Tia Ciça não saiba usar a internet como recurso de comunicação.

(1) [20,2 CP SC] Novembro, 3/2009 querida. ...que bom, que estás novamente, nossa terra, nossa gente! Preciso de ti. Já fazes parte de tudo. Embora a gente se faz presente só no papel, e no fio, teus cartões, tua fala, tú, num todo, eu preciso. Não sei nada de dáblios, ponto.com. Então, eu sou o teu baião de barro, a panela, até a cardosa frita, pro teu pirão. Certo? Aqui, tudo [...] [Amostra Tia Ciça, 3/11/2009] - pedido

Já na carta do dia 23/6/2010, a missivista conta que está muito gripada e teme que tenha pegado a gripe H1N1. Essa gripe, em 2009 e 2010, afetou parte da população mundial e ficou conhecida popularmente no Brasil como gripe suína, por isso a missivista diz que pegou " 1 porco". Nesse sentido, para contar à sobrinha que estava bastante gripada e para evitar que a gripe fosse transmitida à interlocutora, Tia Ciça aconselha a T que leia a missiva e, depois, jogue-a fora.

(2) [20,2 CP SC] Querida. Tô podre. Peguei 1 porco [uma gripe], horrível, e dôr pelo corpo, até febre, me deu. Lê essa "missiva", e joga fora, deve estar lotada de vírus, bactérias, em geral [...] [Amostra Tia Ciça, 23/6/2010] - conselho

No núcleo das cartas analisadas, encontramos os subtipos injuntivos pedido, conselho e pergunta (explícita à destinatária), de modo que pressupomos que tal pergunta seria respondida numa carta posterior. Selecionamos como exemplo do subtipo injuntivo pedido um excerto da carta de 11/5/1992, na qual Tia Ciça conta para T um causo, que ouviu na infância, sobre o casamento da prima C. Na carta, a missivista relata que, diante da dificuldade financeira da época, foi servida uma colher de açúcar branco, que era a "maravilha do momento", para cada convidado da festa de casamento de C. Ao finalizar a história, Tia Ciça explica que "essa colher de açúcar branco" está representada no cartão-convite para a festa da neta $\mathrm{M}$, e pede para que a sobrinha $\mathrm{T}$ faça companhia a ela na festa. 
(3) [20,2 CP SC] [...] Essa estória que ficou na história (não sei se escrevi certo) me foi contada pela própria C., nas minhas alucinações de 4 anos de febre amarela. Hoje, eu quero que tu partilhes dessa colher de açúcar branco, comigo, tão bem representada pelo cartão da $M$. [...] Quero que tu, que sempre recebes minhas neuras e protestos, venha comigo à essa festa, essa doçura de amor [...] [Amostra Tia Ciça, 11/5/1992] pedido

O subtipo injuntivo conselho, presente no núcleo da carta, é ilustrado em passagem da correspondência de 31/10/1996, em que a missivista, em resposta a sua interlocutora, disse que quer fazer parte da festa da sobrinha (pressupomos que, na carta anterior, $\mathrm{T}$ estivesse organizando uma festa de sonho), e a aconselha a sonhar e ser feliz, como pode ser visto no trecho (4).

(4) [20,2 CP SC] [...] Quero fazer parte dessa festa. A do teu sonho. Sonha mesmo, de olho aberto, fechado voa a imaginação. Com asas de borboletas, porque, é primavera, em tudo e em todos. Lembra sempre, que, ser feliz, é querer. É sentir, a felicidade. [Amostra Tia Ciça, 31/10/1996] - conselho

Como exemplo de subtipo injuntivo pergunta (explícita à destinatária), também no núcleo, apresentamos um excerto da carta de 22/2/2010, em que Tia Ciça comenta sobre o seu dedo quebrado do pé e, em seguida, questiona a sobrinha sobre o pé dela, com a intenção de saber se T decidiu ou não operá-lo. Seguidamente, a missivista aconselha a sobrinha a procurar o melhor ortopedista para tal tratamento.

(5) [20,2 CP SC] E eu, de dedo quebrado, como sempre! Nessa perna, já quebrei tudo. Nem vou +, engessar. E o teu pé? Operas mesmo? Vai no melhor ortopedista. Bate tudo, até, o pé no chão. [Amostra Tia Ciça, 22/2/2010] - pergunta e conselho

No fechamento das cartas analisadas, encontramos, igualmente, os subtipos injuntivos pedido, conselho e pergunta, estratégias para manter a conexão do diálogo em futuras correspondências. Para ilustrar o subtipo pergunta, pinçamos excertos de algumas cartas, como a de $2 / 2003$, em que a 
missivista fala de assuntos variados, relacionados a programas de televisão, e finaliza a carta perguntando à sobrinha o motivo de não vir visitá-la.

(6) [20,2 CP SC] Espero por ti. Porque não vieste mais? Sabes que te adoro. Tia Cissa [Amostra Tia Ciça, 2/2003] - pergunta

Esse subtipo injuntivo pode ser visto, também, na carta de 9/5/1992, em que a missivista conversa com a interlocutora sobre uma telenovela e, no final, questiona sobre os filhos das sobrinhas de T, pedindo para que conte mais sobre eles.

(7) [20,2 CP SC] E os meninos? Conta mais. Deus, nos abençõe. Lindo maio. Tia Ciça. Te amo. [Amostra Tia Ciça, 9/5/1992] pergunta e pedido

Com relação ao subtipo injuntivo pedido, percebemos que, no fechamento de algumas cartas, a missivista pede para que a interlocutora "volte sempre". Nesse sentido, pressupomos que seja um pedido para a sobrinha voltar a visitar a tia ou um pedido para a sobrinha continuar interagindo com a tia através das cartas, como pode ser visto nas ocorrências a seguir.

(8) [20,2 CP SC] Volta sempre porque me fazes Bem. E que Deus sempre nos abençoe. Ciça a tia. [Amostra Tia Ciça, 25/10/1992] - pedido

(9) [20,2 CP SC] [...] Um beijo, obrigada pela atenção e volte sempre. [Amostra Tia Ciça, 13/11/1989] - pedido

É interessante ressaltar as formas variantes de expressão do imperativo de segunda pessoa do português brasileiro nos excertos (8) e (9). De acordo com resultados de Zibetti (2018), que investigou essa amostra de cartas, a missivista, provavelmente por ser muito próxima da interlocutora, faz mais uso da forma verbal indicativa do que da forma subjuntiva, que parece ser usada de modo cristalizado.

Sobre o subtipo injuntivo conselho, apresentamos o excerto da carta de 25/10/1992, em que a missivista relata os problemas pessoais desse período e finaliza a carta com um conselho à sobrinha. 
(10) [20,2 CP SC] [...] Vivo a Vida. Graças a Deus. Faz o mesmo conselho

De modo geral, percebemos que as sequências injuntivas encontradas nas cartas da Tia Ciça apresentam - pela própria natureza do tipo de sequência - enunciados que incitam a ação da interlocutora, seja por meio de pergunta a ser respondida, de conselho a ser seguido ou de pedido a ser atendido. Nesse sentido, é bastante recorrente o uso de verbos no modo imperativo de segunda pessoa, alternando formas variantes do modo indicativo e do modo subjuntivo. Vimos, também, que o uso de sequências injuntivas na parte fechamento da carta é uma estratégia de vínculo de interação que a missivista utiliza para manter o diálogo com a destinatária.

\subsection{2 $\bigcirc$ uso de marcadores discursivos interacionais na amostra cartas do Vale}

Entre as estratégias de interação presentes nas cartas do Vale, chamaram a atenção e foram analisados itens conhecidos como marcadores discursivos (ou conversacionais), mais especificamente os marcadores discursivos interacionais.

Schiffrin (2001) sugere que, embora tenham funções primárias derivadas de seus valores semânticos originais, os marcadores são essencialmente multifuncionais e atuam em diferentes planos do discurso, ajudando a integrar os muitos processos simultâneos envolvidos na construção discursiva e colaborando para estabelecer a coerência. A autora assume que os MDs podem funcionar simultaneamente em três domínios ou planos distintos em que são requeridas diferentes habilidades comunicativas:

Domínio cognitivo: habilidade para representar conceitos e ideias através da língua.

Domínio textual: habilidade para organizar formas e transmitir significados dentro de unidades linguísticas maiores do que uma sentença.

Domínio social e expressivo: capacidade de usar a linguagem para exibir as identidades pessoais e sociais, para transmitir atitudes e 
executar ações e negociar relações entre si e os outros. (adaptado de SCHIFFRIN, 2001, p. 54). ${ }^{8}$

Há vários subgrupos de marcadores discursivos com funções bastante distintas. Um dos subgrupos dos MDs reúne partículas com função basicamente interacional e tem recebido nomenclatura variada: requisitos de apoio discursivo - RADs (MACEDO; SILVA, 1996; VALLE, 2014), busca de aprovação discursiva - BADs (MARCUSCHI, 1989; URBANO, 1997), marcadores de controle de contato - MCCs (PORTOLÉS, 2007) e marcadores discursivos basicamente interacionais (URBANO, 2006). Sob esses rótulos têm sido inseridos itens de natureza ainda heterogênea, mas com atuações um pouco mais próximas, tais como né?, viu?, sabe?, entende?, certo?, heim?, não é verdade?, uhn?, entre outros, que possuem em comum propriedades interacionais e, por isso, decidimos chamá-los de marcadores discursivos interacionais (MDIs).

Os MDIs atuam, predominantemente, nos planos textual e interacional e seu papel principal seria o de colocar foco, frisando determinadas porções discursivas e cumprindo funções relacionadas tanto com o interlocutor, quanto com a organização do discurso oral. Além disso, tais itens marcam estilo de fala menos monitorada, e funcionam como marcas de identidade linguística (VALLE, 2014).

Apenas a partir da década de 1980 é que o interesse acadêmico sobre itens dessa natureza ganhou fôlego (PICHLER, 2010), mas a maior parte das pesquisas centra-se na fala e não na escrita. Embora essas expressões típicas da oralidade sejam extremamente recorrentes e tenham importante papel no discurso oral, foram frequentemente marginalizadas, mesmo na fala, sendo seu uso na escrita considerado como marca de oralidade e associado a pessoas ainda pouco letradas (KOCH; ELIAS, 2017). Nesse sentido, a presença e o papel estilístico e interacional dos MDIs na escrita, comumente negligenciados, merecem investigação.

8 Trecho original: "Two aspects of communicative knowledge closely related to one another are expressive and social: the ability to use language to display personal and social identities, to convey attitudes and perform actions, and to negotiate relationships between self and other. Others include a cognitive ability to represent concepts and ideas through language and a textual ability to organize forms, and convey meanings, within units of language longer than a single sentence" (SCHIFFRIN, 2001, p. 54). 
$\mathrm{Na}$ amostra cartas do Vale, apesar de MDIs não ocorrerem em nove das 25 cartas da amostra, ${ }^{9}$ encontramos uma grande variedade e frequência desses itens nas demais cartas. Foram identificados ao todo 30 dados de dez MDIs diferentes na amostra, conforme ilustra a Tabela 11.2.

Tabela 11.2 - MDIs encontrados na amostra cartas do Vale

\begin{tabular}{c|c|c}
\hline MDI & Cartas & Número de ocorrências \\
\hline Não é? ${ }^{15}$ & $1,13,16,17,19,21,22,23$ e 25 & 10 \\
\hline Tá? & $6,17,19,22$ e 23 & 5 \\
\hline Sabe(s)? & $7,10,11,12$ e 16 & 5 \\
\hline Hen/em? & 5 e 23 & 2 \\
\hline Não acha(s)? & 8 e 19 & 2 \\
\hline Certo? & 19 e 22 & 1 \\
\hline O’ Kei? & 13 & 1 \\
\hline Sim? & 19 & 1 \\
\hline Compreendes? & 22 & 1 \\
\hline Concordas? & 23 &
\end{tabular}

De modo mais amplo, lançando um primeiro olhar para a tabela, percebe-se a variedade de formas presentes na amostra, a maioria delas derivada de verbos ou de construções com verbos.

Entre os três itens mais recorrentes, temos dois MDIs derivados de verbos: tá? (cinco ocorrências), tipicamente fático por seu caráter reduzido e por derivar de verbo relacional; e sabe? (cinco ocorrências), derivado de verbo cognitivo. Urbano (2006), ao propor a análise de marcadores discursivos na fala, agrupa esses dois itens, dadas suas características em comum: fonte verbal, função fática de natureza interrogativa e forma de ocorrência apenas no presente do indicativo. Valle (2014), ademais, destaca o caráter menos interacional e mais relacional de sabe?, item em estágio mais avançado no processo de gramaticalização, segundo a autora,

9 Não foram encontrados MDIs nas cartas 2, 3, 4, 9, 14, 15, 18, 20 e 24. 
se comparado aos marcadores que têm como fonte o verbo entender, tais como entende?, entendeu?, entendesse?, tás entendendo?.

O MDI mais frequente entre todos, não é? (dez ocorrências), também é o que apresenta maior combinação com outros elementos: compreendes, não é?; sabes, não é?; não é um fato? e não é mesmo?. Interessante notar que tais construções ilustram possíveis estágios anteriores de não é? em sua trajetória de gramaticalização, que, em última instância, está presente comumente na fala em sua forma ainda mais reduzida, como né?. Urbano (2006) sugere que esse MDI tenha seguido o seguinte percurso de mudança: Isso não é verdade? > Não é verdade? > Não é? > Num é? > Né?. Contudo, pode-se perceber que qualquer uma das construções estendidas encontradas nas cartas em análise poderia dar origem ao uso reduzido. Em relação à função discursiva, o autor destaca que, por ser o marcador mais predominante na fala, apresentando frequência muito superior a todos os outros MDIs em conjunto, não é? apresenta-se mais esvaziado de seu conteúdo semântico, atuando como pontuante do discurso.

De modo mais específico, um primeiro aspecto observado nas cartas da amostra diz respeito à relação entre o uso de MDIs e o grau de intimidade entre missivistas e destinatário. $\mathrm{O}$ uso de marcadores parece ser mais comum entre interlocutores mais íntimos, que já se conhecem pessoalmente e que compartilham vivências e conhecimentos de mundo. As missivistas que eram namoradas do destinatário usam mais esses marcadores, principalmente a Remetente $\mathrm{O}$, que sozinha faz uso de mais da metade dos dados (19 MDIs), sendo que muitos deles concentram-se em cartas que escreve para se explicar e deixar claros certos aspectos do relacionamento. Vejamos o trecho a seguir, da carta 19, em que a missivista expõe aspectos delicados do relacionamento e pede perdão ao destinatário por considerar que lhe provocou ciúmes com outro rapaz.

(11) [20,2 CP SC] [Destinatário] N, eu sentia tudo por | ti, talvés não crês, mas como | tu o disseste ter eu complexo de | inferioridade, sim, diante de | um alguém que é para mim | o infinito, e muito além dos | aléns, e achei que era impossí- | vel eu viver do lado dêsse al- | guém, estou errada, não é? || A realidade não escon- | de a realidade! || Agora tudo está em tuas | mãos, [Destinatário] $\mathrm{N}$, onde eu te en- | contrar, seja aonde for, desejo | pedir-te de joelhos "Perdão, pelo | [fol. 3r] meu grande êrro! || Contudo, 
sei que tens um coração | grande, acolhedor, e sabes reparar e | dar-me o teu Perdão. [...] Desculpe eu [ilegível] te dizer isto: | Conforme o rapaz, expliquei-o | que não era possível, nem êle tentando, | nos falar-mos,! certo? || Desejo-te muitas felicidades, saúde | paz e muito Amor. || Êxito no conjunto e nos | trabalhos, rezarei por ti todas as | noites; de: || Quem te quer muito mais que antes || [Remetente] O || 2-7-69. || [fol. 3v] [Destinatário] $\mathrm{N}$ - eu avisarei o dia | para você vir até aqui, tá? | não leve a mal sim? | Isto é para evitar alguma | coisa, compreendes, não é? || Agradeço-te. || [Remetente] O [Amostra do Vale]

Em geral, as missivistas que mantêm apenas relação de amizade com o destinatário usam poucos MDIs e outras - como a Remetente V (aluna do destinatário) e a Remetente Z (que conheceu o destinatário por foto através de uma prima) - não usam nenhum marcador interacional. Vejamos o trecho da carta 14 (onde não há nenhum MDI), em que, em tom bastante formal, a missivista, aluna do destinatário, pede-lhe desculpas por carta anterior com conteúdo impróprio, segundo sua avaliação. ${ }^{10}$

(12) [20,2 CP SC] Eu | sentia-me obrigada a escrever embora | estava muito errada. Peço ao senhor, | desculpa. Qualquer dia vou falar | lá no grupo com você, sôbre o fato. | Como me aconteceu ter mandado | uma cartinha assim pesada à você. | Depois de ter mandado a mesma | para mim começou a ser melhor. | S. [Destinatário] $\mathrm{N}$, perdoe. O que agora quero ser | para você, uma melhor colega, pois | antes mal e mal podíamos nos con- | versar. Esperando que aceite; e que devo | agradecer tudo o que escreveu para $\mid$ mim. S. [Destinatário] $\mathrm{N}$; quero fazer com você maior | amizade; do que com meus colegas. Pois | acho você de maior valor. || [fol. 2r] Termino aqui com um forte | abraço de sua aluna: | [Remetente] V [Amostra do Vale]

Ainda assim, é difícil precisar se é a intimidade entre missivistas e destinatário que promove o uso de MDIs ou se esse uso faria parte do estilo individual das missivistas.

10 A carta anterior a esta não consta no conjunto das cartas da amostra. 
Um segundo aspecto importante a ser observado está relacionado à função dos MDIs nas cartas pessoais. Contrariando suposições de que, na fala, os MDIs seriam usados predominantemente no plano interacional, Valle (2014) verificou, em entrevistas sociolinguísticas, que os marcadores interacionais atuam predominantemente no plano textual (apesar de manterem carga interacional), colocando foco em determinadas porções e organizando o discurso oral.

Já nas cartas pessoais, a atuação parece estar justamente mais relacionada ao plano interacional, na medida em que as missivistas (i) trazem à tona o conhecimento de vivências partilhadas e (ii) deixam pontas soltas a serem emendadas pelo interlocutor em sua carta de resposta. Vejamos o trecho abaixo.

(13) [20,2 CP SC] [Destinatário] N, referente aquêle | assunto de sábado, ou da carta, tenho | o seguinte a te dizer: Felizes aquele | no qual sabem agir bem com a cons- | ciência; isto é ter virtudes espirituais, | sem mesmo poder satisfazer alguém | em outro sentido; sabes, não é? || Digo-te! Aceito-te pelo sublime | que tu és! O homem valhe pelo que | sabe, pelo que tem de bom espiritual- | mente e não pelo que é fisicamen- | te em minha opinião! || [não há o nome da Remetente, mas pela letra trata-se da [Remetente] O [Amostra do Vale]

Percebe-se que a missivista faz referência a outra carta e dá a entender que não pode ter contato mais íntimo/físico com o destinatário. Nesse caso, o uso de sabes, não é? parece marcar o conhecimento que ambos partilham e que, dado o tema em certa medida delicado, não precisa ser explicitado na carta.

De modo geral, cabe ainda notar que a grande variedade de MDIs encontrada nas cartas pode estar relacionada às escolhas estilísticas das diferentes remetentes, já que, conforme Valle (2014), o uso desses elementos também parece ser guiado por escolhas individuais ligadas a aspectos identitários. Além disso, destaca-se como ponto importante da presente análise a percepção de que o uso de MDIs pode estar associado a interlocutores mais íntimos, cumprindo funções interacionais. 


\section{1.4.3 As formas de tratamento nominal na amostra cartas de Elza Bertaso}

$\mathrm{Na}$ amostra de cartas pessoais escritas por Elza Bertaso, investigamos as formas de tratamento nominal (FTNs) empregadas pela remetente, com vistas a verificar a origem, as categorias e as funções atribuídas na díade mãe e filha. As FTNs são um conjunto de expressões utilizadas para se dirigir a outra pessoa participante do discurso (KERBRAT-ORECCHIONI, 2011) e se constituem como uma das ferramentas de que dispõem os interlocutores para iniciarem o contato. As FTNs se diferenciam quanto à origem, à categoria e à função.

A origem das FTNs pode ser pronominal (tu, você, senhor ou senhora, entre outras) ou nominal (Carla, amor, coração, besta, entre outras). Há casos de ausência total de quaisquer FTNs em certas situações de interação, e isso provavelmente se deve ao fato de que não se dispõe, no repertório linguístico, de nenhuma forma realmente satisfatória, tais como em conversas familiares ou quando necessitamos chamar alguém que não é nem um estranho, nem uma pessoa próxima. Nessas situações "[...] monsieur [senhor] é muito formal, o seu nome resultaria por demais familiar, e o sobrenome um pouco brusco [...]" (KERBRAT-ORECCHIONI, 2011, p. 20, grifo do autor).

Segundo Kerbrat-Orecchioni (2011), as FTNs se distribuem em diferentes categorias:

a) os nomes de pessoa (os sobrenomes ou patronímicos, os nomes próprios ou nomes de batismo, os diminutivos e os apelidos);

b) as formas de tratamento de caráter geral na relação não familiar (senhor/senhora);

c) os títulos honoríicos (chefe, patrão, mestre, capitão);

d) os nomes de profissão e de função (motorista, chaveiro, eletricista);

e) os termos de parentesco (papai, vovó, primo);

f) os rótulos de caráter improvisado e ocasional (ô loira, ô do casaco verde);

g) as formas afetivas de valor negativo (babaca, imbecil) e as de valor positivo (querido, docinho, meu anjo). 
Kerbrat-Orecchioni (2011) destaca que as FTNs desempenham uma variedade de funções na interação e cada uma delas se subdivide em diferentes níveis. A primeira função é de organização da interação, que comporta duas subfunções: (i) de interpelação (serve para chamar a atenção de alguém ou estabelecer com ela um início de troca) e (ii) de seleção do alocutário e gestão dos turnos de fala (serve para selecionar seu destinatário principal dentre outros possíveis). A segunda função diz respeito ao emprego das FTNs de forma esparsa em momentos da interação para reforçar o impacto do enunciado em que não há mudança de interlocutor. A terceira e última função das FTNs consiste em marcar, em relação à forma de tratamento pronominal, um tipo de relação socioafetiva. Nesse caso, são três as principais dimensões relacionais que organizam a interação: (i) eixo horizontal (serve para instaurar uma distância ou proximidade entre os dois interlocutores); (ii) eixo vertical (serve para instaurar entre os interlocutores uma relação de igualdade ou de hierarquia); e (iii) eixo consensual ou conflitual.

$\mathrm{Na}$ amostra cartas de Elza Bertaso, tínhamos por hipótese que, quanto à categoria, ao se dirigir à mãe, a missivista usaria FTNs combinadas, ou seja, da categoria termos de parentesco com formas afetivas de valor positivo. Quanto à função, nossa expectativa era de que Elza utilizasse FTNs de interpelação e do eixo horizontal, tendo em vista que as cartas são dirigidas à sua mãe, a quem via de regra, no início do século $\mathrm{XX}$, devia respeito e subordinação.

No total, localizamos 137 ocorrências de FTNs nominais e pronominais na amostra de 82 cartas, conforme se verifica na Tabela 11.3.

Tabela 11.3 - FTNs nominais e pronominais encontradas na amostra cartas de Elza Bertaso

\begin{tabular}{c|c}
\hline FTNs nominais e pronominais & $\begin{array}{c}\text { Número de } \\
\text { ocorrências }\end{array}$ \\
\hline Querida mamãe/minha querida mamãe/amada mamãe & 112 \\
\hline A senhora/Sa/Sra./Snra. & 17 \\
\hline $\mathrm{Tu}$ & 8 \\
\hline
\end{tabular}

Elza adota apenas três formas de FTNs, mas a mais recorrente nas cartas é "Querida mamãe" e variantes, como exemplificado a seguir. 
(14) [20,1 CP SC] Querida Mamãe, peço-te mandar-me dizer, quaes foram as ultimas palavras que o nosso querido Ari disse. [Amostra E. Bertaso]

Essa FTN de origem nominal apresenta a combinação de duas categorias, quais sejam, o uso da forma afetiva de valor positivo (querida) com o termo de parentesco (mãe, mamãe).

Localizamos duas ocorrências do ano de 1920 em que Elza faz uso de FTNs afetivas de valor positivo no grau superlativo (indicando a intensidade da qualidade do ser) junto ao termo de parentesco (queridíssima mamãe).

(15) [20,1 CP SC] Queridissima Mamãe. Esta em minhas mãos tua querida cartinha, que me deu imensas alegrias. [Amostra E. Bertaso]

Outros dois tipos de FTNs são empregados por Elza para se reportar à mãe: "a senhora" ou variantes e "tu". Esse emprego corrobora o que afirmam Coelho e Görski (2011): os pronomes senhor/senhora/senhorita são usados de uma pessoa mais jovem para uma pessoa mais velha (para um pai ou uma mãe); o pronome tu, por sua vez, é usado para referência à segunda pessoa preferencialmente nas relações íntimas e menos formais, conforme os trechos a seguir.

(16) [20,1 CP SC] Um beijo no Jayme e no Serafim e o papae. E a senhora receba saudades da vovó e vovo e tios e tias e de vossa filha. [Amostra E. Bertaso]

(17) [20,1 CP SC] A Leda está tão grande e gordinha que tu nem imaginas. [Amostra E. Bertaso]

No que tange à função dessas FTNs nas cartas de Elza, verifica-se a recorrência da função fática (função 1), que visa iniciar um diálogo de maior proximidade com a mãe, já que não podia fazê-lo pessoalmente. Essa função é mais proeminente nos vocativos de abertura, já que nos gêneros escritos, principalmente nas cartas pessoais, são elementos que constituem a estrutura do gênero epistolar. Chama-nos a atenção o fato de as FTNs "a senhora" (e variantes) e "tu", em (16) e (17), não constarem na abertura das cartas, mas preencherem principalmente a função de manutenção do 
contato com o interlocutor, que é a próxima função identificada na amostra examinada.

Outra função (função 2) que se observa nas cartas dirigidas à mãe diz respeito ao emprego das FTNs ao longo do gênero epistolar para reforçar/ manter o impacto do enunciado em que não há mudança de interlocutor, como se verifica em diversos trechos ao longo das cartas.

(18) [20,1 CP SC] Principalmente a $\mathbf{S}^{\mathbf{a}}$, boa Mãe, há de sentir muitíssimo a sua morte. Mas console-se, querida Mãe, nosso querido Ary é agora um anjinho, Como vai a $S^{a}$, querida Mamãe, o querido Papae, e meus queridos irmãozinhos? [Amostra E. Bertaso]

Como se percebe em (18), apesar de a missivista empregar as FTNs com função de reforço do enunciado, ainda assim se percebem marcas de familiaridade, respeito e formalidade devido aos diferentes papéis sociais nesse contexto de uso. Há certa distância respeitosa entre as interlocutoras marcada pelo uso formal da FTN pronominal (senhora, $S^{a}$, boa Mãe e $S^{a}$, querida Mamãe) associada com um termo de parentesco (mãe/mamãe). Nessas ocorrências, há também o uso de formas afetivas de valor positivo (boa e querida), o que revela uma tentativa de proximidade entre as interlocutoras, apesar da distância geográfica que as separava.

Essa função de organização da interação também pode ser percebida de diferentes maneiras ao longo da amostra: no emprego da FTN e no uso de frases interrogativas direcionadas à mãe.

(19) [20,1 CP SC] A Sra chegou bem ahi? [Amostra E. Bertaso]

A Tabela 11.4 mostra a distribuição das ocorrências das FTNs nominais e pronominais, segundo a sua função no gênero epistolar: 82 ocorrências da função 1 (fática/organização da interação) e 55 ocorrências da função 2 (reforço do enunciado). 
Tabela 11.4 - FTNs nominais e pronominais segundo a função na amostra cartas de Elza Bertaso

\begin{tabular}{c|c|c}
$\begin{array}{c}\text { FTNs nominais e } \\
\text { pronominais }\end{array}$ & $\begin{array}{c}\text { Número de ocorrências } \\
\text { da função 1 }\end{array}$ & $\begin{array}{c}\text { Número de ocorrências } \\
\text { da função 2 }\end{array}$ \\
\hline $\begin{array}{c}\text { Querida mamãe/minha querida } \\
\text { mamãe/amada mamãe }\end{array}$ & 82 & 30 \\
\hline A senhora/Sa/Sra./Snra. & 0 & 17 \\
\hline $\mathrm{Tu}$ & 0 & 8 \\
\hline
\end{tabular}

A maior parte das FTNs se concentra em posição de abertura das correspondências, o que já instaura uma tentativa de aproximação com a interlocutora. Essa aproximação também pode ser verificada em algumas cartas em que Elza usa a FTN pronominal "comtigo" para referência a sua mãe.

(20) [20,1 CP SC] Venho conversar alguns instantes comtigo desejando-te assim como a papai e aos irmãos muita saúde a as benções divinas. [Amostra E. Bertaso]

Quando se emprega a FTN “contigo", supõe-se um tratamento mais íntimo com o interlocutor, ou, pelo menos, que a forma seja usada numa relação entre pares (simétrica) ou de superior para inferior (assimétrica), o que não é o caso nesse contexto de uso.

Para finalizar nossa análise, cremos ser relevante destacar, nas cartas examinadas, o uso variável de FTNs de origem possessiva "tua", "sua" e "vossa" para referência direta à mãe, combinadas com o termo de parentesco "filha", conforme apresentamos nos trechos a seguir.

(21) [20,1 CP SC] Tua Filha Elza. [Amostra E. Bertaso]

(22) [20,1 CP SC] Receba beijos e abraços de Sua filha extremosa. [Amostra E. Bertaso]

(23) [20,1 CP SC] Sem mais receba um apertado abraço de vossa filha que muito vos estima. [Amostra E. Bertaso]

Essa diversidade de usos dos possessivos nas FTNs, conforme se verifica na Tabela 11.5, ocorre principalmente no fechamento das correspondências. 
Tabela 11.5 - FTNs pronominais combinadas com termos de parentesco na amostra cartas de Elza Bertaso

\begin{tabular}{c|c}
\hline FTNs pronominais + termos de parentesco & $\begin{array}{c}\text { Número de } \\
\text { ocorrências }\end{array}$ \\
\hline $\begin{array}{c}\text { Tua filha, Tua filha Elza, Tua filha querida Elza, } \\
\text { entre outras }\end{array}$ & 61 \\
\hline Sua filha Elza, Sua filha grata, entre outras & 11 \\
\hline Vossa filha, Vossa filha do coração, entre outras & 5 \\
\hline
\end{tabular}

Do total de 61 ocorrências de FTNs constituídas pelo pronome possessivo "tua", em 14 delas Elza emprega o pronome "tua" combinado ao substantivo "filha", mas no diminutivo, com valor de intimidade ou carinho, para referir a si mesma nas despedidas das cartas endereçadas à mãe.

(24) [20,1 CP SC] Beija-te saudosamente tua filhinha. [Amostra E. Bertaso]

De modo geral, percebemos que, ao se dirigir à mãe, a missivista Elza prefere adotar a FTNs "Querida mamãe" e suas variantes. Essa FTN é constituída pela combinação das categorias formas afetivas de valor positivo com termos de parentesco. Quanto à função, a maioria das FTNs empregadas por Elza exerce a função fática e se concentra em posição de abertura das correspondências, o que já instaura uma tentativa de aproximação com a interlocutora. É saliente, no gênero epistolar examinado, datado no início do século XX, a presença de muitas marcas de afetividade e de respeito no tratamento com a mãe.

\subsection{Considerações finais}

No presente capítulo, foram examinadas estratégias de interação utilizadas no gênero carta pessoal. Os resultados da análise das três amostras investigadas permitem algumas considerações que julgamos interessantes.

$\mathrm{Na}$ amostra cartas da Tia Ciça, foram analisadas as sequências injuntivas que apresentam funções prescritivas que sobressaíram na escrita da missivista: conselho, pedido e pergunta. A análise evidenciou que: (i) essas 
funções apresentam enunciados que incitam a (re)ação da interlocutora, sendo bastante recorrente o uso de verbos no modo imperativo, com alternância de formas variantes do indicativo e do subjuntivo; e (ii) a frequência de uso de sequências injuntivas é maior na parte fechamento do que nas outras partes constitutivas do gênero epistolar, o que nos leva a crer que seja uma estratégia de vínculo de interação que a missivista usa para manter o diálogo com a destinatária.

$\mathrm{Na}$ amostra cartas do Vale, apesar de não estarem presentes em todas as cartas, percebeu-se o uso de variadas formas de marcadores discursivos interacionais, 30 ocorrências no total, sendo não é?, sabe? e tá? as mais recorrentes. Dois aspectos relevantes foram observados em relação ao uso de MDIs: (i) o grau de intimidade entre missivista e destinatário parece regular o uso dos marcadores, sendo que tais itens aparecem com mais frequência entre interlocutores mais íntimos; e (ii) a função dos marcadores nas cartas pessoais está mais relacionada ao plano interacional, fazendo emergir conhecimento de vivências partilhadas e deixando pontas soltas a serem emendadas pelo interlocutor em sua carta de resposta.

$\mathrm{Na}$ amostra cartas de Elza Bertaso, identificamos três tipos de formas de tratamento nominal (FTNs) para o tratamento com a mãe. A forma predominante é de origem nominal e apresenta a combinação de duas categorias, quais sejam, a forma afetiva de valor positivo (querida) com o uso de termo de parentesco (mãe, mamãe). Quanto à função, há a recorrência da função fática das FTNs, principalmente nos vocativos de abertura das cartas, o que sinaliza o início de um diálogo de maior proximidade com a mãe, já que a filha não podia fazê-lo pessoalmente. Outra função presente nas FTNs identificadas no gênero epistolar é de reforço/manutenção do enunciado em que não há mudança de interlocutor. De modo geral, o que se percebe nas FTNs empregadas nas cartas dirigidas à mãe são marcas de familiaridade, respeito e, em alguns momentos, formalidade, devido aos diferentes papéis sociais desempenhados nessa díade.

Ressaltamos que naturalmente não se esgotam aqui as investigações discutidas neste capítulo. Ao contrário, entendemos que o aprofundamento de análise de estratégias interacionais é de extrema relevância para pesquisas que tomem o gênero cartas pessoais como foco. 


\section{Referências}

AUSTIN, J. L. Quando dizer é fazer. Tradução de Danilo Marcondes de Souza Filho. Porto Alegre: Artes Médicas, 1990 [1962].

BAKHTIN, M. Estética da criação verbal. Tradução do russo de Paulo Bezerra. São Paulo: WMF Martins Fontes, 2011 [1979].

BOUVET, N. La escritura epistolar. Buenos Aires: Eudeba, 2006.

COELHO, I. L.; GÖRSKI, E. M. A variação no uso dos pronomes tu e você em Santa Catarina. In: COUTO, L. R.; LOPES, C. R. dos S. (org.). As formas de tratamento em português e em espanhol: variação, mudança e funções conversacionais. Niterói: Editora da UFF, 2011. p. 263-287.

CONDE SILVESTRE, J. C. Sociolingüística histórica. Madrid: Gredos, 2007.

GALVÃO, M. A. M.; SILVA, L. A. Notas sobre a amizade: um estudo acerca do envolvimento interacional em cartas pessoais. Filologia e Linguística Portuguesa, São Paulo, v. 14, n. 2, p. 309-341, 2012.

KERBRAT-ORECCHIONI, C. Modelos de variações intraculturais e interculturais: as formas de tratamento nominais em francês. Tradução de Fernando Afonso de Almeida e Leticia Rebollo Couto. In: COUTO, L. R.; LOPES, C. R. dos S. (org.). As formas de tratamento em português e em espanhol: variação, mudança e funções conversacionais. Niterói: Editora da UFF, 2011. p. 19-46.

KOCH, I. V. Ler e escrever: estratégias de produção textual. São Paulo: Contexto, 2009.

KOCH, I. V.; ELIAS, V. M. Ler e escrever: estratégias de produção textual. 2. ed. São Paulo: Contexto, 2017.

KOCH, P.; OESTERREICHER, W. Oralidad y escrituralidad a la luz de la teoría del lenguaje. In: KOCH, P.; OESTERREICHER, W. Lengua hablada en la Romania: español, francés, italiano. Madrid: Gredos, 2007. p. 20-42.

MACEDO, A.; SILVA, G. M. de O. Análise sociolinguística de alguns marcadores conversacionais. In: MACEDO, A.; RONCARATI, C.; MOLLICA, M. C. (org.). Variação e discurso. Rio de Janeiro: Tempo Brasileiro, 1996. p. 11-49.

MARCUSCHI, L. A. Marcadores conversacionais do português brasileiro: formas, funções e definições. In: CASTILHO, A. (org.). Português culto falado no Brasil. Campinas: Editora da UNICAMP, 1989. p. 281-322.

MARCUSCHI, L. A. Da fala para a escrita: atividades de retextualização. São Paulo: Cortez, 2001. 
MARCUSCHI, L. A. Gêneros textuais: definição e funcionalidade. In: DIONISIO, A. P.; MACHADO, A. R.; BEZERRA, M. A. (org.). Gêneros textuais e ensino. Rio de Janeiro: Lucerna, 2002. p. 19-36.

MARCUSCHI, L. A. Produção textual, análise de gêneros e compreensão. São Paulo: Parábola, 2008.

MUNICÍPIO DE NOVA TRENTO. Histórico. Disponível em: http://www. novatrento. sc.gov.br/cms/pagina/ver/codMapaItem/37323. Acesso em: 4 set. 2020.

PICHLER, H. Methods in discourse variation analysis: reflections on the way forward. Journal of Sociolinguistics, v. 14, n. 5, p. 581-608, 2010.

PORTOLÉS, J. Marcadores del discurso. 4. ed. Barcelona: Ariel, 2007.

SCHAPUIS WENDLING, I.; VOJNIAK, F. Prática de escrita no Oeste Catarinense: uma história de escrita epistolar a partir do acervo da família Bertaso. In: SEMINÁRIO DE ENSINO, PESQUISA E EXTENSÃO DA UFFS, 7., 2017, Chapecó. Anais [...]. Chapecó: UFFS, v. 7, n. 1, fev. 2018. Disponível em: https://periodicos.uffs.edu.br/index.php/SEPE-UFFS/article/view/6588. Acesso em: 4 set. 2020.

SCHIFFRIN, D. Discourse markers: language, meaning and context. In: SCHIFFRIN, D.; TANNEN, D.; HAMILTON, H. E. (ed.). The handbook of discourse analysis. Malden, MA: Blackwell, 2001. p. 54-75.

SEARLE, J. R. Expressão e significado: estudos da teoria dos atos da fala. Tradução de Ana Cecília G. A. de Camargo e Ana Luiza Marcondes Garcia. São Paulo: Martins Fontes, 1995 [1979].

SILVA, V. L. P. da. Variações tipológicas no gênero textual carta. In: $\mathrm{KOCH}$, I. V.; BARROS, K. S. M. de (org.). Tópicos em linguística de texto e análise da conversação. Natal: EDUFRN, 1997. p. 118-124.

SILVA, J. Q. G. Um estudo sobre o gênero carta pessoal: das práticas comunicativas aos indícios de interatividade na escrita dos textos. 2002. 209 f. Tese (Doutorado em Linguística) - Programa de Pós-Graduação em Estudos Linguísticos, Universidade Federal de Minas Gerais, Belo Horizonte, 2002.

SIMON, P. Queridos paes: uma história da escrita epistolar no Oeste Catarinense através das cartas de Elza Bertaso à sua família. 2015. 46 f. Trabalho de Conclusão de Curso (Graduação em História) - Universidade Federal da Fronteira Sul, Chapecó, 2015.

TRAVAGLIA, L. C. Aspectos da pesquisa sobre tipologia textual. Revista de Estudos da Linguagem, Belo Horizonte, v. 20, n. 2, p. 361-387, jul./dez. 2012. 
URBANO, H. Marcadores discursivos basicamente interacionais. In: JUBRAN, C. C. A. S.; KOCH, I. G. V. (org.). Gramática do português culto falado no Brasil. Campinas: Editora da UNICAMP, 2006. p. 497-528.

URBANO, H. Marcadores conversacionais. In: PRETI, D. (org.). Análise de textos orais. 3. ed. São Paulo: Humanitas, 1997. p. 81-101.

VALLE, C. R. M. Multifuncionalidade, mudança e variação de marcadores discursivos derivados de verbos cognitivos: forças semântico-pragmáticas, estilísticas e identitárias em competição. 2014. 415 f. Tese (Doutorado em Linguística) - Programa de Pós-Graduação em Linguística, Universidade Federal de Santa Catarina, Florianópolis, 2014.

VICENZI, R. Colonizadora Bertaso e a (des)ocupação no Oeste Catarinense. Cadernos do CEOM, Chapecó, ano 19, n. 25 - Narrativas, 2014. Disponível em: https://bell.unochapeco.edu.br/revistas/index.php/rcc/article/ download/2061/1139. Acesso em: 4 set. 2020.

ZANELATTO, J. H. Comparação da imigração europeia e inserção sociopolítica dos imigrantes e seus descendentes nas regiões sul, Vale do Itajaí e norte de Santa Catarina (1850-1920). Saeculum - Revista de História, João Pessoa, jan./jun. 2011. Disponível em: http://www.periodicos.ufpb.br/ojs/index. php/srh/article/ view/12433/7195. Acesso em: 4 set. 2020.

ZIBETTI, E. M. de O. Uma proposta metodológica para o estudo da alternância estilística na amostra Cartas da Tia Ciça. 2018. 176 f. Dissertação (Mestrado em Linguística) - Programa de Pós-Graduação em Linguística, Universidade Federal de Santa Catarina, Florianópolis, 2018. 


\section{Sobre os autores}

\section{Ana Kelly Borba da Silva Brustolin}

Cursou Letras Português (2005) e mestrado em Linguística (2009) na Universidade Federal de Santa Catarina. Lecionou Língua Portuguesa em escolas da rede pública e privada, curso técnico e ensino superior. Possui livros e artigos científicos publicados na área e atua como professora de Redação no Colégio Energia. É colunista do jornal OCP News e colaboradora voluntária do grupo de pesquisa Núcleo Interinstitucional de Pesquisa VARSUL/SC. E-mail: anakellybrustolin@ gmail.com

\section{Ana Lívia Agostinho}

Possui doutorado em Filologia e Língua Portuguesa pela Universidade de São Paulo. Realizou estágio pós-doutoral no Departamento de Linguística da Universidade da Califórnia em Berkeley, Estados Unidos. É professora no Departamento de Língua e Literatura Vernáculas e no Programa de Pós-Graduação em Linguística da Universidade Federal de Santa Catarina, onde desenvolve pesquisa nas áreas de Fonologia e Contato Linguístico. Realiza trabalho de campo em São Tomé e Príncipe e Guiné Equatorial desde 2009. É membro do projeto VARSUL desde 2016. E-mail: a.agostinho@ufsc.br

\section{Anna Lyssa do Nascimento Donato Machado}

É bacharel em Letras Português e Inglês pela Universidade Federal do Rio de Janeiro, mestre e doutoranda em Letras Vernáculas (Língua Portuguesa) pela mesma universidade. Atua na área de Linguística, com ênfase na sintaxe diacrônica, a partir de uma abordagem formal, e está vinculada ao projeto Para a História do Português Brasileiro (PHPB). E-mail: annalyssadonato@gmail.com 


\section{Anna Beatriz Cavalcante de Melo da Cruz}

É licenciada em Letras Português e Literaturas de Língua Portuguesa pela Universidade Federal do Rio de Janeiro, mestre e doutoranda em Letras Vernáculas pela mesma instituição. Vinculada ao PHPB, no projeto "Posição do sujeito e estrutura informacional da sentença", atua na área de Linguística Histórica, com ênfase nos estudos sobre sintaxe diacrônica, mudança linguística e estrutura informacional da sentença.E-mail: annabeatrizcruz@letras.ufrj.br

\section{Aroldo Leal de Andrade}

É professor adjunto na Faculdade de Letras da Universidade Federal de Minas Gerais. É doutor em Linguística pela UNICAMP e mestre em Linguística pela UnB. Suas principais linhas de pesquisa são a mudança gramatical em variedades do português e a interface sintaxe-estrutura informacional. É coordenador do projeto "Retórica e sintaxe do português no detalhe" (CNPq 437100/2018-9). É membro do PHPB desde 2018 e colaborador desde 2014. E-mail: aroldoleal@ufmg.br

\section{Bruna Brasil Albuquerque de Carvalho}

É licenciada em Letras Português e Italiano pela Universidade Federal do Rio de Janeiro e mestre em Língua Portuguesa pelo Programa de Pós-Graduação em Letras Vernáculas da mesma instituição. Atualmente, é doutoranda do referido programa, com pesquisa vinculada à linha de pesquisa Língua e sociedade: variação e mudança. Colaboradora do projeto Para a História do Português Brasileiro. E-mail: brunabrasil@letras.ufrj.br

\section{Carla Regina Martins Valle}

É licenciada em Letras (1999) pela Universidade Federal de Santa Catarina (UFSC). Concluiu mestrado (2001), doutorado (2014) e pós-doutorado (2018) em Linguística pelo Programa de Pós-Graduação em Linguística da UFSC. É professora no Departamento de Língua e Literatura Vernáculas da UFSC, atuando na área de Sociolinguística e Dialetologia, e está vinculada ao Programa de Mestrado Profissional em Letras. Coordena o Laboratório de Estudos de Variação Linguística e Práticas Pedagógicas (LABVAR) e é membro do projeto VARSUL. E-mail: carla.valle@ufsc.br

\section{Cecília Augusta Vieira Pinto}

É doutora em Linguística pelo Programa de Pós-Graduação em Linguística da Universidade Federal de Santa Catarina e membro colaborador do projeto PHPB-SC, vinculado ao Núcleo VARSUL. Concentra seus estudos na área de Sociolinguística, focando na variação e mudança na sintaxe. Em seu doutorado, estudou a trajetória de mudança dos preenchimentos do sujeito e do objeto direto 
anafóricos em cartas pessoais de Santa Catarina dos séculos XIX e XX. Atualmente, é professora de Língua Portuguesa na educação básica. E-mail: cecilia88augusta@ gmail.com

\section{Cláudia Andrea Rost Snichelotto}

É professora livre-docente da Universidade Federal da Fronteira Sul (campus Chapecó-SC). Doutora (2009) e mestre (2002) em Linguística, na área de concentração Sociolinguística, pela Universidade Federal de Santa Catarina. Graduada em Letras Português e Literaturas de Língua Portuguesa (1993) pela Pontifícia Universidade Católica do Rio Grande do Sul. É pesquisadora colaboradora do Núcleo Interinstitucional de Pesquisa VARSUL/SC e do grupo de pesquisa Para a História do Português Brasileiro em Santa Catarina, ambos sediados na UFSC.E-mail: rostclaudia@hotmail.com

\section{Cristine Gorski Severo}

É docente da Universidade Federal de Santa Catarina. Atua no Programa de PósGraduação em Linguística e no Doutorado Interdisciplinar em Ciências Humanas. Tem pós-doutorado (2014) em Políticas Linguísticas pela Universidade Estadual da Pensilvânia, Estados Unidos. Pesquisa os temas: história sociopolítica das línguas no Brasil e políticas linguísticas em contextos coloniais e pós-coloniais de uso da língua portuguesa. Lidera o grupo de pesquisa Políticas Linguísticas Críticas. Participa, como pesquisadora, do VARSUL/SC. É presidente do Comitê de Políticas Públicas da Associação Brasileira de Linguística (ABRALIN). E-mail: crisgorski@gmail.com

\section{Edair Maria Görski}

É mestre e doutora em Linguística pela Universidade Federal do Rio de Janeiro e atualmente é professora (aposentada) permanente do Programa de PósGraduação em Linguística da Universidade Federal de Santa Catarina, instituição na qual ingressou como docente em 1994. Atua nas áreas de Teoria Linguística e Sociolinguística e Dialetologia. É membro do Núcleo Interinstitucional de Pesquisa VARSUL.E-mail: edair.gorski@ufsc.br

\section{Érica Marciano de Oliveira}

É doutoranda do Programa de Pós-Graduação em Linguística da Universidade Federal de Santa Catarina e bolsista Capes desde 2018. É integrante do projeto Para a História do Português Brasileiro em Santa Catarina (PHPB-SC), do projeto Variação Linguística na Região Sul do Brasil (VARSUL) e do projeto "Variação linguística: aspectos estilísticos e identitários". Seus interesses estão voltados a pesquisas sobre variação e mudança linguística, estilo e identidade. E-mail: ericamarcianodeoliveira@gmail.com 


\section{Gésyka Mafra}

É mestre em Linguística (2019) pela Universidade Federal de Santa Catarina na linha de pesquisa Contato, variação e mudança linguística. E-mail: gesykams@ gmail.com

\section{Grazielle Helena Scheidt}

Possui licenciatura em Letras Português (2015) pela Universidade Federal de Santa Catarina. É mestre em Linguística (2018) pelo Programa de Pós-Graduação em Linguística da mesma instituição. Atualmente, é doutoranda em Linguística do referido programa, bolsista CNPq e integrante do projeto $\mathrm{PHPB}-\mathrm{SC}$, vinculado ao Núcleo VARSUL, e do projeto "Sintaxe histórica e o português do Brasil", coordenado pelo professor Marco Antonio Rocha Martins. E-mail: graziellescheidt@ gmail.com

\section{Helena Gouveia}

É licenciada em Letras Português (2012) pela Universidade Federal de Santa Catarina (UFSC), mestre (2019) pelo Programa de Pós-Graduação em Linguística da UFSC e membro colaborador do projeto Para a História do Português Brasileiro em Santa Catarina (PHPB-SC). Atualmente, é doutoranda do Programa de PósGraduação em Linguística da UFSC na linha de pesquisa Contato, variação e mudança linguística. E-mail: helenaagouveia@gmail.com

\section{Isabel de Oliveira e Silva Monguilhott}

Mestre e doutora em Linguística, na área de concentração Sociolinguística, pela Universidade Federal de Santa Catarina (UFSC). Professora associada do Departamento de Metodologia de Ensino do Centro de Ciências da Educação e do Mestrado Profissional em Letras da UFSC. Desenvolve pesquisa na área de Sociolinguística, com ênfase no ensino de gramática. Atualmente, é coordenadora regional do projeto VARSUL/SC e membro do projeto PHPB-SC. E-mail: isabel. monguilhott@ufsc.br

\section{Ivelã Pereira}

É licenciada e bacharel em Letras Português, mestre e doutora em Linguística pela Universidade Federal de Santa Catarina, com período de doutorado sanduíche na Universidade de Lisboa. É integrante do grupo VARSUL (agência UFSC), colaborando com o PHPB-SC, e professora de Língua Portuguesa do quadro efetivo no Instituto Federal de Educação de Santa Catarina (campus Chapecó). Suas áreas de interesse se direcionam à Sociolinguística, Contato Linguístico, Morfologia e Educação de Jovens e Adultos. E-mail: ivela.pereira@ifsc.edu.br 


\section{Izete Lehmkuhl Coelho}

É graduada em Letras Português e Inglês, mestre em Literatura e doutora em Linguística pela UFSC. Desenvolveu estudos de pós-doutorado em Linguística na UNICAMP, sob a supervisão de Mary Kato, e na UFRJ, sob a supervisão de Célia Lopes e de Silvia Regina de Oliveira Cavalcante. Atualmente, é professora (aposentada) permanente do Programa de Pós-Graduação em Linguística da UFSC, atuando na área de Sociolinguística e Dialetologia. É bolsista de produtividade $\mathrm{PQ}-2$ do $\mathrm{CNPq}$, coordenadora regional do projeto PHPB-SC e membro do projeto VARSUL da UFSC. E-mail: izete.lehmkuhl.coelho@ufsc.br

\section{Juliana Flores das Chagas}

É licenciada em Letras Português (2012), mestre em Sociolinguística (2017) e doutoranda pela Universidade Federal de Santa Catarina. Desde 2018, atua em uma empresa de tecnologia na área de inteligência artificial. É membro do projeto VARSUL e do projeto PHPB-SC.E-mail: flores.juliana@outlook.com

\section{Juliana Regina da Silva}

É bacharel e licenciada em Letras Português pela Universidade Federal de Santa Catarina. Atualmente, é mestranda do Programa de Pós-Graduação em Linguística da mesma instituição. É voluntária do projeto Para a História do Português Brasileiro em Santa Catarina (PHPB-SC), participando, também como pesquisadora, do Núcleo de Estudos Gramaticais. Tem experiência na área de Linguística, com ênfase na linguística gerativa. E-mail: juregi@hotmail.com

\section{Loremi Loregian-Penkal}

É professora associada na UNICENTRO. É graduada em Letras Português e Italiano e mestre em Linguística pela UFSC. É doutora em Letras pela UFPR e pós-doutora em Sociolinguística pela UFPR/CNPq e em Contato Linguístico pela UFSC. Foi bolsista de Iniciação Científica do CNPq no projeto VARSUL da UFSC de 1989 a 1995, agência à qual continua vinculada como pesquisadora. Detentora do Talian, é membro efetivo do Comitê Nacional de Gestão da Língua Talian e da Associação dos Difusores do Talian (ASSODITA).E-mail: llpenkal@unicentro.br

\section{Marco Antonio Rocha Martins}

É doutor (2009) e mestre (2005) em Linguística pela Universidade Federal de Santa Catarina (UFSC), com pós-doutorado (2019) pela Universidade de Colônia, Alemanha. É professor no Departamento de Língua e Literatura Vernáculas e no Programa de Pós-Graduação em Linguística da UFSC; bolsista de produtividade PQ-2 do CNPq e membro do projeto VARSUL. Foi coordenador do Programa de Pós-Graduação em Linguística da UFSC (biênio 2016-2018) e coordenador 
do GT de Sociolinguística da ANPOLL (biênios 2010-2012 e 2012-2014). E-mail: marcomartins.ufsc@gmail.com

\section{Marizete Bortolanza Spessatto}

É doutora em Educação, com estágio de doutoramento na Universidade de Pádua, Itália, e mestre em Linguística pela Universidade Federal de Santa Catarina. Docente do Instituto Federal de Educação de Santa Catarina. Integra o Colegiado do Programa de Mestrado Profissional em Rede ProfEPT. Desenvolve pesquisas junto ao VARSUL/SC desde 1999, com ênfase na investigação da interferência dos dialetos italianos na fala e na escrita em português da população residente no oeste de Santa Catarina. E-mail: spessatto.mari@gmail.com

\section{Patrícia Corrêa Ferminio}

É licenciada em Letras Português e Inglês (2014) pela Universidade do Extremo Sul de Santa Catarina e mestre em Linguística (2017) pela Universidade Federal de Santa Catarina. Desde 2018 é professora efetiva da rede estadual de ensino catarinense. E-mail: patricia_ferminio@hotmail.com

\section{Paulino Vandresen}

É professor aposentado da Universidade Federal de Santa Catarina. Fez estágio pósdoutoral na Universidade da Califórnia em Los Angeles (UCLA), Estados Unidos, bolsista Fulbright. Tem vasta experiência na área de Linguística, com ênfase em Teoria e Análise Linguística, atuando principalmente nos seguintes temas: variação linguística, bilinguismo, linguística, língua portuguesa e sociolinguística. Graduado em Letras Clássicas (1963) pela Universidade Federal de Santa Catarina, mestre em Arts in Linguistics (1969) pela UCLA e doutor em Linguística e Letras (1971) pela Pontifícia Universidade Católica do Rio Grande do Sul. E-mail: paulinov@terra.com.br

\section{Raquel Gomes Chaves}

Está vinculada, como professora colaboradora, à Universidade Estadual do Paraná (UNESPAR) - campus Paranaguá. É doutora pela Universidade Federal de Santa Catarina (UFSC) na linha de pesquisa Sociolinguística e dialetologia e dedica-se ao estudo de fenômenos variáveis de interface. Atualmente integra os projetos VARSUL (agência UFSC), Para a História do Português Brasileiro em Santa Catarina (PHPB-SC) e MorpPhon Circle (UFRGS). E-mail: chavesraquelgomes@ gmail.com

\section{Silvia Regina de Oliveira Cavalcante}

Professora associada da Faculdade de Letras da UFRJ, fez graduação e mestrado em Letras na UFRJ e doutorado em Linguística na UNICAMP. Trabalha com 
mudança linguística, sintaxe diacrônica e faz parte da equipe do PHPB do Rio de Janeiro. E-mail: silviare@gmail.com

\section{Tatiana Schwochow Pimpão}

É doutora (2012) e mestre (1999) em Linguística pela Universidade Federal de Santa Catarina, com pós-doutorado (2020) pela mesma universidade. É professora no Instituto de Letras e Artes e no Curso de Pós-Graduação Lato Sensu em Linguística e Ensino de Língua Portuguesa da Universidade Federal do Rio Grande e membro do projeto VARSUL/SC. Coordena o projeto "Mapeamento do modo subjuntivo no português do Brasil”. E-mail: tatianapimpao@furg.br

\section{Thaissa Frota Teixeira Araujo Silva}

É licenciada em Letras Português e Literaturas de Língua Portuguesa pela Universidade Federal do Rio de Janeiro e mestre em Língua Portuguesa pelo Programa de Pós-Graduação em Letras Vernáculas da mesma instituição. Atualmente, é doutoranda em Língua Portuguesa do referido programa, com pesquisa vinculada à linha de pesquisa Língua e sociedade: variação e mudança. Colaboradora do projeto Para a História do Português Brasileiro. E-mail: thaissafrota@gmail.com

\section{Thiago Laurentino de Oliveira}

É mestre e doutor em Língua Portuguesa pelo Programa de Pós-Graduação em Letras Vernáculas da Universidade Federal do Rio de Janeiro (UFRJ). Professor adjunto de Língua Portuguesa e membro do Programa de Pós-Graduação em Linguística da UFRJ, atuando na linha de pesquisa Variação e mudança linguística. Colaborador do projeto Para a História do Português Brasileiro. E-mail: thiagolaurentino@letras.ufrj.br

\section{Vanessa Grando}

É bacharel e licenciada em Letras Português pela Universidade Federal de Santa Catarina e mestranda do Programa de Pós-Graduação em Linguística da mesma universidade. Sua pesquisa concentra-se na área de Sociolinguística, com ênfase na investigação da variação e mudança das formas de tratamento, em especial dos pronomes de segunda pessoa do singular. E-mail: vanessapgrando@gmail.com 


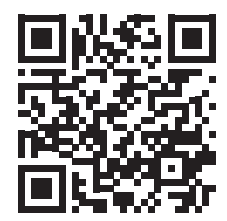

Este livro foi editorado com as fontes Minion Pro e Futura. Publicado on-line em: editora.ufsc.br/estante-aberta. 
Esta coletânea reúne textos que analisam diversos fenômenos linguísticos do português escrito em Santa Catarina nos séculos XIX e XX, com base em documentos que constituem um corpus representativo da escrita catarinense desse período.

Apoio:

$\mathrm{PP}$ 